$4(24) 2019$

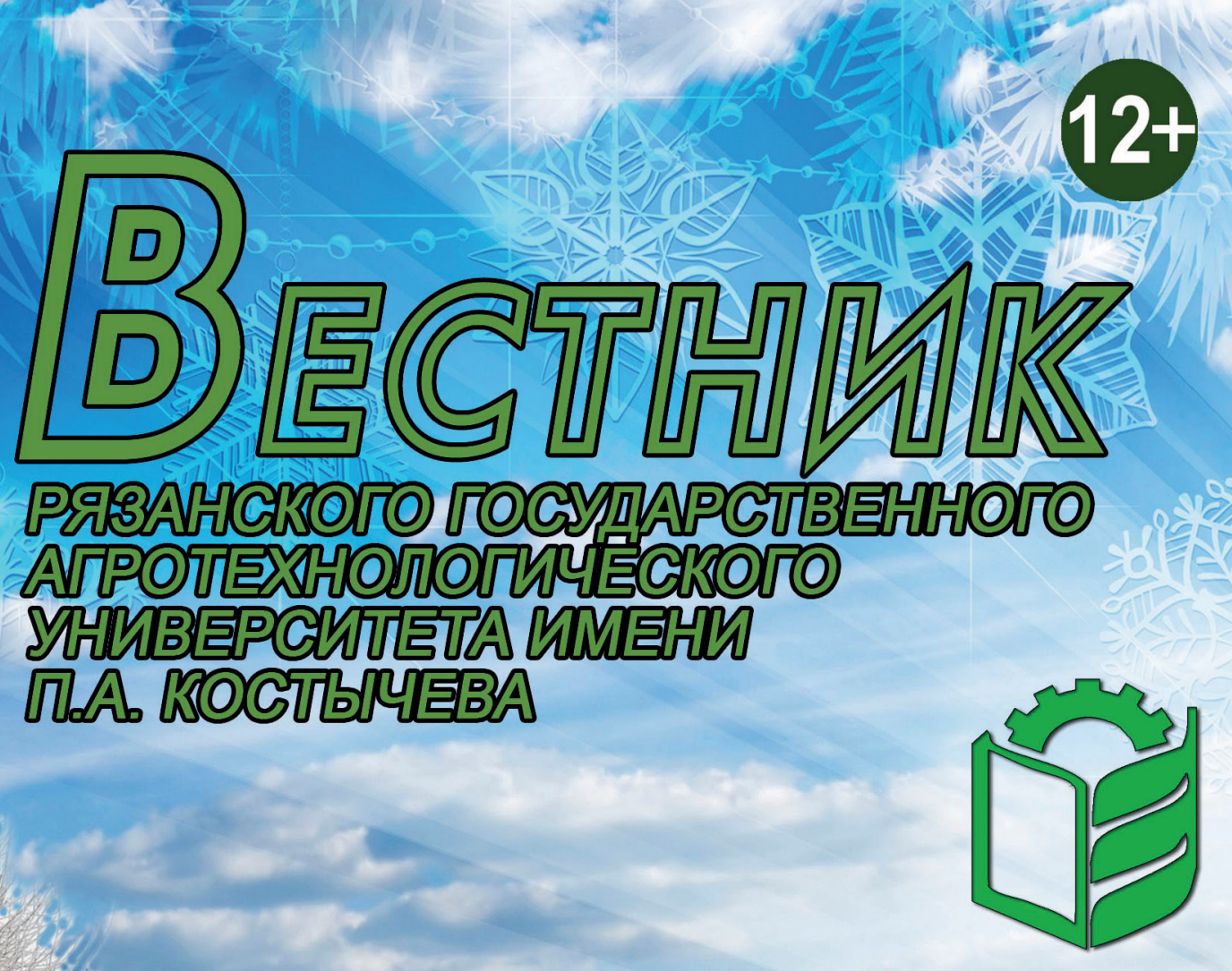

АГРОТЕХНОЛОГИЧЕСКИЙ УНИВЕРСИТЕТ

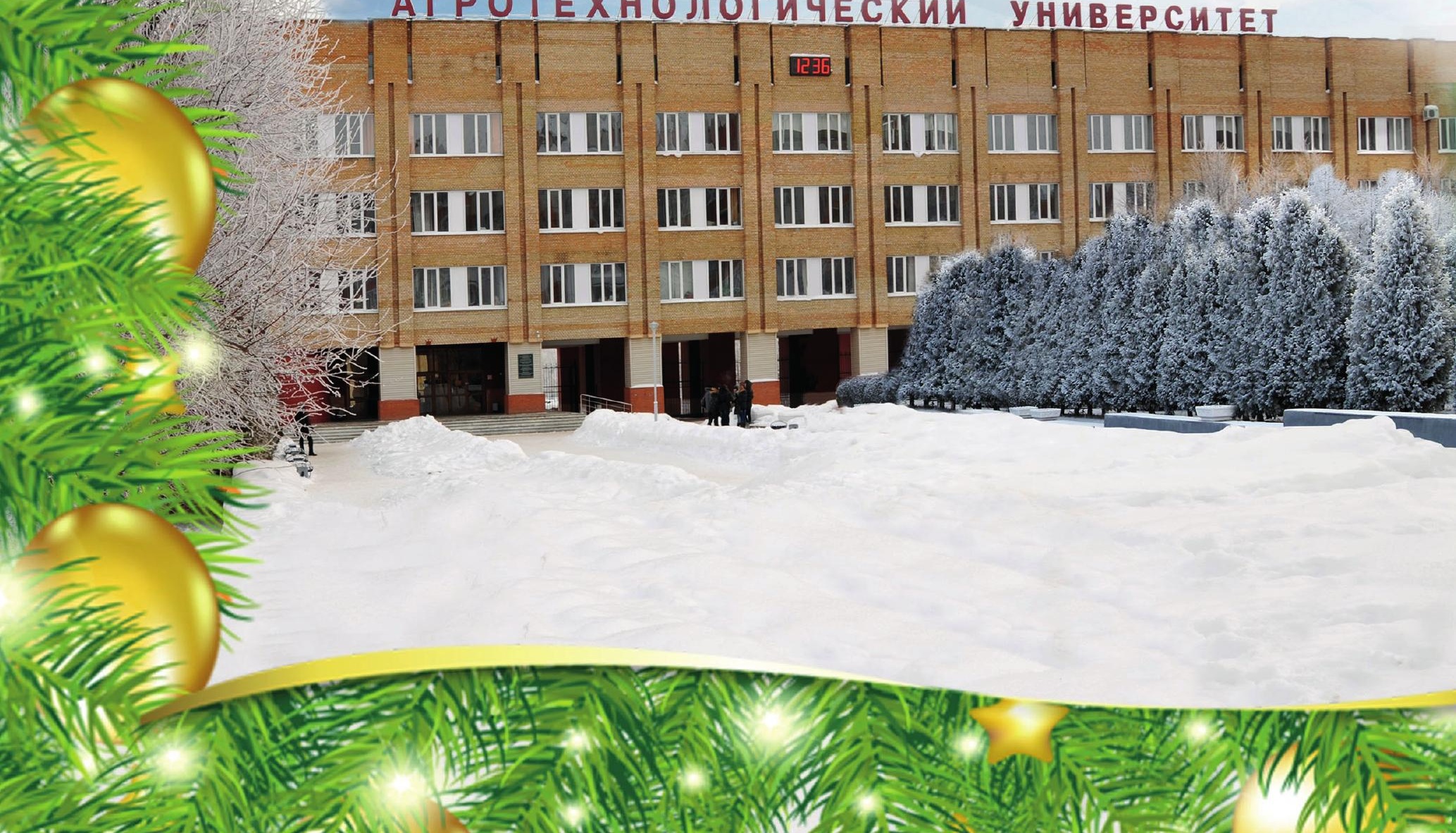




\section{ВЕСТНИК \\ РЯЗАНСКОГО ГОСУДАРСТВЕННОГО \\ АГРОТЕХНОЛОГИЧЕСКОГО УНИВЕРСИТЕТА имени П. А. КОСТЫЧЕВА}

Входит в Перечень рецензируемых научных изданий, в которых должны быть опубликованы основные научные результаты диссертаций на соискание ученой степени кандидата наук, на соискание ученой степени доктора наук, по научным специальностям и соответствующим им отраслям науки

05.20.01 - Технологии и средства механизации сельского хозяйства (технические науки)

05.20.01 - Технологии и средства механизации сельского хозяйства (сельскохозяйственные науки)

05.20.03 - Технологии и средства технического обслуживания в сельском хозяйстве (технические науки)

06.01.01 - Общее земледелие растениеводство (сельскохозяйственные науки)

06.01.02 - Мелиорация, рекультивация и охрана земель (сельскохозяйственные науки)

06.01.04 - Агрохимия (сельскохозяйственные науки)

06.02.05 - Ветеринарная санитария, экология, зоогигиена и ветеринарно-санитарная экспертиза (биологические науки)

06.02.05 - Ветеринарная санитария, экология, зоогигиена и ветеринарно-санитарная экспертиза (ветеринарные науки)

06.02.07-Разведение селекция игенетика сельскохозяйственныхживотных (сельскохозяйственные науки)

06.02.07 - Разведение селекция и генетика сельскохозяйственных животных (биологические науки)

06.02.10 - Частная зоотехния, технология производства продуктов животноводства (сельскохозяйственные науки)

\section{Научно-производственный журнал \\ Издается с 2009 года \\ Выходит один раз в квартал \\ №4 (44), 2019}

Учредитель - ФГБОУ ВО «Рязанский государственный агротехнологический университет имени П. А. Костычева»

СОСТАВ

редакционной коллегии и редакции журнала «Вестник РГАТУ»

Главный редактор

Н. В. Бышов,

д-р техн. наук, профрессор
Заместитель

главного редактора

Л. Н. Лазуткина

д-р пед. наук, доцент
Технический редактор

М. Ю. Пикушина, канд. эконом. наук, доцент

\section{Члены редакционной коллегии: \\ Сельскохозяйственные науки}

Л. Д. Варламова, д-р с.-х. наук, профессор

М. А. Габибов, д-р с.-х. наук,профессор

В. В. Калашников, д-р с.-х. наук, профессор

О. И. Кальницкая, д-р вет. наук, доцент

С. А. Клементьева, д-р биол. наук

А. А. Коровушкин, д-р биол. наук, профрессор

А. В. Коршунов, д-р с.-х. наук, профессор

Я. В. Костин, д-р с.-х. наук, профессор

Н. А. Кузьмин, д-р с.-х. наук, профессор

В. И. Лебедев, д-р с.-х. наук, профессор

Ю. А. Мажайский, д-р с.-х. наук, профессор

В. П. Максименко, д-р с.-х. наук, профессор
Н. И. Морозова, д-р с.-х. наук, профрессор

М. Д. Новак, д-р биол. наук, профессор

А. И. Новак, д-р биол. наук, доцент

Г. В. Ольгаренко, д-р с.-х. наук, профессор

А. Н. Постников, д-р с.-х. наук, профессор

В. Г. Семенов, д-р биол. наук, профессор

Д.И. Удавлиев, д-р биол. наук, профессор

Р. Н. Ушаков, д-р с.-х. наук, профессор

Г. Н. Фадькин, канд. с.-х. наук, доцент

Л. А. Храброва, д-р с.-х. наук, профессор

А. Ф. Шевхужев д-р с. -.Х. наук, профессор

\section{Технические науки}

С. Н. Борычев, д-р техн. наук, профессор

П. П. Гамаюнов, д-р техн. наук, профессор

И. К. Данилов, д-р техн. наук, доцент

М. Ю. Костенко, д-р техн. наук, доцент

В. И. Криштафович, д-р техн. наук, профессор

Г. К. Рембалович, д-р техн. наук, доцент

А. П. Савельев, д-р техн. наук, профессор

О. В. Савина, д-р с.-х. наук, профессор

И. А. Успенский, д-р техн. наук, профессор

М. Н. Чаткин, д-р техн. наук, профессор

Компьютерная верстка и дизайн - Н. В. Симонова

Корректор - Е. Л. Малинина

Перевод - В. В. Романов

Адрес редакции: 390044, г. Рязань, ул. Костычева, д. 1., ауд. 103, тел. 8(4912)34-30-27, e-mail: vestnik@rgatu.ru Тираж 700. Заказ № 1441. Дата выхода в свет 27.12.2019г.
Свидетельство о регистрации СМИ ПИ № ФС77-51956, выдано Федеральной службой по надзору в сфери связи, информационных технологии и масовых коммуникаций 29 ноября 2012 г. О. Костычева 1. ауд. 103. Цена издания 185 руб. 50 коп. Подписной индекс издания в катологе "Пресса России" 82422 


\section{RYAZAN STATE AGROTECHNOF OLOGICAL UNIVERSITY \\ Named after P.A. Kostychev \\ Scientific-Production Journal}

It is included in the list of peer-reviewed scientific publications, which should publish the main scientific results of dissertations for the degree of Candidate of Science, for the degree of Doctor of Science, on scientific specialties and their respective branches of science:

05.20.01 - Technologies and means of agricultural mechanization (Technical Sciences)

05.20.01 - Technologies and means of agricultural mechanization (Agricultural Sciences)

05.20.03 - Technologies and means of technical maintenance in agriculture (Technical Sciences)

06.01.01 - General agriculture, plant growing (Agricultural Sciences)

06.01.02 - Irrigation, land reclamation and land protection (Agricultural Sciences)

06.01.04 - Agrochemistry (Agricultural Sciences)

06.02.05 - Veterinary sanitation, ecology, zoo hygiene, and veterinary-sanitary expertise (Biological Sciences)

06.02.05 - Veterinary sanitation, ecology, zoo hygiene, and veterinary-sanitary expertise (Veterinary Sciences)

06.02.07 - Breeding, selection and genetics of farm animals (Agricultural Sciences)

06.02.07 - Breeding, selection and genetics of farm animals (Biological Sciences)

06.02.10 - Private livestock, technology of livestock products production (Agricultural Sciences)

Issued since 2009

ssued once a quarter

\#4 (44), 2019

Founder - FSBEI HPE "Ryazan State Agrotechnological University Named after P.A. Kostychev"

\section{Editor in Chief}

N.V. Byshov,

Doctor of Technical Science, Full Professor
“RSATU Herald” EDITORIAL STAFF

\section{Editor in Chief Deputies}

L.N. Lazutkina,

Doctor of Pedagogical Science,

Associate Professor

Editorial Staff:

Agricultural Science

\begin{abstract}
L. D. Varlamova, Doctor of Agricultural Science, Full Professor
M. A. Gabibov, Doctoror of Agricultural Science, Full Professor

V. V. Kalashnikov, Doctor of Agricultural Science, Full Professor

O. I. Kaliczkaya, Doctor of Veterinary Science, Associate Professor

S. A. Klementyeva, Doctor of Biological Science

A. A. Korovushkin, Doctor of Biological Science, Full Professor

A. V. Korshunov, Doctor of Agricultural Science, Full Professor,

Y. V. Kostin, Doctor of Agricultural Science, Full Professor

N. A. Kuzmin, Doctor of Agricultural Science, Full Professor

V. I. Lebedev, Doctor of Agricultural Science, Full Professor

Y. A. Mazhayskiy, Doctor of Agricultural Science, Full Professorof

V. P. Maksimenko, Doctor of Agricultural Science, Full Professorof

N. I. Morozova, Doctor of Agricultural Science, Full Professor
\end{abstract}

M. D. Novak, Doctor of Biological Science, Full Professor

A. I. Novak, Doctor of Biological Science, Associate Professor

G. V. Olgarenko, Doctor of Agricultural Science, Full Professor

A. N. Postnikov, Doctor of Agricultural Science, Full Professor

V. G. Semenov, Doctor of Biological Science, Full Professor

D. I. Udavliev, Doctor of Biological Science, Full Professor

R. N. Ushakov, Doctor of Agricultural Science, Full Professor

G. N. Fadkin, Candidate of Agricultural Science, Associate Professor,

L. A. Khrabrova, Doctor of Agricultural Science, Full Professor, A. F. Shevkhuzhev, Doctor of Agricultural Science, Full Professor,

\section{Technical Science}

S. N. Borychev, Doctor of Technical Science, Full Professor P. P. Gamayunov, Doctor of Technical Science, Full Professor

I. K. Danilov, Doctor of Technical Science, Associate Professor

M. Y. Kostenko, Doctor of Technical Science, Associate Professor

V. I. Krishtafovich Doctor of Technical Science, Full Professor,

G. K. Rembalovich, Doctor of Technical Science, Associate

Professor,

A. P. Savelyev, Doctor of Technical Science, Full

Professor,

O. V. Savina, Doctor of Agricultural Science, Full Professor

I. A. Uspenskiy, Doctor of Technical Science, Full Professor

M. N Chatkin, Doctor of Technical Science, Full Professor, Professor

Computer-Aided Makeup and Design - N.V. Simonova

Proof-Reader - E.L. Malinina

Translation - V.V. Romanov

Editorial address: 390044, Ryazan, Kostycheva str., 1., RM. 103. tel: 8(4912)34-30-27, e-mail: vestnik@rgatu.ru Circulation 700. Order No. 1441. Date of publication Date of publication. 27.12.2019r.
Certificate of registration of mass media PI № FS77-51956, issued by the Federal service for supervision in the field of communications, information technology and mass communications November 29, 2012

Printed in the Publishing house of the RGATU, Ryazan, Kostycheva str., 1., RM. 103. Price edition 185 rubles 50 kopecks Subscription index of the publication in the prospectus of the "Press of Russia" 82422 


\section{Содержание}

\section{СЕЛЬСКОХОЗЯЙСТВЕННЫЕ НАУКИ}

АРИСТОВ А. В., ЕСАУЛОВА Л. А., ИОНОВ В. В. СИСТЕМА КОРМЛЕНИЯ, ПОВЫШАЮЩАЯ БИОРЕСУРСНЫЙ ПОТЕНЦИАЛ ДОЙНЫХ КОРОВ НА ЖИВОТНОВОДЧЕСКИХ КОМПЛЕКСАХ ООО «ЭКОНИВААГРО» В УСЛОВИЯХ ВОРОНЕЖСКОЙ ОБЛАСТИ

БЫЧКУНОВА Н.Г., СТРЕКОЗОВ Н. И., СИВКИН Н. В., КОНТЭ А. Ф. СОСТОЯНИЕ И ПРОДУКТИВНОСТЬ КОРОВ В ПЕРВУЮ ТРЕТЬ ЛАКТАЦИИ В СВЯЗИ С ИЗМЕНЕНИЕМ КРАТНОСТИ ДОЕНИЯ В ТРАНЗИТНЫЙ ПЕРИОД

ГЕРЦЕВА К. А., КИСЕЛЕВА Е. В., ДУБОВ Д. В., РУДНАЯ А. В., ГОРШКОВА Ю. Р. РАСПРОСТРАНЕНИЕ НЕЗАРАЗНОЙ ПАТОЛОГИИ СРЕДИ БЕЗНАДЗОРНЫХ СОБАК В УСЛОВИЯХ ГОРОДА РЯЗАНИ

КАШИРИНА Л. Г., МОРОЗОВА Н. И., ИВАНИЩЕВ К. А., РОМАНОВ К. И. СОСТАВ МОЛОКА КОРОВ И СЛИВОЧНОГО МАСЛА, ИЗГОТОВЛЕННОГО ИЗ НЕГО, ПОД ВЛИЯНИЕМ АНТИОКСИДАНТОВ

КОЗАК С. С., СЕМЕНОВ В. Г., АБДРАИМОВ Р. Т., КОЗАК Ю. А. УСКОРЕННЫЙ МЕТОД ПОДСЧЕТА МЕЗОФИЛЬНЫХ АЭРОБНЫХ И ФАКУЛЬТАТИВНО-АНАЭРОБНЫХ МИКРООРГАНИЗМОВ В ПТИЦЕПРОДУКТАХ

КОРОВУШКИН А. А., НЕФЕДОВА С. А., ЯКУНИН Ю. В., ТУНИКОВ Г. М. РАЗРАБОТКА РАЦИОНОВ С ПРИМЕНЕНИЕМ НЕМОДИФИЦИРОВАННЫХ МИКРОПОРИСТЫХ ГУМИНОВЫХ КИСЛОТ ИЗ ЛЕОНАРДИТА ДЛЯ КОРМЛЕНИЯ КАРПОВ МОНГУШ Л. Т. ПОКРОВНЫЙ И БЕСПОКРОВНЫЙ ПОСЕВ МНОГОЛЕТНИХ ТРАВ В УСЛОВИЯХ РЕСПУБЛИКИ ТЫВА

ПОЛИЩУК С. Д., ЧУРИЛОВ Г. И., ЧУРИЛОВ Д.Г., ЧУРИЛОВА В. В., АРАПОВ И. С., ЛОМОВА Ю. В. ВЛИЯНИЕ СТРОЕНИЯ НАНОЧАСТИЦ НА МЕХАНИЗМ ИХ ВЗАИМОДЕЙСТВИЯ С ЖИВЫМИ СИСТЕМАМИ

САВИНА О. В., МАКАРОВ В.А., МАКАРОВА О. В., ГАСПАРЯН С.В. ОРГАНИЧЕСКИЕ УДОБРЕНИЯ КАК ФАКТОР ПОВЫШЕНИЯ ПЛОДОРОДИЯ ПОЧВЫ И ЭФФЕКТИВНОСТИ РАСТЕНИЕВОДСТВА

СЕМЕНОВ В. Г., ИВАНОВ Н. Г., ЛЯГИНА Е. Е. ПРОДУКТИВНЫЕ КАЧЕСТВА КУР РОДИТЕЛЬСКОГО СТАДА БРОЙЛЕРОВ НА ФОНЕ ИММУНОКОРРЕКЦИИ ОРГАНИЗМА

СТУПИН А. С., ВИНОГРАДОВ Д. В., ЛУПОВА Е. И., ФАДЬКИН Г. Н., САЗОНКИН К. Д. ИСПОЛЬЗОВАНИЕ ПРОТРАВИТЕЛЕЙ В ПОСЕВАХ РАПСА В УСЛОВИЯХ РЯЗАНСКОЙ ОБЛАСТИ

ТУНИКОВ Г. М., МОРОЗОВА Н. И., МУСАЕВ Ф. А., МОРОЗОВА О. А., КОРОВУШКИН А. А. СОВРЕМЕННЫЕ ТЕНДЕНЦИИ ПРОИЗВОДСТВА МОЛОКА В УСЛОВИЯХ ИНТЕНСИВНОЙ ТЕХНОЛОГИИ ТЕХНИЧЕСКИЕ НАУКИ

БОГДАНЧИКОВ И. Ю. РЕЗУЛЬТАТЫ ЛАБОРАТОРНЫХ ИССЛЕДОВАНИЙ ПРОЦЕССА РАСПРОСТРАНЕНИЯ РАБОЧЕГО РАСТВОРА В СОЛОМЕ

БЫШОВ Д. Н., КАШИРИН Д. Е., УСПЕНСКИЙ И. А., ЮХИН И. А., МОРОЗОВ С. С. МАТЕМАТИЧЕСКОЕ МОДЕЛИРОВАНИЕ ПРОЦЕССА ВАКУУМНОЙ ИНФРАКРАСНОЙ СУШКИ ПЕРГОВЫХ СОТОВ

КОСТЕНКО М. Ю., БЕЗНОСЮК Р. В., ГОРЯЧКИНА И. Н., РЕМБАЛОВИЧ Г. К., БОРИСОВ Г. А., ЛАТЫШЕНОК М. Б. ИССЛЕДОВАНИЕ РАБОТЫ ГЕНЕРАТОРА ГОРЯЧЕГО ТУМАНА ПРИ ОБРАБОТКЕ СТЕБЛЕСТОЯ

КОСТЕНКО М. Ю., РЕМБАЛОВИЧ Г. К., ГОРЯЧКИНА И. Н., БЕЗНОСЮК Р. В., БОРИСОВ Г. А. ИССЛЕДОВАНИЕ ВЛИЯНИЯ ОБРАБОТКИ СЕМЯН ЯЧМЕНЯ ГОРЯЧИМ ТУМАНОМ БИОЛОГИЧЕСКИХ ПРЕПАРАТОВ И ГУМИНОВЫХ ПРОДУКТОВ ПАНФЕРОВ Н. С., МИТРОФАНОВ С. В., ПЕСТРЯКОВ Е. В., БЛАГОВ Д. А. ПРОГРАММНЫЙ КОМПЛЕКС ПО ФОРМИРОВАНИЮ РАЦИОНАЛЬНОГО ПАРКА ТЕХНИКИ ДЛЯ ПРОВЕДЕНИЯ АГРОХИМИЧЕСКИХ РАБОТ

ПЛОТНИКОВ С. А., КАРТАШЕВИЧ А. Н., ПЛЯГО А. В. ИССЛЕДОВАНИЕ ЭКОЛОГИЧЕСКИХ ПОКАЗАТЕЛЕЙ АВТОТРАКТОРНОГО ДИЗЕЛЯ ПРИ РАБОТЕ НА ПРЕДЕЛЬНЫХ СОСТАВАХ ЭТЭ

РЯЗАНЦЕВ А. И., АНТИПОВ А. О., СМИРНОВ А. И., МАЛЬКО И. В., ЕВСЕЕВ Е.Ю. ТЕХНОЛОГИЧЕСКИЕ ОСОБЕННОСТИ ПОЛИВА И ПОКАЗАТЕЛИ ОЦЕНКИ ЭФФЕКТИВНОСТИ ХОДОВОЙ СИСТЕМЫ ДОЖДЕВАЛЬНОЙ МАШИНЫ «КУБАНЬ-ЛК1»

ТЕТЕРИН В. С., ГАПЕЕВА Н. Н., МИТРОФАНОВ С. В., ПАНФЕРОВ Н. С., ГАЙБАРЯН М. А. СПОСОБ ПРОИЗВОДСТВА КОМПЛЕКСНЫХ ОРГАНОМИНЕРАЛЬНЫХ УДОБРЕНИЙ И ТЕХНОЛОГИЧЕСКАЯ ЛИНИЯ ДЛЯ ЕГО ОСУЩЕСТВЛЕНИЯ ЧУРИЛОВ Д. Г., СТЕКОЛЬНИКОВ Ю. А., АРАПОВ И. С., ШЕМЯКИН А. В., АНДРЕЕВ К. П. ПРОМЫШЛЕННОЕ ИСПОЛЬЗОВАНИЕ ХРОМИРОВАНИЯ ПРИ РЕМОНТЕ ДЕТАЛЕЙ СЕЛЬСКОХОЗЯЙСТВЕННОЙ ТЕХНИКИ ТРИБУНА МОЛОДЫХ УЧЁНЫХ

ВИНОГРАДОВ Д. В., НАУМЦЕВА К. В., ЛУПОВА Е. И., СОКОЛОВ А. А., АНТОШИНА О. А. УРОЖАЙНОСТЬ ГОРЧИЦЫ БЕЛОЙ ПРИ ИСПОЛЬЗОВАНИИ СОВРЕМЕННЫХ ЖИДКИХ УДОБРЕНИЙ В НЕЧЕРНОЗЕМНОЙ ЗОНЕ РОССИИ КАРТАШЕВИЧ А. Н., ПЛОТНИКОВ С. А., МОТОВИЛОВА М. В. ОЦЕНКА РЕГУЛИРОВОЧНЫХ ПОКАЗАТЕЛЕЙ ДИЗЕЛЯ ПРИ ВЫСОКОТЕМПЕРАТУРНОМ ВОЗДЕЙСТВИИ НА ДТ

КУЗНЕЦОВ А. В. ИССЛЕДОВАНИЕ ВЛИЯНИЯ РАСПОЛОЖЕНИЯ НАСАДОК ДОЖДЕВАЛЬНЫХ МАШИН НА КАЧЕСТВО ПОЛИВА

юБИЛЯРЫ 


\section{Content}

\section{AGRICULTURAL SCIENCE}

ARISTOV A. V., ESAULOVA L. A., IONOV V. V. FEEDING SYSTEM INCREASING BIO-RESOURCE POTENTIAL OF DAIRY COWS ON ANIMAL-AGRO ANIMAL COMPLEXES IN VORONEZH REGION

BYCHKUNOVA N.G., STREKOZOV N. I., SIVKIN N. V., CONTE A.F. THE CONDITION AND PRODUCTIVITY OF COWS IN THE FIRST THIRD IN CONNECTION WITH A SHORT-TERM CHANGE OF MILKING FREQUENCY IN TRANSIT PERIOD

GERTSEVA K. A., KISELEVA E. V., DUBOV D. V., RUDNAYA A. V., GORCHKOVA Y.R. HE SPREAD OF NONCOMMUNICABLE DISEASE AMONG STRAY DOGS IN THE CITY OF RYAZAN

KASHIRINA L. G., MOROZOVA N. I., IVANISCHEV K. A., ROMANOV K. I. THE COMPOSITION OF COW MILK AND SWEET BUTTER MADE FROM IT, UNDER THE INFLUENCE OF ANTIOXIDANTS

KOZAK S. S., SEMENOV V.G., ABDRAIMOV R. T. KOZAK Y. A. OF THE ACCELERATED METHOD OF CALCULATION OF MEZO-FILNYH AEROBIC AND OPTIONALLY ANAEROBIC MICROORGANISMS IN POULTRY-FARMING PRODUCTS

KOROVUSHKIN A. A., NEFEDOVA S. A., YAKUNIN Y. V.,TUNIKOV G.M. DEVELOPMENT OF DIETS USING UNMODIFIED MICROPOROUS HUMIC ACIDS FROM LEONARDITE FOR CARP FEEDING

MONGUSH L.T. INTEGUMENTARY AND BLOODLESS CROP OF LONG-TERM GRASSES IN CONDITIONS OF REPUBLIC TUVA

POLISCHUK S. D., CHURILOV G. I., CHURILOV D. G., CHURILOVA V. V., ARAPOV I. S., LOMOVA J. V. THE INFLUENCE OF THE STRUCTURE OF NANOPARTICLES ON THE MECHANISM OF THEIR INTERACTION WITH LIVING SYSTEMS

SAVINA O.V., MAKAROV V. A., MAKAROVA O. V., GASPARYAN S. V. ORGANIC FERTILIZERS AS A FACTOR OF INCREASING SOIL FERTILITY AND EFFICIENCY

SEMENOV V. G., IVANOV N. G., LYAGINA E. E. PRODUCTIVE QUALITIES OF HENS OF A PARENTAL FLOCK OF BROILERS AGAINST THE BACKGROUND OF IMMUNOCORRECTION OF ORGANISM

STUPIN A. S., VINOGRADOV D. V., LUPOVA E. I., FADKIN G. N., SAZONKIN K. D.THE USE OF GRAINERS IN RAPE SEEDS UNDER THE CONDITIONS OF THE RYAZAN REGION

TUNIKOV G. M., MOROZOVA N. I., MUSAEV F. A., MOROZOVA O. A., KOROVUSHKIN A. A. PRODUCTIVE LONGEVITY OF COWS IN CONDITIONS OF INTENSIVE MILK PRODUCTION TECHNOLOGY

\section{TECHNICAL SCIENCE}

BOGDANCHIKOV I. Y. RESULTS OF LABORATORY STUDIES OF PROCESS OF WORKING SOLUTION DISTRIBUTION IN STRAW

BYSHOV D. N., KASHIRI D. YE., USPENSKIY I. A., YUKHIN I. A., MOROZOV S. S. MATHEMATICAL MODELING OF THE PROCESS OF VACUUM INFRARED DRYING OF HONEYCOMBS

KOSTENKO M. Y., BEZNOSYUK R. V.,GORYACHKINA I. N., REMBALOVICH G. K.,BORISOV G.A., LATYSHONOK M. B. INVESTIGATION OF THE OPERATION OF THE HOT MIST GENERATOR IN THE PROCESSING OF STEMS KOSTENKO M. Y.., REMBALOVICH G. K., GORYACHKINA I. N., BEZNOSUK R. V., BORISOV G. A. INVESTIGATION OF THE EFFECT OF HOT MIST TREATMENT OF BIOLOGICAL PREPARATIONS AND HUMIC PRODUCTS OF BARLEY SEEDS

PANFYOROV N. S., MITROFANOV S. V., PESTRYAKOV E.V., BLAGOV D. A. SOFTWARE PACKAGE FOR FORMING A RATIONAL MACHINERY SYSTEM FOR PERFORMING AGROCHEMICAL OPERATIONS

PLOTNUKOV S. A., KARTASHEVICH A. N., PLYAGO A. V. RESEARCH OF ECOLOGICAL INDICATORS OF THE AUTOTRACTOR DIESEL ENGINE AT WORK ON LIMITING STRUCTURES ETE

RYAZANTSEV A. I., ANTIPOV A. O., SMIRNOV A. I., MALKO I. V., YEVSEYEVY. Y., TECHNOLOGICAL FEATURES OF IRRIGATION AND PERFORMANCE EVALUATION OF THE RUNNING SYSTEM DM "KUBAN-LK1»

TETERIN V. S., GAPEEVA N. N., MITROFANOV S. V., PANFYOROV N.S., GAYBARYAN M. A. METHOD AND PROCESS LINE FOR PRODUCING COMPLEX ORGANICMINERAL FERTILIZERS

CHURILOV D. G., STEKOLNIKOV Y. A., ARAPOV I. S., SHEMYAKIN A. V., ANDREEV K. P. GRAIN SEEDS GERMINATION STIMULATION WITH INCOHERENT RED LIGHT: THEORY AND PRACTICE ITRIBUNE OF YOUNG SCIENTISTS

VINOGRADOV D.V., NAUMTSEVA K. V., LUPOVA E. I., SOKOLOV A. A., ANTOSHINA O. A. THE YIELD OF WHITE MUSTARD IN THE USE OF MODERN LIQUID FERTILIZERS

KARTASHEVICH A. N., PLOTNUKOV S. A., MOTOVILOVA M. V. ESTIMATION OF ADJUSTING INDICATORS OF DIESEL UNDER HIGH-TEMPERATURE EXPOSURE TO DT

KUZNETSOV A. V. STUDY OF THE INFLUENCE OF LOCATION OF SPRINKLING HEADS ON IRRIGATION QUALITY AHEROES OF THE DAY 


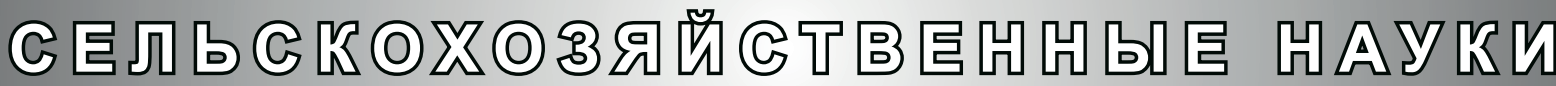

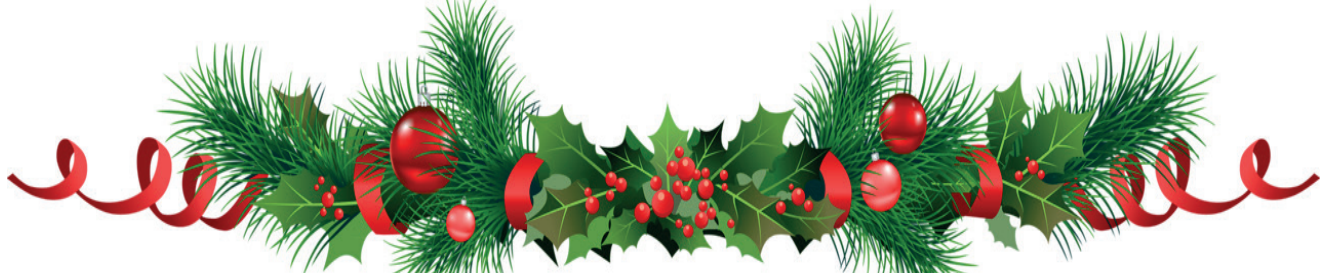

УДК 636.085.2:636.2.034

DOI 10.36508/RSATU.2019.85.38.001

\section{СИСТЕМА КОРМЛЕНИЯ, ПОВЫШАЮЩАЯ БИОРЕСУРСНЫЙ ПОТЕНЦИАЛ ДОЙНЫХ КОРОВ НА ЖИВОТНОВОДЧЕСКИХ КОМПЛЕКСАХ ООО «ЭКОНИВААГРО» \\ В УСЛОВИЯХ ВОРОНЕЖСКОЙ ОБЛАСТИ}

АРИСТОВАлександрВасильевич, канд.с.-х.наук, зав. кафредройобщейзоотехнии, alevas75@mail.ru

ЕСАУЛОВА Лидия Алексеевна, канд. биол. наук, доцент кафредры общей зоотехнии, esaulovalida@ yandex.ru

ФГБОУ ВО «Воронежский государственный аграрный университет им. императора Петра І»,

г. Воронеж, т.8920 4200307

ИОНОВ Вячеслав Вячеславович, зам. директора производственного хозяйства Восточное ООО «ЭкоНиваАгро», Воронежская область, Лискинский район, село Щучье,vyacheslav.ionov@ ekoniva-apk.com

В работе рассмотрено фрормирование групп коров на кормление по фразам лактации. Рассмотрены основные причины замены пропиленгликоля глицерином. Для обоснования исключения из рационов дойных коров сена приведен расчет потерь питательных веществ при разных способах консервирования люцерны, отмечено, что при заготовке сена потери протеина составляют $34,71 \%$, неструктурных углеводов 36,36\% относительно зелёной массы, в результате энергетическая питательность снижается на 22,48\%. При заготовке сенажа процент потерь значительно меньще по сравнению с сеном. Анализ структуры корма посредством пенсильванской сортирующей системы показал соответствие содержания частичек корма при просеве на сите с разным диаметром ячеек нормативным требованиям. Применение адсорбента микотоксинов "SaproSORB» показало, что выход молока на один килограмм сухого вещества рациона увеличился на 6,74\%, себестоимость 1 кг молока с применением Сапросорба снижается на 0,16 рубля. При учёте потребления сухого вещества на одну голову в сутки в условиях жары отмечено увеличение поедаемости корма при сокращении внесения воды (более сухие рационы СВ 55\% против СВ 50\%), увеличение молочной продуктивности. Сравнение химического состава сенажа без использования и с использованием консерванта «Best-Sil» показало снижение доли лигнина на 17,2\%, увеличение легкоусвояемых углеводов на 21,6\%, чистой энергиии лактации на 7,2\%. Контроль работы корн-крекера комбайна и крупность резки кукурузы на силос производится посредством специального набора сит по отработанной методике. Экономический расчёт эфрфрективности использования соевого, подсолнечного шротов и рекомендуемого использования зерна экструдированной сои собственного производства даёт экономию затрат корма на 1 ке молока 0,94 рубля, за счет снижения стоимости рационов. Контроль полноценности кормления коров и корректировка кормления производится как с учётом зоотехнических, так и биохимических показателей.

Ключевые слова: высокопродуктивные дойные коровы, сухое вещество, адсорбент микотоксинов, экструзия сои, потери питательных веществ, структурная клетчатка, работа корн-крекера комбайна, консервация силосованных кормов, энергетческие кормовые добавки.

\section{Введение}

ООО «ЭкоНиваАгро» работает с марта 2002 года. Главное направление деятельности - молочное животноводство. Предприятие является крупнейшим производителем молока в Воронежской области - 665 тонн ежедневно, а это более $25 \%$ от общеобластного показателя. В состав предприятия входит 26 животноводческих подразделения: девять современных молочных комплексов и 17 реконструированных животноводческих ферм, в настоящее время компания динамично развивается. Так, в апреле 2019 года в Пителинском районе Рязанской области был запущен в работу животноводческий комплекс на 2800 го- лов дойного стада. Затем в Маслянинском районе Новосибирской области был открыт животноводческий комплекс на 6000 голов дойного стада. В настоящее время компания ведёт строительство ещё 15 животноводческих комплексов в разных регионах страны. Президентом группы компаний «ЭкоНива» является Штефран Дюрр, поэтому в хозяйствах внедрена немецкая система кормления молочного скота [10].

\section{Материал и методика исследований}

Целью нашей работы было рассмотрение некоторых особенностей организации кормления и мероприятий по её коррекции на высокотехнологичных современных молочных комплексах груп-

(C) Аристов А. В., Есаулова Л. А., Ионов В. В, 2019 г. 
пы компаний ЭкоНиваАгро.

В работе рассмотрены следующие вопросы:

- особенности формирования групп на кормление по фазам лактации;

- основные причины замены пропиленгликоля глицерином;

- приведен расчет потерь питательных веществ при разных способах консервирования лю- церны, дано обоснование отсутствия в рационах дойных коров сена;

- произведён анализ структуры корма с помощью пенсильванской сортирующей системы;

- рассчитана экономическая эффрективность применения адсорбента микотоксинов «SaproSORB» в условиях ЖК «Высокое» в соответствии со схемой, представленной в таблице 1;

Таблица 1 - Схема исследований по включению адсорбента микотоксинов «SaproSORB

\begin{tabular}{|c|c|}
\hline Группы & Рационы \\
\hline $\begin{array}{l}\text { Внутрихозяйственный } \\
\text { рацион (базовый) }\end{array}$ & $\begin{array}{l}\text { Силос кукурузный - 19,97 кг, жом свекловичный гранулированный - } \\
0,68 \text { кг, сенаж люцерновый - 13,07 кг. Концентрат представлен: солью } \\
\text { поваренной - 0,05 кг, жиром защищенным - 0,25 кг, кукурузой - 4,55 } \\
\text { кг, шротом соевым - 2,16 кг, рапсовым - 2,84 кг, ячменём - 3,41 кг. } \\
\text { Кормовые добавки вносятся посредством комбикорма № } 10-1,631 \text { кг. }\end{array}$ \\
\hline $\begin{array}{l}\text { Рекомендуемый рацион с адсорбен- } \\
\text { том микотоксинов «SaproSORB» }\end{array}$ & $\begin{array}{l}\text { Силос кукурузный - 19,97 кг, жом свекловичный гранулированный - } \\
\text { 0,68 кг, сенаж люцерновый - 13,07 кг. Концентрат представлен: солью } \\
\text { поваренной - 0,05 кг, жиром защищенным - 0,25 кг, кукурузой - 4,55 } \\
\text { кг, шротом соевым - 2,16 кг, рапсовым - 2,84 кг, ячменём - 3,41 кг. } \\
\text { Кормовые добавки вносятся посредством комбикорма № } 10-1,631 \text { кг; } \\
\text { SaproSORB - 0,2 кг. }\end{array}$ \\
\hline
\end{tabular}

- рассмотрен расчет потребления сухого вещества дойными коровами на одну голову в сутки при разной влажности кормосмеси в летний период;

- сравнение химического состава сенажа на животноводческих комплексах ООО «ЭкоНиваАгро» без использования и с использованием консерванта «Best-Sil»;

Таблица 2 - Схема исследований по включению в состав рационов дойных коров соевого, подсолнечного шротов и сои экструдированной

\begin{tabular}{|c|c|}
\hline Группы & Рационы \\
\hline $\begin{array}{l}\text { Внутрихозяйственный } \\
\text { рацион (базовый) с соевым шротом }\end{array}$ & $\begin{array}{l}\text { Силос кукурузный - 23,16 кг, жом свекловичный гранулированный - } \\
\text { 1,72 кг, сенаж люцерновый - 8,52 кг, солома ячменная - 2,27 кг. Кон- } \\
\text { центрат: жир пальмовый защищенный - 0,3 кг, кукуруза - 5,04 кг, шрот } \\
\text { соевый - 2,7 кг, рапсовый - 2,11 кг, пшеница - 1,8 кг, мел - 0,04 кг. } \\
\text { Комбикорм - концентрат № } 10-1,6 \text { кг. }\end{array}$ \\
\hline $\begin{array}{l}\text { Внутрихозяйственный } \\
\text { рацион (базовый) с подсолнечным } \\
\text { шротом }\end{array}$ & $\begin{array}{l}\text { Силос кукурузный - 23,16 кг, жом свекловичный гранулирован- } \\
\text { ный - 1,72 кг, сенаж люцерновый }-8,52 \text { кг, солома ячменная - 2,27 } \\
\text { кг. Концентрат: жир пальмовый защищенный - 0,3 кг, кукуруза } \\
-5,04 \text { кг, шрот подсолнечный }-2,8 \text { кг, рапсовый }-2,11 \text { кг, пшени- } \\
\text { ца - 1,8 кг, мел - 0,04 кг. Комбикорм - концентрат № } 10-1,6 \text { кг. }\end{array}$ \\
\hline $\begin{array}{l}\text { Рекомендованный рацион с экстру- } \\
\text { дированной соей }\end{array}$ & $\begin{array}{l}\text { Силос кукурузный - 23,16 кг, жом свекловичный гранулированный - } \\
\text { 1,72 кг, сенаж люцерновый - 8,52 кг, солома ячменная - 2,27 кг. Кон- } \\
\text { центрат: жир пальмовый защищенный - 0,3 кг, кукуруза - 5,04 кг, шрот } \\
\text { соевый - } 1 \text { кг, рапсовый - 2,11 кг, соя экструдированная - 1,7 кг, пше- } \\
\text { ница - 1,8 кг, мел - 0,04 кг. Комбикорм - концентрат № } 10-1,6 \text { кг. }\end{array}$ \\
\hline
\end{tabular}

- в соответствии с рассмотренными биохимическими исследованиями крови крупного рогатого скота рассмотрены возможные мероприятия по корректировке рационов.

Научная новизна работы заключается в рассмотрении и корректировке технологических процессов организации кормления высокопродуктивных дойных коров по зарубежной системе с целью повышения их продуктивности.

\section{Результаты}

Лактация коровы начинается с рождением теленка. В этот период организм коровы испытывает очень большую нагрузку на обмен веществ.

В ЭкоНиваАгро новотельных коров до 10 дня после отела объединяют в группу Д-0 и содержат на умеренном кормлении. Так содержание чистой энергии лактации в этот период составляет 5,7 МДж на 1 кг сухого вещества кормосмеси, при содержании 46,8\% концентрированных кормов от сухого вещества рациона. До недавнего времени в хозяйстве в качестве энергетической кормовой добавки новотельным коровам скармливали пропиленгликоль. Его вводили через зонд коровам в послеотельный период в течение семи дней.

В настоящее время взамен пропиленгликоля используется глицерин. Данная кормовая добавка является побочным продуктом производства био- 
дизеля при переработке рапса на масло. Глицерин активно используется организмом коровы при синтезе глюкозы, которая является основным источником энергетического обмена [3].

Основные причины замены пропиленгликоля глицерином:

- глицерин оказался экономичнее, чем пропиленгликоль;

- применение глицерина технологичнее - он вносится в кормосмесь в миксер. Глицерин - это жидкость коричневого цвета, которая придаёт сладкий вкус и препятствует сепарации корма за счёт вязкой сиропообразной консистенции, что улучшает поедаемость кормов;

- ключевым моментом по замене пропиленгликоля на глицерин явился тот факт, что после дренчевания пропиленгликолем у коров появлялся запах лука из ротовой полости, через 8-12 часов - падеж. При вскрытии запах лука исходил от пищеварительных органов и даже от мяса.

После прохождения транзитного (критического) периода коров переводят в группу Д-1 высокопродуктивных.

На животноводческом комплексе «Высокое» рацион в этот период рассчитан на продуктивность коров 45 литров, содержание чистой энергии лактации - 6,7 МДж на 1 кг сухого вещества кормосмеси, что выше, чем в рационе Д-0, на 17,5\%, при содержании 57\% концентратов против 46,8\% От сухого вещества рациона Д-0.

В базовый рацион в этот период включены: силос кукурузный, жом свекловичный, сенаж люцерновый. Концентрат представлен: солью поваренной, жиром защищенным, кукурузой, шротом соевым, рапсовым, ячменём. Кормовые добавки вносятся посредством комбикорма №10, имеющего следующий состав: зерно ячменя $61,2 \%$, мел кормовой $12,1 \%$, соль $8,1 \%$, премикс для коров фирмы КаудайсМкорма 9,3\% и сода 9,3\%.

Отметим что в рационах группы Д-1 сено не используется. Общепринято, что основная необходимость использования сена полигастричным животным - это обеспечение рационов клетчаткой.

Профрессор Дитер Шпаар [8], отмечает, что заготовка сена - самый старый вид консервирования грубых кормов. Важную роль сено занимает при экстенсивном скотоводстве. Значение сена как ос-новной составной части в кормлении жвачных животных в последние годы по всей Европе снизилось Обеспечить рационы клетчаткой удается за счет использования сенажа. Преимущество заготовки сенажа люцернового в хозяйстве по сравнению с сеном люцерновым отражено в таблице 3, составленной на основании данных зооанализа хозяйства.

Таблица 3 - Потери питательных веществ при разных способах консервирования люцерны

\begin{tabular}{|c|c|c|c|c|c|c|}
\hline \multirow[b]{2}{*}{ Вид корма } & \multirow{2}{*}{$\begin{array}{c}\text { Сухое } \\
\text { вещество } \\
\text { корма, г/кг }\end{array}$} & \multicolumn{5}{|c|}{ Содержание питательных веществ, г/кг } \\
\hline & & ЧЭЛ, МДж & $\begin{array}{c}\text { Сырой } \\
\text { протеин }\end{array}$ & $\begin{array}{c}\text { Неструктур- } \\
\text { ные углеводы }\end{array}$ & $\begin{array}{l}\text { Сырой } \\
\text { жир }\end{array}$ & НДК \\
\hline Зеленая масса & 377,7 & 2,23 & 86,4 & 131,4 & 7,2 & 131,2 \\
\hline Зеленая масса & 1000 & 5,90 & 228,75 & 347,90 & 19,06 & 347,37 \\
\hline Сено & 913,3 & 4,18 & 136,4 & 202,2 & 15,9 & 524,8 \\
\hline Сено & 1000 & 4,58 & 149,35 & 221,39 & 17,41 & 574,62 \\
\hline $\begin{array}{l}\text { \% относительно } \\
\text { травы }\end{array}$ & $x$ & 77,52 & 65,29 & 63,64 & 91,33 & 165,42 \\
\hline Сенаж & 439,3 & 2,42 & 94,2 & 110,8 & 14 & 183,4 \\
\hline Сенаж & 1000 & 5,51 & 214,43 & 252,22 & 31,87 & 417,48 \\
\hline $\begin{array}{l}\text { \% относительно } \\
\text { травы }\end{array}$ & $x$ & 93,30 & 93,74 & 72,50 & 167,18 & 120,19 \\
\hline
\end{tabular}

В таблице представлен пересчет питательных веществ в зелёной массе, в сене и сенаже люцерновых на сухое вещество корма. Так как сравнение содержания питательных веществ в кормах с разной влажностью не корректно.

Из таблицы видно, что при заготовке сена происходят сильные потери питательных веществ; так, потери протеина составляют $34,71 \%$, неструктурных углеводов $36,36 \%$, в результате энергетическая питательность снижается на 22,48\%. При заготовке сенажа процент потерь значительно меньше относительно сена.

Основные корма должны не только обеспечи- вать животное сырой клетчаткой, но и обеспечивать структурной клетчаткой, то есть клетчатка должна находиться в частичках корма определённого размера. Если основные корма не обеспечивают структуру рациона, тогда в рацион включают сено. Контроль обеспеченности животных структурной клетчаткой производят по средствам «Пенсильванского сита». Использование пенсильванской сортирующей системы представлено на сайтах soft-agro и progressivefarm [13,15].Нами была произведена оценка структуры корма в четырех точках кормового стола (табл. 4).

Таблица 4 - Анализ структуры корма на Пенсильванском сите

\begin{tabular}{|c|c|c|c|c|c|c|c|c|c|}
\hline \multirow{2}{*}{ Норма } & \multicolumn{2}{|c|}{ точка } & \multicolumn{2}{c|}{2 точка } & \multicolumn{2}{c|}{3 точка } & \multicolumn{2}{|c|}{4 точка } & Сред- \\
\cline { 2 - 8 } & Физ. & $\%$ & Физ. & $\%$ & Физ. & $\%$ & Физ. & $\%$ & нее \\
\hline Верхнее 2-8\% & 50 & 10 & 60 & 12 & 55 & 11 & 70 & 14 & 11,75 \\
\hline \hline
\end{tabular}


Продолжение таблицы 4

\begin{tabular}{|l|c|c|c|c|c|c|c|c|c|}
\hline Среднее 30-50\% & 175 & 35 & 190 & 38 & 195 & 39 & 170 & 34 & 36,5 \\
\hline Нижнее 10-20\% & 80 & 16 & 75 & 15 & 70 & 14 & 60 & 12 & 14,25 \\
\hline Поддон менее 40\% & 195 & 39 & 175 & 35 & 180 & 36 & 200 & 40 & 37,5 \\
\hline
\end{tabular}

Из таблицы видно, что полученные результаты соответствуют нормативным значениям кроме верхнего сита; множество источников сообщает, что на верхнем сите должно оставаться $10-15 \%$ корма, что согласуется с теорией профилактики смещения сычуга [6].

Таким образом, вводить сено для повышения структуры корма на ЖК Высокое нет необходимости.

На ЖК Высокое для повышения продуктивности коров был поставлен производственный опыт с использованием адсорбента микотоксинов «SaproSORB» - углеродистого сорбента микотоксинов широкого спектра действия, получаемого из природного сапропеля путем его термической об-

работки с последующим фракционированием.

Положительный эффрект при применении данного препарата уже был получен во многих производствах, в том числе при проведении производственного эксперимента на ЗАО «Петелиновская птицефабрика» Московской области на цыплятах бройлерах кросса ISA F-15 [9]. Caпросорб смешивается с монокормом из расчета 0,2 кг на голову в сутки. Стоимость 1 кг составляет 100 рублей. Таким образом, рацион с применением Сапросорба будет дороже на 20 рублей относительно базового внутрихозяйственного. Экономическая эфффективность кормления дойных коров с применением адсорбента микотоксинов «SaproSORB» представлена в таблице 5.

Таблица 5 - Экономическая эффективность кормления дойных коров с применением адсорбента микотоксинов «SaproSORB»

\begin{tabular}{|l|c|c|}
\hline \multicolumn{1}{|c|}{ Показатель } & Рацион базовый & Рацион с Сапросорбом \\
\hline $\begin{array}{l}\text { Потреблено сухого вещества } \\
\text { рациона, кг }\end{array}$ & 23,64 & 23,64 \\
\hline Получено молока, кг/гол/сут & 42 & 45 \\
\hline $\begin{array}{l}\text { Из 1 кг сухого вещества получе- } \\
\text { но молока, кг }\end{array}$ & 1,78 & 1,9 \\
\hline Стоимость рациона руб & 380,0 & 400,0 \\
\hline Себестоимость 1 кг молока, руб & 9,05 & 8,89 \\
\hline $\begin{array}{l}\text { Экономия затрат корма на 1 кг } \\
\text { молока, руб. }\end{array}$ & & 0,16 \\
\hline
\end{tabular}

Из таблицы 5 экономической эфффективности кормления дойных коров с применением адсорбента микотоксинов «SaproSORB» видно, что, хотя стоимость рациона увеличилась, выход молока на один килограмм сухого вещества увеличился на 6,74\%, себестоимость 1 кг молока с применением Сапросорба снизилась на 0,16 рубля.

Экономия затрат корма на все поголовье в год составит: $2880^{*} 0,16^{*} 365=168192$ рубля.

Дойные коровы потребляют максимум корма тогда, когда количество сухого вещества в общем рационе составляет $40-55 \%[4,7]$.

Обычно в рацион, содержание сухого вещества в котором превышает 55\%, добавляют воду для предотвращения сепарации корма. Но бывают и исключения из правил: так, в ЭкоНива Агро на животноводческом комплексе «Верхний Икорец» в летний период 2018 года в условиях жары при дополнительном добавлении воды (СВ 50\%) суточное потребление корма было невысоким, так как влажный корм пропадал быстрее. Остатки на кормовом столе превышали нормативные значения (3-5\%). При сокращении внесения воды (более сухие рационы СВ 55\%) поедаемость корма в этот период увеличилась (табл. 6). Пониженное потребление корма можно объяснить порчей корма в условиях жары и высокой влажности.

Таблица 6 - Расчет потребления сухого вещества на 1 голову в сутки при разной влажности кормосмеси в летний период

\begin{tabular}{|c|c|c|c|c|c|c|c|}
\hline $\begin{array}{c}\text { Количе- } \\
\text { ство голов }\end{array}$ & $\begin{array}{c}\text { Раздали, } \\
\text { кг }\end{array}$ & Съели, кг & Остаток, кг & СВ, \% & $\begin{array}{c}\text { Суточное } \\
\text { потребление } \\
\text { корма, кг/гол }\end{array}$ & $\begin{array}{c}\text { СВ/голову, } \\
\text { кг }\end{array}$ & Остатки, \% \\
\hline 103 & 4990 & 4366,2 & 623,83 & 50 & 42,39 & 21,20 & 12,50 \\
\hline 103 & 4990 & 4766,2 & 223,83 & 55 & 46,27 & 25,45 & 4,49 \\
\hline
\end{tabular}

Ежегодно хозяйство стремится к улучшению качества основных кормов и в 2018 году в хозяйстве был проведен производственный опыт по использованию препарата Best-Sil для консервации сенажа люцернового.

Серия опытов по применению данного препарата была проведнга в различных хозяйствах Владимиром Молодкиным, руководителем направле- ния по кормопроизводству ГК АгроБалтТрейд.

В состав консерванта входят Лиофилизированные бактерии Lactobacillus plantarum, Enterococcus faecium и Pediococcus pentosaceus, а также наполнитель [10].

Мы произвели сравнение химического состава корма на шести разных животноводческих комплексах ООО ЭкоНиваАгро без использования и 
с использованием консерванта, в сухом веществе корма. В результате применения консерванта доля сырого протеина не изменилась. Положительным моментом является снижение доли низко ценной в питательном отношении фракции углеводов - лигнина на 17,2\%. Уровень легкоусвояемых углеводов увеличивается на 21,6\%, вместе с этим увеличивается и количество чистой энергии лактации на 7,2\%.

В хозяйстве традиционно заготавливается силос из кукурузы. Начало уборки кукурузы на силос - стадия восковой спелости зерна. Зерно должно быть разрушено минимум на 4 части, для этого используют корн-крекеры. При заготовке силоса производят определение эффрективности работы корн-крекера комбайна посредством специального сита с двумя сменными экранами диаметром отверстий 6 мм и 12 мм. Для проведения контроля отбирают в поле из наполненного одним комбайном транспорта пробу зеленой массы кукурузы не менее чем из трех точек. Объем пробы должен быть таким, чтобы лоток для просеивания зеленой массы кукурузы был заполнен наполовину. Устанавливают матрицу с крупным ситом (12мм), высыпают отобранную пробу в лоток. Выполняют поступательные движения (вперед-назад, влевовправо) до момента прекращения просыпания массы. Отдельно высыпают сход с сита (на рисунке куча справа), проход через сито отправяют на сито с мелкой матрицей (6мм), проход через мелкую матрицу группируют в отдельную кучу (на рисунке средняя куча). Сход с мелкой матрицы отправляют в ведро с чистой водой для промывания, тщательно размешивают руками не касаясь дна ведра, извлекают всплывшую часть массы руками в отдельную кучу (на рисунке слева). Проливают воду с оставшейся смесью через мелкое сито таким образом, чтобы отсутствовали остатки пробы в емкости. Анализируют результаты промытой массы с дна ведра. Зерно кукурузы должно быть раздроблено минимум на 4 части, не раздробленное должно отсутствовать, что свидетельствует о корректной настройке корн-крекера. Необходимо также проанализировать каждую из трех сгуртованных проб, их однородность свидетельствует о корректной настройке режущих элементов комбайнов (рис.)

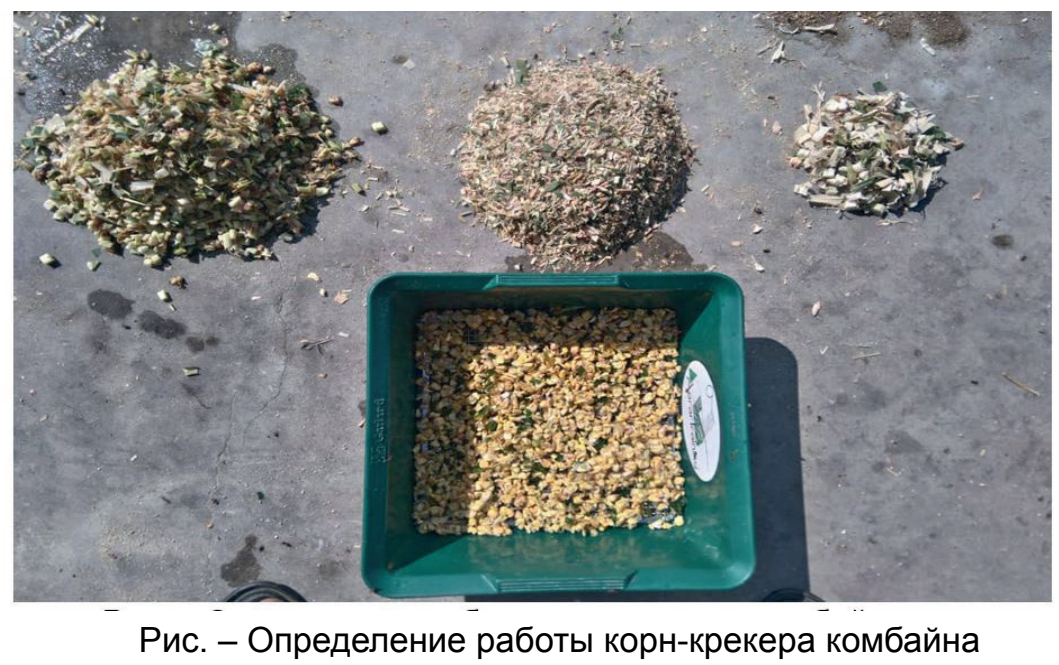

В рационах дойных коров в хозяйстве одним из самых дорогих составляющих является соевый шрот. Соепродукты включают в рационы полигастричных животных с целью повышения уровня нерасщепляемого в рубце протеина (НРП), фракция которого необходима для лучшей усвояемости сырого протеина $[12,14]$.

В хозяйстве возникают такие ситуации, когда соевый шрот отсутствует, в этом случае его по уровню сырого протеина заменяют подсолнечным шротом, но уровень НРП при этом падает, вместе с этим падает уровень молочной продуктивности.

По опыту многих хозяйств альтернативой использования дорогостоящего соевого шрота является использование полножировой сои, тем более что в хозяйстве её выращивают. Урожайность сои составляет 18 ц/га, при стоимости 15390 рублей за тонну, что гораздо дешевле покупного соевого шрота (32 634 рублей за тонну). Однако наряду с питательными веществами в сое находятся антипитательные вещеста [1]. Об этом также сообщает эксперт сельскохозяйственной палаты Нижней Австрии Геральд Штогмюллер [16].
Наилучшим способом инактивации антипитательных факторов в соевых бобах является их экструдирование [2], при котором также повышается уровень НРП.

По данным доктора Дж. Вейзмена (Ноттингемский университет), использование экструзии, позволяет получить корм с высокой энергетической ценностью (4224 ккал/кг для птицы), высоким уровнем усвоения азота (84\%), при хорошем качестве протеина [14].

Полная замена соевого шрота на сою экструдированную по мнению специалистов хозяйства невозможна ввиду повышения уровня жира, состоящего из ненасыщенных жирных кислот, пагубно влияющих на рубцовое пищеварение.

Из таблицы 7 экономической эффективности кормления дойных коров с использованием соевого шрота, подсолнечного шрота и экструдированной сои видно, что использование зерна сои собственного производства даёт экономию затрат корма на 1 кг молока 0,94 руб за счет снижения стоимости рационов. 
Таблица 7 - Экономическая эфффективность кормления дойных коров с использованием соевого шрота, подсолнечного шрота и экструдированной сои

\begin{tabular}{|l|c|c|c|}
\hline \multicolumn{1}{|c|}{ Показатели } & $\begin{array}{c}\text { Рацион базовый с } \\
\text { соевым шротом }\end{array}$ & $\begin{array}{c}\text { Рацион с подсол- } \\
\text { нечным шротом }\end{array}$ & $\begin{array}{c}\text { Рацион с частичной } \\
\text { заменой соевого шрота } \\
\text { экструдированной соей }\end{array}$ \\
\hline $\begin{array}{l}\text { Потреблено сухого вещества } \\
\text { рациона, кг }\end{array}$ & 24,73 & 24,82 & 24,76 \\
\hline Получено молока, кг/гол/сут & 35 & 30 & 35 \\
\hline $\begin{array}{l}\text { Из 1 кг сухого вещества получено } \\
\text { молока, кг }\end{array}$ & 1,42 & 1,21 & 1,41 \\
\hline Стоимость рациона & 370 & 328 & 337 \\
\hline Себестоимость 1 кг молока, руб & 10,57 & 10,93 & 9,63 \\
\hline $\begin{array}{l}\text { Экономия затрат корма на 1 кг } \\
\text { молока, руб. }\end{array}$ & 0,36 & & 0,94 \\
\hline
\end{tabular}
вит:

Экономия затрат на поголовье при этом соста-

2800 голов 10000 кг * 0,94 рубля $=28000000$ ${ }^{*} 0,94=26320000$ руб.

Экономическая эффрективность была рассчитана без учета затрат на экструдирование. Рассчитаем экономию затрат с использование экструдера фрирмы Экспро М [11].

1. Расход экструдированной сои в год составит:

1,7 кг/гол/сут²800 голов *300 дней $=1428000$ Кг.

2. Время, которое понадобится для экструдирования заданного объема зерна сои, при производительности 1200 кг/час:

1 ч - 1200 кг

$\mathrm{X} \mathrm{ч}-1428000$ кг

$\mathrm{X}=1190$ ч.

3. Количество затраченной энергии, если мощность экструдера составляет 112,25 кВт/час:

$14-112,25 \mathrm{kBT}$

1190 ч $-\mathrm{x} \mathrm{KBT}$

$\mathrm{X}=133875 \mathrm{kBT}$

4. Средства, потраченные на экструзию, если стоимость 1 кВт 3,74 рубля:

$1 \mathrm{\kappa Bт}-3,74$ руб

$133875-\mathrm{x}$ руб

$X=500692,5$ руб.

Таким образом, экономия затрат корма при частичной замене соевого шрота экструдированной соей составит: 26320000 - 500 692,5 = 25819308 рублей. Экономия затрат корма с учетом стоимости экструдера 1320000 рублей составит: 25819 $308-1320000=24499308$ рублей.

Сухостойный период у коров подразделяется на два периода: Сух-1 - первые 40 дней сухостоя, когда коровы содержатся на поддерживающем уровне кормления и Сух- 2 - коровы за 20 дней до отёла. В этот период в рационах коров набор кор- мов такой же, как и у дойных коров, концентрация энергии в сухом веществе выше, чем в Сух-1, также в этот период в рацион включаются анионные соли для предотвращения родильного пареза.

Анализируя таблицу 8 биохимических исследований крови крупного рогатого скота, отметим максимальное содержание белка (в пределах нормативных значений) в группе Д-1, что свидетельствует о повышенной белоксинтезирующей функции печени; это отмечается обычно при высококонцентратном типе кормления. В этой же группе повышено содержание мочевины (выше нормативных значений), что свидетельствует о повышенном содержании в рационах этой группы сырого протеина.

В группе Сух-2 отмечается гипергликемия, что свидетельствует о повышенной углеводной нагрузке и изнашивании поджелудочной железы.

В группе Д-1 отмечается пониженный уровень гемоглобина, что может быть свидетельством анемий, истощения, гемолиза эритроцитов.

В крови всех групп животных повышен уровень ACAT, особенно в Д-1, что имеет важное значение для дифференциальной диагностики болезней печени.

Повышенные показатели фосфора отмечаются в группе Д-1 и Сух-1,2. Повышение фосфора отмечается при гипофункции паращитовидных желез (что является нормой у сухостойных коров, поэтому у этой группы коров верхний показатель выше нормативных значений), высококонцен-тратном типе кормления (он входит в оболочку пленчатых зерновых культур).

Повышенный уровень натрия в крови в группах Д-0, Сух-1,2 обусловлен избыточным поступлением источников натрия.

Микроэлементы поступают с премиксами, во всех группах завышен уровень цинка [5]

Таблица 8 - Биохимические исследования крови крупного рогатого скота

\begin{tabular}{|l|c|c|c|c|c|}
\hline \multicolumn{1}{|c|}{ Показатели } & $\begin{array}{c}\text { Оптимальные } \\
\text { величины }\end{array}$ & $\begin{array}{c}\text { Д-0 } \\
(\mathrm{n}=10)\end{array}$ & $\begin{array}{c}\text { Д-1 } \\
(\mathrm{n}=10)\end{array}$ & $\begin{array}{c}\text { Сух-1 } \\
(\mathrm{n}=5)\end{array}$ & $\begin{array}{c}\text { Сух-2 } \\
(\mathrm{n}=10)\end{array}$ \\
\hline Об. белок, г/л & $72-86$ & $65,6 \pm 5$ & $77,2 \pm 3,4$ & $64,5 \pm 2,27$ & $60,7 \pm 4,9$ \\
\hline $\begin{array}{l}\text { Креатинин, } \\
\text { мкМ/л }\end{array}$ & $39,8-160$ & $66,7 \pm 13,5$ & $69,4 \pm 10,5$ & $87,6 \pm 9,61$ & $63,8 \pm 14,2$ \\
\hline
\end{tabular}


Продолжение таблицы 8

\begin{tabular}{|l|c|c|c|c|c|}
\hline Мочевина, мМ/л & $3,3-6,7$ & $5,14 \pm 0,9$ & $7,1 \pm 0,8$ & $6,3 \pm 0,72$ & $6,47 \pm 1,4$ \\
\hline Глюкоза, мМ/л & $2-3,5$ & $3,75 \pm 0,4$ & & & $4,47 \pm 0,2$ \\
\hline Гемоглобин, г/л & $99-129$ & $99,14 \pm 7,3$ & $94,9 \pm 9,4$ & $101,3 \pm 8,96$ & $110,6 \pm 9,2$ \\
\hline АсАТ, Е/л & $10-50$ & $111,86 \pm 11,6$ & $128,8 \pm 33,3$ & $81,4 \pm 15,49$ & $81,8 \pm 14,6$ \\
\hline АлАТ, Е/л & $5-40$ & $25,62 \pm 8,5$ & $41 \pm 20,5$ & $34 \pm 4,2$ & $25,77 \pm 9,9$ \\
\hline Щ, Е/л & $42-200$ & $148,6 \pm 39,9$ & $104,5 \pm 53,2$ & $261,6 \pm 94,4$ & $194,8 \pm 80,7$ \\
\hline Кальций, мМ/л & $2,5-3,1$ & $2,75 \pm 0,2$ & $2,6 \pm 0,2$ & $2,7 \pm 0,11$ & $2,75 \pm 0,2$ \\
\hline Фосфор, мМ/л & $1,45-1,94$ & $1,7 \pm 0,1$ & $2 \pm 0,2$ & $2,2 \pm 0,05$ & $2 \pm 0,3$ \\
\hline Магний, мг/\% & $2-3$ & $2,12 \pm 0,1$ & $2,2 \pm 0,05$ & $2,2 \pm 0,02$ & $2,22 \pm 0,1$ \\
\hline Калий, мМ/л & $4,1-4,86$ & $5,22 \pm 0,7$ & $4,4 \pm 0,4$ & $4,5 \pm 0,69$ & $2,68 \pm 0,1$ \\
\hline Натрий, мМ/л & $139-148$ & $154,8 \pm 19,5$ & $137,1 \pm 12,3$ & $159 \pm 14,13$ & $155,1 \pm 9,7$ \\
\hline Медь, мкМ/л & $14-19$ & $15,9 \pm 2,31$ & $15,9 \pm 2,31$ & $15,3 \pm 3,74$ & $14 \pm 2,78$ \\
\hline Цинк, мкМ/л & $43-74$ & $37,6 \pm 3,74$ & $37,6 \pm 3,74$ & $42,1 \pm 6,22$ & $40,4 \pm 4,43$ \\
\hline Железо, мкМ/л & $3,6-5,4$ & $4,4 \pm 0,16$ & $4,4 \pm 0,16$ & $4,6 \pm 0,34$ & $4,5 \pm 0,39$ \\
\hline Кобальт, мкМ/л & $0,5-0,9$ & $0,7 \pm 0,09$ & $0,7 \pm 0,09$ & $0,6 \pm 0,08$ & $0,6 \pm 0,13$ \\
\hline Селен, мкМ/л & $1,0-1,6$ & $1,1 \pm 0,18$ & $1,1 \pm 0,18$ & $1,2 \pm 0,19$ & $1,3 \pm 0,21$ \\
\hline
\end{tabular}

\section{Выводы}

Таким образом, ООО «ЭкоНиваАгро» является хозяйством с интенсивным ведением молочного животноводства, где для контроля полноценности кормления дойных коров учитываются современные общемировые научнообоснованные показатели и набор кормов, обеспечивающих возможность балансирования учитываемых показателей, а также кормовых добавок, помогающих регулировать обменные процессы в организме животных, что позволяет получать высокую продуктивность дойных коров. Особое внимание уделяется заготовке качественных основных кормов. Наряду с зоотехническим контролем обеспечивается биохимический контроль полноценности кормления.

\section{Список литературы}

1.Антипитательные факторы кормов: справочная книга / Н. И. Чернышев [и др.]. - Воронеж : ОАО Воронежская областная типография, 2013. -206 c.

2.Афранасьев, В. А. Приоритетные методы тепловой обработки зерновых компонентов в технологии комбикормов: монография / В. А. Афанасьев, А. Н. Остриков. - Воронеж, 2015. - 336 с.

3.Глицерин для коров: [электронный ресурс]. - режим доступа:http://msk.agroserver.ru/kormovyedobavki/glitserin-dlya-korov-495092.htm

4.Количество корма, которое фактически поедает корова : [Электронный ресурс]. - Режим доступа: https://soft-agro.com/korovy/kolichestvokorma-kotoroe-fakticheski-poedaet-korova.html

5.Кондрахин, И. Н. Методы ветеринарной клинической лабораторной диагностики : справочник / И. Н. Кондрахин. - М. : Колос, 2008. - 289 с.

6.Контроль смещения сычуга у коров [сайт] [Электронный ресурс]. - Режим доступа: http:// www.milkua.info/ru/post/kontrol-smesenia-sycuga-ukorov.

7.Кормление коров по сухому веществу: [сайт] [электронный ресурс]. - Режим доступа: http:// viktoriy.ru/kormlenie-po-sv
8. Кочишь, И. И. Оценка сорбционной способности адсорбента отечественного производства и его эффективность при выращивании цыплятбройлеров [Электронный ресурс] / И. Н. Кочишь, С. H. Коломиец - Режим доступа: http://cyberleninka. ru/article/n/otsenka-sorbtsionnoy-sposobnostiadsorbenta-otechestvennogo-proizvodstva-i-egoeffektivnosti-pri-vyraschivanii-tsyplyat-broylerov.pdf

9. Молодкин, Вадим Потенциал препаратов «Best-Sil»: первое знакомство и почему с ними удобно работать? [Электронный ресурс]. - Режим доступа:https://agrovesti.net/lib/tech/ fodder-production-tech/potentsial-preparatov-bestsil-pervoe-znakomstvo-i-pochemu-s-nimi-udobnorabotat.html

10.Молочное животноводство[Электронный pecypc]. - Режим доступа: https://ekoniva-apk.ru/ agricultural-production/dairy-farming

11.Оборудование для производства комбикорма [Электронный ресурс]. - Режим доступа: http:// www.eks-bio.ru/

12.Производство полножирной сои и ее использование в кормлении животных, рыб и птиц [Электронный ресурс]. - Режим доступа: http://basu-rus. com/ru/info/articles/proizvodstvo-polnozhirnoy-soi. html

13.Сита для кормов. Определяем структурность корма [Электронный ресурс]. - Режим доступа: http://www.progressivefarm.info/2016/10/26/ sita-dlya-kormov-opredelyaem-strukturnost-korma/

14.Сырая полножирная соя в кормлении КРС - на что обращать внимание? [Электронный pecypc]. - Режим доступа: soft-agro.com/krs-naotkorme/syraya-polnozhirnaya-soya-v-kormlenii-krsna-chto-obrashhat-vnimanie.html

15.Три системы оценки структурности корма: сырая и структурная клетчатка, показатель структуры корма и NDF, ADF, ADL [Электронный ресурс]. - Режим доступа: https://soft-agro.com/korovy/tri- 


\section{FEEDING SYSTEM INCREASING BIO-RESOURCE POTENTIAL OF DAIRY COWS ON ANIMAL-AGRO ANIMAL COMPLEXES IN VORONEZH REGION}

Aristov Alexander V., Candidate of Agricultural Sciences, Head of the Department of General Zootechnics, Voronezh State Agrarian University named after Emperor Peter I ", Voronezh Russia, alevas75@mail.ru

Esaulova Lidiya A., Candidate of biological sciences, associate professor of the Department of General Zootechnics, Voronezh State Agrarian University named after Emperor Peter I ", Voronezh Russia, esaulovalida@yandex.ru

Ionov Vyacheslav V., Deputy Director of Vostochnoye Production Facilities EkoNivaAgro LLC, 397926 Voronezh Region, Liskinsky District, Shchuchye Village, Sovetskaya Street, 33, vyacheslav.ionov@ekonivaapk.com

The paper considers the formation of groups of cows for feeding by lactation phases. The main reasons for the replacement of propylene glycol with glycerin are considered. To justify the absence of hay dairy cows in the diets, the calculation of nutrient losses is given for different methods of preserving alfalfa, it is noted that protein loss is $34.71 \%$, non-structural carbohydrates $36.36 \%$ relative to the green mass when hay is harvested, as a result, energy nutrition is reduced by $22,48 \%$ When harvesting haylage, the percentage of losses is much less relative to hay. An assessment of the analysis of the feed structure using the means of the Pencil sorting system showed that the content of feed particles during screening on a sieve with different cell diameters is in compliance with regulatory requirements. The use of SaproSORB mycotoxin adsorbent showed that the yield of milk per 1 kilogram of dry matter of the diet increased by $6.74 \%$, the cost of $1 \mathrm{~kg}$ of milk using Saprosorb reduced by 0.16 rubles. When taking into account the consumption of dry matter per 1 head per day in hot conditions, an increase in feed intake was noted with a decrease in water intake (more dry diets of SV 55\% versus SV 50\%), an increase in milk productivity. Comparison of the chemical composition of silage without using and using the West-Sil preservative showed a decrease in the lignin fraction by $17.2 \%$, an increase in easily digestible carbohydrates by $21.6 \%$, and net energy and lactation by $7.2 \%$. The control of the work of the combine cracker and the size of the corn cutting into silage is carried out by means of a special set of sieves according to the well-established methodology. An economic calculation of the efficiency of using soybean and sunflower meal and the recommended use of extruded soybean grain of our own production saves feed costs per $1 \mathrm{~kg}$ of milk 0.94 rubles, due to a decrease in the cost of rations. Monitoring the usefulness of feeding cows and adjusting feeding is carried out taking into account zootechnical and biochemical parameters.

Key words: Highly productive dairy cows, dry matter, mycotoxin adsorbent, soybean extrusion, nutrient loss, structural cell

1.Antipitatel'nye faktory kormov: spravochnaja kniga /[N. I. CHernyshev [i dr.] ;. - Voronezh, OAO Voronezhskaja oblastnaja tipografija. - 2013. - 206 s.

2.Afanas'ev V.A. Prioritetnye metody teplovoj obrabotki zernovyh komponentov v tehnologii kombikormov: monografija N.A. Afanas'ev, A.N. Ostrikov. - Voronezh: 2015. - 336 s.

3.Glicerin dlja korov: [sajt] [jelektronnyj resurs]. - rezhim dostupa:http://msk.agroserver.ru/kormovyedobavki/glitserin-dlya-korov-495092.htm

4.Kolichestvo korma, kotoroe fakticheski poedaet korova : [sajt] [JElektronnyj resurs]. - Rezhim dostupa: https://soft-agro.com/korovy/kolichestvo-korma-kotoroe-fakticheski-poedaet-korova.html

5.Kondrahin I.N. Metody veterinarnoj klinicheskoj laboratornoj diagnostiki/l.N. Kondrahin. - Spravochnik - M.: Kolos. - 2008. -289 s.

6.Kontrol' smeshhenija sychuga u korov [sajt] [JElektronnyj re-surs]. - Rezhim dostupa: http://www.milkua. info/ru/post/kontrol-smesenia-sycuga-u-korov.

7.Kormlenie korov po suhomu veshhestvu: [sajt] [jelektronnyj resurs]. - rezhim dostupa: http://viktoriy.ru/ kormlenie-po-sv

8.Kochish' I.I. Ocenka sorbcionnoj sposobnosti adsorbenta otechestvennogo proizvodstva i ego jeffektivnost' pri vyrashhivanii cypljat-brojlerov /I.N. Kochish', S.N. Kolomiec [sajt] [JElektronnyj resurs]. - Rezhim dostupa: http://cyberleninka.ru/article/n/otsenka-sorbtsionnoy-sposobnosti-adsorbenta-otechestvennogo-proizvodstvai-ego-effektivnosti-pri-vyraschivanii-tsyplyat-broylerov.pdf

9. Molodkin Vadim Potencial preparatov «Best-Sil»: pervoe znakomstvo i pochemu s nimi udobno rabotat'? [sajt] [JElektronnyj resurs]. - Rezhim dostupa:https://agrovesti.net/lib/tech/fodder-production-tech/potentsialpreparatov-best-sil-pervoe-znakomstvo-i-pochemu-s-nimi-udobno-rabotat.html

10.Molochnoe zhivotnovodstvo[sajt] [JElektronnyj resurs]. - Rezhim dostupa: https://ekoniva-apk.ru/ agricultural-production/dairy-farming

11. Oborudovanie dlja proizvodstva kombikorma [sajt] [JElektronnyj resurs]. - Rezhim dostupa: http://www. eks-bio.rul

12.Proizvodstvo polnozhirnoj soi $i$ ee ispol'zovanie $v$ kormlenii zhivotnyh, ryb i ptic [sajt] [JElektronnyj resurs]. - Rezhim dostupa: http://basu-rus.com/ru/info/articles/proizvodstvo-polnozhirnoy-soi.html

13. Sita dlja kormov. Opredeljaem strukturnost' korma [sajt] [JElektronnyj resurs]. - Rezhim dostupa: http:// www.progressivefarm.info/2016/10/26/sita-dlya-kormov-opredelyaem-strukturnost-korma/

14.Syraja polnozhirnaja soja v kormlenii KRS - na chto obrashhat' vnimanie? [sajt] [JElektronnyj resurs]. 
- Rezhim dostupa: soft-agro.com/krs-na-otkorme/syraya-polnozhirnaya-soya-v-kormlenii-krs-na-chtoobrashhat-vnimanie.html

15. Tri sistemy ocenki strukturnosti korma: syraja i strukturnaja kletchatka, pokazatel' struktury korma i NDF, $A D F, A D L$ [sajt] [JElektronnyj resurs]. - Rezhim dostupa: https://soft-agro.com/korovy/tri-

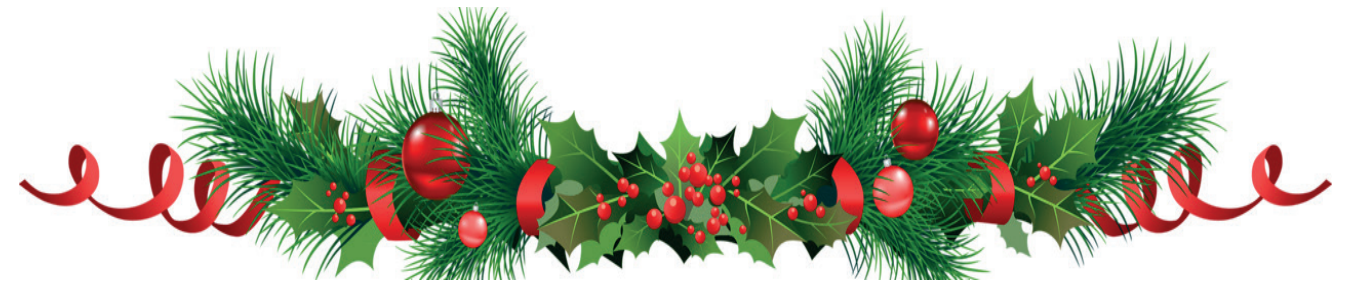

УДК 612.664:637.114+636.2.034

DOI 10.36508/RSATU.2019.88.62.002

\section{СОСТОЯНИЕ И ПРОДУКТИВНОСТЬ КОРОВ В ПЕРВУЮ ТРЕТЬ ЛАКТАЦИИ В СВЯЗИ С ИЗМЕНЕНИЕМ КРАТНОСТИ ДОЕНИЯ В ТРАНЗИТНЫЙ ПЕРИОД}

БЫЧкУНОВА Надежда Геннадьевна, младший научный сотрудник, аспирант отдела генетики, разведения сельскохозяйственных животных и технологий животноводства, bychkunova2016@ yandex.ru

СТРЕКОЗОВ Николай Иванович, д-р с.-х. наук, академик РАН, главный научный сотрудник, руководитель отдела генетики, разведения сельскохозяйственных животных и технологий животноводcmвa,ni.strekozov@mail.ru

СИВКИН Николай Викторович, канд. с.-х. наук, учёный секретарь nsivkin@mail.ru

КОНТЭ Александр Федорович, канд. с.-х. наук, научный сотрудник отдела популяционной генетики и генетических основ разведения животных, alexandrconte@yandex.ru

ФГБНУ «Федеральный научный центр животноводства - ВИЖ имени академика Л.К. Эрнста»

В нормализации продуктивного долголетия важно поддержание энергетического баланса организма коров в период новотельности. Достигается это оптимизацией технологических режимов эксплуатации, в том числе изменением кратности доения, что и являлось целью работы. Исследования проведены на молочном комплексе беспривязного содержания коров на 700 скотомест. Новотельных коров первой группы первые 20 дней после отела доили 2 раза в сутки с интервалом в 12 часов, а затем переводили на трехкратное доение до 90 дня лактации. Во второй группе применялось трехкратное доение с отела до 90 дня лактации. Все коровы с 91 дня лактации и до запуска доились двукратно. Выявлены достоверные различия по количеству дней от отела до окончания отечности вымени и его выраженности в баллах. В группе с двукратным доением коров продолжительность активной мобилизации жировых запасов тела составила 2 мес. со снижением упитанности на 0,47 балла, а у аналогов с трехкратным доением - 3 мес. и 0,51 балла соответственно. Коровы и первотелки второй группы за начальный период лактации превосходили первую по удою на 539,7 к己

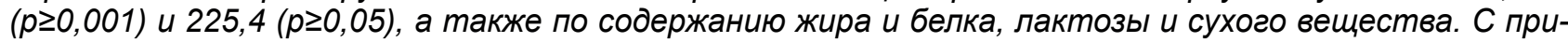
менением технологического приема двукратного доения коров транзитного периода с переходом на трехкратное с 21 дня лактации в первые 100 дней лактации снижается молочная продуктивность, но нормализуется продолжительность и интенсивность использования тканевых резервов тела, а также удлиняется период послеотельной отечности вымени и, как следствие, возрастает количество соматических клеток в молоке.

Ключевые слова: кратность доения, черно-пестрая порода, новотельные коровы, отечность вымени, упитанность, удой.

\section{Введение}

Развитие животноводства имеет прочную связь с продовольственной безопасностью регионов, а также страны в целом. Повышение объемов производства молока, молочных продуктов и его рентабельности обеспечивается интенсификацией отрасли и внедрением технологий, в большей степени учитывающих биологические особенности животных и создающих условия для максимального проявления генетического потенциала продуктивности при продолжительном хозяйственном использовании [1].

Черно-пестрая порода крупного рогатого скота характеризуется самой высокой молочной продуктивностью, наибольшей приспособленностью к промышленной технологии молочных комплексов. Кроме того, животные этой породы обладают широкой нормой реакции, что позволяет разводить их в различных условиях [4].

В мировой практике принято считать, что молочная продуктивность коров зависит на 50-60\% от уровня кормления и качества кормов, на 20$25 \%$ от селекционной работы и воспроизводства, на $20-25 \%$ от условий содержания и технологии доения [3].

Существенное влияние на молочную продуктивность оказывает технология доения, особенно его кратность. Особое значение кратность доения приобретает в высокопродуктивных стадах, где реализуются селекционные программы совершен-

(С) Бычкунова Н. Г., Стрекозов Н. .И., Сивкин Н. В., Контэ А. Ф., 2019 г. 
ствования пород $[8,9]$.

Современная интенсивная технология производства молока предлагает беспривязное содержание коров и двукратное доение в доильном зале. При этом зачастую в цехе раздоя животных используют трехкратное доение. Перевод в цех производства молока может сопровождаться возникновением сильнейшего технологического стресса по причине смены способа содержания и кратности доения. Это, в свою очередь, сопровождается резким снижением продуктивности в переходный период и оставляет свой отпечаток на продуктивности за лактацию [2].

Физиологическое проявление отечности молочной железы является следствием изменения в обмене веществ, что часто наблюдается у стельных коров перед отелом. Проявление отечности может вызывать дискомфорт у животного и создать такие проблемы в управлении, как трудности с надеванием доильного аппарата, повышенным риском травмы сосков и мастита вымени. Тяжелый отек вымени может привести к снижению производства молока [10].

Послеродовой период особенно важен для здоровья животных. В нормальных условиях содержания упитанность динамична, достигая наивысшей оценки перед отелом; наиболее интенсивно она снижается в первую треть лактации, затем запасы жировой, мышечной и костной тканей восполняются. Наиболее это заметно у высокопродуктивных коров в новотельный период.

В первые недели после отела двукратное доение призвано сдерживать раздой, а в последующие три месяца переход на трехкратное доение, наоборот, - стимулировать, позволяя коровам избегать чрезмерного "энергетического голодания», и создавая условия для нормализации воспроизводительной и продуктивной функции.

Цель исследований - определить влияние кратковременного изменения кратности доения в новотельный период на упитанность, функциональное состояние вымени и продуктивность коров черно-пестрой породы.

\section{Материалы и методы исследований}

Исследования проведены на молочном комплексе беспривязного содержания коров на 700 скотомест. За два-три дня до отела коровы 1-й и 2-й групп переводили в родовой сектор, на привязь. Новотельных коров первой группы первые 20 дней после отела доили 2 раза в сутки, с интервалом в 12 часов, а затем переводили на трехкратное доение до 90 дня лактации. Во второй группе применялось трехкратное доение с отела до 90 дня лактации. Все подконтрольные животные с 91 дня лактации и до запуска доились два раза в день. Обе группы получали однотипную полнорационную кормосмесь.

Оценку состояния вымени новотельных коров после отела проводили в соответствии с методикой «Оценки отечности вымени», согласно10балльной системе:

0) видимый отек отсутствует;

1) отечность заметна возле основания выме- ни около одной или двух четвертей;

2) отечность заметна возле основания вымени около трех или четырех четвертей;

3) отечность покрывает нижнюю половину вымени;

4) отечность появляется в средней части вымени в области пупка;

5) большое распространение отека вдоль средней линии вымени и области пупка;

6) отечность полностью покрыла вымя. Центральная линия поддерживающей связки вымени пропала;

7) распространение отечности из средней части вымени в область грудины;

8) распространение отечности из средней части вымени в сторону спины. Подкожная брюшная вена невидна;

9) распространение отечности в область бедер;

10) сильная отечность. Наблюдается на внешних половых органах. Отечность наблюдается также во всех вышеописанных областях [11].

Упитанность исследуемых животных оценивали по 5-балльной шкале ежемесячно согласно методике [5]. Шкала предусматривает 5-балльную оценку с интервалом шага 0,25 , что позволяет более точно оценить упитанность животных по классам. Оценка упитанности осуществлялась путем осмотра животных:

- сбоку: лопатки, области ребер и голодной ямки, остистых и поперечных отростков поясницы и крестца, заполненность тканями между маклаками и седалищными буграми;

- сзади: корень хвоста, область анального отверстия и вульвы, позвоночник, область между маклаками [6].

Потребление животными корма и питательных веществ в новотельный период и раздой изучали по результатам контрольных кормлений за два дня. Для этого в исследуемых группах отбирали по 3 типичных (экстерьер, упитанность и физиологическое состояние) животных. Кормосмесь взвешивали и раздавали утром - в 9.30-10.00 и обеспечивали кормление вволю, по поедаемости. Учитывали при проведении контрольных кормлений частоту сокращений рубца - производили упор кулака в область голодной ямки и количество жевательных движений. Показания температуры тела учитывали электронным термометром - ректально.

Отбор средней пробы кормосмеси осуществляли с кормового стола равномерно по всему фронту кормления, затем помещали в полиэтиленовый пакет согласно ГОСТ 8756.0-70 и ГОСТ 26313-84.

Химический анализ проб кормов, их остатков выполняли в лаборатории химико-аналитических исследований ФГБНУ ФНЦ ВИЖ им. Л.К. Эрнста согласно методическим рекомендациям ВИЖ (общая влага, абсолютно сухое вещество, протеин, жир, клетчатка, зола, кальций, фоссрор) [7].

Первоначальная и гигроскопическая влага определены высушиванием до постоянной массы образцов при температуре $65^{\circ} \mathrm{C}$ и $105^{\circ} \mathrm{C}$ соот- 
ветственно.

В пробах кормосмеси оценивалось содержание: жира (метод Рушковского); азота (метод Къельдаля); клетчатки (метод Геннеберга и Штомана); золы (посредством сжигания в муфельной печи); безазотистых экстрактивных веществ (БЭВ) (расчетный метод); кальция (комплексометрический метод); фоосфора (калориметрическим методом).

Молочную продуктивность коров определяли по результатам ежемесячных контрольных доек по правилам ведения учета в племенном скотоводстве молочного и молочно-мясного направлений продуктивности (Приказ МСХ РФ от 01 февраля 2011 г. № 25).

Результаты исследований и их обсуждение

Подопытные группы животных, сформированные по принципу пар-аналогов, по продуктивности матерей и состоянию тканевых резервов тела существенно не различались. При постановке на привязь, сектор проведения отелов и послеотельного содержания, упитанность исследуемых животных была на уровне 3,10-3,08 балла. Выражен- ность отечности вымени во 2-й группе была выше на 0,41 балла, что, вероятно, связано с интенсивностью отложения подкожного жира и водно-солевым балансом организма.

В новотельный период, на фоне роста удоев молока, недостаток потребления питательных веществ восполняется за счет тканевых резервов тела. Энергетические запасы используются коровой тогда, когда ее организм неспособен потребить столько питательных веществ кормосмеси, сколько ей необходимо для удовлетворения ее потребности в энергии. Этот период приходится на начальную стадию лактации. Именно в этот период продуктивность может достигать своего пика. Поэтому в этот период необходимо более тщательно проводить мониторинг изменений упитанности животных. В первой группе, с двукратным доением коров, продолжительность активной мобилизации жировых запасов тела составила 2 мес. со снижением упитанности на 0,48 балла, а у аналогов с трехкратным доением - 3 мес. и 0,52 балла соответственно (рис.).

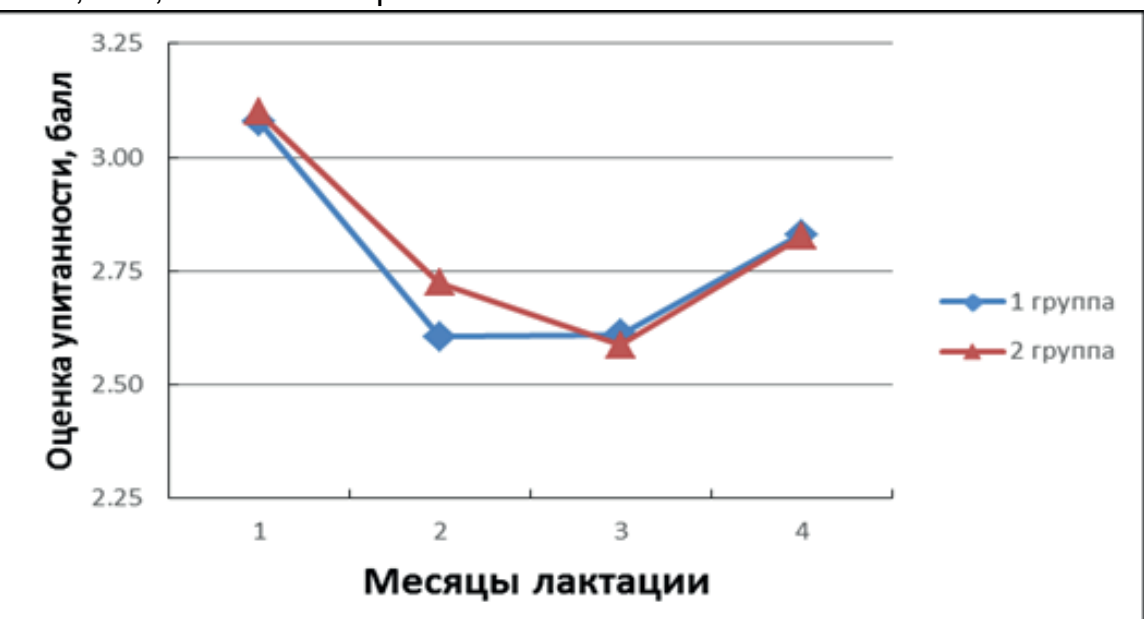

Рис. - Изменение упитанности коров в новотельный период

Увеличение оценочных показателей упитанности свидетельствует о положительной динамике энергетического баланса организма животных; такие изменения в опытных группах отмечены с 3-4-го месяца лактации.

Кормление коров является важным звеном в технологической цепи молочных ферм и комплексов. Рациональная организация условий кормления и содержания способствует своевременному запуску, нормальному течению стельности, получению здоровых телят и достижению высокой молочной продуктивности, а также оптимизации затрат труда на единицу получаемой продукции. На комплексе применяется круглогодовое однотипное кормление коров полнорационной кормосмесью, раздаваемой на кормовой стол. Утром остатки корма удаляются, кормление начинают с 8 часов 30 минут, а во второй половине дня поверх кормосмеси раскладывают сено.

В новотельный период между 1-й и 2-й группой животных различий в задаваемой кормосмеси по составу и питательности не наблюдалось. Животные получали однотипную полнорационную кор- мосмесь. Кормосмесь состояла из комбикорма, сена злаково-бобового, силоса кукурузного, сенажа многолетних трав, патоки, поваренной соли и мела.

Контрольные кормления показали, что коровы 2-й группы за первые 100 дней лактации корма поедали активнее: преимущество по потреблению сырого протеина 8,5 и сырой клетчатки - 15,7 кг и сырого жира - 3,5 кг (табл. 1).

Таблица 1 - Потребление питательных веществ кормосмеси животными

\begin{tabular}{|c|c|c|}
\hline \multirow[t]{2}{*}{ Показатели } & \multicolumn{2}{|c|}{$\begin{array}{l}\text { Новотельные коровы, } \\
20 \text { дней после отела }\end{array}$} \\
\hline & 1-я группа & 2-я группа \\
\hline Потребили, кг & 3102.0 & 3379.0 \\
\hline Сырой протеин, кг & 94.9 & 103.4 \\
\hline Сырая клетчатка, кг & 175.3 & 191.0 \\
\hline Сырой жир, кг & 39.1 & 42.6 \\
\hline Кальций, кг & 2.05 & 2.25 \\
\hline Фосфор, кг & 1.17 & 1.27 \\
\hline
\end{tabular}


Для животных во 2-й группе характерен менее продолжительный период жвачки (на 9,9\%) и повышенная сократительная функция рубца, как следствие менее выраженного «кормового стресса» при переводе на рационы для новотельных животных (табл. 2).

Таблица 2 - Пищевые реакции исследуемых животных

\begin{tabular}{|l|c|c|}
\hline \multirow{2}{*}{\multicolumn{1}{|c|}{ Показатели }} & \multicolumn{2}{|c|}{ Новотельные коровы, } \\
\cline { 2 - 3 } & 20 дней после отела \\
\hline Сокращения рубца, раз & 3.9 & 4.4 \\
\hline $\begin{array}{l}\text { Продолжительность } \\
\text { жвачки, мин. }\end{array}$ & 47.2 & 42.5 \\
\hline ЧСС & 53.1 & 56.0 \\
\hline
\end{tabular}

Физиологическое проявление отечности вымени является следствием нарушения обмена веществ, что зачастую может наблюдаться у молочных коров в период глубокой стельности.
Большая разветвленная сеть сосудов и капилляров в молочной железе коров делает ткань более восприимчивой к развитию локализованного отека в связи с увеличением тока крови и лимфы. Помимо этого, молочная железа подвергается экстенсивному росту и физиологическим изменениям в конце стельности, что, вероятно, также способствует развитию отека.

Выявлены достоверные различия между исследуемыми группами по количеству дней от отела до исчезновения признаков отечности вымени при трехкратном доении. Вероятно, за счет более частого опорожнения молочных желез, массажа вымени, способствующего оттоку лимфы после отела, отечность спадала быстрее у коров и первотелок 2-й группы на 0,73-0,77 дня ( $p \geq 0,05)$, на 0,41-0,42 балла.

Отток лимфы, и в целом приход вымени к естественному состоянию является свидетельством положительного влияния трехкратного опорожнения молочных желез и эффректа массажа на интенсивность кровоснабжения (табл. 3).

Таблица 3 - Функциональное состояние вымени коров

\begin{tabular}{|l|c|c|c|c|}
\hline \multirow{2}{*}{ Показатели } & \multicolumn{2}{c|}{1 группа } & \multicolumn{2}{c|}{2 группа } \\
\cline { 2 - 5 } & Коровы & Первотелки & Коровы & Первотелки \\
\hline Период после отельной отечности вымени, дни & $2,25 \pm 0,24$ & $2,15 \pm 0,29$ & $2,67 \pm 0,18$ & $2,56 \pm 0,13$ \\
\hline Оценка отечности вымени, балл & $4,67 \pm 0,19^{*}$ & $4,43 \pm 0,23^{*}$ & $3,90 \pm 0,23$ & $3,70 \pm 0,26$ \\
\hline
\end{tabular}

* $-p \geq 0,05$

Одним из наиболее важных периодов лактации являются первые 100 дней лактации. Именно в этот период молочная продуктивность и качественные показатели состава молока во многом зависят от технологии содержания и доения, здоровья животных и уровня кормления. Стабильный режим трехкратного доения в период новотельности и раздоя, ожидаемо, обеспечил более вы- сокую молочную продуктивность, а с ней и вынос питательных веществ организма; от коров и первотелок, соответственно, надоено больше молочного жира на 17,6 и 18,4 кг ( $\geq 20,05)$, молочного белка на 14,6 и 19,6 кг ( $p \geq 0,001)$, лактозы на 15,3 кг ( $p \geq 0,001)$ и 29,9 кг ( $p \geq 0,05)$, сухого вещества молока на 43 кг ( $p \geq 0,001)$ и 80,2 кг ( $p \geq 0,05)$ (табл. 4)

Таблица 4 - Молочная продуктивность коров в первые 100 дней лактации

\begin{tabular}{|l|c|c|c|c|}
\hline \multirow{2}{*}{ Показатели } & \multicolumn{2}{c|}{1 группа } & \multicolumn{2}{c|}{2 группа } \\
\cline { 2 - 5 } & Коровы & Первотелки & Коровы & Первотелки \\
\hline Удой, кг & $2535,4 \pm 83,3^{* * *}$ & $2707,2 \pm 70,8^{*}$ & $3075,1 \pm 84,5$ & $2932,6 \pm 87,7$ \\
\hline Массовая доля жира, \% & $3,88 \pm 0,20$ & $3,39 \pm 0,21$ & $3,76 \pm 0,11$ & $3,78 \pm 0,13$ \\
\hline Молочный жир, кг & $98,7 \pm 6,4^{*}$ & $92,5 \pm 7,4^{*}$ & $116,3 \pm 5,9$ & $110,9 \pm 5,2$ \\
\hline Массовая доля белка, \% & $3,39 \pm 0,08$ & $3,11 \pm 0,06^{* *}$ & $3,43 \pm 0,06$ & $3,35 \pm 0,05$ \\
\hline Молочный белок, кг & $85,8 \pm 3,3^{* * *}$ & $83,8 \pm 1,4^{* * *}$ & $105,4 \pm 3,5$ & $98,4 \pm 3,5$ \\
\hline Массовая доля лактозы, \% & $4,95 \pm 0,05$ & $4,88 \pm 0,10$ & $5,05 \pm 0,05$ & $5,01 \pm 0,05$ \\
\hline Лактоза, кг & $125,6 \pm 4,4^{* * *}$ & $132,2 \pm 4,7^{*}$ & $155,5 \pm 4,8$ & $147,5 \pm 4,9$ \\
\hline Содержание сухого в-ва, \% & $13,1 \pm 0,19$ & $12,5 \pm 0,21^{*}$ & $13,4 \pm 0,20$ & $13,0 \pm 0,16$ \\
\hline Сухое вещество, кг & $333,4 \pm 12,7^{* * *}$ & $339,6 \pm 11,4^{*}$ & $413,6 \pm 15,2$ & $382,6 \pm 12,9$ \\
\hline Кол-во сом. клеток, тыс/см ${ }^{3}$ & $402,8 \pm 51,8$ & $265,0 \pm 50,4$ & $350,4 \pm 51,5$ & $224,9 \pm 40,6$ \\
\hline
\end{tabular}

$$
{ }^{*}-p \geq 0,05 ;{ }^{* *}-p \geq 0,01 ;{ }^{* * *}-p \geq 0,001
$$

\section{Заключение}

Таким образом, с применением технологического приема двукратного доения коров транзит- ного периода с переходом на трехкратное с 21 дня лактации в первые 100 дней лактации снижается молочная продуктивность, но нормализуется про- 
должительность и интенсивность использования тканевых резервов тела, а также удлиняется период послеотельной отечности вымени и, как следствие, возрастает количество соматических клеток в молоке.

Исследования проведены при поддержке Министерства науки и высшего образования РФ, тема ГЗ АААА-A18-118021590129-9 и AAAA-A18-118021590134-3.

\section{Список литературы}

1. Амерханов, Х. Научное обеспечение конкурентности молочного скотоводства / Х. Амерханов, Н. Стрекозов // Молочное и мясное скотоводство. - 2012. - Спецвып. - С. 2-6.

2. Китаев, Е. А. Молочная продуктивность коров в зависимости от способа содержания и кратности доения / Е. А. Китаев, С. В. Карамаев, А. С. Карамаева // Известия НВ АУК. - №1. - 2011. - С. 2-4.

3. Коробко, А. В. Влияние различных фракторов на молочную продуктивность коров белорусской черно-пестрой породы в КСУП «Оборона страны» / А. В. Коробко, Е. П. Драгун, И. А. Дешко // Актуальные проблемы интенсивного развития животноводства. - 2015. - № 18 (2). - С. 158-166.

4. Пустотина, Г. Ф. Хозяйственно-биологические особенности скота черно-пестрой породы в экологических условиях Южного Урала / Г. Ф. Пустотина, Л. Г. Сурундаева // Известия Оренбург- ского государственного аграрного университета. 2004. - № 2 (2-1) . - С. 109-111.

5. Методика оценки упитанности коров молочно-мясных пород / Н.В. Сивкин [и др.]. - Дубровицы, 2006. - 16 с.

6. Молочное скотоводство России / Н. И. Стрекозов, Х. А. Амерханов, Н. Г. Первов. - Москва, 2006. - 191 с.

7. Раецкая, Ю. И. Методы зоотехнических и биохимических анализов кормов, продуктов обмена и животноводческой продукции / Ю. И. Раецкая, В. Н. Сухарева, В. Т. Самохин. - Дубровицы : ВИЖ. $-1970 .-123 \mathrm{c}$.

8. Соловьева, О. И. Ранговая корреляция молочной продуктивности коров при переводе с трехкратного на двукратное доение / О. И. Соловьева // Достижения науки и техники АПК. - 2008. - №11. - С. 51-52.

9. Туников, Г. М. Разведение животных с основами частной зоотехнии / Г. М. Туников, А. А. Коровушкин. - СПб. : Лань, 2016. - 744 с.

10. Dentine, M.R., McDaniel, B.T. Variation of edema scores from herd-year, age, calving month, and sire / M.R. Dentine, B.T. McDaniel // J. Dairy Sci. 1983; 66: 2391-2399.

11. Tucker, W.B. Evaluation of a system for rating edema in dairy cattle / W.B. Tucker, G.D. Adams, M. Lema, M. Aslam, I.S. Shin, P. Le Ruyet, L. Weeks // J. Dairy Sci., 1992; 75; 2382-2387.

\section{THE CONDITION AND PRODUCTIVITY OF COWS IN THE FIRST THIRD IN CONNECTION WITH A SHORT-TERM CHANGE OF MILKING FREQUENCY IN TRANSIT PERIOD}

Bychkunova Nadezhda G., junior scientific researcher, postgraduate student of Genetic, Breeding of Farm Animals and Livestock Technologies, L.K. Ernst Federal Science Center for Animal Husbandry, bychkunova2016@yandex.ru

Strekozov Nikolay l., doctor of agricultural sciences, Academician of RAN, chief scientific researcher of Genetic, Breeding of Farm Animals and Livestock Technologies, L.K. Ernst Federal Science Center for Animal Husbandry, ni.strekozov@mail.ru

Sivkin Nikolay V., Candidate of agricultural sciences, scientific secretary, L.K. Ernst Federal Science Center for Animal Husbandry, nsivkin@mail.ru

Conte Alexander F., Candidate of agricultural sciences, scientific researcher of Population Genetics and Genetic Bases of Animal Breeding Department, L.K. Ernst Federal Science Center for Animal Husbandry alexandrconte@yandex.ru

In the normalization of productive longevity of cows, it is important to maintain the energy balance of the body during the postpartum period. This achieved by optimizing the technological modes of operation, including changing the frequency of milking, which was the purpose of the work. On a dairy farm of loose cows on 700 places carried out researches. The fresh cows of the first group milked for the first 20 days after calving twice a day, at an interval of 12 hours, and then transferred to 3-times daily milking, to 90 days of lactation. In the second group, 3-times daily milking used from calving to 90 days of lactation, the interval between milking was 6 hours. All cows were milking twice from 91 days of lactation until the start. There were significant differences in the number of days from calving to the end of the udder edema and its severity in points. In the group with 2-times daily milking of cows, the duration of active mobilization of body fat reserves was 2 months with a decrease in fatness by 0.48 points, and for analogues with 3-times daily milking - 3 months and 0.52 points, respectively. The cows and 1st calving cows of the second group for the first lactation period exceed the first group of milk yield by $539.7 \mathrm{~kg}(p>0.001)$ and 225,4 ( $p>0,05)$, as well as by the content of fat and protein, lactose and dry matter. Thus, with the use of technological reception of 2-times daily milking cows transit period with the transition to 3-times daily milking from 21 days of lactation, the milk production decreases, but the duration and intensity of use of tissue reserves of the body is normalized and the period of udder edema is prolonged in postpartum, and as a result the number of somatic cells in milk.

Key words: milking frequency, black-and-white breed, fresh cows, udder edema, fatness, milk yield. 


\section{Literatura}

1. Amerhanov, H., Strekozov, N. Nauchnoe obespechenie konkurentnosti molochnogo skotovodstva / H. Amerhanov, N. Strekozov // Molochnoe i myasnoe skotovodstvoю - 2012. - Specvyp. - S.2-6.

2. Kitaev E. A. Molochnaya produktivnost' korov v zavisimosti ot sposoba soderzhaniya i kratnosti doeniya / E. A. Kitaev, S. V. Karamaev, A. S. Karamaeva // Izvestiya NV AUK. - №1. - 2011. - S. 2-4.

3. Korobko, A. V. Vliyanie razlichnyh faktorov na molochnuyu produktivnost' korov belorusskoj chernopestroj porody v KSUP "Oborona strany» / A.V. Korobko, E.P. Dragun, I.A. Deshko // Aktu-al'nye problemy intensivnogo razvitiya zhivotnovodstva. - №18 (2). - 2015. - S.158-166.

4. Pustotina, G.F. Hozyajstvenno-biologicheskie osobennosti skota cherno-pestroj porody v ekologicheskih usloviyah Yuzhnogo Urala / G.F. Pustotina, L.G. Surundaeva // Iz-vestiya Orenburgskogo gosudarstvennogo agrarnogo universiteta. - 2 (2-1). - 2004. - S.109-111.

5. Metodika ocenki upitannosti korov molochno-myasnyh porod / N.V. Sivkin [i dr.]. - Dubrovicy, 2006. - 16 s.

6. Molochnoe skotovodstvo Rossii / N.I. Strekozov, H.A. Amerhanov, N.G. Pervov-Moskva, 2006. - S. 191.

7. Raeckaya, YU.I. Metody zootekhnicheskih i biohimicheskih analizov kormov, produktov obmena $i$ zhivotnovodcheskoj produkcii / YU.I. Raeckaya, V.N. Suhareva, V.T. Samohin - Dubrovicy: VIZH. - 1970. $123 s$.

8. Solov'eva, O.I. Rangovaya korrelyaciya molochnoj produktivnosti korov pri perevode s trekh-kratnogo na dvukratnoe doenie / O.I. Solov'eva // Dostizheniya nauki i tekhniki APK. - №11. - 2008. - S.51-52.

9. Tunikov G.M. Razvedenie zhivotnyh s osnovami chastnoj zootekhnii / G.M. Tunikov, A.A. Korovushkin. - S.-Pb.: Lan', 2016. - 744 s.

10. Dentine, M.R., McDaniel, B.T. Variation of edema scores from herd-year, age, calving month, and sire / M.R. Dentine, B.T. McDaniel // J. Dairy Sci. 1983; 66: 2391-2399.

11. Tucker, W.B. Evaluation of a system for rating edema in dairy cattle / W.B. Tucker, G.D. Adams, M. Lema, M. Aslam, I.S. Shin, P. Le Ruyet, L. Weeks // J. Dairy Sci., 1992; 75; 2382-2387.

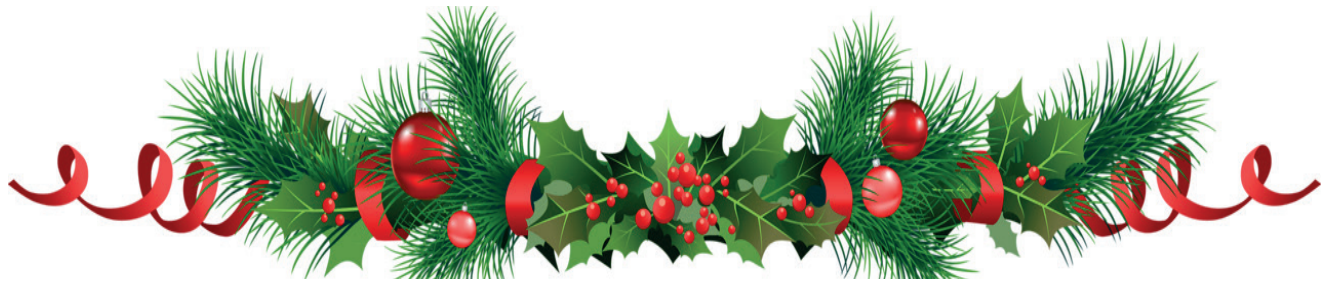

УДк 636.7

DOI 10.36508/RSATU.2019.37.75.003

\section{РАСПРОСТРАНЕНИЕ НЕЗАРАЗНОЙ ПАТОЛОГИИ СРЕДИ БЕЗНАДЗОРНЫХ СОБАК В УСЛОВИЯХ ГОРОДА РЯЗАНИ}

ГЕРЦЕВА Ксения Аркадьевна, канд. биол. наук, доцент каф. ветеринарно-санитарной экспертизы, хирургии, акушерства и внутренних болезней животных (ВБЖ), okavet@ya.ru

КИСЕЛЕВА Елена Владимировна, канд. биол. наук, доцент каф. ветеринарно-санитарной экспертизы, хирургии, акушерства и ВБЖ, super.juliakiseleva2013@уandex.ru

ДУБОВ Дмитрий Владимирович, канд. биол. наук, доцент кафр. ветеринарно-санитарной экспертизы, хирургии, акушерства и ВБЖ, dmitriy.dubov2018@уandex.ru

РУДНАЯ Антонина Владимировна, преподаватель фракультета довузовской подготовки и среднего профессионального образования, rudnaya.antonina@yandex.ru

Рязанский государственный агротехнологический университет им. П. А. Костычева

ГОРШКОВА Юлия Романовна, сотрудник (волонтер) МБУ «Городская служба по контролю за безнадзорными животными», г. Рязань, uliagorskova7@gmail.ru

Целью исследований стало изучение результатов диспансеризации поголовья собак и установление степени распространения незаразной патологии у безнадзорных собак в условиях приютов 2. Рязани. Объектами исследования являлись собаки, принадлежащие приютам МУП «Городская служба по контролю за безнадзорными животными». Проблема безнадзорных собак является сложной и многогранной, требующей глубокого комплексного подхода. В ней можно выделить множество составляющих. Это и санитарно-эпидемиологическая опасность популяции безнадзорных животных в городской среде, и опасность агрессивных собачьих стай, и вопрос перепроизводства домашних питомцев (безответственные владельцы выбрасывают ненужных им щенков, тем самым пополняя ряды бродячих животных), и т.п. В настоящее время на территории города Рязани осуществляет свою деятельность муниципальное бюджетное учреждение «Городская служба по контролю за безнадзорными животными». Одной из задач этой службы, а также частных современных приютов для безнадзорных животных, является оказание своевременной ветеринарной помощи с последующей адаптацией, поиск и определение собак на постоянное место жительства в ответственные семьи. Собаки, помимо обязательного проведения лечебно-профрилактических мероприятий в отно-

(С Герцева К. А., Кисилева Е. В., Дубов Д. В., Рудная А. В., Горшкова Ю. Р., 2019г. 
шении заразных инфекционных и паразитарных болезней, нуждаются также и в терапии незаразных патологий. Поэтому оценка распространения незаразной патологии является актуальной задачей для понимания объема необходимой терапии и профилактики обнаруженных болезней у безнадзорных собак, т.к. здоровая собака будет иметь больше шансов на приобретение нового хозяина. Авторами проведена диспансеризация поголовья безнадзорных собак в условиях приютов. Изучена ветеринарная и зоотехническая документация, дан анализ условиям содержания и кормления животных, выявлены основные фракторы риска развития незаразной патологии у безнадзорных собак. Выяснили, что численность клинически здоровых животных в условиях приюта МУП «Городская служба по контролю за безнадзорными животными» составила 84,9\% от общего поголовья. Показатели зоогигиенических параметров в приютах соответствовали установленным инструкцией нормам. $K$ основным факторами риска развития незаразной патологии у безнадзорных собак следует отнести несбалансированное кормление, наличие ранговой иерархии в вольерах. Установили, что наиболее частой незаразной патологией безнадзорных собак являются болезни пищеварительной системы, которая составляет 47,8\%. Своевременное обнаружение и лечение незаразной патологии у безнадзорных собак в быстрые сроки позволит им стать клинически здоровыми, что значительно повышает шансы на приобретение нового хозяина.

Ключевые слова: безнадзорная собака, приют, незаразная патология, диспансеризация.

\section{Введение}

Собака как домашнее животное давно является спутником человека и участником его жизни. За длительный период совместного существования (30-40 тыс. лет) сфрера использования собак все более расширялась - это охота, пастьба скота, специальные службы в армии, связь, транспорт, розыск, помощь в повседневной жизни, сценическое искусство. Собака давно стала для многих членом семьи, доставляя владельцам радость и сглаживая разные проявления душевного дискомфорта [3]. Однако, по данным статистики, число бродячих животных в нашей стране неуклонно растет [9]. Такая неутешительная статистика, по мнению Сорокиной А. И., объясняется как нехваткой приютов для бездомных животных, так и безответственностью и жестокостью заводчиков [10]. Напомним, что на территории Рязанской области действует постановление главы администрации от 19 сентября 1994 года N 531 «Об упорядочении содержания собак и кошек в городах и других населенных пунктах области» [7]. Согласно проведенным Рыбалко В.Н. исследованиям, о собаках, обитающих на улицах городов, известно еще с XVIII века, и для их обозначения существует общепринятый термин «собаки-парии», применяемый в Азии [9]. Антонович А. А. в своих исследованиях отмечает, что в Российском научном сообществе нет единой терминологии для собак, свободно живущих в городе, отдельно от человека [1]. В различной литературе они могут обозначаться по-разному: бездомные, вольные, безнадзорные, бродячие, одичавшие и т.д. В независимости от названия этих собак и понимания бездомной или синантропной собаки, проблема безнадзорных собак является сложной и многогранной, требующей глубокого комплексного подхода. В ней можно выделить множество составляющих. Это и санитарно-эпидемиологическая опасность популяции безнадзорных животных в городской среде, и опасность агрессивных собачьих стай, и вопрос перепроизводства домашних питомцев (безответственные владельцы выбрасывают ненужных им щенков, тем самым пополняя ряды бродячих животных), и т.п. В настоящее время на территории города Рязани осуществляет свою деятельность муниципальное бюджетное учреждение «Городская служба по контролю за безнадзорными животными». Одной из задач этой службы, а также частных современных приютов для безнадзорных животных, является оказание своевременной ветеринарной помощи с последующей адаптацией, поиск и определение собак на постоянное место жительства в ответственные семьи. Собаки, помимо обязательного проведения лечебно-профилактических мероприятий в отношении заразных инфекционных и паразитарных болезней, нуждаются также и в терапии незаразных патологий. Поэтому оценка распространения незаразной патологии является актуальной задачей для понимания объема необходимой терапии и профилактики обнаруженных болезней у безнадзорных собак, т.к. здоровая собака будет иметь больше шансов на приобретение нового хозяина.

Цель работы: провести диспансеризацию поголовья собак и установить степень распространения незаразной патологии у безнадзорных собак в условиях приютов г. Рязани.

\section{Материалы и методы исследований}

Научно-исследовательская работа проводилась в период с января по декабрь 2018 года на базе двух приютов города Рязани, принадлежащих МУП «Городская служба по контролю за безнадзорными животными», а также на кафедре ветеринарно-санитарной экспертизы, хирургии, акушерства и внутренних болезней животных РГАТУ. В ходе проведения диспансеризации были изучены журналы регистрации животных, журнал вакцинации и обработок животных, журналы учета проведения дезинфекции и дератизации, компьютерная база регистрации животных. Была произведена оценка зоогигиенических параметров и кормления животных по общепринятым методикам. Также был проведен клинический осмотр у $100 \%$ собак с обязательной термометрией. Всего были проведены исследования 571 собаки. Субклинические проявления незаразных болезней в данной работе мы не рассматривали.

\section{Результаты исследований}

Проведенными исследованиями мы установили, что численность взрослых собак в условиях питомников на 01.01.2019 года составила 571 
собак, из них самок - 410 голов $(71,8 \%)$, самцов - 161 голов (28,2\%) (рис. 1). Мы предполагаем, что высокая численность сук среди безнадзорных собак указывает на потенциал восстановления популяции в природе. Кроме этого, высокая численность самок указывает на востребованность процедуры стерилизации как одного из способов коррекции численности безнадзорных собак. Мы провели годовой анализ поступивших животных и выяснили, что в 2018 году поступили 184 собаки, из них 158 (85,9\%) доставлены в приюты методом отлова, 26 (14,3\%) собак в приюты сдали владельцы животных (отказники). За 2018 год обрели дом 149 собак, из них 80 щенков и 58 половозрелых собак. Стоит отметить, что 11 бездомных собак после вакцинации, плановой стерилизации или кастрации, клипсования были выпущены обратно на улицы. Выпуск «обработанных» собак производится в тех случаях, когда собаки не обладают социализацией и не представляют угрозу для человека. Хотя, по мнению многих специалистов, этот гуманный шаг не может быть оправдан с точки зрения санитарно-эпидемиологического благополучия местности [5]. Исследования показали, что за 2018 год в условиях исследуемых приютов умерло 29 собак, в том числе из-за ранговых драк в условиях вольеров - 18 голов, по причине болезней - 8 голов, путем эутаназии - 3 головы. Вынужденная эутаназия собак в условиях приютов производится ветеринарным специалистом в случае тяжелой травмы или болезни, серьезного психического расстройства (невроза). Наиболее часто из половозрелых собак встречались особи 3-4-хлетнего возраста. Процент породистых собак составил $2,9 \%$. Согласно изученной документации мы выяснили, что в условиях приютов все поголовье собак регулярно 1 раз в квартал обрабатывается от экто- и эндопаразитов, план вакцинации собак осуществляется полностью (бешенство, чума плотоядных, гепатит, парвовирусный энтерит, парагрипп, лептоспироз).

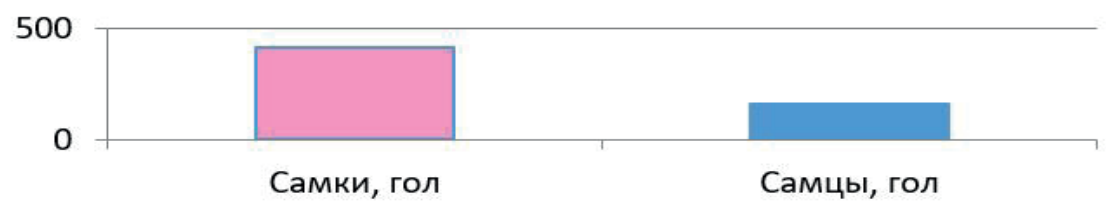

Рис. 1 - Половая структура безнадзорных собак в условиях МБУ «Городская служба по контролю за безнадзорными животными»

В питомниках строго соблюдается карантин вновь прибывших животных в течение 30 дней. Территория питомника два раза в год обрабатывается от грызунов и эктопаразитов. Анализ условий содержания безнадзорных собак показал, что животные содержатся групповым беспривязным способом. Собаки находятся в кирпичных и деревянных помещениях, разделенных на кабины и пристроенные к ним вольеры. Размер вольеров соответствует $3 \times 2 \times 2,2$ м. Полы, где содержатся больные и ослабленные животные - деревянные, в остальных помещениях - бетонные. Имеется выгульная площадка с газоном. Освещение в течение дня в помещениях достаточное (50-70 люкс). Загазованность и сквозняки отсутствуют, проветривание регулярное. В целом показатели температуры, влажности, загазованности, освещенности в вольерах соответствовали нормам технологического проектирования ветеринарных объектов для городов и иных населенных пунктов [6].

Посадка собак в вольеры изначально осуществляется согласно ранговой иерархии, но в процессе жизнедеятельности собак появляются новые лидеры, которые способствуют развитию травматизма. Поэтому ранговую иерархию можно отнести к фракторам риска развития незаразной патологии. Стоит отметить, что все суки и кобели, поступившие в приют, в течение последующих 1-2 недель проходят процедуру хирургической стерилизации или кастрации, а также клипсования. Каждая собака по номеру на клипсе регистрируется в цифровой базе данных компьютерной системы для последующего отслеживания. Послеоперационная передержка собак производится в отапливаемом боксе (изоляторе) до выздоровления в течение 2-3 недель.

Гигиенические обработки собак, такие как стрижка шерсти (по необходимости), подрезка когтей, чистка зубов и ушей проводятся регулярно каждые 2 месяца. Анализируя рацион животных, мы выяснили, что кормление собак двукратное: утром в 9.00 ч, вечером в 16.00 ч. Тип кормления натуральный с расчетом на 1 кг веса взрослой собаки 50 ккал. Объем корма рассчитывается из расчета 2-3\% от веса собаки с учетом индивидуальных особенностей. Так, на собаку массой 20 кг необходимо 400-600 г корма. Применяется стандартная комбинация компонентов: мясопродукты (куриный фрарш, требуха, ливер, кости) - 45\%, крупы (перловка, гречка, рис, макароны, хлеб) $40 \%$, овощи (морковь) - 15\%. Дополнительно в виде подкормок добавляется подсолнечное масло и пищевая сера. Поение осуществляется вволю с помощью поилок в виде ведра. Вода в течение дня меняется двукратно. Для взрослого поголовья собак в рационе используют пищевые отходы из столовых. Таким образом, несбалансированное кормление собак является фрактором риска развития незаразной патологии.

Транспортировка собак с мест отлова до приютов осуществляется автомобильным грузовым транспортом с предварительно проведенной седацией животного медитином 0,1\% в дозе 30-50 мкг/кг. Транспортировка и отлов собак строго регламентируется инструкцией по отлову, транспортировке, временному содержанию, подбору трупов безнадзорных животных на территории города Рязани [4]. Клинические исследования поголовья 
показали, что численность здоровых животных составила 84,9\%. У остальных животных наблюдалась как заразная, так и незаразная патология. Количество животных с незаразной патологией составило 12,1\% (69 голов). При более детальном изучении мы выяснили, что патология пищевари-

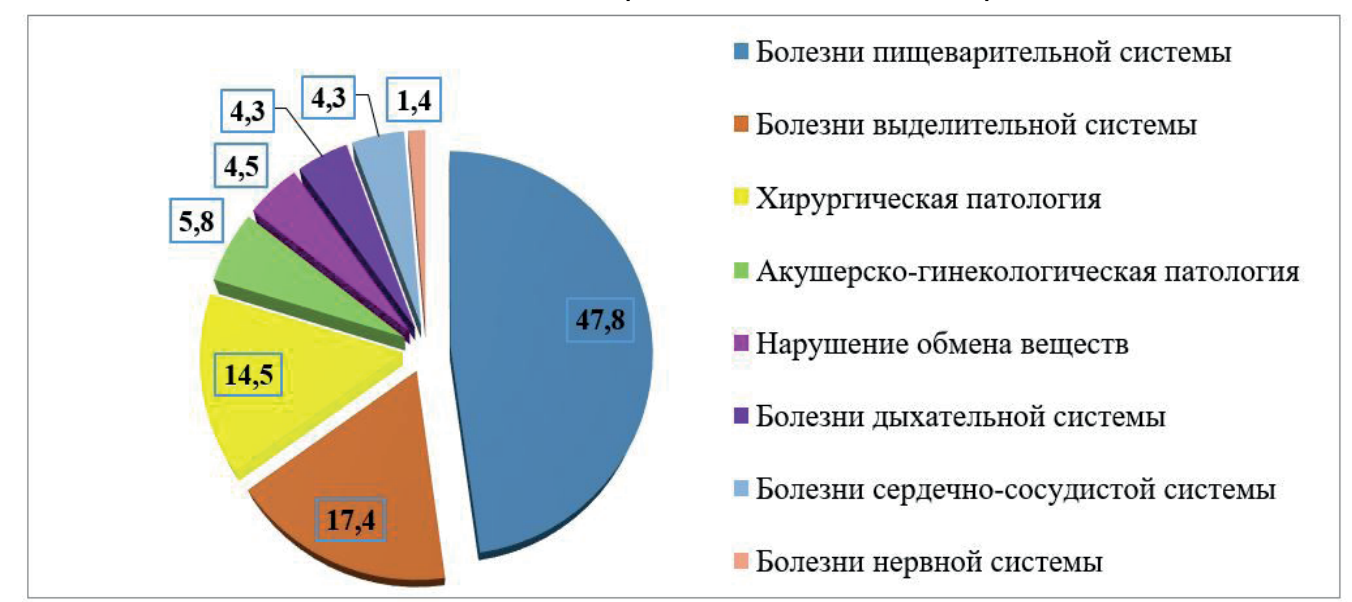

Рис. 2 - Нозологический профиль незаразной патологии у собак в условиях МБУ «Городская служба по контролю за безнадзорными животными».

Стоит отметить, что мы не рассматривали такие болезни как неврозы и стресс, так как вновь поступающие животные находились в фазе тревоги и адаптации. Необходимо отметить, что среди заболеваний пищеварительной системы наиболее часто встречался хронический гастроэнтерит у щенков. Самовыздоровления на воле щенков, больных гастроэнтеритом, не происходило из-за стихийного кормления собак падалью, отходами пищевого производства. В условиях приюта хронический гастроэнтерит чаще имел парвовирусное происхождение, борьба с ним затруднялась из-за высокой скученности животных, недостаточного места для карантина больных щенков, алиментарного истощения поступающих щенков (рис. 3).

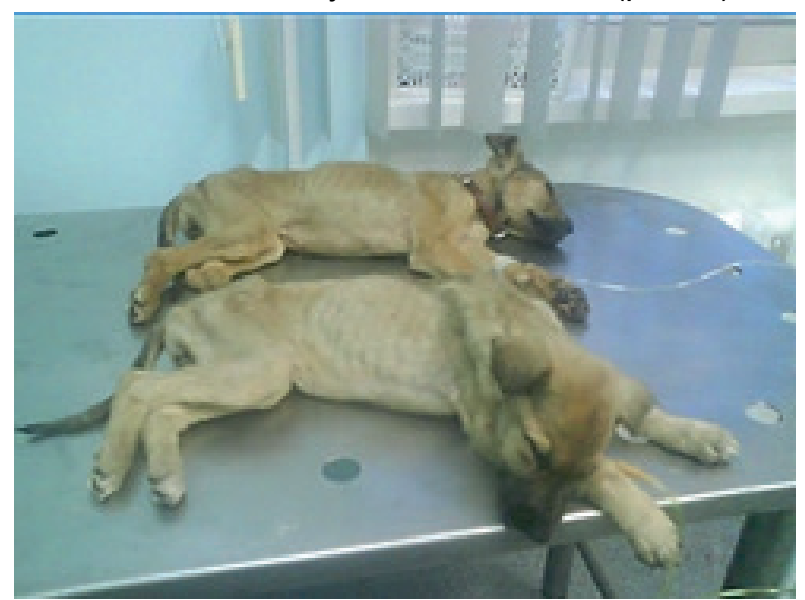

Рис. 3 - Щенки безнадзорных собак, больные острым парвовирусным энтеритом

Среди болезней пищеварительной системы у взрослого поголовья за 2018 год отмечены случаи гастрита, панкреатита, инородных предметов в желудочно-кишечном тракте. Болезни выделительной системы занимают второе место в нозологи- тельной системы составляла 47,8\%, выделительной системы - 17,4\%, хирургическая патология - 14,5\%, акушерско-гинекологическая патология - 5,8\%, болезней обмена веществ - 4,5\%, дыхательной системы - 4,3\%, сердечно-сосудистой системы - 4,3\%,нервной системы - 1,4\% (рис. 2).

— Болезни пищеварительной системы
— Болезни выделительной системы
" Хирургическая патология
" Акушерско-гинекологическая патология
— Нарушение обмена веществ
— Болезни дыхательной системы
- Болезни сердечно-сосудистой системы
= Болезни нервной системы

ческом профиле и составляют 17,4\%. Так, среди самок достаточно часто встречаются ювенальные циститы, у взрослого поголовья мочекаменная болезнь, а также парез мочевого пузыря. Эти заболевания в большинстве случаев имеют хроническое течение и чаще встречаются у собак «отказников». Мы предполагаем, что такое распространение болезней мочевыделительной системы связано с ослабленным иммунитетом на фоне сильного стресса из-за потери места жительства. На третьем месте по распространенности занимают хирургические болезни. Среди взрослого поголовья безнадзорных собак лидирующими незаразными болезнями были хирургические патологии, которые встречались в 14,5\% случаев. Среди хирургической патологии наиболее часто регистрировались переломы, вывихи, ушибы, раны и др. (рис.4).

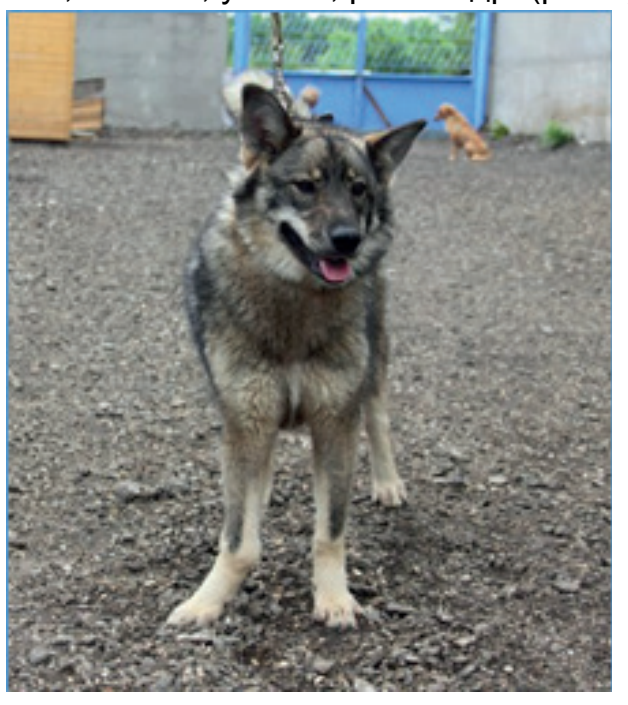

Рис. 4 - Сука «Лайма», возраст 3 года, неправильно сросшийся перелом передней конечности 
Большинство хирургических болезней собаки приобретают вследствие ранговых драк в бродячей стае, автоаварий, негуманного отношения человека к бездомным собакам. Также часто встречались собаки с последствиями насильственного жестокого обращения, такими как избиение, утопление, падение, ножевые ранения, огнестрельные ранения и др. (рис. 5).

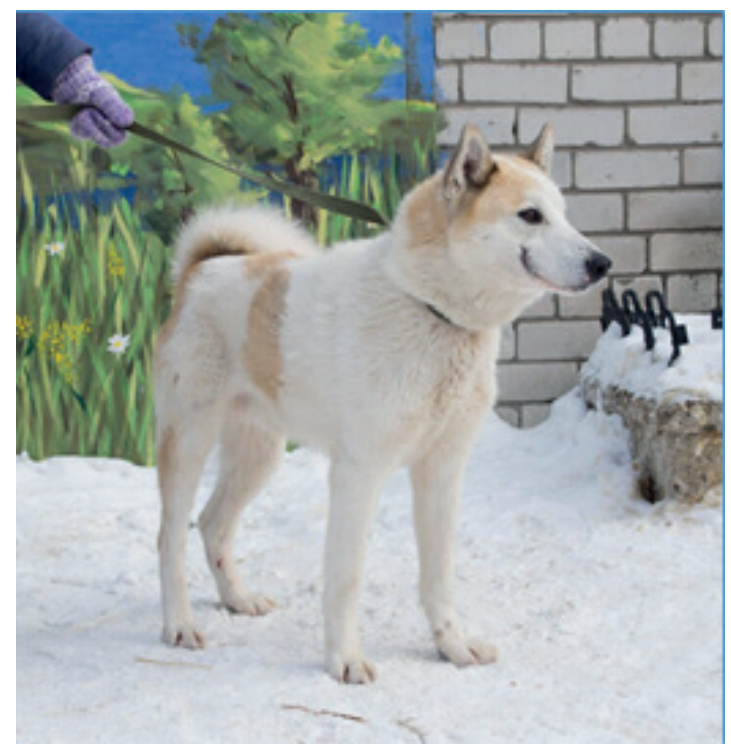

Рис. 5 - Рубцовые изменения насильственного характера на морде пострадавшей безнадзорной собаки

Стоит отметить, что хирургические патологии у безнадзорных собак являются также следствием автоаварий. За изучаемый период были зафиксированы особи с открытыми переломами, разрывом спинного мозга, размозжением мягких тканей, сотрясением головного мозга. Отдельное место в хирургической патологии занимают болезни глаз. Так, нами обнаружено несколько особей с последствиями травмы глаза. Наиболее распространены такие болезни глаз, как кератит, кератоконъюнктивит, катаракта, язва роговицы и др. (рис.6).

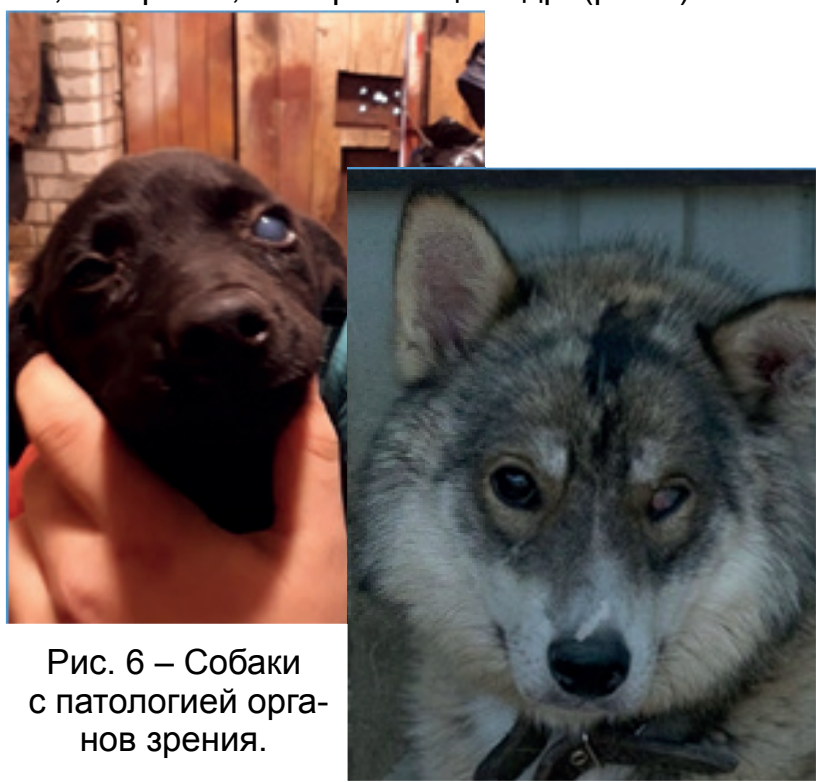

Нарушение обмена веществ у безнадзорных собак встречается в 4,5\% случаев, из них чаще регистрировалось истощение и ожирение (рис. 7). Мы предполагаем, что ожирение развивалось непосредственно в питомнике вследствие действия нескольких фракторов риска, таких как несбалансированное кормление, недостаточный моцион, алиментарный дистресс, проявление лидерских качеств и захват пищи.

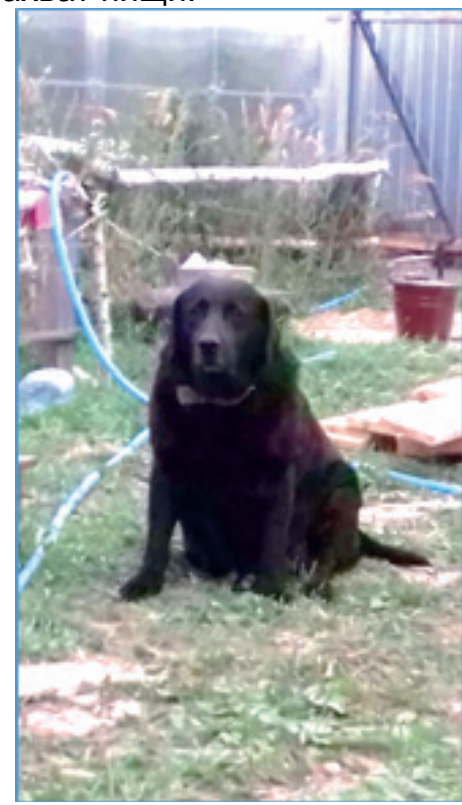

Рис. 7 - Алиментарная дистрофия (ожирение) у суки «Шерри»

К болезням обмена веществ следует отнести отравления собак ядовитыми приманками, чаще всего изониазидом, либо дикумарином, которые вызывают хроническое кровотечение из естественных отверстий организма, приводящее к летальному исходу. Среди болезней дыхательной системы, которые составляют 4,3\%, наиболее часто встречаются такие патологии как гайморит, коллапс трахеи, обструктивный бронхит. Болезни сердечно-сосудистой системы составляют $4,3 \%$ и фриксируются только при клиническом проявлении у собак. Наиболее часто встречаются дилатационные кардиомиопатии у взрослых собак и вторичные миокардиты у щенков. Болезни нервной системы составляют $1,4 \%$ и в основном представлены единичными случаями эпилепсии, теплового удара. К сожалению, сложные незаразные патологии у безнадзорных собак в условиях приютов трудно поддаются лечению в связи с экономическими и фризическими трудностями. Послеоперационная реабилитация собак в условиях приюта затруднительна из-за ограничений в площади и нехватки обслуживающего персонала. Однако большинство больных собак получают необходимую ветеринарную помощь и имеют благоприятный прогноз в плане выздоровления.

Особо хотелось бы отметить вклад студентовволонтёров ветеринарного профиля ФГБОУ ВО Рязанского ГАТУ в оказание необходимой помощи безнадзорным животным (рис.8). 


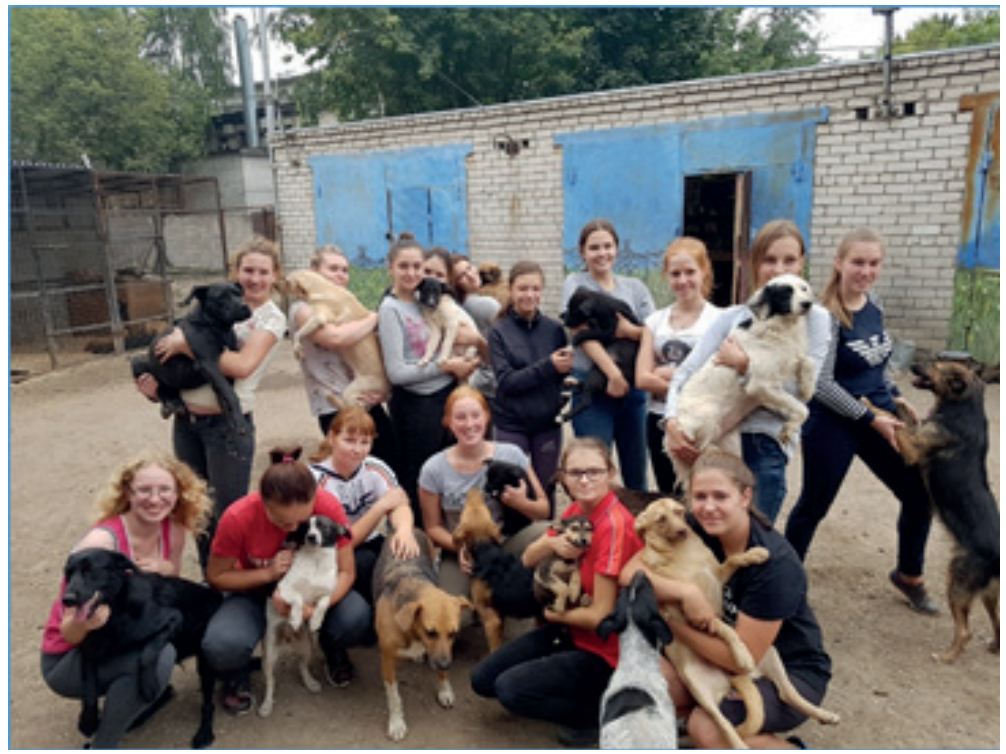

Рис. 8 - Студенты-волонтёры ФГБОУ ВО Рязанского ГАТУ ФДП и СПО в МУП «Городская служба по контролю за безнадзорными животными»

Ухаживая за собаками, проводя лечебно-профилактические мероприятия в приютах, студенты отрабатывают приобретенные в ВУЗе умения и навыки, получая колоссальный опыт в работе с животными.

\section{Выводы}

Таким образом, мы выяснили, что численность здоровых животных в условиях приюта МУП «Городская служба по контролю за безнадзорными животными» составила 84,9\%. Показатели зоогигиенических параметров в приютах соответствовали установленным инструкцией нормам. К основным фракторами риска развития незаразной патологии у безнадзорных собак следует отнести несбалансированное кормление, наличие ранговой иерархии в вольерах. Установили, что наиболее частой незаразной патологией безнадзорных собак являются болезни пищеварительной системы, которая составляет 47,8\%. Своевременное обнаружение и лечение незаразной патологии у безнадзорных собак в быстрые сроки позволит им стать клинически здоровыми, что значительно повышает шансы на приобретение нового хозяина.

\section{Список литературы}

1. Антонович, А. А. Особенности номенклатуры синантропных собак [Текст] / А. А. Антонович, С. С. Бакшеева, В. В. Власов // Вестник КрасГАУ. - 2016. - № 4. - C. 22-28.

2. Васильев, А. Г. О территориальном поведение собак в городе [Текст] / А. Г. Васильев. // $\mathrm{V}$ съезд Всесоюзного териологического общества АН СССР 29 января-2 февраля 1990 г. Москва. т. 3. - Москва, 1990. - С. 9-10.

3. Гельберт, М. Д. Физиологические основы поведения и дрессировки собак [Текст] / М. Д. Гельберт. - М.: КолосС, 2007. - 237 с.

4. Инструкция по отлову, транспортировке, временному содержанию, подбору трупов безнадзорных животных на территории города Рязани [Электронный ресурс] / Благоустройство города. Официальный сайт администрации города Ряза- ни. - Режим доступа: http://admrzn.ru/gorodskayasreda/upravlenie-blagoustrojstva/zashita-zhivotnyh

5. Минина, Е. А. Проблема правового регулирования обращения с животными [Электронный ресурс] / Е. А. Минина // Журнал российского права. № 12. 2014. - С.80-88. - Режим доступа: https://cyberleninka.ru/article/n/problemy-pravovogoregulirovaniya-obrascheniya-s-zhivotnymi

6. Нормы технологического проектирования ветеринарных объектов для городов и иных населенных пунктов НТП-АПК 1.10.07.002-02 [Электронный ресурс] / Система нормативных документов в АПК 01.01.2003 / Министерство сельского хозяйства. - Режим доступа: http://gostbank. metaltorg.ru/data/norms new/ntp/10.pdf

7. Об упорядочении содержания собак и кошек в городах и других населенных пунктах Рязанской области [Электронный ресурс] / Электронный фонд правовой и нормативно-технической документации. - Режим доступа: http://docs.cntd.ru/ document/906506984

8. Рахманов, А. И. Проблема бродячих собак в городах [Электронный ресурс] // Ветеринарная патология / А. И. Рахманов. № 1. 2002. - С.136-140. Режим доступа: http://www.animalsprotectiontribune. ru/DokRahm.html

9. Рыбалко, А. В. Обзор мирового опыта в решении проблемы бездомных животных [Электронный ресурс] // Ветеринарная патология" №2 (17), 2006 г. - С. 12-19. - Режим доступа: http://www. animalsprotectiontribune.ru/Kommentmir.html

10. Сорокина, А. В. Совершенствование методов сдерживания воспроизводства бездомных животных в крупных населенных пунктах [Электронный ресурс] / А. В. Сорокина: ...авторефрерат дис. ... кандидата биологических наук: 16.00.06 / Казан. гос. акад. ветеринар. медицины им. Н. Э. Баумана. - Казань, 2001. - 23 с. - Режим доступа: https://xn--90ax2c.xn--p1ai/catal og/000199_000009_002278901/ 


\section{HE SPREAD OF NON-COMMUNICABLE DISEASE AMONG STRAY DOGS IN THE CITY OF RYAZAN}

Gertseva Ksenia A., candidate of biological sciences, associate Professor of veterinary and sanitary examination, surgery, obstetrics and internal diseases of animals, okavet@ya.ru

Kiseleva Elena V., candidate of biological sciences, associate Professor of veterinary and sanitary examination, surgery, obstetrics and internal diseases of animals, super.juliakiseleva2013@yandex.ru

Dubov Dmitriy V., candidate of biological sciences, associate Professor of veterinary and sanitary examination, surgery, obstetrics and internal diseases of animals, dmitriy.dubov2018@yandex.ru

Rudnaya Antonina V., teacher of the faculty of pre-University training and secondary vocational education, rudnaya.antonina@yandex.ru

Ryazan State Agrotechnological University Named after P.A. Kostychev

Gorchkova Yuliya R., employee (volunteer) of MBU "City service for control of neglected animals", uliagorskova7@gmail.ru

The aim of the research was to study the results of medical examination of the number of dogs and to establish the degree of spread of non-infectious diseases in neglected dogs in the shelters of Ryazan. The objects of the study were dogs belonging to the shelters of the MUP "City service for the control of neglected animals". The problem of stray dogs - is complex and multifaceted, requiring a deep integrated approach. There are many components. This-and sanitary-epidemiological danger of the population of neglected animals in the urban environment, and the danger of aggressive canine flocks, and the issue of overproduction of Pets (irresponsible owners throw out their unwanted puppies, thereby replenishing the ranks of stray animals). Currently in the city of Ryazan carries out its activities municipal budget institution "City service for the control of stray animals." One of the objectives of the service, as well as private modern shelters for stray animals is the provision of timely veterinary assistance and then adapt, search and identification of dogs in permanent residence in a responsible family. In addition to the compulsory treatment and preventive measures against communicable infectious and parasitic diseases, dogs also need therapy for non-communicable pathologies. Therefore, the assessment of spread of non-communicable disease is an urgent task for understanding the extent of the necessary therapy and prevention of diseases discovered among street dogs, because a healthy dog will have large chances of acquiring a new host. A medical examination of the number of stray dogs in shelters. The veterinary and zootechnical documentation is studied, the analysis of conditions of the maintenance and feeding of animals is given, the main risk factors of development of non-contagious pathology at neglected dogs are revealed. The leading non-infectious diseases of the livestock of the studied dogs are established.

Key words: neglected dog, shelter, non-infectious pathology, medical examination.

\section{Literatura}

1. Antonovich, A. A. Osobennosti nomenklatury sinantropnyh sobak [Tekst] / A.A. Antonovich, S. S. Baksheeva, V. V. Vlasov. - Vestnik KrasGAU, № 4, 2016. - S.22-28.

2. Vasil'ev, A. G. O territorial'nom povedenie sobak $v$ gorode // $V$ sezd Vsesojuznogo teriologicheskogo obshhestva AN SSSR [Tekst] / A. G. Vasil'ev. 29 janvarja-2 fevralja 1990 g. Moskva. t. 3. 1990. Moskva. - S. 9-10.

3. Gel'bert, M. D. Fiziologicheskie osnovy povedenija i dressirovki sobak [Tekst] / M. D. Gel'bert. - M.: Koloss, 2007. $-237 \mathrm{~s}$.

4. Instrukcija po otlovu, transportirovke, vremennomu soderzhaniju, podboru trupov beznadzornyh zhivotnyh na territorii goroda Rjazani [JElektronnyj resurs]/Blagoustrojstvo goroda. Oficial'nyj sajt administracii goroda Rjazani. - Rezhim dostupa: http://admrzn.ru/gorodskaya-sreda/upravlenie-blagoustrojstva/zashitazhivotnyh

5. Minina, E. A. Problema pravovogo regulirovanija obrashhenija s zhivotnymi [JElektronnyj resurs] / E. A. Minina // ZHurnal rossijskogo prava. № 12. 2014. - S.80-88. - Rezhim dostupa: https://cyberleninka.ru/ article/n/problemy-pravovogo-regulirovaniya-obrascheniya-s-zhivotnymi

6. Normy tehnologicheskogo proektirovanija veterinarnyh obektov dlja gorodov $i$ inyh naselennyh punktov NTP-APK 1.10.07.002-02 [JElektronnyj resurs] / Sistema normativnyh dokumentov V APK 01.01.2003 / Ministerstvo sel'skogo hozjajstva. - Rezhim dostupa: http://gostbank.metaltorg.ru/data/norms_new/ntp/10. pdf

7. Ob uporjadochenii soderzhanija sobak $i$ koshek $v$ gorodah $i$ drugih naselennyh punktah Rjazanskoj oblasti [JElektronnyj resurs] / JElektronnyj fond pravovoj i normativno-tehnicheskoj dokumentacii. - Rezhim dostupa: $h$ ttp://docs.cntd.ru/document/906506984

8. Rahmanov, A. I. Problema brodjachih sobak v gorodah [JElektronnyj resurs] // Veterinarnaja patologija / A. I. Rahmanov. № 1. 2002. - S.136-140. - Rezhim dostupa: http://www.animalsprotectiontribune.ru/ DokRahm.html

9. Rybalko, A. V. Obzor mirovogo opyta v reshenii problemy bezdomnyh zhivotnyh [JElektronnyj resurs] // Veterinarnaja patologija" №2 (17), 2006 g. - S. 12-19. - Rezhim dostupa: http://www.animalsprotectiontribune. ru/Kommentmir.html

10. Sorokina, A. V. Sovershenstvovanie metodov sderzhivanija vosproizvodstva bezdomnyh zhivotnyh v krupnyh naselennyh punktah [JElektronnyj resurs] /A. V. Sorokina: ... avtoreferat dis. ... kandidata biologicheskih nauk: 16.00.06 / Kazan. gos. akad. veterinar. mediciny im. N. JE. Baumana. - Kazan', 2001. - 23 s. - Rezhim dostupa: https://xn--90ax2c.xn--p1ai/catalog/000199_000009_002278901/ 


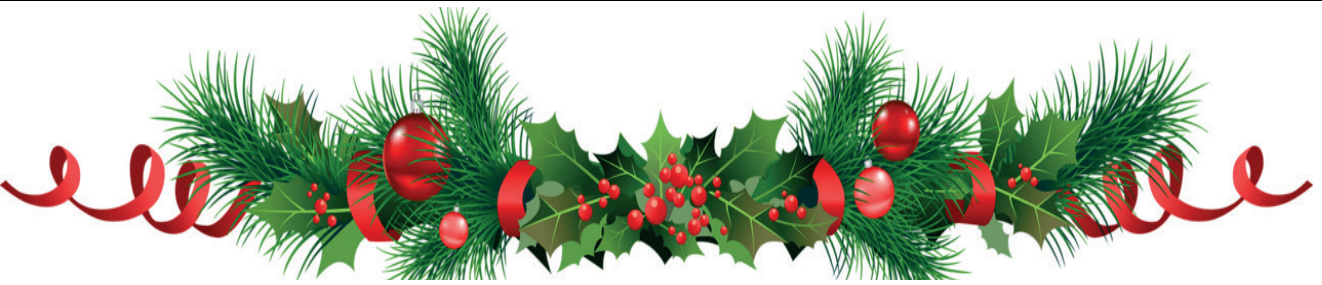

УДК 542.943:636.03

DOI 10.36508/RSATU.2019.87.95.004

\section{СОСТАВ МОЛОКА КОРОВ И СЛИВОЧНОГО МАСЛА, ИЗГОТОВЛЕННОГО ИЗ НЕГО, ПОД ВЛИЯНИЕМ АНТИОКСИДАНТОВ}

КАШИРИНА Лидия Григорьевна, д-р биол. наук, професссор, зав. кафредрой анатомии и фризиологии сельскохозяйственных животных, kashirina@rgatu.ru

МОРОЗОВА Нина Ивановна, д-р с.-х. наук, професссор, зав. кафредрой технологии производства и переработки сельскохозяйственной продукции, morozova@rgatu.ru

ИВАНИЩЕВ Константин Александрович, ассистент кафредры анатомии и фризиологии сельскохозяйственных животных, konstantinivanishev@mail.ru

РОМАНОВ Кирилл Игоревич, ассистент кафедры анатомии и фризиологии сельскохозяйственных животных, kirill.romanov1993@mail.ru

Рязанский государственный агротехнологический университет имени П.А. Костычева

Цель исследований - определение влияния антиоксидантных препаратов «Е-селен» и «Бутофран» на продуктивность новотельных коров, состав молока, дисперсность молочного жира и жирнокислотный состав сливочного масла. Исследования были выполнены на 12 головах новотельных коров-аналогов черно-пестрой породы в возрасте трех лет, сформированных в три группы - контрольную и две опытные по 4 головы в каждой в условиях ООО «Заря» Рязанского района Рязанской области. Дисперсность молочного жира определяли по количеству и диаметру молочных жировых шариков. Из молока готовили сладко-сливочное масло традиционным способом, в соответствии с действующим ГОСТом. Анализ масла на жирнокислотный состав проводили в ООО «Московская независимая лаборатория качества сырья и пищевых продуктов», с использованием аппаратно-программного комплекса для медицинских исследований на базе хроматографра "Хроматэк-Кристалл 5000», с помощью программы «Excel». Определено влияние вышеуказанных препаратов на уровень продуктивности коров, состав молока, дисперсность молочного жира, жирнокислотный состав сливочного масла. При применении препаратов, обладающих антиоксидантной активностью, происходит торможение процессов перекисного окисления липидов в организме коров на разных стадиях лактации и свободные радикалы не накапливаются в организме. Наиболее выраженной активностью обладал препарат «Бутофран», при его использовании изменялся дисперсный состав молочного жира в молоке в сторону увеличения количества жировых шариков с преобладанием крупной фрракции. Это оказало положительное влияние на изменение состава жирных кислот в сливочном масле, на увеличение фрракции ненасыщенных жирных кислот и улучшение качественных показателей сливочного масла.

Ключевые слова: новотельные коровы, антиоксидантные препараты, молоко, жировые шарики, сливочное масло, ненасыщенные жирные кислоты.

\section{Введение}

Натуральные молочные продукты - это незаменимый источник легкоусвояемых белков, жиров, углеводов и минералов. Молоко и молочная продукция в рационах россиян традиционно занимают одно из важнейших мест. Среднестатистический россиянин в год потребляет около 250 кг молока и молочных продуктов. Регулярное потребление молочных продуктов положительно влияет на здоровье людей, укрепляя иммунную защиту организма, повышая работоспособность и физическую выносливость, улучшая настроение. Натуральное молоко обладает уникальной способностью выводить из организма токсины и радионуклиды. Молоко хорошего качества можно получать только от здоровых животных. Нормальная фрункция любого организма зависит от внутренних факторов, к которым относят его функциональные резервы. Процессы перекисного окисления липидов (ПОЛ), происходят постоянно в живом организме и вызывают неспецифическую адаптивную стресс-реакцию. Она может быть вызвана также напряженным фризиологическим состоянием животных, например лактационным периодом, родами, а также болезнями $[1,4]$. Усиление процессов перекисного окисления липидов обычно сопровождается образованием большого количества свободных радикалов, которые вызывают в организме комплекс изменений на клеточном уровне - снижение активности ряда ферментных систем, угнетение синтеза белков и т.д. Антиоксидантная система в организме существует для защиты от чрезмерного образования свободных радикалов. При длительном воздействии на организм животных неблагоприятных фракторов фрункциональные резервы собственной антиоксидантной системы могут снижаться, и в этом случае она не будет в полной мере справляться с регуляцией свободнорадикальных реакций [2]. Такое состояние организма называют окислительным стрессом [6]. Для снижения окислительных процессов в периоды напряженного физиологического состояния животным необходимо вводить дополнительно антиоксидантные препараты [7].

() Каширина Л. Г., Морозова Н. И., Иванищев К. А., Романов К. И., 2019 г. 
Цель наших исследований состояла в определении влияния витаминсодержащих препаратов «Е-селен» и «Бутофран», обладающих антиоксидантными свойствами, на продуктивность новотельных коров, состав молока, дисперсность молочного жира и жирнокислотный состав сливочного масла.

\section{Материал и методы исследования}

Эксперимент был выполнен в зимне-стойловый период на 12 головах новотельных коров-аналогов черно-пестрой породы в возрасте трех лет, в условиях ООО «Заря» Рязанского района Рязанской области», сфрормированных в три группы по 4 головы в каждой: контрольную и две опытные. Животные контрольной группы были интактными. На коровах опытной группы 1 был применен препарат «Е-селен», опытной группы 2 - «Бутофран», которые вводились в организм в виде внутримышечных инъекций в дозе 10 мл/голову в течение 5 месяцев, начиная со второго месяца лактации.

«Е-селен» содержит в составе селенит натрия (0,5 мг/мл) и ацетат токоферола (50 мг/мл) и вспомогательные компоненты - солютол, бензиловый спирт и дистиллированную воду.

«Бутофан» - бутафоосфан и витамин В12 (цианокобаламин). Бутафросфан стимулирует обменные процессы и повышает резистентность организма. Витамин В12 активизирует процессы кроветворения.

Кормление и содержание животных соответствовало зоотехническим норма [11]. Продуктивность коров и качество молока изучали индивидуально в период проведения контрольных доек. Исследования молока выполнялись в межкафедральной научно-исследовательской лаборатории фракультета ветеринарной медицины и биотехнологии ФГБОУ ВО РГАТУ. Массовая долю жира и белка в молоке - на приборе «Лактан 1-4».Оценка дисперсности молочного жира проводилась по количеству и диаметру молочных жировых шариков [4].

Из молока коров готовили сладко-сливочное масло традиционным способом, в соответствии с действующим ГОСТ Р 52054-2003 [10]. Анализ масла на жирнокислотный состав был выполнен в ООО «Московской независимой лаборатории качества сырья и пищевых продуктов», с использованием аппаратно-программного комплекса для медицинских исследований на базе хроматографа «Хроматэк-Кристалл 5000», с помощью программы «Excel». Результаты анализов подвергнуты статистической обработке.

Результаты исследований и обсуждение

Молочная продуктивность коров изучалась на протяжении пяти месяцев лактации после отела. На втором месяце лактации коровам опытных групп дополнительно были введены антиоксидантные препараты для активизации собственной антиоксидантной системы организма. Результаты инъекций проявили себя на третьем месяце лактации. В этот период, в так называемый «разгар» лактации, удой во всех группах был самым высоким, увеличившись по сравнению со вторым месяцем (в литрах): в контроле на 1,1 в опытной группе 1 на 1,3 и в опытной группе 2 на 7,4. Для наглядности результатов продуктивности коров по группам был произведен перерасчет удоя на базисную жирность. При этом на третьем месяце лактации удой коров в опытных группах увеличился по сравнению с контролем, причем в опытной группе 2, где был применен препарат «Бутофран», он стал достоверно выше на 8,6 литра, а в опытной группе 1, где испытывался препарат «Е-селен» - на 1,0 литр (табл. 1).

\begin{tabular}{|c|c|c|c|}
\hline Группа & Суточный удой, кг & Содержание жира, \% & $\begin{array}{c}\text { Суточный удой в пересчете на } \\
\text { базисную жирность, } 3,4 \%\end{array}$ \\
\hline \multicolumn{4}{|c|}{ 1-й месяц лактации } \\
\hline Контрольная & $24,2 \pm 4,34$ & $3,72 \pm 0,26$ & $26,3 \pm 4,82$ \\
\hline Опытная 1 & $24,7 \pm 4,78$ & $3,55 \pm 0,18$ & $25,4 \pm 4,31$ \\
\hline Опытная 2 & $24,7 \pm 7,27$ & $3,60 \pm 0,30$ & $26,1 \pm 5,36$ \\
\hline \multicolumn{4}{|c|}{ 2-й месяц лактации } \\
\hline Контрольная & $25,7 \pm 7,36$ & $3,63 \pm 0,37$ & $27,2 \pm 5,54$ \\
\hline Опытная 1 & $25,7 \pm 5,6$ & $3,68 \pm 0,12$ & $27,9 \pm 6,12$ \\
\hline Опытная 2 & $25,6 \pm 5,8$ & $3,46 \pm 0,40$ & $26,3 \pm 4,75$ \\
\hline \multicolumn{4}{|c|}{ 3-й месяц лактации } \\
\hline Контрольная & $26,8 \pm 11,1$ & $3,58 \pm 0,26$ & $28,3 \pm 6,13$ \\
\hline Опытная 1 & $27,0 \pm 6,68$ & $3,75 \pm 0,19$ & $29,3 \pm 5,82$ \\
\hline Опытная 2 & $33,0 \pm 10,9^{* \star}$ & $3,81 \pm 0,31$ & $36,8 \pm 9,82^{*}$ \\
\hline \multicolumn{4}{|c|}{ 4-й месяц лактации } \\
\hline Контрольная & $23,4 \pm 4,9$ & $3,57 \pm 0,21$ & $24,7 \pm 4,21$ \\
\hline Опытная 1 & $24,7 \pm 5,6$ & $3,75 \pm 0,07$ & $26,8 \pm 4,90$ \\
\hline Опытная 2 & $24,2 \pm 6,1$ & $3,77 \pm 0,29^{*}$ & $26,3 \pm 5,12$ \\
\hline \multicolumn{4}{|c|}{ 5-й месяц лактации } \\
\hline Контрольная & $24,5 \pm 9,1$ & $3,65 \pm 0,15$ & $25,9 \pm 8,82$ \\
\hline
\end{tabular}


Продолжение таблицы 1

\begin{tabular}{|l|l|l|l|}
\hline Опытная 1 & $25,0 \pm 6,0$ & $3,78 \pm 0,35$ & $27,2 \pm 6,07$ \\
\hline Опытная 2 & $24,8 \pm 8,5$ & $3,70 \pm 0,13$ & $26,9 \pm 5,12$ \\
\hline
\end{tabular}

Примечание: достоверность разницы показателей по сравнению с контрольной группой * $-p \leq 0,05,{ }^{* *}-p \leq 0,01$, *** $-p \leq 0,001$. В последующих таблицах обозначения те же

На 4-м месяце лактации по сравнению с 3-м наблюдалось снижение удоя во всех группах, однако в опытных группах уровень его продолжал сохранять более высокие показатели по сравнению с контролем. Продуктивность коров на 5-м месяце лактации в опытных группах была значительно выше по сравнению с контролем, что явилось ответной реакцией на деятельность антиаксидантных препаратов и активизацию собственной антиоксидантной системы. Дополнительное введение антиоксидантных препаратов повлияло не только на повышение удоя, но и на увеличение жирности молока. Повышение жирности молока имеет большое экономическое значение для производителей, но в основном оказывает влияние на энергетические составляющие рационов питания человека. Молочный жир хорошо усваивается организмом, поскольку температура его плавления относительно низкая - $28-31^{\circ} \mathrm{C}$, в молоке он находится в виде эмульсии жировых шариков в молочной плазме. Плазма - молочная жидкость без жира, в которой имеются все составляющие молока. Диаметр жировых шариков в среднем от 2,0 до 2,5 мкм. Размеры и количество их в молоке зависят как от породных особенностей животных, так и от зоотехнических факторов. При свободнорадикальном окислении молочный жир подвергается самоокислению, что впоследствии приводит к порче как молока, так и полученной из него продукции. Антиоксиданты влияют на задержку окислительной порчи. В самом молоке содержится ряд естественных антиоксидантов - это токоферолы, аскорбиновая кислота, каротин, фосфолипиды и другие, но в большинстве случаев количества их не достаточно для ингибирования окислительных процессов.

В задачи эксперимента входило определение влияния вышеуказанных антиоксидантов на дисперсность молочного жира в молоке коров (табл. 2), которая, как известно, зависит от стадии лактации, от породных особенностей животных, условий содержания и т.д. [5]. К молоку, предназначенному для производства масла, предъявляются особые требования: это уровень жира, его состав и степень дисперсности жировых шариков. Чем больше размер жировых шариков, тем выше степень использования жира при производстве масла. Стопроцентное использование отмечено при размере жировых шариков свыше 8 мкм. При размере их выше 3 мкм использование может составлять приблизительно $78 \%$ [11]. Нашими исследованиями установлено, что применение витаминсодержащих препаратов оказало влияние на изменение дисперсности молочного жира, в частности, на увеличение крупной фракции молочных жировых шариков.

В молоке коров опытных групп, полученном на третьем месяце лактации, под влиянием препаратов наблюдалось увеличение общего количества жировых шариков по сравнению с контролем, и в последующие месяцы данная тенденция сохранялась.

На четвертом и пятом месяцах в группе интактных животных интенсивность процессов перекисного окисления липидов была выше по сравнению с этими показателями в опытных группах, что отразилось на уменьшении величины жировых шариков и их количестве. В опытных группах, наоборот, наблюдалось увеличение их количества с преобладанием крупной фракции, особенно в молоке коров опытной группы 2, где был применен антиоксидантный препарат «Бутофан». Разница с контролем составила $16,27 \%$ в пользу опытных животных (табл. 2), где увеличилось количество шариков крупной и средней фракции с одновременным уменьшением мелкой. В опытной группе 1 наблюдались те же изменения, и подобная тенденция сохранялась в последующие месяцы лактации.

Таблица 2 - Дисперсности молочного жира в молоке коров $(\mathrm{n}=12)$

\begin{tabular}{|l|c|c|c|c|c|}
\hline \multicolumn{1}{|c|}{ Группы } & $\begin{array}{c}\text { Количество } \\
\text { молочных жировых } \\
\text { шариков,млрд/мл }\end{array}$ & $\begin{array}{c}\text { Средний } \\
\text { диаметр } \\
\text { жирового } \\
\text { шарика,мкм }\end{array}$ & $\begin{array}{c}\text { Доля } \\
\text { мелких } \\
\text { шариков } \\
\text { (до 2 мкм), \% }\end{array}$ & $\begin{array}{c}\text { Доля } \\
\text { средних } \\
\text { шариков } \\
(2-3 \text { мкм), \% }\end{array}$ & $\begin{array}{c}\text { Доля крупных } \\
\text { шариков } \\
(>3 \text { мкм), \% }\end{array}$ \\
\hline \multicolumn{7}{|c|}{ й месяц лактации } \\
\hline Контрольная & $2,669 \pm 158$ & $4,24 \pm 0,06$ & 8,16 & 15,46 & 76,8 \\
\hline Опытная 1 & $2,631 \pm 132$ & $4,24 \pm 0,08$ & 8,19 & 14,98 & 76,6 \\
\hline Опытная 2 & $2,639 \pm 139$ & $4,25 \pm 0,05$ & 8,16 & 15,45 & 77,1 \\
\hline \multicolumn{7}{|c|}{$2-$ й месяц лактации } \\
\hline Контрольная & $2,641 \pm 0,141$ & $5,31 \pm 0,06$ & 3,46 & 9,92 & 86,6 \\
\hline Опытная 1 & $2,657 \pm 0,147$ & $5,27 \pm 0,07$ & 3,52 & 9,87 & 85,8 \\
\hline
\end{tabular}


Продолжение таблицы 2

\begin{tabular}{|l|c|c|c|c|c|}
\hline Опытная 2 & $2,612 \pm 0,131$ & $5,33 \pm 0,04$ & 3,47 & 9,92 & $76,2^{*}$ \\
\hline \multicolumn{7}{|c|}{$3-$ й месяц лактации } \\
\hline Контрольная & $2,630 \pm 0,133$ & $5,12 \pm 0,06$ & 3,94 & 9,53 & 86,5 \\
\hline Опытная 1 & $2,677 \pm 0,153$ & $5,30 \pm 0,08$ & 3,29 & 9,80 & 89,6 \\
\hline Опытная 2 & $3,058 \pm 0,157^{* *}$ & $5,28 \pm 0,04$ & 3,35 & 9,78 & 90,2 \\
\hline \multicolumn{7}{|c|}{4 -й месяц лактации } \\
\hline Контрольная & $2,598 \pm 0,134$ & $5,4 \pm 0,06$ & 4,72 & 12,3 & 82,9 \\
\hline Опытная 1 & $2,671 \pm 0,160$ & $5,19 \pm 0,06$ & 4,12 & 14,7 & 88,5 \\
\hline Опытная 2 & $2,675 \pm 0,162$ & $5,21 \pm 0,07$ & 3,98 & 15,12 & 88,8 \\
\hline \multicolumn{7}{|c|}{$5-$ й месяц лактации } \\
\hline Контрольная & $2,638 \pm 0,138$ & $5,15 \pm 0,04$ & 4,51 & 11,8 & 82,9 \\
\hline Опытная 1 & $2,896 \pm 0,159$ & $5,25 \pm 0,08$ & 4,15 & 14,4 & 86,2 \\
\hline Опытная 2 & $2,642 \pm 0,143$ & $5,19 \pm 0,06$ & 4,07 & 15,2 & 85,3 \\
\hline
\end{tabular}

На консистенцию сливочного масла, стойкость его при хранении, вкусовые качества определяющее влияние оказывает состав молочного жира [11]. Молочный жир представляет собой смесь глицеридов, свободных жирных кислот и других веществ. В зависимости от химической природы жирные кислоты в молочном жире представлены двумя группами - насыщенными и ненасыщенными. Насыщенных и ненасыщенных жирных кислот в молочном жире около 150. Ненасыщенные жирные кислоты являются непредельными, в структуре которых присутствует одна или несколько двойных связей. Биологические компоненты молочного жира активны, они влияют на проницаемость стенок кровеносных сосудов, на их эластичность, на холестериновый обмен в организме и т. д. Отличительной особенностью полиненасыщенные жирных кислот является то, что они не вырабатываются организмом человека и должны поступать извне с пищей.

В структуре насыщенных жирных кислот двойные связи отсутствуют. При бесконтрольном потреблении продуктов с большим содержанием насыщенных жирных кислот можно спровоцировать развитие множества заболеваний. Но совсем исключать их из рациона не следует, поскольку они являются источником энергии, участвуют в синтезе гормонов, транспорте и усвоении витаминов, микроэлементов и т.д. [4].

Концентрация насыщенных жирных кислот в сливочном масле, изготовленном из молока коров, полученном под воздействием антиоксидантов, к концу исследований была на 5,7\% ниже, чем в молоке интактных животных. Насыщенные и ненасыщенные жирные кислоты в организме животных находятся во взаимосвязи и одни из них могут трансформироваться в другие [1].

В молоке коров опытных групп, по сравнению с контролем, наблюдалось увеличение концентрации ненасыщенных жирных кислот - в опытной группе 1 на 16,6\%, а в опытной группе 2 - на $31,1 \%$. Данные изменения происходили под влиянием антиоксидантных препаратов, которые снижали реакции перекисного окисления липидов в организме коров и тем самым защищали ненасыщенные кислоты от окисления, повышая их концентрацию в сливочном масле и, как следствие, улучшая качественные показатели его (рис.). Сумма полиненасыщенных жирных кислот в сливочном масле, изготовленном из молока коров под влиянием витаминсодержащих препаратов, полученном из молока коров на третьем месяце лактации, самой высокой была в опытной группе 1, почти на $6,5 \%$ выше, чем в опытной группе 2 и на 7,9\%, чем в контроле. Было установлено, что препараты «Е-селен» и «Бутофран», используемые в эксперименте, влияли на снижение процессов перекисного окисления липидов в организме коров, улучшая ветеринарно-санитарные и технологические показатели молока и продуктов, изготовленных из него.

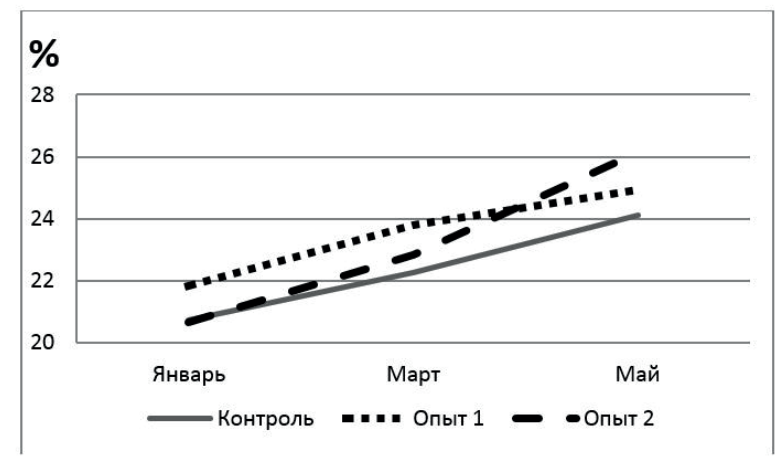

Рис. - Сумма полиненасыщенных жирных кислот в сливочном масле

\section{Заключение}

Для увеличения продуктивности коров и получения молока с улучшенными биологическими качествами производители применяют различные приемы и используют разные препараты, которые зачастую оказывают отрицательное воздействие на здоровье животных. Использование антиоксидантов является одним из способов увеличения продуктивности коров и сохранения их здоровья.

Антиоксидантные препараты «Е-селен» и «Бу- 
тофран» нормализовали метаболические и регенеративные процессы в организме коров, оказывали стимулирующее влияние на жировой обмен, снижая интенсивность процессов перекисного окисления липидов. При этом увеличивалось количество ненасыщенных жирных кислот в молоке и сливочном масле, изготовленном из него. Экспериментальными исследованиями установлено, что применение препаратов оказало положительное влияние на снижение процессов ПОЛ в организме новотельных коров. Наибольшую активность проявил препарат «Бутофан». Применение его продолжало удерживать продуктивные показатели коров на высоком уровне до конца эксперимента. В молоке коров опытных группах происходило увеличение количества жировых шариков с преобладанием крупной фракции, особенно в молоке коров опытной группы 2, под воздействием препарата «Бутофран». Это повлияло на увеличение количества ненасыщенных жирных кислот в сливочном масле и улучшало его качественные показатели. Результаты исследований по применению антиоксидантных препаратов позволяют использовать их для повышения молочной продуктивности коров, улучшения технологических показателей молока и получения биологически безопасных, биологически полноценных молочных продуктов.

\section{Список литературы}

1. Кармолиев, Р. Х. Биохимические процессы при свободнорадикальном окислении и антиоксидантной защите. Профилактика окислительного стресса у животных [Текст] / Р. Х. Кармлиев // Сельскохозяйственная биология. - 2002. - № 2. - С 19-28.

2. Каширина, Л. Г. Перекисное окисление липидов и антиоксидантная защита организма у молочных коров разной продуктивности [Текст] / Л. Г. Каширина, А. В. Антонов, И. А. Плющик // Вестник РГАТУ. - 2013. - № 1. - С. 8-12.

3. Каширина, Л. Г. Продуктивность и качество молока коров под влиянием препаратов «Е-селен» и «Бутофран» [Текст] / Л. Г. Каширина, К. А. Иванищев, К. И. Романов // Вестник РГАТУ им. П.А. Костычева. - 2016. - №4. - С. 15-19.

4. Каширина, Л. Г. Влияние перекисного окисления липидов на качество молочного жира у коров [Текст] / Л. Г. Каширина, А. В. Антонов, И. А. Плющик // Инновационные направления и методы реализации научных исследований в АПК : сборник научных трудов преподавателей и аспирантов
РГАТУ. - Рязань, 2012. - С. 378-381.

5. Каширина, Л. Г. Влияние перекисного окисления липидов на молочную продуктивность и дисперсность молочного жира у коров [Текст] / Л. Г. Каширина, И. А. Плющик // Современная наука глазами молодых учёных: достижения, проблемы, перспективы : Материалы межвузовской научнопрактической конференцииФГБОУ ВО РГАТУ. Рязань, 2014. - С. 98-104.

6. Каширина, Л. Г. Влияние антиоксидантов на продуктивность и качество молока коров [Текст] / Л. Г. Каширина, К. А. Иванищев, К. И. Романов // Аграрная наука в условиях модернизации и инновационного развития АПК России : сборник материалов Всероссийской научно-методической конференции с международным участием, посвященная 100-летию академика Д.К. Беляева, г. Иваново ноябрь 2017. - С. 266-271.

7. Влияние антиоксидантов «Е-селен» и «Бутофран» на некоторые гематологические показатели и продуктивность новотельных коров [Текст] / Л. Г. Каширина, И. А. Плющик, К. А. Иванищев, К. И. Романов // Актуальные направления научных исследований в АПК: от теории к практике : материалы национальной научно-практической конференции 10 ноября 2017 года, г. Волгоград, часть 1. - Волгоград, 2017. - С. 180-184.

8. Антиоксидантная защита организма и продуктивность новотельных коров при применении препарата «Бутофан» [Текст] / Л. Г. Каширина, И. А. Плющик, К. А. Иванищев, К. И. Романов // Экологическое состояние природной среды и научнопрактические аспекты современных агротехнологий : сборник материалов научно-практической конференции РГАТУ, март 2018 г. Часть 1. - Рязань : РГАТУ, 2018. - С.168-173.

9. Котова, О. Г. Повышение качества сливочного масла. - М. : Пищевая промышленность, 1979. - 127 c.

10. Молоко, молочные продукты и консервы молочные: технические условия: сборник [Текст] М. : «Стандартинформ», 2008. - 327 с.

11. Нормы и рационы кормления сельскохозяйственных животных [Текст] /А. П. Калашников, В. И. Фисинин, В. В. Щеглов [и др.]. - М. : Колос, 2003. - 456 c.

12. Технология молока и молочных продуктов [Текст] / Г. Н. Крусь, А. Г. Храмцов, С. В. Карпычев; под ред. А. М. Шалыгиной. - М. : Колос, 2006. - С. 55.

\section{THE COMPOSITION OF COW MILK AND SWEET BUTTER MADE FROM IT, UNDER THE INFLUENCE OF ANTIOXIDANTS}

Kashirina Lidia G., Doctor of Biological Science, Full Professor, Department of Anatomy and Physiology of Agricultural Animals, kashirina@rgatu.ru

Morozova Nina I., Doctor of Agricultural Science, Full Professor, Department of Agricultural Production and Processing Technology, morozova@rgatu.ru

Ivanischev Konstantin A., Assistant, Department of Anatomy and Physiology of Agricultural Animals, konstantinivanishev@mail.ru

Romanov Kirill I., Assistant, Department of Anatomy and Physiology of Agricultural Animals, kirill. romanov1993@mail.ru

Ryazan State Agrotechnological University Named after P.A. Kostychev

The purpose of the research is to determine the effect of antioxidant preparations E-selenium and Butofan 
on the productivity of newly calved cows, the composition of milk, the dispersion of milk fat and the fatty acid composition of butter. The studies were performed with 12 newly calved cows - analogues of a black-andwhite breed at the age of 3 years old, formed in three groups - a control and two experimental ones having 4 animals each at LLC Zarya, Ryazan district of Ryazan region. The dispersion of milk fat was determined by the number and diameter of milk fat globules. Sweet butter was prepared from milk in the traditional way, in accordance with the current GOST. An analysis of the butter for the fatty acid composition was carried out at Moscow Independent Laboratory for the Quality of Raw Materials and Food Products, LLC, using the hardwaresoftware complex for medical research, based on Chromatek-Crystal 5,000 chromatograph with the help of Excel program. The influence of the above preparations on the level of cow productivity, milk composition, dispersion of milk fat and fatty acid composition of butter was determined. When using preparations with antioxidant activity, processes of inhibition of lipid peroxidation processes in the body of cows at different stages of lactation occured and free radicals did not accumulate in the body. Butofan preparation had the most pronounced activity when used. The dispersed composition of milk fat in milk changed in the direction of increasing the number of fat globules with a predominance of a large fraction. This had some positive effect on the change in the composition of fatty acids in butter, on the increase in the fraction of unsaturated fatty acids and the improvement of the quality parameters of butter.

Key words: newly calved cow, antioxidant preparations, milk, fat globules, sweet butter, unsaturated fatty acids.

\section{Literatura}

1.Karmoliev R.H. Biohimicheskie processy pri svobodnoradikal'nom okislenii iantioksidantnoj zashhite. Profilaktika okislitel'nogo stressa u zhivotnyh [Tekst] /R.H. Karmliev //Sel'skohozjajstvennaja biologija. - 2002. - №2. S 19-28.

2.Kashirina, L.G. Perekisnoe okislenie lipidov $i$ antioksidantnaja zashhita organizma u molochnyh korov raznoj produktivnosti [Tekst] /L.G. Kashirina, A.V. Antonov, I.A. Pljushhik // Vestnik RGATU. - 2013. - № 1. S. 8-12.

3.Kashirina L.G., Ivanishhev K.A., Romanov K.I. Produktivnost' i kachestvo moloka korov pod vlijaniem preparatov «E-selen» $i$ «Butofan» [Tekst] / Kashirina L.G., Ivanishhev K.A., Romanov K.I.// Vestnik RGATU im. P.A. Kostycheva - 2016. - №4. - S.15-19.

4.Kashirina L.G., Antonov A.V., Pljushhik I.A. Vlijanie perekisnogo okislenija lipidov na kachestvo molochnogo zhira u korov [tekst] / Kashirina L.G., Antonov A. V., Pljushhik I.A. // Innovacionnye napravlenija $i$ metody realizacii nauchnyh issledovanij v APK» Sbornik nauchnyh trudov prepodavatelej $i$ aspirantov RGATU - 2012. - S. 378-381.

5.Kashirina L.G., Pljushhik I. A. Vlijanie perekisnogo okislenija lipidov na molochnuju produktivnost' $i$ dispersnost' molochnogo zhira u korov [tekst] / Kashirina L.G., Pljushhik I. A. // Sovremennaja nauka glazami molodyh uchjonyh: dostizhenija, problemy, perspektivy. Materialy mezhvuzovskoj nauchno-prakticheskoj konferenciiFGBOU VO RGATU, Rjazan' - 2014. S. 98-104.

6.Kashirina L.G., Ivanishhev K.A., Romanov K.I. Vlijanie antioksidantov na produktivnost' i kachestvo moloka korov «Agrarnaja nauka v uslovijah modernizacii i innovacionnogo razvitija APK Rossii» [tekst] / Kashirina L.G., Ivanishhev K.A., Romanov K.I. I/Sbornik materialov Vserossijskoj nauchno-metodicheskoj konferencii s mezhdunarodnym uchastiem, posvjashhennaja 100-letiju akademika D.K. Beljaeva, g. Ivanovo nojabr' 2017. - S. 266-271.

7.Kashirina L.G., Pljushhik I.A., Ivanishhev K.A., Romanov K.I. Vlijanie antioksidantov «E-selen» $i$ «Butofan» na nekotorye gematologicheskie pokazateli i produktivnost' novotel'nyh korov [tekst] / Kashirina L.G., Pljushhik I.A., Ivanishhev K.A., Romanov K.I.// Materialy nacional'noj nauchno-prakticheskoj konferencii "Aktual'nye napravlenija nauchnyh issledovanij v APK: ot teorii k praktike» 10 nojabrja 2017 goda, g. Volgograd, chast' 1. S. $180-184$.

8.Kashirina L.G., Pljushhik I.A., Ivanishhev K.A., Romanov K.I. Antioksidantnaja zashhita organizma i produktivnost' novotel'nyh korov pri primenenii preparata «Butofan» [tekst] /Kashirina L.G., Pljushhik I.A., Ivanishhev K.A., Romanov K.I. I/Sbornik materialov nauchno-prakticheskoj konferencii RGATU "JEkologicheskoe sostojanie prirodnoj sredy i nauchno- prakticheskie aspekty sovremennyh agrotehnologij». Rjazan' RGATU, mart 2018 g. CHast' 1. S.168-173.

9.Kotova O.G. Povyshenie kachestva slivochnogo masla. M.: Pishhevaja promyshlennost', $1979 .-127$ s.

10.Moloko, molochnye produkty i konservy molochnye: tehnicheskie uslovija: sbornik [Tekst] - M.: "Standartinform», 2008. - 327 s.

11.Normy i raciony kormlenija sel'skohozjajstvennyh zhivotnyh [Tekst] /A.P. Kalashnikov, V.I. Fisinin, V.V. SHHeglov i dr.// - M.: Kolos, 2003. - 456 s.

12. Tehnologija moloka i molochnyh produktov [Tekst]/G.N. Krus', A.G. Hramcov, S. V. Karpychev; pod red. A.M. SHalyginoj// - M.: Kolos, 2006. - S. 55.

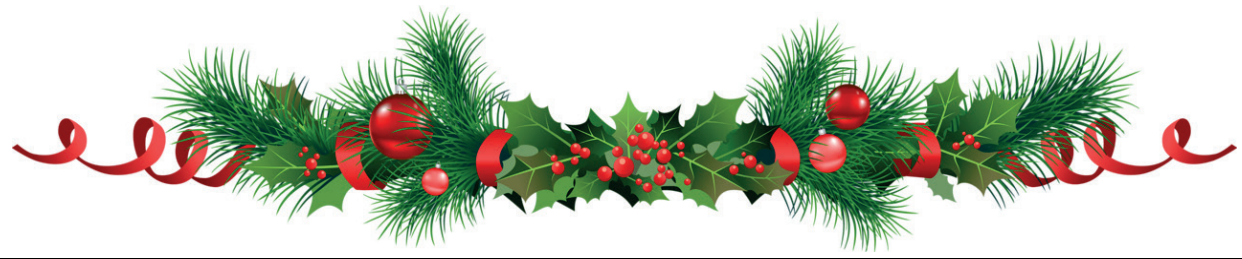




\section{УСКОРЕННЫЙ МЕТОД ПОДСЧЕТА МЕЗОФИЛЬНЫХ АЭРОБНЫХ И ФАКУЛЬТАТИВНО-АНАЭРОБНЫХ МИКРООРГАНИЗМОВ В ПТИЦЕПРОДУКТАХ}

КОЗАК Сергей Степанович, д-р вет. наук, профрессор, гл. научный сотрудник лаборатории санитарно-гигиенической оценки сырья и продуктов, ВНИИПП - филиал ФГБНУ ФНЦ «Всероссийский научно-исследовательский и технологический институт птицеводства» $P A H$, vniippkozak@gmail.com

СЕМЕНОВ Владимир Григорьевич, д-р биол. наук, профессор, заведующий кафредрой морфологии, акушерства и терапии ФГБОУ ВО Чувашская ГСХА, semenov_v.g@list.ru

АБДРАИМОВ Рафат Турсыналиевич, аспирант, vniippkozak@gmail.com

КОЗАК Юлия Александровна, канд. вет. наук, вед. научный сотрудник лаборатории санитарногигиенической оценки сырья и продуктов, vniippkozak@gmail.com

ВНИИПП - филиал ФГБНУ ФНЦ «Всероссийский научно-исследовательский и технологический институт птицеводства» РАН

Проведена апробация и произведены сравнительные испытания тест-пластин, предназначенных для подсчета количества мезофильных аэробных и фракультативно-анаэробных микроорганизмов (КМАФАнМ) в птицепродуктах. Лабораторные испытания включали в себя выявление диапазонов чувствительности тест-пластин для определения КМАФАнМ, подсчет процента их извлекаемости (\% всхожести) с поверхности тест-пластин, а также проведение их сравнительных испытаний с помощью классического метода анализа. Тест-пластины типа 1 содержат готовую питательную среду, гель и тетразолиевый индикатор; используются для подсчета КМАФАнМ в образцах пищевых продуктов, продовольственном сырье, а также при мониторинге окружающей среды. Тест-пластины типа 2 предназначены для экспрессного подсчета КМАФАнМ в пищевых продуктах и объектах внешней среды, содержат готовую питательную среду, водорастворимый желирующий агент, иветной индикатор. При сравнении чувствительности классических сред и тест-пластин типа 1 и типа 2 при определении КМАФАнМ была установлена высокая чувствительность как питательного агара, так и испытуемых тест-пластин. Для плотных сред она составляет не менее 0,1 мл суспензии из 6-го разведения. В наших исследованиях на всех чашках и тест-пластинах из 6 и 7 разведений выявлен рост типичных колоний, что свидетельствует о высокой чувствительности. Установлено, что процент извлекаемости на тест-пластинах хороший: на тест-пластинах типа 1-98,9\%, на тест-пластинах типа 2 - 86,8\%. При сравнительном исследовании классического метода и тестпластин был получен хороший результат. Во всех случаях результаты исследований на КМАФАнМ тест-пластин сопоставим с классическим методом: процент извлекаемости апробируемого материала составил более $80 \%$, в некоторых случаях - даже $100 \%$. Тест-пластины для определения КМАФАнМ просты в использовании, надежны, имеют длительный срок хранения (1 год), с их применением уменьшаются сроки проведения анализа, уменьшается трудоемкость исследований.

Ключевые слова: тест-пластины для подсчета КМАФАнМ, классические среды, птицепродукты.

\section{Введение}

Выпуск безопасной продукции является одной из ключевых задач пищевой промышленности. Традиционные методы выявления микрофрлоры занимают время, и на получение результатов уходит достаточно большое количество времени, поэтому иногда уже невозможно исправить ситуацию. В свете изложенного остается актуальной разработка быстрых, относительно недорогих и более динамичных методов оценки микробного загрязнения [3].

Аэробные и фракультативно-анаэробные бактерии могут присутствовать в различных пищевых продуктах, их количество служит индикатором микробного загрязнения. Общеизвестно, что вероятность присутствия патогенных бактерий в объектах среды обитания повышается по мере роста общей микробной контаминации. Точное выявление количества аэробных и фракультативно-анаэробных бактерий в сырье, конечном продукте и объектах внешней среды является важным критерием оценки качества произведенного продукта, его безопасности на пищевом производстве [2].

В данной работе был исследован метод опре- деления КМАФАнМ на тест-пластинах. На их поверхность была нанесена питательная среда, благоприятная для роста микроорганизмов. Специальное вещество, содержащееся в составе питательной среды, при комнатной температуре превращается в гель при добавлении жидкости. Образуемая гелеобразная питательная среда позволяет проводить учет численности микроорганизмов.

Преимущества данного метода заключаются в том, что пластины всегда готовы для немедленного использования: исключается время на подготовку среды - появляется возможность выполнить тесты в два раза быстрее, уменьшается потребность в проведении контроля качества в сертифицированных лабораториях (каждая коробка пластин имеет сертификат качества), становится менее трудоемким процесс уборки. Кроме того, компактный размер пленки позволяет сэкономить рабочую площадь лаборатории и уменьшить площади, необходимые для хранения, увеличивает продолжительность хранения тестов (до 1 года) в сравнении с методом использования готовых питательных сред. 


\section{Материалы и методы}

Методика проведения работ была основана на лабораторных испытаниях. Она включала несколько этапов работы: выявление диапазонов чувствительности тест-пластин для определения КМАФАнМ, определение процента извлекаемости (\% всхожести) на тест-пластинах, проведение сравнительных испытаний с использованием классического метода анализа [1].

При выполнении работы были использованы:

- тест-пластины типа 1: в их состав включены питательная среда, гель, индикатор тетразолиевый, который облегчает подсчет колоний; они используются для подсчета КМАФАнМ в образцах пищевых продуктов, продовольственном сырье, а также при осуществлении мониторинга окружающей среды. Посевы термостатируются при температуре $30 \pm 1^{\circ} \mathrm{C}$ в течение $48 \pm 3$ ч.

- тест-пластины типа 2 для экспрессного подсчета КМАФАнМ в пищевых продуктах, объектах внешней среды (воздух, производственные поверхности). В их состав включены готовая питательная среда, желирующий водорастворимый агент, индикатор цветной, облегчающий учет колоний. Посевы термостатируются при температуре $37 \pm 1^{\circ} \mathrm{C}$ в течение $24 \pm 2$ ч.

Определение КМАФАнМ с использованием тест-пластин проводили в соответствии с инструкцией по применению.

На тест-пластинах подсчитывали все окрашен- ные колонии после инкубирования посевов вне зависимости от их размера и интенсивности. На тест-пластине типа 1 - все красные колонии, на тест-пластине типа 2 - все красные и синие колонии. Для подсчета применяли лупы, стандартный счетчик колоний или автоматическое считывающее устройство. В тех случаях, когда число колоний было более трехсот, на тест-пластинах наблюдалось окрашивание в красный, розовый либо синий цвета всей зоны роста. При этом посередине тест-пластины отсутствуют колонии, а по периферии, наоборот, они отчетливо видны. Поэтому с целью более точного подсчета количества микроорганизмов нужно повысить разведение образца и повторно провести анализ.

В посевах разведений, количество колоний в которых не превышало трехсот, следует проводить подсчет. Результаты подсчета количества колоний будут наиболее достоверными тогда, когда хотя бы на одной пластине содержится не менее пятнадцати колоний.

\section{Результаты экспериментальных исследований}

Выявление чувствительности питательных сред

Чувствительность питательных сред должна составлять не менее 0,1 мл суспензии из 6-го разведения для плотных и 1 мл из 7-го разведения для жидких сред. Результаты разведения суспензии тестового штамма приведены в табл. 1.

Таблица 1 - Разведение суспензии тестового штамма

\begin{tabular}{|c|c|c|c|}
\hline Показатель, КОЕ/на чашку & \multicolumn{3}{|c|}{ Результат } \\
\hline Количество колоний при посеве 0,1 мл из 6 разведений & 101 & 99 & 107 \\
\hline $\begin{array}{l}\text { Среднее количество колоний на чашке при посеве } 0,1 \text { мл из } 6 \text { раз- } \\
\text { ведения } \\
\text { Норма }=100 \pm 20\end{array}$ & \multicolumn{3}{|c|}{102} \\
\hline Количество колоний при посеве 0,1 мл из 7 разведения & 9 & 12 & 11 \\
\hline $\begin{array}{l}\text { Среднее количество колоний на чашке при посеве } 0,1 \text { мл из } 7 \text { раз- } \\
\text { ведения } \\
\text { Норма } 1 / 10 \text { от среднего значения для 6-го разведения }\end{array}$ & \multicolumn{3}{|c|}{10} \\
\hline
\end{tabular}

С целью выявления чувствительности питательных сред использовали суспензию тестового штамма из 5, 6, 7 и 8 разведений по 0,1 мл. Посев каждой дозы суспензии живых клеток выполняли в объеме не менее чем на три чашки или пластины. В таблице 1 представлены результаты контроля разведения суспензии тестового штамма.

Данные, представленные в таблице, свиде-

Таблица 2 - Определение показателей чувствительности питательного агара и тест-пластин

\begin{tabular}{|c|c|c|c|c|c|}
\hline \multirow{2}{*}{$\begin{array}{c}\text { Наименование } \\
\text { среды }\end{array}$} & $\begin{array}{c}\text { Номер чашки или } \\
\text { пластины }\end{array}$ & \multicolumn{3}{|c|}{ Условия посева - по 0,1 мл из разведения: } \\
\cline { 2 - 6 } & 1 & 5 & 6 & 7 & 8 \\
\hline \multirow{3}{*}{ Питательный агар } & 2 & + & + & + & - \\
\cline { 2 - 6 } & 3 & + & + & + & - \\
\hline \multirow{2}{*}{$\begin{array}{c}\text { Tест-пластины } \\
\text { тип 1 }\end{array}$} & 1 & + & + & + & - \\
\cline { 2 - 6 } & 2 & + & + & + & - \\
\hline
\end{tabular}

тельствуют о том, что разведение суспензии было произведено корректно: в 6-ом разведении выросло около $100 \mathrm{KOE} / \mathrm{на} \mathrm{чашку,} \mathrm{в} \mathrm{7-ом} \mathrm{разведе-}$ нии - около 10, что соответствует норме, которая используется при определении чувствительности. Результаты определения чувствительности питательного агара и тест-пластин представлены в таблице 2. 
Продолжение таблицы 2

\begin{tabular}{|l|l|l|l|l|l|}
\hline \multirow{2}{*}{$\begin{array}{l}\text { Тест-пластины } \\
\text { тип } 2\end{array}$} & 1 & + & + & + & - \\
\cline { 2 - 6 } & 2 & + & + & + & - \\
\cline { 2 - 6 }
\end{tabular}

Данные, представленные в таблице 2, свидетельствуют о том, что чувствительность и питательного агара, и тест-пластин хорошая: на всех чашках из 6 и 7 разведений наблюдается рост колоний. Из 8-го разведения на испытуемых средах их рост не наблюдался.

\section{Определение процента извлекаемости} (\% всхожести)

Посев производили как на питательный агар (контроль), так и на тест-пластины. Всхожесть определяли соотношением числа колоний на испытуемой питательной среде к числу колоний в контрольном варианте в процентах.

Результаты экспериментальных исследований представлены в таблице 3 .

Таблица 3 - Определение процента извлекаемости на тест-пластинах

\begin{tabular}{|l|c|c|c|c|c|c|}
\hline \multirow{2}{*}{ Среда } & \multicolumn{7}{|c|}{ Количество колоний } & \multirow{2}{*}{$\begin{array}{c}\text { Среднее количе- } \\
\text { ство колоний }\end{array}$} \\
\cline { 2 - 6 } & 1 & 2 & 3 & 4 & 5 & 56,4 \\
\hline Питательный агар & 54 & 58 & 53 & 61 & 56 & 55,8 \\
\hline Тест-пластины тип 1 & 55 & 57 & 52 & 59 & 56 & 49,0 \\
\hline \% всхожести & \multicolumn{7}{|c|}{98,9} \\
\hline Тест-пластины тип 2 & 52 & 49 & 47 & 54 & 43 & \\
\hline \% всхожести & \multicolumn{7}{|c|}{86,8} \\
\hline
\end{tabular}

Данные, представленные в таблице 3, свидетельствуют о том, что процент извлекаемости (\% всхожести) на тест-пластинах хороший (более 80\%): на тест-пластинах типа 1 - 98,9\%, на тестпластинах типа 2 - 86,8\%.

Сравнительные испытания результатов определения КМАФАнМ в образцах пищевых продуктов классическим и экспрессным методом с применением тест-пластин

Результаты экспериментальных исследований представлены в таблице 4.

Таблица 4 - Сличительные испытания результатов определения КМАФАнМ

\begin{tabular}{|c|c|c|c|c|c|}
\hline \multirow{2}{*}{$\begin{array}{l}\text { Наименование } \\
\text { образца }\end{array}$} & \multicolumn{5}{|c|}{$\begin{array}{l}\text { Микробиологические исследования на определение } \\
\text { КМАФАнМ, КОЕ в } 1 \text { г продукта \% извлекаемости }\end{array}$} \\
\hline & $\begin{array}{l}\text { классичес- } \\
\text { ким методом }\end{array}$ & $\begin{array}{c}\text { с применением } \\
\text { тест-пластин } \\
\text { тип } 1\end{array}$ & $\begin{array}{c}\% \\
\text { извлекаемо- } \\
\text { сти }\end{array}$ & $\begin{array}{c}\text { с примене- } \\
\text { нием тест- } \\
\text { пластин тип } 2\end{array}$ & $\begin{array}{l}\text { \% извле- } \\
\text { каемости }\end{array}$ \\
\hline $\begin{array}{l}\text { Смыв со скорлупы яйца } \\
\text { образец № } 1\end{array}$ & $8,2 \cdot 10^{3}$ & $8,4 \cdot 10^{3}$ & 102,4 & $7,9 \cdot 10^{3}$ & 96,3 \\
\hline -//- образец № 2 & $2 \cdot 101$ & $2 \cdot 10^{1}$ & 100 & $2 \cdot 10^{1}$ & 100 \\
\hline -//- образец № 3 & $2,5 \cdot 10^{4}$ & $2,3 \cdot 10^{4}$ & 92,0 & $2,1 \cdot 10^{4}$ & 84,0 \\
\hline -//- образец № 4 & $7,7 \cdot 10^{3}$ & $6,5 \cdot 10^{3}$ & 84,4 & $6,2 \cdot 10^{3}$ & 80,5 \\
\hline -//- образец № 5 & $3,3 \cdot 10^{3}$ & $2,8 \cdot 10^{3}$ & 84,8 & $2,7 \cdot 10^{3}$ & 81,8 \\
\hline -//- образец № 6 & $2,5 \cdot 10^{3}$ & $2,5 \cdot 10^{3}$ & 100 & $2,3 \cdot 10^{3}$ & 92,0 \\
\hline -//- образец № 7 & $3,8 \cdot 10^{3}$ & $3,4 \cdot 10^{3}$ & 89,4 & $3,5 \cdot 10^{3}$ & 92,1 \\
\hline $\begin{array}{l}\text { Мясо птицы механиче- } \\
\text { ской обвалки }\end{array}$ & $2,6 \cdot 10^{3}$ & $2,4 \cdot 10^{3}$ & 92,3 & $2,1 \cdot 10^{3}$ & 80,7 \\
\hline $\begin{array}{l}\text { Мясо птицы механиче- } \\
\text { ской обвалки }\end{array}$ & $6,2 \cdot 10^{2}$ & $5,6 \cdot 10^{2}$ & 90,3 & $5,2 \cdot 10^{2}$ & 83,8 \\
\hline $\begin{array}{l}\text { Мясо птицы механиче- } \\
\text { ской обвалки }\end{array}$ & $3,5 \cdot 10^{3}$ & $2,9 \cdot 10^{3}$ & 82,8 & $2,8 \cdot 10^{3}$ & 80,0 \\
\hline $\begin{array}{l}\text { Мясо птицы механиче- } \\
\text { ской обвалки }\end{array}$ & $6,0 \cdot 10^{2}$ & $5,2 \cdot 10^{2}$ & 86,6 & $5,4 \cdot 10^{2}$ & 90,0 \\
\hline $\begin{array}{l}\text { Мясо птицы механиче- } \\
\text { ской обвалки }\end{array}$ & $1,7 \cdot 10^{4}$ & $1,6 \cdot 10^{4}$ & 94,1 & $1,4 \cdot 10^{4}$ & 82,3 \\
\hline $\begin{array}{l}\text { Мясо птицы механиче- } \\
\text { ской обвалки }\end{array}$ & $8,1 \cdot 10^{4}$ & $7,2 \cdot 10^{4}$ & 88,8 & $7,3 \cdot 10^{4}$ & 90,1 \\
\hline
\end{tabular}


Продолжение таблицы 4

\begin{tabular}{|l|c|c|c|c|c|}
\hline $\begin{array}{l}\text { Мясо птицы механиче- } \\
\text { ской обвалки }\end{array}$ & 30 & 30 & 100 & $<10$ & 100 \\
\hline Голень кур & $<10$ & $<10$ & 100 & $<10$ & 100 \\
\hline Окорочок кур & $5,4 \cdot 10^{3}$ & $5,2 \cdot 10^{3}$ & 96,2 & $5,1 \cdot 10^{3}$ & 94,4 \\
\hline Крыло кур & $3,4 \cdot 10^{4}$ & $2,9 \cdot 10^{4}$ & 85,2 & $2,9 \cdot 10^{4}$ & 85,2 \\
\hline Полутушка кур & $<10$ & $<10$ & 100 & $<10$ & 100 \\
\hline Полутушка кур & $<10$ & $<10$ & 100 & $<10$ & 100 \\
\hline $\begin{array}{l}\text { Мясо птицы механиче- } \\
\text { ской обвалки }\end{array}$ & $6,8 \cdot 10^{4}$ & $5,8 \cdot 10^{4}$ & 85,3 & $5,5 \cdot 10^{4}$ & 80,8 \\
\hline $\begin{array}{l}\text { Мясо птицы механиче- } \\
\text { ской обвалки }\end{array}$ & $6,4 \cdot 10^{4}$ & $6,1 \cdot 10^{4}$ & 95,3 & $5,9 \cdot 10^{4}$ & 92,2 \\
\hline Голень кур & $5,8 \cdot 10^{3}$ & $5,3 \cdot 10^{3}$ & 91,3 & $5,4 \cdot 10^{3}$ & 93,1 \\
\hline Грудка кур & $1,1 \cdot 10^{3}$ & $9,6 \cdot 10^{2}$ & 87,2 & $9,4 \cdot 10^{2}$ & 85,4 \\
\hline Филе грудки кур & $6,3 \cdot 10^{2}$ & $5,8 \cdot 10^{2}$ & 92,1 & $5,3 \cdot 10^{2}$ & 84,1 \\
\hline
\end{tabular}

Образцы продуктов из мяса птицы и яиц, поступающих в исследовательский лабораторный центр для определения количества КМАФАнМ, исследовали двумя методами, классическим и экспрессным, с применением тест-пластин с последующим сравнением полученных результатов. Всего было исследовано 17 образцов пищевых продуктов и 7 образцов смывов с поверхности скорлупы яиц.

Данные, представленные в таблице 4, свидетельствуют о том, что при определении КМАФАнМ

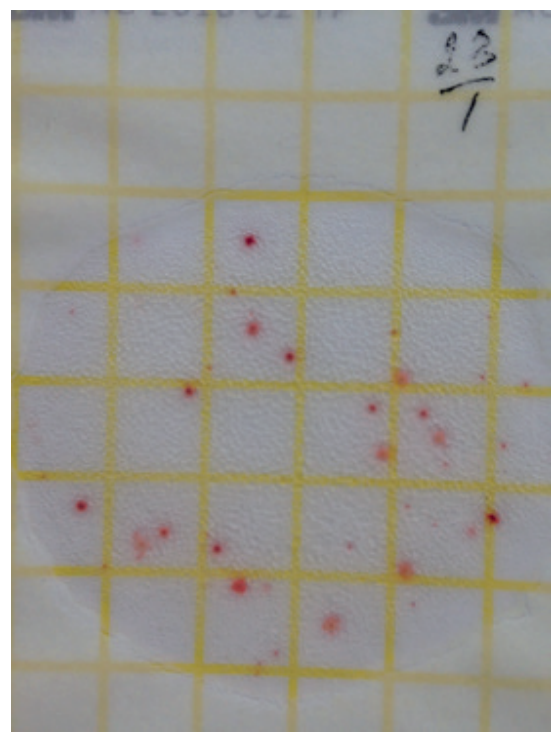

Рис. 1 - Рост микроорганизмов на тест-пластинах тип 1

\section{Выводы}

В результате проведенной работы по тестированию тест-пластин для определения КМАФАнМ в птицепродуктах было установлено следующее:

- при сравнении чувствительности классических сред (питательный агар) при определении КМАФАнМ и тест-пластин типа 1 и типа 2 была выявлена высокая чувствительность как питательного агара, так и испытуемых тест-пластин. Для плотных питательных сред чувствитель- в образцах пищевых продуктов классическим и экспресс-методом с применением тест-пластин результат сравнительных испытаний положительный. Во всех случаях он сопоставим с классическим методом: процент извлекаемости составил более $80 \%$, а в некоторых случаях достигал $100 \%$.

На рисунках 1 и 2 представлены колонии мезофильных аэробных и фракультативно-анаэробных микроорганизмов на тест-пластинах после инкубации.

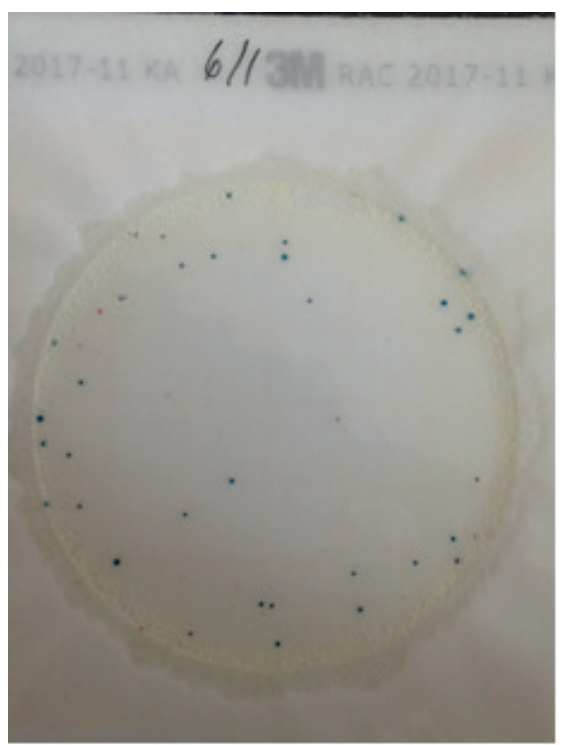

Рис. 2 - Рост микроорганизмов на тест-пластинах тип 2

ность должна быть не менее 0,1 мл суспензии из шестого разведения. В опыте на всех чашках и тест-пластинах из 6 и 7 разведений выявлен рост типичных колоний, что свидетельствует об их высокой чувствительности;

- процент извлекаемости (\% всхожести) на тест-пластинах хороший: на тест-пластинах типа 1 - 98,9\%, на тест-пластинах типа 2 - 86,8\%.

- при сравнительных исследованиях пищевых продуктов, поступающих в лабораторию, с по- 
мощью классического метода и тест-пластин был получен положительный результат.

Во всех случаях результаты исследования на КМАФАнМ сопоставимы с классическим методом: процент извлекаемости составил более $80 \%$, в некоторых случаях - даже $100 \%$.

По результатам апробации метода можно сделать вывод о том, что тест-пластины для определения КМАФАнМ просты в использовании, надежны, имеют длительный срок хранения (1 год). При их применении уменьшаются сроки проведения анализа, трудоемкость исследований.

Результаты исследований были использованы при разработке государственного стандарта 7702.2.1 - «Продукты убоя птицы, продукция из мяса птицы и объекты окружающей производственной среды. Методы определения количества мезофильных аэробных и фракультативно-анаэробных микроорганизмов».

\section{Список литературы}

1. ГОСТ 31468-2012 «Мясо птицы, субпродукты и полуфабрикаты из мяса птицы. Метод выявления сальмонелл». - Режим доступа: docs.cntd. ru>document/464671970.

2. Козак, С. С. Экспресс-метод определения количества мезофильных аэробных и факультативно-анаэробных микроорганизмов в птицепродуктах / С. С. Козак, П. С. Левин // Птица и птицепродукты. - 2015. - № 1. - С. 18-23.

3. Соколов, Д. М. Автоматизация микробиологических исследований при оценке безопасности пищевых продуктов и сырья / Д. М. Соколов, М. С. Соколов // Молочная промышленность. - 2014. № 2. - С. 70-73.

\section{OF THE ACCELERATED METHOD OF CALCULATION OF MEZO-FILNYHAEROBIC AND OPTIONALLY ANAEROBIC MICROORGANISMS IN POULTRY-FARMING PRODUCTS}

Kozak Sergey S., is a doctor of veterinary sciences, professor, chief researcher of the laboratory for sanitary and hygienic assessment of raw materials and products, All-Russian Research Institute of the Poultry Industry (VNIIPP) - branch of the Federal State Budgetary Scientific Institution of the Federal Scientific Center "All-Russian Research and Technology Institute poultry farming of the Russian Academy of Sciences, vniippkozak@gmail.com

Semenov Vladimir G., is a doctor of biological science, professor, head of the department of morphology, obstetrics and therapy of Chuvash State Agricultural Academy, semenov_v.g@list.ru

Abdraimov Rafat T., is a graduate student, vniippkozak@gmail.com

Kozak Yulia A., is a candidate of veterinary, leading researcher of the laboratory for sanitary and hygienic assessment of raw materials and products, vniippkozak@gmail.com

All-Russian Research Institute of the Poultry Industry (VNIIPP) - branch of the Federal State Budgetary Scientific Institution of the Federal Scientific Center "All-Russian Research and Technology Institute poultry farming of the Russian Academy of Sciences

Approbation and comparative tests of test-plates designed to count the number of mesophilic aerobic and facultative anaerobic microorganisms (NMAFAnM) in poultry products were carried out. Laboratory tests included identifying the sensitivity ranges of test plates for determining NMAFAnM, calculating the percentage of their recoverability (\% germination) from the surface of the test-plates, as well as conducting their comparative tests using the classical analysis method. Type 1 test-plates contain ready-made nutrient medium, gel and tetrazolium indicator; they are used to calculate NMAFAnM in food samples, food raw materials, and also when monitoring the environment. Type 2 test-plates are intended for express counting of NMAFAnM in food products and environmental objects; they contain ready-made nutrient medium, a water-soluble gelling agent and a color indicator. When comparing the sensitivity of classical media and type 1 and type 2 test-plates when determining NMAFAnM, a high sensitivity of both nutrient agar and test test-plates was established. For solid media, it is at least $0.1 \mathrm{ml}$ of a suspension of 6 dilutions. In our studies, the growth of typical colonies was revealed on all plates and test-plates from 6 and 7 dilutions, which indicates high sensitivity. The recovery rate on the test-plates was found to be good: $98.9 \%$ on type 1 test-plates and $86.8 \%$ on type 2 test-plates. In a comparative study of the classical method and test-plates, a good result was obtained. In all cases, the results of studies on NMAFAnM test-plates are comparable with the classical method: the percentage of extractability of the tested material was more than $80 \%$, in some cases even $100 \%$. Test-plates for determining NMAFAnM are easy to use, reliable, have a long shelf life (1 year), with their use, the analysis time is reduced, and the complexity of research is reduced.

Key words: test-plates for calculation NMAFAnM, classical environments, poultry products.

\section{Literatura}

1. GOST 31468-2012 «Myaso pticy, subprodukty i polufabrikaty iz myasa pticy. Metod vyyavleniya sal'monell». - Rezhim dostupa: docs.cntd.ru>document/464671970.

2. Kozak, S. S. Ekspress-metod opredeleniya kolichestva mezofil'nyh aerobnyh i fakul'tativno-anaerobnyh mikroorganizmov v pticeproduktah / S. S. Kozak, P. S. Levin // Ptica i pticeprodukty. - M., 2015. - № 1. - S. 18-23.

3. Sokolov, D. M. Avtomatizaciya mikrobiologicheskih issledovanij pri ocenke bezopasnosti pishchevyh produktov i syr'ya / D. M. Sokolov, M. S. Sokolov // Molochnaya promyshlennost'. - M., 2014. - № 2. - S. 70-73. 


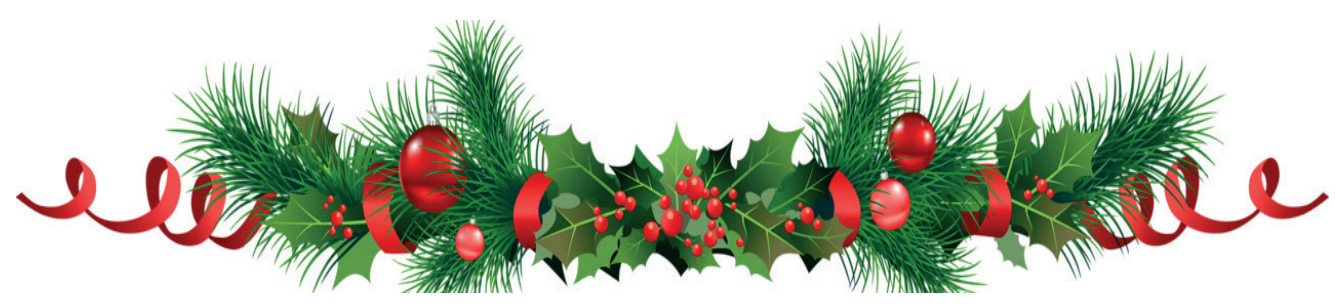

УДК 619:615

DOI 10.36508/RSATU.2019.25.96.006

\section{РАЗРАБОТКА РАЦИОНОВ С ПРИМЕНЕНИЕМ НЕМОДИФИЦИРОВАННЫХ МИКРОПОРИСТЫХ ГУМИНОВЫХ КИСЛОТ ИЗ ЛЕОНАРДИТА ДЛЯ КОРМЛЕНИЯ КАРПОВ}

КОРОВУШКИН Алексей Александрович, д-р биол. наук, профрессор кафредры зоотехнии и биологиu, korovuschkin@mail.ru

НЕФЕДОВА Светлана Александровна, д-р биол. наук, профрессор кафедры зоотехнии и биолоzuu,nefedova-s-a@mail.ru

ЯКУНИН Юрий Викторович, cm. преподаватель кафредры эксплуатации машинно-тракторного парка, yakunin0104@yandex.ru

тУникОВ Геннадий Михайлович, д-р с.-х. наук, профрессор кафедры зоотехнии и биологии, university@rgatu.ru

Рязанский государственный агротехнологический университет имени П. А. Костычева, г. Рязань

Статья посвящена анализу разработки рационов с применением немодифицированных микропористых гуминовых кислот из леонардита для кормления карпов (Сурrinus carpio Linnaeus). Предлагаемые рационы являются эфрфективными для трофрики сеголетков, так как комбикорм, обогащенный гуминовыми кислотами из леонардита, оказывает положительное воздействие на рыбоводно-биологические показатели, обеспечивая необходимые для товарного рыбоводства рост и развитие карпов. Сеголетков опытной группы (п=200) первые 30 дней кормили комбикормом, составленным согласно разработанному рецепту КРК-110-2, обогащенному немодифицированными микропористыми гуминовыми кислотами за счет добавки в него «Reasil Humic Health» (2 а на 100 ка живой массы рыбы). В контрольной группе применяли тот же комбикорм, но без гуминовых кислот. В эксперименте, проведенном в условиях установки замкнутого водоиспользования (УЗВ) в научнообразовательном центре аквакультуры и рыбоводства ФГБОУ ВО РГАТУ, благодаря обогащению комбикорма гуматами из леонардита средняя живая масса сеголетков в конце эксперимента при плотности посадки в бассейне 200 штук выше в опытной группе по сравнению с контрольной на 23,7\%, среднесуточный прирост - на 39,7\%, что экономически выгодно хозяйствам, занимающимся прудовой аквакультурой. При приготовлении комбикормов необходимо использовать леонардит со следующими свойствами: немодифрицированные микропористые гуминовые кислоты (78-80\%); кислотность 6,4 pH, влажность 55\%, озоленность 12\%. Результаты научной разработки создают основу инновационного развития отечественной аквакультуры в сфере оптимизации кормления; обеспечивают переход к передовым производственным технологиям в прудовом рыбоводстве; повышают показатели роста и развития рыб с учетом требований к высокопродуктивному и экологически чистому производству.

Ключевые слова: леонардит, немодифицированные микропористые гуминовые кислоты, комбикорм, аквакультура, кормление карпов, рационы.

\section{Введение}

Современное развитие рыбоводства определяется все возрастающим интересом к искусственному разведению объектов аквакультуры. Одним из фракторов успешного развития рыбоводного хозяйства является использование качественных комбикормов. Создание многокомпонентных комбикормов, изготовленных по научно-обоснованным рецептурам, являются центром внимания производителей данного вида сельскохозяйственной продукции. Оптимизация ветеринарно-санитарных требований к качеству кормов является стимулом для улучшения показателей выпускаемой продукции, расширения ассортимента, учета инноваций по обогащению кормов минеральнобелково-витаминными веществами и биологически активными добавками $[12,17,18]$.

В основном в прудовом рыбоводстве использу- ются дорогостоящие импортные комбикорма, расходы на них велики, при этом они не всегда обеспечивают желаемые показатели рыбопродукции. Отсюда появляется необходимость разработки рецептур комбикормов российского производства, которые обеспечат рост и развитие объектов аквакультуры для максимального достижения товарных показателей. Особое место в разработке кормов для их использования в рыбоводстве необходимо уделять органическим добавкам, обладающим свойствами стимуляции метаболизма. Недостатком является то, что отечественная комбикормовая промышленность выпускает недостаточное количество некоторых традиционных компонентов (продукты микробиального синтеза, витазар и др.), которые необходимо вводить в трофику рыб для интенсификации производства качественной рыбопродукции [7]. При этом в Рос-

() Коровушкин А. А, Нефедова С.А. Якунин Ю. В., Туников Г.М. 2019 г. 
сийской Федерации разработаны оригинальные питательные кормовые ингредиенты животного и растительного происхождения, содержащие легкоусвояемый белок, углеводы, другие эссенциальные вещества [13], в том числе гуминовые кислоты.

Долгое время предпринимались попытки переносить на рыб опыт кормления сельскохозяйственных животных [6], интерес к применению добавок в рыбоводстве к комбикормам появился по аналогии с другими отраслями животноводства. В качестве успешных примеров в скотоводстве можно привести белковый концентрат «Organic» и «Бацелл-М», [16], премикс П-63-1 [15] стимулирующий мясные и молочные показатели соответственно. Доказан положительный эффект по применению гуматов в свиноводстве: сдаточный вес животных возрастает на 12 кг/гол., снижается смертность, проявляется устойчивость к заболеваниям. Нормализация обмена веществ у свиней под действием гуматов, добавленных в кормосмесь, происходит до шестимесячного возраста, при условии, если в рационе содержится вещества 300 мг/кг живой массы на одну голову ежедневно [10]. В звероводстве добавка гуматов к трофике животных нормализует показатели по рождаемости, увеличивается приплод, у потомства стимулируется рост и развитие. В овцеводстве широко используются калиевые соли гуминовых кислот («Гумивал», производитель ООО «Лигфарм») при профилактике у ягнят микотоксикоза; у овец обнаруживается увеличение содержания общего протеина, альбуминов в крови, нормализуется концентрация мочевины и холестерина, улучшается пищеварение, отмечается ускорение регенерации ран, что обусловлено антиоксидантными свойствами гуматов [1].

В промышленном птицеводстве при работе с цыплятами-бройлерами эффективно проявили себя добавки: гумат натрия (200-400 г/т) - повышение живой массы цыплят составило 2,7\% при снижении затрат комбикорма на ожидаемый прирост на 2,1-6,2\% [9]; гуминовые кислоты из леонардита «Reasil Humic Health» в кормлении и «Reasil Humic Vet» в поении, такой подход к трофике позволил увеличить показатели сохранности поголовья, энергии роста молодняка [3], товарных качеств. Сравнение двух доз добавки «Reasil Humic Health» в кормосмесь показало, что на физиологические и продуктивные качества цыплят-бройлеров не влияет увеличение концентрации препарата, оптимально добавлять 2 г/кг комбикорма [14].

У рыб эффекттвность добавки гуминовых кислот в рацион недостаточно изучена.

Для повышения рыбоводно-биологических показателей и ускорения роста объектов аквакультуры используются ферментные добавки в кормосмеси, что позволяет сократить сроки выращивания рыб, уменьшать этим кормовые затраты. Высока эффективность для осетровых рыб использования отечественных комбикормов с каротиноидными препаратами [4,6], а также витазара, рыбного и мидийного гидролизатов [2]. В настоящее время важно разрабатывать для объектов аквакультуры органические полнорационные отечественные комбикорма, в том числе, с добавлением немоди- фрицированных микропористых гуминовых кислот из леонардита, которые оказывают протекторную и регуляторную функции на органы пищеварения и обеспечивают высокие продуктивные качества. Это направление научных исследований и является одной из приоритетных целей в работе научно-образовательного центра аквакультуры и рыбоводства ФГБОУ ВО РГАТУ (НОЦ аквакультуры и рыбоводства).

\section{Материалы и методы}

Научно-исследовательская работа выполнена в 2019 году по заказу Министерства сельского хозяйства РФ в рамках темы «Проведение исследований и разработка рецептуры полнорационных комбикормов для рыб с немодифицированными микропористыми гуминовыми кислотами из леонардита» (№ госрегистрации ААА-A19-119032090033-9 от 20.03.193) в ФГБОУ ВО РГАТУ в НОЦ аквакультуры и рыбоводства. Результаты внедрены в ассоциации «Большая рыба» (г. Семикаракорск Ростовской обл.) и ПСК «Курчанский» (Краснодарский край Темрюкский район, пос. «Светлый путь»).

Биологическим материалом для проведения эксперимента послужили сеголетки карпа (Cyprinus carpio Linnaeus), которые были размещены с сентября по ноябрь (90 дней) в установке замкнутого водоиспользования (УЗВ) (рис.).

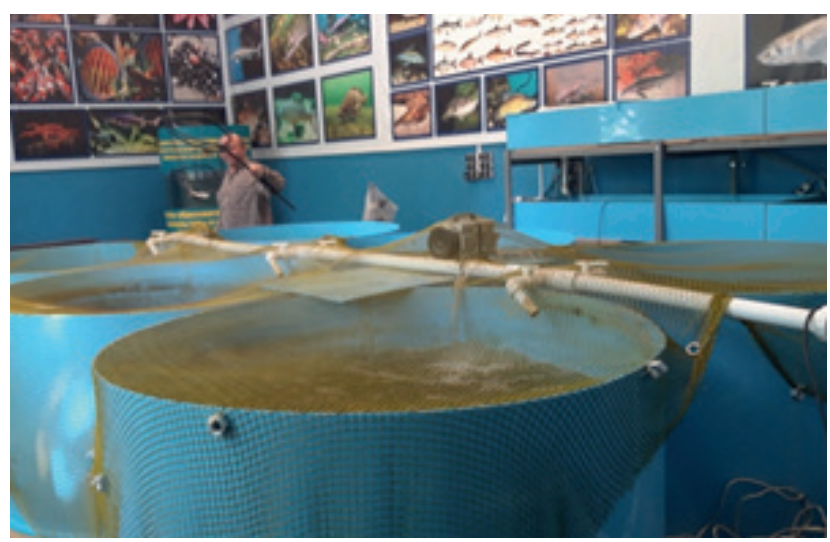

Рис. - УЗВ в НОЦ аквакультуры и рыбоводства ФГБОУ ВО РГАТУ

В начале эксперимента средняя живая масса рыб составляла 121 г. Сеголетков опытной группы (п=200 в одном бассейне УЗВ) первые 30 дней кормили комбикормом, составленным согласно разработанному рецепту КРК-110-4-12 (табл. 1), обогащенному гуминовыми кислотами за счет добавки в него «Reasil Humic Health» (2 г на 100 кг живой массы рыбы). К контрольной группе (п=200 в одном бассейне УЗВ) применяли тот же комбикорм, но без гуминовых кислот. Итоговый контроль рыбоводно-биологических показателей осуществили на 90-й день эксперимента (табл. 2).

Гидрохимический и технический режим работы УЗВ контролировали три раза в сутки, поддерживали температуру воды $22^{\circ} \mathrm{C}$ при концентрации кислорода 7-8 мг/л, насыщаемости кислородом не менее 70\%. На бассейны УЗВ (6 штук) установили автоматические кормушки, осуществляющие 
шестиразовое кормление карпов в течение дня.

Рыбоводно-биологические исследования проводили по общепринятым методикам Ю.А. Превезенцева [8]. Для расчета рецептов комбикормовконцентратов использовали программу «Корм Оптима Эксперт». Данные обрабатывались статистически по методу Стьюдента с использованием программы «Microsoft Excel».

\section{Результаты исследований}

Гуматы из леонардита являются катализато- рами метаболических процессов и представляют собой смесь гуминовых кислот (78-80\%); кислотность препарата составляет $6,4 \mathrm{pH}$, влажность $55 \%$, озоленность - 12\% [14]. Для эфффективного кормления карпов нами разработаны рецепты комбикормов, обогащенных немодифицированными микропористыми гуминовыми кислотами из леонардита, за счет добавки в них препарата «Reasil Humic Health» (2 г на 100 кг живой массы рыбы) (табл. 1).

Таблица 1 - Рецепты комбикормов, обогащенных немодифицированными микропористыми гуминовыми кислотами из леонардита

\begin{tabular}{|c|c|c|c|c|c|c|c|c|c|}
\hline \multirow[b]{2}{*}{ Компоненты, \% } & \multicolumn{9}{|c|}{ Рецепты } \\
\hline & $\begin{array}{l}\text { ПК- } \\
110- \\
2-6\end{array}$ & $\begin{array}{l}\text { ПК- } \\
110-1\end{array}$ & $\begin{array}{c}\text { ПК- } \\
110- \\
1-8\end{array}$ & $\begin{array}{c}\text { ПК } \\
110-2\end{array}$ & $\begin{array}{c}\text { ПК } \\
110-2-9\end{array}$ & $\begin{array}{c}П К \\
110-3\end{array}$ & $\begin{array}{c}П К \\
110- \\
3-11\end{array}$ & $\begin{array}{c}П К \\
110- \\
4-12\end{array}$ & $\begin{array}{c}\text { ПК } \\
110- \\
3-7\end{array}$ \\
\hline Пшеница & 4,985 & 1,485 & 4,985 & 1,485 & 9,985 & 1,485 & 2,985 & 2,985 & 4,985 \\
\hline Ячмень & 15 & & 18 & & 14 & & 14 & 15 & 10 \\
\hline Ячмень без пленок & 5 & 50 & 8 & 50 & 18 & 49 & 14 & 15 & 10 \\
\hline Кукуруза & 5 & & 5 & & 5 & & 5 & 5 & 13 \\
\hline Отруби пшеничные & 8 & & 8 & & 5 & & 6 & 5 & 8 \\
\hline Шрот соевый & 8 & 20 & 6 & 20 & 8 & & 9 & 8 & 8 \\
\hline Жмых подсолнечниковый & 8 & & 6 & & 16 & & 8 & 8 & 8 \\
\hline Шрот подсолнечниковый & 10 & 17,5 & 4 & 17,5 & & 17,5 & 7 & 8 & 8 \\
\hline Шрот соевый & & & & & & 20 & & & \\
\hline Мука мясная & 1 & 3 & 3 & 3 & 2 & 3 & 2 & 2 & 1 \\
\hline Мука рыбная & 10 & 1,2 & 12 & 1,2 & 7 & 11,17 & 7 & 6 & 4 \\
\hline Дрожжи кормовые & 2 & 5 & 3 & 5 & 3 & 5,03 & 3 & 3 & 3 \\
\hline Монокальцийфосфат & 1 & 1,8 & 1 & 1,8 & 1 & 1,8 & 1 & 1 & 1 \\
\hline Мел кормовой & 1 & & 0,5 & & 0,5 & & 0,5 & 0,5 & 0,5 \\
\hline Известняковая мука & 1 & & 0,5 & & 0,5 & & 0,5 & 0,5 & 0,5 \\
\hline Reasil Humic Health & 0,0015 & 0,015 & 0,015 & 0,015 & 0,015 & 0,015 & 0,015 & 0,015 & 0,015 \\
\hline $\begin{array}{l}\text { П110 для карпов теплово- } \\
\text { дных хозяйств }\end{array}$ & & & & & & 1 & & & \\
\hline итого & 100 & 100 & 100 & 100 & 100 & 100 & 100 & 100 & 100 \\
\hline Сырой протеин & 23,97 & 26,01 & 23,85 & 26,01 & 22,83 & 25,88 & 22,91 & 22,29 & 20,65 \\
\hline Сырая клетчатка & 6,61 & 6 & 4,12 & 6 & 6,05 & 5,97 & 6,02 & 6,12 & 6,23 \\
\hline Лизин & 1,16 & 1,24 & 5,17 & 1,24 & 1,08 & 1,24 & 1,1 & 1,04 & 0,93 \\
\hline Кальций & 1,52 & 0,73 & 1,21 & 0,73 & & 0,73 & & & 0,9 \\
\hline Фосфрор & 0,96 & 1 & & 1 & & 1 & & & 0,83 \\
\hline
\end{tabular}

Нами разработаны следующие рецепты комбикормов-концентратов: ПК-110-3-7 - для двух- и трехлеток карпа; ПК-110-1, ПК-110-2, ПК-110-3 необходимо использовать для сеголеток; ПК-1101-8 - для рыб живой массой менее 0,1 г; ПК110-2-9 рассчитан для рыб живой массой от 0,1 до 1,0 г; ПК-110-3-11 - для рыб от 1,0 до 50,0 г; ПК-110-4-12 - свыше 50 г. Полнорационные комбикорма составлены с учетом возрастных групп, навески (живой массы), включают до 17 компонентов, что дало возможность их сбалансированность.
Результаты исследований показали эффрективность использования кормовой добавки «Reasil Humic Health» в рационе для сеголетков карпов. Кормление рыб комбикормом, составленным по разработанной рецептуре, необходимо осуществлять 30 дней, начиная с того момента, когда сеголетки достигнут живой массы в среднем 121 г.

Рыбоводно-биологические показатели сеголетков карпов, в рационе которых использованы немодифицированные микропористые гуминовые кислоты из леонардита, представлены в таблице 2. 
Табл. 2 - Рыбоводно-биологические показатели сеголетков карпов

\begin{tabular}{|l|c|c|}
\hline \multicolumn{1}{|c|}{ Показатели } & \multicolumn{2}{c|}{ Группы } \\
\cline { 2 - 3 } & контрольная & опытная \\
\hline Плотность посадки сеголетков, шт./1м ${ }^{3}$ & 200 & 200 \\
\hline Живая масса сеголетков в начале эксперимента, г & $121,2 \pm 11,1$ & $121,5 \pm 10,5$ \\
\hline Живая масса сеголетков в конце эксперимента, г & $226,3 \pm 17,5$ & $296,5 \pm 19,4^{*}$ \\
\hline $\begin{array}{l}\text { Среднесуточный прирост сеголетков за 90 дней экспери- } \\
\text { мента, г }\end{array}$ & 1,17 & $1,94^{*}$ \\
\hline Отход сеголетков, \% & 1 & 1 \\
\hline
\end{tabular}

Примечание: разность между показателями достоверна: * - при p<0,05;

В эксперименте, проведенном в условиях установки замкнутого водоиспользования (УЗВ), благодаря обогащению комбикорма гуматами средняя живая масса сеголетков в конце эксперимента (на 90-й день) при плотности посадки в бассейне 200 экземпляров выше в опытной группе по сравнению с контрольной на 23,7\%, среднесуточный прирост - на 39,7\%, что выгодно хозяйствам, занимающимся прудовой аквакультурой.

\section{Заключение}

Организация полноценного кормления рыб и разработка рецептур комбикормов для объектов аквакультуры предусматривает четкое представление о потребностях различных возрастных групп в элементах питания $[5,11]$. Комбикорм является одной из основных статей расходов рыбоводного хозяйства, улучшение его продуктивных качеств определяет экономический эффрект аквакультуры. Актуально расширять фракционный состав комбикормов, который определяет уровень метаболизма при трофике рыб. При обогащении рационов добавлением к комбикормам немодифицированных микропористых гуминовых кислот возможно стимулировать у рыб регуляторную, протекторную, транспортную, аккумулятивную функции пищеварительного тракта.

Предлагаемые в данной работе рационы с применением немодифицированных микропористых гуминовых кислот из леонардита для кормления карпов (Cyprinus carpio Linnaeus) являются эфрфективными для трофики сеголетков, так как комбикорм, обогащенный гуматами, оказывает положительное воздействие на рыбоводно-биологические показатели, обеспечивая необходимые для товарного рыбоводства рост и развитие объектов аквакультуры. Благодаря обогащению комбикорма гуматами из леонардита средняя живая масса сеголетков в конце эксперимента, при плотности посадки в бассейне 200 штук, выше в опытной группе по сравнению с контрольной на 23,7\%, среднесуточный прирост - на $39,7 \%$, что выгодно хозяйствам, занимающимся прудовой аквакультурой. При приготовлении комбикормов необходимо использовать леонардит со следующими свойствами: немодифицированные микропористые гуминовые кислоты (78-80\%); кислотность 6,4 pH, влажность $55 \%$, озоленность $12 \%$.

Считаем необходимым продолжить научные исследования по оптимизации рационов для рыб путем обогащения комбикормов немодифицированными микропористыми гуминовыми кислотами, причем, не только для карпов, но и для других объектов рыбоводства.

\section{Список литературы}

1. Абакин, С.С. Терапевтические эфрфекты гуминовых кислот при лечении микотоксикоза молодняка овец / С.С. Абакин, А.А. Грекова // Сборник научных трудов Всероссийского научноисследовательского института овцеводства и козоводства. - Ставрополь: изд. Ставропольского НИИ животноводства и кормопроизводства, 2011. - C. 117.

2. Зубкова, Е.Б. Оптимизация состава комбикормов для осетровых рыб с использованием витазара и белковых гидролизатов: автореф. дис. ... канд. с.-х. наук / Е.Б. Зубкова; Астрахань, 2001.

3. Корсаков, К.В. Препарат на основе гуминовых кислот в рационе цыплят-бройлеров / К.В. Корсаков, А.А. Васильев, Е.С. Петраков и др. // Зоотехния. - 2018. - № 8. - С.104.

4. Митрофранова, М.А. Биологическая оценка использования разных каротиноидных препаратов в составе новых комбикормов при искусственном воспроизводстве осетровых рыб: автореф. дис. ... канд. с.-х. наук / М.А. Митрофранова; Астрахань, 2005.

5. Ожерельева, О.Н. Разработка и научное обоснование способа приготовления экструдированных полнорационньіх комбикормов для рыб осетровых пород: автореф. дис. ... канд. техн. Наук / О.Н. Ожерельева; Воронеж, 2008.

6. Остроумова, И.Н. Биологические основы кормления рыб / И.Н. Остроумова. - СПб.: Издательство ГосНИОРХ, 2012. - 564 с.

7. Пономарев, С.В. Корма и кормление рыб в аквакультуре / С.В. Пономарев, Ю.Н. Грозеску, А.А. Бахарева. - Москва.: Издательство МОРКНИГА, 2013. - 417 c.

8. Превезенцев, Ю.А. Практикум по прудовомурыбоводству / Ю.А. Превезенцев. - Москва: Издательство Пищевая промышленность, 1982. - 23 с.

9. Сафонов, А.В. Фармакологическая характеристика и эффективность применения гумивала в птицеводстве : автореф. дис. ... канд. с.-х. наук/ А.В. Сафонов. - Воронеж, 2007.

10. Смирнова, Е.А. Влияние гумата натрия на рост, развитие и гематологические показатели молодняка свиней крупной белой породы: автореф. 
дис. канд. с.-х. наук / Е.А. Смирнова. - Кострома, 2007.

11. Торжков, Н.И. Программный комплекс «Рацион 2+» для составления и балансирования рационов для сельскохозяйственных животных / Н.И. Торжков, Ж.С. Майорова // Международный журнал экспериментального образования, 2015. № 5.

12. Шенцова, Е.С. Разработка научных и практических основ технологии биологически ценных комбикормов : автореферат дис. ... доктора техн. наук / Е.С. Шенцова. - Воронеж, 2013. - 40 с.

13. Шмаков, Н.Ф. Эффрективность добавки мидийного гидролизата в корм радужной форели [Текст]/ Н.Ф. Шмаков, Д.Н. Шмаков, И.В. Пятаков // Сб.: Вопросы физиологии и кормления рыб: материалы ВНИИПРХ. - Вып.№ 74. - Москва: Издательство ВНИИПРХ, 1999.- С. 112-119.

14. Использование добавки на основе гуминовых кислот / К.В. Корсаков, А.А. Васильев, С.П. Москаленко и др. // Птицеводство. - 2018. - №5.
- C.22-25.

15. Применение минерально-витаминных добавок при выращивании молодняка крупного рогатого скота / Л.Н. Гамко, С.И. Шепелев, С.Е. Яковлева // Вестник РГАТУ. - 2018. - № 2 (38). - С. 9-14.

16. Эффрективность использования белкового концентрата «Organic» в кормлении молодняка мясных пород в период доращивания / Б.Т. Абилов, Г.Т. Бобрышова, А.И. Зарытовский и др.// Вестник РГАТУ. - 2018. - № 2 (38). - С. 5-9.

17. Blancheton, J.P. Recent developments in recirculation systems. - Seafarming today and tomorrow: Abstracts and extended communications of contributions presented at the International conference «Aquaculture Europe 2002». - Italy, Trieste, 2002.

18. Blancheton, J.P Water quality and rainbow troutperformance in aDanish Mod-elFarm recirculating system: comparison with a flow through system. Aquacultural engineering, 2009.- Vol. 40. - № 3.

\section{DEVELOPMENT OF DIETS USING UNMODIFIED MICROPOROUS HUMIC ACIDS FROM LEONARDITE FOR CARP FEEDING}

Korovushkin Alexey A., doctor of biology and science, professor of the department of zootechnology and biology, korovuschkin@mail.ru

Nefedova Svetlana A., doctor of biology and science, professor of the department of zootechnology and biology, nefedova-s-a@mail.ru

Yakunin Yury V., art. lecturer, department of machine and tractor park operation, Yakunin0104@yandex.ru

Tunikov Gennady M., doctor of agricultural sciences, professor of the department of zootechnology and biology, university@rgatu.ru

Ryazan State Agrotechnological University Named after P.A. Kostychev

The article analyzes the development of diets using unmodified microporous humic acids from leonardite for feeding carp (Cyprinus sagrio Linnaeus). The proposed rations are effective for the trophism of juveniles, as feed enriched with humic acids from leonardite has a positive effect on fish-biological indicators, providing the necessary growth and development of carp for commercial fish farming. Youngsters of the experimental group ( $n=200)$ for the first 30 days were fed compound feed, compiled according to the developed recipe KRK-110-2, enriched with unmodified microporous humic acids due to the addition of "Reasil Humic Health" (2 $\mathrm{g}$ per $100 \mathrm{~kg}$ of live weight of fish). The same compound feed was applied to the control group, but without humic acids. In the experiment conducted under the conditions of installation of closed water efficiency (CWE) in the scientific-educational center of aquaculture and fish farming, thanks to the enrichment of feed humate extracted from lignite, the average live weight of fingerlings at the end of the experiment at a density of landing in the pool of 200 pieces, higher in the experimental group compared with the control $23.7 \%$, the average increase of $39.7 \%$, which is economically beneficial to farmers engaged in pond aquaculture. When preparing compound feeds, leonardite with the following properties should be used: unmodified microporous humic acids (78-80 \%); acidity $6.4 \mathrm{pH}$, humidity $55 \%$, ash content $12 \%$. The results of scientific development form the basis of innovative development of domestic aquaculture in the field of feed optimization, ensure the transition to advanced production technologies in pond fish farming; increase the growth and development of fish, taking into account the requirements for highly productive and environmentally friendly production.

Key words: leonardite, unmodified microporous humic acids, feed, aquaculture, carp feeding, diet.

\section{Literatura}

1. Abakin, S.S. Terapevticheskie effekty guminovyx kislot pri lechenii mikotoksikoza molodnyaka ovecz I S.S. Abakin, A.A. Grekova // Sbornik nauchnyx trudov Vserossijskogo nauchno-issledovatel'skogo instituta ovcevodstva i kozovodstva. - Stavropol': izd. Stavropol'skogo NII zhivotnovodstva i kormoproizvodstva, 2011. - S. 117.

2. Zubkova, E.B. Optimizaciya sostava kombikormov dlya osetrovyx ryb s ispol'zovaniem vitazara $i$ belkovyx gidrolizatov: avtoref. dis. ... kand. s.-x. nauk / E.B. Zubkova; Astraxan', 2001.

3. Korsakov, K.V. Preparat na osnove guminovyx kislot v racione cyplyat-brojlerov / K. V. Korsakov, A.A. Vasil'ev, E.S. Petrakov i dr. // Zootexniya. - 2018. - № 8. - S.104.

4. Mitrofanova, M.A. Biologicheskaya ocenka ispol'zovaniya raznyx karotinoidnyx preparatov $v$ sostave novyx kombikormov pri iskusstvennom vosproizvodstve osetrovyx ryb: avtoref. dis. ... kand. s.-x. nauk / M.A. Mitrofanova; Astraxan', 2005. 
5. Ozhereleva, O.N. Razrabotka i nauchnoe obosnovanie sposoba prigotovleniya ekstrudirovannyx polnoracionnix kombikormov dlya ryb osetrovyx porod: avtoref. dis. ... kand. texn. nauk / O.N. Ozherel'eva; Voronezh, 2008.

6. Ostroumova, I.N. Biologicheskie osnovy kormleniya ryb / I.N. Ostroumova. - SPb.: Izdatel'stvo GosNIORX, 2012. - 564 s.

7. Ponomarev, S.V. Korma i kormlenie ryb v akvakulture / S.V. Ponomarev, Yu.N. Grozesku, A.A. Baxareva. - Moskva.: Izdatel'stvo MORKNIGA, 2013. - 417 s.

8. Prevezencev, Yu.A. Praktikum po prudovomu rybovodstvu /Yu.A. Prevezencev. - Moskva: Izdatel'stvo Pishhevaya promyshlennost', 1982. - 23 s.

9. Safonov, A.V. Farmakologicheskaya xarakteristika i effektivnost primeneniya gumivala v pticevodstve : avtoref. dis. ... kand. s.-x. nauk/ A.V. Safonov. - Voronezh, 2007.

10. Smirnova, E.A. Vliyanie gumata natriya na rost, razvitie i gematologicheskie pokazateli molodnyaka svinej krupnoj beloj porody: avtoref. dis. ... kand. s.-x. nauk / E.A. Smirnova. - Kostroma, 2007.

11. Torzhkov, N.I. Programmnyj kompleks «Racion 2+» dlya sostavleniya i balansirovaniya racionov dlya sel'skoxozyajstvennyx zhivotnyx /N.I. Torzhkov, Zh.S. Majorova//Mezhdunarodnyj zhurnal eksperimental'nogo obrazovaniya, 2015. - № 5.

12. Shenczova, E.S. Razrabotka nauchnyx i prakticheskix osnov texnologii biologicheski cennyx kombikormov : avtoreferat dis. ... doktora texn. nauk / E.S. Shenczova. - Voronezh, 2013. - 40 s.

13. Shmakov, N.F. E'ffektivnost' dobavki midijnogo gidrolizata v korm raduzhnoj foreli / N.F. Shmakov, D.N. Shmakov, I.V. Pyatakov // Sb.: Voprosy fiziologii i kormleniya ryb: materialy` VNIIPRX. - .№ 74 . - Moskva: Izdatel'stvo VNIIPRX, 1999.- S. 112-119.

14. Ispol zovanie dobavki na osnove guminovyx kislot / K. V. Korsakov, A.A. Vasil'ev, S.P. Moskalenko i dr. // Pticevodstvo. - 2018. - №5. - S.22-25.

15. Primenenie mineral 'no-vitaminnyx dobavok pri vyrashhivanii molodnyaka krupnogo rogatogo skota / L.N. Gamko, S.I. Shepelev, S.E. Yakovleva // Vestnik RGATU. - 2018. - № 2 (38). - S. 9-14.

16. E'ffektivnost" ispol'zovaniya belkovogo koncentrata "Organic» $v$ kormlenii molodnyaka myasnyx porod v period dorashhivaniya / B.T. Abilov, G.T. Bobry`shova, A.I. Zary`tovskij i dr.// Vestnik RGATU. - 2018. - № 2 (38). - S. 5-9.

17. Blancheton J. P. Poslednie razrabotki v sistemax recirkulyacii. - Morskoe delo segodnya i zavtra: tezisy dokladov i rasshirennye soobshheniya, predstavlennye na mezhdunarodnoj konferencii «Akvakultura Evropy 2002». - Italiya, Triest, 2002.

18. Blancheton J. P, Belaud A.A. Kachestvo vody i proizvoditelnost raduzhnoj foreli $v$ datskoj sisteme recirkulyacii Mod-el Farm: sravnenie s protochnoj sistemoj. - Akvakulturnaya inzheneriya, 2009.- Tom. 40. - № 3.

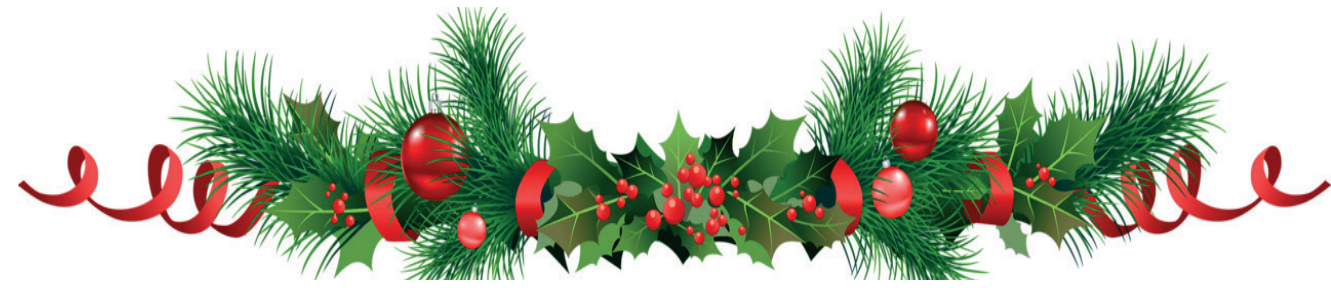

Удк 633.31

DOI 10.36508/RSATU.2019.23.24.007

ПОКРОВНЫЙ И БЕСПОКРОВНЫЙ ПОСЕВ МНОГОЛЕТНИХ ТРАВ В УСЛОВИЯХ РЕСПУБЛИКИ ТЫВА

МОНГУШ Лилия Тангытовна, старший научный сотрудник Тувинского научно-исследовательского института сельского хозяйства», lilya.mongush.60@mail.ru

В статье представлены результаты изучения разных способов посева многолетних трав. Культурные сенокосы региона на сегодняшний день являются, в основном, старовозрастными и низкоурожайными, в связи с чем создание сеяных сенокосов очень актуально. При этом способы посева трав изучены слабо. Опыт заложен в 2018 году на опытном поле ФГБНУ «Тувинский НИИСХ». Цель опыта - сравнительное изучение многолетних трав при разных способах посева в степной зоне Республики Тыва, определение влияния на их продуктивность разных покровных культур. Были посеяны многолетние травы: люцерна, эспарцет, кострец в чистом виде и в виде смеси. Посев проведен беспокровно и под покровом следующих злаковых культур: просо, овес, ячмень и суданская трава. Опыт двухфакторный: фрактор A - покровная культура, фрактор В - многолетние травы. При сравнительном изучении многолетних трав при разных способах посева в условиях степной зоны Республики Тыва установлено, что в год посева суммарный урожай зеленой массы многолетних трав и покровных культур значительно превышал урожай беспокровных посевов. Наиболее урожайным оказался вариант, где в качестве покровной культуры использовали суданскую траву (16,21 m/2а). Наименьшая урожайность зеленой массы отмечена на посевах многолетних трав без покрова (1,56 m/2а).

Ключевые слова: способ посева, покровные культуры, многолетние травы, зеленая масса, урожайность, продуктивность.

() Монгуш Л. Т., 2019г. 


\section{Введение}

Создание в условиях Республики Тыва сеяных сенокосов из многолетних трав очень актуально. В среднем по республике обеспеченность кормами одной условной головы составляет 4,5 ц. кормовых единиц, т.е. в недостаточном количестве. Кроме того, заготовленное сено относится ко второму классу. Способы посева многолетних трав изучены слабо. Поэтому был заложен опыт по покровному и беспокровному способу посева многолетних трав. Получение наибольшей продуктивности растениеводства с единицы площади посевов всегда оставалось первостепенной задачей как среди исследователей, так и практиков.

При возделывании многолетних трав под покровом культур уже в первый год пользования обеспечивается высокая урожайность с посевной площади, следовательно, и низкая себестоимость продукции. При выборе способа посева трав в конкретных условиях необходимо знать недостатки и преимущества каждого способа и выбирать в соответствии с этим наиболее приемлемый в данных условиях (с учетом природных, почвенноклиматических и хозяйственных условий). Продуктивность многолетних трав зависит от выбора покровной культуры, которая должна обладать рядом признаков, способствующих меньшему угнетению ею подпокровных трав. Подпокровный посев многолетних трав более целесообразен $[1,2,8,9,10]$. Хозяйства получают сено не только из многолетних трав, но и дополнительно сено из покровной культуры. Следовательно, в тех местах, где позволяют условия увлажнения, и где нет значительного угнетения трав со стороны покровной культуры, авторы рекомендуют применять подпокровный посев многолетних трав.

Однако, отдавая предпочтение подпокровному способу посева трав, исследователи подчеркивают, что под покровом высокоурожайных зерновых культур наблюдается массовое выпадение трав. Отсюда возникла необходимость изучения новых способов и сроков сева многолетних трав. К покровной культуре предъявляют следующие требования: неполегаемость, невысокая облиственность, ранние сроки уборки. Однако некоторые исследователи считают, что возможности растений в подпокровных посевах ограничены из-за дефицита влаги и иссушения почвы [5].

Цель исследований: сравнительное изучение многолетних трав при разных способах посева в условиях степной зоны Республики Тыва, определение влияния на их продуктивность разных покровных культур.

\section{Условия и методика проведения исследований}

Опыт по изучению различных способов посева многолетних трав был поставлен на экспериментальном поле ФГБНУ «Тувинский НИИСХ» в 2018 году.

Почва опытного участка зональная - темнокаштановая, среднесуглинистая. Содержание гумуса $-3,59 \%$ в слое 0-10 см. Почвы относительно хорошо обеспечены калием (138-222 мг/кг почвы). Содержание подвижного фосфора составляет 16 мг/кг, общего азота - 0,20\%.

Почва под опыты обработана по Зональной системе земледелия Тувинской АССР [4].

В опыте изучен посев многолетних трав с покровной культурой и без покрова. В качестве покровных культур использованы следующие злаковые культуры: просо, ячмень, овес, суданская трава. Глубина заделки мелкосеменных культур составляет 2-3 см, ячменя, овса - 6-8 см. Норма посева люцерны - 14 кг/га, эспарцета - 40 кг/га, костреца безостого - 22 кг/га. Соотношение норм посева в тройных смесях 50:25:25. Общая норма посева 25-30 кг/га. Посев проведен в 2 следа: сначала посеяны покровные культуры сеялкой СЗП-3,6, поверху проведен посев многолетних трав: люцерна, эспарцет, кострец, люцерна + эспарцет + кострец. Опыт двухфакторный: фактор А - покровная культура, фактор В - виды многолетних трав. Повторность опыта четырехкратная. Контроль - многолетние травы без покрова.

Лабораторные исследования химсостава и питательности кормов проводились в лаборатории ФГБНУ «Тувинский НИИСХ».

Наблюдения и учеты проведены по методическим указаниям Всероссийского научно-исследовательского института кормов [6]. Статистическая обработка результатов научного эксперимента проведена с помощью программ пакета Snedecor $[3,7]$. Метеорологические условия приведены по данным Сосновской метеостанции Тандынского кожууна Республики Тыва.

Вегетационный период в год закладки опыта (2018 г) характеризовался относительной засушливостью в начале роста растений и высокой увлажненностью во второй половине лета.

Дефицит атмосферных осадков наблюдался в I и III декадах июня. В июле выпало осадков на 66,3 мм выше среднемноголетней нормы. Сумма активных температур выше $5^{\circ} \mathrm{C}$ за вегетационный сезон составила 1418,4 градусов, сумма активных температур выше $10^{\circ} \mathrm{C}-742,6$ градусов.

Появление всходов однолетних злаковых культур отмечено через 10-12 дней после посева. В начале вегетации доминировали покровные культуры. Удлинение сроков появления всходов было связано с засушливыми условиями I и III декады июня, когда выпало соответственно 2,1 мм и 2,8 мм осадков за декаду, что привело к иссушению верхних слоев почвы (2,05 мм продуктивной влаги в слое 0-10 см). Малое количество осадков препятствовало своевременному появлению всходов многолетних трав.

Учет урожая зеленой массы покровных культур был проведен в начале фразы колошения. В год посева многолетних трав урожай сформировался в основном за счет покровных культур (табл. 1). Доля покровных культур варьировала от 76,50\% (эспарцет с овсом) до 91,31\% (люцерна с ячменем). 
Таблица 1 - Доля участия покровной культуры в сложении урожая, \%

\begin{tabular}{|l|c|c|c|c|}
\hline \multirow{2}{*}{\multicolumn{1}{c|}{ Виды трав }} & \multicolumn{3}{|c|}{ Доля покровной культуры } \\
\cline { 2 - 5 } & просо & ячмень & овес & суданка \\
\hline Люцерна & 83,6 & 91,3 & 78,9 & 82,7 \\
\hline Эспарцет & 78,2 & 85,1 & 76,5 & 81,9 \\
\hline Кострец & 87,2 & 86,3 & 89,2 & 88,3 \\
\hline $\begin{array}{l}\text { Люцерна+Эспарцет+ } \\
\text { Кострец }\end{array}$ & 77,4 & 80,1 & 81,3 & 82,7 \\
\hline
\end{tabular}

Наибольшая урожайность зеленой массы в среднем отмечена на посевах многолетних трав под покровом суданской травы (16,21 т/га). Доля суданки составила в среднем 82,71\%. Под покровом ячменя наблюдалось появление наименьшего количества люцерны, эспарцета и костреца, что связано с тем, что после обильных июльских осадков ячмень хорошо раскустился и затенял молодые всходы многолетних трав. Наибольшее ко-

личество всходов трав имелось под покровом суданки, что, по-видимому, связано с биологической особенностью развития суданки - с замедленным развитием её в начале роста, что способствовало быстрому появлению всходов многолетних трав без затенения. Наименьшая урожайность зеленой массы отмечена на посевах многолетних трав без покрова (от 0,72 т/га до 2,02 т/га) (табл.2).

Таблица 2 - Суммарная урожайность покровных культур и подпокровных многолетних трав І-го года жизни, т/га

\begin{tabular}{|l|c|c|c|c|c|}
\hline \multirow{2}{*}{$\begin{array}{c}\text { Покровная культура } \\
\text { (фрактор А) }\end{array}$} & \multicolumn{4}{|c|}{ Виды многолетних трав (фактор В) } & \multirow{2}{*}{ Среднее } \\
\cline { 2 - 6 } & люцерна & эспарцет & кострец & $\begin{array}{c}\text { люцерна+эспарцет } \\
\text { +кострец }\end{array}$ & 1,56 \\
\hline Беспокровно & 1,40 & 2,13 & 0,72 & 2,02 & 14,86 \\
\hline Просо & 15,54 & 16,74 & 12,9 & 14,33 & 15,52 \\
\hline Ячмень & 15,22 & 18,25 & 13,6 & 15,05 & 14,34 \\
\hline Овес & 14,0 & 14,6 & 11,65 & 17,19 & 16,21 \\
\hline Суданка & 14,5 & 18,35 & 14,25 & 17,3 & \\
\hline НСР (5\%) & \multicolumn{2}{|c|}{ фактор А - 3,203. Фактор В - 2,60. Частные - 8,65. } \\
\hline
\end{tabular}

Наименьшую урожайность зеленой массы показали многолетние травы без покрова (1,56 т/га).

По содержанию сырого протеина, кормовых единиц, обменной энергии лучшие показатели получены у бобовых многолетних трав люцерны (8,92 г, 0,58 корм. ед., 8,38 МДж) и эспарцета $(8,41$ г, 0,58 корм. ед., 8,36 МДж). Покровные культуры являются представителями семейства злаковых (мятликовых), поэтому по сравнению с многолетними бобовыми имели значимо низкие показатели по содержанию кормовых единиц (от 0,41 до 0,43), обменной энергии (от 6,64 до 6,90 МДж).

Анализ продуктивности многолетних трав при разных способах посева показал, что по фрактору А (покровная культура) сбор сухого вещества, кормовых единиц, обменной энергии достоверно выше контроля под покровом проса, суданки, овса; на уровне контроля под покровом ячменя (табл. 3).

По фактору В (виды многолетних трав) на посевах люцерны, эспарцета, костреца продуктивность сухого вещества, кормовых единиц и обменной энергии выше контроля под просом, суданкой; не значимо ниже под ячменем. На варианте из трёх компонентов (люцерна+эспарцет+кострец) все показатели достоверно выше контроля.

Таблица 3 - Продуктивность многолетних трав І-го года жизни (2018 г)

\begin{tabular}{|c|c|c|c|c|c|c|c|c|c|c|c|c|}
\hline \multirow{3}{*}{ 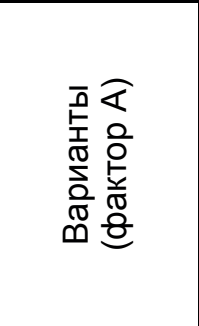 } & \multicolumn{12}{|c|}{ Виды многолетних трав (фактор В) } \\
\hline & \multicolumn{3}{|c|}{ люцерна } & \multicolumn{3}{|c|}{ эспарцет } & \multicolumn{3}{|c|}{ кострец } & \multicolumn{3}{|c|}{$\begin{array}{c}\text { люцерна+ эспар- } \\
\text { цет+ кострец }\end{array}$} \\
\hline & 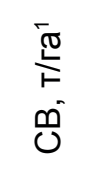 & 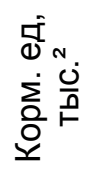 & 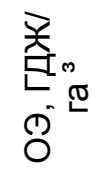 & $\begin{array}{l}\frac{\pi}{5} \\
\frac{5}{F} \\
0 \\
0\end{array}$ & 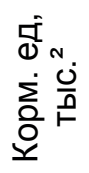 & 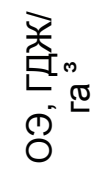 & 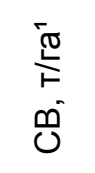 & 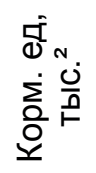 & 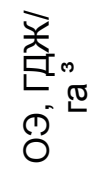 & 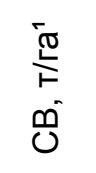 & 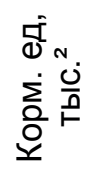 & $\begin{array}{l}\text { 흠 } \\
\text { 믄 } \\
\text { त) }^{-1} \\
0\end{array}$ \\
\hline $\begin{array}{c}\text { Беспокров- } \\
\text { но }\end{array}$ & 0,63 & 0,82 & 11,68 & 0,84 & 1,21 & 17,47 & 0,32 & 0,38 & 6,47 & 0,97 & 1,03 & 15,49 \\
\hline Просо & 1,14 & 1,51 & 21,37 & 1,43 & 2,07 & 29,92 & 0,74 & 0,87 & 14,77 & 1,58 & 1,64 & 24,79 \\
\hline Ячмень & 0,61 & 0,78 & 11,10 & 1,07 & 1,55 & 20,24 & 0,56 & 0,69 & 11,68 & 1,45 & 1,51 & 22,74 \\
\hline
\end{tabular}


Продолжение таблицы 3

\begin{tabular}{|c|c|c|c|c|c|c|c|c|c|c|c|c|}
\hline Овес & 1,34 & 1,74 & 24,76 & 1,34 & 1,95 & 28,12 & 0,94 & 1,12 & 18,88 & 1,56 & 1,66 & 24,08 \\
\hline Суданка & 1,13 & 1,75 & 20,99 & 1,30 & 1,89 & 27,29 & 0,74 & 0,88 & 14,94 & 1,49 & 1,56 & 21,70 \\
\hline HCP (5\%) & \multicolumn{5}{|c|}{$\begin{array}{l}\text { Сухое вещество } \\
\text { Фактор А - } 0,325 \\
\text { Фактор В - 0,272 } \\
\text { Частные средние - 0,878 }\end{array}$} & \multicolumn{4}{|c|}{$\begin{array}{l}\text { Кормовые единицы } \\
\text { Фактор А - 0,422 } \\
\text { Фактор В - 0,353 } \\
\text { Частные средние - 1,140 }\end{array}$} & \multicolumn{3}{|c|}{$\begin{array}{l}\text { Обменная энергия } \\
\text { Фактор А - 6,36 } \\
\text { Фактор В - 5,32 } \\
\text { Частные средние - } \\
17,17\end{array}$} \\
\hline
\end{tabular}

Примечание:

1 СВ - сухое вещество;

2 Корм. ед. - кормовые единицы;

3 ОЭ - обменная энергия.

Подпокровные посевы многолетних трав после перезимовки отрастали позднее беспокровных. Наибольшая сохранность растений отмечена на посевах без покрова (80\%), наименьшая - под покровом ячменя (45\%), что, по-видимому, связано с тем, что растения под покровом были развиты слабее, чем беспокровные, так как покровные растения сильно затеняли всходы многолетних трав. Сохранность растений после перезимовки зависела от подготовки растений к зиме и количества растений, сформированных в первый год жизни.

\section{Заключение}

При сравнительном изучении многолетних трав при разных способах посева в условиях степной зоны Республики Тыва установлено, что в первый год жизни многолетних трав суммарный урожай посеянных трав и покровных культур значительно превышает урожай беспокровных посевов. Наибольшая суммарная урожайность с покровными культурами получена на вариантах, где покровной культурой является суданская трава (16,21 т/га).

\section{Список литературы}

1. Гончаров, П. Л. Кормовые культуры Сибири (Биолого-ботанические основы возделывания). Новосибирск: Изд-во Новосиб. ун-та, 1992. - 289 с.

2. Гончаров, П. Л. Научные основы травосеяния в Сибири. - М. : Агропромиздат, 1986. - 288 с.
3. Доспехов, Б. А. Методика полевого опыта. М.: Колос, 1985. - 267 с.

4. Зональная система земледелия Тувинской АССР. - Новосибирск : Сиб. отд-ние ВАСХНИЛ, 1982. $182 \mathrm{c}$.

5. Кшникаткина, А. Н. Влияние покровных культур на продуктивность клевера паннонского (Trifollium pannonicum Jago) в лесостепи Среднего Поволжья / А. Н. Кшникаткина, А. С Игнатьев // Нива Поволжья. - 2012. - №3 (24). - С. 3-8.

6. Методические указания по проведению опытов с кормовыми культурами. М.: ВНИИ кормов им. В.Р. Вильямса, 1987. - 82 с.

7. Сорокин, О. Д. Прикладная статистика на компьютере. - Краснообск : РПО СО РАСХН, 2004. -162 c.

8. Сурин, Н. А. Перспективные культуры и сорта бобовых многолетних трав для создания сенокосов в условиях Республики Тыва / Н. А. Сурин, Л. Т. Монгуш // Сибирский вестник сельскохозяйственной науки. - 2014. - №3. - С. 38-43.

9. Тюльдюков, В. А. Интенсивное использование многолетних трав и травосмесей в Нечерноземной зоне РСФСР. - М. : Изд-во МСХА, 1992. - 96 с.

10. Юрцовский, М. А. Система уплотненного использования пашни. - М.: Колос, 1967. - 200 с.

\section{INTEGUMENTARY AND BLOODLESS CROP OF LONG-TERM GRASSES IN CONDITIONS OF REPUBLIC TUVA}

Mongush Liliya Tangytovna, senior scientific employee Tuvinian Scientific Research institute of Agriculture, lilya.mongush.60@mail.ru.

In clause the results of study of different ways of crop of long-term grasses are submitted. The basic part of cultural haymakings of region for today are old-age and low-yielding, in this connection the creation seeded of haymakings is very urgent. Thus ways of crop of grasses are investigated poorly. Experience is incorporated in 2018 on skilled-experimental field FSBSI Tuvinian SRIA. The purpose of researches: comparative studying of long-term grasses at different ways of crop in conditions of a steppe zone of Republic Tuva, definition of influence on their efficiency of different integumentary cultures. Long-term grasses were sown: lucerne, sainfoin, rump in the pure state and as a mix. Crop is carried out bloodless and under a cover of the following cereal cultures: millet, овec, barley and a Sudanese grass. Experience two-factorial: the factor A - integumentary culture, the factor B - long-term grasses. At comparative study of long-term grasses at different ways of crop in conditions of a steppe zone of Republic Tuva is established, that per year of crop the total crop of green weight of long-term grasses and integumentary of cultures considerably exceeded a crop bloodless of crops. Most fruitful has appeared variant, where in quality integumentary of culture used sudanese a grass $(16,21 \mathrm{t} /$ ha). The least productivity of green weight is marked on crops of long-term grasses without a cover (1,56 t/ha).

Key words: a way of crop, integumentary cultures, long-term grasses, green weight, productivity, efficiency. 


\section{Literatura}

1. Goncharov P.L. Kormovye kultury Sibiri (Biologo-botaniheskie osnovy vozdelyvania). Novosibirsk: Izd-vo Novosib. un-ta, 1992. 289 s. 4.

2. Goncharov P.L Nauchnye osnovy travoseania v Sibiri. M.: Agropromizdat, 1986. $288 \mathrm{~s}$.

3. Dospehob B.A. Metodika polevogo opyta. M.: Kolos. 1985. $267 \mathrm{~s}$.

4. Zonalnaa sistema zemledeliya Tuvinskoy ASSR. Novosibirsk: Sib. otd-nie VASHNIL. 1982. $182 \mathrm{~s}$.

5. Kshnikatkina A.N., Ignatev A.S. Vlianie pokrovnyh kultur na produktivnost klevera pannonskogo (Trifollium pannonicum Jago) v lesostepi Srednego Povolgya / Niva Povolgya. 2012. №3 (24). S. 3-8.

6. Metodicheskie ukazania po provedeniu opytov s kormovymi kulturami. M.: VNII kormov im. V.R. Vilamsa. 1987. $82 \mathrm{~s}$.

7. Sorokin O.D. Prikladnaa statistika na komputere. Krasnoobsk: RPO SO RASHN. 2004. $162 \mathrm{s.}$

8. Surin, N.A. Perspektivnye kultury i sorta bobovyh mnogoletnih trav dla sozdania senokosov $v$ usloviah Respubliki Tyva // Sibirskii vestnik selskohozaistvennoy nauki. 2014. №3. S. 38-43.

9. Tuldikov V.A. Intensivnoe ispolzovanie mnogoletnih trav i travosmesey $v$ Nechernozemnoy zone RSFSR. M.: Izd-vo MSHA, 1992. $96 \mathrm{~s}$.

10. Yurcovskiy M.A. Sistema uplotnennogo ispolzovania pashni. M.: Kolos, 1967. 200 s.

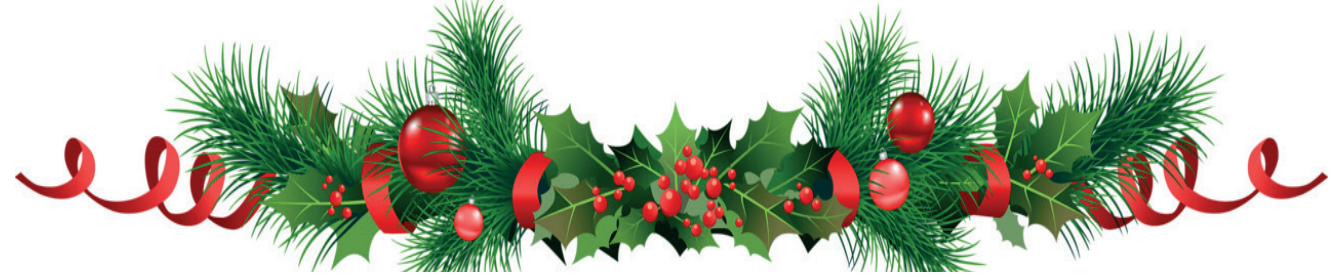

УДК 620.3:631.8

DOI 10.36508/RSATU.2019.32.87.008

\section{ВЛИЯНИЕ СТРОЕНИЯ НАНОЧАСТИЦ НА МЕХАНИЗМ ИХ ВЗАИМОДЕЙСТВИЯ С ЖИВЫМИ СИСТЕМАМИ}

полищук Светлана Дмитриевна, д-р техн. наук, профрессор кафееры лесного дела, агрохимии и экологии, Рязанский государственный агротехнологический университет имени П.А. Костычева, svpolishuk@mail.ru

ЧУРИЛОВ Геннадий Иванович, д-р биол. наук, профрессор кафедры общей и фрармацевтической химии, Рязанский государственный медицинский университет имени академика И.П. Павлова,genchurilov@yandex.ru

чурИЛОв Дмитрий Геннадьевич, канд. техн. наук, доцент кафредры технологии металлов и ремонта машин, churilov.dmitry@yandex.ru

чУРИЛОВА Вероника Вячеславовна, ассистент кафедры лесного дела, агрохимии и экологии, veronicka.churilova@yandex.ru

АРАПОВ Илья Сергеевич, аспирант кафедры технологии металлов и ремонта машин, arapow. ilya@yandex.ru

ЛОМОВА Юлия Валерьевна, канд. вет. наук, доцент кафеедры эпизоотологии, микробиологии и паразитологии, u.v.lomova@mail.ru

Рязанский государственный агротехнологический университет имени П.А. Костычева

Исследование выполнено при фринансовой поддержке РФФИ в рамках научного проекта № 18-3300510.

Биологическая активность наночастиц зависит от фризико-химических характеристик частиц. Химическое взаимодействие наночастии с жидкой средой, по-нашему мнению, является одним из определяющих фракторов их биологической активности. Изменение $\mathrm{pH}$ среды за счет высокой восстановительной способности наночастии повышает проницаемость мембран, способствуя биоаккумуляции наночастиц или усилению их биосовместимости. Данная способность зависит от той инфоормации (тех свойств), которой обладают частицы разных размеров, состава и фризико-химических характеристик. Высокой биологической активностью обладают наночастицы металлов железа, кобальта, меди размером 35-60 нм в количестве 0,01-10,0 г на тонну семян, полученные низкотемпературной металлизацией нанодисперсных порошков гидроксидов. Наночастицы оксидов металлов размером 20-80 нм снижают рост и развитие растений, и в отличие от наночастиц металлов, они аккумулируются в структурах растений, понижая активность фритогормонов и фрерментов. При этом аномальная дозовая зависимость эфрфекта в области сверхнизких концентраций биологически активных веществ зарегистрирована на уровне ответа не только клетки или целостного организма (растения), но и отдельных биомакромолекул (фрерментов). В наших исследованиях мы обнаружили, что всякий раз при введении сверхмалых доз биологически активного вещества в организм животного, клеточную культуру или в модельную систему, содержащую суспензию

(С) Полищук С. Д.. Чурилов Г. И., Чурилов Д. Г., Чурилова В. В., Арапов И. С., Ломова Ю. В., 2019 г. 
мембран, отмечается изменение структурных характеристик мембран. В свою очередь изменения структуры мембран могут приводить к изменению фрунционального состояния клетки, а наличие полимодальности в ответе можно объяснить сменой механизма действия вещества в том или ином концентрационном интервале на структуру мембраны.

Ключевые слова: наночастицы, биологическая активность, биоакуммуляция,зависимость «доза-эфффект»

\section{Введение}

Характер наблюдаемых нами уже в течение 10 лет биологических эффректов: изменение морфофизиологических показателей роста и развития растений; активности ферментов и фритогормонов [1-4]; показателей окислительной модификации белков [5-8], вызываемых различными по площади удельной поверхности и физико-химическим свойствам наночастицами, указывает, что причинами этих явлений являются процессы, связанные с действием определенного регуляторного сигнала в биологических системах. Все живые организмы обладают единообразно устроенной системой, функция которой заключается в восприятии, считывании, распространении и уничтожении информации, постоянно поступающей извне. Биологический эффект должен быть связан с передачей информации, универсальной для любых биологических объектов, которая с высокой степенью надежности функционирует в системе: это агент (препарат) - клетка и ее структуры, и этим требованиям удовлетворяют мембрана и система надмолекулярных структур микроокружения клетки.

Малыми и сверхмалыми дозами считают дозы, эффрективность которых нельзя объяснить с помощью традиционных представлений [9-11], следовательно, сами наночастицы микроэлементов и их оксидов, для которых характерны квантовомеханические свойства, можно отнести к «малым или сверхмалым». Для наночастиц металлов наблюдается одно из характерных свойств эффекта - МД-колебательный характер дозовой зависимости величины наблюдаемых показателей, а также наличие "мертвой зоны" (интервала доз между двумя пиками биологических эффектов, в котором не проявляется биологическая активность. Это обусловлено, на наш взгляд, волновым характером распространения пространственных перестроек проницаемости мембран и надмолекулярных структур под влиянием энергетического воздействия наночастиц, повышающих концентрацию протонов.

При определении данного явления в случае сверхнизких концентраций биологически активных веществ интересной является идея о параметрическом резонансе [12], которая нашла подтверждение в наших работах. Речь идет как о возможном механизме действия наночастиц на клеточном и субклеточном уровнях. Параметрический резонанс возникает при совпадении временных параметров запускаемых биологически активными веществами внутриклеточных процессов и характерного времени подхода вещества к мишени. В результате связывания активного вещества с его мишенью фермент (рецептор) переходит в конформационно неравновесное состояние, ко- торое на определенной стадии обеспечивает его максимальную активность.В рамках этих представлений находит свое объяснение и наблюдаемое нами уменьшение активности фермента при возрастании дозы действующего вещества.

В работе [13] рассматриваются представления об аллостерическом взаимодействии каталитических центров в молекуле фрермента. Если фермент или рецептор содержит несколько центров с разным сродством к субстрату, то, когда вводятся низкие дозы препарата, его молекулы преимущественно связываются с высокоэффективным центром фермента. При увеличении дозы в действие вступает второй ферментный центр. Он взаимодействует аллостерически с первым центром, понижая его сродство к субстрату, и тогда все молекулы, которые были связаны с первым центром, сходят с него. Снова с ним связаться они могут только после того, как концентрация препарата приблизится к значению константы диссоциации комплекса лиганда с первым центром, достигнутой под воздействием второго центра. Следовательно, биологическая система, испытывающая влияние МД, может реагировать на первые, наиболее быстрые единичные молекулы, а не на их стационарные концентрации (момент первого достижения). Считаем, что в основе биологических эффектов, производимых наночастицами, лежит поэтапное изменение пространственной организации специализированных надмолекулярных структур микроокружения клетки и ее цитоплазмы (ВКМ, плазматическая мембрана, цитоскелет, ядерный матрикс), для каждой из которых выявлена и доказана значимость в протекании важнейших биологических процессов.

Биологическая активность наночастиц зависит от многих фракторов, в том числе размера и способности накапливаться или биосовместимости. Было изучено влияние наночастиц металлов $\mathrm{Cu}$, $\mathrm{Co}, \mathrm{Fe}, \mathrm{Zn}$, а также их оксидов.

При определении влияния наночастиц металлов $\mathrm{Cu}, \mathrm{Co}, \mathrm{Fe}, \mathrm{Zn}$, полученных низкотемпературной металлизацией [14], на рост и развитие растений (вика, горчица, пшеница, огурец) было доказано, что они проявляют высокую биологическую активность в интервале концентраций 0,01-100 г/т (тонну семян), проявляя одинаковую закономерность. Величина активности зависит от площади удельной поверхности и размеров. Частицы размером до 20 нм показывают более высокую активность при низких концентрациях до 5 г/т (тонну семян). Для таких размеров наночастиц при 0,05 г/т относительно контроля возрастают энергия прорастания на 16-20\%; всхожесть на 14$16 \%$; длина надземной части - до $60 \%$, подземной $-128 \%$. Это намного выше, чем для частиц с более 
высоким размером (35-60 нм) при той же концентрации: $10-12 \%, 8-14 \%, 37 \%-40 \%, 18-25 \%$ соответственно. Через трое суток масса ростка возрастает на $65 \%$, на 7-й день - на 21\%; корешка - на $65 \%$ (третьи сутки) и 70\% (7-е сутки); для размеров 3560 нм -повышение массы ростков и корешков на 3-е сутки составило соответственно 15,4\% и 39\%.

Причем, если наночастицы металлов размером 20 нм активны в пределах концентраций 0,0110 г/т (рисунки 1,2), то у частиц размером 40-60 нм активность сохраняется до 100 г/т и даже при концентрациях 500 г/т угнетения растений не происходит (рис.3).

Теоретические и экспериментальные исследования малых частиц показывают, что размер частиц является активной переменной, определяю- щей состояние системы. Наночастицы меньших размеров имеют высокую величину поверхности раздела. Как следствие, такие нанообъекты проявляют высокую физико-химическую активность. Объекты исследования - энергия прорастания семян и их морфо-физиологические показатели. Результаты показывают, что «малые» дозы более эфффективны, поскольку у организмов, видимо, нет системы защиты от них и их сигнал в большей степени стимулирует процессы прорастания семян. В области «малых» доз на единицу массы семян эффект влияния значительно выше, чем при «больших» дозах, но усиление эффректа влияния наночастиц с повышением концентрации идет до определенного предела.

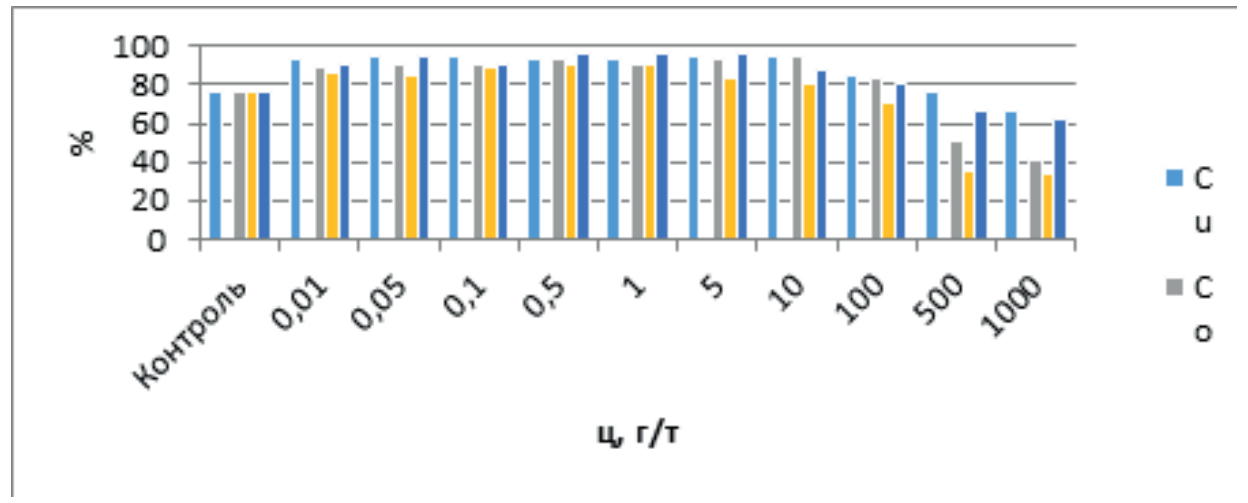

Рис. 1 - Энергия прорастания семян горчицы при воздействии наночастиц размером 20 нм

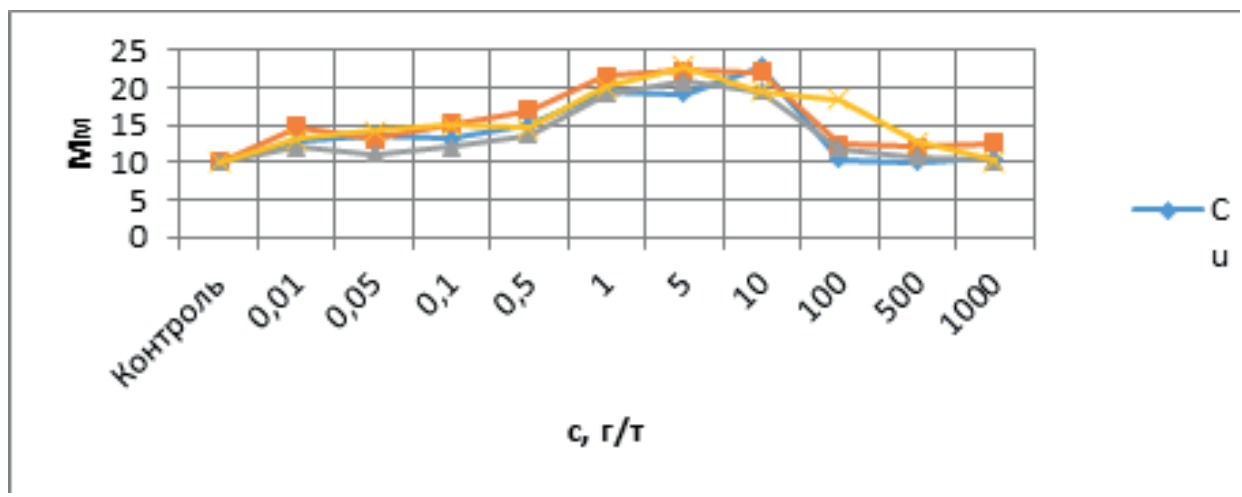

Рис. 2 - Длина 5-ти дневных проростков горчицы привоздействии наночастиц размером 20 нм

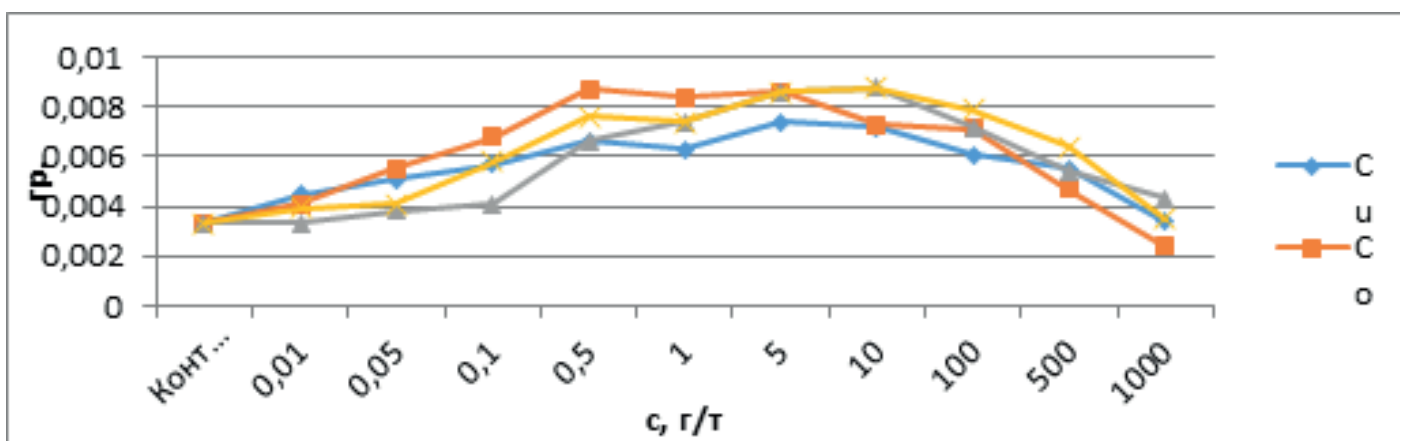

Рис. 3 - Масса проростков 5-ти дневных проростков горчицы при воздействии наночастиц размером 35-60 нм 


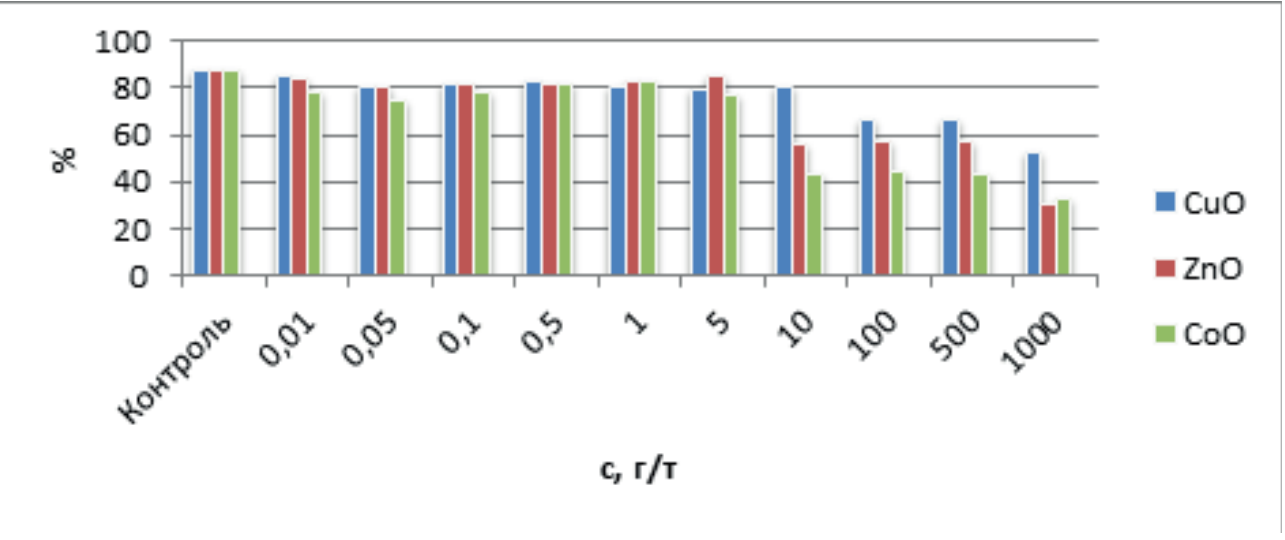

Рис. 4 - Энергия прорастания семян горчицы при воздействии наночастиц оксидов размером 20-60 нм

Оксиды меди, цинка, кобальта размером 20-60 нм угнетают рост и развитие растений (рис.4).

Для оксидов в отличие от металлов при проведении электронно-микроскопического анализа с помощью просвечивающего электронного микроскопа [15] было зафиксировано, что после обра- ботки растений коллоидными растворами наночастиц разных размеров в небольшом количестве они концентрируются на поверхности растений (рис. 5) и накапливаются в структуре растений (рис. 6,7).

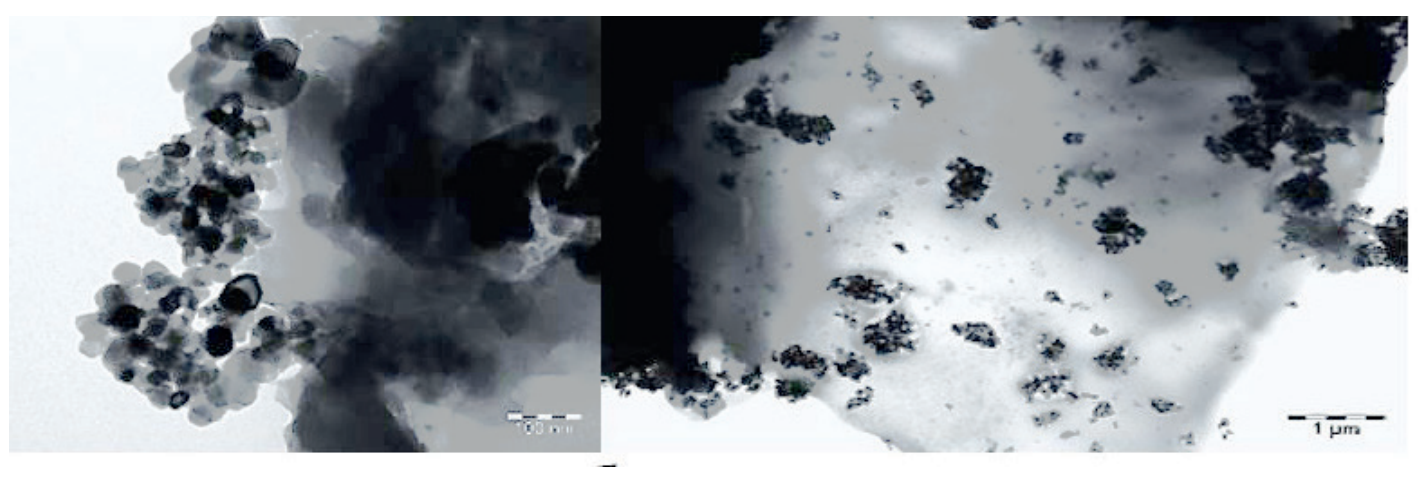

Рис. 5 - Электронно-микроскопическое изображение наночастиц на поверхности растений непосредственно после обработки

На фоотографиях видно, что наночастицы оксидов внутри биообъектов находятся в виде агрегатов, т.е. они склонны к образованию плотных агломератов сложной формы размером порядка 200-300 нм. Вероятно, это объясняется образованием «корон» из биологических макромолекул вокруг чужеродных частиц, при этом получаются сложные молекулярные комплексы, обладающие низкой агрегационной устойчивостью. Чем ниже размер наночастиц, тем выше степень агрегатизации. Это предполагает соблюдение мер предосто- рожности при их практическом использовании в составе нанопрепаратов. Оксиды, как было показано ранее, или в меньшей степени чем металлы стимулируют рост растений, или замедляют его (оксиды меди, цинка, железа и кобальта) и причиной может быть их аккумуляция, что не характерно для наночастиц металлов.

Все представленные фотографии сделаны с вершковой части горчицы, в корешках проращенных семян горчицы наночастиц не обнаружено (табл.1).

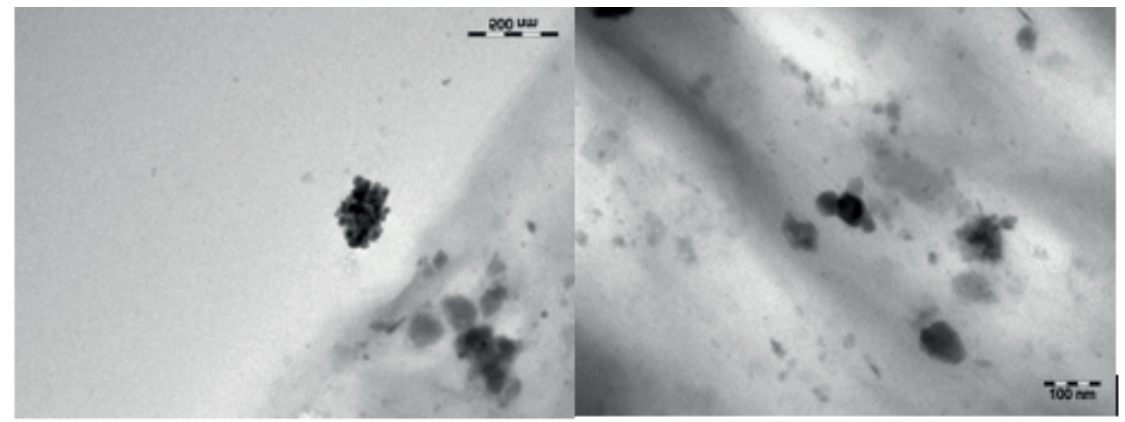

Рис. 6 - Фотографии вершков пророщенной горчицы с видимыми включениями наночастиц оксида цинка 


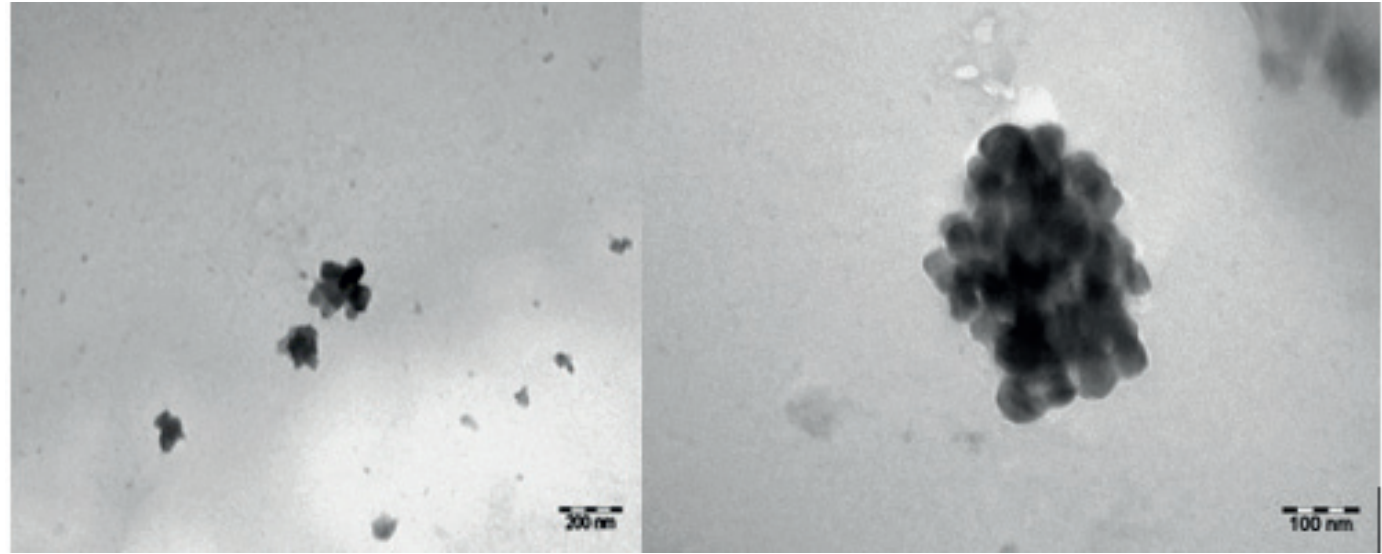

Рис. 7 - Фотография вершков пророщенной горчицы с видимыми включениями наночастиц оксида меди

Таблица 1- Качественный анализ наличия наночастиц в высших растениях «+»- обнаружены, «-»- не обнаружены

\begin{tabular}{|l|l|l|l|l|}
\hline \multicolumn{2}{|c|}{ Объект } & $\mathrm{CuO}$ & $\mathrm{CoO}$ & $\mathrm{ZnO}$ \\
\hline \multirow{2}{*}{ Горчица } & вершки & + & + & + \\
\cline { 2 - 5 } & корешки & - & - & - \\
\hline \multirow{2}{*}{ Пшеница } & вершки & + & - & + \\
\cline { 2 - 5 } & корешки & - & + & + \\
\hline \multirow{2}{*}{ Огурец } & вершки & + & + & + \\
\cline { 2 - 5 } & корешки & - & - & - \\
\hline \multirow{2}{*}{ Вика } & вершки & + & + & + \\
\cline { 2 - 5 } & корешки & - & - & - \\
\hline
\end{tabular}

Изменение $\mathrm{pH}$ среды за счет высокой восстановительной способности наночастиц, видимо, повышает проницаемость мембран, способствуя биоаккумуляции наночастиц или усилению их биосовместимости. Данная способность зависит от той информации (тех свойств), которой обладают частицы разных размеров, состава и физико-химических характеристик. Согласно результатам наших работ наночастицы металлов и оксидов различаются по характеру воздействия.

Как и в случае анализа морфофиизологических показателей, активность ферментов соответствует нормальному развитию растений в присутствии наночастиц металлов размером 20 нм до концентрации 10 г/т, а при размерах частиц 35-60 нм - до 100 г/т, далее происходит угнетение. Комплексное исследование влияния различных концентраций и размеров наночастиц на активность трех ферментов-антиоксидантов (СОД, каталазы и пероксидазы) [16-19]позволило установить: активность пероксидазы при максимальных морфофизиологических показателях высокая и снижается в «мертвых зонах» как при низких, так и высоких концентрациях наночастиц металлов. Активность СОД и каталазы в исследуемых культурах достоверно снижалась в условиях максимальных морфофизиологических показателей и резко возрастала при концентрациях больше 100 г/т для наночастиц размером 35-60 нм, и выше 10 г/т при размере до 20 нм.

Для наночастиц размером 35-60 нм пределом устойчивости служит концентрация намного выше 100г/т;дляразмеровдо10нм-винтервале 10-100г/т.

Активность ферментов для наночастиц оксидов меди, кобальта и цинка размером 20-60 нм увеличивается, и отклонения от контроля имеют значения меньше $30 \%$, то есть они безопасны для развития растений только в пределах концентраций 0,001-1,0 г/т. При более высоких концентрациях (больше 10,0 г/т) отклонения активности относительно контроля выше 30\%, что свидетельствует о начале угнетения роста и развития растений. Следует контролировать содержание и накопление наночастиц оксидов в окружающей среде, так как высокие концентрации могут быть опасными, тем более, что они накапливаются и возможна их передача в пищевых цепях. При одинаковой концентрации наночастиц активность ферментов различается и по месту определения - корни, ростки.

Малый размер наночастиц (не более 100 нм) позволяет им проходить через биологические мембраны, накапливаться во внутренней среде, возможно, опосредованно влиять на геном митохондрий (мтДНК), что в свою очередь запускает или замедляет механизм биосинтеза митохондриальных белков-фрерментов и, как следствие, активацию энергетических процессов. Большая удельная поверхность наночастиц маленьких размеров повышает химический потенциал на межфазных границах и приводит к увеличению проходимости и высокой реакционной способности. Химическое взаимодействие наночастиц с жидкой средой является, по-нашему мнению, одним из определяющих факторов их биологической активности; изменение $\mathrm{pH}$ среды за счет высокой восстановительной способности наночастиц, видимо, повышает проницаемость мембран, способствуя биоаккумуляции наночастиц (в случае оксид) или усилению их биосовместимости. Данная способность зависит от той информации (тех свойств), которой обладают частицы разных размеров, состава и физико-химических характеристик.

На разных этапах развития и роста растений соотношение фитогормонов меняется как в ростках, так и в корнях под влиянием различных 
факторов внешней среды. Такие изменения корректируют направление и скорость роста растительных организмов. Гормоны моделируют весь процесс развития растения, могут изменять его направление, оказывая действие на ферменты, регулирующие активность других гормонов.Было изучено действие наночастиц металлов кобальта, железа, цинка, меди и оксидов меди, цинка и кобальта на активность фитогормонов цитокининов (ЦК), гибберелловой (ГК), абсцизовой (АБК), индолилуксусной (ИУК) кислот горчицы белой, выращенных в песочном субстрате в течение месяца. Наночастицы металлов обладают практически одинаковыми физическими характеристиками, но разными химическими, и их действие различается количественным содержанием, но характер эффективности действия одинаков.

В интервале концентраций 0,001-10,0 г/т под действием наночастиц металлов содержание ИУК возрастает. Так как с увеличением количества ИУК усиливается содержание в клетках АТФ [2024] и коэфффициент, показывающий соотношение фосфорилирования и окисления, следовательно, при этих концентрациях наночастиц возрастает энергетическая эффрективность дыхания растений, и это приводит к большим изменениям активности различных фрерментативных реакций. Наночастицы должны усиливать передвижения питательных веществ и воды, что является одной из причин усиления роста растений, которое мы наблюдали в предыдущих опытах. Далее значения ИУК уменьшаются, приближаясь к контрольным показателям. Увеличение содержания гибберелловой, абсцизовой и индолилуксусной кислот сохраняется до концентрации 10 г/т, причем наиболее интенсивно при увеличении концентрации наночастиц размером 30-60 нм. Такие выводы достоверно характерны и для действия наночастиц кобальта, меди, цинка и железа.

Для наночастиц размером до 20 нм в целом наблюдается аналогичная зависимость: доза (концентрация)-эффрект (активность фритогормонов) - как в случае частиц размером 35-60 нм; при этом более высокая активность ЦК, ГК и ИУК относительно контроля характерна при более низких концентрациях 0,01-1,0 г/т и эти изменения выше, чем для наночастиц размером 35-60 нм. Следует отметить, что количество абсцизовой кислоты практически не изменяется, зависимость доза-эффект для данного гормона отсутствует. Наиболее высокая активность ИУК наблюдается в пределах концентраций наночастиц кобальта размером 3560 нм 1-10 г/т; для размера до 10 нм активность смещается в сторону меньших концентраций 0,1-1,0 г/т, при этих концентрациях возрастает активность остальных фитогормонов при уменьшении содержания АБК.

При контакте семян с наночастицами оксида меди, цинка и кобальта количество АБК увеличивается относительно контроля. При концентрации 1,0 г/т - на 11,0\%, а при 10,0 г/т - на 40,9\%. Также и основные морфофизиологические показатели при 100 г/т изменяют свои значения от 32 до 53\%, что подтверждает ранее сделанный вывод об опасности применения оксидов в концентрациях выше 10,0 г/т.

\section{Заключение}

Если учесть, что наночастицы, как мы предполагаем, являются источником дополнительного количества протонов и информации, которую получают клетки от высокоэнергетических наночастиц через мембранные или цитоплазматические рецепторы, то эти факторы должны приводить к изменению гормонального статуса в клетках, стимулировать или подавлять активность тех или иных эндогенных фитогормонов. А информация зависит от размеров, состава и концентрации наночастиц. Биологически активные наночастицы, действуя на уровень фитогормонов, могут влиять на состояние биомембран и опосредованно выступать регулятором белоксинтезирующих клеток растений. Наночастицы оксидов аккумулируются в структуре растений, что доказано методами СЭМ и ПЭМ, причиной чего являются:

- высокая их адгезия к поверхностям живых систем;

- отрицательный заряд и размер наночастиц. Стенки растений полупроницаемы, диаметр пор в стенках клетки составляет 5-20 нм и это позволяет мигрировать маленьким молекулам. Но пропускная способность может меняться, так как могут образовываться новые каналы под действием наночастиц, проходящих через мембраны клеток;

- устойчивое образование агломератов, которые эффрективнее задерживаются в клетках растений, понижая рост и развитие растений.

\section{Список литературы}

1. ChurilovG.I., PolischukS.D., KuznetsovDenis., BorychevS.N., ByshovN.V. Churilov D.G. Agro ecological grounding for the application of metalnanopowders in agriculture//Int. J. Nanotechnol. 2018. Vol. 15, Nos. 4/5. PP. 258-279

2. Полищук С.Д, Обидина И.В., Чурилов Д.Г., Чурилова В.В., Чурилов Г.И. Морфологические показатели ростков риса, обработанных ультрадисперсным порошком железа//Вестник РГАТУ. 2018. № 4 (40). C.36-41

3.Чурилов Д.Г., Горохова М.Н., Бударина Г.И., Полищук С.Д., Бакунин И.В.

Особенности роста и развития кукурузы и подсолнечника при обработке семян наночастицами кобальта.// Труды ГОСНИТИ. 2011. Т. 107. № 2. С. 46-48

4.GennadyChurilov, Quoc Buu Ngo, Hoai Chau Nguyen. Physiological and Biochemical Effects of Nanocrystalline Metals on maize plant // Proceeding of 4th International Workshop on Advanced Materials and NanoScience, 2013. Nov 12-14. PP. $282-285$

5. Муравлева Л.Е. [и др.] Окислительная модификация белков: проблемы и перспективы исследования // Фундаментальные исследования 2010. - № 1. - С.74-78.

6. Губский Ю.И. [и др.]. Токсикологические последствия окислительной модификации белков при различных патологических состояниях// Co- 
временные проблемы токсикологии, т.8, № 3. 2005. - c.20-27.

7. Толочко 3.С., Спиридонов В.К. Окислительная модификация белков в крови крыс при повреждении капсаицин-чувствительных нервов и изменении уровня оксида азота. // Российский фиизиологический журнал им. И.М. Сеченова. - Т.96, № 1. - 2010. - с.77-84.

8.Абаленихина Ю.В., Фомина М.А., Чурилов Г.И., Иванычева Ю.Н. Активность катепсинов тимуса крыс под влиянием меди в ультрадисперсной форме. Научное обозрение. 2012, № 5, С 76-82

9.Бурлакова Е. Б., Конрадов А. А., Мальцева Е. Л. Действие сверхмалых доз биологически активных веществ и низкоинтенсивных фризических фракторов

//Химическая фризика». 2003. Т. 22, № 2.

10. Зайцев, С.В., Ефанов, А.М., Сазанов, Л.А. Общие закономерности и возможные механизмы действия биологически активных веществ в сверхмалых дозах // Рос. хим. ж. -1999 - T. XLIII, № 5 - C. 28-33.

11.Бурлакова Е.Б., Конрадов А.А., Мальцева Е.Л. Действие сверхмалых доз биологически активных веществ и низкоинтенсивных фризических фракторов // Проблемы регуляции в биологических системах. Биофизические аспекты / под общей ред. А.Б. Рубина. - М.-Ижевск: НИЦ «Регулярная и хаотическая динамика», Институт компьютерных исследований, 2007. - С. 390-423.

12.Блюменфельд Л .А. Параметрический резонанс как возможный механизм действия сверхнизких концентраций биологически активных веществ на клеточном и субклеточном уровнях // Биофизика. - 1993. -Вып. 1. - С. 129-132.

13.Блюменфельд, Л.А. Понятие конструкции в биологической физике. К вопросу о механизме действия сверхмалых доз // Рос. хим. ж. $-1999-$ Т. XLIII, № 5 - C. 15-20.

14. Арсентьева И.П., Дзидзигури Э.Л. и др.,Закономерности строения и биологическая активность нанопорошков железа// Перспективные материалы. -2004.- 2004.-№4.- С.64-66

15.Векилова, Г.В. Дифракционные и микроскопические методы и приборы для анализа наночастици наноматериалов/ Г.В. Векилова, А.Н. Иванов, Ю.Д. Ягодкин: Москва,

МИСиС. - 2009. - 145 с.

16. Бояркин А.Н. Быстрый метод определения активности пероксидазы // Биохимия. - 1951. - Т. 16, Вып. 4. -С. 352.

17.Ермаков, А.И. Методы биохимического исследования растений/ А.И.Ермаков, В.В. Арасимович, Н.П Ярош.,Ю.В.Перуанский, Г.А.Луковникова, М.И. Иконникова. - Л.: Агропромиздат, 1987. - С. 43-44.

18..Аверьянов, А.А. Активные формы кислорода и иммунитет растений/ А.А. Аверьянов // Успехи современной биологии.- 1991. -Т. 111. - № 5. - С. 722-737.

19.Полищук С.Д, Обидина И.В., Чурилов Д.Г., Чурилова В.В., Чурилов Г.И. Морфологические показатели ростков риса, обработанных ультрадисперсным порошком железа//Вестник РГАТУ. 2018. № 4 (40). C.36-41

20.Кулаева, О.Н. Гормональная регуляция фризиологических процессов у растений на уровне РНК и белка /О.Н Кулаева, - М: Наука, 1982.- 351 с.

21. Скулачев В.П. Законы биоэнергетики/ Скулачев В.П. // Соросовский Образовательный Журнал.-1997.-№ 1.-С. 9-14.

22. Романовский Ю.М., Тихонов А.Н. Молекулярные преобразователи живой клетки. Протонная АТФ-синтаза - вращающийся мотор./ Романовский Ю.М., Тихонов А.Н. //Успехи фиизических наук. - 2010. - Том 180. - №9. - С 932-956.

23. Курсанов, А.Л. Внутренняя организация фризиологических процессов у растений / А.Л. Курсанов // Ученый и аудитория. - М: Наука, 1982. - С. 145-161 c.

24.Макроносов, А.Т. Интеграция функций роста и фотосинтеза/ А.Т. Макроносов // Физиология растений. 1983.- Вып. 5.- Т.30- С. 868-880.

\section{THE INFLUENCE OF THE STRUCTURE OF NANOPARTICLES ON THE MECHANISM OF THEIR INTERACTION WITH LIVING SYSTEMS}

Polischuk Svetlana D., Doctor of Technical Science, Professor, Department of Forestry, Agrochemistry and Ecology, Ryazan State Agrotechnological University Named after P.A. Kostychev, svpolishuk@mail.ru

Churilov Gennadiy I., Doctor of Biological Science, Professor, Department of General Chemistry, Ryazan State Medical University Named after Academician I.P. Pavlov, genchurilov@yandex.ru

Churilov Dmitriy G., Candidate of Technical Science, Associate Professor, Department of Metal Technology and Machine Repair, churilov.dmitry@yandex.ru

Churilova Veronika V., Assistant, Department of Forestry, Agrochemistry and Ecology, veronicka. churilova@yandex.ru

Arapov Ilya S., Post Graduate Student, Department of Metal Technology and Machine Repair, arapow. ilya@yandex.ru.

Lomova Julia V., Candidate of Veterinary Science, Associate Professor of the Department of Epizootology, Microbiology and Parasitology, u.v.lomova@mail.ru

Ryazan State Agrotechnological University Named after P.A. Kostychev

The biological activity of nanoparticles depends on the physical-chemical characteristics of the particles. The chemical interaction of nanoparticles with a liquid medium, in our opinion, is one of the determining factors in their biological activity. A change in the $\mathrm{pH}$ of the medium due to the high reducing ажжжжжbility of nanoparticles increases the permeability of membranes, promoting bio-accumulation of nanoparticles or enhancing their 
bio-compatibility. This ability depends on the information (those properties) of particles of different sizes, their composition and physical-chemical characteristics. Metal nanoparticles of iron, cobalt, copper of 35-60 nm in the amount of 0.01-10.0 g per ton of seeds, obtained by low-temperature metallization of nanodispersed hydroxide powders, possess high biological activity. Nanoparticles of metal oxides with a size of 20-80 nm reduce plant growth and development, and unlike metal nanoparticles, they accumulate in plant structures, reducing the activity of phytohormones and enzymes. In this case, an abnormal dose dependence of the effect of ultra-low concentrations of biologically active substances is recorded at the level of response not only of the cell or the whole organism (plant), but also of individual bio-macromolecules (enzymes). The studies showed that every time an ultra-low dose of a biologically active substance is introduced into an animal, a cell culture, or into a model system containing a suspension of membranes, a change in the structural characteristics of the membranes is noted. In turn, changes in the structure of membranes can lead to a change in the functional state of the cell, and the presence of polymodality in the response can be explained by a change in the mechanism of action of a substance in a particular concentration range on the membrane structure.

Key words: nanoparticles, biological activity, bioaccumulation, dose-effect relationship

\section{Literatura}

1. Churilov G.I., Polischuk S.D., Kuznetsov Denis., Borychev S.N., Byshov N.V. Churilov D.G. Agro ecological grounding for the application of metal nanopowders in agriculture//Int. J. Nanotechnol. 2018. Vol. 15, Nos. 4/5. RR. 258-279

2. Polishhuk S.D, Obidina I.V., CHurilov D.G., CHurilova V.V., CHurilov G.I. Morfologicheskie pokazateli rostkov risa, obrabotannyh ul'tradispersnym poroshkom zheleza//Vestnik RGATU. 2018. № 4 (40). S.36-41

3.CHurilov D.G., Gorohova M.N., Budarina G.I., Polishhuk S.D., Bakunin I.V.

Osobennosti rosta i razvitija kukuruzy i podsolnechnika pri obrabotke semjan nanochasticami kobal'ta.// Trudy GOSNITI. 2011. T. 107. № 2. S. 46-48

4.Gennady Churilov, Quoc Buu Ngo, Hoai Chau Nguyen. Physiological and Biochemical Effects of Nanocrystalline Metals on maize plant // Proceeding of 4th International Workshop on Advanced Materials and NanoScience, 2013. Nov 12-14. RR. $282-285$

5. Muravleva L.E. [i dr.] Okislitel'naja modifikacija belkov: problemy i perspektivy issledovanija // Fundamental'nye issledovanija - 2010. - № 1. - S.74-78.

6. Gubskij JU.I. [i dr.]. Toksikologicheskie posledstvija okislitel'noj modifikacii belkov pri razlichnyh patologicheskih sostojanijah// Sovremennye problemy toksikologii, t.8, № 3. - 2005. - s.20-27.

7. Tolochko Z.S., Spiridonov V.K. Okislitel'naja modifikacija belkov v krovi krys pri povrezhdenii kapsaicinchuvstvitel'nyh nervov i izmenenii urovnja oksida azota. // Rossijskij fiziologicheskij zhurnal im. I.M. Sechenova. - T.96, № 1. - 2010. - s.77-84.

8.Abalenihina JU.V., Fomina M.A., CHurilov G.I., Ivanycheva JU.N. Aktivnost' katepsinov timusa krys pod vlijaniem medi v ul'tradispersnoj forme. Nauchnoe obozrenie. 2012, № 5, S 76-82

9.Burlakova E. B., Konradov A. A., Mal'ceva E. L. Dejstvie sverhmalyh doz biologicheski aktivnyh veshhestv i nizkointensivnyh fizicheskih faktorov

//Himicheskaja fizika». 2003. T. 22, № 2.

10. Zajcev, S.V., Efanov, A.M., Sazanov, L.A. Obshhie zakonomernosti i vozmozhnye mehanizmy dejstvija biologicheski aktivnyh veshhestv v sverhmalyh dozah // Ros. him. zh. $-1999-$ T. XLIII, № 5-S. $28-33$.

11. Burlakova E.B., Konradov A.A., Mal'ceva E.L. Dejstvie sverhmalyh doz biologicheski aktivnyh veshhestv i nizkointensivnyh fizicheskih faktorov // Problemy reguljacii v biologicheskih sistemah. Biofizicheskie aspekty / pod obshhej red. A.B. Rubina. - M.-Izhevsk: NIC «Reguljarnaja i haoticheskaja dinamika», Institut komp'juternyh issledovanij, 2007. - S. 390-423.

12.Bljumenfel'd L.A. Parametricheskij rezonans kak vozmozhnyj mehanizm dejstvija sverhnizkih koncentracij biologicheski aktivnyh veshhestv na kletochnom i subkletochnom urovnjah // Biofizika. - 1993. -Vyp. 1. - S. 129-132.

13.Bljumenfel'd, L.A. Ponjatie konstrukcii v biologicheskoj fizike. $K$ voprosu o mehanizme dejstvija sverhmalyh doz // Ros. him. zh. -1999- T. XLIII, № 5 - S. 15-20.

14. Arsent'eva I.P., Dzidziguri JE.L. i dr.,Zakonomernosti stroenija i biologicheskaja aktivnost' nanoporoshkov zheleza// Perspektivnye materialy. -2004.- 2004.-№4.- S.64-66

15. Vekilova, G.V. Difrakcionnye i mikroskopicheskie metody i pribory dlja analiza

nanochastici nanomaterialov/ G.V. Vekilova, A.N. Ivanov, JU.D. JAgodkin: Moskva,

MISiS. - 2009. - 145 s.

16. Bojarkin A.N. Bystryj metod opredelenija aktivnosti peroksidazy // Biohimija. - 1951. - T. 16, Vyp. 4. $-S .352$.

17.Ermakov, A.I. Metody biohimicheskogo issledovanija rastenij/ A.I.Ermakov, V.V. Arasimovich, N.P JArosh., JU.V.Peruanskij, G.A.Lukovnikova, M.I. Ikonnikova. - L.: Agropromizdat, 1987. - S. 43-44.

18..Aver'janov, A.A. Aktivnye formy kisloroda i immunitet rastenij/ A.A. Aver'janov // Uspehi sovremennoj biologii.- 1991. -T. 111. - № 5. - S. 722-737.

19.Polishhuk S.D, Obidina I.V., CHurilov D.G., CHurilova V.V., CHurilov G.I. Morfologicheskie pokazateli rostkov risa, obrabotannyh ul'tradispersnym poroshkom zheleza//Vestnik RGATU. 2018. № 4 (40). S.36-41 
20. Kulaeva, O.N. Gormonal'naja reguljacija fiziologicheskih processov u rastenij na urovne RNK i belka /O.N Kulaeva, - M: Nauka, 1982.- 351 s.

21. Skulachev V.P. Zakony biojenergetiki/ Skulachev V.P. // Sorosovskij Obrazovatel'nyj ZHurnal.-1997.-№ 1.-S. 9-14.

22. Romanovskij JU.M., Tihonov A.N. Molekuljarnye preobrazovateli zhivoj kletki. Protonnaja ATF-sintaza - vrashhajushhijsja motor./ Romanovskij JU.M., Tihonov A.N. I/Uspehi fizicheskih nauk. - 2010. - Tom 180. №9. - S 932-956.

23. Kursanov, A.L. Vnutrennjaja organizacija fiziologicheskih processov u rastenij /A.L. Kursanov // Uchenyj i auditorija. - M: Nauka, 1982. - S. 145-161 s.

24.Makronosov, A.T. Integracija funkcij rosta i fotosinteza/ A.T. Makronosov // Fiziologija rastenij. 1983.Vyp. 5.- T.30- S. $868-880$.

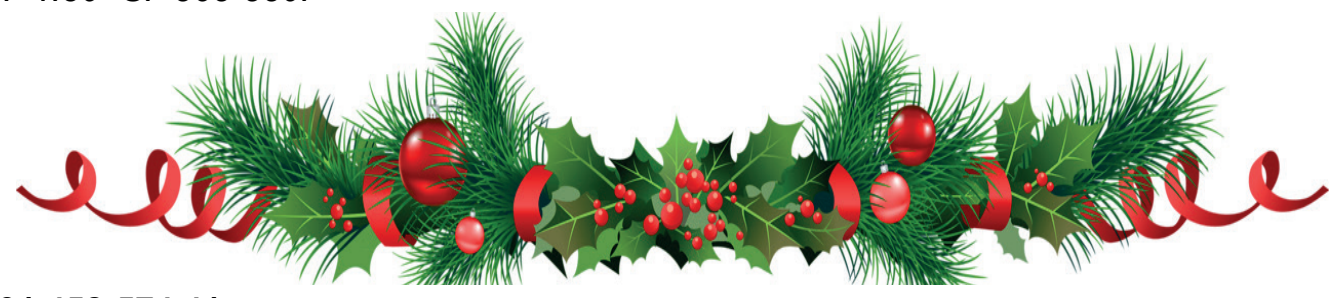

УдК 631.452:574.41

DOI 10.36508/RSATU.2019.68.67.009

ОРГАНИЧЕСКИЕ УДОБРЕНИЯ КАК ФАКТОР ПОВЫШЕНИЯ ПЛОДОРОДИЯ ПОЧВЫ И ЭФФЕКТИВНОСТИ РАСТЕНИЕВОДСТВА

САВИНА Ольга Васильевна, д-р с.-х. наук, профрессор кафедры маркетинга и товароведения,

Savina-999@mail.ru

МАКАРОВ Валентин Алексеевич, д-р техн. наук, профрессор кафеедры организации транспортных процессов и безопасноти жизнедеятельности, va_makarov@rambler.ru

Рязанский государственный агротехнологический университет имени П.А. Костычева, va_ makarov@rambler.ru

МАКАРОВА Ольга Владимировна, д-р экон. наук, профрессор кафредры экономики и менеджмента,

Академия права и управления (Академия ФСИН России, г. Рязань, $m \_o v \_2302 @ b k . r u$

ГАСПАРЯн Светлана Валентиновна, канд. экон. наук, доцент, Академия права и управления (Академия ФСИН России), г. Рязань, gasparyan.svetlana@yandex.ru

Целью работы явились теоретические и практические разработки по системному применению органических удобрений и мероприятий для поддержания бездефицитного баланса гумуса в севообороте, представляющие научно-прикладной интерес для повышения эфффективности растениеводства. Органические удобрения являются одним из основных средств производства Российского земледелия, средством, получаемым из собственных источников, которые уже в течение нескольких столетий улучшают плодородие почвы и повышают её продуктивность. Они играют решающую роль в поступлении органических и питательных веществ в почву. В современном земледелии постоянно осуществляется воспроизводство всех показателей плодородия почв до приведения их в состояние, близкое к параметрам модели плодородия для данного типа и вида почв. Однако первостепенное значение принадлежит воспроизводству наиболее важных из них. Таким важным интегральным показателем является наличие в почве сельскохозяйственного назначения органического вещества - гумуса. Оно в этом случае рассматривается как вещественно-энергетическая и структурно-экологическая основа плодородия почвы. Эфффективное развитие земледелия неразрывно связано с системным применением удобрений и постоянным совершенствованием технологий их внесения при возделывании сельскохозяйственных культур. Для решения этой задачи предлагается разработанная авторами методика применения органических удобрений в системе задач по производству продукции растениеводства и мероприятий для поддержания бездефицитного баланса гумуса в севообороте. При составлении баланса питательных веществ учитываются дозы внесения органических удобрений и вынос по основной удобряемой культуре. Приводятся схема по балансу питательных веществ с использованием удобрений в севообороте, а также классификационная характеристика качества навоза и химический состав соломы. В выводах показано, что основным показателем эфффективности питательных веществ является количество валовой продукции, полученной от действия удобрений.

Ключевые слова: почва, гумус, органические удобрения, бездесрицитный баланс.

\section{Введение}

Продовольственная и экономическая безопасность России зависит от состояния такого уникального природного ресурса как земля (почва). Состояние почвы определяет в конечном итоге уровень качества жизни человека. В сельском хозяйстве почва и растения - огромная химико-биологическая машина, которая работает, используя бесплатную энергию солнца, а почва представляет собой бесплатную, данную природой, огромную производственную силу.

Важнейший показатель плодородия почв за-

(C) Савина О. В., Макаров В. А., Макарова О. В., Гаспорян С. В., 2019 г. 
ключается в содержании в ней органического вещества (гумуса). Гумус - это основной показатель плодородия почвы, самый главный, только ей присущий компонент и необходимый элемент минерального питания сельскохозяйственных культур. При разложении гумуса растения в определённой степени обеспечиваются питательными веществами - продуктами его распада.

Главным звеном в пополнении почвы новым количеством гумуса является углерод. Содержание гумуса в пахотном горизонте почвы считается стабильным показателем, но на многих почвах, особенно интенсивно обрабатываемых, да ещё и с промывным водным режимом, динамика содержания его в почве весьма подвижна. При содержании гумуса в пахотном слое почвы от 50 до 150-200 т/га ежегодные его потери могут достигать 2-2,5 т/га. Поэтому в системе земледелия необходимо исходить из реальных возможностей воспроизводства органического вещества в пахотных горизонтах почвы. Наиболее эфффективно эти возможности реализуются при долговременном систематическом воздействии комплекса практических приёмов по воспроизводству органического вещества $[6,7]$.

Безусловно, для расширенного воспроизводства плодородия почвы большое значение имеют процессы ведения сельского хозяйства с положительным балансом гумуса, а для того, чтобы управлять этим балансом, необходимо знать его приходные и расходные статьи. Исследованиями по данному вопросу установлено, что основными приходными статьями гумуса являются его накопление при гумификации пожнивных и растительных остатков и внесении органических удобрений, а основными расходными статьями являются минерализация и потери, связанные с системой обработки почвы, питанием растений и с эрозией почвы [1-6].

Установлено, что падение гумуса в почвах на $10-20 \%$ приводит к снижению урожайности сельскохозяйственных культур на 20-50\%, а уменьшение содержания гумуса более чем на $50 \%$ вызывает снижение урожайности на $60-80 \%[6,8]$.

Основной причиной, вызывающей снижение содержания гумуса, является нарушение круговорота органических веществ в почве, заключающееся в недостаточности объёмов применения органических удобрений.

Наличие легкодоступных растениям питательных веществ, внесённых с органическими удобрениями, делает их похожими на минеральные удобрения, однако процесс использования питательных веществ в них более длителен, что и объясняет их последействие, создаёт возможность внесения, в зависимости от типов почвы, один раз в несколько лет.

Недостаток питательных веществ, внесённых с органическими удобрениями для удовлетворения потребности растений под планируемую урожайность, должен восполняться дополнительным внесением минеральных удобрений.

Вместе с тем установлено, что длительное и одностороннее применение отдельных видов ми- неральных удобрений негативно воздействует на агрофизические свойства почвы. Так, систематическое применение на почвах только одних минеральных удобрений приводит к снижению общей и капиллярной влагоёмкости почвы, содержанию в ней водоносных агрегатов, повышению кислотности, а также накоплению нитратов как в почве, так и самих растениях [5].

За последние 10 лет применение минеральных удобрений в России несколько выросло, но и сегодня до пиковых значений 25-летней давности еще достаточно далеко. Сегодня в России на гектар пашни с применением минеральных удобрений приходится до 38 кг действующего вещества, в то время как в развитых странах Европы и США оно достигает порядка 130-140 кг [10].

Всё это приводит к тому, что в последние годы содержание гумуса в почвах сокращается, и в среднем по России доля пашни с низким его содержанием увеличилась на 4,5\%. Одной из существенных причин падения гумуса в пашне является ежегодное снижение количества вносимых органических удобрений. Статистика показывает, что объём внесения органических удобрений с 2001-2016 гг. снизился с 60,6 млн тонн до 48,3 млн тонн в год [10].

Регулирование круговорота веществ в земледелии с учётом расширенного воспроизводства плодородия почв тесно связано с применением агрохимических средств. Иного пути поддержания высокого плодородия пахотных земель нет.

\section{Материал и методы исследования}

Целью работы явились теоретические разработки по системному применению органических удобрений и мероприятий для поддержания бездефицитного баланса гумуса в севообороте, представляющие научно-прикладной интерес для повышения эфффективности растениеводства. Эффрективное развитие земледелия неразрывно связано с системным применением удобрений и постоянным совершенствованием технологий их внесения при возделывании сельскохозяйственных культур. Для решения этой задачи предлагается разработанная авторами модель применения органических удобрений в системе задач по производству продукции растениеводства и мероприятий для поддержания бездефицитного баланса гумуса в севообороте. При составлении баланса питательных веществ учитываются дозы внесения органических удобрений и вынос по основной удобряемой культуре.

Приводится схема по балансу питательных веществ с использованием удобрений в севообороте, а также классификационная характеристика качества навоза и химический состав соломы. Дозы внесения органических удобрений зависят от требований возделываемых культурных растений, типов почвы, удобрений предшествующей культуры и сроков их внесения, сроков и способов обработки почвы, а также климатических условий и ряда других причин.

При программировании урожайности сельскохозяйственных культур используются два принципиальных подхода к расчету доз применения 
удобрений: балансовый, основанный на учете использования растениями питательных веществ из почвы и удобрений; статистический, основанный на анализе многолетних экспериментальных данных и результатов агрохимических опытов с удобрениями [6].

При проектировании урожайности и расчёта доз применяемых удобрений используются следующие данные:

- вынос питательных веществ (кг) из почвы на одну тонну основной продукции удобряемой культуры;

- коэффрициенты использования элементов питания из органических удобрений удобряемой культурой;

- данные по содержанию элементов питания в почве по результатам исследований агрохимической лаборатории и картограммам содержания этих элементов питания;

- планируемая урожайность и средний фактический полученный урожай за последние 5 лет.

\section{Результаты и их обсуждение}

Эфффективность удобрений, степень их воздействия на урожай, преимущественное влияние того или иного элемента питания на продуктивность сельскохозяйственных культур зависят от сложного комплекса факторов. Производственные и экономические составляющие современного сельскохозяйственного производства и проблемы охраны окружающей среды возродили интерес к применению одного из старейших средств химизации в земледелии - органических удобрений. Более ответственное отношение к органическим удобрениям вызвано также тем, что плодородие наших почв и особенно «старая» сила почвы требуют существенного улучшения.

Роль органических удобрений в современном земледелии значительно возрастает в связи с происходящими процессами минерализации органического вещества, что обусловлено широким внедрением пропашной системы, уплотняющим воздействием на почву при работе тяжёлых машин и механизмов, сокращением посева многолетних трав, снижением уровня применения минеральных удобрений и других средств химизации, а также постоянно происходящими эрозионными процессами.

Подтверждением сказанному выше являются данные исследований ряда научно-исследовательских институтов, учреждений и организаций, где результаты периодических почвенных обследований проектно-изыскательскими станциями показали, что отмечается общее снижение гумусированности почв - основы её плодородия и продуктивности.

Достижение бездефицитного и положительного баланса гумуса неразрывно связано с увеличением объёмов использования органических удобрений на основе применения всех видов органического сырья, обеспечивающих строгое соблюдение хозяйственно-биологического круговорота в земледелии, высокую их окупаемость при сохранении экологически чистой окружающей среды.

Объём поглощённых растениями питательных веществ, отвечающих требованиям культур в севообороте для бездефицитного баланса гумуса, отражает общую потребность их в питательных веществах $[1,6]$. Расчёт обеспечения этой потребности элементами минерального питания учитывает лишь реализацию питательных веществ, вынесенных растениями. Считается, что питательные вещества органических удобрений обогащают почву, однако в балансе питательных веществ в севообороте при возделывании сельскохозяйственных культур они не всегда учитываются агрономической службой.

Такой подход к планированию поступления питательных веществ в почву не всегда отвечает требованиям, предъявляемым к системе земледелия, поскольку:

- общий уровень поступления питательных веществ от применения только минеральных удобрений является относительно высоким, а их эффективность постоянно снижается;

- постоянное применение высоких доз минеральных удобрений приводит к тому, что многие хозяйства не заботятся о применении органических удобрений и не принимают меры к повышению их качества и эффрективной отдачи от них.

Поэтому одна из основных задач Российского земледелия заключается в проведении мероприятий, ведущих к увеличению объёмов и более эффективному использованию органических удобрений, повышению их качества и, следовательно, к росту эффективной отдачи от использования минеральных удобрений.

На содержание действующего вещества в органических удобрениях существенное влияние оказывают следующие факторы:

- выход органических удобрений с ферм и комплексов;

- технология их приготовления к внесению:

- содержание полученных питательных веществ в этих удобрениях;

- количество легкодоступных для растений питательных веществ и его соотношение с питательными элементами, связанными с органическим веществом, особенно с азотом (табл. 1).

- условия применения, которые характеризуются сроками внесения, механическим составом почвы, потребностями культуры или севообороTOM.

В первую очередь в каждом севообороте необходимо определять потребность почвы в органических веществах. Для обеспечения этой потребности необходимо создать условия для производства органических удобрений и на основе анализа конкретных данных определить возможное поступление органических веществ в почву севооборота.

Дефицит в балансе органических веществ необходимо устранить, например, запашкой соломы или соломы с зелёным удобрением [11]; если этого недостаточно, необходимо перевезти органические удобрения с "чужих", но территориально наиболее выгодно расположенных, ферм, где имеется излишек органических веществ. 
Таблица 1 - Количество связанного азота в органических удобрениях [11]

\begin{tabular}{|c|c|c|c|}
\hline $\begin{array}{l}\text { Органическое } \\
\text { удобрение }\end{array}$ & $\begin{array}{c}\text { Качество органиче- } \\
\text { ских веществ }\end{array}$ & $\begin{array}{c}\text { Среднее содержание азота в } \\
\text { органическом удобрении, \% }\end{array}$ & $\begin{array}{l}\text { Доля азота, связанного в ор- } \\
\text { ганических веществах, \% }\end{array}$ \\
\hline Навозная жижа & $\begin{array}{c}\text { Легкоразлагающи- } \\
\text { еся }\end{array}$ & 0,23 & 10 \\
\hline $\begin{array}{c}\text { Бесподстилоч- } \\
\text { ный навоз }\end{array}$ & $\begin{array}{c}\text { Легкоразлагающи- } \\
\text { еся }\end{array}$ & 0,41 & $40-50$ \\
\hline Навоз & Нестабильные & 0,42 & 65 \\
\hline Компост & Стабильные & 0,39 & 90 \\
\hline Солома & Неразложившиеся & 0,43 & 100 \\
\hline
\end{tabular}

Выход питательных веществ (кг) в органических удобрениях определяют следующим образом.

- Содержание питательных элементов в органических веществах в процентах умножают на 1000 кг и делят на 100, получая содержание питательных элементов (кг) в одной тонне органических веществ (кг/га).

- Коэфффициент перевода используют при расчёте содержания произведенных и особенно действующих питательных веществ, внесённых в виде органических удобрений, в том случае, когда ориентировочное их содержание по плану применения удобрений равно единице.

Количество действующего вещества, возмещённое в общей потребности в питательных веществах органическими удобрениями, устанавливается на основе потребности в азоте. Однако одновременно в балансе питательных веществ определяют содержание фоссфора и калия в самих органических удобрениях.

Эфрфективность органических удобрений зависит от действующего вещества и содержания азота, связанного с органическим веществом, и, следовательно, от условий применения удобрений. Чем больше определённый вид органических удобрений содержит азота в легкодоступной (усвояемой) для растений форме, тем больше требуется обращать внимание на механический состав почвы и сроки внесения удобрений. С этим связано также прямое действие и последействие NPK в органических удобрениях, что отражено в общем балансе и поступлении питательных веществ в почву.

На рисунке приведена схема по балансу питательных веществ с использованием удобрений в севообороте.

После составления схемы по балансу питательных веществ определяют потребность пашни в органических веществах по установленным нормативам, соответствующим механическому составу почвы и концентрации отдельных культур в севообороте (в диапазоне от 0 до 3 т/га): в начале для отдельных полей, участков определённых территорий (т в сумме или т/га); затем для всей территории (т или т/га).

Устанавливают возможность обеспечения потребности пашни в органических веществах доступными органическими удобрениями (т или т/га). Для учета качества органических удобрений используют данные по классификационной характеристике качества навоза и химическому составу соломы, приведенные в таблицах 2,3.

Расчётным путём устанавливают балансовую разность (т или т/га). Решают вопрос о распределении органических удобрений между отдельными севооборотами данного хозяйства.

Дополнительные источники органических веществ - солому, торф, зелёное удобрение - используют в случае, когда:

- обнаружен дефицит органических веществ;

- выявлена необходимость повышенного поступления органических веществ в почву (даже при положительном балансе) и необходимо:

a) внести бесподстилочный навоз совместно с зелёными удобрениями (при наличии больших площадей легких почв, чтобы ускорить круговорот углерода и мобилизацию азота);

б) эфффективно использовать тройное сочетание органических удобрений (солома + зеленое удобрение + бесподстилочный навоз или навозная жижа), особенно при большой площади низко плодородных почв или при рекультивации.

Большему накоплению органического вещества в почве способствует уплотнение севооборотов промежуточными посевами и использование зелёной массы растений на удобрение. Изучение запашки в паровом поле различных сидератов в НИИСХ Северного Зауралья показало, что наибольшее количество органического вещества попало в почву с надземной массой и корнями клевера (10 т/га, что лишь на 2,2 т/га меньше, чем при внесении 40 т/га навоза) по сравнению с люпином и донником. При этом в зелёной массе сидерата содержание азота в 2-2,5 раза больше, чем в навозе, а фоссрора и калия - примерно одинаковое с ним $[2,3]$. 
Таблица 2 - Классификационная характеристика качества навоза [11]

\begin{tabular}{|c|c|c|c|}
\hline \multirow{2}{*}{$\begin{array}{l}\text { Показатели } \\
\text { качества }\end{array}$} & \multicolumn{3}{|c|}{ Классность } \\
\hline & 1 & 11 & 111 \\
\hline Сухое вещество,\% & 24 & 22 & 19 \\
\hline Органические & 19 & 17 & 14 \\
\hline $\mathrm{N}_{\text {общий }}$ & 0,56 & 0,48 & 0,29 \\
\hline $\mathrm{N}_{\mathrm{NH} 4}$ & 0,20 & 0,19 & 0,12 \\
\hline $\mathrm{P} / \mathrm{P}_{2}^{4} 05$ & $0,14 / 0,32$ & $0,11 / 0,24$ & $0,07 / 0,15$ \\
\hline $\mathrm{K} / \mathrm{K}_{2}^{2} \mathrm{O}$ & $0,58 / 0,70$ & $0,37 / 0,52$ & $0,25 / 0,35$ \\
\hline $\mathrm{Ca} / \mathrm{Ca} O$ & $0,43 / 0,60$ & $0,37 / 0,52$ & $0,25 / 0,35$ \\
\hline $\mathrm{Mg} / \mathrm{MgO}$ & $0,06 / 0,10$ & $0,05 / 0,08$ & $0,01 / 0,06$ \\
\hline $\mathrm{Na} / \mathrm{Na}_{2} \mathrm{O}$ & $0,15 / 0,20$ & $0,12 / 0,16$ & $0,10 / 0,13$ \\
\hline $\mathrm{pH}$ & 7,0 & 7,0 & 6,7 \\
\hline
\end{tabular}

Таблица 3 - Химический состав различных видов соломы [11]

\begin{tabular}{|c|c|c|c|c|c|c|c|c|c|c|c|}
\hline \multirow{3}{*}{ Солома } & \multicolumn{11}{|c|}{ Содержание в свежем виде, \% } \\
\hline & \multirow{2}{*}{$\begin{array}{l}\text { Сухое } \\
\text { веще- } \\
\text { ство }\end{array}$} & \multirow{2}{*}{$\begin{array}{c}\text { Органи- } \\
\text { ческие } \\
\text { вещества }\end{array}$} & \multirow{2}{*}{$\begin{array}{c}\text { Азот } \\
(\mathrm{N})\end{array}$} & \multicolumn{2}{|c|}{ Фосфрор } & \multicolumn{2}{|c|}{ Калий } & \multicolumn{2}{|c|}{ Кальций } & \multicolumn{2}{|c|}{ Магний } \\
\hline & & & & $P$ & $\mathrm{P}_{2} \mathrm{O}_{5}$ & K & $\mathrm{K}_{2} \mathrm{O}$ & $\mathrm{Ca}$ & $\mathrm{CaO}$ & $\mathrm{Mg}$ & $\mathrm{MgO}$ \\
\hline Пшеничн & 86 & 82 & 0,45 & 0,07 & 0,16 & 0,064 & 0,77 & 0,21 & 0,29 & 0,07 & 0,12 \\
\hline Ржан & 86 & 82 & 0,34 & 0,07 & 0,16 & 0,56 & 0,68 & 0,33 & 0,46 & 0,05 & 0,08 \\
\hline Ячменная & 86 & 82 & 0,50 & 0,08 & 0,18 & 1,01 & 1,22 & 0,28 & 0,39 & 0,05 & 0,08 \\
\hline Овсяная & 86 & 82 & 0,42 & 0,13 & 0,29 & 1,20 & 1,45 & 0,24 & 0,34 & 0,07 & 0,12 \\
\hline В среднем & 86 & 82 & 0,43 & 0,09 & 0,21 & 0,85 & 1,03 & 0,24 & 0,34 & 0,06 & 0,10 \\
\hline Кукурузная & 85 & 80 & 0,49 & 0,16 & 0,36 & 1,35 & 1,63 & 0,33 & 0,47 & 0,14 & 0,24 \\
\hline Рапсовая & 84 & 80 & 0,58 & 0,11 & 0,24 & 0,91 & 1,10 & 0,82 & 1,15 & 0,14 & 0,23 \\
\hline $\begin{array}{l}\text { Зернобобо- } \\
\text { вых культур }\end{array}$ & 88 & 80 & 1,34 & 0,14 & 0,32 & 1,12 & 1,35 & 0,89 & 1,25 & 0,15 & 0,25 \\
\hline
\end{tabular}

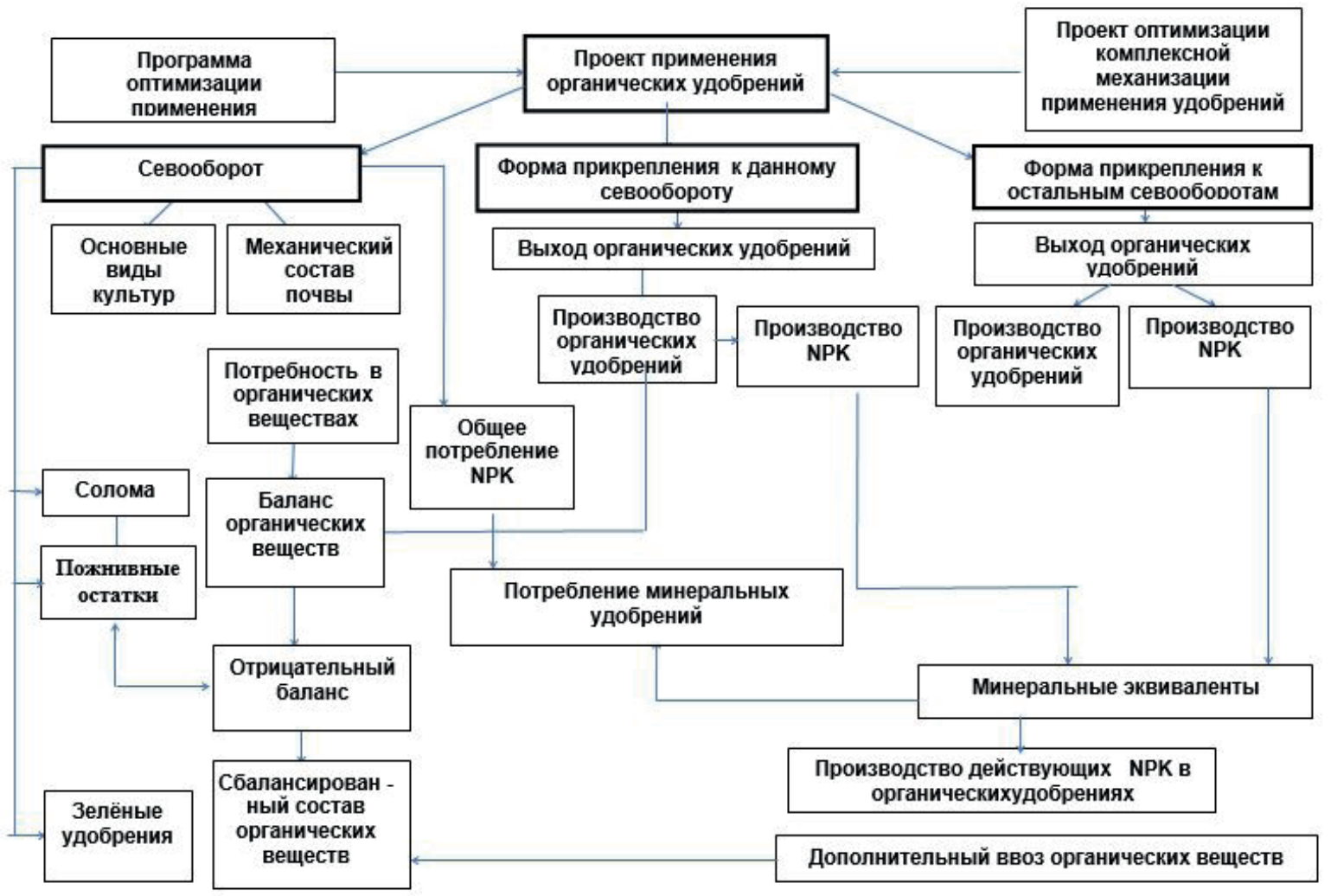

Рис. - Установление баланса питательных веществ в севообороте путем использования удобрений 


\section{Заключение}

Основным показателем эфффективности использования питательных веществ из органических и минеральных удобрений является количество валовой продукции растениеводства или урожайность сухой массы культур, полученная под действием удобрений. Предложенная модель установления баланса питательных веществ в севообороте с использованием удобрений может быть использована в практической деятельности производителей растениеводческой продукции. Эти данные позволяют уточнить так называемый производственный (количество зерновых единиц на 1 кг N) или урожайный (кг сухого вещества на 1 кг N) эфффект от внесённых или усвоенных растениями питательных веществ, особенно азота, и в перспективе также количество полученной продукции растениеводства.

\section{Список литературы}

1. Концепция оптимизации органического вещества почв в агроландшафтах / В. И. Кирюшин, Н. Ф. Ганжара, И. С. Кауричев [и др.]. - М. : Изд. MCXA, 1993. - 96 c.

2.Крупенников, И. А. Чернозёмы и экологическое земледелие / И. А. Крупенников, Б. П. Боинчан. - Бельцъ, 2004. - 168 с.

3.Лыков, А. М. Органическое вещество пахотных почв Нечерноземья / А. М. Лыков, А. И. Уськов, М. Н. Новиков. - М. : РАСХН, 2004. - 730 с.

4. Биологизация земледелия в Нечернозёмной зоне / М. Н. Новиков, В. М. Тежилин, О. А. Самохина [и др.]. - Владимир : ВНИПТИОУ, 2004. - 260 с.

5.Расширенное воспроизводство плодородия почв в интенсивном земледелии Нечерноземья / под ред. Н. З. Милащенко. - М. : ВИУА, 1993. -864 с.

6.Лошаков, В. Г. Севооборот и плодородие почвы. - М. : ВНИИА, 2012. - 512 с.

7.Шкарда, М. Производство и применение ор- ганических удобрений / пер. с чешского. - М. : Агропромиздат, 1985 . - $564 \mathrm{c}$.

8. Макаров, В. А. К вопросу производства органических удобрений в системе повышения плодородия почв / В. А. Макаров, С. В. Гаспарян // Проблемы механизации агрохимического обеспечения сельского хозяйства : сб. науч. тр. по материалам круглого стола Всероссийского совещания руководителей агрохимических служб Минсельхоза России / ФГБГУ ВНИМС. - Рязань : ФГБНУ BНИМС, 2016. - C.79-85.

9. Макаров. В. А. Обоснование организационных форм потребности в удобрениях для зернопродуктового подкомплекса / В. А. Макаров С. В. Гаспарян // Проблемы механизации агрохимического обеспечения сельского хозяйства: сб. науч. тр. / ФГБНУ ВНИМС - Рязань: ФГБНУ ВНИМС, 2017. - C.222-230.

10.Чекмарёв, П. А. Система удобрения в условиях биологизации земледелия / П. А. Чекмарёв, С. В. Лукин // Достижения науки и техники АПК. 2012. - №14. - С. 10-12.

11. Макаров, В.А. Повышение качества фрункционирования производства и применения органических удобрений в сельскохозяйственном производстве (Диссертация на соисканиеученой степени доктора технических наук). - Рязань: РГСХА, 1997. $-330 \mathrm{c}$.

12. Усенко, В.И. Научные основы рационального органических удобрений на черноземах Западной Сибирипроизводстве (Диссертация на соискание ученой степени доктора сельскохозяйственных наук). - Барнаул: АГАУ, 2000. - 360 с.

13. Платонова, О. В. Качество клубней и хрустящего картофеля зависит от удобрений/О. В. Платонова, О. В. Савина//Картофель и овощи. -2009. -№ 2. -С. 17-18

\section{ORGANIC FERTILIZERS AS A FACTOR OF INCREASING SOIL FERTILITY AND EFFICIENCY OF GROWING}

Savina Olga V., Full Professor, Doctor of Agricultural Science, Ryazan State Agrotechnological University Named after P.A. Kostychev, savina-999@mail.ru

Makarov Valentin A., Full Professor, Doctor of Tech.Science, Ryazan State Agrotechnological University Named after P.A. Kostychev, va_makarov@rambler.ru

Makarova Olga V., Full Professor, Doctor of Economic Science, Academy of Law and Management(Academy of the Federal Penitentiary Service of Russia), m_ov_2302@bk.ru

Gasparyan Svetlana V., Associate Professor, candidate of Economic Sciences, Academy of Law and Management (Academy of the Federal Penitentiary Service of Russia), gasparyan.svetlana@yandex.ru

The aim of the work was the theoretical and practical development of systematic use of organic fertilizers and measures to maintain a deficit-free balance of humus in crop rotation-those of scientific and applied interest to improve the efficiency of crop production. Organic fertilizers are one of the main means of production of the Russian agriculture, the means received from own sources which within several centuries improves fertility of the soil and increases its productivity. They play a crucial role in the flow of organic and nutrient substances into the soil. In modern agriculture is constantly carried out reproduction of all indicators of soil fertility to bring them into a state close to the parameters of the fertility model for this type and type of soil. However, the reproduction of the most important of them is of paramount importance. Such an important integral indicator is the presence in the soil of agricultural organic matter - humus. In this case it is considered as a materialenergy and structural-ecological basis of soil fertility. The effective development of agriculture is inextricably linked to the systematic use of fertilizers and the continuous improvement of technologies for their application in the cultivation of agricultural crops. To solve this problem, the authors propose a method of application of organic fertilizers in the system of tasks for the production of crop production and measures to maintain a 
deficit-free balance of humus in crop rotation. When drawing up the balance of nutrients, the doses of organic fertilizers and the removal of the main fertilized culture are taken into account. The scheme on the balance of nutrients with the use of fertilizers in crop rotation, as well as the classification characteristics of the quality of manure, and the chemical composition of straw are presented. The conclusions show that the main indicator of the effectiveness of nutrients is the amount of gross output obtained from the action of fertilizers.

Key words. Soil, humus, organic fertilizers, deficit-free balance.

\section{Literatura}

1. Kirjushin V.I., Ganzhara N.F., Kaurichev I.S. i dr. Koncepcija optimizacii organicheskogo veshhestva pochv $v$ agrolandshaftah. - M.: Izd. MSHA, 1993. - 96 s.

2.Krupennikov I.A., Boinchan B.P. Chernozjomy i jekologicheskoe zemledelie. - Bel'c\#, 2004. - 168 s.

3.Lykov A.M., Us'kov A.I. Novikov M.N. Organicheskoe veshhestvo pahotnyh pochv Nechernoze-m'ja. - M.: RASHN, 2004. - 730 s.

4.Novikov M.N., Tezhilin V.M., Samohina O.A. i dr. Biologizacija zemledelija v Necherno-zjomnoj zone. - Vladimir: VNIPTIOU, 2004. -260 s.

5. Rasshirennoe vosproizvodstvo plodorodija pochv v intensivnom zemledelii Nechernozem'ja / Pod red. N.Z. Milashhenko. - M.: VIUA, 1993. - 864 s.

6.Loshakov V.G. Sevooborot i plodorodie pochvy.- M.: VNIIA, 2012. -512 s.

7.Shkarda M. Proizvodstvo i primenenie organicheskih udobrenij. Perevod s cheshskogo. M.: Agropromizdat, 1985. - $564 \mathrm{~s}$.

8. Makarov V.A., Gasparjan S.V. K voprosu proizvodstva organicheskih udobrenij v sisteme povyshenija plodorodija pochv // Problemy mehanizacii agrohimicheskogo obespechenija sel'skogo hozjajstva: sb. nauch. tr. po materialam kruglogo stola Vserossijskogo soveshhanija rukovoditelej agrohimicheskih sluzhb Minsel'hoza Rossii / FGBGU VNIMS. - Rjazan': FGBNU VNIMS, 2016. - S.79-85.

9. Makarov V.A. Gacparjan S.V. Obosnovanie organizacionnyh form potrebnosti v udobre-nijah dlja zernoproduktovogo podkompleksa // Problemy mehanizacii agrohimicheskogo obespeche-nija sel'skogo hozjajstva: sb. nauch. tr. / FGBNU VNIMS - Rjazan': FGBNU VNIMS, 2017. - S.222-230.

10. Chekmarjov P.A., Lukin S. V. Sistema udobrenija v uslovijah biologizacii zemledelija //Dostizhenija nauki i tehniki APK 2012, №14. - S.10-12.

11. Makarov, V.A. Povyshenie kachestva funkcionirovaniya proizvodstva i primeneniya organicheskih udobrenij $v$ sel'skohozyajstvennom proizvodstve (Dissertaciya na soiskanieuchenoj stepeni doktora tekhnicheskih nauk). - Ryazan': RGSKHA, 1997. -330 s.

12. Usenko, V.I. Nauchnye osnovy racional'nogo organicheskih udobrenij na chernozemah Zapadnoj Sibiriproizvodstve (Dissertaciya na soiskanie uchenoj stepeni doktora sel'skohozyajstvennyh nauk). - Barnaul: AGAU, 2000. - $360 \mathrm{~s}$.

13.Platonova, O. V. Kachestvo klubnej i hrustjashhego kartofelja zavisit ot udobrenij/O. V. Platonova, O. V. Savina//Kartofel' i ovoshhi. -2009. -№ 2. -S. 17-18

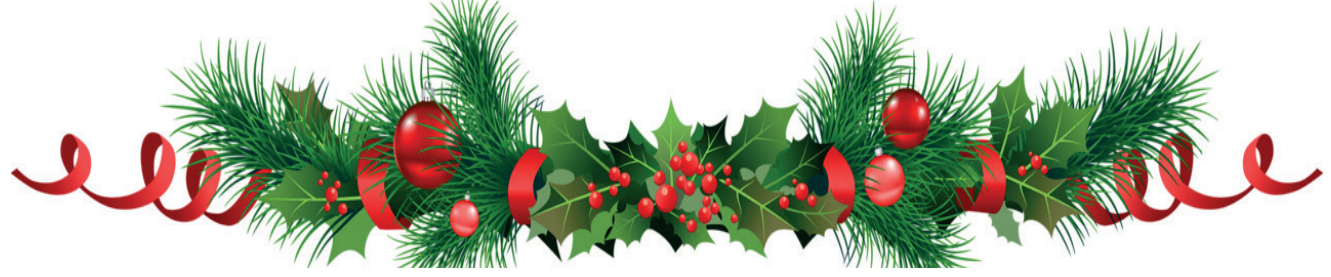

УДК 636.52/.5

DOI 10.36508/RSATU.2019.55.88.010

\section{ПРОДУКТИВНЫЕ КАЧЕСТВА КУР РОДИТЕЛЬСКОГО СТАДА БРОЙЛЕРОВ НА ФОНЕ ИММУНОКОРРЕКЦИИ ОРГАНИЗМА}

СЕМЕНОВ Владимир Григорьевич, д-р биол. наук, профрессор, зав. кафедрой морфологии, акушерства и терапиu, semenov_v.g@list.ru

ИВАНОВ Николай Григорьевич, канд. вет. наук, доцент кафедры эпизоотологии, паразитологии и ветеринарно-санитарной экспертизы, ivanov nikolay 57@mail.ru

ЛЯГИНА Елена Евгеньевна, аспирант кафедры морфологии, акушерства и терапии, lenova987@ icloud.com

ФГБОУ ВО Чувашская ГСХА

Разработан биопрепарат Prevention-N-C и дано научно-практическое обоснование целесообразности его применения в сопоставлении с ранее апробированным препаратом PS-7 для реализации биоресурсного потенциала продуктивных качеств кур родительского стада бройлеров кросса Hubbard F-15 за счет активизации неспецифической резистентности организма. Апробированные биопрепараты повышают яйценоскость кур, что проявляется в интенсивном ее нарастании в начальный период продуктивности и более раннем достижении пика яйценоскости. Интенсив-

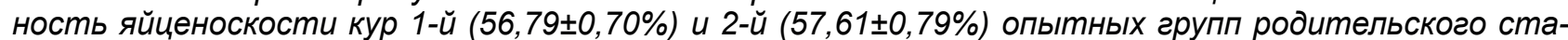

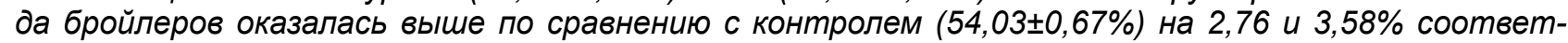

() Семенов В. Г., Иванов Н. Г., Лягина Е. Е., 2019 г. 
ственно (P<0,05-0,01). Установлено, что куры-несушки второй опытной группы принесли за 70

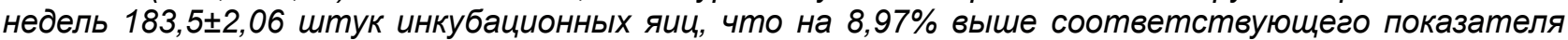
в контрольной группе $(168,4 \pm 2,25$ штук) и на 3,03\% больше, чем в 1-й опытной группе $(178,1 \pm 2,53$ штук). Количество инкубационных яиц кур родительского стада бройлеров первой опытной группы оказалось выше на 5,76\%, чем в контроле. Оплодотворенность яиц в 1-й и 2-й опытных группах была выше соответственно на 1,7 и 2,2\%, чем в контрольной группе. По результатам инкубации выводимость яиц в 1-й и 2-й опытных группах достоверно превышала контрольную группу на 4,8 и 5,4\% соответственно. Лучшие результаты по выводу цыплят получены в 1-й и 2-й опытных группах - 78,3 и 79,5\% соответственно, и намного ниже в контрольной группе - 77,3\%.

Ключевые слова: куры родительского стада бройлеров, кросс Hubbard F-15, биопрепараты, неспецифрическая резистентность, продуктивные качества

\section{Введение}

Птицеводство является одной из наукоемких и динамичных отраслей АПК Российской Федерации и вносит определенный вклад в обеспечение продовольственной безопасности. Биологическая особенность птицы конверсировать питательные вещества корма в продукцию превосходит таковую у животных, что обусловило динамику производства мяса птицы, как наиболее эффективной продукции. Однако в условиях промышленного птицеводства добиться получения биологически полноценной продукции проблематично вследствие прессинга эколого-технологических факторов среды обитания, что негативно отражается на здоровье птицы [3-5, 8, 15].

Повышенная плотность посадки птицы на единицу площади пола, ее круглогодовое пребывание в птичниках с максимальным использованием объема помещения, то есть с клеточным содержанием, а также интенсивность физиологических процессов приводят к ухудшению здоровья птицы, что сопровождается понижением физиологической реактивности и неспецифических защитных сил организма, нарушениями метаболизма. Как следствие, не реализуется биоресурсный потенциал организма, в том числе продуктивность и сохранность [1, 6, 7, 12-14].

В свете вышеизложенного разработка и внедрение в производство экологически безопасных комплексных биопрепаратов для реализации биоресурсного потенциала птицы представляет определенный научный и практический интерес [2, $9-11,16]$.

Таблица 1 - Микроклимат в помещениях для кур родительского стада

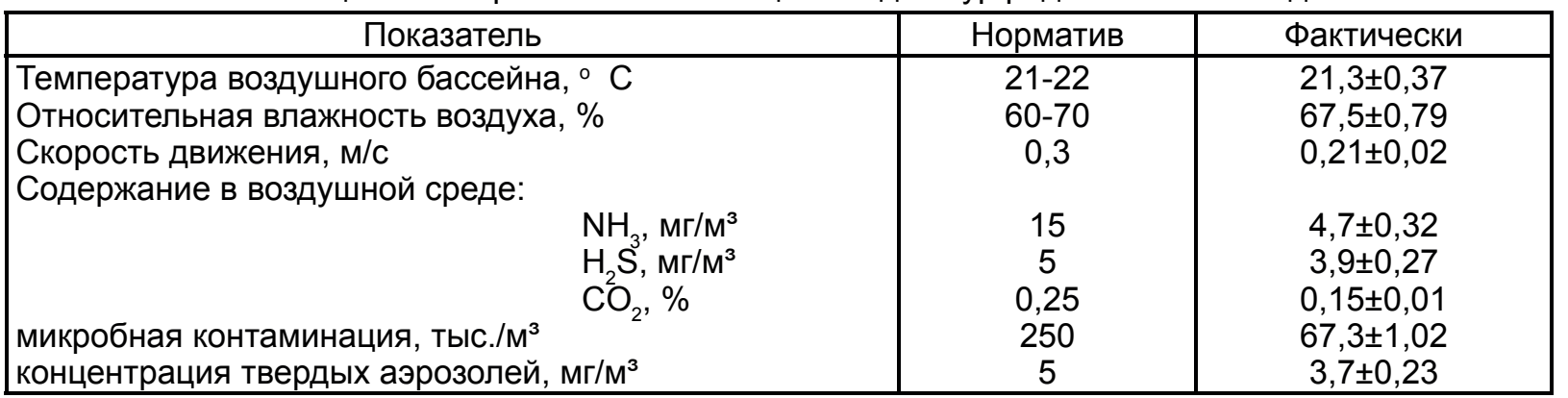

Из данных таблицы 1 следует, что параметры воздушного бассейна в птичнике были в пределах зоогигиенических норм и характеризовались следующими значениями: температура воздушной среды - 21,3 $\pm 0,37^{\circ} \mathrm{C}$, относительная влажность воздуха - 67,5 $\pm 0,79 \%$, его скорость движения - 0,21 \pm 0,02 м/с, концентрация микробных тел $67,3 \pm 1,02$ тыс./M³, уровень аммиака $-4,7 \pm$
Цель настоящей работы - обеспечение здоровья и реализация биоресурсного потенциала продуктивных качеств кур родительского стада бройлеров активизацией неспецифической резистентности организма биопрепаратами.

\section{Материалы и методы}

Научно-исследовательская работа проведена в период с 2015 по 2019 гг. на крупном аграрном индустриальном предприятии по производству продукции птицеводства. Объектами исследований были куры родительского стада бройлеров фрранцузского кросса Hubbard F-15. Для проведения производственного опыта сформировали три группы птиц методом групп-аналогов по 1000 голов в каждой: контрольная, 1-я опытная и 2-я опытная. Условия содержания и кормления птиц всех групп были одинаковыми и соответствовали руководствам по содержанию и кормлению родительского стада Hubbard F-15. Курам 1-й опытной группы в возрасте 21-23 недель трехкратно с интервалом в 7 суток скармливали с кормом биопрепарат PS-7 в дозе 0,1 мл/кг массы тела, 2-й опытной группы - Prevention-N-C. На биопрепараты PS-7 и Prevention-N-C, предназначенные для усиления неспецифических защитных сил организма птицы в профилактике заболеваний, получены патенты РФ на изобретения № 2486896 и № 2622981.

\section{Результаты экспериментальных} исследований

Основные показатели микроклимата в помещениях для содержания птицы приведены в табл. 1.

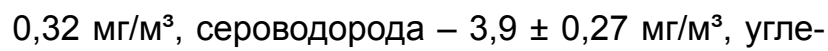

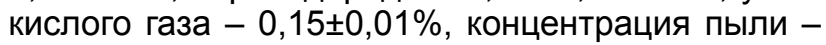
$3,7 \pm 0,23 \mathrm{mr} / \mathrm{M}^{3}$.

На птицефабрике предусмотрено автоматизированное регулирование режима и интенсивности освещения. Искусственный световой режим помещений для бройлеров приведен в таблице 2. 
Таблица 2 - Режим освещенности помещений для кур маточного стада бройлеров

\begin{tabular}{|c|c|c|c|}
\hline \multicolumn{2}{|c|}{ Возраст птицы } & \multirow{2}{*}{$\begin{array}{c}\text { Продолжительность } \\
\text { светового дня, ч }\end{array}$} & \multirow{2}{*}{$\begin{array}{c}\text { Освещенность, } \\
л к\end{array}$} \\
\hline недель & дней & & \\
\hline 23 & $155-161$ & 13 & 20 \\
\hline 24 & $162-168$ & 13 & 20 \\
\hline 25 & $169-175$ & 14 & 20 \\
\hline 26 & $176-182$ & 14 & $25-30$ \\
\hline 27 & 183-189 & $14-30$ & $25-30$ \\
\hline $28-36$ & $190-252$ & 15 & $25-30$ \\
\hline $37-42$ & 253-294 & $15-30$ & $25-30$ \\
\hline $43-70$ & $295-490$ & 16 & $25-30$ \\
\hline
\end{tabular}

Из представленной таблицы следует, что для кур-несушек продолжительность светового дня увеличивают с 10 до 16 часов к концу продуктивного периода, а освещенность - с 10 до 30 лк.

Режим прерывистого освещения кур-несушек приведен в таблице 3.

Таблица 3 - Режим прерывистого освещения кур родительского стада

\begin{tabular}{|c|c|c|}
\hline $\begin{array}{c}\text { Возраст птицы, } \\
\text { недель }\end{array}$ & $\begin{array}{c}\text { Время } \\
\text { включения }\end{array}$ & $\begin{array}{c}\text { Время } \\
\text { выключе- } \\
\text { ния }\end{array}$ \\
\hline \multirow{2}{*}{$21-43$} & $10^{00}$ & $13^{00}$ \\
& $15^{00}$ & $20^{00}$ \\
& $22^{00}$ & $7^{00}$ \\
\hline $44-70$ & $9^{00}$ & $12^{00}$ \\
& $14^{00}$ & $17^{00}$ \\
& $24^{00}$ & $2^{30}$ \\
\hline
\end{tabular}

Рационы для кур маточного стада бройлеров соответствовали нормам и рационам кормления и удовлетворяли потребности организма птицы в энергии, питательных веществах, макро- и микро- элементах, витаминах и незаменимых аминокислотах.

Динамика массы кур-несушек за период яйцекладки представлена в таблице 4.

Из этой таблицы следует, что живая масса оказалась выше у кур-несушек опытных групп, выращенных на фоне применения биопрепаратов. К примеру, если в 28-недельном возрасте куры родительского стада бройлеров опытных 1-й и 2-й групп превосходили по живой массе контрольных сверстниц соответственно на 7,0 и 12,0 г, то в 34-недельном возрасте - на 9,0 и 13,0 г, а к завершению периода яйцекладки (70 недель) - на 13,0 и 18,0 г, однако выявленные изменения оказались недостоверными (P>0,05). Таким образом, скармливание курам-несушкам комбикорма, обогащенного биопрепаратами PS-7 и Prevention-N-C, не оказывает влияния на интенсивность их роста.

Яйценоскость кур родительского стада бройлеров кросса Hubbard F-15 подопытных групп в зависимости от возраста на начальную несушку представлена в таблице 5.

Таблица 4 - Динамика живой массы кур родительского стада бройлеров,г

\begin{tabular}{|c|c|c|c|}
\hline \multirow{2}{*}{$\begin{array}{c}\text { Возраст, } \\
\text { недель }\end{array}$} & \multicolumn{3}{|c|}{ Группа } \\
\hline & контрольная & 1-я опытная & 2-я опытная \\
\hline 21 & 1964 & 1965 & 1963 \\
\hline 22 & 2048 & 2050 & 2053 \\
\hline 23 & 2137 & 2140 & 2144 \\
\hline 24 & 2234 & 2237 & 2241 \\
\hline 25 & 2335 & 2340 & 2345 \\
\hline 26 & 2444 & 2450 & 2455 \\
\hline 27 & 2553 & 2560 & 2565 \\
\hline 28 & 2623 & 2630 & 2635 \\
\hline 29 & 2684 & 2690 & 2695 \\
\hline 30 & 2714 & 2720 & 2726 \\
\hline 31 & 2738 & 2745 & 2750 \\
\hline 32 & 2747 & 2755 & 2759 \\
\hline 34 & 2766 & 2775 & 2779 \\
\hline 36 & 2784 & 2795 & 2800 \\
\hline 38 & 2802 & 2815 & 2820 \\
\hline 40 & 2821 & 2835 & 2840 \\
\hline 50 & 2917 & 2935 & 2941 \\
\hline 60 & 3020 & 3035 & 3039 \\
\hline 70 & 3062 & 3075 & 3080 \\
\hline
\end{tabular}


Таблица 5 - Яйценоскость кур родительского стада бройлеров

\begin{tabular}{|c|c|c|c|}
\hline \multirow{2}{*}{$\begin{array}{c}\text { Возраст, } \\
\text { недель }\end{array}$} & \multicolumn{3}{|c|}{ Группа } \\
\hline & контрольная & 1-я опытная & 2-я опытная \\
\hline 24 & 0,1 & 0,1 & 0,3 \\
\hline 25 & 0,5 & 1,1 & 1,2 \\
\hline 26 & 2,5 & 2,8 & 3,5 \\
\hline 27 & 3,9 & 4,4 & 5,4 \\
\hline 28 & 4,5 & 5,8 & 5,9 \\
\hline 29 & 5,5 & 5,9 & 5,9 \\
\hline 30 & 5,7 & 5,8 & 5,8 \\
\hline 31 & 5,9 & 5,7 & 5,8 \\
\hline 32 & 5,6 & 5,6 & 5,7 \\
\hline 33 & 5,3 & 5,5 & 5,6 \\
\hline 34 & 5,2 & 5,4 & 5,5 \\
\hline 35 & 5,1 & 5,3 & 5,4 \\
\hline 36 & 5,1 & 5,3 & 5,3 \\
\hline 37 & 5,0 & 5,2 & 5,2 \\
\hline 38 & 4,9 & 5,0 & 5,1 \\
\hline 39 & 4,9 & 5,0 & 5,0 \\
\hline 40 & 4,8 & 4,9 & 4,9 \\
\hline 41 & 4,8 & 4,9 & 4,9 \\
\hline 42 & 4,6 & 4,7 & 4,7 \\
\hline 43 & 4,6 & 4,7 & 4,7 \\
\hline 44 & 4,4 & 4,5 & 4,5 \\
\hline 45 & 4,4 & 4,5 & 4,5 \\
\hline 46 & 4,3 & 4,4 & 4,4 \\
\hline 47 & 4,2 & 4,3 & 4,3 \\
\hline 48 & 4,1 & 4,2 & 4,2 \\
\hline 49 & 4,0 & 4,2 & 4,2 \\
\hline 50 & 3,9 & 4,0 & 4,0 \\
\hline 51 & 3,8 & 4,0 & 4,0 \\
\hline 52 & 3,7 & 3,9 & 3,9 \\
\hline 53 & 3,6 & 3,8 & 3,8 \\
\hline 54 & 3,5 & 3,7 & 3,7 \\
\hline 55 & 3,4 & 3,6 & 3,6 \\
\hline 56 & 3,3 & 3,6 & 3,6 \\
\hline 57 & 3,2 & 3,4 & 3,4 \\
\hline 58 & 3,2 & 3,4 & 3,4 \\
\hline 59 & 3,1 & 3,3 & 3,3 \\
\hline 60 & 3,0 & 3,2 & 3,2 \\
\hline 61 & 3,0 & 3,2 & 3,2 \\
\hline 62 & 2,9 & 3,0 & 3,0 \\
\hline 63 & 2,8 & 3,0 & 3,0 \\
\hline 64 & 2,8 & 2,9 & 2,9 \\
\hline 65 & 2,7 & 2,8 & 2,8 \\
\hline 66 & 2,6 & 2,8 & 2,8 \\
\hline 67 & 2,5 & 2,6 & 2,6 \\
\hline 68 & 2,4 & 2,6 & 2,6 \\
\hline 69 & 2,3 & 2,5 & 2,5 \\
\hline 70 & 2,2 & 2,4 & 2,4 \\
\hline Итого & $177,8 \pm 2,37$ & $186,9 \pm 2,06^{*}$ & $189,6 \pm 2,34^{* *}$ \\
\hline
\end{tabular}

Из представленной таблицы видно, что яичная продуктивность кур-несушек второй опытной группы оказалась наибольшей, а именно, яйценоскость на начальную несушку за семьдесят недель составила 189,6 яиц, что выше на 11,8 и 2,7 яиц, нежели в контроле $(177,8 \pm 2,37$ яиц) и в 1-й опытной группе (186,9 яиц). Яичная продуктивность на начальную несушку у кур родительского стада бройлеров первой опытной группы оказалась выше на 9,1 штук или на 5,12\%, нежели в контроле.
Если куры-несушки контрольной группы достигли пика яйценоскости в 31-недельном возрасте, то 1-й опытной группы - в 29 недель и 2-й опытной в 28-недельном возрасте.

Сравнительный анализ яйценоскости несушек подопытных групп позволяет заключить, что биопрепараты PS-7 и Prevention-N-C стимулируют указанную продуктивность.

Показатели яичной продуктивности птицы отражены в таблице 6. 
Таблица 6 - Яичная продуктивность кур маточного стада бройлеров

\begin{tabular}{|c|c|c|c|}
\hline \multirow[t]{2}{*}{ Показатель } & \multicolumn{3}{|c|}{ Группа } \\
\hline & контрольная & 1-я опытная & 2-я опытная \\
\hline Начальное поголовье, гол & 150 & 150 & 150 \\
\hline Среднее поголовье, гол & 134 & 137 & 140 \\
\hline $\begin{array}{r}\text { Валовой сбор яиц, } \\
\text { штук } \\
\text { к контролю }\end{array}$ & 26670 & $\begin{array}{l}28035 \\
105,1\end{array}$ & $\begin{array}{l}28440 \\
106,6\end{array}$ \\
\hline $\begin{array}{l}\text { Яйценоскость на начальную } \\
\text { несушку, } \\
\text { штук } \\
\% \text { к контролю }\end{array}$ & $177,8 \pm 2,37$ & $\begin{array}{c}186,9 \pm 2,06^{*} \\
105,1\end{array}$ & $\begin{array}{c}189,6 \pm 2,34^{* *} \\
106,6\end{array}$ \\
\hline $\begin{array}{l}\text { Яйценоскость на среднюю несуш- } \\
\text { ку, } \\
\text { штук } \\
\% \text { к контролю }\end{array}$ & $199,1 \pm 0,74$ & $\begin{array}{c}204,6 \pm 1,11^{* *} \\
102,8\end{array}$ & $\begin{array}{c}203,1 \pm 0,90^{* *} \\
102,0\end{array}$ \\
\hline $\begin{array}{l}\text { Возраст кур при достижении раз- } \\
\text { ных уровней яйцекладки } \\
\\
\end{array}$ & $\begin{array}{l}27,0 \\
31,0\end{array}$ & $\begin{array}{l}26,5 \\
29,0\end{array}$ & $\begin{array}{l}26,0 \\
28,0\end{array}$ \\
\hline Пик яйцекладки, \% & 84,3 & 84,3 & 84,3 \\
\hline
\end{tabular}

Из данных таблицы 6 отчетливо видно, что в опытных 1-й и 2-й группах валовое производство яиц составило 28,03 и 28,44 тыс. шт. соответственно, что на 5,1 и 6,6\% больше, нежели в контроле.

В первой и второй опытных группах на среднюю несушку получено на 5,5 и 4,0 яйца больше, чем в контроле $(P<0,01)$. На начальную несушку наивысшая яйценоскость установлена у птиц 1-й и 2-й опытных групп, и она составила в среднем $186,9 \pm 2,06$ и 189,6 $\pm 2,34$ шт. яиц, то есть оказалась выше на 9,1 и 11,8 яиц, нежели в контроле $(177,8 \pm 2,37$ шт. яиц; $P<0,05-0,01)$.

Уровень 50-процентной яйцекладки достигнут в 1-й опытной группе в возрасте 26,5 недель, во 2-й опытной - 26,0 недель, а в контроле - 27 недель. Несушки в контроле достигли пика яйценоскости в возрасте 31 неделя, 1-й опытной группе - 29 недель и во 2-й опытной - в 28-недельном возрасте.

Использование биопрепаратов способствовало повышению жизнеспособности птицы вследствие нормализации физиологического статуса и активизации неспецифических защитных сил организма. Так, сохранность птицы оказалась в контроле 89,3\%, в 1-й опытной группе - 91,3 и во 2-й опытной $-93,3 \%$.

Нами установлена избирательная мобилизация морфологического и биохимического профилей крови, фракторов неспецифической резистентности организма кур родительского стада бройлеров. Апробированные в опытах препараты оказывали следующий биологический эффект:

- стимулировали синтез красных кровяных телец и гемоглобина, однако не повлияли на продукцию лейкоцитов;

- активизировали метаболизм белка за счет синтеза ү-глобулиновой и альбуминовой фракций;

- стимулировали неспецифические защитные силы организма.

Средняя масса яиц кур 1-й и 2-й опытных групп за продуктивный период составила $63,18 \pm 0,21$ и $64,11 \pm 0,19$ г, что соответственно на 2,7 и $4,2 \%$ больше, чем в контроле $(61,52 \pm 0,37$ г).

Индекс формы яйца подопытных групп варьировал в пределах 77,1-77,5\% в 24-34-недельном возрасте кур, 76,7-78,7\% - 35-40-недельном и 76,9-77,7\% - в 41-70-недельном возрасте.

Куры 1-й и 2-й опытных групп превосходили по средней массе скорлупы яиц контрольных сверстниц на 0,2 и 0,4 г в возрасте 24-34 недель, на 0,1 и 0,3 г - 35-40 недель и на 0,2 и 0,5 г - 41-70 недель.

Показатель индекс белка, как в контроле, так и в опытных группах оказался более $70 \%$ и соответствовал требованиям для инкубационных яиц. Индекс желтка яиц варьировал в контрольной группе с 46,3 до 49,3\%, в 1-й опытной - с 45,3 до $47,5 \%$ и во 2-й опытной - с 44,7 до 47,9\%.

Единица Хау у кур-несушек 1-й и 2-й опытных групп во все сроки продуктивного периода оказалась выше, нежели в контрольной группе: на 0,7 и 0,9\% в возрасте 24-34 недель, на 2,8 и 2,6\% 35-40-недель и на 0,6 и 1,9\% - 41-70 недель.

Куры 2-й опытной группы принесли за 70 недель 183,5 2,06 штук инкубационных яиц, что на $8,97 \%$ выше, чем в контроле $(168,4 \pm 2,25$ штук) и на $3,03 \%$ больше, нежели в 1-й опытной группе $(178,1 \pm 2,53$ штук).

После овоскопирования на 7-е сутки инкубирования выявлено, что количество яиц с «кровяным кольцом» в контроле составило $3,3 \%$, что на 1,4 и 1,8\% выше, нежели в опытных 1-й и 2-й группах. Во время последующего просмотра яиц на 11-е сутки инкубирования установлено, что «замерших цыплят» в опытных группах оказалось меньше на 
1,6 и 2,2\%, нежели в контрольной группе. Овоскопирование на 18-е сутки инкубирования яиц показало, что «задохликов» было на 0,4 и 0,4\% больше в контроле, чем в опытных 1-й и 2-й группах.

Оплодотворенность яиц в опытных 1-й и 2-й группах оказалась на 1,7 и 2,2\% больше, нежели в контроле. Выводимость яиц в опытных 1-й и 2-й группах была больше на 4,8 и 5,4\%, чем в контроле.

Лучшие результаты по выводу цыплят получены в 1-й и 2-й опытных группах - соответственно 78,3 и 79,5\%, и намного ниже в контрольной группе $-77,3 \%$.

\section{Вывод}

Иммунопрофилактика организма кур родительского стада бройлеров кросса Hubbard F-15 до перевода их в цех продукции биопрепаратами PS-7 и Prevention-N-C повышает яичную продуктивность кур маточного стада, их воспроизводительные функции, уменьшает отходы инкубации и брак яиц.

\section{Список литературы}

1. Дарьин, А. И. Качество яиц кур-несушек родительского стада бройлеров / А. И. Дарьин, Д. И. Карчев // Научно-информационное обеспечение инновационного развития АПК : мат. VIII междунар. науч.-практ. конф. "ИнформАгро-2016". - Пенза : ФГБНУ "Росинформагротех", 2016. - С. 346-348.

2. Влияние эхинацеи пурпурной на биохимический состав инкубационных яиц мясных кур / А. И. Дарьин, Н. Н. Кердяшов, А. А. Наумов, Т. В. Шишкина // Нива Поволжья. - 2019. - № 1(50). - С. 64-71.

3. Егорова, А. В. Основные направления работы с мясными курами родительского стада бройлеров / А. В. Егорова // Птицеводство. - 2017. - № 3. - C. 16-21.

4. Иванова, Е. Е. Биостимуляция роста и развития цыплят-бройлеров / Е. Е. Иванова, Д. А. Никитин // Продовольственная безопасность и устойчивое развитие АПК: мат. междунар. науч.-практ. конф. - Чебоксары, 2015. - С. 424-427.

5. Карчев, Д. И. Динамика инкубационных качеств яиц кур родительского стада бройлеров / Д. И. Карчев, Д. Д. Ивашкина // Инновационные идеи молодых исследователей для агропромышленного комплекса России : Сб. статей всерос. науч.практ. конф. молодых ученых. - Пенза, 2017. - С. 114-116.

6. Определение микробиоценозов кишечника кур яичных кроссов / И. И. Кочиш, М. Н. Романов, И.Н. Никонов, Л.А. Ильина, Г.Ю. Лаптев // Мировые и Российский тренды развития птицеводства. Реалии и вызовы будущего: мат. XIX междунар. конфр. - Сергиев Посад, 2018.- С.240-243.

7. Османян, А. К. Возраст кур родительского стада и эффрективность выращивания бройлеров / А. К. Османян, Д. И. Рыбаков // Доклады Тимирязевской сельскохозяйственной академии: сборник статей. - М., 2016.- С. 244-248.

\section{PRODUCTIVE QUALITIES OF HENS OF A PARENTAL FLOCK OF BROILERS AGAINST THE BACKGROUND OF IMMUNOCORRECTION OF ORGANISM}

Semenov Vladimir G., doctor of biological science, professor, head of the department of morphology, obstetrics and therapy, semenov_v.g@list.ru

Ivanov Nikolay G., candidate of veterinary sciences, associate professor of the department of epizootology,
8. Петрянкин, Ф. П. Иммуностимуляторы в практике ветеринарной медицины : монография / Ф. П. Петрянкин, В.Г. Семенов, Н.Г. Иванов. - Чебоксары, 2015. - 272 с.

9. Семенов, В. Г. Обеспечение неспецифической устойчивости и реализация продуктивных качеств кур родительского стада бройлеров / В. Г. Семенов, Е. Е. Лягина, Д. А. Никитин // Современные аспекты развития сельского хозяйства Юго-Западного региона Казахстана : мат. междунар. науч.-практ. конф., посвящ. 60-летию проф. академика АСХН РК Паржанова Ж.А.- Республика Казахстан, Шымкент, 2018.- С. 339-345.

10. Третьякова, Е.Н. Влияние биологически активных веществ и пробиотиков на продуктивные качества птицы родительского стада кросса "ROSS-308" / Е.Н. Третьякова, И.А. Скоркина, Д.В. Машталер //Вестник Мичуринского государственного аграрного университета.- Мичуринск, 2016. № 1. C. 43-46.

11. Коррекция неспецифической резистентности и специфического иммуногенеза организма в реализации биопотенциала птицы / В. Г. Тюрин, В. Г. Семенов, Н. Г. Иванов, Е. Е. Иванова // Современные проблемы ветеринарной патологии и биотехнологии в агропромышленном комплексе : мат. междунар. науч.-практ. конф., посвящ. 95-летию РУП «Институт экспериментальной ветеринарии им. С.Н. Вышелесского». - Минск, 2017. - С. 390-394.

12. Фисинин, В. И. Биологические и экономические аспекты производства мяса бройлеров в клетках и на полу / В. И. Фисинин, А. Ш. Кавтарашвили // Птицеводство. - 2016. - № 5.- С. 25-31.

13. Фисинин, В. И. Стратегические тренды развития мирового и отечественного птицеводства: состояние, вызовы, перспективы / В. И. Фисинин // Мировые и Российский тренды развития птицеводства. Реалии и вызовы будущего : мат. XIX междунар. конф. - Сергиев Посад, 2018. - С.9-49.

14. Эффрективность выращивания бройлеров в зависимости от содержания энергии и аминокислот в престартерных рационах / В. И. Фисинин, И.А. Егоров, Т.В. Егорова, С.А. Портнов // Мировые и Российские тренды развития птицеводства. Реалии и вызовы будущего : мат. XIX междунар. конф.- Сергиев Посад, 2018.- С. 326-328.

15. Щепеткина, С. В. Организация системы контроля антимикробных препаратов в птицеводстве / С. В. Щепеткина // Мировые и Российский тренды развития птицеводства. Реалии и вызовы будущего: мат. XIX междунар. конф. - Сергиев Посад, 2018. - C.703-706.

16. Юрина, А. С. Влияние биологически активной добавки "Виготон" на качество инкубационных яиц, полученных от кур родительского стада бройлеров / А. С. Юрина, Р. А. Мерзленко // Актуальные вопросы сельскохозяйственной биологии. - Белгород, 2018. - № 4(10). - С. 36-41. 
parasitology and veterinary-sanitary examination, ivanov_nikolay_57@mail.ru

Lyagina Elena E., graduate student of the department of morphōogy, obstetrics and therapy, lenova987@ icloud.com

Chuvash State Agricultural Academy

Biological preparation Prevention-N-C has been developed and scientific and practical justification of its expediency in comparison with previously tested preparation PS-7 for realization of biological resource potential of productive qualities of hens of parent herd of Hubbard F-15 cross broilers due to activation of non-specific resistance of organism. Tested biopreparations increase the egg content of chickens, which manifests itself in its intense growth during the initial period of productivity and earlier reaching the peak of egg content. The egg intensity of chickens 1 st (56.79 $\pm 0.70 \%)$ and $2 n d(57.61 \pm 0.79 \%)$ of the test groups of the parent broiler herd was higher compared to the control $(54.03 \pm 0.67 \%)$ by 2.76 and $3.58 \%$, respectively $(P<0.05-0.01)$. It was found that the carrying chickens of the second experimental group brought $183.5 \pm 2.06$ pieces of incubation eggs in 70 weeks, which is $8.97 \%$ higher than the corresponding indicator in the control group (168.4 \pm 2.25 pieces) and $3.03 \%$ more than in 1 experimental group (178.1 \pm 2.53 pieces). The number of incubation eggs of the parent broiler herd of the first test group was $5.76 \%$ higher than in the control. The fertilization of eggs in the 1 st and 2 nd test groups was 1.7 and 2.2\% higher, respectively, than in the control group. According to the results of incubation, egg output in the 1st and 2nd test groups significantly exceeded the control group by 4.8 and $5.4 \%$, respectively. The best results on chicken withdrawal were obtained in the 1 st and 2 nd test groups 78.3 and $79.5 \%$, respectively, and much lower in the control group $-77.3 \%$.

Key words: Chickens of parent broiler herds, Hubbard F-15 cross, biopreparations, nonspecific resistance, productive qualities

\section{Literatura}

1. Dar'in, A.I. Kachestvo jaic kur-nesushek roditel'skogo stada brojlerov / A.I. Dar'in, D.I. Karchev // Nauchno-informacionnoe obespechenie innovacionnogo razvitija APK: mat. VIII mezhdunar. nauch.-prakt. konf. "InformAgro-2016".- FGBNU "Rosinformagroteh".- Penza, 2016.- S. 346-348.

2. Dar'in, A.l. Vlijanie jehinacei purpurnoj na biohimicheskij sostav inkubacionnyh jaic mjasnyh kur / A.l. Dar'in, N.N. Kerdjashov, A.A. Naumov, T.V. SHishkina // Niva Povolzh'ja.- Penza, 2019.- № 1(50).- S. $64-71$.

3. Egorova, A.V. Osnovnye napravlenija raboty s mjasnymi kurami roditel'skogo stada brojlerov / A.V. Egorova // Pticevodstvo.- M., 2017.- № 3.- S. 16-21.

4. Ivanova, E.E. Biostimuljacija rosta irazvitija cypljat-brojlerov/E.E. Ivanova, D.A. Nikitin//Prodovol'stvennaja bezopasnost' i ustojchivoe razvitie APK: mat. mezhdunar. nauch.-prakt. konf.- CHeboksary, 2015.- S.424-427.

5. Karchev, D.I. Dinamika inkubacionnyh kachestv jaic kur roditel'skogo stada brojlerov / D.I. Karchev, D.D. Ivashkina // Innovacionnye idei molodyh issledovatelej dlja agropromyshlennogo kompleksa Rossii: Sb. statej vseros. nauch.-prakt. konf. molodyh uchenyh.- Penza, 2017.- S. 114-116.

6. Kochish, I.I. Opredelenie mikrobiocenozov kishechnika kur jaichnyh krossov / I.I. Kochish, M.N. Romanov, I.N. Nikonov, L.A. II'ina, G.JU. Laptev // Mirovye i Rossijskij trendy razvitija pticevodstva. Realii $i$ vyzovy budushhego: mat. XIX mezhdunar. konf.- Sergiev Posad, 2018.- S.240-243.

7. Osmanjan, A.K. Vozrast kur roditel'skogo stada i jeffektivnost' vyrashhivanija brojlerov / A.K. Osmanjan, D.I. Rybakov //Doklady Timirjazevskoj sel'skohozjajstvennoj akademii: sbornik statej.- M., 2016.- S. 244-248.

8. Petrjankin, F.P. Immunostimuljatory v praktike veterinarnoj mediciny / F.P. Petrjankin, V.G. Semenov, N.G. Ivanov // Monografija.- CHeboksary, 2015.- 272 s.

9. Semenov, V.G. Obespechenie nespecificheskoj ustojchivosti i realizacija produktivnyh kachestv kur roditel'skogo stada brojlerov / V.G. Semenov, E.E. Ljagina, D.A. Nikitin // Sovremennye aspekty razvitija sel'skogo hozjajstva JUgo-Zapadnogo regiona Kazahstana: mat. mezhdunar. nauch.-prakt. konf., posvjashh. 60-letiju prof. akademika ASHN RK Parzhanova ZH.A.- Respublika Kazahstan, SHymkent, 2018.- S. 339-345.

10. Tret'jakova, E.N. Vlijanie biologicheski aktivnyh veshhestv i probiotikov na produktivnye kachestva pticy roditel'skogo stada krossa "ROSS-308" / E.N. Tret'jakova, I.A. Skorkina, D. V. Mashtaler//Vestnik Michurinskogo gosudarstvennogo agrarnogo universiteta.- Michurinsk, 2016. № 1. S. 43-46.

11. Tjurin, V.G. Korrekcija nespecificheskoj rezistentnosti i specificheskogo immunogeneza organizma $v$ realizacii biopotenciala pticy / V.G. Tjurin, V.G. Semenov, N.G. Ivanov, E.E. Ivanova // Sovremennye problemy veterinarnoj patologii i biotehnologii v agropromyshlennom komplekse: mat. mezhdunar. nauch.-prakt. konf., posvjashh.95-letijuRUP «Institutjeksperimental'nojveterinariiim. S. N. Vyshelesskogo».-Minsk, 2017.-S.390-394.

12. Fisinin, V.I. Biologicheskie i jekonomicheskie aspekty proizvodstva mjasa brojlerov $v$ kletkah i na polu N.I. Fisinin, A.SH. Kavtarashvili //Pticevodstvo.- M., 2016. - №5.- 25-31 s.

13. Fisinin, V.I. Strategicheskie trendy razvitija mirovogo $i$ otechestvennogo pticevodstva: sostojanie, vyzovy, perspektivy / V.I. Fisinin // Mirovye i Rossijskij trendy razvitija pticevodstva. Realii i vyzovy budushhego: mat. XIX mezhdunar. konf.- Sergiev Posad, 2018.- S.9-49.

14. Fisinin, V.I. JEffektivnost' vyrashhivanija brojlerov v zavisimosti ot soderzhanija jenergii $i$ aminokislot $v$ prestarternyh racionah / V.I. Fisinin, I.A. Egorov, T.V. Egorova, S.A. Portnov //Mirovye i Rossijskie trendy razvitija pticevodstva. Realii i vyzovy budushhego: mat. XIX mezhdunar. konf.- Sergiev Posad, 2018.- S.326-328.

15. SHHepetkina, S.V. Organizacija sistemy kontrolja antimikrobnyh preparatov v pticevodstve / S.V. SHHepetkina // Mirovye $i$ Rossijskij trendy razvitija pticevodstva. Realii i vyzovy budushhego: mat. XIX 
mezhdunar. konf.- Sergiev Posad, 2018.- S.703-706.

16. JUrina, A.S. Vlijanie biologicheski aktivnoj dobavki "Vigoton" na kachestvo inkubacionnyh jaic, poluchennyh ot kur roditel'skogo stada brojlerov / A.S. JUrina, R.A. Merzlenko //Aktual'nye voprosy sel'skohozjajstvennoj biologii.- Belgorod, 2018.- № 4(10).- S. 36-41.

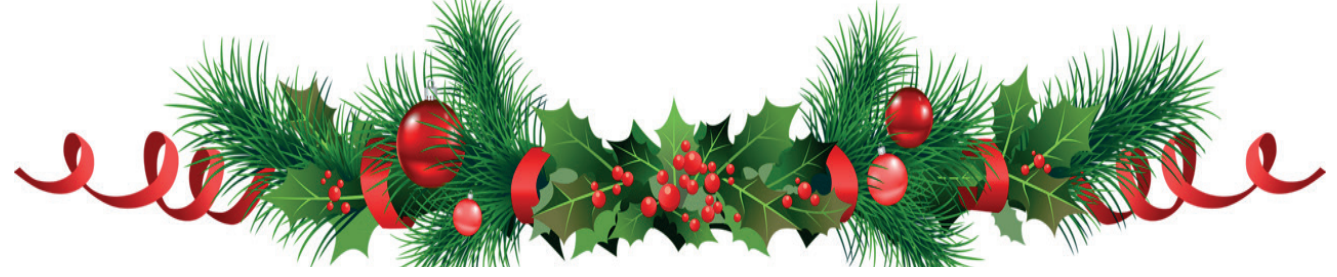

УДК 633.853.483:631.894

DOI 10.36508/RSATU.2019.95.65.011

\section{ИСПОЛЬЗОВАНИЕ ПРОТРАВИТЕЛЕЙ В ПОСЕВАХ РАПСА В УСЛОВИЯХ РЯЗАНСКОЙ ОБЛАСТИ}

СтУПИн Александр Сергеевич, канд. с.-х. наук, доцент кафедры агрономии и агротехнологий, stupin32@yandex.ru

ВИНОГРАДОВ Дмитрий Валериевич, д-р биол. наук, професссор, зав. кафедрой агрономии и агротехнологий, vdv-rz@rambler.ru

ЛУПОВА Екатерина Ивановна, канд. биол. наук, доцент кафедры агрономии и агротехнологий, katya.lilu@mail.ru

ФАДЬКИн Геннадий Николаевич, канд. с.-х. наук, доцент, зав. кафредрой лесного дела, агрохимии, экологии, селекции и семеноводства, g-fadkin@mail.ru

САЗОНКИн Кирилл Дмитриевич, магистрант 2 курса кафедры агрономии и агротехнологий, kirill.sazonkin@mail.ru

Рязанский государственный агротехнологический университет имени П.А. Костычева

Определен видовой состав крестоцветных блошек в Рязанской области. Проведен подбор препаратов для защиты рапса ярового от крестоцветных блошек. Для этого применен системный подход к изучению воздействия пестицидов на вредителя. Представлена сравнительная эффрективность препаратов разной химической природы, предназначенных для борьбы с крестоцветными блошками на рапсе яровом. Установлен видовой состав фитофрагов в агроценозе рапса в условиях региона. Исследованиями подтверждено, что протравливание семян - необходимый прием в агротехнологии, в том числе на рапсе в борьбе с крестоцветными блошками. В исследованиях выявлено, что наиболее эфрфективными против комплекса крестоцветных блошек являются протравители Круйзер Рапс, КС и Модесто, КС. Их применение позволило снизить численность крестоиветных блошек в 2,5 раза по сравнению с контролем и получить максимальную в среднем за три года прибавку урожая (40,5\%) за счет приемлемого уровня подавления популяций вредителей и продолжительности действия. Предложено для защиты всходов рапса от крестоцветных блошек рекомендовать к широкому внедрению в производство протравители семян типа Круйзер Рапс, КС и Модесто, КС. Такие препараты подавляют вредителей до уровня ниже экономического порога вредоносности, обеспечивают существенную прибавку урожая, оказывают минимальное негативное влияние на нецелевые организмы агроценоза, их применение исключает проведение дополнительной инсектицидной обработки.

Ключевые слова: рапс яровой, масличные культуры, протравители, вредители, урожайность, Рязанская область.

\section{Введение}

Действие комплекса вредных организмов в посевах рапса может привести к потерям 30-60\% урожая или, при условии массового развития, даже к полной гибели посевов [1-4]. Поэтому уход за посевами рапса должен быть комплексным и включать в себя все мероприятия, направленные на сохранение всходов, уничтожение сорняков, защиту растений от вредителей и болезней, а также на создание благоприятных условий для их роста и развития. Из опасных вредителей самыми распространенными являются крестоцветные блошки. Наиболее часто вредят блошки светлоногая - Phyllotreta nemorum L, выемчатая - Ph.vittala F., волнистая - Ph. Nudulata Kutsch., синяя - Ph. Nigripes F. и чёрная - Ph. atra F. Распространены повсеместно, повреждают посевы рапса и других культур семейства капустных. Вредят также жуки и личинки. Имаго - мелкие, прыгающие, с одноцветными или двуцветными надкрыльями. Личинки светло-желтые, червеобразные. Жуки вредят всходам рапса, выедая язвочки на листьях. В дальнейшем листья засыхают и отмирают. В сухую жаркую погоду способны за один день уничтожить всходы $[5,6]$. При использовании химического метода борьбы важное значение придается ассортименту используемых препаратов, который постоянно обновляется. При совершенствовании ассортимента химических средств защиты растений существенное значение придается препаратам, проявляющим избирательность действия и не влияющим отрицательно на полезных насеко-

( С Ступин А. С., Виноградов Д. В., Лупова Е. И., Фадькин Г. Н., Сазонкин К. Д., 2019 г. 
мых, что позволяет снизить пестицидный пресс на окружающую среду.

\section{Объекты и методы исследований}

Целью данной работы являлось исследование воздействия протравителей на вредителей в технологии возделывания рапса ярового в условиях Рязанской области. Для выполнения поставленной цели необходимо было решить следующие задачи:

- определить биологическую эфрфективность изучаемых инсектицидов в борьбе с крестоцветными блошками;

- изучить влияние применяемых протравителей на урожайность рапса ярового.

Полевые опыты проводились в 2017-2019 гг., на опытной агротехнологической станции УНИЦ «Агротехнопарк» ФГБОУ ВО РГАТУ.

Почва опытного участка - серая лесная тяжелосуглинистая. Агрохимическая характеристика почвы: $\mathrm{pH}$ - 5,3; содержание гумуса - 2,8\%, подвижного фоссфора - 143-151 мг/кг, обменного калия - 210-233 мг/кг почвы. Объектом изучения был сорт рапса ярового Ратник.

Использовали в опыте препараты: Табу, ВСК (500 г/л имидаклоприда); Чинук,СК (100 г/л мидаклоприда+100 г/л бета-цифлутрина); Имидалит, ТПС (500 г/л имидаклоприда + 50 г/л бифентрина ); Фурадан, ТПС (350 г/л карбофурана); Хинуфур, КС (436 г/л карбофурана); Модесто, КС (400 г/л клотианидина +80 г/л бета-цифлутрина); Круйзер, КС (350 г/л тиаметоксама); Круйзер Рапс, КС (280 г/л тиаметоксама + 32,3 г/л мефеноксама + 8 г/л фрлудиоксонила).

Полевой опыт содержал девять вариантов, площадь делянки - 25 м², повторность четырех- кратная. Агротехника выращивания рапса ярового - общепринятая для данной зоны. Биологическую эффективность инсектицидов в борьбе с вредителями рапса ярового устанавливали согласно «Методическим указаниям по регистрационным испытаниям инсектицидов, акарицидов, моллюскоцидов и родентицидов в сельском хозяйстве» [7].

\section{Результаты исследований}

В посевах максимальное повреждение растений отмечено в первые 3-4 недели в связи с активным действием крестоцветных блошек. У крестоцветных блошек много общего в биологии развития и характере причиняемых повреждений и наносимого вреда. Весной в конце апреля - начале мая, как только почва оттает и покажется первая растительность, блошки выходят из мест, где зимовали. Вначале они питаются разными сорняками из семейства капустных, а с появлением всходов ярового рапса переходят на них. Имаго выедают на листьях язвочки диаметром 1,5-2 мм. Листья, поврежденные в сильной степени, засыхают, а при поражении точек роста растение погибает. Оживленность блошек возрастает в сухую и жаркую погоду, в течение одного дня они способны уничтожить всходы рапса на значительных площадях. В 2019 году, в связи с аномальной первой половиной вегетации, сухой и жаркой, наблюдалась высокая плотность вредителя, в связи с чем возрастала роль протравителя в технологии производства семян рапса.

Результаты по действию препаратов в борьбе с блошками крестоцветными при протравливании семян рапса в 2017-2019 гг. представлены на рисунке 1.

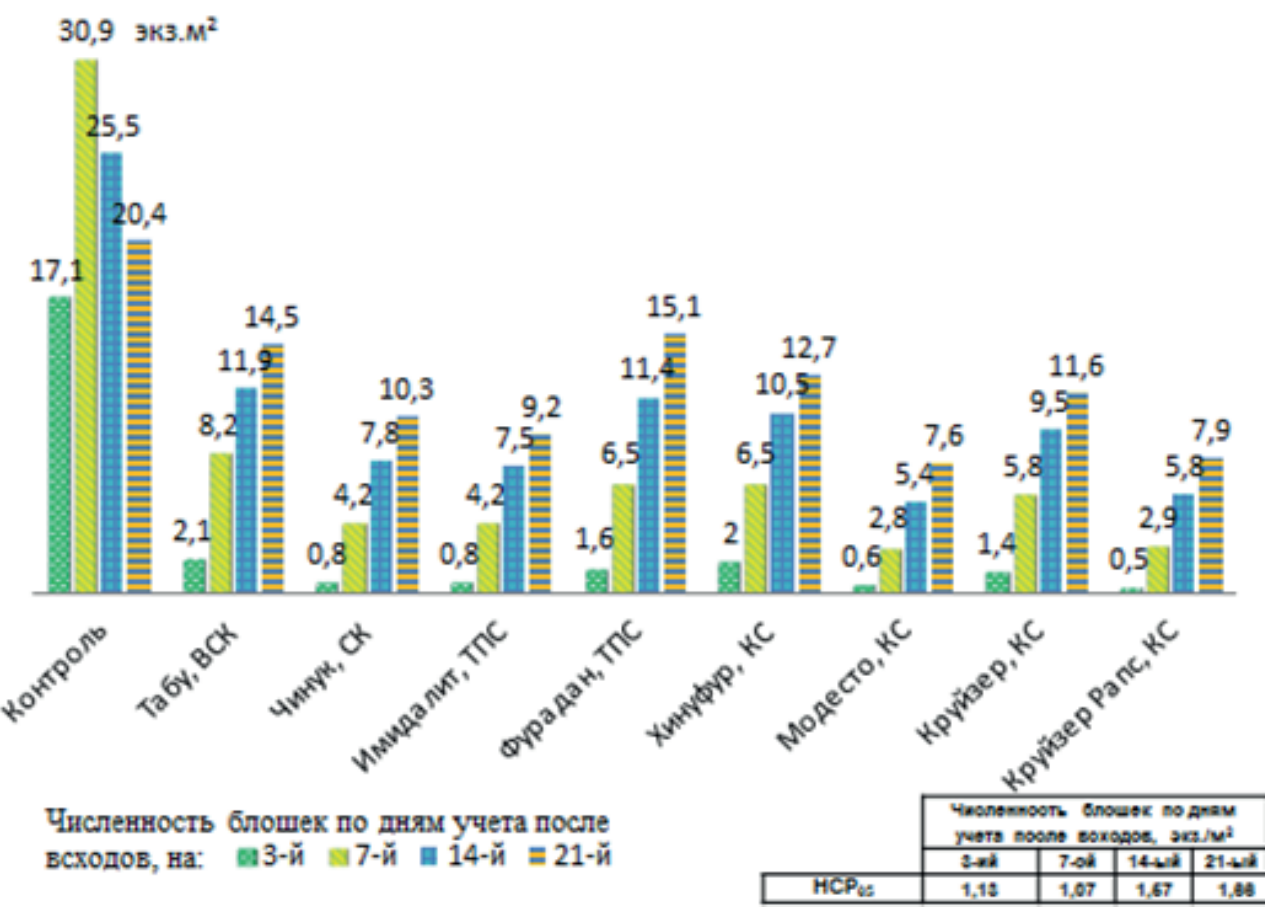

Рис. 1 - Биологическая эффрективность инсектицидов в борьбе с блошками крестоцветными при обработке семян рапса ярового 
В опытах на третий день после появления всходов общее количество крестоцветных блошек при применении инсектицидов снижалось на 86,3-95,6\%. Максимальная эфффективность отмечена на варианте с действием Круйзер Рапс, КС и Модесто, КС (95,6 и 95,0\%). Отметим и действие других препаратов. В исследованиях высокую длительность токсического действия имели варианты с обработкой Модесто, КС и Круйзер Рапс, КС. Данные инсектициды обладают длительным периодом защитного действия от вредителей - в течение 2-3 недель. В течение данного периода растения рапса успешно развиваются и преодолевают критический период роста и развития, до- стигая 3-4 настоящих листьев, когда блошки для культуры практически неопасны.

При использовании исследуемых инсектицидов необходимость наземного внесения препаратов на рапс с целью защиты их от блошек, чаще всего, отпадает. Опрыскивание растений ярового рапса инсектицидами необходимо осуществлять, когда количество вредных объектов превышает экономический порог вредоносности (ЭПВ 8-10 жуков на $\left.1 \mathrm{~m}^{2}\right)$.

Исследуемые инсектициды при защите рапса от крестоцветных блошек оказали действие, в конечном итоге, на структуру урожая, урожайность культуры (рис. 2).

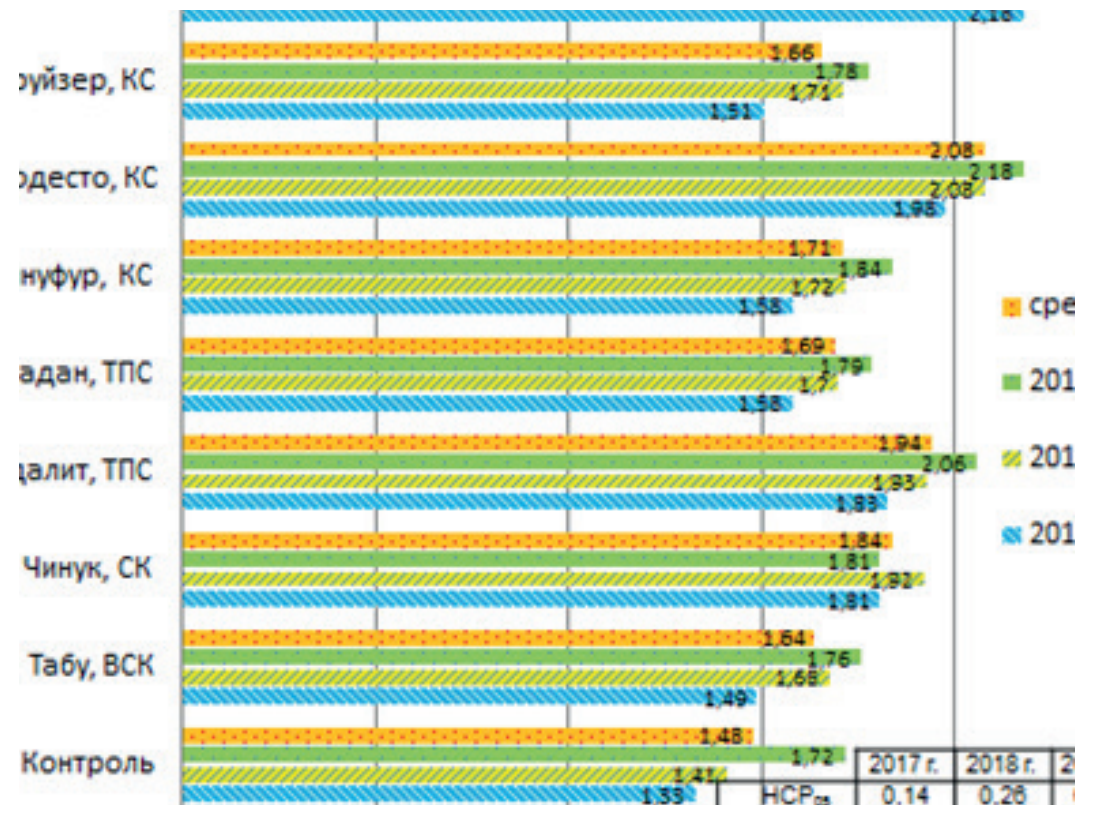

Рис. 2 - Урожайность ярового рапса при использовании инсектицидных протравителей, т/га

Из рисунка 2 видно, что использование инсектицидных препаратов способствует получению достоверной прибавки маслосемян от 0,16 до 0,60 т/га. Максимальная урожайность культуры получена на вариантах, где семена заблаговременно перед посевом обрабатывали протравителями Модесто, КС и Круйзер Рапс, КС.

\section{Выводы}

Исследованиями подтверждено, что протравливание семян - необходимый прием в технологии производства семян, в том числе на рапсе в борьбе с крестоцветными блошками.

Наиболее эффрективными против комплекса крестоцветных блошек являются протравители Круйзер Рапс, КС и Модесто, КС. Их применение позволило снизить численность крестоцветных блошек в 2,5 раза по сравнению с контролем и получить максимальную в среднем за три года прибавку урожая $(40,5 \%)$ за счет приемлемого уровня подавления популяций вредителей и продолжительности действия.

Для эфрфективной защиты всходов рапса от крестоцветных блошек можно рекомендовать к широкому внедрению в производство протравители семян типа Круйзер Рапс, КС и Модесто, КС. Такие препараты позволяет сократить количество дополнительных инсектицидных опрыскиваний.

\section{Список литературы}

1. Практикум по растениеводству [Текст] / Д. В. Виноградов, Н. В. Вавилова, Н. А. Дуктова, Е. И. Лупова. - Рязань, 2018. - 320 с.

2.Виноградов, Д. В. Эфффективность химической защиты ярового рапса в Рязанской области [Текст] / Д. В. Виноградов, П. Н. Балабко, А. В. Жулин // Агро XXI. - 2010. - № 1. - С. 7.

3.Ильинский, А. В. Экологические основы природопользования: учебное пособие [Текст] / А. В. Ильинский, Д. В. Виноградов, Д. В. Данчеев. - Рязань : ФГБОУ ВО РГАТУ, 2017. - 128 с.

4.Лупова, Е.И. Технология производства яровых рапса и сурепицы в Нечерноземной зоне России : учебное пособие [Текст] / Е. И. Лупова, Д. В. Виноградов. Рязань, 2018. - 86с.

5. Практикум по земледелию [Текст] / А. С. Мастеров, Д. В. Виноградов, М. В. Потапенко, С. И. Трапков, П. Н. Балабко, Е. И. Лупова. - Рязань, 2018. - 256 c.

6.Методика государственного сортоиспытания сельскохозяйственных культур [Текст] / под ред. М. А. Федина. - Москва, 1983. - Вып. 3. - 184 с.

7.Методические указания по регистрационным испытаниям инсектицидов, акарицидов, моллю- 
скоцидов и родентицидов в сельском хозяйстве [Текст] / Рос. акад. с.-х. наук, Всерос. науч.-исслед. ин-т защиты растений, Инновац. центр за- щиты растений ; [под ред. В.И. Долженко и др.]. - СПб. : Всерос. науч.-исслед. ин-т защиты растений, 2004. - 363 с.

\section{THE USE OF GRAINERS IN RAPE SEEDS UNDER THE CONDITIONS OF THE RYAZAN REGION}

Stupin Alexander S., Ph.D. s.h. Sciences, Associate Professor, Department of Agronomy and Agricultural Technology, stupin32@yandex.ru

Vinogradov Dmitry V., Dr. Biol. sciences, professor, head. Department of Agronomy and Agricultural Technology, vdv-rz@ rambler.ru

Lupova Ekaterina I., Ph.D. biol. Sciences, Associate Professor, Department of Agronomy and Agricultural Technology, katya.lilu@mail.ru

Fadkin Gennady N., Ph.D. s.h. Sciences, Associate Professor, Department of Forestry, Agricultural Chemistry, Ecology, Breeding and Seed Production, g-fadkin@mail.ru

Sazonkin Kirill D., 2nd year undergraduate of the Department of Agronomy and Agricultural Technology, kirill.sazonkin@mail.ru

The species composition of cruciferous fleas in the Ryazan region was determined. The selection of preparations for the protection of spring rape from cruciferous fleas was carried out. For this, a systematic approach to the study of the effects of pesticides on the pest was applied. Comparative effectiveness of preparations of different chemical nature intended for controlling cruciferous flea on spring rape is provided. The species composition of phytophages in the rape agrocenosis in the region has been established. Studies have confirmed that seed dressing is a necessary technique in agricultural technology, including canola in the fight against cruciferous flea. The studies revealed that the most effective against the cruciferous flea complex are the protectants Kruiser Rape, KS and Modesto, KS. Their use made it possible to reduce the number of cruciferous fleas by 2.5 times in comparison with the control and to obtain the maximum yield increase on average over three years (40.5\%) due to an acceptable level of suppression of pest populations and duration of action. It is proposed to protect seedlings of rapeseed against cruciferous fleas that seed dressers such as Kruiser Rapeseed, KS and Modesto, KS should be widely introduced into production. Such drugs suppress pests to a level below the economic threshold of harmfulness, provide a significant increase in yield, have a minimal negative effect on non-target organisms of agrocenosis, their use excludes additional insecticidal treatment.

Key words: spring rape, oilseeds, dressing, pests, productivity, Ryazan region

\section{Literatura}

1.Vinogradov, D. V. Praktikum po rastenievodstvu [Tekst] / D. V. Vinogradov, N.V. Vavilova, N.A. Duktova, E.I. Lupova // Ryazan, 2018. 320 s.

2. Vinogradov, D.V. EHffektivnost' himicheskoj zashchity yarovogo rapsa v Ryazanskoj oblasti [Tekst] / D.V. Vinogradov, P.N. Balabko, A.V. ZHulin // Agro XXI. 2010. № 1. S. 7.

3.llinskiy, A.V. Ekologicheskie osnovy pripodopolzovaniya: uchebnoe posobie [Tekst] / A.V. Ilinskiy, D.V. Vinogradov, D.V. Dancheev // Ryazan: FGBOU VO RGATU, $2017-128 \mathrm{~s}$.

4.Lupova E.I. Technologiya proizvodstva yrovih rapsa I surepici v nechernozemnoi zoni Rossii [Tekst] / E.I. Lupova, D.V. Vinogradov // Uchebnoe posobie. Ryazan, 2018. $86 \mathrm{~s}$.

5.Masterov, A.S. praktikum po zemledeliyu [Tekst] / A.S. Masterov, D.V. Vinogradov, M.V. Potapenko, S.I. Trapkov, P.N. Balabko, E.I. Lupova // Ryazan, 2018. 256 s.

6.Metodika gosudarstvennogo sortoisputaniya selskohozyaistvennih kultur [Tekst] / Pod. red. Fedina M.A. // Moskva, 1983. vip.3. 184 s.

7.Metodicheskie ukazaniya po registracionnim ispyitaniyam insekticidam, akaricidov, molyskocidov, rodenticidov v selskom hozaistve. S-Pb. Vseross. Institute zashity rastenii, 2004.-363s.

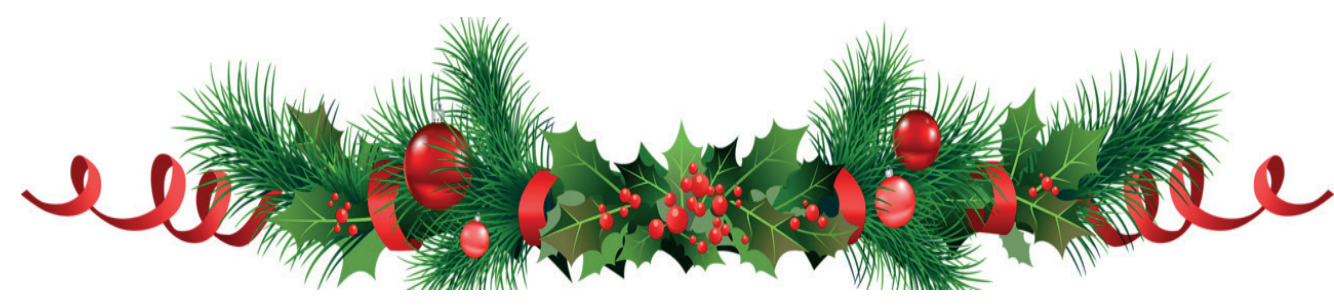




\section{СОВРЕМЕННЫЕ ТЕНДЕНЦИИ ПРОИЗВОДСТВА МОЛОКА В УСЛОВИЯХ ИНТЕНСИВНОЙ ТЕХНОЛОГИИ}

тУников Геннадий Михайлови, д-р с.-х. наук, профрессор кафредры зоотехнии и биологии, university@rgatu.ru

МОРОЗОВА Нина Ивановна, д-р с.-х. наук, профессор, зав. кафедрой технологии производства и переработки сельскохозяйственной продукции, morozova@rgatu.ru

МУСАЕВ Фаррух Атауллахович, д-р с.-х. наук, профрессор кафредры технологии производства и переработки сельскохозяйственной продукции, musaev@rgatu.ru

МОРОЗОВА Ольга Александровна, канд. с.-х. наук, преподаватель ФДП и СПО, 505om@таil.ru

КОРОВУШКИн Алексей Александрович д-р биол. наук, профрессор кафредры зоотехнии и биолоzuu, korovuschkin@mail.ru

Рязанский государственный агротехнологический университет имени П. А. Костычева

В Рязанской области за последние годы наблюдается тенденция сокращения поголовья дойных коров. Одновременно с этой тенденцией молочная продуктивность коров ежегодно увеличивается и по итогам 2018 года она составила 6872 кг. Общее поголовье крупного рогатого скота стабильно и составляет 161,5 тыс. голов. Наибольшее поголовье крупного рогатого скота - 74918 голов или 54,5\% от общего поголовья, из них 45270 коров или 85,0\%, сосредоточено в пяти районах области: Рязанском, Рыбновском, Александро-Невском, Захаровском и Старожиловском. Производство молока составило 367986 тыс. m, что на 23719 тыс. m или 6,4\% больше уровня прошлого года. Максимальный объем производства молока на предприятиях Рязанского района - 60,7 тыс. m, Рыбновского - 50,3 тыс. m, Александро-Невского - 34,8 тыс. m, Старожиловского - 31,8 тыс. $m$ и Захаровского - 30127 тыс. m. Крупнейшие предприятия по объёму производства сырого молока: ООО "Авангард" Рязанского района - 30,05 тыс. m; ООО "Вакинское Агро" Рыбновского района - 25,7 тыс. m; ООО "ОКА МОЛОКО" ОП № 3 Пителинского района - 18,2 тыс. т.; ООО "АПК Русь" Рыбновского района -17,6 тыс. m. Для реализации генетического потенциала голштинского скота в Рязанской области создаются комфортные условия содержания, кормления, доения и первичной обработки молока в предприятиях: ООО «Авангард»; роботизированная фрерма «Вакинское Агро»; $А$ О "Рассвет"; СПК «Русь»; колхоз им. Ленина Касимовского района. Надой молока на одну фуражную корову по сравнению с прошлым годом увеличился на 605 ке или 9,6\% и составил 6872 ке. Максимальная молочная продуктивность коров - 10205 кг - в АО "Рассвет" Рязанского района; в ООО "ОКА МОЛОКО" ОП № 3 Пителинского района - 9885 ке и в колхозе им. Ленина Касимовского района 9838 ке. В девяти хозяйствах области надоили более 8000 ке. Однако высокая молочная продуктивность коров приводит к быстрой смене поколений животных за счет снижения воспроизводительной способности, яловости, мастита, травматизма и непригодности к машинному доению. Для успешного развития молочного скотоводства необходимо несколько кардинальных условий: наличие генетически обусловленного высокопродуктивного скота, хорошая кормовая база, современная специализированная технология производства молока, необходимые мощности по переработке молока и рынок сбыта. Одним из основных резервов увеличения молочной продуктивности коров является увеличение продуктивного долголетия, так как животные до выбытия из стада не успевают использовать свой продуктивный потенциал.

Ключевые слова: крупный рогатый скот, коровы, молочная продуктивность, производство молока, продуктивное долголетие, кормление, содержание, интенсивная технология.

\section{Введение}

Молочное скотоводство России было и остается одной из основных и перспективных отраслей животноводства, так как производством молока занимаются свыше 90\% сельскохозяйственных предприятий в нашей стране.

За последние годы в отрасли произошли изменения в технологии содержания, кормления, доения и первичной обработке молока. На многих фермах и молочных комплексах внедрено беспривязное круглогодовое стойловое содержание коров, доение осуществляется в автоматизированных доильных залах и роботами.

Задача отечественного молочного скотоводства заключается в обеспечении населения моло- ком и молочными продуктами высокого качества, которые должны быть безопасными, рентабельными и конкурентоспособными.

В условиях интенсивной технологии увеличение объемов производства молока и повышение его качества должно базироваться на стабилизации поголовья скота, разведении высокопродуктивного голштинского скота, внедрении новых технологических процессов, основанных на инновационных и автоматизированных технологиях производства [1, 3, 7, 9,10].

\section{Материал и методы исследований}

Экспериментальные исследования и анализ производственных данных проводился по итогам 2017 и 2018 годов в хозяйствах Рязанского райо-

() Туников Г. М.. Морозова Н. И., Мусаев Ф. А., Морозова О. А., Коровушкин А. А., 2019 г. 
на: ООО "Авангард", АО "Рассвет"; Рыбновского района: ООО "Вакинское Агро" и ООО "АПК Русь"; ООО "ОКА МОЛОКО" ОП № 3 Пителинского района; колхозе им. Ленина Касимовского района; АО "Октябрьское" Пронского района; СПК "Ряжский агроцентр "Ряжского района; ООО "ОКА МОЛОКО" Чучковского района; СПК "Мир" АлександроНевского и др.

Проведен анализ численности поголовья крупного рогатого скота, коров, молочной продуктивности и объемов производства молока в районах области: Рязанском (19048 голов), Рыбновском (16417 голов), Александро-Невском (13762 головы), Захаровском (12963 головы) и Старожиловском (12728 голов).

Проанализировано большое количество статистических и бонитировочных сведений как по конкретным хозяйствам, так и по сводным ведомостям [1-9].

Результаты собственных исследований

Рязанская область наращивает мощности производства молока за счет увеличения рынка сбыта и инвестиционных проектов, особенно в таких предприятиях, как ООО Агромолкомбинат «Рязанский», где завершена реализация крупного инвестиционного проекта по увеличению мощности по переработке, распределению и хранению молочной продукции в Рязани, ОАО «Старожиловский молочный комбинат», молочный завод ООО «Вакинское Агро» с производственной мощностью 120 тонн молока в сутки.

Благодаря внедрению автоматизированных технологий по переработке молока по сравнению с 2017 годом объем производства молока сырого увеличился на 23,7 тыс. т., масла сладкосливочного - более чем на 9\%, а производство творога на $14 \%$.
Современное состояние отрасли молочного скотоводства в нашем регионе определяется наличием общего поголовья крупного рогатого скота, коров, породного потенциала, внедрением инновационных технологий производства молока, а, следовательно, информационно-консультационным обслуживанием АПК, внедрением научных исследований и формированием кадрового потенциала

По итогам 2018 года общее поголовье крупного рогатого скота в Рязанской области составило 161,5 тыс. голов или 97,6\% к уровню 2017 года.

Основное поголовье крупного рогатого скота сосредоточено в сельскохозяйственных предприятиях - 136,5 тыс. голов (84,5\%). Общее поголовье коров на 1 января 2018 года составило во всех категориях хозяйств области 63,6 тыс. голов, что на 3,0 тыс. голов меньше по сравнению с предыдущим годом. В сельскохозяйственных предприятиях насчитывается 53,2 тыс. голов или 83,6\% к общей численности поголовья.

Наибольшее поголовье крупного рогатого скота - 74918 голов или $54,5 \%$ от общей численности скота сосредоточено в пяти районах области: Рязанском (19048 голов), Рыбновском (16417 голов), Александро-Невском (13762 головы), Захаровском (12963 головы) и Старожиловском (12728 голов). Общее поголовье коров в перечисленных районах составило 45270 голов или $85,0 \%$ от общего поголовья коров в Рязанской области.

Производство молока в хозяйствах всех категорий составило 367986 тыс. т, что на 23719 тыс. т или $6,4 \%$ больше уровня прошлого года.

Производство молока по районам области, обеспечившим наибольший объем и прибавку, приведено в таблице 1.

Таблица 1 - Производство молока по районам Рязанской области, т

\begin{tabular}{|l|c|c|c|c|}
\hline \multirow{2}{*}{$\begin{array}{c}\text { Наименование } \\
\text { районов }\end{array}$} & \multicolumn{2}{|c|}{ С начала года } & за декабрь \\
\cline { 2 - 5 } & 2018 г & 2017 г. & 2018 г. & $\begin{array}{c}+;- \text { к } \\
2017 \text { г. }\end{array}$ \\
\hline Захаровский & 30127 & -480 & 2430 & -61 \\
\hline Касимовский & 27378 & +1604 & 2431 & +261 \\
\hline $\begin{array}{l}\text { Александро-Не- } \\
\text { вский }\end{array}$ & 34827 & +1579 & 2724 & -137 \\
\hline Рыбновский & 50307 & +7531 & 3820 & +98 \\
\hline Ряжский & 19410 & +2743 & 1522 & +374 \\
\hline Рязанский & 60743 & +6996 & 5291 & +877 \\
\hline Старожиловский & 31848 & +1770 & 2628 & -100 \\
\hline Чучковский & 11433 & +2732 & 903 & +35 \\
\hline $\begin{array}{l}\text { Итого по восьми } \\
\text { районам }\end{array}$ & 266073 & +24475 & 21749 & +1347 \\
\hline Итого по области & 367986 & +23719 & 29408 & +926 \\
\hline
\end{tabular}

Максимальный объем производства молока в предприятиях Рязанского района - 60,7 тыс. т или $16,5 \%$ от областного объёма, в Рыбновском районе - 50,3 тыс. т (13,6\%), в Александро-Невском районе - 34,8 тыс. т $(9,5 \%)$, Старожиловском 31,8 тыс. $(8,7 \%)$ и Захаровском -30127 тыс. (8,2\%).

В таблице 2 приведен список крупнейших пред- приятий по объёму производства сырого молока: ООО "Авангард" Рязанского района - 30,05 тыс. т; ООО "Вакинское Агро" Рыбновского района $-25,7$ тыс. т; ООО "ОКА МОЛОКО" ОП № 3 Пителинского района - 18,2 тыс. т.; ООО "АПК Русь" Рыбновского района - 17,6 тыс. т. 
Таблица 2 - Лучшие предприятия Рязанской области по валовому объёму производства молока и продуктивности по итогам 2018 года

\begin{tabular}{|c|c|c|c|c|c|c|}
\hline \multirow[t]{2}{*}{ Хозяйство } & \multicolumn{2}{|c|}{$\begin{array}{c}\text { Надой на } \\
\text { фуражную корову, кг }\end{array}$} & \multicolumn{2}{|c|}{$\begin{array}{l}\text { Валовой надой } \\
\text { молока, тонн }\end{array}$} & \multicolumn{2}{|c|}{$\begin{array}{c}\text { Наличие } \\
\text { коров, голов }\end{array}$} \\
\hline & 2018 год & $+/-$ к 2017 & 2018 год & +/-к 2017 & 2018 год & $+/-\kappa 2017$ \\
\hline $\begin{array}{l}\text { ООО "Авангард" Рязанского } \\
\text { района }\end{array}$ & 7719 & +447 & 30045 & +2192 & 3950 & - \\
\hline $\begin{array}{l}\text { ООО "Вакинское Агро" Рыбнов- } \\
\text { ского района }\end{array}$ & 8946 & +577 & 25747 & +3452 & 3014 & +201 \\
\hline $\begin{array}{l}\text { ООО "ОКА МОЛОКО" ОП № } 3 \\
\text { Пителинского района }\end{array}$ & 9885 & +894 & 18228 & +2701 & 2203 & +603 \\
\hline $\begin{array}{l}\text { ООО "АПК Русь" Рыбновского } \\
\text { района }\end{array}$ & 8762 & +834 & 17629 & +5213 & 2146 & +144 \\
\hline АО "Рассвет" Рязанского района & 10205 & +1318 & 15124 & +2850 & 1528 & +64 \\
\hline $\begin{array}{l}\text { Колхоз им. Ленина Касимовского } \\
\text { района }\end{array}$ & 9838 & +694 & 14550 & +899 & 1500 & +30 \\
\hline $\begin{array}{l}\text { АО "Октябрьское" Пронского } \\
\text { района }\end{array}$ & 8620 & +380 & 14508 & -94 & 1683 & - \\
\hline $\begin{array}{l}\text { СПК "Ряжский } \\
\text { агроцентр"Ряжского района }\end{array}$ & 8682 & +844 & 12155 & +1182 & 1400 & - \\
\hline $\begin{array}{l}\text { ООО "ОКА МОЛОКО" Чучковско- } \\
\text { го района }\end{array}$ & 9124 & +1127 & 11049 & +3115 & 1292 & +142 \\
\hline $\begin{array}{l}\text { СПК "Мир" Александро-Невского } \\
\text { района }\end{array}$ & 8231 & +251 & 10034 & +1152 & 1219 & - \\
\hline
\end{tabular}

Надой молока на одну фруражную корову по сравнению с прошлым годом увеличился на 605 кг или 9,6\% и составил 6872 кг. Максимальная молочная продуктивность коров - 10205 кг получена в АО "Рассвет" Рязанского района; в ООО "ОКА
МОЛОКО" ОП № 3 Пителинского района - 9885 кг и в колхозе им. Ленина Касимовского района 9838 кг. В девяти хозяйствах области надоили более 8000 кг (табл. 3).

Таблица 3 - Молочная продуктивность коров в лучших хозяйствах

Рязанской области по итогам 2018 года, кг

\begin{tabular}{|l|c|c|}
\hline \multicolumn{1}{|c|}{ Надой на фуражную корову, кг } & Надой на фуражную корову, кг & +/-к 2017 году \\
\hline АО "Рассвет" Рязанского района & 10205 & +1318 \\
\hline $\begin{array}{l}\text { ООО "ОКА МОЛОКО" ОП № З Пителинского } \\
\text { района }\end{array}$ & 9885 & +894 \\
\hline Колхо им. Ленина Касимовского района & 9838 & +694 \\
\hline ООО "ОКА МОЛОКО" Чучковского района & 9124 & +1127 \\
\hline ООО "Вакинское Агро" Рыбновского района & 8946 & +577 \\
\hline ООО "Простор" Захаровского района & 8837 & +194 \\
\hline ООО "АПК Русь" " Рыбновского района & 8762 & +834 \\
\hline СПК "Ряжский агроцентр" Ряжского района & 8682 & +844 \\
\hline СПК "Нива" Александро-Невского района & 8639 & -34 \\
\hline АО "Октябрьское" Пронского района & 8620 & +380 \\
\hline СПК "Мир" " Александро-Невского района & 8231 & +251 \\
\hline Колхоз (СПК) имени Ленина Старожиловский & 8147 & +356 \\
\hline ООО "Надежда" Александро-Невского района & 8122 & +180 \\
\hline
\end{tabular}

Особенно заметен успех, благодаря инвестициям и субсидированиям, в ООО «Вакинское Агро», где налажено производство молока с законченным циклом с поголовьем 3420 голов, со строительством собственного комбикормового завода и самостоятельного предприятия по многоуровневой переработке молока. Надо отметить, что в этом хозяйстве впервые в области было внедрено доение коров роботами с использованием 34-х аппаратов, что является рекордом не только в Росси, но и в Европе. Завершено строительство двух роботизированных ферм на 400 голов в колхозе им. Ленина Касимовского района. Успешно работает новая молочно-товарная ферма на 1200 голов в ЗАО «Победа» Захаровского района.

Большие перспективы имеют строящиеся животноводческие комплексы в Шацком и Пителинском районах за счет 15-летних кредитов. На 
субсидирование реализованного молока было направлено более 230 млн рублей, на содержание и приобретение племенного молодняка - более 300 млн рублей.

Резервов увеличения молочной продуктивности довольно много, и далеко не использованных также. Этому посвящено большое количество научных исследований и рекомендаций [1-9].

В данной работе эти резервы рассматриваются С точки зрения сроков хозяйственного использования коров или их продуктивного долголетия.

В настоящее время начинает снижаться продуктивность коров по сравнению с первым отелом и только тогда наступает время их выбраковки.

Существуют разные системы выбраковки и выранжировки стада. Даже были рекомендации сверхинтенсивного выращивания телок и их максимальной эксплуатации по первой лактации, с последующей выбраковкой.

Однако корова дает не только молоко, но и теленка, что не менее важно. Из-за того, что корова за жизнь приносит только 2-3 теленка, приходится покупать телочек для ремонта стада, а эти громадные средства можно было бы направить на улучшение кормления коров, ремонтируя стадо за счет собственного приплода.

Исследования показали, что двадцать лет назад коровы черно-пестрой породы в среднем пребывали в стаде 6,3 года, что соответствует четырем лактациям [2], а в хозяйствах с более низкой продуктивностью продолжительность хозяйственного использования коров составляла пять лактаций.

В результате изменения технологии содержания коров (стойловое), рационов кормления (без пастбищ), доения и других фракторов произошло снижение продуктивного долголетия коров почти на одну лактацию. А в хозяйствах с высокой молочной продуктивностью это снижение более заметно, так как коэффрициент корреляции между продолжительностью использования коров и удоем составляет 0,159, т.е. чем выше удой, тем меньший срок корова пребывает в стаде.

Срок продуктивного долголетия коров складывается из двух производственных циклов: выращивания телок от рождения до первого отела и от первой лактации до выбытия из стада. При этом долголетие коров зависит от генетических факторов (продуктивные качества и здоровье родителей, наследуемость этого признака и др.) и в большей мере от френотипических фракторов (кормление, содержание и уход, доение, система выбраковки и выранжировки стада).

Правильное выращивание ремонтных телок - основа получения высококопродуктивных животных в течение многих лактаций. Это позволяет выявить потенциальную продуктивность коров в ранний период, а также получить достоверную оценку по первой лактации. В среднем в условиях Рязанской области нормы выращивания ремонтных телок должны быть следующими (табл. 4).

Особое внимание необходимо уделять выращиванию телочек в период 12-18 месяцев, когда создается угроза ожирения животных, что негативно сказывается на их воспроизводительных функциях.
В молочный период телочки должны получать молоко матери (молозиво) в целом 400 кг цельного молока, сено, сенаж, концентраты вволю.

Таблица 4 - Прирост и живая масса телок в разном возрастном периоде

\begin{tabular}{|c|c|c|}
\hline $\begin{array}{c}\text { Возраст, } \\
\text { мес. }\end{array}$ & $\begin{array}{c}\text { Среднесуточ- } \\
\text { ный прирост, г }\end{array}$ & $\begin{array}{c}\text { Живая масса в } \\
\text { конце периода }\end{array}$ \\
\hline До 6 & $750-800$ & $170-180$ \\
\hline $6-12$ & $720-770$ & $300-310$ \\
\hline $12-18$ & $600-670$ & $410-450$ \\
\hline $18-24$ & $700-750$ & $410-450$ \\
\hline
\end{tabular}

Половое созревание телок наступает в 8-9 месяцев, их живая масса должна быть в пределах 210-230 кг. Как правило, осеменяют телок в 18-20 месяцев.

Продуктивное долголетие обусловлено генетическим фрактором. Коэффициент наследуемости этого показателя, хотя и не очень высокий у коров разных пород $(0,028-0,135)$, но отбор у коров по этому показателю совместно с селекцией по пригодности коров к машинному доению, форме вымени, фрорме копытец и крепости копытцевого рога, даст несомненный эффект.

Технология содержания коров в крупных молочных комплексах в настоящее время отработана досконально. Главные зоотехнические требования сводятся к созданию температуры в помещениях: в пределах $10-15^{\circ} \mathrm{C}$ - зимой, $20-25^{\circ} \mathrm{C}$ - летом, относительная влажность - 70-75\%, скорость движения воздуха 0,5 м/с, содержание углекислого газа - 0,25\%, аммиака не более $20 \mathrm{mr} / \mathrm{M}^{2}$.

Кормление коров является самым мощным фрактором увеличения производства молока [3]. Количество и качество молока в значительной мере зависят от соотношения питательных веществ.

В целом считается: на величину удоя коров примерно на $60 \%$ влияет кормление, а все остальное приходится на генотип животных и другие факторы.

В структуре рациона на обменную энергию приходится 52\%, на протеин 33\%, минеральные вещества - 15\%. Оптимальное сахаро-протеиновое соотношение составляет 1:1. В рационе для молочного скота сухого вещества должно быть не менее $14 \%$, кальциево-фоссфорное отношение -в пределах 1,5-3,0\%. В рационе на каждый килограмм молока в сочном корме должно содержаться 150-180 г сахара.

Кормление низкопродуктивных коров обходится в 1,5-2 раза дороже по сравнению с высокопродуктивными. Решающую роль в эфффективности кормления играют комбинированные корма, каждый килограмм должен содержать протеина 140150 г зимой и 110-130 г - летом. В зимнее время в обязательном порядке должно скармливаться 3-4 кг сена, а в летнее время - зеленые корма культурных пастбищ. Хороший аппетит коров является главным признаком для отбора коров в основное стадо.

Сложившийся опыт показывает, что выбраковка коров основного стада составляет 22-25\% 
в год, при этом требуется за год вырастить нетелей в расчете на 100 коров 42\%. Выбытие телок при выращивании должно быть не более $12 \%$, выранжировка первотелок - 3\%, выбраковка первотелок - 60\%. В структуре стада предусматриваеся на каждые 100 коров иметь 37 нетелей и 50 телок старше 12 месяцев. Высший суточный удой в первые 90 дней лактации должен составлять не менее 20 кг молока с интенсивностью молокоотдачи не менее 1,4 кг/мин.

Прибыльотсодержаниякоровыначинаетсятолько с третьей лактации, в связи с чем большинство коров практически не достигает генетического потолка и не выявляет свой продуктивный потенциал.

В промышленном животноводстве коров чаще всего бракуют по причине различных заболеваний. Чаще выбраковывают по причине мастита $(21,4 \%)$, несколько реже по причинам яловости $(14,9 \%)$, заболевания конечностей - 13,1\%, низкой продуктивности - 9,3\%, травм и несчастных случаев - 7,8\%, по старости - 4,8\% коров.

В условиях Рязанской области, как показали наши расчеты, каждая корова в среднем должна дать 30 тонн молока, только тогда окупятся все расходы на ее содержание. Следовательно, она должна иметь, как минимум 4 лактации, а увеличение продуктивногодолголетия на 0,5 лактации позволит увеличить ее продуктивность более чем на $12 \%$.

В целом наблюдается такая тенденция: повышение продуктивности коров несколько сглаживает сокращение сроков продуктивного долголетия, но не решает проблемы увеличения продуктивности и выхода телят.

\section{Заключение}

Для достижения успешного развития молочного скотоводства необходимо несколько кардинальных условий: наличие генетически обусловленного высокопродуктивного скота, хорошая кормовая база, современная специализированная технология производства молока, необходимые мощности по переработке молока и рынок сбыта.

По итогам 2018 года общее поголовье крупного рогатого скота в Рязанской области стабильно и составило 161,5 тыс. голов. Основное поголовье скота и коров сосредоточено в сельскохозяйственных предприятиях - 136,5 тыс. голов (84,5\%), в том числе 53,2 тыс. или 83,6\% коров к общей численности их поголовья (63,6 тыс. голов). Наибольшее поголовье крупного рогатого скота - 74918 голов или 54,5\% и коров - 45270 голов или 85,0\% сосредоточено в пяти районах области: Рязанском, Рыбновском, Александро-Невском, Захаровском и Старожиловском.

Производство молока составило 367986 тыс. т, что на 23719 тыс. т или 6,4\% больше уровня прошлого года. Максимальный объем производства молока в предприятиях Рязанского района 60,7 тыс. т или $16,5 \%$ от областного объёма, в Рыбновском районе - 50,3 тыс. т $(13,6 \%)$, Александро-Невском районе 34,8 тыс. т $(9,5 \%)$, Старожиловском 31,8тыс.т(8,7\%)иЗахаровском-30127тыс.т(8,2\%). Крупнейшие предприятия по объёму производ- ства сырого молока: ООО "Авангард" Рязанского района - 30,05 тыс. т; ООО "Вакинское Агро" Рыбновского района - 25,7 тыс. т; ООО "ОКА МОЛОКО" ОП № 3 Пителинского района - 18,2 тыс. т.; ООО "АПК Русь" Рыбновского района - 17,6 тыс. т.

Надой молока на одну фуражную корову по сравнению с прошлым годом увеличился на 605 кг или 9,6\% и составил 6872 кг. Максимальная молочная продуктивность коров - 10205 кг - в АО "Рассвет" Рязанского района; в ООО "ОКА МОЛОКО" ОП № 3 Пителинского района - 9885 кг и в колхозе им. Ленина Касимовского района 9838 кг. В девяти хозяйствах области надоили более 8000 кг на одну фуражную корову.

Для реализации генетического потенциала голштинского скота в Рязанской области создаются комфортные условия содержания, кормления, доения и первичной обработки молока в предприятиях: ООО «Авангард»; роботизированная ферма «Вакинское Агро»; АО "Рассвет"; СПК «Русь»; колхоз им. Ленина Касимовского района.

Одним из основных резервов увеличения молочной продуктивности коров является увеличение продуктивного долголетия, так как животные до выбытия из стада не успевают использовать свой продуктивный потенциал.

\section{Список литературы}

1.Бышова, Н.Г. Инновационные технологии в производстве молока. Монография /Н.Г. Бышова, Г.М. Туников, Н.И. Морозова, Ф.А. Мусаев, Л.В. Иванова. - Рязань, 2013. - 156 с.

2.Павлюхин, А.М. Продолжительность хозяйственного использования коров и эффективность селекции по этому признаку: автореф. дис. ... канд. с.-х. наук: 06.04.02 /Павлюхин Андрей Михайлович. - Рязань, 2004. - 19.

3.Туников, Г.М. Рекомендации по увеличению молочной продуктивности коров и комплексному повышению качества молока в личных и крестьянских (фермерских) хозяйствах. /Г.М. Туников, Н.И. Морозова, И.Г. Шашкова, В.Н. Барсуков. -Рязань, 2007. - 97 c.

4.Рязанская область в цифрах: статистический сборник. - Рязань. -Рязаньстат, 2016.-2018 гг.

5.Туников, Г.М. Современное состояние и стратегия развития АПК Рязанской области на рубеже XXI столетия. [Текст]. /Г.М. Туников, И.М. Стародумов, А.М. Павлюхин. - Рязань, 2001.- 158-160.

6. Туников, Г.М. Разведение животных с основами частной зоотехнии: учебник. [Текст]. /Г.М. Туников, А.А. Коровушкин. Санкт-Петербург: Лань, 2016. - 744 c.

7. Морозова, Н.И. Сравнительная оценка молочной продуктивности коров голштинской породы голландской и венгерской селекции. [Текст] /Н.И. Морозова, Ф.А. Мусаев Ф.А., Л.В. Иванова. // Зоотехния. - 2012. - №5. - С. 22.

8.. Морозова, Н.И. Молочная продуктивность и качество молока в зависимости от линейной принадлежности коров. [Текст] /Н.И. Морозова, Ф.А. Мусаев // Молочная промышленность. - 2007. -№ 7. - С. 24.

9.. Мусаев, Ф.А. Технология производства молочных продуктов по стандартам России. 
[Текст]. Рязань, 2009.

10.Шевхужев, А.Ф. Современные технологии производства молока с использова-

нием голштинского скота. [Текст] /А.Ф. Шевхужев. - Москва. -«ИЛЕКСА».- 2015.- 392 с

\section{PRODUCTIVE LONGEVITY OF COWS IN CONDITIONS OF INTENSIVE MILK PRODUCTION TECHNOLOGY}

Tunikov Gennady M., doctor of agricultural Sciences, Professor of the Department of animal science and biology, university@rgatu.ru

Morozova Nina I., doctor of agricultural Sciences, Professor, head of the Department of technology of production and processing of agricultural products, morozova@rgatu.ru

Musaev Farrukh A., doctor of agricultural Sciences, Professor of the Department of technology of production and processing of agricultural products, musaev@rgatu.ru

Morozova Olga A., Candidate of agricultural sciences, 505om@mail.ru

Korovushkin AlexeyA., Dr. Biol. Professor of the Department of animal science and biology, korovuschkin@ mail.ru

Ryazan state agrotechnological University named after P. A. Kostychev

In the Ryazan region in recent years there has been a tendency to reduce the number of dairy cows. Simultaneously with this trend, the dairy productivity of cows increases annually and at the end of 2018 it amounted to $6872 \mathrm{~kg}$. the Total number of cattle is stable and is 161.5 thousand heads, including 53.2 thousand heads. The largest number of cattle-74918 heads or $54.5 \%$, including 45270 cows or $85.0 \%$ is concentrated in five districts of the region: Ryazan, Rybnovsky, Alexander Nevsky, Zakharovsky and Starozhilovsky. Milk production amounted to 367986 thousand. tons, which is 23719 thousand tons or $6.4 \%$ more than last year. The maximum volume of milk production at the enterprises of the Ryazan area - 60,7 thousand $t$ Rybnovskiy - 50,3 thousand tons, Alexander Nevsky - 34.8 thousand tonnes Sadovaya - 31.8 thousand tons and Zakharovskaya - 30127 tons the Largest enterprises by production volume of raw milk: "Avangard" Ryazan region - of 30.05 kt; of "Vakinskoe agro" Rybnovsky district - 25.7 thousand tons; OOO "OKA MILK" OP \# 3 Pitelino district is 18.2 thousand tons; OOO "APK Rus" Rybnovsky district -17,6 thousand tons. To realize the genetic potential of Holstein cattle in the Ryazan region, comfortable conditions for keeping, feeding, milking and primary processing of milk are created in the enterprises: LLC "Avangard"; robotic farm "Vakinskoye agro"; JSC "Dawn"; SEC "Rus"; collective farm. Lenin Kasimov district. Milk yield per 1 forage cow compared to last year increased by $605 \mathrm{~kg}$ or $9.6 \%$ and amounted to $6872 \mathrm{~kg}$. the Maximum milk productivity of cows- $10205 \mathrm{~kg}$ in JSC "Dawn" Ryazan region; in LLC "OKA MILK" OP No. 3 Pitelinsky district-9885 kg and in the collective farm. In Kasimov district $9838 \mathrm{~kg}$ in nine farms of the region more than $8000 \mathrm{~kg}$ were fed. However, the high milk productivity of cows leads to a rapid change of generations of animals due to a decrease in reproductive capacity, cowhide, mastitis, injuries and unsuitability for machine milking. For the successful development of dairy cattle breeding, several cardinal conditions are necessary: the presence of genetically determined highly productive cattle, a good fodder base, modern specialized technology of milk production, the necessary capacity for milk processing and the market. One of the main reserves of increasing milk productivity of cows is to increase productive longevity, as animals do not have time to use their productive potential before leaving the herd.

Key words: cattle, cows, milk productivity, milk yield, milk production, factors, productive longevity, feeding, maintenance, intensive technology.

1.Byshova, N.G. Innovacionnye tekhnologii v proizvodstve moloka. Monografiya /N.G. Byshova, G.M. Tunikov, N.I. Morozova, F.A. Musaev, L.V. Ivanova. - Ryazan', 2013. - 156 s.

2.Pavlyuhin, A.M. Prodolzhitel'nost' hozyajstvennogo ispol'zovaniya korov i effektivnost' selekcii po etomu priznaku: avtoref. dis. ... kand. s.-h. nauk: 06.04.02 /Pavlyuhin Andrej Mihajlovich. - Ryazan', 2004. - 19.

3. Tunikov, G.M. Rekomendacii po uvelicheniyu molochnoj produktivnosti korov i kompleksnomu povysheniyu kachestva moloka v lichnyh i krest'yanskih (fermerskih) hozyajstvah. /G.M. Tunikov, N.I. Morozova, I.G. SHashkova, V.N. Barsukov. -Ryazan', 2007. - 97 s.

4.Ryazanskaya oblast' v cifrah: statisticheskij sbornik. - Ryazan'. -Ryazan'stat, 2016.-2018 gg.

5.Tunikov, G.M. Sovremennoe sostoyanie i strategiya razvitiya APK Ryazanskoj oblasti na rubezhe XXI stoletiya. [Tekst]. /G.M. Tunikov, I.M. Starodumov, A.M. Pavlyuhin. - Ryazan', 2001.- 158-160.

6. Tunikov, G.M. Razvedenie zhivotnyh s osnovami chastnoj zootekhnii: uchebnik. [Tekst]. /G.M. Tunikov, A.A. Korovushkin. Sankt-Peterburg: Lan', 2016. -744 s.

7. .Morozova, N.I. Sravnitel'naya ocenka molochnoj produktivnosti korov golshtinskoj porody gollandskoj i vengerskoj selekcii. [Tekst]/N.I. Morozova, F.A. Musaev F.A., L.V. Ivanova. //Zootekhniya. - 2012. - №5. - S. 22.

8.. Morozova, N.I. Molochnaya produktivnost' i kachestvo moloka $v$ zavisimosti ot linejnoj prinadlezhnosti korov. [Tekst]/N.I. Morozova, F.A. Musaev I/Molochnaya promyshlennost'. - 2007. -№ 7. - S. 24.

9.. Musaev, F.A. Tekhnologiya proizvodstva molochnyh produktov po standartam Rossii. [Tekst]. Ryazan', 2009.

10.SHevhuzhev, A.F. Sovremennye tekhnologii proizvodstva moloka s ispol'zovaniem golshtinskogo skota. [Tekst] /A.F. SHevhuzhev. - Moskva. -«ILEKSA».- 2015.- 392 s 


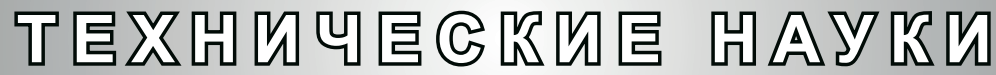

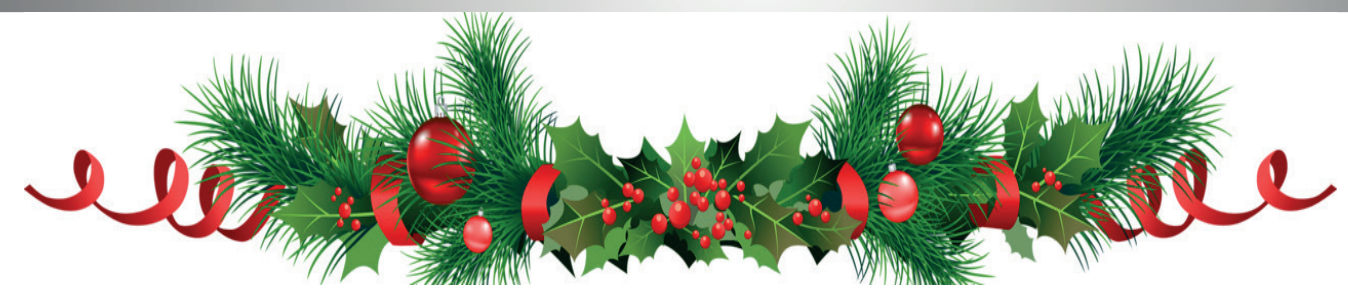

Удк 631.171

DOI 10.36508/RSATU.2019.63.19.013

\section{РЕЗУЛЬТАТЫ ЛАБОРАТОРНЫХ ИССЛЕДОВАНИЙ ПРОЦЕССА РАСПРОСТРАНЕНИЯ РАБОЧЕГО РАСТВОРА В СОЛОМЕ}

БоГдАНчИков Илья Юрьевич канд. техн. наук, доцент кафедры эксплуатации машинно-тракторного парка, СМY62.rgatu@mail.ru,

Рязанский государственный агротехнологический университет имени П.А. Костычева

При проведении полевых испытаний машины для утилизации незерновой части урожая в качестве удобрения было установлено, что при установке вылета фоорсунки за распределительные заслонки возможно разделять поток измельчённой растительной массы на два различных слоя. Первый слой - обработанный рабочим раствором препарата, ускоряющего процесс разложения; второй, из растительного материала, проходит над соплом распылительных форсунок и остаётся сухим (не обработанным рабочим раствором). Так, при установке крайних значений вылета фрорсунки за распределительные заслонки $\Delta_{\max }=45 \mathrm{~mm} \mathrm{u} \Delta_{\min }=0 \mathrm{Mм}$ при помощи тепловизора засвидетельствовали образование необработанного слоя над обработанным по разности их температур. Рабочий раствор готовится путём смешивания биологических удобрений с водой, температура раствора не более $+5^{\circ}-10^{\circ} \mathrm{C}$, а температура соломы в валке составляет $+22^{\circ} \mathrm{C}$ и более. Была выдвинута гипотеза о том, что верхний, не обработанный рабочим раствором, слой может защищать нижний, обработанный, от воздействия окружающей среды и исключить испарение рабочего раствора до момента заделки удобрения в почву. В результате лабораторных исследований были получены нелинейные зависимости изменения влажности и температуры внутри слоя соломы, обработанной рабочим раствором. Было установлено, что первые 20 минут после обработки влага под действием силы тяжести стремительно перемещается в нижнюю часть слоя, после чего начинает подниматься вверх и испаряться. В полевых условиях измельчённая и обработанная рабочим раствором растительная масса попадает на почву хорошо перемешенная и с усвоенной влагой более 90\%, что приводит к интенсивному её испарению. Необработанный слой соломы, уложенный поверх обработанного, может считаться защитным и при условии их равенства по толщине способен сдерживать интенсивность испарения до 1 часа при температуре воздуха не более $+25^{\circ} \mathrm{C}$.

Ключевые слова: незерновая часть урожая, солома, утилизация, удобрение, защитный слой, усвояемость, влажность, испарение.

\section{Введение}

Задача по повышению плодородия является одной из самых приоритетных, так как от решения ее зависит здоровье всего населения Земли [1-5]. Любой продукт, потребляемый человеком в пищу, проходит путь, начиная его в почве, поэтому от здоровья почвы зависит и здоровье людей. Использование побочной продукции растениеводства в качестве удобрения позволяет сократить негативное воздействие на почву на 40-45\% и оказать благотворное влияние на формирование гумуса $[1,3,6,7]$.

В рамках темы НИР по заказу Минсельхоза РФ в 2018-2019 гг. проводятся работы по созданию машины для эффективной утилизации незерновй части урожая [8] в качестве удобрения. В ходе полевых испытаний данной машины было установлено, что при установке вылета фрорсунки $\Delta$ за распределительные заслонки (рис. 1) возможно разделение потока измельчённой растительной массы на два различных слоя. Первый - обработанный рабочим раствором препарата, ускоряющего процесс разложения и второй, который образуется из растительного материала, проходящего над соплом распылительных форсунок, и остаётся сухим (не обработанным рабочим раствором) [9]. При установке крайних значений вылета форсунки за распределительные заслонки $\Delta_{\text {max }}=45$ мм и $\Delta_{\min }=0$ мм при помощи тепловизора FLIR Systemsi 3 (рабочий раствор готовится путём смешивания биологических удобрений с водой, с температурой раствора не более $+5^{\circ}-10^{\circ} \mathrm{C}$, а температура соломы в валке составляет $+22^{\circ} \mathrm{C}$ и более) засвидетельствовали образование необработанного слоя над обработанным слоем [9] (рис. 2).

Было выдвинуто предположение о том, что верхний, не обработанный рабочим раствором, слой может защищать нижний, обработанный, от

() Богданчиков И. Ю., 2019 г. 
воздействия окружающей среды (солнечных лучей) и исключать испарение рабочего раствора до момента заделки удобрения в почву. Поэтому необходимо изучить процесс распространения рабочего раствора в соломе.

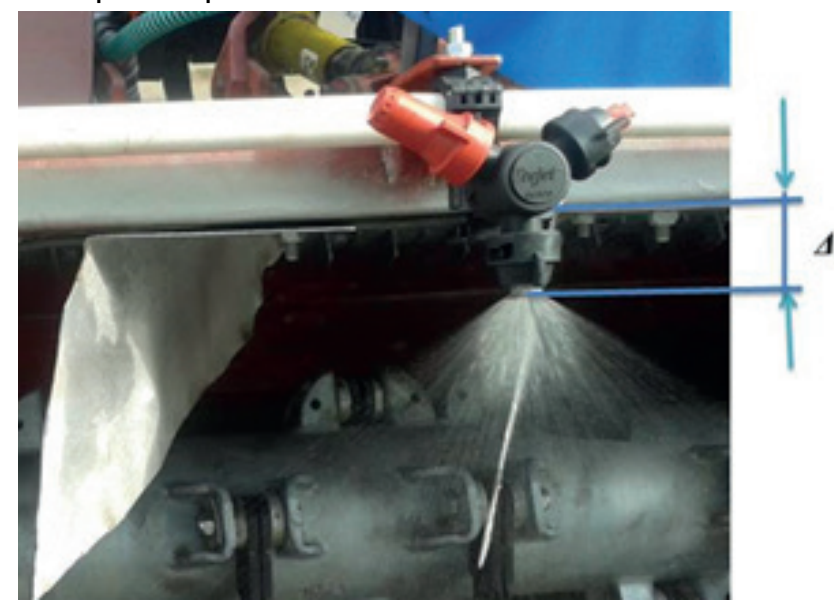

$\Delta$ - вылет форсунки за распределительные заслонки

Рис. 1 - Расположение форсунки в рассматриваемой машине

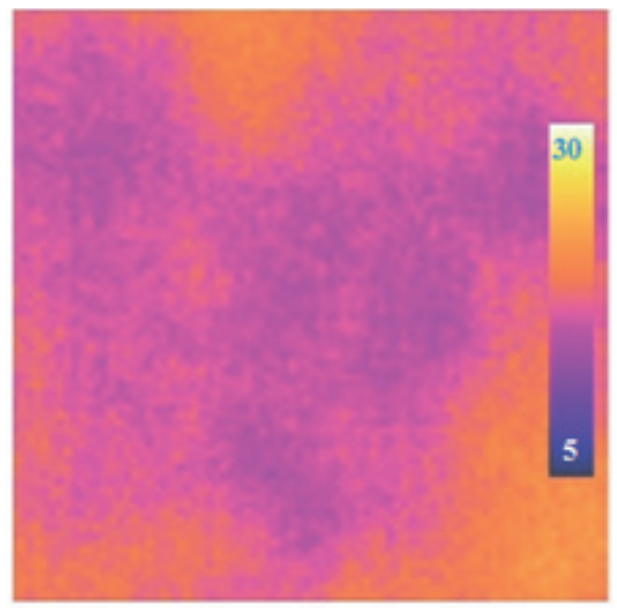

$a$

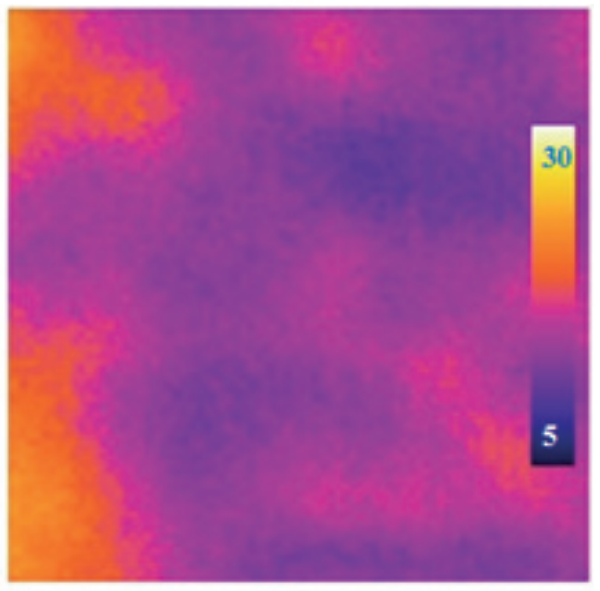

6

а - необработанный слой; б - вся масса обработана рабочим раствором Рис. 2 - Показания тепловизора

\section{Методика исследований}

Для изучения процесса распространения рабочего раствора в лабораторных условиях на подносах размером 530×330 мм формировали слой соломы толщиной 10-12 мм с частицами длиной не более 50 мм (специально измельчили до таких размеров для удобства заполнения алюминиевых бюксов, чтобы использовать для контрольного измерения влажности образцов влагомер ЭЛВЕС2М). Масса навески в каждом подносе составила 70-100 г, влажность 1,5-3,\% при температуре окружающего воздуха $20-26^{\circ} \mathrm{C}$. Имитация распылительной фрорсунки достигалась при помощи ручного опрыскивателя с мелкодисперсным распылением. В качестве рабочего раствора применялась вода в объёме 50 мл с температурой $10^{\circ}-12^{\circ} \mathrm{C}$.

На первом этапе исследований солома обрабатывалась водой и при помощи двух датчиков температуры и влажности DHT22, размещённых на нижней и верхней границах слоя, подсоединённых через контроллер Irduino uno к компьютеру, фиксировали происходящие изменения в течение 120 минут (рис. 3а). Каждый час извлекались пробы массой не более 3 г и определялась влажность образца при помощи влагомера ЭЛВЕС-2М. Эксперимент проводился с трехкратной повторностью, по полученным результатам строились графики (рисунки 4 и 5).

На втором этапе на обработанный слой соломы укладывался сухой слой (необработанный) одинаковый с обработанным по размерам, массе, температуре и влажности. В данном случае выделялись три границы (рис. 3б): нижняя (1), промежуточная (2) между обработанной и не обработанной соломой и верхняя (3). Соответственно использовались три датчика температуры и влажности DHT22. Эксперимент проводился с трехкратной повторностью в течение 180 минут, и по полученным результатам строились графики (рисунки 6 и 7).

Влажность растительной массы определяли по формуле:

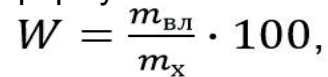

где $\mathrm{W}$ - влажность растительной массы, \%; $\mathrm{m}_{\mathrm{x}}$ - масса образца до сушки, кг; $\mathrm{m}_{\text {вл }}^{\mathrm{x}}$ масса влаги, кг.

Масса впитавшегося рабочего раствора определялась из выражения

$$
m_{\text {вл }}=m_{\mathrm{x}}-m_{\text {сух }}
$$

где $\mathrm{m}_{\text {сух }}$ - масса образца после сушки, кг (например, во влагомере ЭЛВЕС-2М).

Это делает возможным провести проверочный расчёт, так как нам известны исходные параметры соломы (её влажность и масса), а также масса вносимой влаги. Отклонения показаний датчиков не превысили 4,3\%, влагомера ЭЛВЕС-2М - не более $1 \%$.

В полевых условиях брались пробы обработанной соломы и при помощи влагомера ЭЛВЕС-2М определялась влажность, а расчётным путем - усвояемость рабочего раствора. 


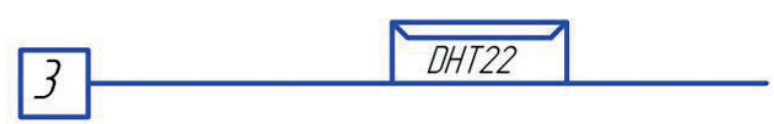

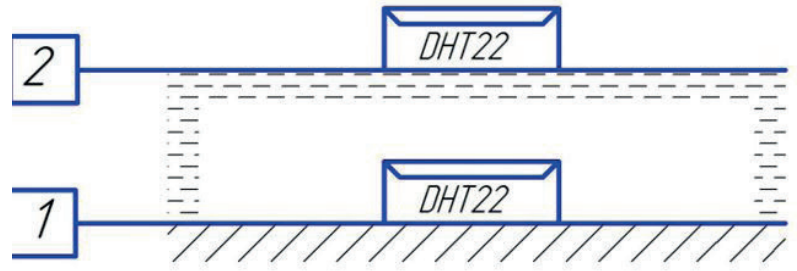

a

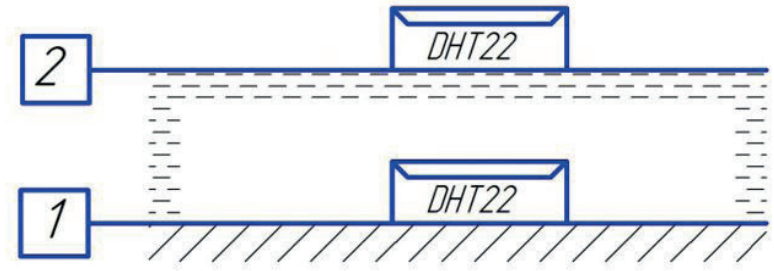

$\delta$

a - первый этап эксперимента; б - второй этап эксперимента (с верхним, необработанным, слоем)

1,2,3 - границы измерения влажности и температуры датчиками DHT22

Рис. 3 - Схема расположения датчиков в исследуемых слоях соломы

\section{Результаты}

По усреднённым значениям были построены графики изменения влажности (рис. 4) и температуры (рис. 5) для первого этапа исследования с одним слоем. Температура вносимой жидкости была ниже температуры соломы не менее чем на $10^{\circ} \mathrm{C}$, это делалась для того, чтобы фриксировать распространение влаги и температуры в исследу- емом слое соломы. В ряде экспериментов применялись датчики температуры и влажности DHT11, которые при контакте с влагой фиксировали значение влажности до 99,9\%, при этом продолжая фриксировать изменение температуры. В ходе выполнения работы отказались от датчиков DHT11 и перешли к датчикам DHT22, как более точным и надёжным.

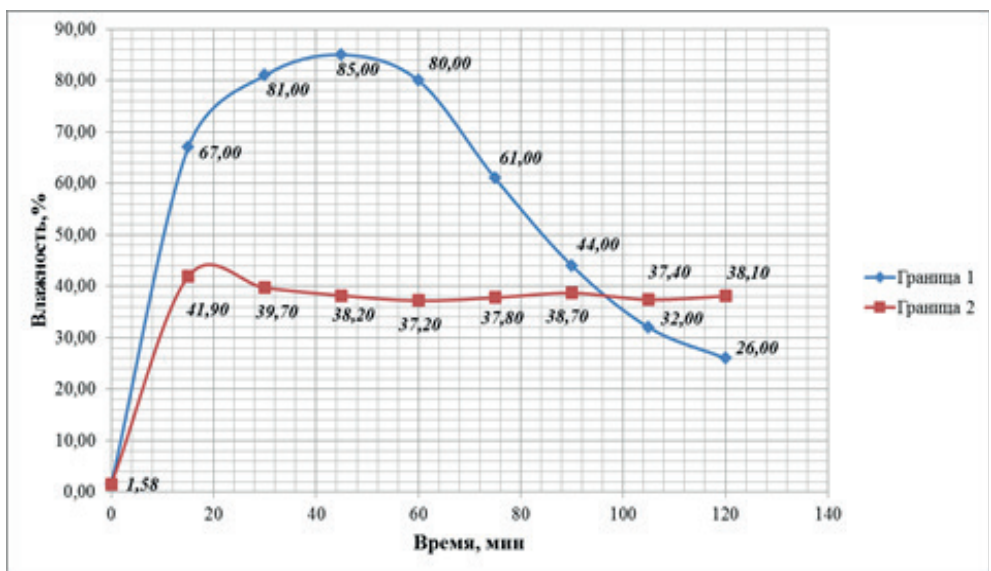

Рис. 4 - Изменение влажности в исследуемом слое соломы

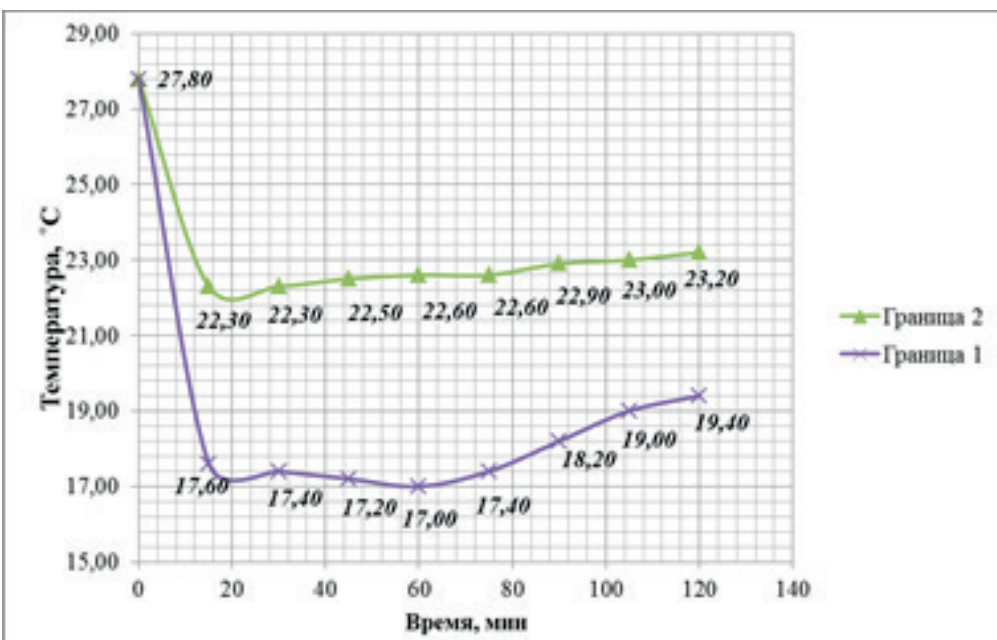

Рис. 5 - Изменение температуры в исследуемом слое соломы

На рисунках 6 и 7 представлены графрики изменения влажности и температуры (построены по усреднённым данным), полученные на втором этапе исследования с верхним, необработанным, слоем 


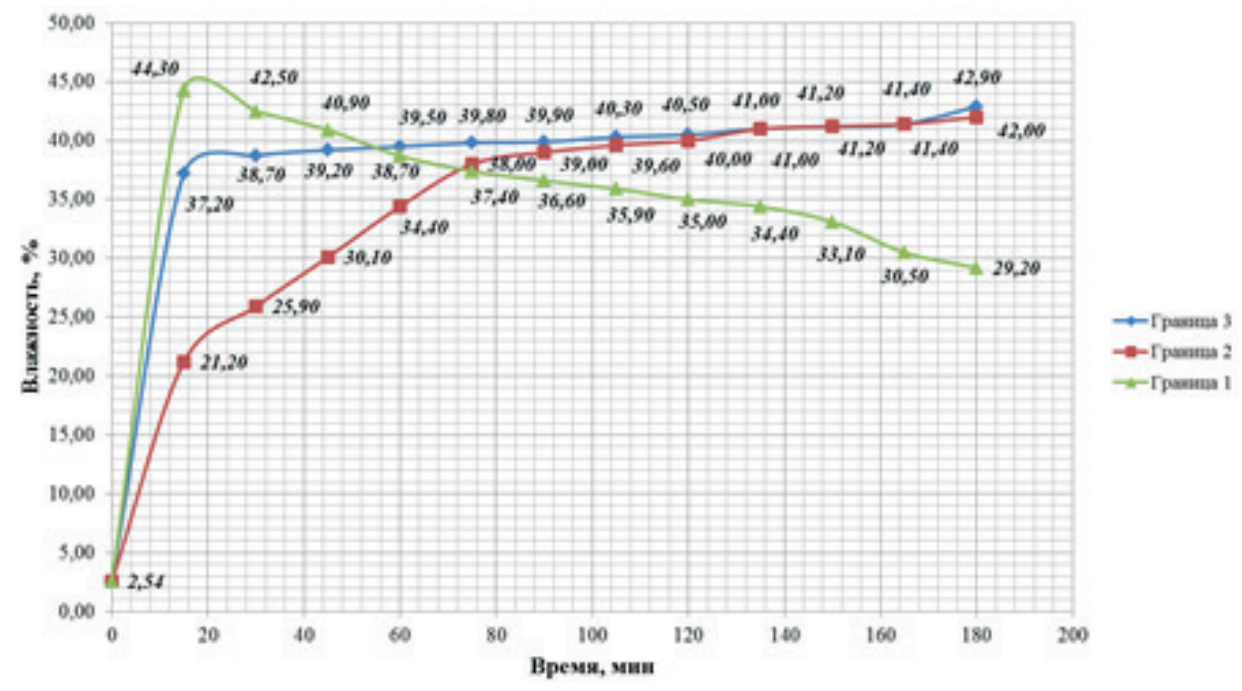

Рис. 6 - Изменение влажности в исследуемых слоях соломы (с верхним, необработанным, слоем)

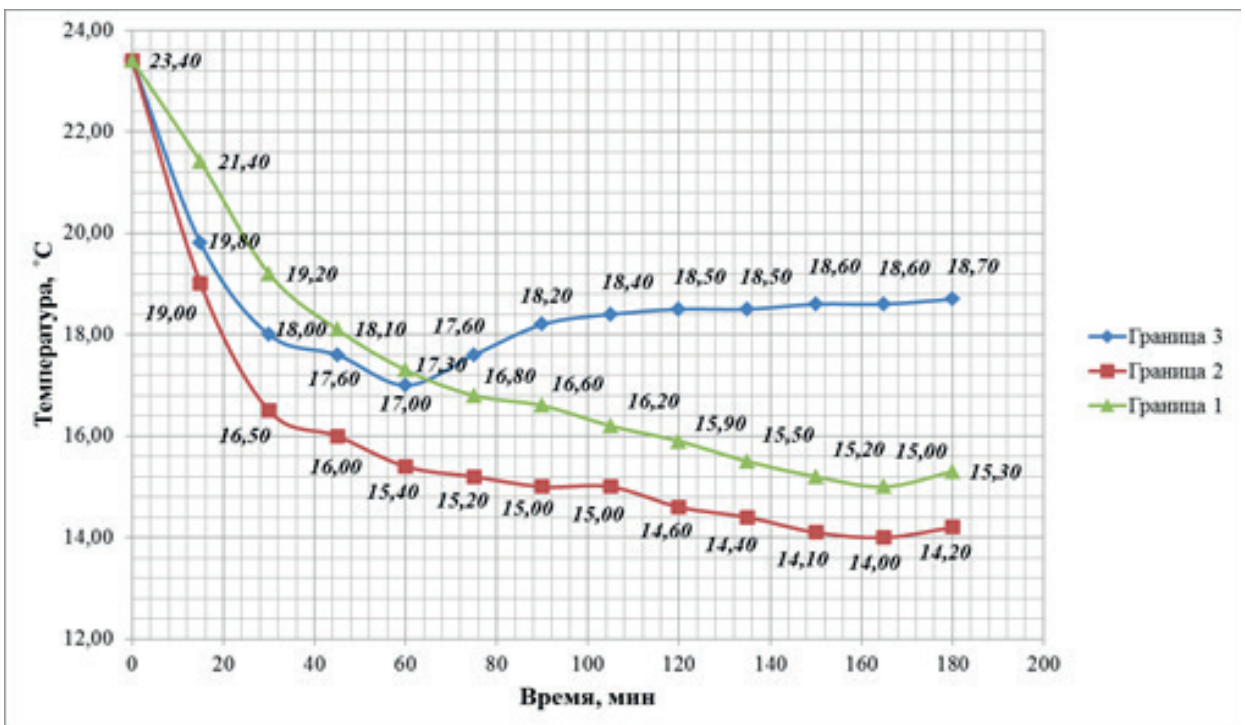

Рис. 7 - Изменение температуры в исследуемых слоях соломы (с верхним, необработанным, слоем)

При укрытии обработанного слоя сухим наблюдается распространение влаги как к границе 1 (под действием силы тяжести), так и к границе 3 (благодаря капиллярному явлению). Стебли зерновых представляют собой полые цилиндрические трубки с диаметром внутренней полости, превышающим толщину стенки, которые напоминают пчелиные соты [10]. Зная среднюю длину стеблей и их диаметр [11], можно примерно оценить максимально возможный объём влаги, который способна впитать одна из соломенных частичек:

$V_{\mathrm{B}}=\frac{2 \cdot \pi \cdot \sigma \cdot R}{\rho \cdot g}$,

где $\mathrm{V}_{\text {в }}$ - объём влаги, $\mathrm{M}^{3}$;

$\sigma-$ коэффрициент поверхностного натяжения;

$\mathrm{R}$ - радиус стебля, м;

$\rho$ - плотность рабочего раствора, $\mathrm{m}^{3} / \mathrm{\kappa}$;

$\mathrm{g}$ - ускорение свободного падения, $\mathrm{m}^{2} / \mathrm{c}$.

В лабораторных условиях не учитывались вихревые потоки воздуха, которые создаются ротором измельчителя, что способствует лучшему перемешиванию обработанной массы и достижению усвояемости рабочего раствора более $90 \%$ (табл.).

Таблица - Средние значения усвояемости рабочего раствора (получены в ходе полевых испытаний

\begin{tabular}{|c|c|c|c|c|c|}
\hline Показатель & $\begin{array}{c}\text { Масса } \\
\text { навески } \\
\text { (исходная) } \\
\mathrm{m}_{\mathrm{B}}, \text { г } \\
\end{array}$ & $\begin{array}{c}\text { Масса } \\
\text { сухой } \\
\text { навески } \\
\mathrm{m}_{\text {сух }}, \text { г }\end{array}$ & $\begin{array}{c}\text { Масса } \\
\text { впитавшейся } \\
\text { влаги } \\
\text { m }_{\text {вп }}, г\end{array}$ & $\begin{array}{c}\text { Влажность } \\
W=\frac{m_{1}-m_{2}}{m_{1}} \cdot \\
100 \%, \%\end{array}$ & $\begin{array}{c}\text { Усвояемость } \\
\text { рабочего } \\
\text { раствора, \% }\end{array}$ \\
\hline \multirow{4}{*}{$\begin{array}{l}\text { пробы до } \\
\text { прохода } \\
\text { опытной } \\
\text { машины }\end{array}$} & 3,282 & 3,203 & 0,079 & 7,9 & - \\
\hline & 2,859 & 2,802 & 0,056 & 5,6 & - \\
\hline & 3,110 & 3,028 & 0,083 & 8,3 & - \\
\hline & 3,055 & 2,983 & 0,072 & 7,2 & - \\
\hline
\end{tabular}


Продолжение таблицы

\begin{tabular}{|l|c|c|c|c|c|}
\hline \multirow{2}{*}{$\begin{array}{l}\text { пробы по- } \\
\text { сле прохода }\end{array}$} & 3,515 & 3,249 & 0,267 & 26,6 & 91,5 \\
\cline { 2 - 6 } $\begin{array}{l}\text { матной } \\
\text { машины }\end{array}$ & 3,042 & 2,841 & 0,201 & 20,1 & 90,1 \\
\cline { 2 - 6 } & 3,298 & 3,033 & 0,266 & 26,6 & 92,6 \\
\hline
\end{tabular}

Как видно из таблицы, перемешивание частиц обработанной соломы способствует лучшей усвояемости рабочего раствора, но при этом отсутствие защитного слоя приводит к интенсивному испарению влаги.

\section{Выводы}

В результате проведенных исследований были получены зависимости изменения влажности и температуры внутри слоя соломы, обработанного рабочим раствором. В первые 20 минут после обработки влага под действием силы тяжести стремительно перемещается в нижнюю часть слоя, после чего начинает подниматься вверх и испаряться. В полевых условиях измельчённая растительная масса, попадая под действие факелов распыла форсунок, движется с некоторым ускорением, сообщённым ротором и воздушными завихрениями, что способствует её перемешиванию и впитыванию рабочего раствора более чем на $90 \%$. В результате на поверхность поля попадает органическое удобрение в виде измельчённой соломы, обработанной рабочим раствором биопрепаратов, ускоряющим процесс её деструкции. Влага интенсивно испаряется в воздушную среду, снижая с каждой минутой эффрективность применения удобрения. Не обработанный слой соломы, уложенный поверх обработанного, может считаться защитным и при условии равенства слоев по толщине способен сдерживать интенсивность испарения до 1 часа.

\section{Список литературы}

1. К вопросу об эффективном использовании соломы для сохранения почвенного плодородия / Н. В. Бышов, А. Н. Бачурин, И. Ю. Богданчиков, А. И. Мартышов // Инновационные направления и методы реализации научных исследований в АПК : материалы науч.-практич. конф. 2012 г. - Рязань : РГАТУ, 2012. - С. 59-63.

2. Русакова, И. В. Биопрепараты для разложения растительных остатков в агроэкосистемах [Текст] / И.В. Русакова // Juvenis scientia. - 2018. - № 9. - C. 4-9.

3. Андреев, М. И. Влияние интенсивных систем земледелия на почвенную биоту / М. И. Андреев, О. Г. Марьина-Чермных // Вестник Марийского го- сударственного университета. Серия: Сельскохозяйственные науки. Экономические науки. - 2017. - № 4 (12). - C. 11-16.

4. Русакова, И. В. Биопрепараты-деструкторы послеуборочных растительных остатков. - Рига : Изд-во LAP LAMBERT, 2018. - 101 с.

5. Сохранение баланса микроэлементов в почве - один из фракторов повышения урожайности / В. Б. Любченко, С. В. Митрофанов, В.С. Никитин, Н.Б. Горохова // Инновации в АПК: стимулы и барьеры. - 2017. - С. 183-186.

6. Фадькин, Г. Н. Миграция азота в системе «удобрение-почва-растение» под влиянием длительного применения удобрений / Г. Н. Фадькин, Д. В. Виноградов, А. В. Щур, Г. Д. Гогмачадзе // АгроЭкоИнфо. - 2015. - № 4. - С. 23-28.

7. Бойков, В. М. Использование незерновой части урожая для повышения плодородия почвы [Текст] / В. М. Бойков, С. В. Старцев, О. Н. Чурляева // Аграрный научный журнал. - №3. - 2015. - С. 47-49.

8. Модернизация измельчителя-мульчировщика / Н. В. Бышов, К. Н. Дрожжин, А. Н. Бачурин, И. Ю. Богданчиков // Сельский механизатор. - 2013. - № 5. - С. 8-9.

9. Богданчиков, И. Ю. К вопросу о формировании защитного слоя при утилизации незерновой части урожая / И. Ю. Богданчиков, А. Н. Михеев, А. А. Качармин // Материалы межд. нучн.-пр. конф. «Аграрная наука в инновационном развитии АПК»26-28 ноября 2018 года. - п. Майский Изд-во. ФГБОУ ВО Белгородский ГАУ, 2018. - С. 25-29.

10. Харина, М. В. Состав, структура и перспективы энергоресурсосберегающей переработки соломы злаковых культур / М. В. Харина, Л. М. Терехова, В. М. Емельянов // Вестник Казанского технологического университета. - 2014. - Т. 17. № 24. - С. 168-174.

11. Лукьянова, И. В. Анализ видовых и сортовых особенностей устойчивости стеблей зерновых культур к полеганию с учетом их фризико-механических свойств и архитектоники для использования в селекции : автореф. дис. ... д-ра биол. наук. - Краснодар: ФГОУ ВПО «Кубанский государственный аграрный университет», - 2008. - 51 с.

\section{RESULTS OF LABORATORY STUDIES OF PROCESS \\ OF WORKING SOLUTION DISTRIBUTION IN STRAW}

Bogdanchikov llya Yu., of Cand.Tech.Sci., associate professor of operation of the machine and tractor park, CMY62.rgatu@mail.ru,

Ryazan state agrotechnological university of P.A. Kostychev

During field tests of the machine for recycling the non-dead part of the crop as a fertilizer, it was found that when changing the flow of the nozzle behind the distribution shutters, it is possible to divide the flow of crushed plant mass into two different layers. The first - treated with working solution of preparation accelerating decomposition process and the second, from vegetable material, which passes over nozzle of spraying nozzles and remains dry (not treated with working solution). Thus, when setting the extreme values of the nozzle departure beyond 
the distribution flaps $\Delta_{\max }=45 \mathrm{~mm}$ and $\Delta_{\min }=0 \mathrm{~mm}$ with the help of a thermal imager, the formation of an untreated layer above the temperature-differential treated layer was witnessed. Working solution prepares by mixing of biological fertilizers with water, with a temperature of solution no more than 5 of $-10^{\circ}$ With, and straw temperature in a roll is $22^{\circ}$ With and more. It has been hypothesized that the top layer not treated with the working solution can protect the bottom layer treated from the environment and avoid evaporation of the working solution until the fertiliser is embedded in the soil. Laboratory studies resulted in non-linear changes in humidity and temperature within the straw layer treated with the working solution. It was found that the first 20 minutes after the treatment, moisture is rapidly moved by gravity to the bottom of the layer, after which it begins to rise and evaporate. Under field conditions ground and treated with working solution plant mass will get on soil well mixed and with absorbed moisture more than $90 \%$, which leads to its intensive evaporation. The processed straw layer laid over processed can be considered as protective and on condition of their equality on thickness, is capable to constrain intensity of evaporation till 1 o'clock at air temperature no more than $25^{\circ}$.

Key words: незерновая часть урожая, солома, утилизация, удобрение, защитный слой, усвояемость, влажность, испарение.

1. K voprosu ob effektivnom ispol'zovanii solomy dlya sohraneniya pochvennogo plodorodiya /N.V. Byshov, A.N. Bachurin, I.YU. Bogdanchikov, A.I. Martyshov // Innovacionnye napravleniya i metody realizacii nauchnyh issledovanij v APK: materialy nauch.-praktich. konf. 2012 g. - Ryazan': RGATU, 2012. - S.59-63.

2. Rusakova, I.V. Biopreparaty dlya razlozheniya rastitel'nyh ostatkov $v$ agroekosistemah [Tekst] / I.V. Rusakova // Juvenis scientia. - 2018. - №9. - S. 4-9.

3. Andreev M.I. Vliyanie intensivnyh sistem zemledeliya na pochvennuyu biotu /M.I. Andreev, O.G. Mar'inaCHermnyh // Vestnik Marijskogo gosudarstvennogo universiteta. Seriya: Sel'skohozyajstvennye nauki. Ekonomicheskie nauki. - 2017. - № 4 (12). - S.11-16.

4. Rusakova I.V. Biopreparaty-destruktory posleuborochnyh rastitel'nyh ostatkov.- Riga: Izd-vo LAP LAMBERT, - 2018, - $101 \mathrm{~s}$.

5. Sohranenie balansa mikroelementov $v$ pochve - odin iz faktorov povysheniya urozhajnosti [Tekst] / V.B.Lyubchenko, S. V. Mitrofanov, V.S. Nikitin, N.B. Gorohova // Innovacii v APK: stimuly i bar'ery. - 2017. - S. 183-186.

6. Fad'kin, G.N. Migraciya azota v sisteme «udobrenie-pochva-rastenie» pod vliyaniem dlitel'nogo primeneniya udobrenij /G.N. Fad'kin, D. V. Vinogradov, A. V. SHCHur, G.D. Gogmachadze//AgroEkolnfo. -2015. -№4. -S. 23-28.

7. Bojkov, V.M. Ispol'zovanie nezernovoj chasti urozhaya dlya povysheniya plodorodiya pochvy [Tekst] / V.M. Bojkov, S.V. Starcev, O.N. CHurlyaeva // Agrarnyj nauchnyj zhurnal - №3 - 2015. - S.47-49.

8. Modernizaciya izmel'chitelya-mul'chirovshchika / N.V. Byshov, K.N. Drozhzhin, A.N. Bachurin, I.YU. Bogdanchikov //Sel'skij mekhanizator. -2013. -№ 5. -S. 8-9.

9. Bogdanchikov, I.YU. K voprosu o formirovanii zashchitnogo sloya pri utilizacii nezernovoj chasti urozhaya [Tekst] / I.YU. Bogdanchikov, A.N. Miheev, A.A. Kacharmin // Materialy mezhd. Nuchn.-pr. konf. "Agrarnaya nauka v innovacionnom razvitii APK»26-28 noyabrya 2018 goda: p. Majskij: Izd-vo.: FGBOU VO Belgorodskij GAU, 2018. - S. 25-29.

10. Harina, M.V. Sostav, struktura i perspektivy energoresursosberegayushchej pererabotki solomy zlakovyh kul'tur [Tekst] / M.V. Harina, L.M. Terekhova, V.M. Emel'yanov // Vestnik Kazanskogo tekhnologicheskogo universiteta. - 2014. - T. 17. - № 24. - S. 168-174.

11. Luk'yanova, I.V. Analiz vidovyh i sortovyh osobennostej ustojchivosti steblej zernovyh kul'tur k poleganiyu $s$ uchetom ih fiziko-mekhanicheskih svojstv i arhitektoniki dlya ispol'zovaniya v selekcii: avtoref. dis. ... d-ra biol. nauk. Krasnodar: FGOU VPO «Kubanskij gosudarstvennyj agrarnyj universitet», - 2008.

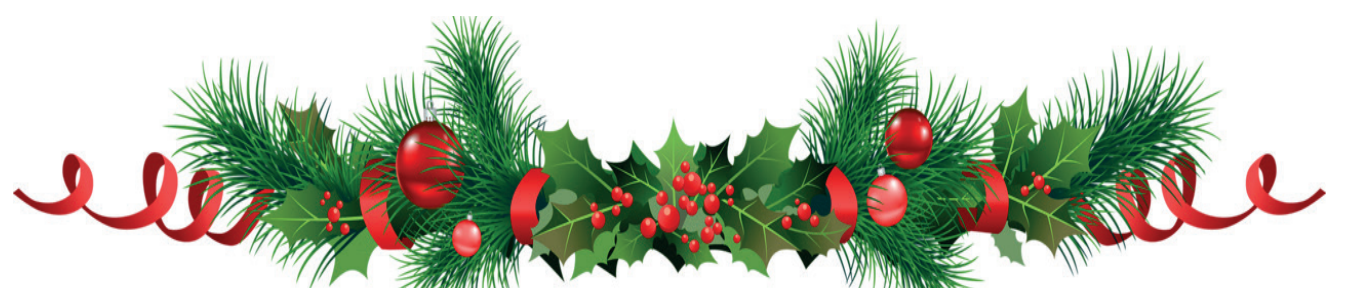




\title{
МАТЕМАТИЧЕСКОЕ МОДЕЛИРОВАНИЕ ПРОЦЕССА ВАКУУМНОЙ ИНФРАКРАСНОЙ СУШКИ ПЕРГОВЫХ СОТОВ
}

\begin{abstract}
Бышов Дмитрий Николаевич, канд. техн. наук, доцент каф. эксплуатации машинно-трактор-
\end{abstract} ного парка

КАШИРИн Дмитрий Евгеньевич, д-р техн. наук, доцент, зав. кафредрой электроснабжения, kadm76@mail.ru

УСПЕНСКИЙ Иван Алексеевич, д-р техн. наук, профрессор, зав. кафредрой технической эксплуатации транспорта, ivan.uspensckij@yandex.ru

Юхин Иван Александрович, д-р техн. наук, доцент, зав. каф. автомобильной техники и теплоэнергетики, yuival@rambler.ru

МОРОЗОВ Сергей Сергеевич, соискатель, mars37603@mail.ru

Рязанский государственный агротехнологический университет имени П.А. Костычева

Наиболее перспективной технологией сушки перговых сотов в настоящее время является вакуумная инфракрасная сушка, однако это направление на сегодня недостаточно исследовано. В данной статье произведено теоретическое исследование тепло- и влагообмена в процессе вакуумной инфракрасной сушки перговых сотов. Описаны граничные условия в процессе сушки и получены системы уравнений тепло- и влагообмена. Приведена методика решения задач тепло и влагообмена в процессе вакуумной инфракрасной сушки. Разработана методика численных расчетов температуры и влагосодержания пергового сота в процессе сушки. Проведено численное моделирование процесса вакуумной инфракрасной сушки перговых сотов, по результатам которого построены графические зависимости изменения температуры и влагосодержания пергового сота при изменении глубины и времени нагрева. Из полученных данных видно, что прогревание пергового сота происходит от центра к внешней границе. С уменьшением глубины нагрева температура изменяется медленнее в результате конвекции на внешней границе пергового сота. Наибольшая скорость влагообмена наблюдается в приповерхностных слоях, поэтому влагосодержание пергового сота на внешней границе близко к влагосодержанию омывающего воздуха. Максимально допустимая температура нагрева перговых сотов достигается за 1,2 часа, а средняя температура перговых сотов увеличивается с $25^{\circ} \mathrm{C}$ до $60^{\circ} \mathrm{C}$ за 2 часа. Среднее влагосодержание перговых сотов уменьша-

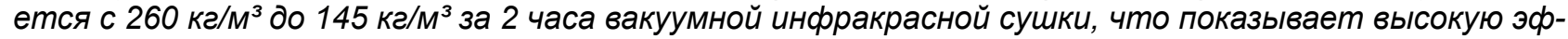
фрективность исследуемой технологии при достаточно низкой удельной мощности нагревателей.

Ключевые слова: пчелиные соты, перга, ИК излучение, вакуумная сушка, математическое моделирование.

\section{Введение}

В современном животноводстве пчеловодство играет важную роль: опыление сельскохозяйственных растений позволяет увеличить урожайность и качество получаемых плодов [1-6]. В то же время основным источником заработка пчеловодческих хозяйств является реализация продуктов пчеловодства [7-10]. Одним из наиболее ценных продуктов является перга. Насыщенная биологически-активными компонентами, перга является уникальным природным лекарственным препаратом, применяемым для лечения и профилактики целого ряда заболеваний $[11,12]$. Однако большое количество перговых гранул утрачивается в процессе выбраковки старых сотов в связи с отсутствием высокоэффективных способов извлечения [13].

В основе технологии получения перги лежит процесс сушки перговых сотов, предполагающий снижение влажности перговых гранул до требований ГОСТ 31776-2012. В связи с простотой изготовления сушильных установок наибольшее распространение в настоящее время получила конвективная сушка перги горячим воздухом [14, 15]. Однако данный способ обладает рядом недостатков: высокая энергоемкость и продолжительность процесса (около 40-45 часов).
Наиболее перспективной технологией сушки в настоящее время является вакуумная инфракрасная сушка, поскольку именно она наилучшим образом подготавливает перговые соты к предстоящему измельчению $[16,17]$. Преимуществом данного способа является высокая интенсивность процесса сушки за счет снижения температуры кипения воды. В связи с небольшой продолжительностью процесса сушки (около 2 часов), энергоемкость вакуумных инфракрасных установок значительно ниже их аналогов [18]. Однако данное направление на сегодняшний день недостаточно исследовано.

\section{Цель исследования}

В связи с вышесказанным, целью исследования является изучение тепло- и влагообмена в процессе вакуумной инфракрасной сушки перговых сотов, а также разработка методики численных расчетов температуры и влагосодержания пергового сота в процессе сушки.

\section{Материалы и методы}

Для теоретического исследования теплообмена в процессе вакуумной инфракрасной сушки пергового сота отклонение температуры продукта $\theta(\mathrm{x}, \mathrm{t})$ от температуры окружающей среды запишем как:

$$
\theta(x, t)=T(x, t)-T_{\mathrm{cp}}
$$

() Бышов Д. Н., Каширин Д. Е., Успенский И. А., Юхин И. А.. Морозов С. С., 2019 г. 
где $\mathrm{T}(\mathrm{x}, \mathrm{t})$ - температура в некоторой точке и в момент времени $t, \mathrm{~K}$;

$\mathrm{T}_{\text {cp }}$ - температура окружающей среды, K.

Так как поглощение инфракрасного излучения происходит преимущественно при х $\approx$, то мощность тепловых источников $W_{\text {Den }}$ будет равна:

$$
W_{d e n} \cdot a \cdot b=\int_{0}^{a}\left(\int_{0}^{b}\left(\int_{0}^{h} A e^{\frac{x-h}{\beta}} d x\right) d y\right) d z
$$

где a, b, h - геометрические размеры перговых сотов, мм;

$\beta$ - глубина проникновения инфракрасного излучения, мм;

А - постоянный множитель.

Примем следующие допущения:

- температура окружающей среды постоянна;

- мощность нагревателя постоянна;

- перговый сот имеет вид неограниченной пластины толщиной $2 \mathrm{~h}$.

Тогда граничное условие в центре пластины примет вид:

$\frac{\partial \theta(0, t)}{\partial x}=0, t>0$.

Второе граничное условие:

$\frac{\partial \theta(h, t)}{\partial x}+\lambda \theta(h, t)=0, t>0$,

где $\lambda=\frac{\alpha}{\kappa}$ коэффициент внешнего теплообмена, $\frac{1}{\text { м; }}$

$\alpha-$ интенсивность потока энергии через границы $\frac{\text { Дж }}{\mathrm{M}^{2} \cdot \text { сек· } K}$;

к - коэфффициент теплопроводности, $\frac{\text { Дж }}{\mathrm{M} \cdot с е к \cdot K}$.

Получаем систему уравнений теплообмена

$\frac{\partial \theta(x, t)}{\partial t}=a^{2} \frac{\partial^{2} \theta(x, t)}{\partial x^{2}}+\frac{f(x, t)}{c \rho}, t>0,0<x<h ;(5)$

$\frac{\partial \theta(0, t)}{\partial x}=0, t>0$

$\frac{\partial \theta(h, t)}{\partial x}+\lambda \theta(h, t)=0, t>0, t>0$;

$\theta(x, 0)=0,0<x<h$.

где $a^{2}=\frac{\kappa}{c \cdot \rho}-$ температуропроводность, $\frac{\mathrm{m}^{2}}{\text { сек }}$;

c - удельная теплоемкость пергового сота, $\frac{\text { Дж}}{\kappa г \cdot К}$

$\rho$ - плотность пергового сота, $\frac{\kappa \Gamma}{\mathrm{M}^{3}}$;

$f(x, t)=A \cdot e^{\frac{x-h}{\beta}}-$ плотность объемных тепловых источников, $\frac{\text { Дж }}{\mathrm{m}^{3} \cdot \text { сек }}$.
Для решения полученной системы уравнений построим несколько вспомогательных задач. Приняв $\mathrm{f}(\mathrm{x}, \mathrm{t})=0$ и применив метод разделения переменных, представим решение этих задач в виде:

$\theta(x, t)=X(x) \cdot T(t)$.

Тогда решения для пространственной составляющей:

$$
\begin{aligned}
& U^{\prime \prime}+\gamma^{2} U=0,0<x<h ; \\
& U^{\prime}(0)=0 ; \\
& U^{\prime}(h)+\lambda U(h)=0 .
\end{aligned}
$$

После определения всех величин нетривиальное решение задачи примет вид:

$$
\int_{0}^{h} U_{k}(x) \cdot U_{l}(x) d x=\frac{h\left(2 \mu_{k}+\sin 2 \mu_{k}\right)}{4 \mu_{k}} \cdot \delta_{k l}
$$

где $\delta_{k l}-$ символ Кронекера, $\mu=\gamma h$.

Уравнение для решения временной составляющей

$T^{\prime}+\frac{a^{2} \mu^{2}}{h^{2}} T=0$.

Частное решение данного уравнения находится методом непосредственного интегрирования. Таким образом, решение временной составляющей имеет вид:

$$
\theta(x, t)=\sum_{k=1}^{\infty} A_{k} \cdot \cos \frac{\mu_{k}}{h} x \cdot e^{-\frac{\mu_{k}^{2} a^{2}}{h^{2}} t} .
$$

Для решения основной задачи воспользуемся функцией источника (функцией Грина):

$$
\begin{aligned}
& G(x, \xi, t, \tau)=\sum_{k=1}^{\infty} \frac{4 \mu_{k}}{h\left(2 \mu_{k}+\sin 2 \mu_{k}\right)} \cos \frac{\mu_{k}}{h} x . \\
& \cdot \cos \frac{\mu_{k}}{h} \xi \cdot e^{-\frac{\mu_{k}^{2} a^{2}}{h^{2}}(t-\tau)} .
\end{aligned}
$$

Общее решение задачи теплообмена представляет собой свертку функции Грина с функцией объемных источников:

$$
\theta(x, t)=\int_{0}^{h}\left(\int_{0}^{t} G(x, \xi, t, \tau) \cdot f_{x}(\xi) \cdot f_{t}(\tau) d \tau\right) d \xi .
$$

Таким образом, окончательный вид решения задачи теплообмена можно записать так:

$T(x, t)=T_{c p}+\frac{4 W_{d e n} h^{2}}{c \rho a^{2}\left(1-e^{-\frac{h}{\beta}}\right)} \sum_{k=1}^{\infty} \phi_{\mathrm{k}} \cos \frac{\mu_{k}}{h} x\left(1-e^{-\frac{\mu_{k}^{2} a^{2}}{h^{2}} t}\right)$.

где $\phi_{k}=\frac{h \cdot \cos \mu_{k}-h \cdot e^{-\frac{h}{\beta}}+\beta \mu_{k} \sin \mu_{k}}{\mu_{k}\left(2 \mu_{k}+\sin 2 \mu_{k}\right)\left(\beta^{2} \cdot \mu_{k}^{2}+h^{2}\right)}$.

Для теоретического исследования влагообмена в процессе вакуумной инфракрасной сушки 
пергового сота примем отклонение влагосодержания как:

$$
\theta(x, t)=u(x, t)-u_{\text {сред}} .
$$

Граничные условия остаются неизменными, поэтому система уравнений влагообмена примет вид

$$
\begin{aligned}
& \frac{\partial \theta(x, t)}{\partial t}=a^{2} \frac{\partial^{2} \theta(x, t)}{\partial x^{2}}+ \\
& +a^{2} \delta \frac{\partial^{2} T}{\partial x^{2}}, 0<x<h, t>0 ; \\
& \frac{\partial \theta(0, t)}{\partial x}=0, t>0 ; \\
& \frac{\partial \theta(h, t)}{\partial x}+\lambda \theta(h, t)=0, t>0 ;
\end{aligned}
$$

$\theta(x, 0)=\theta_{0}=u_{0}-u_{\text {сред }}, 0<x<h$,

$$
\text { где } a^{2}=\frac{D}{c}-\text { коэфрфициент массопередачи, }
$$

$\frac{\mathrm{m}^{2}}{\text { сек }} ; \delta$ - толщина условного пограничного слоя,

$$
\frac{\text { кг }}{\mathrm{M}^{3} \cdot K} ; \quad \text { с - коэфффициент пористости. }
$$

В силу линейности краевой задачи её решение представимо в виде суммы вспомогательных задач

$\theta(x, t)=\theta^{(1)}(x, t)+\theta^{(2)}(x, t)$.

Так как решение данных уравнений аналогично решению вспомогательных задач теплообмена методом разделения переменных, первая вспомогательная задача примет вид

$$
\begin{aligned}
& \theta^{(1)}(x, t)=\theta_{0} \sum_{k=1}^{\infty} \frac{4 \sin \mu_{k}}{2 \mu_{k}+\sin 2 \mu_{k}} \cdot \cos \frac{\mu_{k}}{h} x . \\
& \cdot e^{-\frac{\mu_{k}^{2} a^{2}}{h^{2}} t} .
\end{aligned}
$$

Решение второй вспомогательной задачи

$\theta^{(2)}(x, t)=\int_{0}^{h}\left(\int_{0}^{t} G(x, \xi, t, \tau) a^{2} \delta \frac{\partial^{2} T(\xi, \tau)}{\partial x^{2}} d \tau\right) d \xi$.

Тогда окончательный вид решения уравнения

$$
u(x, t)=\theta^{(1)}(x, t)+\theta^{(2)}(x, t)+u_{\text {сред }} \text {. }
$$

\section{Результаты и их обсуждение}

Моделирование процесса вакуумной инфракрасной сушки перговых сотов проводили в системе автоматизированного проектирования РТС Mathcad Prime 5. Графические зависимости изменения температуры пергового сота при изменении глубины и времени нагрева, полученные в ходе численного моделирования, представлены на ри-

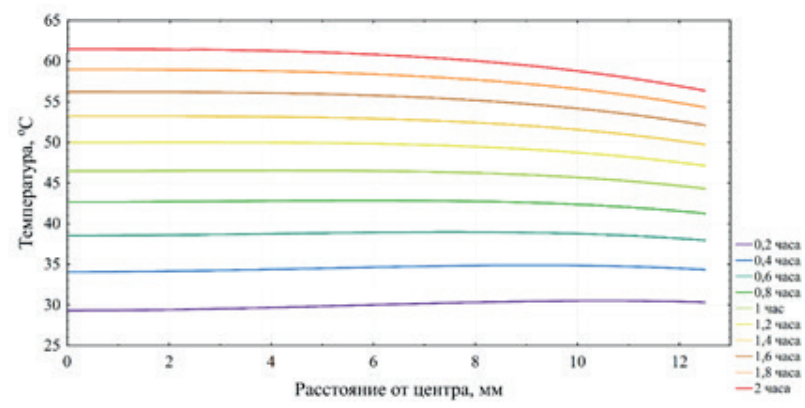

Рис. 1 - Графическая зависимость температуры пергового сота от продолжительности процесса сушки

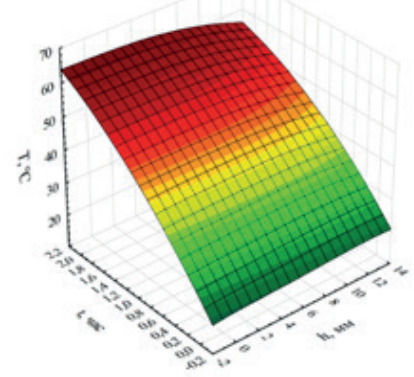

Рис. 2 - Графическая зависимость изменения температуры пергового сота по глубине в процессе сушки

Графические зависимости влагосодержания пергового сота по глубине от продолжительности процесса сушки представлены на рисунках 3, 4.

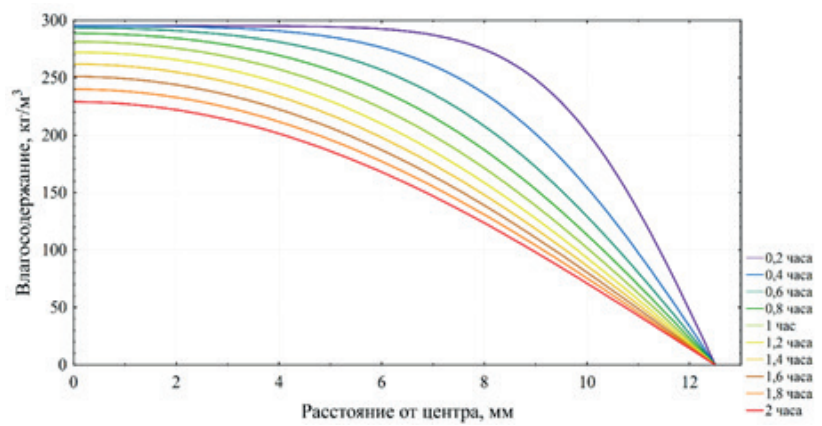

Рис. 3 - Графическая зависимость влагосодержания пергового сота от продолжительности процесса сушки

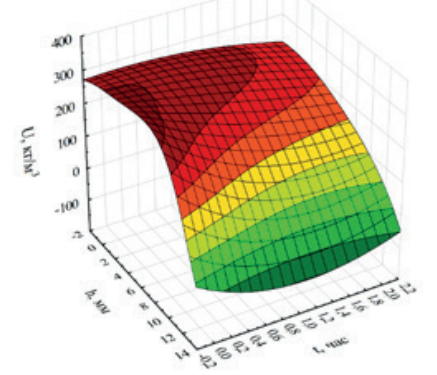

Рис. 4 - Графическая зависимость влагосодержания пергового сота по глубине от продолжительности процесса сушки 
Анализируя полученные графические зависимости, можно сделать следующие выводы:

- прогревание пергового сота происходит от центра к внешней границе;

- поскольку с уменьшением глубины нагрева температура изменяется медленнее, можно сделать вывод, что на внешней границе происходит конвекция;

- с увеличением продолжительности сушки изменение средней температуры уменьшается, следовательно, стабилизируются и условия испарения.

Таким образом, максимально допустимая температура нагрева перговых сотов достигается за 1,2 часа, а средняя температура перговых сотов увеличивается с $25^{\circ} \mathrm{C}$ до $60^{\circ} \mathrm{C}$ за 2 часа вакуумной инфракрасной сушки, что показывает высокую эфффективность исследуемой технологии при достаточно низкой удельной мощности нагревателей.

Проведено теоретическое исследование тепло- и влагоообмена в процессе вакуумной инфракрасной сушки перговых сотов. Разработана методика численных расчетов температуры и влагосодержания пергового сота в процессе сушки. По результатам проведенного исследования построены графические зависимости изменения температуры и влагосодержания пергового сота.

Анализ полученных графических зависимостей показывает, что прогревание пергового сота происходит от центра к внешней границе. С уменьшением глубины нагрева температура изменяется медленнее в результате конвекции на внешней границе пергового сота. С увеличением продолжительности сушки изменение средней температуры уменьшается, следовательно, стабилизируются и условия испарения. Медленнее всего влага извлекается из глубинных слоев. Наибольшая скорость влагообмена наблюдается в приповерхностных слоях, поэтому влагосодержание пергового сота на внешней границе близко к влагосодержанию омывающего воздуха. Так как уменьшение влагосодержания практически не зависит от мощности нагревателей, можно сделать вывод, что скорость вакуумной сушки ограничена коэффициентом массопередачи через слои продукта.

Максимально допустимая температура нагрева перговых сотов достигается за 1,2 часа, а средняя температура перговых сотов увеличивается с $25^{\circ} \mathrm{C}$ до $60^{\circ} \mathrm{C}$ за 2 часа. Среднее влагосодержание перговых сотов уменьшается с 260 кг/м³ до 145 кг/ $\mathrm{M}^{3}$ за 2 часа вакуумной инфракрасной сушки, что показывает высокую эффективность исследуемой технологии при достаточно низкой удельной мощности нагревателей.

\section{Список литературы}

1.Бышов Д. Н. Результаты многофракторного экспериментального исследования дисперсионных свойств перги / Д. Н. Бышов, Д. Е. Каширин, В. В. Павлов // Вестник Красноярского государственного аграрного университета. - 2017. - № 2 (125). - C. 115-121.

2. Влияние препаратов прополиса и перги на гематологические показатели крови кроликов [текст] / Л. Г. Каширина, И. А Кондакова, А. В. Ельцова, А. В. Романцова // Актуальные проблемы ветеринарной медицины и биологии : Материалы международной научно-практической конференции, посвященной 150-летию ветеринарной службы Оренбурга. - Оренбург, 2003. - С. 60-62.

3. Пат. № 2275800 РФ. Установка для извлечения перги из перговых сотов / Д.Е. Каширин. - Заявл. 28.12.2004; опубл. 10.05.2006, бюл. № 13. 6c.

4. Пат. № 2412590 РФ. Установка для извлечения и очистки перги из сотов / Д.Е. Каширин. - Заявл. 07.12.2009; опубл. 27.02.2011, бюл. № 6. - 9с.

5. Каширина, Л. Г. Влияние белково-кормовой добавки «БКД-С» на некоторые физиологические показатели и пророст массы цыплят - бройлеров кросса «Смена-7» [текст] / Л. Г. Каширина, С. Е. Митрофанова // Сборник научных трудов профессорско-преподавательского состава и молодых ученых РГАТУ : Материалы научно-практической конференции. Т.1.- Рязань, 2011. - С.11-16.

6. Бышов Д. Н. Исследование гранулометрического состава загрязненного воскового сырья / Д.Н. Бышов, Д.Е. Каширин, В.В. Павлов // В сборнике: Энергоэффективные и ресурсосберегающие технологии и системы сборник научных трудов международной научно-практической конференции, посвященной памяти доктора технических наук, профессора Ф. Х. Бурумкулова. Институт механики и энергетики; Ответственный за выпуск: Столяров А.В. - 2016. - С. 463-465.

7. Каширин Д.Е. Конвективная сушка перги / Д.Е. Каширин // Пчеловодство. - 2009.- № 8 - С. $46-47$.

8. К вопросу вакуумной инфракрасной сушки перги / Д. Н. Бышов, Д. Е. Каширин, С. Н. Гобелев, С. С. Морозов, А. В. Протасов // Вестник Рязанского государственного агротехнологического университета им. П.А. Костычева. - 2016. - Т. 29. - № 1. - C. 56-59.

9. Каширина, Л. Г. Физиологические ослновы использования в питании жвачных животных гранули-рованных и брикетилрованных кормов : автореф. дис. ... д-ра. биолог. наук / Каширина Л.Г. - Рязань, 1995.

10. Исследование адгезионных свойств перги, содержащейся в пчелиных сотах / Д. Н. Бышов, Д. Е. Каширин, А. В. Куприянов, В. В. Павлов // Вестник Красноярского государственного аграрного университета. - 2015. - № 7. - С. 174-178.

11. Бышов, Д. Н. Исследование дисперсионных свойств перги различного гранулометрического состава / Д. Н. Бышов, Д. Е. Каширин, В. В. Павлов // Вестник Рязанского государственного агротехнологического университета им. П.А. Костычева. - 2017. - № 1 (33). - С. 69-74.

12. Бышов, Д. Н. Исследование гигроскопических свойств загрязнителей воскового сырья / Д. Н. Бышов, Д. Е. Каширин, В. В. Павлов // Электронный научно-методический журнал Омского ГАУ. - 2016. - № S2. - С. 35.

13. Пат. № 2397639 РФ. Способ извлечения перги из сотов / Д.Е. Каширин. - Заявл. 17.04.2009; 
опубл. 27.08.2010, бюл. № 24. - 5с.

14. Повышение качества перги путем механической очистки / Д. Н. Бышов, Д. Е. Каширин, В. В. Павлов, В .В. Коченов // В сборнике: Проблемы и решения современной аграрной экономики : Материалы конференции. - 2017. - С. 19-20.

15. Каширин, Д. Е. Вакуумная сушка перги / Д. Е. Каширин // Пчеловодство. - 2006. - № 4. - С. 50.

16.Бышов, Н.В.Исследованиегигроскопических свойств перги / Н. В. Бышов, Д. Е. Каширин, А. В. Куприянов // Вестник Мичуринского государственного аграрного университета. - 2011. - №2-2. - С. 14-15.

17. Бышов, Д. Н. К вопросу механизированной очистки воскового сырья / Д. Н. Бышов, Д. Е. Каширин, В. В. Павлов // В сборнике: Аграная наука в инновационном развитии АПК: Материалы международного молодежного аграрного фрорума : Сборник научных статей / Под редакцией В.А. Бабушкина. 2018. С. 49-55.

18. Пат. № 93302 РФ. Измельчитель перговых сотов /Д.Е. Каширин. - Заявл. 26.01.2010; опубл. 27.04.2010, бюл. № 12. - 2с.

\title{
MATHEMATICAL MODELING OF THE PROCESS OF VACUUM INFRARED DRYING OF HONEYCOMBS
}

\author{
Byshov Dmitriy N., Candidate of Technical Sciences, Associate Professor, \\ Kashiri Dmitriy Ye., Doctor technical sciences, Associate Professor, kadm76@mail.ru \\ Uspenskiy Ivan A., Dr. tech. Professor, ivan.uspensckij@yandex.ru \\ Yukhin Ivan A., doctor of engineering. associate Professor, yuival@rambler.ru \\ Morozov Sergei S., applicant, mars37603@mail.ru \\ Ryazan State Agrotechnological University Named after P.A. Kostychev
}

Vacuum infrared drying is currently the most promising technology for drying honeycombs, but this direction has not been sufficiently studied to date. This article carried out a theoretical study of heat and moisture in the process of vacuum infrared drying of honeycombs. The boundary conditions in the drying process are described and the systems of equations of heat and moisture exchange are obtained. The technique of solving problems of heat and moisture exchange in the process of vacuum infrared drying. A method for numerical calculations of the temperature and moisture content of the honeycombs drying has been developed. A numerical simulation of the process of vacuum infrared drying of honeycombs was carried out. Based on the results, graphical dependences of changes in temperature and moisture content of honeycombs with a change in the depth and heating time were constructed. From the data obtained, it is seen that the warming of the honeycomb occurs from the center to the outer boundary. With a decrease in the depth of heating, the temperature changes more slowly as a result of convection at the outer boundary of the honeycomb. The highest rate of moisture exchange is observed in the surface layers; therefore, the moisture content of the honeycomb at the outer boundary is close to the moisture content of the washing air. The maximum permissible temperature of heating honeycombs is reached in 1.2 hours, and the average temperature of honeycombs is increased from $25^{\circ} \mathrm{C}$ to $60^{\circ} \mathrm{C}$ in 2 hours. The average moisture content of honeycombs decreases from 260 $\mathrm{kg} / \mathrm{m}^{3}$ to $145 \mathrm{~kg} / \mathrm{m}^{3}$ in 2 hours of vacuum infrared drying, which shows the high efficiency of the technology under study with a sufficiently low specific power of the heaters.

Key words: bee honeycombs, bee bread, IR radiation, vacuum drying, mathematical modeling

\section{Literatura}

1.Byshov D.N. Rezul'taty mnogofaktornogo eksperimental'nogo issledovaniya dispersionnyh svojstv pergi / D.N. Byshov, D.E. Kashirin, V.V. Pavlov // Vestnik Krasnoyarskogo gosudarstvennogo agrarnogo universiteta. - 2017. - №2 (125). - S. 115-121.

2.Kashirina L.G., Kondakova I.A., RomancovaA.V. Vliyanie preparatov propolisaipergina gematologicheskie pokazateli krovi krolikov [tekst] / Kashirina L.G., Kondakova I.A., El'cova A.V., Romancova A.V. // «Aktual'nye problemy veterinarnoj mediciny $i$ biologii». Materialy mezhdunarodnoj nauchno-prakticheskoj konferencii, posvyashchennoj 150-letiyu veterinarnoj sluzhby.- Orenburga - 2003.- s. 60-62.

3. Pat. № 2275800 RF. Ustanovka dlya izvlecheniya pergi iz pergovyh sotov / D.E. Kashirin. - Zayavl. 28.12.2004; opubl. 10.05.2006, byul. № 13. - 6s.

4. Pat. № 2412590 RF. Ustanovka dlya izvlecheniya i ochistki pergi iz sotov / D.E. Kashirin. - Zayavl. 07.12.2009; opubl. 27.02.2011, byul. № 6. - 9s.

5. Kashirina L.G., Mitrofanova S.E. Vliyanie belkovo-kormovoj dobavki «BKD-S» na nekotorye fiziologicheskie pokazateli i prorost massy cyplyat - brojlerov krossa "Smena-7» [tekst] / Kashirina L.G., Mitrofanova S.E. // Sbornik nauchnyh trudov professorsko-prepodavatel'skogo sostava i molodyh uchenyh RGATU. Materialy nauchno-prakticheskoj konferencii. T.1.- Ryazan', 2011g.- S.11-16.

6. Byshov D.N. Issledovanie granulometricheskogo sostava zagryaznennogo voskovogo syr'ya / D.N. Byshov, D.E. Kashirin, S.N. V.V. Pavlov // V sbornike: Energoeffektivnye i resursosberegayushchie tekhnologii i sistemy cbornik nauchnyh trudov mezhdunarodnoj nauchno-prakticheskoj konferencii, posvyashchennoj pamyati doktora tekhnicheskih nauk, professora F. H. Burumkulova. Institut mekhaniki ienergetiki; Otvetstvennyj za vypusk: Stolyarov A.V. - 2016. - S. 463-465.

7. Kashirin D.E. Konvektivnaya sushka pergi / D.E. Kashirin // Pchelovodstvo. - 2009.- № 8 - S. 46-47.

8. Byshov D.N. K voprosu vakuumnoj infrakrasnoj sushki pergi / D.N. Byshov, D.E. Kashirin, S.N. Gobelev, 
S.S. Morozov, A.V. Protasov // Vestnik Ryazanskogo gosudarstvennogo agrotekhnologicheskogo universiteta im. P.A. Kostycheva. - 2016. - T. 29. - № 1. - S. 56-59.

9. Kashirina L.G. Fiziologicheskie osnovy ispol'zovaniya v pitanii zhvachnyh zhivotnyh granuli-rovannyh $i$ briketirovannyh kormov [tekst] / Kashirina L.G. // Avtoreferat dissertacii na soiskanie uchenoj stepeni d.b.n. Ryazan', 1995.

10. Byshov D.N. Issledovanie adgezionnyh svojstv pergi, soderzhashchejsya v pchelinyh sotah / D.N. Byshov, D.E. Kashirin, A.V. Kupriyanov, V.V. Pavlov // Vestnik Krasnoyarskogo gosudarstvennogo agrarnogo universiteta. - 2015. - № 7. - S. 174-178.

11. Byshov D.N. Issledovanie dispersionnyh svojstv pergi razlichnogo granulometricheskogo sostava / D.N. Byshov, D.E. Kashirin, V.V. Pavlov // Vestnik Ryazanskogo gosudarstvennogo agrotekhnologicheskogo universiteta im. P.A. Kostycheva. - 2017. - № 1 (33). - S. 69-74.

12. Byshov D.N. Issledovanie gigroskopicheskih svojstv zagryaznitelej voskovogo syr'ya / D.N. Byshov, D.E. Kashirin, V.V. Pavlov // Elektronnyj nauchno-metodicheskij zhurnal Omskogo GAU. - 2016. - № S2. - S. 35. 13. Pat. № 2397639 RF. Sposob izvlecheniya pergi iz sotov / D.E. Kashirin. - Zayavl. 17.04.2009; opubl. 27.08.2010, byul. № 24. - 5s.

14. Byshov D.N. Povyshenie kachestva pergi putem mekhanicheskoj ochistki / D.N. Byshov, D.E. Kashirin, V.V. Pavlov, V.V. Kochenov // V sbornike: Problemy i resheniya sovremennoj agrarnoj ekonomiki Materialy konferencii. - 2017. - S. 19-20.

15. Kashirin D.E. Vakuumnaya sushka pergi / D.E. Kashirin // Pchelovodstvo. - 2006. - № 4. - S. 50.

16. Byshov N.V. Issledovanie gigroskopicheskih svojstv pergi / N.V. Byshov, D. E. Kashirin, A.V. Kupriyanov // Vestnik Michurinskogo gosudarstvennogo agrarnogo universiteta №2-2, 2011. S.14-15.

17. Byshov D.N. K voprosu mekhanizirovannoj ochistki voskovogo syr'ya / D.N. Byshov, D.E. Kashirin, V.V. Pavlov // V sbornike: Agranaya nauka $v$ innovacionnom razvitii APK Materialy mezhdunarodnogo molodezhnogo agrarnogo foruma. Sbornik nauchnyh statej. Pod redakciej V.A. Babushkina. 2018. S. 49-55.

18. Pat. № 93302 RF. Izmel'chitel' pergovyh sotov /D.E. Kashirin. - Zayavl. 26.01.2010; opubl. 27.04.2010, byul. № 12. -2 s.

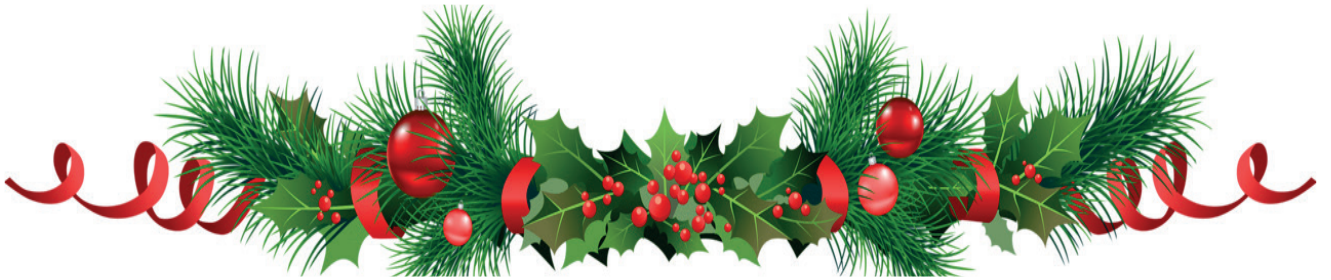

УДК 631.87

DOI 10.36508/RSATU.2019.23.11.015

\section{ИССЛЕДОВАНИЕ РАБОТЫ ГЕНЕРАТОРА ГОРЯЧЕГО ТУМАНА ПРИ ОБРАБОТКЕ СТЕБЛЕСТОЯ}
КОСТЕНКО Михаил Юрьевич, д-р техн. наук, профреcсop, kostenko.mihail2016@yandex.ru
БЕЗНОСЮК Роман Владимирович, канд. техн. наук, доцент, romario345830@yandex.ru
ГОРЯЧКИНА Ирина Николаевна, канд. техн. наук, доцент, gin.81@mail.ru
РЕМБАЛОВИЧ Георгий Константинович, д-р техн. наук, декан, rgk.rgatu@yandex.ru
БОРИСОВ Геннадий Александрович, д-р техн. наук, професcop, tmirm@yandex.ru
ЛАТЫШЕНОК Михаил Борисович, д-р техн. наук, профрессор, tmirm@yandex.ru
Рязанский государственный агротехнологический университет имени П.А. Костычева

Опрыскивание является универсальным способом применения защитно-стимулирующих веществ. Эфрфективность опрыскивания зависит от концентрации растворов, размера капель и их осаждения на поверхности листьев. Множество мелких капель имеют такой же объем препарата, что и одна крупная капля, но контактируют с большей площадью растения, что обеспечивает наиболее быстрое и одновременное проникновение препарата. Обработка растений предъявляет определенные технические и технологические требования к техническим средствам, которые должны выполнять сразу несколько технологических операций одновременно - образование защитной пленки микроэлементов и биопрепаратов на их поверхности, равномерная доставка капель к растениям. Наиболее предъявляемым требованиям отвечают генераторы горячего тумана, которые позволяют получать ультрадисперсные аэрозоли. Исследование движения аэрозолей затруднено из-за взаимопроникновения двух сплошных сред - горячего тумана и воздуха, а также обтекания препятствий в виде растений. Кроме того, горячий туман имеет более высокую температуру в сравнении с окружающим воздухом и растениями, поэтому применение классических положений аэродинамики затруднено. Распространение горячего тумана в стеблях растений возможно исследовать экспериментально. Так как капли горячего тумана имеют более высокую температуру, чем обрабатываемые объекты, они быстро испаряются. Поэтому в качестве рабочего раствора использовали 20\%-й водный раствор соли NaCl. Распределение кристаллов по размерам исследовали с помощью статистического анализа. Средний размер капель горячего тумана составляет 9,5 мкм. Расход рабочего раствора на данном режиме генератора составляет 3,0 л/ч, расход топлива - 2,1 л/ч.

() Костенко М. Ю., Безносюк Р. В., Горячкина И. Н., Рембалович Г. К., Борисов Г. А., Латышенок М. Б., 2019 г. 
Следует отметить, что наибольший размер капель наблюдается на краях поддона, что обусловлено инерционным распределением горячего тумана. Исследования распределения капель горячего тумана в стеблестое растений показали, что наибольшее покрытие каплями обрабатываемой поверхности происходит в непосредственной близости от генератора горячего тумана, при этом

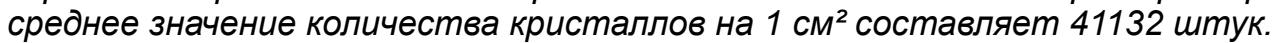

Ключевые слова: горячий туман, защитно-стимулирующие препараты, аэрозоль, равномерность, дисперсность

\section{Введение}

Защиту и стимуляцию растений осуществляют путем обработки листовой поверхности эмульсией или суспензией в капельножидком состоянии. Опрыскивание представляет универсальный способ применения защитно-стимулирующих веществ. Эффрективность опрыскивания зависит от концентрации растворов и размера капель и их осаждения на поверхности листьев, особенно на нижней их стороне, где располагается большее количество устьиц. Наиболее перспективным способом обработки является ультра малообъемное опрыскивание (УМО). Применение УМО предполагает уменьшение эффрективного размера капель защитно-стимулирующих веществ. Применение мелкодисперсных аэрозолей показало, что мелкие капли защитно-стимулирующих веществ значительно увеличивают эффрект препарата, в сравнении с крупными каплями. Множество мелких капель имеют такой же объем препарата, что и одна крупная капля, но контактируют с большей площадью растения, что обеспечивает наиболее быстрое и одновременное проникновение препарата. Это позволяет уменьшать дозировку действующего вещества препарата, а также уменьшать количество растворобразующего вещества. При опрыскивании следует учитывать физико-химические аспекты: свойства применяемых препаратов, размеры капель, количество капель на обрабатываемой поверхности (густота покрытия), расход и концентрацию рабочей жидкости.

Качество опрыскивания оценивают по следующим критериям:

- количество капель на листовой поверхности (на искусственных коллекторах), площадью 1 см²;

- эфффективность использования капель аэрозоля - соотношение распыленного и осевшего количеств рабочей жидкости (капель);

- равномерность распределения капель на обрабатываемых поверхностях.

Особенностью оценки опрыскивания является применение горизонтальных коллекторов в предположении, что капли рабочей жидкости падают исключительно вниз, что не всегда происходит при уменьшении размера капель - они легко подхватываются воздушными потоками и некоторое время витают в зоне обработки.

Также следует отметить влияние погодных условий на процесс опрыскивания, они определяют снос капель препарата, его испарение, равномерность распределения и процент использования препарата. Кроме того, погодные условия могут влиять на скорость распада препарата и смыв препарата осадками.

В зависимости от способа образования, аэрозоли (дисперсные системы, состоящие из капель) классифицируют по методам получения на диспергационные и конденсационные. По дисперсности аэрозоли разделяют на ультрадисперсные аэрозоли с размерами 0,001-0,01 мкм, высокодисперсные аэрозоли 0,01-0,1 мкм, среднедисперсные аэрозоли 0,1-10 мкм, грубодисперсные аэрозоли 10-100 мкм.

\section{Материалы и методы}

Обработка растений предъявляет определенные технические и технологические требования к техническим средствам, которые должны выполнять сразу несколько технологических операций одновременно - образование защитной пленки микроэлементов и биопрепаратов на их поверхности, равномерная доставка капель к растениям. Наиболее предъявляемым требованиям отвечают генераторы горячего тумана, которые позволяют получать ультрадисперсные аэрозоли - новый класс наночастиц. Однако применение ультрадисперсных аэрозолей требует уточнения некоторых вопросов: применяемых доз, равномерности и эффективности распределения капель на растениях, способов улучшения осаждения, особенно на нижней поверхности листьев.

Исследуя технологический процесс обработки растений, следует варьировать конструктивнотехнологические параметры генератора горячего тумана и его рабочие режимы - расход топлива, количество и концентрацию подаваемой рабочей жидкости, температуру горячего тумана, производительность установки, а в качестве функции оптимизации размер капелек горячего тумана и равномерность их распределения.

Для повышения эффективности осаждения капель аэрозоля применяют электростатические способы, способы температурного градиента и инерционные способы. Для горячего тумана наиболее применимы инерционный способ и способ температурного градиента. Осаждение на листовую поверхность происходит в результате взаимодействия капель горячего тумана с растением: капли, обладающие значительным весом в сравнении с частицами воздуха, за счет инерции оседают на листьях и стеблях растений при огибании воздушным потоком препятствий. Также осаждению способствует разница температур капли горячего тумана и растения - температурный градиент. Капля горячего тумана, передвигаясь в потоке, может оседать не только при пересечении ее траектории с растением, но и при нахождении на небольшом расстоянии от обрабатываемой поверхности. Кроме того, при уменьшении инерции потока возникают температурные восходящие потоки, способствующие осаждению капель на нижней стороне листьев.

Анализ показал, что теоретические исследо- 
вания транспортирования и взаимодействия горячего тумана с растениями имеют фрагментарный характер; недостаточно представлены также технические средства для обработки растений горячим туманом защитно-стимулирующих веществ. Отсутствуют исследования по внесению защитно-стимулирующих препаратов в виде капель горячего тумана на растения и распределению их на листовой поверхности. Высокая дисперсность защитно-стимулирующих препаратов, увеличение контактной поверхности, возможность проникновения в объекты сложной формы обуславливают увеличение эффрективности воздействия.

Исследование движения аэрозолей затруднено из-за взаимопроникновения двух сплошных сред - горячего тумана и воздуха, а также обтекания препятствий в виде растений. Кроме того, горячий туман имеет более высокую температуру в сравнении с окружающим воздухом и растениями, и поэтому применение классических положений аэродинамики затруднено. Распространение горячего тумана в стеблях растений возможно исследовать экспериментально. Анализ показал, что вопросы распространения горячего тумана в стеблестое недостаточно изучены - так, отсутствуют данные по равномерности его распределения при обработке растений.

Для исследования распределения капель горячего тумана при обработке стеблей растений была разработана лабораторная установка и искусственные растения (рис. 1)

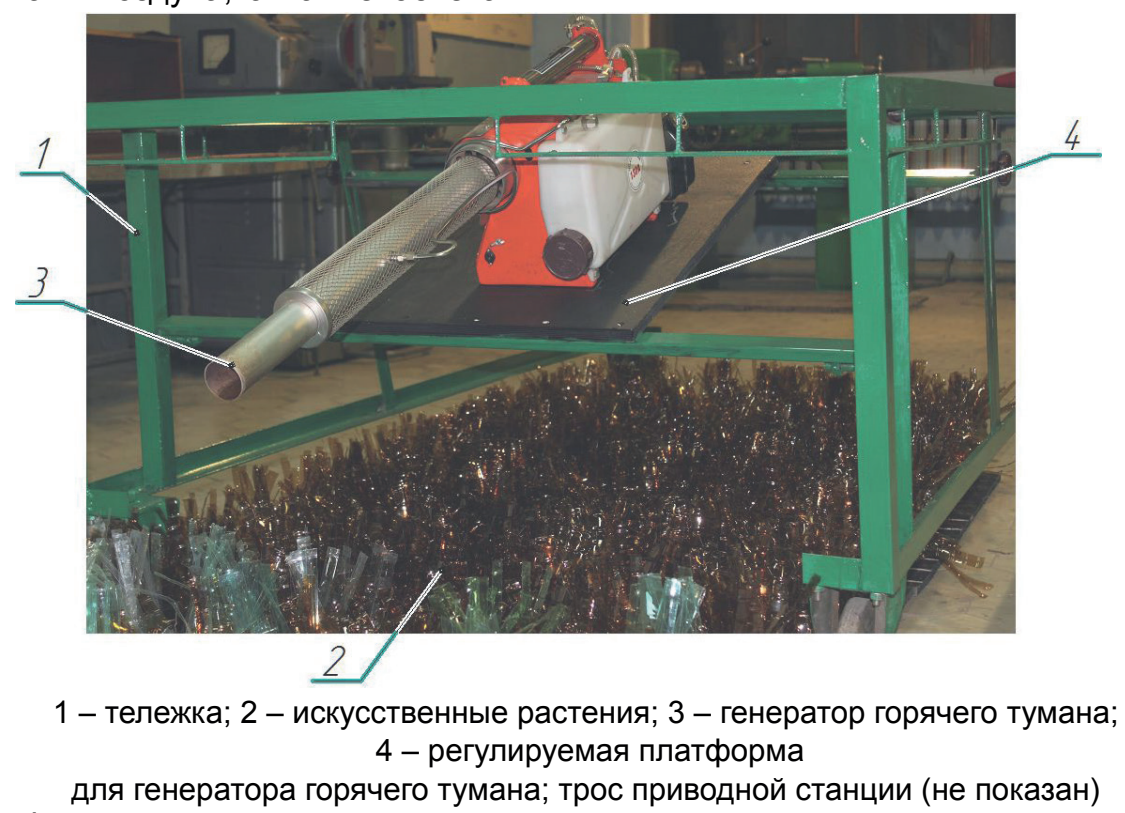

Рис. 1 - Лабораторная установка для исследования распределения капель горячего тумана при обработке стеблей растений

Лабораторная установка для исследования распределения капель горячего тумана при обработке стеблей растений представляет собой тележку 1, на которой устанавливается генератор горячего тумана 3. Движение тележки осуществляли тросом от приводной станции. Угол наклона генератора горячего тумана изменяли с помощью регулируемой платформы 4, на которой находятся камера обработки с наклонными полками внутри нее, расположенными в камере под некоторым углом, и генератор горячего тумана. Генератор горячего тумана марки BF -150 состоит из камеры сгорания с предкамерой подготовки горючей смеси и форсункой, свечи зажигания [2]. Подачу воздуха в предкамеру подготовки горючей смеси осуществляют по каналам, в которых подогревается воздух. При сгорании объем горючей смеси значительно увеличивается, и она поступает в жаровую трубу. В результате рециркуляции воздуха с внешней стороны жаровой трубы дополнительный воздух нагревается и смешивается в выходном сопле с топочными газами. Диспергирующее устройство в виде эжектора установлено в конце жаровой трубы, где происходит теплообмен топочных газов с рабочим раствором. Нагрев рабочего раствора способствует созданию оптимальных условий для образования горячего тумана. В выходном сопле горячий туман смешивается с поступающим нагретым воздухом. Из сопла поток горячего тумана направляется на растения.

Оценку осаждения капель горячего тумана проводили на предметных стеклах, закрепленных в зажимах и установленных на поверхности поддонов в нижней части искусственных растений (рис. 2). На каждый поддон в стеблестое искусственных растений устанавливали 9 пробоотборников (предметных стекол), равномерно располагая их по ширине и длине.

Так как капли горячего тумана имеют более высокую температуру, чем обрабатываемые объекты, они быстро испаряются. Поэтому в качестве рабочего раствора использовали 20\%-й водный раствор соли $\mathrm{NaCl}$. При испарении капли на предметных стеклах оставляли солевые кристаллы. Выбор 20\%-й концентрации обусловлен относительно небольшим отличием размеров кристалла 
и капли горячего тумана [7].

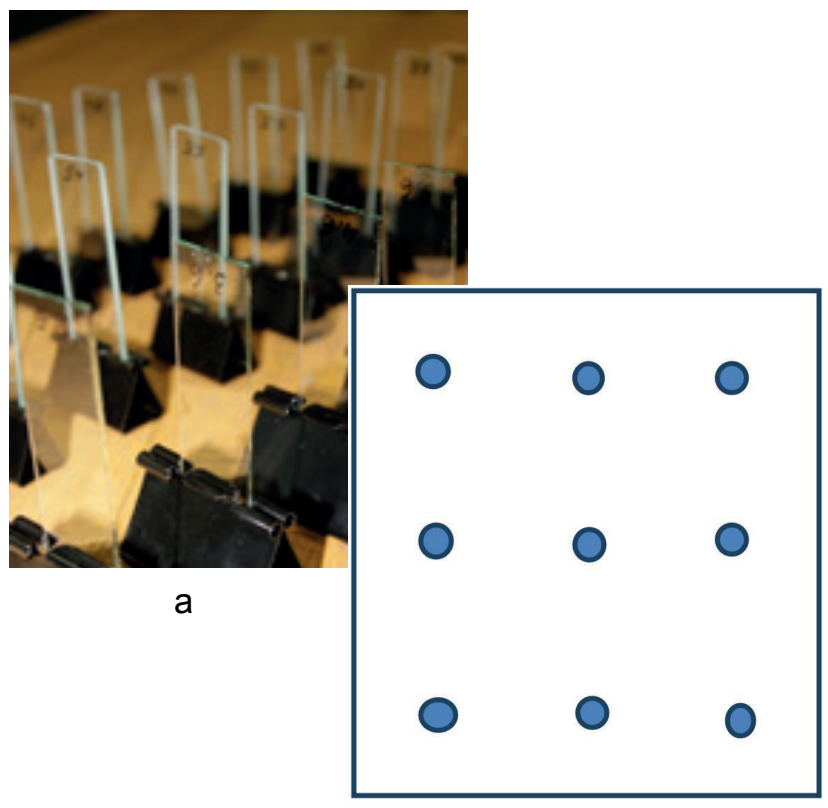

6

a - общий вид пробоотборников (предметных стекол); б - расстановка пробоотборников

Рис. 2 - Общий вид и расстановка пробоотборников (предметных стекол) на поддоне в стеблестое искусственных растений

Оценка уменьшения капли горячего тумана после испарения воды определяется равенством массового содержания соли $\mathrm{NaCl}$ в капле горячего тумана и кристалла после полного испарения

$$
\begin{aligned}
& m=\left(C_{m}\right) \cdot \rho_{p-p a} \\
& V_{1}=\rho_{1} \cdot V_{2}
\end{aligned}
$$

где $\mathrm{m}$ - масса соли $\mathrm{NaCl}$ в капле раствора, кг;

$\left(C_{m}\right)$ - относительная массовая концентрации соли $\mathrm{NaCl}$ в растворе;

$\rho_{\text {p-pa }}, \rho_{1}-$ плотность раствора и соли $\mathrm{NaCl}$ в

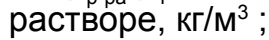

$\mathrm{V}_{1}, \mathrm{~V}_{2}$ - объем капли и соли $\mathrm{NaCl}$ в ней, соответственно, $\mathbf{m}^{3}$.

Выразим объем через диаметр капли и получим уравнение размера кристалла соли (D2), получившегося после испарения воды из начальной капли диаметром (D1):

$$
D_{2}=D_{1} \sqrt[3]{\frac{\left(C_{m}\right)_{2} \cdot \rho_{p-p a}}{\rho_{1}}}
$$

Выражение (3) позволяет оценивать размеры оседающих на предметные стекла капель по определяемым размерам кристаллов. Данная формула может применяться для исследования капель горячего тумана методами микроскопии предметных стекол с кристаллами соли $\mathrm{NaCl}$, что особенно удобно при длительном изучении размеров капель и является единственно возможным способом измерения испаряющихся капель.

Большинство образующихся кристаллов не являются сферическими, поэтому, распределение кристаллов по размерам описали с помощью статистического анализа. Размер кристаллов характеризовали универсальным параметром, называемым эквивалентным диаметром. Эквивалентный диаметр определяли исходя из значения площади, занимаемой кристаллом S на снимке с микроскопа, по фрормуле

$$
D_{2}=2 \sqrt{S / \pi} \text {. }
$$

\section{Результаты}

На основании изучения предметных стекол под микроскопом получены данные по распределению и размерам капель горячего тумана по площади поддона (рис. 3).

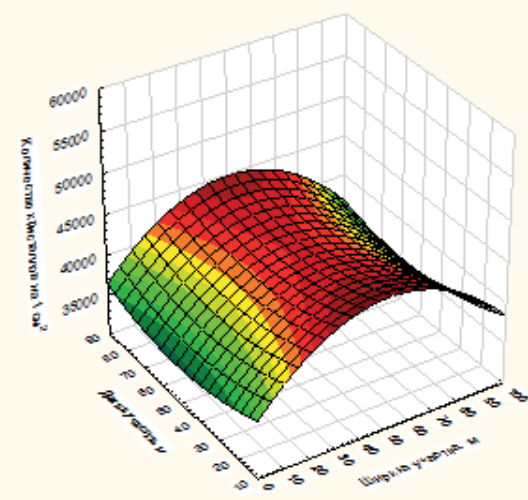

Рис. 3 - Распределение кристаллов соли $\mathrm{NaCl}$ на пробоотборниках поддона

в стеблестое искусственных растений

Из рисунка видно, что кристаллы по площади поддонов (1 $\left.\mathrm{M}^{2}\right)$ располагаются неравномерно, коэффициент вариации U=46,8\%. Наибольшее количество кристаллов располагается в непосредственной близости от генератора горячего тумана, при этом среднее значение количества кристал-

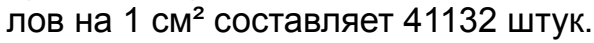

Результаты исследований размера капель горячего тумана представлены на рисунке 4.

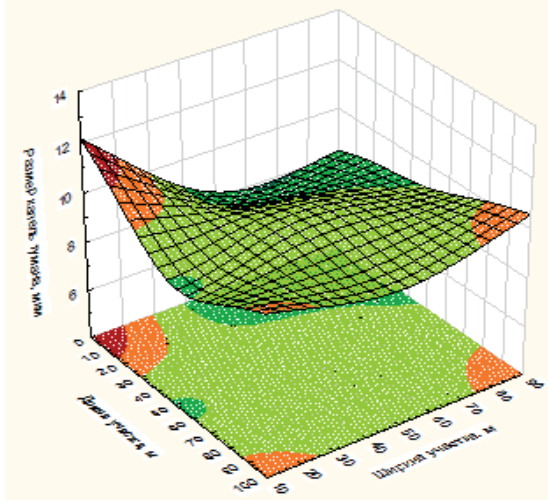

Рис. 4 - Распределение размеров капель горячего тумана на поверхности поддона с искусственными растениями 
Размер капель по площади поддона распределяется также неравномерно, коэффиициент вариации составляет $u=29,9 \%$. Это свидетельствует об относительной неравномерности получаемых капель, которые образуются генератором горячего тумана на данном режиме. Средний размер капель горячего тумана составляет 9,5 мкм. Расход рабочего раствора на данном режиме генератора составляет 3,0 л/ч, расход топлива - 2,1 л/ч. Следует отметить, что наибольший размер капель наблюдается на краях поддона, что обусловлено инерционным распределением горячего тумана.

Изучали также влияние скорости движения на количество капель горячего тумана, осаждаемых на предметных стеклах в стеблестое искусственных растений. Тележка с помощь троса и приводной станции перемещалась на следующих скоростях $\mathrm{V}_{1}=1,51 \mathrm{\kappa m} / ч, V_{2}=3,40 \mathrm{\kappa m} / 4 \mathrm{~V}_{3}=4,67 \mathrm{\kappa м} / ч$.

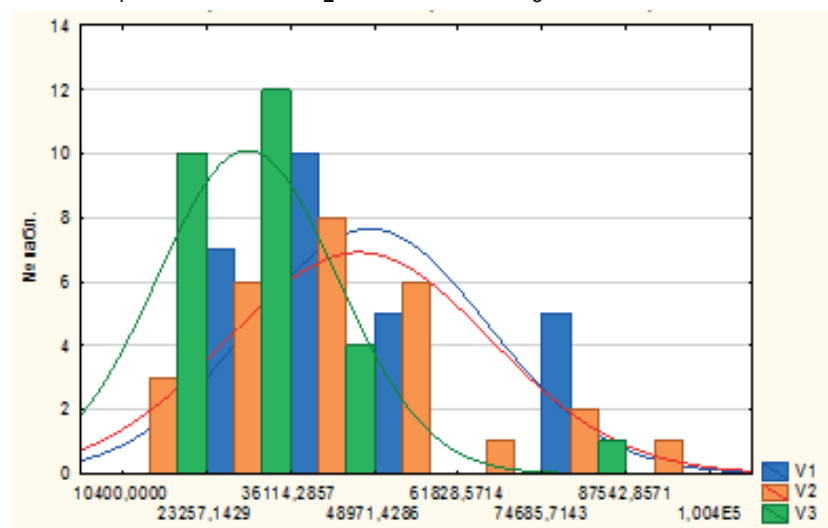

скорости перемещения тележки с генератором горячего тумана: $V_{1}=1,51 \mathrm{kм} / 4, V_{2}=3,40$ км/ч;

$$
\mathrm{V}_{3}=4,67 \mathrm{KM} / \mathrm{4} \text {. }
$$

Рис. 5 - Зависимость количества кристаллов соли $\mathrm{NaCl}$ на $1 \mathrm{~cm}^{2}$ пробоотборников, расположенных в стеблестое искусственных растений от скорости обработки

Из рисунка видно, что увеличение скорости влияет на количество кристаллов соли $\mathrm{NaCl}$ на пробоотборниках в стеблестое искусственных растений. Так, при скорости обработки $\vee 1=1,51$ км/ч среднее количество кристаллов соли $\mathrm{NaCl}$ на $1 \mathrm{~cm}^{2}$ пробоотборников составляет 48011 штук, при скорости $V_{2}=3,40$ км/ч - 46425 штук, при скорости $V_{3}=4,67$ км/ч - 28959 штук.

\section{Обсуждение}

Горячий туман на выходе из сопла имеет температуру около 500-600 С. В результате разницы температур горячего тумана и листовой поверхности растений происходит конденсация горячего тумана защитно-стимулирующих препаратов. Высокая влажность горячего тумана и разность температур обрабатываемых объектов и горячего тумана создают условия для возникновения точки росы. Фазовый переход горячего тумана защитно-стимулирующих препаратов на поверхности листьев способствует осаждению капель [1, 2, 3]. Осаждение капель происходит также за счет инерционного воздействия частиц горячего тумана на листья: каплям горячего тумана, обладающим значительным весом в сравнении с частицами воздуха, сложнее менять траекторию перед препятствием, и они оседают на растениях.

Капли горячего тумана, двигающиеся в направлении инерционного потока, частично попадают в пространство между растениями и через какое-то время начинают двигаться с тепловыми потоками, оседая на более холодных объектах. Характер движения и время витания зависят от размера капель, а также от распространения капель в пространстве [5, 7]

Анализ конструкций современной техники для защиты растений, проведенный В.Ф. Федоренко, В.Г. Селивановым, В.М. Дринчей, показал, что перспективным направлением при нанесения защитных веществ является уменьшение размера капель, количества наносимого раствора и повышение концентрации рабочих растворов [4].

Масловым Г.Г. и Хасановым Э. Р. исследовались вопросы диспергирования аэрозолей, ими проведено исследование получения мелкодисперсных капель с помощью дисковых распылителей, эжекционно-щелевого распылителя [5]

\section{Заключение}

Исследование распределения капель горячего тумана в стеблестое растений показали, что наибольшее покрытие каплями обрабатываемой поверхности происходит в непосредственной близости от генератора горячего тумана, при этом среднее значение количества кристаллов на $1 \mathrm{~cm}^{2}$ составляет 41132 штук. По ширине поддона капли располагаются неравномерно, коэффициент вариации u=46,8\%. Средний размер капель горячего тумана составляет 9,5 мкм. Размер капель по площади поддона распределяется также неравномерно, коэффициент вариации составляет U=29,9\%. Это свидетельствует об относительной неравномерности получаемых капель, которые образуются генератором горячего тумана на данном режиме. Скорость обработки определяет интенсивность покрытия каплями обрабатываемых поверхностей в стеблестое искусственных растений. Так, при скорости обработки $\mathrm{V}_{1}=1,51 \mathrm{~km} / 4$ среднее количество капель на $1 \mathrm{~cm}^{2}$ пробоотборников составляет 48011 штук, при скорости $V_{2}=3,40$ км/ч - 46425 штук, при скорости $V_{3}=4,67$ км/ч - 28959 штук.

\section{Список литературы}

1. Исследование температурного поля в камере обработки при аэрозольной обработке семян [Текст] / М. Ю. Костенко, О.А.Тетерина, В. С. Тетерин, Б. А. Нефедов, Д. В. Иванов. // Вестник АПК Ставрополья. - 2017. - № 4 (28). - С. 10-14.

2. Исследование топографии температурного поля облака генератора горячего тумана [Текст] / М. Ю. Костенко, И. Н. Горячкина, В. С. Мельников, М. В. Евсенина, Н. А. Костенко // Вестник РГАТУ. 2015. - №3. - С. 65-69.

3. Пат. 147211 Российская Федерация, МПК А23К3/00. Устройство для внесения консервирующих препаратов в растительную массу / Костенко М.Ю., Горячкина И.Н., Тетерин В.С., Мельников В.С.; патентообладатель: ФГБОУ ВПО РГАТУ. - №2014122615/13; заявл. 03.06.2014; опубл. 27.10.2014, бюл. №30.

4. Федоренко, В. Ф. Технологические и мето- 
дологические аспекты применения техники для защиты растений в странах ЕС [Текст] : методические рекомендации / В.Ф. Федоренко, В.Г. Селиванов, В. М. Дринча. - Москва, 2016. - 160 с.

5. Хасанов, Э. Р. Научное обоснование и разработка технологических процессов и технических средств предпосевной обработки семян сельскохозяйственных культур : дис. докт. техн. наук: 05.20 .01 [Текст] / Хасанов Эдуард Рифович; Уфpa, 2015. - 294 c.

\section{INVESTIGATION OF THE OPERATION OF THE HOT MIST GENERATOR \\ IN THE PROCESSING OF STEMS}

6. Lefebvre A.H. Atomization and Sprays. Hemisphere, New York, 1989. - 417 P. 14.

7. Ишматов, А. Н. Измерение дисперсности капель в факеле распыла форсунок методом "солевого остатка" / А. Н. Ишматов, Б. И. Ворожцов, В. А. Архипов // Сборник трудов «XXIII семинар по струйным, отрывным и нестационарным течениям (с международным участием)»: Национальный исследовательский Томский политехнический университет. - Бийск - 2012. - с. 177-181

Kostenko Mikhail Y., Dr. tech. Sci., Professor, Department of Metal Technology and Machine Repair, km340010@rambler.ru

Beznosyuk Roman V., Cand. tech. Sci., Associate Professor, Department of Metal Technology and Machine Repair, romario345830@rambler.ru

Goryachkina Irina N., Cand. tech. Sci., Associate Professor, Department of Metal Technology and Machine Repair, gin.81@mail.ru

Rembalovich Georgy K., Dr. tech. Sci., Dean of the Faculty of Road, rgk.rgatu@yandex.ru

Borisov Gennady A., Dr. tech. Sci., Professor, Department of Metal Technology and Machine Repair, tmirm@yandex.ru;

Latyshonok Mikhail B., Dr. tech. Sci., Professor, Department of Metal Technology and Machine Repair, tmirm@yandex.ru

Ryazan State Agrotechnological University Named after P.A. Kostychev

Spraying is a universal method of application of protective and stimulating substances. The effectiveness of spraying depends on the concentration of solutions and the size of the drops and their deposition on the surface of the leaves. Many small drops have the same volume of the drug as one large drop, but contact a larger area of the plant, which provides the fastest and simultaneous penetration of the drug. Treatment of plants imposes certain technical and technological requirements to the technical means, which must perform several technological operations simultaneously-the formation of a protective film of trace elements and biological products on their surface, uniform delivery of drops to plants. The most demanding requirements are met by hot mist generators, which allow to obtain ultrafine aerosols. The study of the movement of aerosols is difficult because of the interpenetration of two continuous media-hot fog and air, as well as the flow of obstacles in the form of plants. In addition, the hot fog has a higher temperature in comparison with the surrounding air and plants, and therefore the application of the classical provisions of aerodynamics is difficult. The distribution of hot mist in the stems of plants can be investigated experimentally. Since hot mist droplets have a higher temperature than the objects being treated, they evaporate quickly. Therefore, a $20 \%$ aqueous solution of $\mathrm{NaCl}$ salt was used as a working solution. The crystal size distribution was studied by static analysis. The average size of hot mist droplets is 9.5 microns. The flow rate of the working solution in this mode of the generator is $3.0 \mathrm{l} / \mathrm{h}$, fuel consumption-2.1 I/ h. It should be noted that the largest size of drops is observed at the edges of the pallet, due to the inertial distribution of hot fog. Studies of the distribution of hot mist droplets in the stem of plants have shown that the greatest coating of the treated surface drops occurs in the immediate vicinity of the hot mist generator, with the average number of crystals per $1 \mathrm{~cm}^{2}$ is 41132 pieces.

Key words: hot mist, protective and stimulating drugs, aerosol, uniformity, dispersion.

\section{Literatura}

1. Kostenko, M.YU. Issledovanie temperaturnogo polya v kamere obrabotki pri aerozol'noj obrabotke semyan [Tekst] / M.YU. Kostenko, O.A. Teterina, V.S. Teterin, B.A. Nefedov, D.V. Ivanov. // Vestnik APK Stavropol'ya. 2017. - № 4 (28). - S. 10 - 14.

2. Kostenko, M.YU. Issledovanie topografii temperaturnogo polya oblaka generatora goryachego tumana [Tekst] / Kostenko M. YU., Goryachkina I. N., Mel'nikov V. S., Evsenina M. V., Kostenko N. A.// Vestnik RGATU, №3, 2015.- Ryazan', RGATU.- S. 65-69.

3. Pat. 147211 Rossijskaya Federaciya, MPK A23K3/00. Ustrojstvo dlya vneseniya konserviruyushchih preparatov v rastitel'nuyu massu / Kostenko M.YU., Goryachkina I.N., Teterin V.S., Mel'nikov V.S.; patentoobladatel': FGBOU VPO RGATU. - №2014122615/13; zayavl. 03.06.2014; opubl. 27.10.2014, byul. №30.

4. Fedorenko, V.F. Tekhnologicheskie i metodologicheskie aspekty primeneniya tekhniki dlya zashchity rastenij v stranah ES [Tekst] / V.F. Fedorenko, V.G. Selivanov, V.M. Drincha // Metodicheskie rekomendacii Moskva, 2016.- $160 \mathrm{~s}$.

5. Hasanov, E.R. Nauchnoe obosnovanie i razrabotka tekhnologicheskih processov i tekhnicheskih sredstv predposevnoj obrabotki semyan sel'skohozyajstvennyh kul'tur : dis. dokt. tekhn. nauk: 05.20.01 [Tekst] / Hasanov Eduard Rifovich; - Ufa, 2015. - 294 s.

6. Lefebvre A.H. Atomization and Sprays. - Hemisphere, New York, 1989. - 417 P. 14.

7. Ishmatov, A.N. Izmerenie dispersnosti kapel' v fakele raspyla forsunok metodom "solevogo ostatka" / A.N. Ishmatov, B.I. Vorozhcov, V.A. Arhipov // Sbornik trudov "XXIII seminar po strujnym, otryvnym i nestacionarnym techeniyam (s mezhdunarodnym uchastiem)»: Nacional'nyj issledovatel'skij Tomskij politekhnicheskij universitet Biisk - 2012-s.177-181 


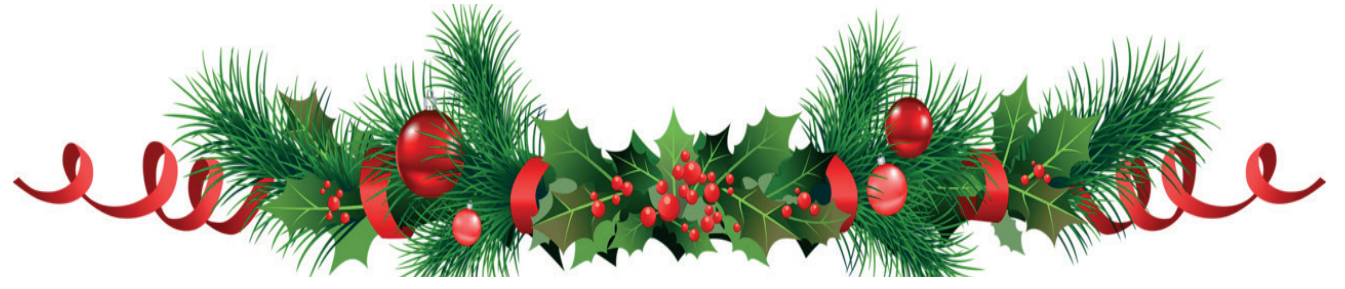

УДК 631.87

DOI 10.36508/RSATU.2019.30.21.016

\section{ИССЛЕДОВАНИЕ ВЛИЯНИЯ ОБРАБОТКИ СЕМЯН ЯЧМЕНЯ ГОРЯЧИМ ТУМАНОМ БИОЛОГИЧЕСКИХ ПРЕПАРАТОВ И ГУМИНОВЫХ ПРОДУКТОВ}

КОСТЕНКО Михаил Юрьевич, д-р техн. наук, профрессор кафредры технологии металлов и ремонта машин, kostenko.mihail2016@yandex.ru

РЕМБАЛОВИЧ Георгий Константинович, д-р техн. наук, декан автодорожного фракультета, rgk.rgatu@yandex.ru

ГОРЯЧКИНА Ирина Николаевна, канд. техн. наук, доцент кафредры организации транспортных процессов и безопасности жизнедеятельности, gin.81@таil.ru

БЕЗНОсюК Роман Владимирович, канд. техн. наук, доцент кафедры технологии металлов и ремонта машин, romario345830@yandex.ru

БОРИСОВ Геннадий Александрович, д-р техн. наук, профрессор кафредры технологии металлов и ремонта машин, tmirm@yandex.ru

Рязанский государственный агротехнологический университет имени П.А. Костычева

Целью исследований явилась оценка влияния обработки горячим туманом биологического препарата Азотовит и гуминовых продуктов Гумат калия, Экорост семян ячменя перед посевом, а также сравнение результатов с общепринятыми технологиями обработки с помощью протравителя семян этими же препаратами. Для полноты исследований обработку производили и химическим препаратом Атик. Высокодисперсный аэрозоль получали с помощью генератора горячего тумана GreenFogBF-130. Обработку производили с помощью устройства с наклонными полками, по которым зерно многократно пересыпалось под действием силы тяжести и подвергалось перемешиванию и воздействию горячего тумана. В результате разницы температур холодного семенного материала и горячего тумана происходил фразовый переход тумана в жидкость, что позволяло получить тонкую плёнку на обрабатываемой поверхности семян ячменя. Это способствовало обеззараживанию и активизации фризико-химических процессов в зерне. Экспериментальные исследования включали восемь вариантов обработки и один без обработки (контроль). Оценивались результаты продуктивности и структура урожая: число растений на $1 \mathrm{M}^{2}$, число сорных растений на $1 \mathrm{~m}^{2}$,

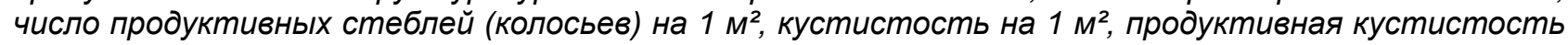

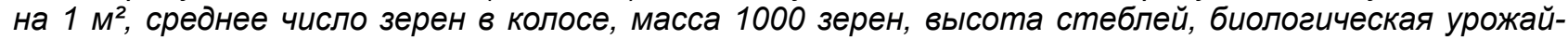
ность. В соответствии с ГОСТ 53900-2010 Ячмень кормовой, ГОСТ 5060-86 Ячмень пивоваренный, ГОСТ 28672-90 Ячмень. Требования при заготовках и поставках, ТP ТС 021/2011 О безопасности пищевой продукции из качественных показателей рассматривались массовая доля влаги, массовая доля протеина, массовая доля клетчатки, массовая доля сахара, массовая доля жира, массовая доля золы, массовая доля крахмала, обменная энергия, крупность, мелкие зерна, сорная и зерновая примесь, фрузариозные зерна, общая токсичность, микотоксин дезоксиниваленол (DON). Лучшие показатели были получены в результате аэрозольной обработки гуминовыми продуктами Гумат калия и Экорост.

Ключевые слова: биологические препараты, гуминовые продукты, аэрозольная обработка, генератор горячего тумана, семена ячменя.

\section{Введение}

Для повышения урожайности ячменя важным приемом является предпосевная обработка семян. Она направлена на защиту и стимулирование фризиологических процессов семян после посева. Предпосевная обработка позволяет повысить всхожесть семян, улучшить качество продукции, устойчивость к болезням, повысить жизнеспособность семян. Наиболее привлекательным является использование для предпосевной обработки биологических препаратов и гуминовых продуктов [2,9].

Ячмень характеризуется коротким периодом поглощения питательных веществ. Компенсировать недостаток питания первого периода вегетации культуры в последующие фазы развития невозможно. Растения ячменя в процессе жизненного цикла проходят следующие фенологические фазы: прорастание семян и всходы, кущение, выход в трубку, колошение, цветение,фрормирование и созревание зерна.

Период прорастание семян-всходы - один из наиболее важных в развитии ячменя. Задержка появления проростков из-за неблагоприятных условий может привести к гибели части семян и снижению полноты всходов. От посевов до всходов проходит 8-14 дней.

Питательные вещества расходуются на формирование новых листьев, рост корней,боковых побегов; в результате начинается кущение.Интенсивность кущения зависит от таких факторов, как

() Костенко М. Ю.,Рембалович Г. К., Горячкина И. Н., Безносюк Р. М., Борисов Г. А., 2019 г. 
густота посевов, влажность, освещенность, температура, оказывает влияние и глубина заделки семян.

Период фразы кущения колеблется от 8-12 до 15-25 дней в зависимости от погодных условий и биологических особенностей сорта. Чем благоприятнее и продолжительнее период кущения, тем крупнее закладывается колос, что положительно сказывается на формировании урожая.

Следующая фраза роста и развития ячменя выход в трубку. В этот момент растение интенсивно потребляет питательные вещества, воду, усиленно растет.

Во время формирования колоса в фазу колошения большое влияние на длину колоса, число колосков и продуктивность оказывают условия внешней среды. Теплая сухая погода способствует быстрому выколашиванию, прохладная и дождливая затягивает процесс. Однако в последнем случае колос формируется с большим числом зерен, возрастает их величина и вес, что увеличивает урожай. Колошение длится в среднем 6-7 дней или 15-18 дней в зависимости от влажности и температуры окружающей среды. В период от колошения до полной зрелости происходит перераспределение органических и минеральных веществ в надземных органах.

Фаза цветения ячменя совпадает с началом колошения или наступает через 1-3 дня после него. В этот период культура чувствительна к почвенной засухе. Недостаток влаги нарушает формирование пыльцы и приводит к частичной стерильности колосков.

Последний этап, определяющий урожайность формирование и созревание зерновки. Различают три фразы спелости: молочную, восковую и полную. Фаза молочной спелости длится 10-12 дней. В этот период налив зерна завершается, зерно достигает максимальных размеров. С окончанием поступления в зерно питательных веществ начинается фраза восковой спелости. Зерно приобретает свойственную ему окраску. Проводящие же пути стебля способны еще перемещать влагу и питательные вещества до полной спелости зерна.

Биологическая особенность ячменя определяет повышенную требовательность к условиям питания именно в начальный период роста и развития. В связи с этим следует рассмотреть использование биологических препаратов и гуминовых продуктов в виде предпосевной обработки. Это способствует стимулированию развития растений и защите от болезней и вредителей [2].

\section{Объекты и методы исследования}

Биологические препараты и гуминовые продукты следует применять в виде высокодисперсных аэрозолей. Их можно получить с помощью генератора горячего тумана GreenFogBF-130 (рис.1) $[4,5,7]$.

Семена ячменя обрабатывали горячим туманом биологических препаратов и гуминовых продуктов. Обработку семенного материала горячим туманом проводили с помощью устройства с наклонными полками, которое крепилось на выгрузном шнеке (рис. 2) [5,7].
Для предпосевной обработки ячменя применяли биологический препарат Азотовит, гуминовые продукты - Гумат калия и Экорост. Для сравнения кроме биологических препаратов и гуминовых продуктов обработку семян провели химическим препаратом Атик. Кроме аэрозольном обработки, предпосевную обработку семян проводили вышеуказанными препаратами с помощью протравителя семян ПС-20. Исследования ячменя сорта Владимир проводились на участке площадью 3,24 га.

Полевые опыты проведены с трёхкратной повторностью, делянки располагались систематически. Опыт включал 8 вариантов и контроль:

1) экорост опрыскивание;

2) экорост аэрозоль;

3) азотовит опрыскивание;

4) азотовит аэрозоль;

5) гумат калия опрыскивание;

6) гумат калия аэрозоль;

7) атик опрыскивание;

8) атик аэрозоль;

9) контроль (без обработки семян).

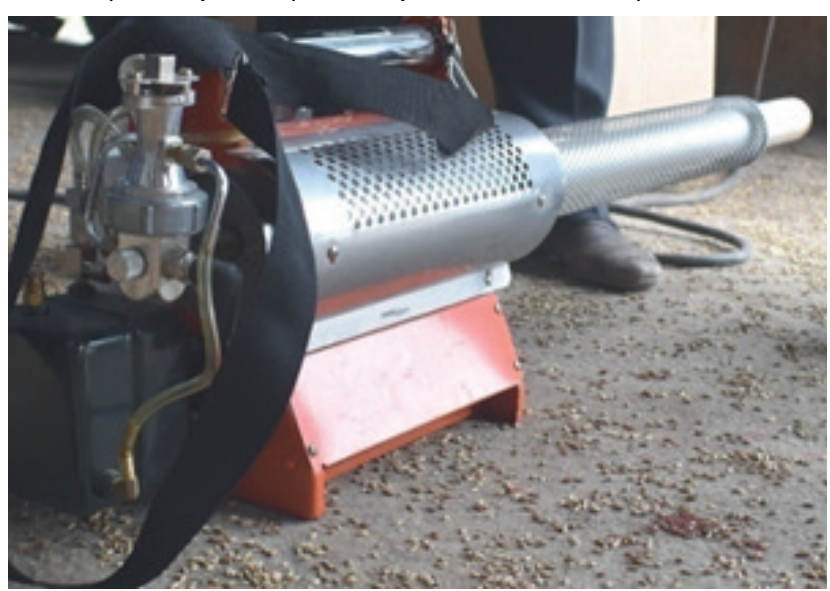

Рис. 1 - Общий вид генератора горячего тумана GreenFogBF-130

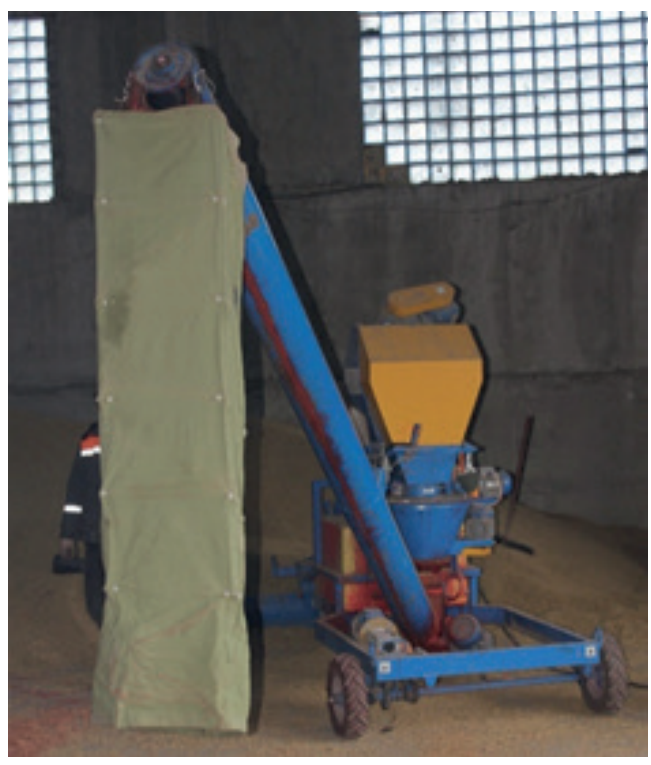

Рис.2 -Общий вид устройства для обработки семян горячим туманом 
В результате исследований изучалось влияние биологических препаратов и гуминовых продуктов и вида обработки на структуру урожая, урожайность, качественные показатели зерна.

\section{Экспериментальная часть}

Водный раствор препаратов с концентрацией $100 \mathrm{~m} / л$ заливали в резервуар генератора горячего тумана. Семена ячменя обрабатывали горячим туманом препаратов температурой $50-60^{\circ} \mathrm{C}$. Взаимодействие семян с горячим туманом происходило в устройстве, где семенной материал перемещался под силой тяжести с полки на полку, обеспечивая тем самым многократное перемешивание и контакт с горячим туманом, увеличивая эффрективность обработки (рис. 3) [1,8]. Из-за разницы температур холодных семян $\left(8^{\circ} \mathrm{C}\right)$ и горячего тумана (50-600С) происходил фразовый переход горячего тумана в жидкость и на поверхности семян образовывалась тонкая плёнка обрабатываемого препарата. Тепловая обработка способствовала активизации физиологических процессов семенного материала $[1,3,6]$.

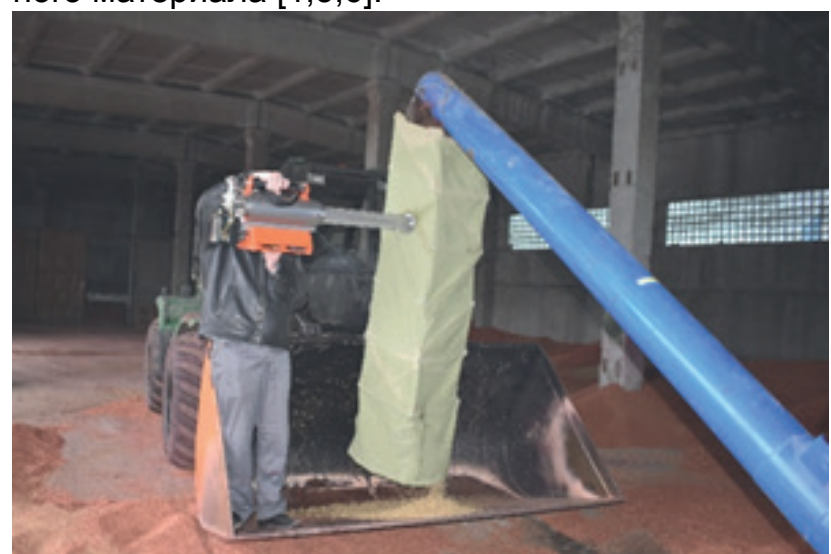

Рис. 3 - Общий вид обработки семян ячменя генератором горячего тумана с помощью устройства

После обработки семена ячменя помещали в мешки, каждый из которых имел бирку с обозначением вида препарата и способа обработки.

После предварительной подготовки почвы осуществлялся посев ячменя на делянках размером $12 \times 300$ м² $^{2}$ для каждого варианта (рис. 4)

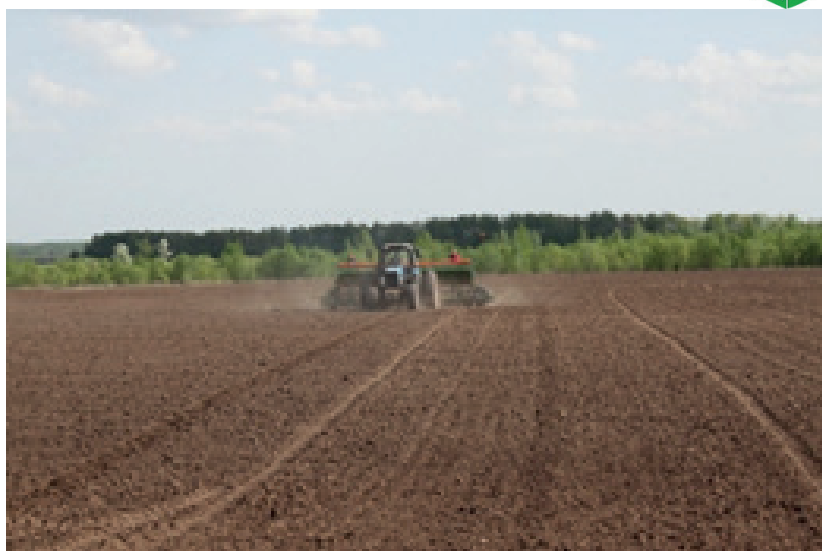

Рис. 4 - Общий вид посева ячменя

Каждая делянка была промаркирована (рис. 5).

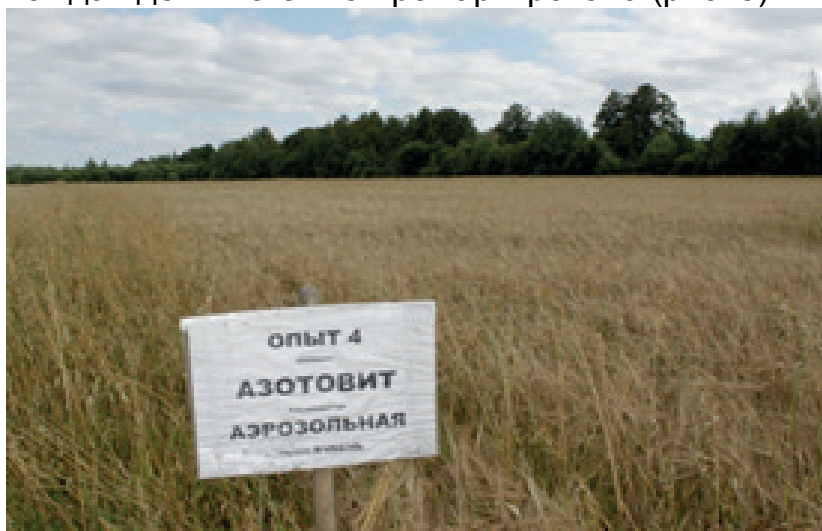

Рис. 5 - Общий вид делянки

В процессе вегетации проводились наблюдения за ростом и развитием ячменя.

\section{Результаты исследований}

Важными показателями, характеризующими развитие ячменя, являются густота растительного покрова и высота растений. Густота стояния растений и густота стеблестоя определяются количеством растений и стеблей, соответственно, на единице площади. Высоту ячменя измеряют в четырех частях участка (по 10 растений в каждой) недалеко от мест определения фаз развития и густоты стояния. Был проведен визуальный сравнительный анализ растений ячменя, обработанных разными способами и препаратами (рис. 6)
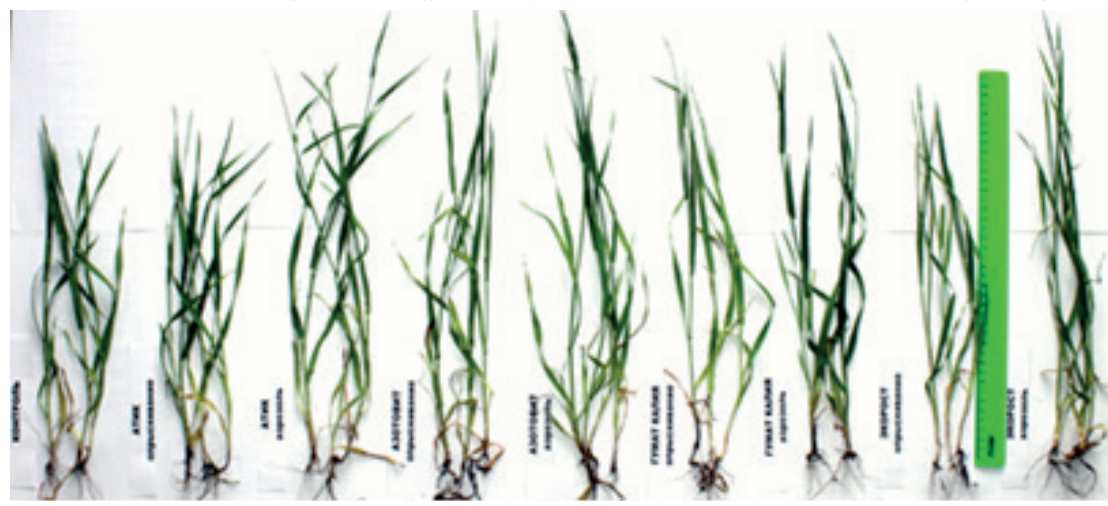

Рис. 6 - Зависимость высоты растения и количества стеблей от препарата и вида обработки

Знания элементов продуктивности, входящих в показатели структуры урожая, позволяют сделать количественный и качественный анализ (таблицы 1, 2). 
Таблица 1 - Результаты продуктивности и определения структуры урожая сельскохозяйственных культур (ячменя)

\begin{tabular}{|c|c|c|c|c|c|c|c|c|c|}
\hline Вариант & $\begin{array}{l}\text { Сор, } \\
\text { число } \\
\text { расте- } \\
\text { ний на } \\
1 \text { м² }^{2}\end{array}$ & 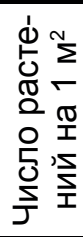 & $\mid \begin{array}{c}\text { Число про- } \\
\text { дуктивных } \\
\text { стеблей } \\
\text { (колосьев) } \\
\text { на } 1 \text { м² }^{2}\end{array}$ & 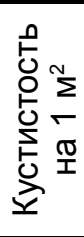 & $\begin{array}{c}\text { Кустистость } \\
\text { на } 1 \mathrm{~m}^{2} \\
\text { Продуктивная } \\
\text { кустистость } \\
\text { на } 1 \mathrm{~m}^{2}\end{array}$ & $\begin{array}{c}\text { Сред- } \\
\text { нее } \\
\text { число } \\
\text { зерен в } \\
\text { колосе } \\
\text { шт. }\end{array}$ & 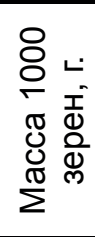 & $\begin{array}{c}\text { Биологи- } \\
\text { ческая } \\
\text { урожай- } \\
\text { ность } \\
\text { ц/га }\end{array}$ & $\begin{array}{c}\text { Высота } \\
\text { стеб- } \\
\text { лей, см }\end{array}$ \\
\hline 1. Контроль & 306 & 483 & 610 & 1,49 & 1,27 & 15 & 45,63 & 41,19 & 57,13 \\
\hline $\begin{array}{c}2 . \\
\text { Атик опры- } \\
\text { скивание }\end{array}$ & 433 & 523 & 793 & 1,79 & 1,54 & 16 & 48,13 & 62,35 & 58,26 \\
\hline $\begin{array}{c}. \\
\text { Атик } \\
\text { аэрозоль }\end{array}$ & 413 & 537 & 727 & 1,69 & 1,41 & 15 & 47,43 & 51,82 & 57,48 \\
\hline $\begin{array}{c}4 . \\
\text { Гумат К } \\
\text { опрыскива- } \\
\text { ние }\end{array}$ & 610 & 507 & 700 & 1,61 & 1,4 & 15 & 49,95 & 53,29 & 57,49 \\
\hline $\begin{array}{c}5 . \\
\text { Гумат К } \\
\text { аэрозоль }\end{array}$ & 443 & 600 & 823 & 1,57 & 1,38 & 16 & 48,19 & 64,55 & 58,33 \\
\hline $\begin{array}{c}6 . \\
\text { Экорост } \\
\text { опрыскива- } \\
\text { ние } \\
\end{array}$ & 320 & 490 & 710 & 1,72 & 1,5 & 16 & 49,68 & 56,58 & 58,4 \\
\hline $\begin{array}{c}7 . \\
\text { Экорост } \\
\text { аэрозоль }\end{array}$ & 463 & 663 & 773 & 1,41 & 1,23 & 15 & 48,27 & 57,86 & 56,62 \\
\hline $\begin{array}{c}\text { 8. Азотовит } \\
\text { опрыскива- } \\
\text { ние }\end{array}$ & 333 & 530 & 700 & 1,66 & 1,36 & 15 & 45,76 & 49,32 & 54,36 \\
\hline $\begin{array}{l}\text { 9. Азотовит } \\
\text { аэрозоль }\end{array}$ & 347 & 533 & 673 & 1,46 & 1,31 & 16 & 49,2 & 51,82 & 58,2 \\
\hline
\end{tabular}

По данным таблицы 1 для наглядности построена диаграмма биологической урожайности ячменя сорта Владимир, семенной материал которого прошел предпосевную аэрозольную обработку и обработку опрыскиванием биологическими препаратами и гуминовыми продуктами, а также химическим препаратом Атик (рис. 7).

Можно отметить, что наилучшим образом себя проявили гуминовые продукты Гумат калия и Экорост в виде аэрозольной обработки. Биоло- гическая урожайность ячменя составила соответственно 64,55 ц/га и 57,86 ц/га. Хороший результат показал и стандартный способ протравливания семян химическим препаратом Атик, биологическая урожайность достигла 62,35 ц/га.

Качественные показатели ячменя были определены после уборки урожая в Рязанской областной ветеринарной лаборатории с учетом нормативных требований на методы испытаний. Результат можно увидеть в таблице 2 .

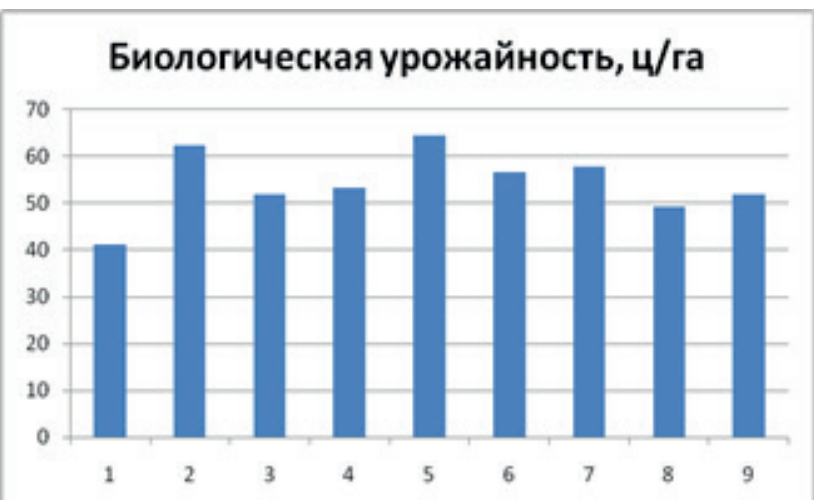

Рис.7 - Распределение биологической урожайности при предпосевной обработке ячменя разными способами и препаратами 
Таблица 2 - Качественные показатели ячменя сорта «Владимир»

\begin{tabular}{|c|c|c|c|c|c|c|c|c|c|}
\hline $\begin{array}{c}\text { Наименование } \\
\text { показателя }\end{array}$ & $\begin{array}{c}\text { 1. Конт- } \\
\text { роль }\end{array}$ & $\begin{array}{c}\text { 2. Эко- } \\
\text { рост } \\
\text { опры- } \\
\text { скива- } \\
\text { ние }\end{array}$ & $\begin{array}{c}3 . \\
\text { Эко- } \\
\text { рост } \\
\text { аэро- } \\
\text { золь }\end{array}$ & $\begin{array}{c}4 . \\
\text { Гумат } \\
\text { калия } \\
\text { опрыски- } \\
\text { вание }\end{array}$ & $\begin{array}{l}\text { 5. Гумат } \\
\text { калия } \\
\text { аэро- } \\
\text { золь }\end{array}$ & $\begin{array}{l}\text { 6. Азото- } \\
\text { вит } \\
\text { опрыски- } \\
\text { вание }\end{array}$ & $\begin{array}{c}7 . \\
\text { Азото- } \\
\text { вит } \\
\text { аэро- } \\
\text { золь }\end{array}$ & $\begin{array}{c}8 . \\
\text { Атик } \\
\text { опры- } \\
\text { скива- } \\
\text { ние }\end{array}$ & $\begin{array}{c}9 . \\
\text { Атик } \\
\text { аэро- } \\
\text { золь }\end{array}$ \\
\hline М.д.протеина,\% & 1,65 & 12,12 & 11,87 & 11,78 & 11,79 & 11,73 & 11,87 & 11,78 & 11,94 \\
\hline М.д.влаги, \% & 12,26 & 13,29 & 13,21 & 12,30 & 12,17 & 12,70 & 12,34 & 12,00 & 11,91 \\
\hline М.д.клетчатки,\% & 6,71 & 7,03 & 6,72 & 6,77 & 6,73 & 7,07 & 7,31 & 7,44 & 6,34 \\
\hline М.д.золы,\% & 2,41 & 2,46 & 2,33 & 2,53 & 2,45 & 2,43 & 2,50 & 2,62 & 2,43 \\
\hline М.д.сахара,\% & 3,34 & 3,37 & 2,80 & 3,40 & 3,34 & 3,65 & 3,26 & 3,03 & 3,42 \\
\hline М.д.жира,\% & 2,15 & 2,26 & 2,28 & 2,35 & 2,15 & 2,04 & 2,22 & 2,17 & 2,14 \\
\hline М.д.крахмала,\% & 43,78 & 42,43 & 43,49 & 43,35 & 43,44 & 42,52 & 41,82 & 41,20 & 44,10 \\
\hline $\begin{array}{l}\text { Обменная энер- } \\
\text { гия, \% }\end{array}$ & 12,76 & 12,79 & 12,83 & 12,79 & 12,75 & 12,72 & 12,72 & 12,68 & 12,77 \\
\hline Крупность, \% & 98,1 & 98,2 & 98,4 & 98,3 & 98,5 & 97,9 & 98,8 & 97,8 & 98,3 \\
\hline Мелких зерен,\% & 1,9 & 1,8 & 1,6 & 1,7 & 1,5 & 2,1 & 1,2 & 2,2 & 1,7 \\
\hline $\begin{array}{l}\text { Зерновой } \\
\text { примеси, \% }\end{array}$ & 1,3 & 1,0 & 1,1 & 1,2 & 1,0 & 2,0 & 1,0 & 1,1 & 1,2 \\
\hline $\begin{array}{l}\text { Сорной } \\
\text { примеси, \% }\end{array}$ & 0,6 & 0,5 & 0,4 & 0,5 & 0,3 & 0,5 & 0,3 & 0,4 & 0,5 \\
\hline $\begin{array}{l}\text { Фузариозных } \\
\text { зерен, \% }\end{array}$ & $\begin{array}{c}\text { Не } \\
\text { обнару- } \\
\text { жено }\end{array}$ & $\begin{array}{c}\text { Не } \\
\text { обнару- } \\
\text { жено }\end{array}$ & $\begin{array}{c}\text { Не } \\
\text { обнару- } \\
\text { жено }\end{array}$ & $\begin{array}{c}\text { Не обна- } \\
\text { ружено }\end{array}$ & $\begin{array}{c}\text { Не обна- } \\
\text { ружено }\end{array}$ & $\begin{array}{c}\text { Не обна- } \\
\text { ружено }\end{array}$ & $\begin{array}{c}\text { Не } \\
\text { обнару- } \\
\text { жено }\end{array}$ & $\begin{array}{c}\text { Не обна- } \\
\text { ружено }\end{array}$ & \begin{tabular}{|c|}
$\mathrm{He}$ \\
обна- \\
руже- \\
но \\
\end{tabular} \\
\hline $\begin{array}{l}\text { Общая } \\
\text { токсичность }\end{array}$ & $\begin{array}{l}\text { Не ток- } \\
\text { сичен }\end{array}$ & $\begin{array}{l}\text { Не ток- } \\
\text { сичен }\end{array}$ & $\begin{array}{l}\text { Не ток- } \\
\text { сичен }\end{array}$ & $\begin{array}{c}\text { Не токси- } \\
\text { чен }\end{array}$ & $\begin{array}{l}\text { Не ток- } \\
\text { сичен }\end{array}$ & $\begin{array}{c}\text { Не токси- } \\
\text { чен }\end{array}$ & $\begin{array}{l}\text { Не ток- } \\
\text { сичен }\end{array}$ & $\begin{array}{l}\text { Не ток- } \\
\text { сичен }\end{array}$ & $\begin{array}{c}\mathrm{He} \\
\text { токси- } \\
\text { чен } \\
\end{array}$ \\
\hline $\begin{array}{l}\text { Микотоксин де- } \\
\text { зоксини-валенол } \\
\text { (DON), мг/кг }\end{array}$ & $\begin{array}{c}\text { Не } \\
\text { обнару- } \\
\text { жено }\end{array}$ & $\begin{array}{c}\text { Не } \\
\text { обнару- } \\
\text { жено }\end{array}$ & $\begin{array}{c}\text { Не } \\
\text { обнару- } \\
\text { жено }\end{array}$ & $\begin{array}{c}\text { Не обна- } \\
\text { ружено }\end{array}$ & $\begin{array}{l}\text { Не обна- } \\
\text { ружено }\end{array}$ & $\begin{array}{l}\text { Не обна- } \\
\text { ружено }\end{array}$ & $\begin{array}{c}\text { Не } \\
\text { обнару- } \\
\text { жено }\end{array}$ & $\begin{array}{c}\text { Не обна- } \\
\text { ружено }\end{array}$ & \begin{tabular}{|c|} 
Не \\
обна- \\
руже- \\
но \\
\end{tabular} \\
\hline
\end{tabular}

Анализируя данные таблицы, можно сказать, что наиболее важные показатели для ячменя в соответствии с ГОСТ 53900-2010 Ячмень кормовой, ГОСТ 5060-86 Ячмень пивоваренный, ГОСТ 28672-90 Ячмень. Требования при заготовках и поставках, ТР ТС 021/2011 О безопасности пищевой продукции по всем вариантам находятся в пределах допустимых значений. Наиболее значимые вынесем в виде диаграммы (рисунки 8, 9).

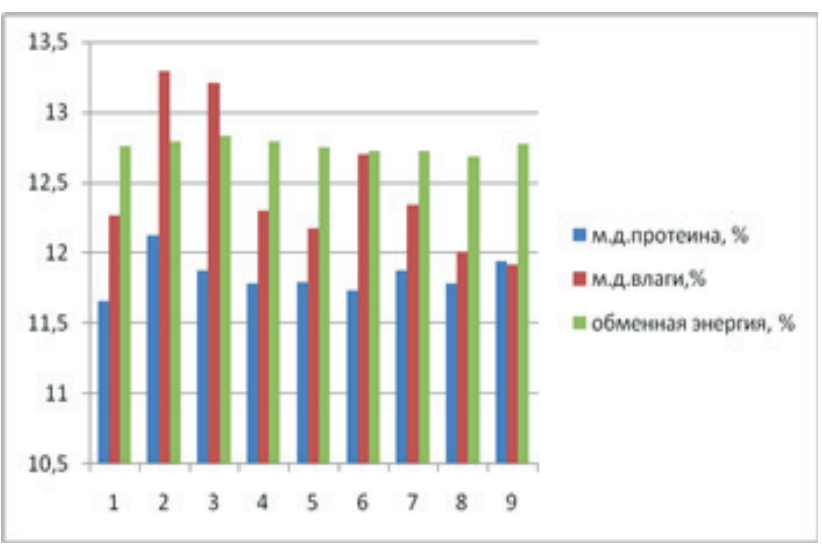

Рис. 8 - Распределение качественных показателей ячменя по вариантам обработки

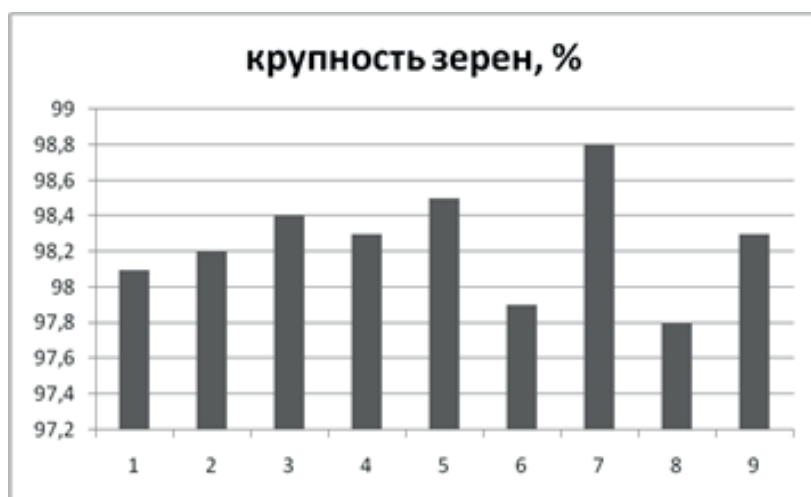

Рис. 9 - Распределение крупности зерен в зависимости от вариантов обработки

Массовая доля протеина - важный показатель для ячменя, идущего на пивоварение. По всем вариантам данный показатель варьирует от $11,65 \%$ (в контрольном зерне) до 12,12\% (при опрыскивании Экоростом). Максимальное допустимое значение для данного показателя $12 \%$.

Массовая доля влаги по всем вариантам находится в пределахдопустимыхзначений, которыезависят от классности зерна и составляют 14,5-15,5\%.

Важным показателем для ячменя кормового является обменная энергия, значение его не должно быть ниже 12\%. Во всех вариантах обмен- 
ная энергия находится примерно на одном уровне, чуть лучший результат наблюдается при обработке гуминовыми продуктами Экорост (12,79\% и $12,83 \%)$ и Гумат калия (12,79\%).

Для пивоваренного ячменя нормируемым показателем является крупность зерен. В зависимости от классности она не должна быть ниже 60-85\%. Результат обработки по всем вариантам гораздо превышает минимальные значения показателя. Кроме того, можно отметить, что после аэрозольной обработки горячим туманом получаем более крупное зерно при применении каждого из препаратов, но наибольший эффект наблюдается при использовании биологического препарата Азотовит $(98,8 \%)$.

Можно заметить в таблице 2 достаточно высокие значения клетчатки в исследуемых образцах $(6,34-7,44 \%)$. Это можно объяснить тем, что оценивалось необмолоченное зерно.

Важное значение с точки зрения безопасности при исследовании зерна разных вариантов обработки имеет отсутствие токсичности и микотоксина дезоксиниваленол (DON). Заключение

По совокупности показателей, на наш взгляд, наилучшие показатели получены именно при аэрозольной обработке горячим туманом. Это обусловлено высокой дисперсностью препарата, равномерным покрытием семян, дополнительным их прогревом и в целом комплексным воздействием на фризико-химические процессы семенного материала. Наибольший эффект по качественным и количественным показателям достигается при использовании гуминовых продуктов Гумата калия и Экороста.

\section{Список литературы}

1. Исследование топографии температурного поля облака генератора горячего тумана [Текст] / М.Ю. Костенко, И. Н. Горячкина, В. С. Мельников, М. В. Евсенина, Н. А. Костенко // Вестник Рязанского государственного агротехнологического университета имени П.А. Костычева. - 2015. - № 3 (27). - С. 65-69.

2. Анализ применения различных видов гуматов и способов их использования при возделывании картофеля [Текст] / М. Ю. Костенко, И. Н. Горячкина, В. С. Тетерин, Н. Н. Гапеева, Н. Н. Новиков, С. В. Митрофранов // Вестник Рязанского государственного агротехнологического университета им.

П.А. Костычева. - 2018. - № 3 (39). - С. 88-93.

3. Теоретические исследования теплового потока в диспергирующем устройстве [Электронный ресурс] / В. С. Мельников, И. Н. Горячкина, М. Ю. Костенко, А. А. Голиков, Н. А. Костенко, Д. О. Соколов //Политематический сетевой электронный научный журнал Кубанского государственного аграрного университета. - 2014. - № 104. - С. 222-236.

4. Тепловой баланс генератора горячего тумана с устройством для диспергирования[Электронный ресурс] / В. С. Мельников, И. Н. Горячкина, М. Ю. Костенко, А. А. Голиков, Н. А. Костенко, Д. О. Соколов // Политематический сетевой электронный научный журнал Кубанского государственного аграрного университета. - 2014. - № 102. - С. 864-876.

5. Установка для нанесения аэрозоля гуматов в потоке сельскохозяйственной продукции [Текст] / О. А. Тетерина, И. Н. Горячкина, М. Ю. Костенко, Г. К. Рембалович, И. А. Юхин // Вестник ВИЭСХ. 2017. - № 4 (29). - С. 124-128.

6. Тепло-массобменные процессы при аэрозольной обработки семян [Текст] / О. А. Тетерина, Б. А. Нефедов, С. Д. Полищук, М. Б. Угланов, М. Ю. Костенко // Вестник Рязанского государственного агротехнологического университета им. П.А. Костычева. - 2017. - № 4 (36). - С. 99 - 103.

7. Тетерина, О. А. Аэрозольная обработка семян стимуляторами роста [Текст] / О. А. Тетерина, В. С. Тетерин, М. Ю. Костенко // Вестник Совета молодых ученых Рязанского государственного агротехнологического университета имени П.А. Костычева. - 2016. - № 2 (3). - С. 6-10.

8. Исследование температурного поля в камере обработке при аэрозольной обработке семян [Текст] / О. А. Тетерина, М. Ю. Костенко, В. С. Тетерин, Б. А. Нефедов, Д. В. Иванов // Вестник АПК Ставрополья. - 2017. - № 4 (28). - С. 10 - 14.

9. Humic and fulvic acids as biostimulants in horticulture/CanellasL.P.[etal.]//ScientiaHorticulturae. 2015. 196. P. $15-27$

\section{INVESTIGATION OF THE EFFECT OF HOT MIST TREATMENT OF BIOLOGICAL PREPARATIONS AND HUMIC PRODUCTS OF BARLEY SEEDS}

Kostenko Mikhail Yu., Dr. tech. sci. Professor, Department of metal technology and repair of machinery, kostenko.mihail2016@yandex.ru

Rembalovich Georgy K., Dr. tech. Sci, Dean of the faculty of roads, rgk.rgatu@yandex.ru

Goryachkina Irina N., Cand. tech. associate Professor of the Department of organization of transport processes and life safety, gin.81@mail.ru

Beznosuk Roman V., Cand. tech. associate Professor, Department of metal technology and repair of machinery, romario345830@yandex.ru

Borisov Gennady A., Dr. tech. sci. Professor, Department of metal technology and repair of machinery, tmirm@yandex.ru

Ryazan state agrotechnological University named after P. A. Kostychev

The aim of the research was to assess the effect of hot mist treatment of the biological preparation Azotovit and humic products potassium HUMATE, barley seeds Ecorost before sowing, as well as to compare the results with conventional technologies of treatment with the help of seed protectant with the same drugs. To complete the research and produce treatment chemicals of Atik. The highly dispersed aerosol was obtained using The greenfogbf-130 hot mist generator. The treatment was carried out using a device with inclined 
shelves, on which the grain was repeatedly poured under the influence of gravity and was subjected to mixing and the influence of hot fog. As a result of the temperature difference between the cold and hot mist of the seed material, a phase transition of the mist into a liquid occurred, which allowed to obtain a thin film on the treated surface of the barley seeds. This contributed to the disinfection and activation of physical and chemical processes in the grain. Experimental studies included eight treatment options and one without treatment (control). The results of productivity and crop structure were evaluated: the number of plants per $1 \mathrm{~m}^{2}$, the number of weeds per $1 \mathrm{~m}^{2}$, the number of productive stems (ears) per $1 \mathrm{~m} 2$, bushiness per $1 \mathrm{~m}^{2}$, productive bushiness per $1 \mathrm{m2}$, the average number of grains per ear, the weight of 1000 grains, the height of stems, biological yield. In accordance with GOST 53900-2010 barley fodder, barley brewing GOST 506086, GOST 28672-90 Barley. Requirements for procurement and supply, TR CU 021/2011 on food safety from qualitative indicators considered the mass fraction of moisture, mass fraction of protein, mass fraction of fiber, mass fraction of sugar, mass fraction of fat, mass fraction of ash, mass fraction of starch, metabolic energy, size, small grains, weed and grain admixture, Fusarium grains, total toxicity, mycotoxin deoxynivalenol (don). The best results were obtained as a result of aerosol treatment with humic products potassium HUMATE and Ecorost.

Key words: biological preparations, humic products, aerosol treatment, hot mist generator, barley seeds.

\section{Literatura}

1. Kostenko M.YU. Issledovanie topografii temperaturnogo polya oblaka generatora goryachego tumana [Tekst] / Kostenko M.YU., Goryachkina I.N., Mel'nikov V.S., Evsenina M.V., Kostenko N.A. // Vestnik Ryazanskogo gosudarstvennogo agrotekhnologicheskogo universiteta imeni P.A. Kostycheva. 2015. № 3 (27). S. 65-69.

2. Kostenko M. YU. Analiz primeneniya razlichnyh vidov gumatov i sposobov ih ispol'zovaniya pri vozdelyvanii kartofelya [Tekst] / Kostenko M.YU., Goryachkina I.N., Teterin V.S., Gapeeva N.N., Novikov N.N., Mitrofanov S.V.// Vestnik Ryazanskogo gosudarstvennogo agrotekhnologicheskogo universiteta im. P.A. Kostycheva. 2018. № 3 (39). S. 88-93.

3. Mel'nikov V.S. Teoreticheskie issledovaniya teplovogo potoka $v$ dispergiruyushchem ustrojstve [Elektronnyj resurs] / Mel'nikov V.S., Goryachkina I.N., Kostenko M.YU., Golikov A.A., Kostenko N.A., Sokolov D.O.//Politematicheskij setevoj elektronnyj nauchnyj zhurnal Kubanskogo gosudarstvennogo agrarnogo universiteta. 2014. № 104. S. 222-236.

4. Mel'nikov V.S. Teplovoj balans generatora goryachego tumana s ustrojstvom dlya dispergirovaniya[Elektronnyj resurs]/Mel'nikov V.S., Goryachkina I.N., Kostenko M.YU., Golikov A.A., Kostenko N.A., Sokolov D.O.//Politematicheskij setevoj elektronnyj nauchnyj zhurnal Kubanskogo gosudarstvennogo agrarnogo universiteta. 2014. № 102. S. 864-876.

5. Teterina O.A. Ustanovka dlya naneseniya aerozolya gumatov v potoke sel'skohozyajstvennoj produkcii [Tekst] / O.A. Teterina, I.N. Goryachkina, M.YU. Kostenko, G.K. Rembalovich, I.A. YUhin // Vestnik VIESKH. - 2017. - № 4 (29). - S. 124-128.

6. Teterina, O.A. Teplo-massobmennye processy pri aerozol'noj obrabotki semyan [Tekst] / O.A. Teterina, B.A. Nefedov, S.D. Polishchuk, M.B. Uglanov, M.YU. Kostenko // Vestnik Ryazanskogo gosudarstvennogo agrotekhnologicheskogo universiteta im. P.A. Kostycheva. 2017. - № 4 (36). -S. 99 - 103.

7. Teterina, O.A. Aerozol'naya obrabotka semyan stimulyatorami rosta [Tekst] / O.A. Teterina, V.S. Teterin, M. YU. Kostenko// Vestnik Soveta molodyh uchenyh Ryazanskogo gosudarstvennogo agrotekhnologicheskogo universiteta imeni P.A. Kostycheva. 2016. - № 2 (3). - S. 6-10.

8. Teterina O.A., Issledovanie temperaturnogo polya v kamere obrabotke pri aerozol'noj obrabotke semyan [Tekst] / O.A. Teterina, M.YU. Kostenko, V.S. Teterin, B.A. Nefedov, D.V. Ivanov. // Vestnik APK Stavropol'ya. 2017. - № 4 (28). - S. 10 - 14.

9. Humic and fulvic acids as biostimulants in horticulture / Canellas L.P.[etal.]// ScientiaHorticulturae. 2015. 196. P. $15-27$

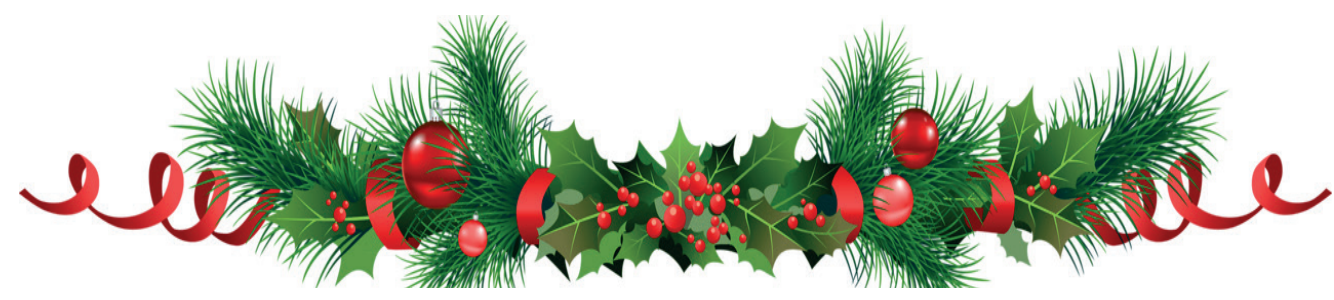


УДК 001.8:[631.333:631.8]: 004.057.2:004.421: 004.62

DOI 10.36508/RSATU.2019.57.82.017

\section{ПРОГРАММНЫЙ КОМПЛЕКС ПО ФОРМИРОВАНИЮ РАЦИОНАЛЬНОГО ПАРКА ТЕХНИКИ ДЛЯ ПРОВЕДЕНИЯ АГРОХИМИЧЕСКИХ РАБОТ}

ПАНФЕРОВ Николай Сергеевич, канд. техн. наук, зам. директора по инновационным разработкам и развитию экспериментального производства, nikolaj-panfyorov@yandex.ru

МИТРОФАНОВ Сергей Владимирович, канд. с.-х. наук, зам. директора по научной работе,

f-mitrofanoff2015@yandex.ru

ПЕСТРЯКОВ Ефим Вадимович, научн. сотрудник, иnlimetal@rambler.ru

БЛАГОВ Дмитрий Андреевич, канд. биол. наук, ст. научн. coтрудник, aspirantyra2013@gmail

Институт технического обеспечения сельского хозяйства - филиал Федерального государственного бюджетного научного учреждения «Федеральный научный агроинженерный центр ВИМ»

В рамках выполнения программы «Цифрровая экономика Российской Федерации», утвержденной распоряжением Правительства Российской Федерации от 25 июля 2017 г. № 1632-р., учеными ИТОСХ - филиала ФГБНУ ФНАЦ ВИМ создан программный комплекс по формированию оптимального комплекса машин и оборудования для проведения агрохимических работ, в рамках которого учитываются индивидуальные особенности хозяйств, такие как уровень финансовой обеспеченности, техническая оснащенность, агроклиматические условия и др. В его основу положен алгоритм расчета рационального парка техники для проведения агрохимических работ, основанный на доработанном, с учетом специфики операций, расчетном методе фоормирования машинно-тракторного парка. $B$ предложенном алгоритме для реализации данной задачи заложена методика многомерного сравнительного анализа рассчитанных ранее вариантов комплектования машинно-тракторного агрегата. Данная методика позволяет объединить наиболее значимые разнонаправленные технические и экономические показатели в единый интегральный показатель оценки эффрективности комплектуемого агрегата. Выбор эфрфективного агрегата определяется по максимальному значению показателя, которое отражает оптимальное сочетание разнонаправленных показателей, характеризующих максимальную разность между их значениями, приходящуюся на единицу обрабатываемой площади - по машинно-тракторному агрегату (MTA), на единицу грузооборота - по тягово-тракторным агрегатам (TTA) или автомобилям. Апробация разработанного программного комплекса проведена в трех хозяйствах Рязанской области, характеризующихся разными уровнями технической оснащенности, размерами и направлениями деятельности. В результате проведенных расчетов по представленным хозяйствам программный комплекс показал возможность его применения в сельскохозяйственных организациях разной степени развития, оснащенности и специализации.

Ключевые слова: удобрения, агрохимикаты, программный комплекс, машинно-тракторный агрегат, интегральный показатель.

\section{Введение}

В настоящее время в сельскохозяйственном производстве находится большой типоразмерный ряд машин как отечественного, так и импортного производства для внесения удобрений и средств защиты растений [1]. Вопрос выбора и обоснования оптимального комплекса технических средств - достаточно сложная задача, поскольку должна решаться в различных природно-климатических, зональных условиях и оказывать влияние на выбор применяемых технологий, организацию проведения работ и качество внесения средств химизации, а также состав сельскохозяйственной техники.

Современные сельскохозяйственные предприятия различаются между собой размером, уровнем технической оснащенности, специализацией и финансированием. В связи с этим проблема выбора рационального комплекса машин характерна для каждого конкретного сельскохозяйственного предприятия [6]. В этой связи обоснование в условиях хозяйств рациональной структуры комплексов технических средств, обеспечивающих качественное выполнение агрохимических операций в современных ресурсосберегающих технологиях возделывания сельскохозяйственных культур, относится к приоритетным научным задачам аграр- ного производства.

Научная новизна данной работы заключается в создании информационно-программного обеспечения для специалистов сельского хозяйства на основе многовариантных решений по формированию оптимального комплекса машин и оборудования для проведения агрохимических работ. Материалы и методы исследований

Объектами исследования являются технические средства и технологии, используемые для внесения минеральных удобрений и средств защиты растений, а также методики и рекомендации по формированию комплекса технических средств для этих целей. Исследования проводились с использованием аналитического, математического, информационно-логического и статистического методов.

Результаты исследований и их обсуждение

В рамках выполнения программы «Цифровая экономика Российской Федерации», утвержденной распоряжением Правительства Российской Федерации от 25 июля 2017 г. № 1632-р., учеными ИТОСХ - филиал ФГБНУ ФНАЦ ВИМ бЫЛо решено создать программу по формированию оптимального комплекса машин и оборудования для проведения агрохимических работ, в которой учитываются индивидуальные особенности хозяйств, 
такие как уровень финансовой обеспеченности, техническая оснащенность, агроклиматические условия и др.

В основу программного комплекса положен расчетный метод определения потребности в технике для проведения агрохимических работ. Данный метод определения потребного количества машин базируется на непосредственных расчетах производительности конкретных видов машин и агрегатов, норм их выработки на механизированных полевых работах в хозяйстве. В основу расчетов заложены как нормативные, так и расчетные показатели подбираемой техники, адаптированные к почвенно-климатическим и производственным условиям ее эксплуатации в хозяйстве. При этом учитываются агротехнические сроки выполнения технологических операций, их продолжительность, система организации рабочего времени и другие показатели, относящиеся к конкретному хозяйству.

Предложен интегральный показатель оценки эфффективности технических средств, в котором учитываются следующие показатели [5]: специфика области применения агрохимических агрегатов и принципы их комплектования; сменная производительность агрегата; коэффицциент использования мощности трактора; коэфффициент загрузки двигателя трактора; эксплуатационные затраты на единицу обрабатываемой площади; расход топлива; амортизационные отчисления; затраты на техническое обслуживание, хранение и ремонт (ТОХР); оплата труда.

Поскольку программа направлена на выбор и сравнение наиболее производительной техники при ее наименьших эксплуатационных затратах, то критерии эфффективности для расчета интегрального показателя располагаются в порядке убывания следующим образом:

- min_am - минимальные амортизационные отчисления, руб./га;

- min_fuel - минимальные затраты на горючесмазочные материалы при выполнении операции, руб./га;

- min_wrk - минимальные затраты на заработную плату, руб./га;

- min_zm - минимальные затраты на ремонт и техническое обслуживание, руб./га;

- max_W - максимальная производительность агрегата, га/ч;

- max_kpd - максимальный коэфффициент использования мощности;

- max_kzd - максимальный коэффрициент загрузки двигателя.

Далее производится расчет веса по каждому критерию эффрективности и преобразование их к нормализованному виду весов, рассчитанных на предыдущем этапе. Следующим действием на основе ранее преобразованных в нормализованный вид критериев эффективности и рассчитанных нормализованных весов определяются интегральные показатели оценки эфффективности каждого из машинно-тракторных агрегатов (MTA), выбранных пользователем:
$K_{i j}^{r}=\sqrt{\alpha_{1}\left(K_{l i j}^{r}\right)^{2}+\alpha_{2}\left(K_{2 i j}^{r}\right)^{2}+\alpha_{3}\left(K_{3}^{r}\right)^{2}+\ldots+\alpha_{7}\left(K_{7}^{r}\right)^{2}}$, где $K_{i j}^{r}$ - интегральный показатель эфрфективности іj-го вида агрегата;

$$
\alpha_{n} \text { - нормализованный вес n-го показателя; }
$$

$K_{l i j}^{r} \div K_{7}^{r}$ - - нормализованные значения соответ

ствующих критериев эффективности, принятых в расчете.

Выбор эффрективного агрегата определяется по максимальному значению интегрального показателя, которое отражает оптимальное сочетание разнонаправленных показателей, характеризующих максимальную разность между их значениями, приходящуюся на единицу обрабатываемой площади - по МТА, на единицу грузооборота - по тягово-тракторным агрегатам (ТТА) или автомобилям.

Перед началом разработки программного комплекса был проведен обзор существующих языков и сред программирования и их соответствие Федеральному закону от 27 июня 2006 года № 149-Ф3 «Об информации, информационных технологиях и о защите информации». В результате проведенного анализа был выбран язык программирования $\mathrm{C}++$, который широко применяется во всех сорерах производства, адаптирован для задач программирования в сельскохозяйственном производстве и удовлетворяет требованиям приведенного выше закона [4].

На следующем этапе был разработан алгоритм работы программы, в основу которого положен описанный ранее доработанный расчетный метод формирования парка техники в хозяйствах [3]. В данном алгоритме учитываются особенности хозяйства, необходимый и вводимый для расчета объем информации, этапы и возможности комплектации техники (рис. 1).

Помимо основной структуры программного комплекса в алгоритме учитывается база данных нормативно-справочной информации (БД НСИ), в которой содержатся все необходимые для расчетов показатели, и накапливается вводимая информация по мере использования программного комплекса в хозяйстве.

По этапам алгоритма работы оператор вводит справочные данные о хозяйстве, основной вид деятельности, технологию возделывания культур, дату, организационно-правовую форму предприятия, после чего происходит переход к следующему этапу - вводу информации БД НСИ. База данных необходима для накопления информации, участвующей в дальнейших расчетах и формировании выходных форм. Специалист может воспользоваться как уже имеющейся в БД НСИ информацией, так и ввести свои данные, например, машинно-тракторный парк хозяйства, средства химизации, применяемые при проведении агрохимических работ. 


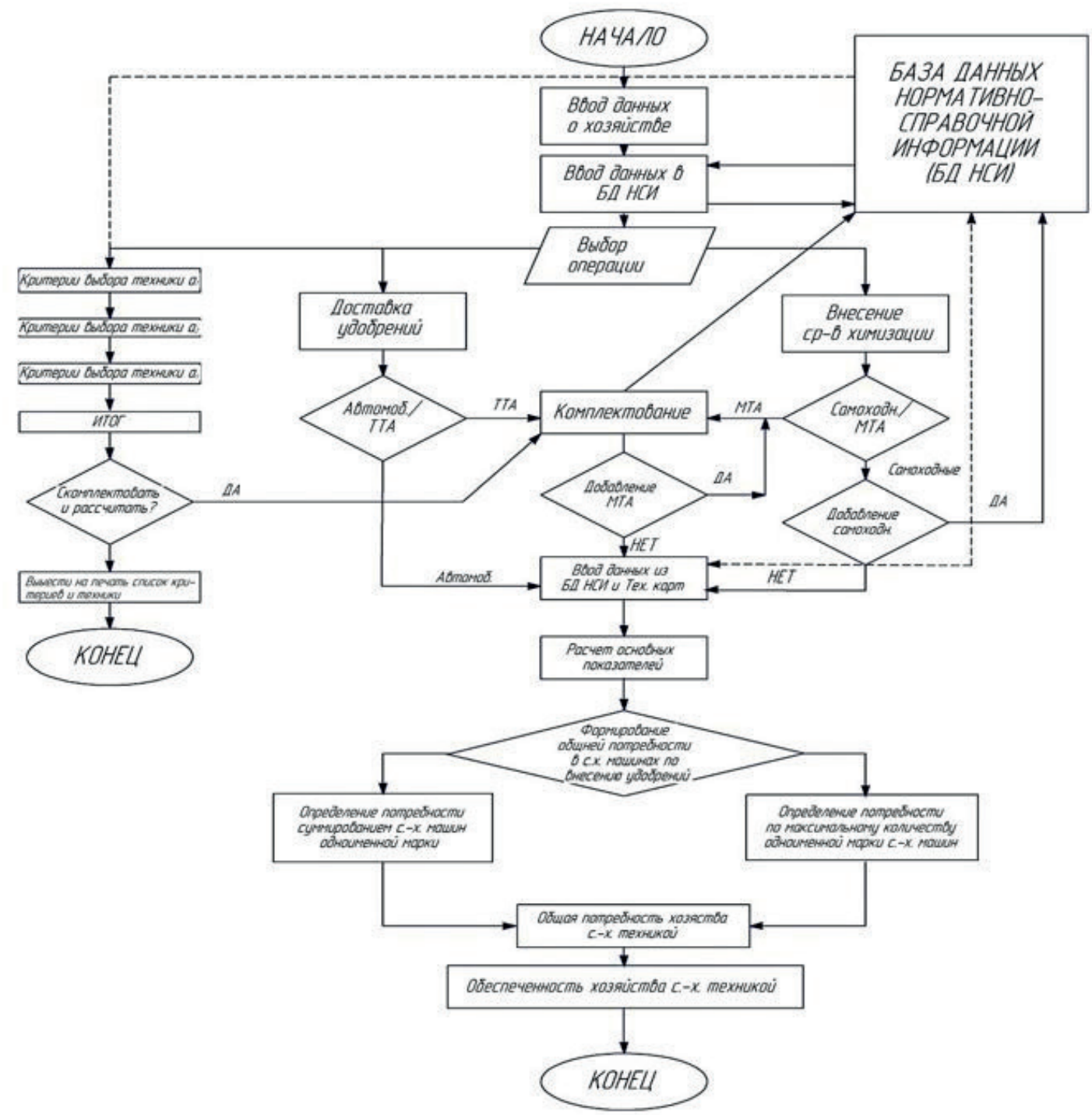

Рис. 1 - Алгоритм формирования комплекса технических средств для проведения агрохимических работ

Пользователь самостоятельно дополняет перечень техники для проведения агрохимических работ, вводя необходимые для расчета данные о технике, имеющейся в хозяйстве или приобретаемой. Также в БД НСИ содержится вся нормативная (постоянная) информация - коэфрфициенты сцепления и трения, виды удобрений и пестицидов, типы почв.

Следующим блоком алгоритма является выбор операции, которую следует рассчитать. При выборе внесения удобрений и агрохимикатов пользователь может выбрать самоходную технику или МТА. случае выбора МТА происходит комплектование машины для внесения удобрений, имеющейся в хозяйстве или приобретаемой, с тяговыми агрегатами (тракторами), имеющимися в хозяйстве или приобретаемыми.

Далее оператор вводит данные о площади и уклоне поля, типе почвы, способе и типе внесения удобрений, норме внесения и прочую информацию, необходимую для расчета. Эти данные берутся из технологической карты хозяйства и БД НСИ в случае выбора самоходной техники после добавления всех вариантов, программа сразу переходит к данному блоку.

После этого происходит расчет основных технико-экономических показателей, потребности в агрегатах на конкретном поле, а также расчет интегрального показателя, который оценивает эфффективность использования выбранного МТА для внесения удобрений или самоходного агрегата. При этом оператору выдается форма со всеми вариантами комплектования и рекомендация по наиболее эфффективному агрегату, на основании которой специалист хозяйства отдает предпочтение одному из рассчитанных вариантов комплектования.

Вторая ветвь алгоритма программы рассчитана на выбор пользователем техники по требуемым критериям a1, a2,...an и может производиться на этапе выбора операции. Чем большее количество критериев будет запрограммировано, тем точнее будет подборка техники, представленной пользователю. При введении значения каждого критерия происходит сортировка из общей базы данных техники и пользователю выводится диапазон не 
более 10 штук требуемой техники, из которого впоследствии выбирается конечный вариант для выбора. Данная ветвь алгоритма будет актуальна, если хозяйство планирует приобрести новую технику под имеющийся трактор или наоборот, новый трактор под имеющиеся машины, а также при замене техники или при формировании нового машинно-тракторного парка хозяйства, при условии,

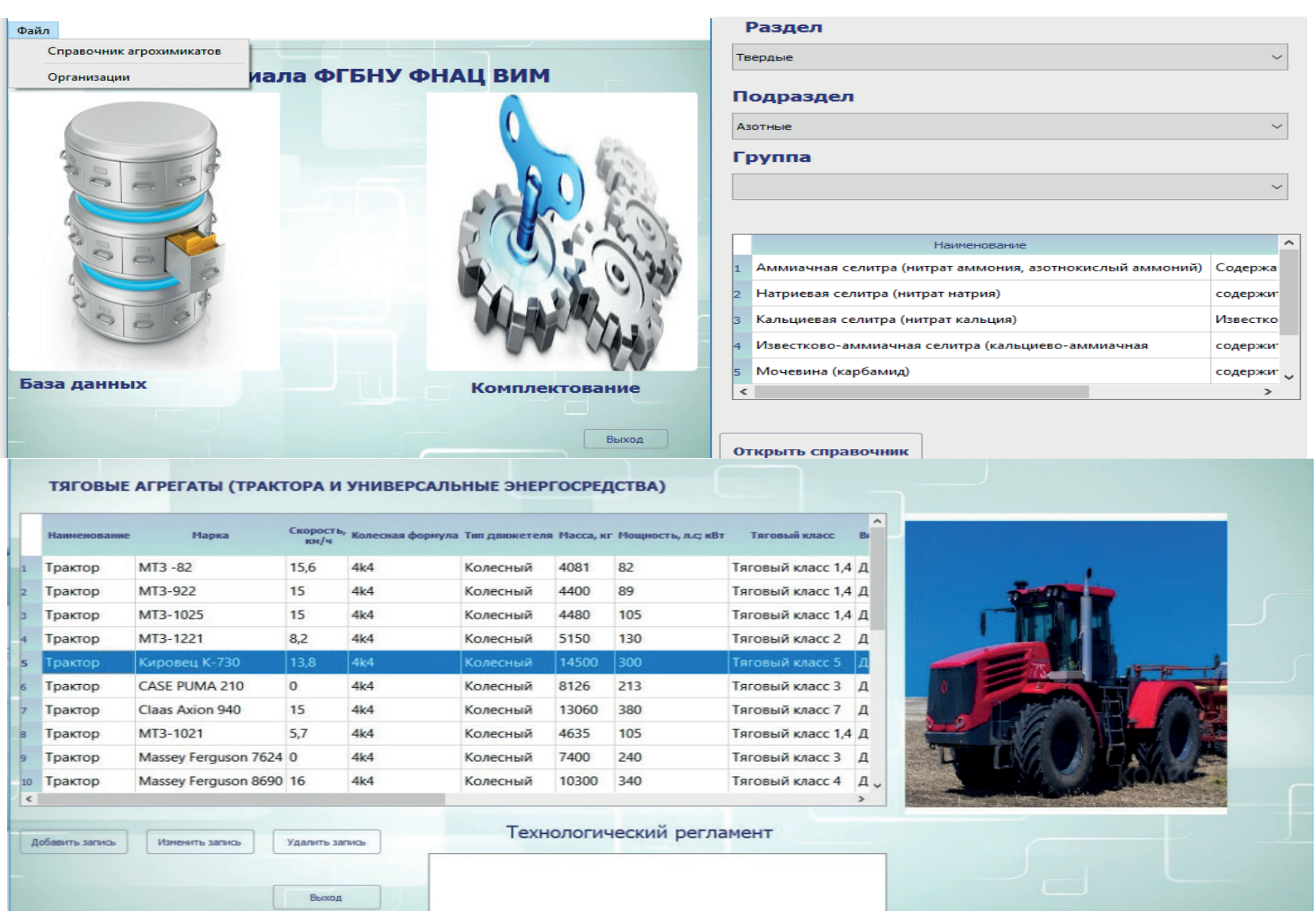

что информация в БД НСИ будет актуализирована. Далее ведется расчет общей потребности в сельскохозяйственных агрегатах путем сопоставления полученных данных с наличием данных агрегатов в хозяйстве, в итоге просчитывается общая потребность хозяйства в сельскохозяйственной технике для проведения агрохимических работ.

Рис. 2 - Пример интерфейса базы данных номативно-справочной информации

На основе вышеизложенных данных был разработан и запатентован программный комплекс по фрормированию комплекса технических средств для проведения агрохимических работ с индивидуальным расчетом техники для каждого поля [2].

С целью оптимизации труда специалистов хозяйств интерфейс программы сделан интуитивно понятным, стандартные параметры выполнены в виде комбобоксов (раскрывающейся шторкой), что исключает возможность ошибки при вводе оператором постоянных данных и коэффрициентов, и поэтому не требует специализированных навыков работы с программными продуктами (рис. 2).

Однако для заполнения базы данных необходимо иметь характеристики техники, планируемой для использования в хозяйстве, а также технологические карты и другую документацию, в том числе бухгалтерскую.

С целью апробации результатов исследований и проверки работоспособности разработанного программного комплекса, а также выявления его недостатков были выбраны три хозяйства Рязанской области разного уровня технической оснащенности, размера и направления деятельности.
Самое крупное и динамично развивающиеся среди них - ООО «Авангард» Рязанского района, являющееся одним из лидеров агропромышленного комплекса района и области в целом. Общая земельная площадь - свыше 14 тыс. га, из них пашни - около 11 тыс. га. В хозяйстве работает более 550 человек. Главные специалисты хозяйства имеют огромный опыт и высокую квалификацию, что положительно влияет на состояние всех структурных подразделений. Специализация хозяйства - молочно-мясное животноводство с развитым производством зерна, картофеля и плодово-ягодной продукции.

Для проведения сельскохозяйственных работ в оптимальные агротехнические сроки хозяйство располагает высокопроизводительной техникой в основном зарубежного производства, но имеются и отечественные технические средства. В целом данное хозяйство обладает достаточным и оптимизированным парком техники для проведения всех сельскохозяйственных работ в соответствующие агротехнические сроки.

Вторым хозяйством было выбрано ООО «Назарьевская слобода» Старожиловского района Ря- 
занской области. Это динамично развивающаяся с 2008 года агрокомпания, производящая высококачественные и экологически чистые овощи, зерновые и масличные культуры. Сегодня площадь хозяйства насчитывает уже более 7 тыс. га.

По оснащенности техническими средствами рассматриваемое хозяйство можно отнести к пограничной зоне (от 3 к 4) оснащенности техникой для агрохимического обеспечения сельского хозяйства. При посещении данного предприятия учеными ИТОСХ было выявлено наличие незадействованной техники, в частности, опрыскивателей AMAZONE, однако весь запланированный объем работ по опрыскиванию был выполнен без их помощи за счет самоходного опрыскивателя John Deere 4590.

Третьим хозяйством стало ООО «Электрон» Шиловского района Рязанской области. Предприятие ведет свою деятельность с 2002 года. Основным видом деятельности является выращивание кормовых культур, заготовка растительных кормов. Численность рабочих - 7 человек.

Расчеты проводились на основании данных, полученных в хозяйствах, основным источником которых стали технологические карты.

В результате проведенных расчетов по представленным хозяйствам программный комплекс показал возможность его применения в сельскохозяйственных организациях разной степени развития, оснащенности и специализации. При этом с помощью данного программного комплекса возможно решение нескольких проблем, связанных с формированием комплексов технических средств для проведения агрохимических работ: проверка скомплектованных МТА (ООО «Авангард»); фрормирование комплекса технических средств для проведения агрохимических работ из техники, представленной в хозяйстве (ООО «Назарьевская слобода»); расчет потребности в технике определенных марок при проведении агрохимических работ (ООО «Электрон»).

\section{Заключение}

В результате проведенных исследований учеными ИТОСХ - филиал ФГБНУ ФНАЦ ВИМ разработан и апробирован программный комплекс
«Формирование комплексов технических средств для химизации сельского хозяйства», который учитывает многообразие условий и возможностей хозяйств. Использование разработанного программного комплекса позволяет формировать рациональный комплекс технических средств для проведения агрохимических работ, что приводит к росту экономической эффрективности проведения агрохимических работ и повышению производительности труда за счет сокращения трудозатрат.

\section{Список литературы}

1. Робототехника в агрохимии точного земледелия / А. Ю. Измайлов, 3.А.Годжаев, В. Г. Сычев, Р. А. Афранасьев // Плодородие. - 2018. - № 1 (100). - C. 53-57.

2.Свидетельство о государственной регистрации программы для ЭВМ № 2018664598 РФ от 20 ноября 2018 г. Формирование комплексов технических средств для химизации сельского хозяйства / Панферов Н.С., Пестряков Е.В., Журавлева О.И., Новиков Н.Н., Сорокин Н.Т.

3.Сорокин, Н. Т. Алгоритм формирования технических комплексов для проведения агрохимических работ / Н. Т. Сорокин, Н. С. Панферов, Е. В. Пестряков // Техника и оборудование для села. - 2018. - № 10. - C. 22 -24.

4.Сорокин, Н. Т. Законодательная база разработки программного обеспечения в условиях политики импортозамещения / Н. Т. Сорокин, Н.C . Панферов, Е. В. Пестряков // Техника и оборудование для села. - 2018. - № 8. - С. 2-5.

5.Ходакова, Т. А. Информатизация процесса формирования рационального состава машиннотракторного парка для проведения агрохимических работ в растениеводстве / Т. А. Ходакова // Инновационное развитие АПК России на базе интеллектуальных машинных технологий : сб. науч. докл. международной научно-техн. конф. (г. Москва, 17-18 сент. 2014 г.). - М. : ФГБНУ ВИМ, 2014. - C. $482-486$.

6.Хомяков, Д. М. Вопросы увеличения потребления минеральных удобрений в Российской Федерации / Д. М. Хомяков, Б. В. Левин // Достижения науки и техники АПК. - 2016. - № 11. - С. 43-44.

\section{SOFTWARE PACKAGE FOR FORMING A RATIONAL MACHINERY SYSTEM FOR PERFORMING AGROCHEMICAL OPERATIONS}

Panfyorov Nikolay S., candidate of technical Sciences, vice-director for innovations and development of pilot-scale production, nikolaj-panfyorov@yandex.ru

Mitrofanov Sergey V., candidate of agricultural Sciences, vice-director for science, f- mitrofanoff2015@ yandex.ru

Pestryakov Efim V., Research Worker, unlimetal@rambler.ru

Blagov Dmitry A., candidate of biological Sciences, Senior Researcher, aspirantyra2013@gmail

Institute for Engineering Support of Agriculture - branch of the Federal State Budgetary Scientific Institution "Federal Scientific Agroengineering Center VIM"

Within the framework of the program Digital Economy of the Russian Federation, approved by the Government of the Russian Federation in its resolution No. 1632-r dated July 25, 2017, the research workers of the Institute for Engineering Support of Agriculture - branch of FSAC VIM have developed a software package to build the optimal machinery and equipment system for performing agrochemical operations, taking into account individual peculiarities of farms, such as: financial sustainability, provision with technical equipment, agroclimatic conditions, etc. It is based on the algorithm of calculating the rational structure of equipment fleet 
for performing agrochemical works on the basis of the calculation method for machine-tractor unit, tailored to specific operations. To solve this problem the proposed algorithm involves a method of multivariate comparative analysis of the calculated variants of building a machine-tractor unit. This method allows combining the most significant technical and economical characteristics into a comprehensive indicator for the assessment of efficiency of the unit being built. The choice of an effective machine is determined by the maximum value, reflecting the optimal combination of different indicators, characterizing the maximum difference between their values per unit of cultivated area - by machine-tractor unit (MTU), per unit of turnover - by tractor-driven units (TDU) or cars. The developed software package has been tested in three farms of Ryazan region with different level of technical equipment, size and field of activity. The calculations carried out on the data of these farms have shown, that the software package can be applied in agricultural enterprises of different levels of development, provision with equipment and specializations.

Key words: fertilizers, agrochemicals, software package, machine-tractor unit, comprehensive indicator.

\section{Literatura}

1. Izmaylov, A. Yu. Robototekhnika v agrokhimii tochnogo zemledeliya / A.Yu. Izmaylov, Z.A. Godzhaev, V.G. Sychev, R.A. Afanas'ev // Plodorodie, 2018. - № 1 (100). - S. 53-57.

2. Svidetel'stvo o gosudarstvennoy registratsii programmy dlya EVM № 2018664598 RF ot 20 noyabrya 2018 g. Formirovanie kompleksov tekhnicheskikh sredstv dlya khimizatsii sel'skogo khozyaystva / Panferov N.S., Pestryakov E.V., Zhuravleva O.I., Novikov N.N., Sorokin N.T.

3. Sorokin, N.T. Algoritm formirovaniya tekhnicheskikh kompleksov dlya provedeniya agrokhimicheskikh rabot/N.T. Sorokin, N.S. Panferov, E.V. Pestryakov //Tekhnika ioborudovanie dlya sela, 2018. - № 10. - S.22-24.

4. Sorokin, N.T. Zakonodatel'naya baza razrabotki programmnogo obespecheniya $v$ usloviyakh politiki importozameshcheniya / N.T. Sorokin, N.S. Panferov, E.V. Pestryakov // Tekhnika i oborudovanie dlya sela, 2018. - №8. - S.2-5.

5. Khodakova, T.A. Informatizatsiya protsessa formirovaniya ratsional'nogo sostava mashinno-traktornogo parka dlya provedeniya agrokhimicheskikh rabot v rastenievodstve / T.A. Khodakova // Innovatsionnoe razvitie APK Rossii na baze intellektual'nykh mashinnykh tekhnologiy: sb. nauch. dokl. mezhdunarodnoy nauchnotekhn. konf. (g. Moskva, 17-18 sent. 2014 g.). - M.: FGBNU VIM, 2014. - S. 482-486.

6. Khomyakov, D.M. Voprosy uvelicheniya potrebleniya mineral'nykh udobreniy v Rossiyskoy Federatsii / D.M. Khomyakov, B.V. Levin // Dostizheniya nauki i tekhniki APK, 2016. - № 11. - S. 43-44.

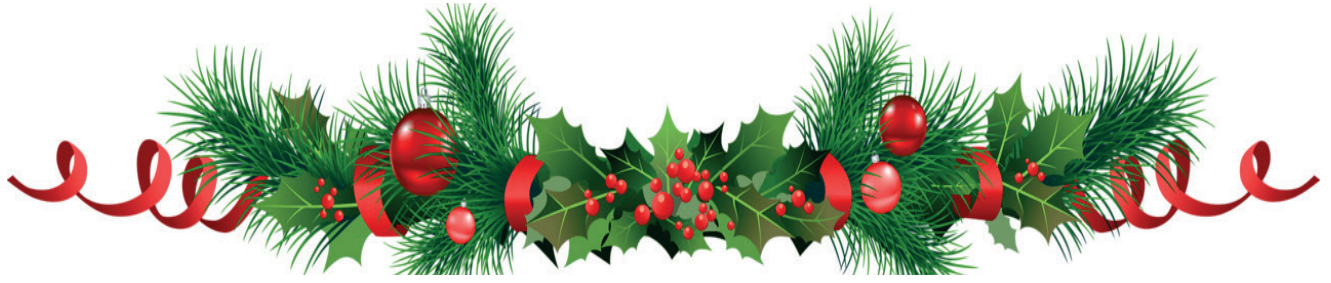

УдК 621.43.057

DOI 10.36508/RSATU.2019.28.73.018

\section{ИССЛЕДОВАНИЕ ЭКОЛОГИЧЕСКИХ ПОКАЗАТЕЛЕЙ АВТОТРАКТОРНОГО ДИЗЕЛЯ ПРИ РАБОТЕ НА ПРЕДЕЛЬНЫХ СОСТАВАХ ЭТЭ}

ПЛОтнИкОВ Сергей Александрович, д-р. техн. наук, профрессор кафедры технологии машиноcmpoения, plotnikovsa@bk.ru

КАРТАШЕВИЧ Анатолий Николаевич, д-р техн. наук, профрессор кафедры технологии машиностроения, Kartashevich@yandex.ru

ПляГО Анатолий Веславович, аспирант кафедры технологии машиностроения, Tоm.PAV@ mail.ru

Вятский государственный университет

Цель исследований - экспериментальное определение токсических показателей дизельного двигателя Д-245.5S2 сельскохозяйственного трактора при его работе на этаноло-топливной эмульсии с предельным содержание этанола в смеси. Объект исследования: экспериментальная установка (двигатель Д-245.5S2, электротормозной стенд RAPIDO SAK N670 с балансирной маятниковой машиной). Испытания дизеля проводились в соответствии с ГОСТ 18509-88. Исследования проводились на дизельном топливе и этаноло-топливной эмульсии с содержанием этанола $20 \%$ и 50\% в смеси. Во время проведения исследований снималась регулировочная характеристика для определения оптимального угла опережения впрыскивания (угол $22^{\circ}$ до верхней мертвой точки (ВМT)). Затем снимались нагрузочные характеристики при частоте вращения коленчатого вала 1800 $м и н^{-1}$ и 1400 мин $^{-1}$ и скоростная характеристика. Во всех экспериментах производилась фриксация эфрфективных и экологических показателей. Опираясь на полученные в результате испытаний экспериментальные данные, были установлены зависимости токсических показателей дизеля при его работе на этаноло-топливной эмульсии. Также были выявлены изменения токсичности и дымно-

() Плотников С. А., Карташевич А. Н., Пляго А. В., 2019 г. 
сти отработавших газов при разных составах топлива. Приведены графики нагрузочной характеристики (экологические показатели) работы двигателя на базовом топливе и на этаноло-топливной эмульсии с содержанием 20\% и 50\% этанола в смеси.

Ключевые слова: дизель, этанол, присадка комплексного действия, альтернативное топливо, дымность, токсичность отработавших газов.

\section{Введение}

Автомобильный транспорт и сельскохозяйственные машины являются одним из источников загрязнения воздушной среды Земли. Значительная часть выбросов вредных веществ осуществляется транспортом с дизельным двигателем. Благодаря своим высоким технико-экономическим показателям дизельный двигатель будет основным силовым агрегатом на коммерческом транспорте и сельскохозяйственной технике еще долгое время [2, 3]. Наряду с коммерческим, растет доля дизелизации легкового автотранспорта. Поэтому работы по улучшению экологических показателей дизельных двигателей будут актуальными.

Исследование состояния вопроса

\section{по применению альтернативного топлива} в Российской Федерации

Применение альтернативного топлива из возобновляемых источников, наряду с базовым топливом ископаемого происхождения, является реалией наших дней по всему земному шару. Это вопрос не только сохранения запасов ископаемого топлива, но и, в большей части, сохранения и улучшения экологической обстановки на Земле. В США на каждой заправочной станции продают как топливо из ископаемых углеводородов, так и альтернативное жидкое топливо из возобновляемых источников. Такая же картина и в Бразилии. Там в качестве возобновляемого источника используется спирт из сахарного тростника, смешиваемый с базовым топливом. Страны Евросоюза также всячески поддерживают применение топлив из возобновляемых источников. Все эти инициативы поддерживаются и на уровне правительств стран. В Российской Федерации вопрос применения альтернативных жидких топлив находится в стадии становления [1]. В лучших вузах страны ведутся исследования по применению альтернативных видов топлива. Это касается вопросов применения не только газообразного топлива - как в бензиновых, так и в дизельных двигателях, но и применения жидких топлив - таких, как спирты. Вопрос применения спиртов в качестве добавки к основному топливу ископаемого происхождения рассматривается уже достаточно давно, начиная с 80-х годов прошлого века; с новой силой этот вопрос возник и достаточно плотно исследуется с 2010 года. Ниже приведен ряд работ по применению спирта - этанола в качестве экологической добавки в базовое топливо.

С середины прошлого столетия в Вятской Государственной сельскохозяйственной академии ведутся работы по применению низших спиртов в качестве добавки в дизельное топливо (ДТ). Работы, в основном, направлены на улучшение как экологических показателей работы дизеля, так и на улучшение эфффективных показателей. К ним можно отнести: «Улучшение экологических по- казателей дизеля 24 10,5/12,0 при работе на метаноле и метиловом эфире рапсового масла с двойной системой топливоподачи путем снижения содержания оксидов азота в отработавших газах» (автор - Копчиков Виктор Николаевич); «Снижение дымности отработавших газов дизеля 44 11,0/12,5 путем применения этаноло-топливных эмульсий» (автор - Шаромов Иван Михайлович); «Исследование рабочего процесса дизеля 44 11,0/12,5 при использовании в качестве топлива этаноло-топливной эмульсии» (автор - Чупраков Андрей Иванович); «Исследование рабочего процесса дизеля 24 10,5/12,0 при работе на этаноле с двойной системой топливоподачи» (автор - Полевщиков Александр Сергеевич). В работах, в основном, исследуется возможность работы дизеля на топливах с добавками товарного, немодифицированного этанола и минимального количества топливных присадок.

Бирюков Владимир Владимирович (МГТУ имени Н.Э.Баумана) работал над проектом «Методы повышения эффективности работы дизеля при использовании этанола в качестве экологической добавки к дизельному топливу». Были проведены исследования работы дизеля Д-245.12С на смесях, содержащих: ДТ - 70\%, рапсовое масло - 30\%; ДТ - 96\%, абсолютный этанол - 4\%. Отмечается, что максимальный эфффект при снижении дымности отработавших газов (ОГ) достигнут при работе на смеси рапсового масла (РМ) с $30 \%$ этилового спирта и составляет 2,0 единицы по шкале Bosch (в абсолютных единицах) - 38\% по сравнению с работой на ДТ. При использовании смеси ДТ + этанол дымность ОГ на режимах внешней скоростной характеристики снизилась на 15-25\%.

В Российском Университете Дружбы Народов исследователь Фернандо Кумар Патабендиге Имал Д. проводил исследования по теме «Совершенствование энергетических и экологических качеств дизеля типа Д-240 добавкой этанола к основному топливу». Была проведена оценка повышения энергетических и экологических качеств дизеля Д-240 добавкой к основному топливу этанола в количестве 30-40\% в массовых долях. В результате разработан метод регулирования работы дизеля в широком диапазоне скоростных и нагрузочных режимов путём «безреечного» регулирования (отключением-включением части цилиндров или циклов).

Как видно из представленного списка работ, взор научного сообщества направлен на улучшение экологических показателей работы дизельного двигателя [4]. Известно, что применение этанола ведет к более жесткой работе двигателя из-за взрывного характера горения этанола в камере сгорания (КС) двигателя [6]. Присадки, применяемые в вышеперечисленных работах, направлены больше на стабилизацию состава этаноло-то- 
пливной эмульсии, нежели на улучшение рабочих процессов, происходящих в цилиндре двигателя. Рассмотрение представленных работ позволило сформулировать основную цель настоящей работы - поиск и исследование комплексных присадок, позволяющих, наряду со стабилизацией этанолотопливной эмульсии (ЭТЭ), значительно измененить процесс сгорания, приближая параметры горения эмульсии к параметрам горения базового топлива[7].

\section{Объекты и методы}

Испытания двигателя производят для оценки его основных показателей. Дизельная топливоподающая аппаратура (ТПА) должна соответствовать требованиям технических условий завода-изготовителя, а форсунка удовлетворять основным параметрам ГОСТ 10579-2017 и ГОСТ 10579-88 $[10,11]$. Испытания дизеля проводились в соответствии с ГОСТ 18509-88 [9]. Дизель нагружался с помощью нагрузочного электротормозного стенда RAPIDO SAK N670 с балансирной маятниковой машиной (рис. 1). Испытательный стенд был оборудован приборами и устройствами для снятия эффрективных показателей, а также токсичности и дымности отработавших газов [5]. Испытания проводились на трех составах топлива: ДТ100\%; ДТ80\% + этанол19\% + присадка комплексного действия 1\%; дТ 50\% + этанол 49\% + присадка комплексного действия $1 \%$.

Первый этап эксперимента состоял в определении стабильности состава этаноло-топливной эмульсии. Были опробованы 4 различных присадки; после анализа результатов эксперимента было решено оставить в дальнейших исследованиях присадку комплексного действия на основе молибдена. Присадка показала наилучшие результаты стабильности этаноло-топливной эмульсии

Вторым этапом являлось исследование работы топливного насоса высокого давления (ТНВД) и форсунок на отмеченных смесях топлив. Испытания не выявили существенных отклонений в работе форсунок и ТПА [8].

Третьим этапом стали стендовые испытания (рис. 1) новых составов топлив на дизельном двигателе Д-245.5S2. Для определения оптимального установочного угла впрыска топлива снималась регулировочная характеристика по установочному углу опережения впрыскивания топлива.

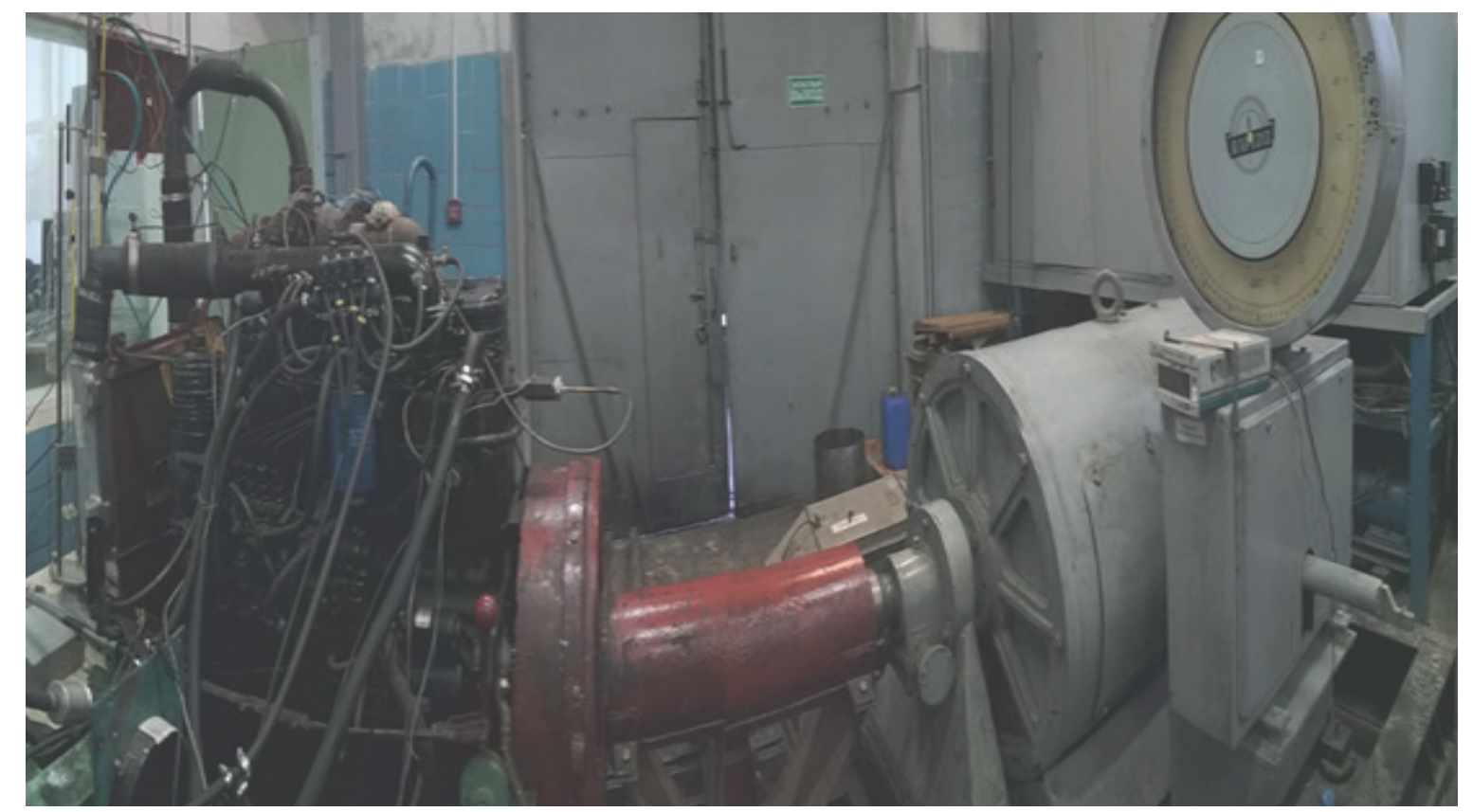

Рис. 1 - Нагрузочный электротормозной стенд RAPIDO SAK N670 с балансирной маятниковой машиной

В ходе испытаний было определено оптимальное значение угла опережения впрыскивания топлива $\theta=22^{\circ}$ до ВМТ. Далее снимались нагрузочные характеристики в номинальном режиме и в режиме максимального крутящего момента, а также скоростная характеристика при номинальной нагрузке. Одновременно записывались эффективные и экологические показатели.

Еще одним важнейшим этапом стендовых испытаний было снятие индикаторной диаграммы работы двигателя на новых составах топлива и расчет показателей тепловыделения.

\section{Экспериментальная часть}

Регулировочная характеристика позволяет исследовать изменения мощностных и экономических показателей дизеля при различных значениях установочного угла опережения впрыскивания топлива и различном содержании этанола в эмульсии при частоте вращения $\mathrm{n}=1800$ мин $^{-1}$. Скоростная характеристика анализирует эффеективные и токсические показатели работы дизельного двигателя в зависимости от изменения частоты вращения коленчатого вала при постоянной нагрузке. Влияние состава эмульсии (по количеству введённого в неё этанола) оценивалось по 
нагрузочным характеристикам, снятым на номинальном скоростном режиме при $\mathrm{n}=1800 \mathrm{мин}^{-1}$ и на частоте вращения $\mathrm{n}=1400$ мин $^{-1}$. Ниже представлены графики экологических показателей при снятии нагрузочных характеристик.

На рис. 2 представлены показатели токсичности работы дизеля при частоте вращения коленчатого вала $\mathrm{n}=1800$ мин $^{-1}$. Как видно из представленного графика, происходит значительное снижение таких вредных показателей, как суммарные оксиды азота $\mathrm{NO}_{x}$ - в 2 раза и сажа $\mathrm{C}$ - в 2,5 раза. Это обуславливается наличием в этаноле атома кислорода О. В свою очередь, менее вредные с фризиологической точки зрения компоненты отработавших газов: монооксид углерода СО, диоксид углерода $\mathrm{CO}_{2}$, суммарные углеводороды $\mathrm{C}_{\mathrm{x}} \mathrm{H}_{\mathrm{y}}$ незначительно возрастают.

На рис. 3 представлены показатели токсичности работы дизеля при частоте вращения коленчатого вала $n=1400$ мин $^{-1}$. Анализ данных показывает, что работа дизельного двигателя на ЭТЭ сопровождается значительным снижением суммарных оксидов азота $\mathrm{NO}_{x}$ и сажи $\mathrm{C}$, и незначительным ростом других токсичных компонентов $\mathrm{CO}$ и $\mathrm{CO}_{2}, \mathrm{C}_{\mathrm{x}} \mathrm{H}_{\mathrm{y}}$. Решающее значение в этом случае оказывает ускорение процесса горения, снижение осредненной температуры цикла и, как следствие, температуры ОГ.

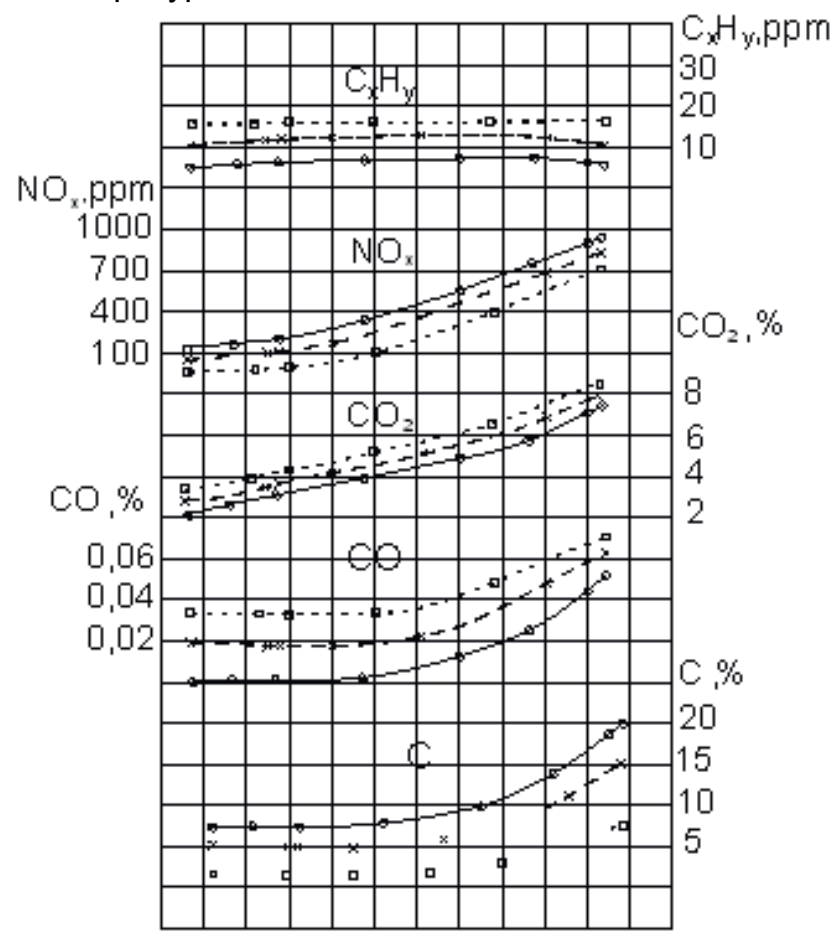

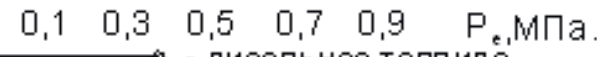

$$
\begin{aligned}
& \text { a - дизельное топиив } \\
& \text { x- - - - } x \text { - 20\% этанола } \\
& \text { 口 - - - - - } 50 \% \text { этанола }
\end{aligned}
$$

Рис. 2 - Нагрузочная характеристика двигателя (дымность и токсичность ОГ) при $\mathrm{n}=1800$ мин $^{-1}$

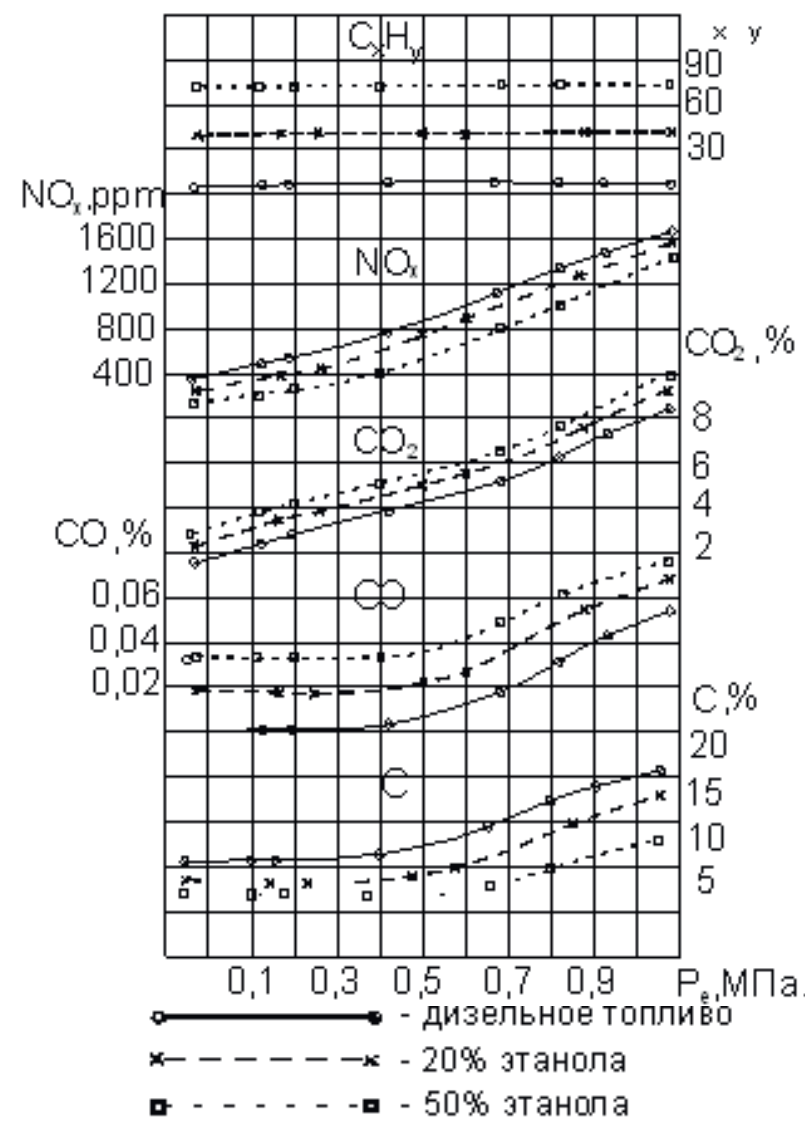

Рис. 3 - Нагрузочная характеристика двигателя (дымность и токсичность ОГ) при $\mathrm{n}=1400$ мин $^{-1}$

\section{Результаты и выводы}

1. Расширенный теоретический анализ классов, типов и групп присадок позволил произвести предварительный их выбор для заданных условий.

2. Лабораторные исследования стабильности предельных составов ЭТЭ подтвердили работоспособность комплексной присадки на основе молибдена.

3. Работа дизеля на ЭТЭ с присадкой комплексного действия не вызывает отказов топливоподающей аппаратуры.

4. Проведенные стендовые испытания выявили улучшение экологических показателей работы дизеля.

\section{Список литературы}

1. Анализ экологических характеристик этанола и его смеси с нефтяным дизельным топливом /В.А. Марков, И.Г. Суровцев, И.И. Блудова, C.А. Зыков // Автогазозаправочный комплекс + Альтернативное Топливо. - М., 2016. - № 5. - С. 18-31.

2. Николаенко, А.В. Теория, конструкция и расчет автотракторных двигателей / А.В. Николаенко. - М., Колос, 1984 - 335 с.

3. Луканин, В.Н. Двигатели внутреннего сгорания / В. Н. Луканин. - М.: Высшая школа, 1995. - 944 c.

4. Ассад, М.С. Продукты сгорания жидких и газообразных топлив: образование, расчет, экс- 
перимент / М.С. Ассад, О.Г. Пенязьков. - Минск: Беларус. Наука, 2010 - 305 с.

5. Кавтарадзе, Р.3. Частично-гомогенное сгорание традиционных и альтернативных топлив в дизелях. Часть 1. Способы гомогенизации сгорания //Транспорт на альтернативном топливе, 2018. - № 1 (61). - С. 37 - 52.

6. Плотников С.А. Улучшение эксплуатационных показателей дизелей путем создания новых альтернативных топлив и совершенствования топливоподающей аппаратуры. Автореф. дисс. докт. техн. наук. - Н-Новгород, 2011. - 40 с.

7. Плотников, С. А. Исследование процесса сгорания и тепловыделения дизеля с термофрорсированием / С.А. Плотников, Ш.В. Бузиков, В.Ф.
Атаманюк // Тракторы и сельхозмашины, 2014. - № 7. - C. 25-27.

8. Плотников, С.А. Влияние состава спиртосодержащего топлива на показатели процесса топливоподачи / С.А. Плотников, С.Н. Гущин, С.Р. Лебедев // Двигателестроение, 2004. - № 3. - С 43-45.

9. ГОСТ 18509-88. Дизели тракторные и комбайновые. Методы стендовых испытаний.

10. ГОСТ 10579-88. Форсунки дизелей. Общие технические условия.

11. ГОСТ 10579-2017 Форсунки дизелей. Технические требования и методы испытаний.

12. Дизели Д-245S2, Д-245.2S2, Д-245.5S2,Д245.16S2,Д-245.16ЛS2, Д-245.42S2, Д-245.43S2. Руководство по эксплуатации.

\section{RESEARCH OF ECOLOGICAL INDICATORS OF THE AUTOTRACTOR DIESEL ENGINE AT WORK ON LIMITING STRUCTURES ETE}

Plotnukov Sergey A., a Dr.Sci.Tech., the professor of chair of technology of mechanical engineering, Vjatsky state university, plotnikovsa@bk.ru

Kartashevich Anatoly N., Dr.Sci.Tech., the professor of chair of technology of mechanical engineering, Vjatsky state university, Kartashevich@yandex.ru

Plyago Anatoly V., the post-graduate student of chair of technology of mechanical engineering, Vjatsky state university, Tom.PAV@mail.ru

The purpose of probes - experimental definition of toxic indicators of diesel engine D-245.5S2 at its work on etanolo-fuel emulsion with limiting the ethanol maintenance in a mixture. Object of probe: experimental installation (engine D-245.5S2, electrobrake stand RAPIDO SAK N670 with balancer by pendular car). Diesel engine tests were spent according to GOST 18509-88. Probes were spent on diesel fuel and etanolo-fuel emulsion with the maintenance of ethanol of $20 \%$ and $50 \%$ to mixtures. During carrying out of probes the adjusting characteristic, for definition of an optimum angle of an injection advance (a corner $22^{\circ}$ to the top dead point (TDP)) acted in film. Then loading characteristics acted in film at rotary speed of a bent shaft of 1800 mines-1 both 1400 mines-1 and the high-speed characteristic. At all experimentals fixing of effective and ecological indicators was made. Leaning against the received experimental data as a result of tests, dependences of toxic indicators of a diesel engine have been established at its work on etanolo-fuel emulsion. Also changes of toxicity and smoke, the fulfilled gases are revealed at different structures of fuel. Schedules of the loading characteristic (ecological indicators) engine works on base fuel and on etanolo-fuel emulsion with the maintenance of $20 \%$ and $50 \%$ of ethanol in a mixture are resulted.

Key words: a diesel engine, ethanol, additives of the complex action, alternative fuel, smoke and toxicity of the fulfilled gases.

\section{Literatura}

1. Markov, V.A. Analiz ekologicheskih harakteristik etanola i ego smesi s neftyanym dizel'nym toplivom $N$.A. Markov, I.G. Surovcev, I.I. Bludova, S.A. Zykov // Avtogazozapravochnyj kompleks + Al'ternativnoe Toplivo. M., 2016. - № 5. - S.18-31.

2. Nikolaenko, A.V. Teoriya, konstrukciya i raschet avtotraktornyh dvigatelej / A. V. Nikolaenko. - M., Kolos, 1984. - $335 \mathrm{~s}$.

3. Lukanin, V.N. Dvigateli vnutrennego sgoraniya / V. N. Lukanin. - M.: Vysshaya shkola, 1995.- 944 s.

4. Assad, M.S. Produkty sgoraniya zhidkih i gazoobraznyh topliv: obrazovanie, raschet, eksperiment / M.S. Assad, O.G. Penyaz'kov. - Minsk: Belarus. Nauka, 2010. - 305 s.

5. Kavtaradze, R.Z. CHastichno-gomogennoe sgoranie tradicionnyz i al'ternativnyh topliv v dizelyah. CHast' 1. Sposoby gomogenizacii sgoraniya //Transport na al'ternativnom toplive, 2018. - № 1 (61). - S. 37 - 52.

6. PlotnikovS.A. Uluchshenieekspluatacionnyhpokazatelejdizelejputem sozdaniyanovyhal'ternativnyhtopliv isovershenstvovaniyatoplivopodayushchejapparatury.Avtoref. diss. dokt. tekhn. nauk.-N-Novgorod, 2011.-40s.

7. Plotnikov, S. A. Issledovanie processa sgoraniya i teplovydeleniya dizelya s termoforsirovaniem / S.A.

Plotnikov, SH.V. Buzikov, V.F. Atamanyuk // ZHurnal Traktory i sel'hozmashiny, 2014. - № 7. - S. 25-27.

8. Plotnikov, S.A. Vliyanie sostava spirtosoderzhashchego topliva na pokazateli processa toplivopodachi /

S.A. Plotnikov, S.N. Gushchin, S.R. Lebedev // ZHurnal Dvigatelestroenie, 2004. - № 3. - S 43-45.

9. GOST 18509-88. Dizeli traktornye i kombajnovye. Metody stendovyh ispytanij.

10. GOST 10579-88. Forsunki dizelej. Obshchie tekhnicheskie usloviya.

11. GOST 10579-2017. Forsunki dizelej. Tekhnicheskie trebovaniya i metody ispytanij.

12. Dizeli D-245S2, $D$-245.2S2, $D$-245.5S2,D-245.16S2,D-245.16LS2, D-245.42S2, $D$-245.43S2. Rukovodstvo po ekspluatacii. $245 S 2$. 


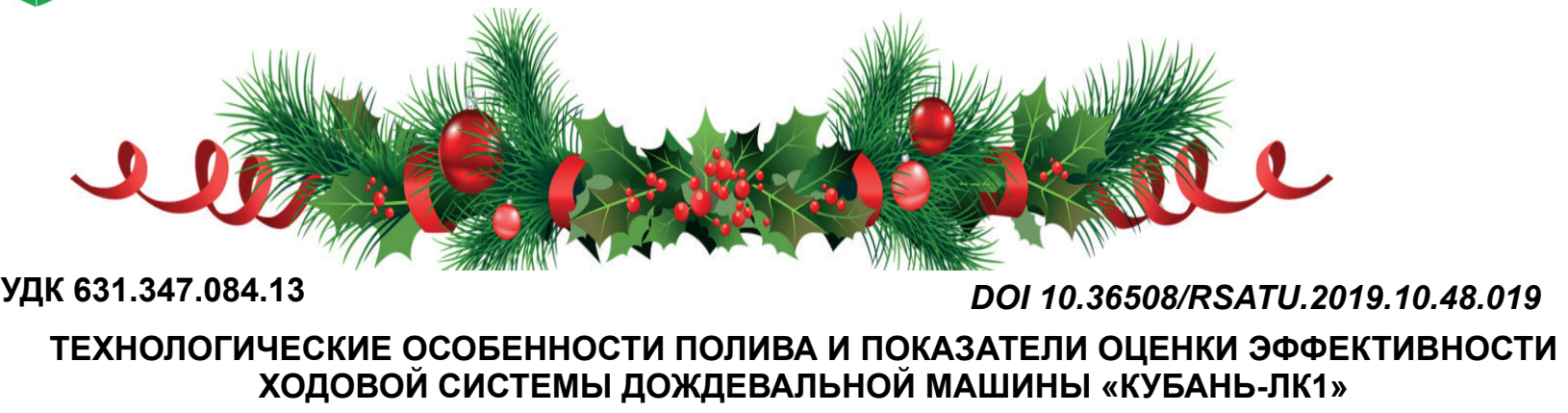

РЯЗАНЦЕВ Анатолий Иванович, д-р техн. наук, профессор кафредры технологии металлов и ремонта машин Рязанского государственного агротехнологического университета имени П.А. Костычева, ryazantsev.41@mail.ru

АНТИПОВ Алексей Олегович, канд. техн. наук, доцент кафедры общетехнических дисциплин, теории и методики профессионального образования Государственного социально-гуманитарного универсumema, antipov.aleksei2010@yandex.ru

СМИРНОВ Алексей Игоревич, аспирант кафедры «Технические системы в АПК» Рязанского государственного агротехнологического университета имени П.А. Костычева, as133634@gmail.com

МАЛЬКО Игорь Валерьевич, канд. техн. наук, доцент, и.о. заведующего кафедрой машиноведения Государственного социально-гуманитарного универсumema, centorion@yandex.ru

EВCEЕВ Евгений Юрьевич, аспирант кафедры технологии металлов и ремонта машин Рязанского государственного агротехнологического университета имени П.А. Костычева, evseеv. evgeniy.1995@yandex.ru

Снижение материалоемкости машин и энергоемкости при производстве полива, в частности, дождевальной машины (ДМ) «Кубань-ЛК1», является важным направлением повышения экономической эффрективности агропромышленного комплекса, поскольку экономное расходование энергетических и материальных ресурсов обеспечивает увеличение объема производства и снижение себестоимости как технологических средств орошения, так и урожая сельскохозяйственных культур. При этом технико-экономические показатели дождевальных машин определяются их конструктивноэксплуатационными характеристиками, зависящими от основных параметров машин и от условий эксплуатации. Наиболее важными из них являются: производительность и энергоемкость. Проведенные исследования ДМ позволили установить, что снижение её производительности зачастую происходит из-за уменьшения коэффрициента использования рабочего времени смены (K жение определяется потерями опорной проходимости тележек машины в местах с низкой несущей способностью почвы (из-за увеличенного колеобразования) и при преодолении подъемов (из-за недостаточных сцепных свойств ходовых систем, или мощности привода). Доказывается, что наиболее объективную оценку роста технического уровня ходовых систем ДМ «Кубань-ЛК1» целесообразно проводить по обобщенному показателю эфффективности, определяющему оптимальные параметры колёсного движителя исходя из максимальных показателей энергетических затрат на передвижение и материалоемкости.

Ключевые слова: дождевальная машина, диск, заравниватель, технология полива.

\section{Введение}

В настоящее время в отечественном сельскохозяйственном машиностроении остро стоит вопрос повышения конкурентоспособности и качества, снижения себестоимости выпускаемой продукции, сокращения затрат на проектирование и доводку новых моделей различных машин.

Анализ показателей эффективности работы позволяет принять обоснованное решение о целесообразности эксплуатации машины в соответствующих условиях производства работ и определить ее технико-экономический уровень на основе изучения различных способов механизации работ, сопоставления образцов техники и прогнозирования возможного эфффекта от ее применения. Сопоставляют машины путем определения и сравнения показателей, позволяющих количественно определить степень эффективности выполнения технологических операций при заданном качестве работы. Обоснованность принятых решений обу- словлена степенью соответствия показателей эффективности функциональному назначению машины, полнотой учета, действующих технических эксплуатационных и социально-экономических фракторов.

Эффективность машины - это способность качественного выполнения требуемых видов работ в заданных условиях эксплуатации с минимальными затратами. Количественная оценка эффрективности - отношение расходов материальных средств к единице продукции. Технический уровень - отношение эффрективности машины к соответствующему значению эталонного образца.

Условия формирования показателей эфффективности определяются соблюдением ряда положений. Показатель должен обеспечивать выявление влияния на эффективность машины всего многообразия определяющих фракторов, технических параметров, условий производства и эксплуатации. Показатели должны помочь получить 
обоснованные рекомендации по выбору рациональных технических и эксплуатационных параметров машины, совокупность которых определяет ее технико-экономическую эффективность, и определить техническую и технико-экономическую целесообразность применениея на объекте группы машин разного типоразмера с учетом условий эксплуатации, производства, потребностей и перспектив развития народного хозяйства.

Анализ используемой в мелиоративном земледелии техники показал широкое распространение в нашей стране способа орошения дождеванием с помощью широкозахватных многоопорных дождевальных машин «Фрегат», «Кубань-ЛК1» (рис. 1).

Наряду с положительными качествами эти машины имеют существенный недостаток - от колес самодвижущихся тележек образуются колеи глубиной до 35 см и больше и шириной 30-70 см, что вызывает значительные показатели сопротивления на передвижение [2].

Известные способы уменьшения колеи (снабжение колес самодвижущихся опор уширителями разных типов; замена металлических колес пневматическими; полив пониженными поливны-

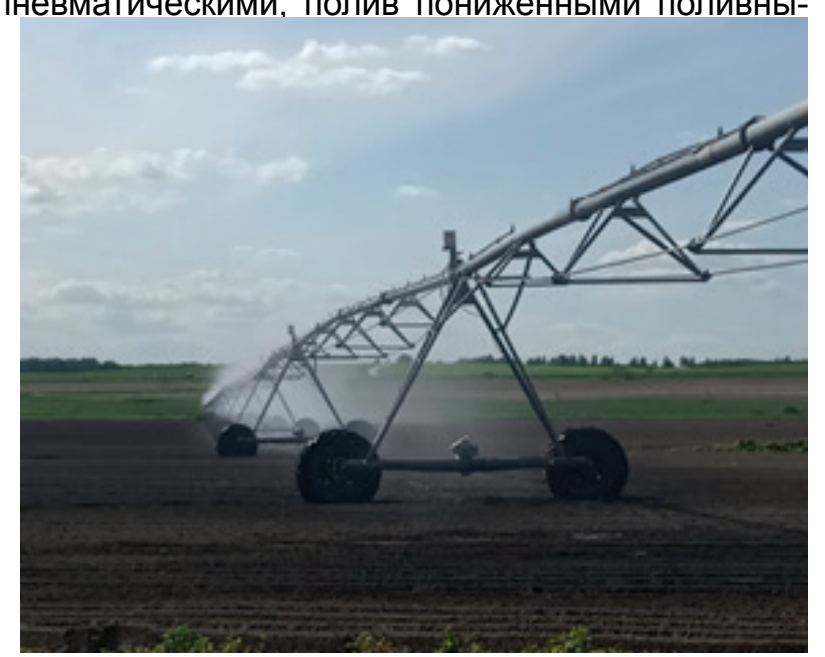

Рис. 1 - Общий вид электрифицциованной дождевальной машины «Кубань-ЛК1»

Технико-экономические показатели дождевальных машин определяются их конструктивно-эксплуатационными характеристиками, зависящими от основных параметров машин и условий их эксплуатации. Наиболее важными из них являются производительность и энергоемкость.

Технологический процесс полива дождевальной машиной «Кубань-ЛК1» включает последовательные операции выдачи поливных норм $\mathrm{m}_{\mathrm{M}}$ во времени на орошаемую площадь:

$$
m_{M}=7400 \frac{R_{k} Q}{V R^{2}}
$$

где $\quad \mathrm{R}_{\mathrm{k}}$ - расстояние от неподвижной опоры до последней тележки, м;

$$
\begin{aligned}
& \mathrm{R} \text { - длина захвата дождем, м; } \\
& \mathrm{Q} \text { - расход воды, л/с; } \\
& \mathrm{V} \text { - скорость движения последней тележ- }
\end{aligned}
$$
ки, м/мин.

Производительность дождевальной машины $\omega_{4}$ за 1 час чистого времени (га) можно вычислить по ми нормами при первых проходах дождевальных машин и другие) не позволяют до конца решить указанную проблему, особенно при поливе многолетних трав, когда за период их использования количество проходов машины по одному следу составляет до 30 и более раз.

Кроме того, отмеченное вызывает необходимость оснащения тележек ДМ широкопрофильными массивными колесными движителями (рис. 2), что обуславливает, наряду с увеличением их материалоемкости, дополнительное повышение энергозатрат на качение [3].

\section{Исследовательская часть}

Снижение материалоемкости машин и энергоемкости при производстве полива, в частности, ДМ «Кубань-ЛК1», является важным направлением повышения экономической эффективности агропромышленного комплекса, поскольку экономное расходование энергетических и материальных ресурсов обеспечивает увеличение объема производства и снижение себестоимости как технологических средств орошения, так и урожая сельскохозяйственных культур [4].

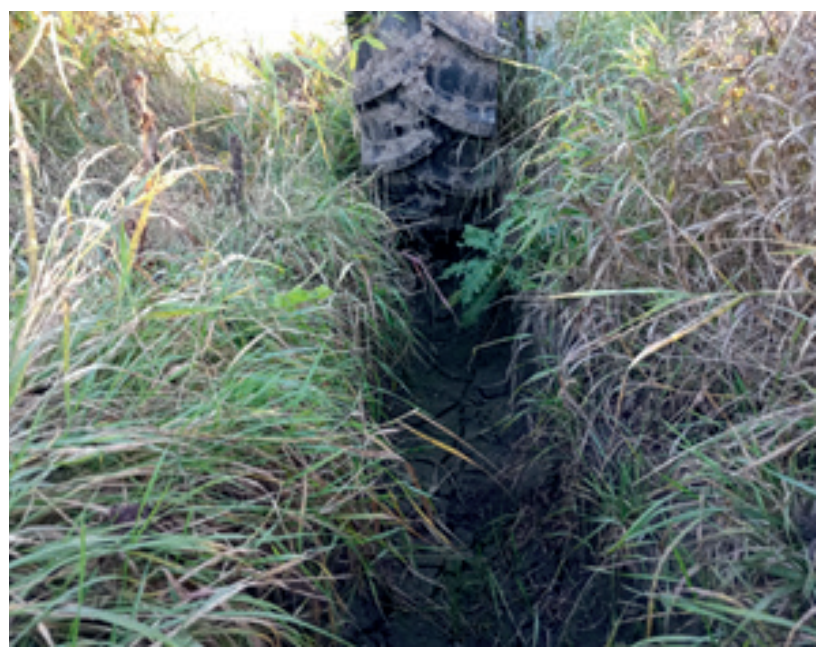

Рис. 2 - Колеобразование серийными ходовыми системами дождевальной машины «Кубань-ЛК1» следующей формуле:

$$
\omega_{\mathrm{Y}}=\frac{3,6 \cdot Q}{m \beta},
$$

С учетом всех потерь воды и времени производительность $\omega_{\text {см }}$ или нагрузка за смену на одну ДМ «Кубань-ЛК1» определяется следующей зависимостью [2]:

$\omega_{\mathrm{CM}}=\frac{3,6 \cdot Q t_{\mathrm{CM}} \cdot K_{\mathrm{CM}}}{m \beta}$,

где $\mathrm{Q}$ - расход воды, л/с;

$\mathrm{m}$ - поливная норма, м³/га;

$\beta$ - коэффициент, учитывающий потери воды на испарение в зоне дождевого облака при дождевании; за смену, ч

$\mathrm{t}_{\mathrm{cm}}$ - продолжительность работы машины $\mathrm{K}_{\mathrm{cm}}$ - коэффрициент использования рабочего времени смены.

По данным исследований ДМ, снижение её 
производительности зачастую происходит из-за уменьшения коэффициента использования рабочего времени смены (Ксм). Его снижение определяется потерями опорной проходимости тележек машины в местах с низкой несущей способностью почвы (из-за увеличенного колеобразования) и при преодолении подъемов (из-за недостаточных сцепных свойств ходовых систем, или мощности привода).

Отмеченные явления вызывают снижение надежности технологического процесса полива ДМ из-за чрезмерно повышенных энергетических затрат на передвижение, вызывающих, в конечном счете, преждевременные аварийные остановки машины по причине искривления трубопровода и срабатывания защиты.

В свое время появилось такое понятие, как «запас прочности», но с увеличением запаса прочности увеличивается и масса изделия, что ведет к повышению в целом материалоемкости машины и энергетических затрат при её эксплуатации.

В процессе эксплуатации сельскохозяйственных машин значительная доля отказов (от 20 до $40 \%$ ) приходится на ходовую часть. Решение проблемы ходовой части во многом определяется её техническим уровнем. Как показывает анализ, оценка производится по следующим показателям: надежность, материалоемкость, тягово-сцепные качества и проходимость, плавность хода, технологичность, степень воздействия на почву (агротехнический показатель). Наиболее эффрективный рост технического уровня дают повышение тягово-сцепных качеств и проходимости, снижение воздействия на почву, улучшение плавности хода.

Оценка технического уровня ходовых систем сельскохозяйственной, в том числе дождевальной техники показывает, что имеется определенное отставание от современных требований по уплотняющему воздействию на почву особенно колесных систем, проходимости в условиях повышенной влажности почвы.

Это всецело относится к существующей конструкции ходовых систем ДМ «Кубань-ЛК1», которые, как отмечалось, из-за увеличенных энергетических затрат на качение и наличия при этом высокой материалоемкости не обеспечивают в полной мере малозатратных и надежных технологий полива.

Предварительно эффрективность ходовой системы ДМ «Кубань-ЛК1» в натуральных единицах целесообразно оценивать по удельным значением материалоемкости и энергоемкости и обобщенному показателю [1].

Удельные значения материалоемкости $\mathrm{m}_{\mathrm{yд}}$ и энергоемкости $\mathrm{N}_{\mathrm{yp}}$ характеризуют соответственно материальные $(\mathrm{m})$ и энергетические (мощностные $\mathrm{N})$ затраты на единицу часовой производительности ДМ $\left(\omega_{4}\right)$.

У лучших ходовых систем ДМ имеются наименьшие величины показателей.

Комплексную оценку эффективности ходовых систем ДМ производят по обобщенному показателю $\mathrm{N}_{\mathrm{nm}}$, характеризующему их энергетические и материальные затраты:

$$
N_{N m}=\frac{N_{\text {уд }}}{\Pi_{\text {уд }}}
$$

где $\Pi_{\text {уд }}$-удельная производительность.

$\Pi_{\text {уд }}=\frac{\omega_{ч}}{m}$ является обратной величине $\mathrm{m}_{\text {уд }}$ и

характеризует производительность машины на единицу массы ходовых систем. Лучшая ходовая система ДМ имеет максимальное значение показателя.

Тогда выражение (4) примет следующий вид [4]:

$N_{n m}=\frac{N \cdot m}{\omega_{\mathrm{u}}^{2}}$

Величина $\mathrm{N}_{\mathrm{nm}}$ показывает, сколько единиц удельной энергоемкости приходится на единицу удельной производительности. Лучшая ходовая система ДМ имеет минимальное значение $\mathrm{N}_{\mathrm{nm}}$

На основе выражения (5) с использованием характеристик по производительности и параметрам ходовой системы, присущим базовой (10 тел.) модификации ДМ «Кубань-ЛК1» (часовая производительность $\omega_{4} \approx 1,0$ га/ч; ориентировочные диапазоны уменьшения за счёт совершенствования затрат мощности привода Nдм с 1,1 до 0,80 кВт и массы колесных движителей ходовой системы с 700 кг до 400 кг), построена графическая зависимость обобщенного показателя эфффективности $\mathrm{N}_{\mathrm{nm}}$ (рис. 3)

Ориентировочно наилучший показатель $\mathrm{N}_{\mathrm{nm}} \approx 320$ для ходовой системы тележки ДМ «Кубань-ЛК1» соответствует мощности её привода не более 0,8 кВт при массе колесных движителей около 400 кг [5].

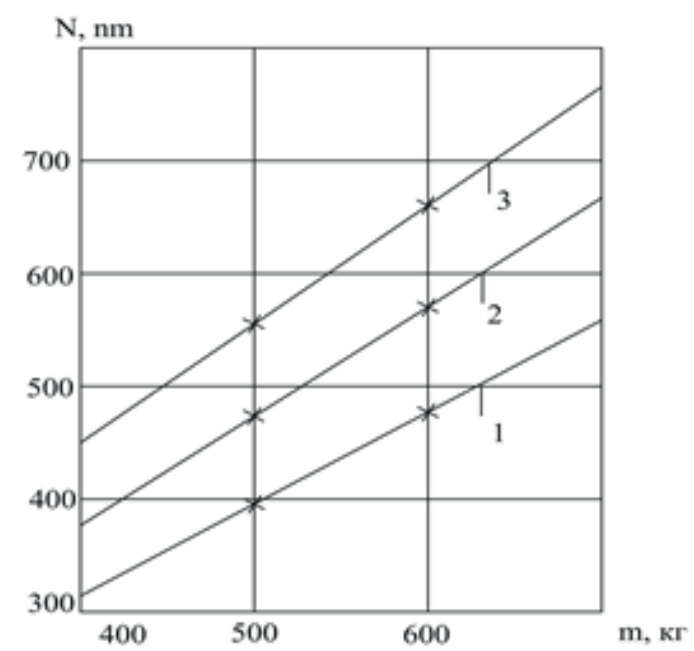

1,2,3 - мощность электропривода, соответственно: $\mathrm{N} 1=0,8 \kappa B т, \mathrm{~N} 2=0,95 \kappa B т, \mathrm{~N} 3=1,1 \mathrm{\kappa B}$ т

Рис. 3 - Зависимость обобщенного показателя эффективности ходовой системы тележки ДМ «Кубань-ЛК1» от её массы

\section{Заключение}

Наиболее объективную оценку роста технического уровня ходовых систем ДМ «Кубань-ЛК1» 
целесообразно проводить по обобщенному показателю эффрективности, определяющему оптимальные параметры колесных движителей исходя из наименьших показателей энергетических затрат на передвижение и материалоемкости.

\section{Список литературы}

1. Боловнев, В. И. Определение оптимальных параметров и выбор землеройных машин в зависимости от условий эксплуатации. - М., 2010

2.Рязанцев, А. И. Эксплуатация транспортных систем многоопорных машин [Текст] / А. И. Рязанцев, А. О. Антипов. - Коломна : ГОУ ВО МО ГСГУ,
2016. -225 c.

3.Рязанцев, А. И. Направления совершенствования дождевальных машин и систем [Текст] / А. И. Рязанцев. - Рязань : ФГБОУ ВПО РГАТУ, 2013. - 306

4.Рязанцев А.И., Егоров Ю.М. Заравниватель колеи дождевальной машины. Свидетельство на полезную модель № 15446, Бюл. № 29, 2000 г.

5.Ryazantsev, A.I. Water conservation while using irrigation devices of multiple supports in the conditions of the Moscow region [Url:] Ryazantsev A.I., Antipov A.O., Olgarenko G.V., Smirnov A.I. Amazonia Investiga. 2019. T. 8. № 18. C. 323-329.

\section{TECHNOLOGICAL FEATURES OF IRRIGATION AND PERFORMANCE EVALUATION OF THE RUNNING SYSTEM DM "KUBAN-LK1»}

Ryazantsev Anatoly l., doctor of technical., professor of technical systems in agriculture, Ryazan State University named after PA Agrotechnological Kostychev, ryazantsev.41@mail.ru

Antipov Aleksey O., Candidate of Technical Sciences, Associate Professor of the Department of General Technical Disciplines, Theory and Methods of Professional Education, State Social and Humanitarian University, antipov.aleksei2010@yandex.ru

Smirnov Aleksey l., engineer, State Social and Humanitarian University, as133634@gmail.com

Malko Igor V., Candidate of Technical Sciences, Associate Professor of the Department with the duties of head of the Department of mechanical engineering, State social and humanitarian University, centorion@ yandex.ru

Yevseyev Yevgeny Yu., post-graduate student of the Department of metal technology and machine repair of the Ryazan state agrotechnological University named after P. A. Kostychev, evseev.evgeniy.1995@yandex.ru

It is proved that the reduction of material consumption of machines and energy consumption in the production of irrigation, in particular, DM "Kuban-LK1", is an important direction to improve the economic efficiency of agriculture, as economical consumption of energy and material resources provides an increase in production and cost reduction, as technological means of irrigation and crop production. At the same time, technical and economic indicators of sprinkler machines are determined by their structural and operational characteristics, depending on the main parameters of the machines and on the operating conditions. The most important of them are: productivity and energy intensity. Conducted research DM has allowed to establish that the decline in performance often occurs due to the reduction in utilization of working time shift (KSM). Its reduction is determined by the losses of the supporting patency of the carts in places with low bearing capacity of the soil (due to increased rutting) and when overcoming climbs (due to insufficient coupling properties of running systems, or drive power). It is proved that the most objective assessment of the growth of the technical level of running systems DM "Kuban-LK1" is advisable to carry out a generalized indicator of the effectiveness of determining the optimal parameters of the wheel drive on the basis of the highest indicators of energy costs for movement and material consumption.

Key words: irrigation system, disc, sorevnovatel, the technology of irrigation.

\section{Literatura}

1.Bolovnev V.I. Opredelenie optimal'nyh parametrov $i$ vybor zemlerojnyh mashin $v$ zavisimosti ot ulovij jekspluatacii. M., 2010

2.Rjazancev, A.I. JEkspluatacija transportnyh sistem mnogoopornyh mashin [Tekst] / A.I. Rjazancev, A.O. Antipov. - Kolomna: GOU VO MO GSGU, 2016. - 225 s.

3.Rjazancev, A.I. Napravlenija sovershenstvovanija dozhdeval'nyh mashin i sistem [Tekst] / A.I. Rjazancev. - Rjazan': FGBOU VPO RGATU, 2013. - 306

4.Rjazancev A.I., Egorov JU.M. Zaravnivatel' kolei dozhdeval'noj mashiny. Svidetel'stvo na poleznuju model' № 15446, Bjul. № 29, $2000 \mathrm{~g}$.

5.Ryazantsev, A.I. Water conservation while using irrigation devices of multiple supports in the conditions of the Moscow region [Url:] Ryazantsev A.I., Antipov A.O., Olgarenko G.V., Smirnov A.I. Amazonia Investiga. 2019. T. 8. № 18. S. 323-329.

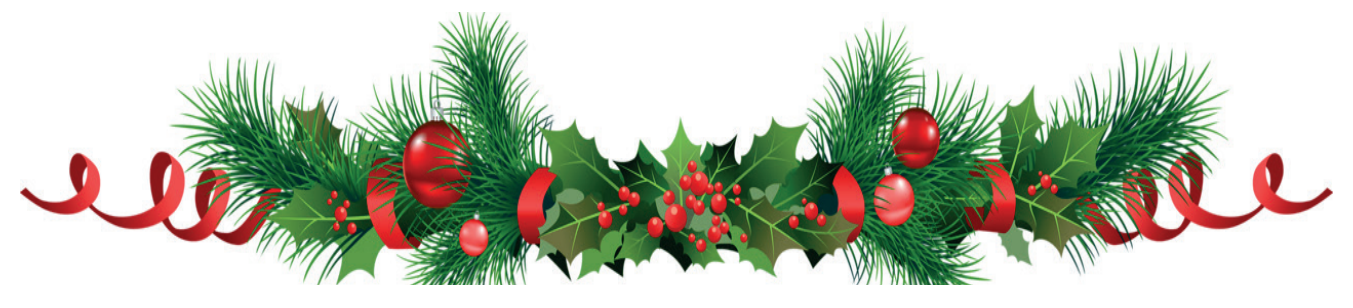




\section{СПОСОБ ПРОИЗВОДСТВА КОМПЛЕКСНЫХ ОРГАНОМИНЕРАЛЬНЫХ УДОБРЕНИЙ И ТЕХНОЛОГИЧЕСКАЯ ЛИНИЯ ДЛЯ ЕГО ОСУЩЕСТВЛЕНИЯ}

TETEPИн Владимир Сергеевич, канд. техн. наук, зав. отделом №2, ст. научный сотрудник, Labio-giant@mail.ru

ГАПЕЕВА Наталья Николаевна, канд. биол. наук, вед. научный сотрудник, gapeevann@mail.ru

МИТРОФАНОВ Сергей Владимирович, канд. с.-х. наук, зам. директора по научной работе, f-mitrofanoff2015@yandex.ru

ПАНФЕРОВ Николай Сергеевич, канд. техн. наук, зам. директора по инновационным разработкам и развитию экспериментального производства, nikolaj-panfyorov@yandex.ru

ГАЙБАРЯН Михаил Арутюнович, канд. техн. наук, вед. научный сотрудник, gnu@vnims.rzn.ru

Институт технического обеспечения сельского хозяйства - фрилиал Федерального государственного бюджетного научного учреждения «Федеральный научный агроинженерный центр ВИМ»

Органоминеральные удобрения, содержащие гуминовые вещества, нашли широкое применение в современном сельскохозяйственном производстве. Их применяют для повышения урожайности сельскохозяйственных культур и качества получаемой продукции, снятия стрессовой нагрузки от обработки пестицидами, повышения плодородия почв и т.д. Эфрфективность использования удобрений на основе гуминовых кислот во многом определяется технологиями их производства, которые можно разделить на химические, физические и комбинированные. Анализ существующих технологий производства органоминеральных (гуминовых) удобрений показал, что большинство из них имеет ряд недостатков. К ним можно отнести длительность, сложность и многоэтапность технологического процесса, энергетическую и экономическую затратность, сложность аппаратурного офрормления, невозможность получения конечного продукта с заданными стабильными характеристиками. В связи с этим разработка эфрфективных инновационных технологий производства органоминеральных удобрений из органического сырья (торфа, биогумуса, сапропеля и бурого угля) является весьма актуальной. Учеными института был разработан способ производства органоминеральных и комплексных на их основе удобрений, который позволяет повысить эффрективность технологического процесса и качественные показатели получаемых удобрений. Согласно предлагаемому способу сырье проходит предварительную подготовку (измельчение, просеивание, гидратация и отделение нерастворимых включений), после чего подвергается щелочной экстракции и кавитационному диспергированию до момента прекращения активного образования солей гуминовых и фульвокислот. Далее суспензия готовых органоминеральных удобрений проходит систему многоступенчатой очистки, а затем, для получения комплексных удобрений, в поток органоминеральных удобрений диффреренцированно вводят питательные микроэлементы. Для осуществления данного способа разработана схема технологической линии по получению органоминеральных и на их основе комплексных удобрений, представляющая собой комплекс оборудования, не требующего дополнительной модернизации при переходе с одного вида сырья на другое.

Ключевые слова: органоминеральные удобрения, способ производства, технологическая линия, гуматы.

\section{Введение}

В настоящее время в связи с активным ростом потребительского спроса на экологически чистую сельскохозяйственную продукцию и внедрением системы органического земледелия производству жидких органоминеральных (гуминовых) удобрений, разрешенных к применению при производстве органической продукции в соответствии с ГОСТ Р 56508-2015 «Продукция органического производства. Правила производства, хранения и транспортирования», уделяется особое внимание.

Органоминеральные удобрения содержат соли гуминовых и фульвовых кислот, элементы питания растений - азот, калий, фосфор, а также микроэлементы. Соли гуминовых и фульвовых кислот ускоряют рост и развитие растений, а также выполняют важные экологические функции.

Применение гуминовых удобрений при выращивании растений приводит к следующим положительным результатам: увеличению содержания хлорофилла и усилению фотосинтеза; усилению роста корней; повышению поглощения питательных веществ из почвы и минеральных удобрений; увеличению урожайности и устойчивости растений при экстремальных воздействиях среды, в частности температуры; снятию токсичного действия избытка пестицидов, минеральных удобрений и засоления; улучшению структуры почв и продуктивному использованию влаги из почвы и осадков, а также регулированию кислотности почвы, повышению устойчивости растений к различным заболеваниям, что позволяет сократить применение ядохимикатов [1- 4].

Таким образом, удобрения на основе гуминовых веществ нашли широкое применение в современном сельскохозяйственном производстве.

Обзор технологий производства органоминеральных удобрений

Эффрективность использования органоминеральных удобрений во многом зависит от их качества, которое, в свою очередь, определяется технологией производства. В настоящее время в С. В., Панферов Н. С., Гайбарян М. А., 2019 г. 
органоминеральные удобрения получают с помощью химических (механохимическое, биохимическое экстрагирование), фризических (механическая, кавитационная, электрогидравлическая обработка, ультразвуковое воздействие), а также комбинированных методов [5].

Наиболее распространенными технологиями производства органоминеральных удобрений являются так называемые технологии «выщелачивания» гуминовых веществ из гуматсодержащего сырья. В основу данных технологий положена способность гуминовых веществ образовывать водорастворимые соли в растворах различных щелочей. Щелочными реагентами для этих целей могут служить: гидроксиды натрия и калия; пирофосфат натрия; аммиак; сода; фтористый, щавелевокислый или уксуснокислый натрий; щавелевокислый аммоний; а также органические растворители: бромистый ацетил, фурфурол, водный диоксан, амины и другие [6].

Часто для повышения выхода гуминовых веществ используют механическое воздействие на сырье. Такие операции основаны на одновременном диспергировании и щелочном экстрагировании органического сырья и получили название «механохимическая активация». При этом происходит повышение реакционной способности и увеличение растворимости вследствие увеличения поверхностей контактирующих фаз, уменьшения размеров частиц, которое сопровождается изменением их химических свойств. Преимуществом механохимического способа является снижение количества химических реагентов, используемых для выделения гуминовых веществ $[7,8]$.

Активация гуминовых кислот возможна и с помощью воздействия различных биологических факторов - биохимические технологии получения органоминеральных удобрений. В качестве таких факторов могут выступать биологически активные вещества или отходы их производства, которые стимулируют вспышку биологической активности в почве. Для этих целей можно также использовать чистые культуры микроорганизмов или ферментов [9].

Применение щелочной экстракции гуминовых веществ позволяет добиваться доступности ряда веществ для питания растений. Однако этот способ их выделения имеет ряд существенных недостатков. Химический способ не способен обеспечить эффективную экстракцию гуминовых веществ. В большинстве препаратов, полученных путем химической и микробиологической активации, отмечается низкое содержание действующих веществ (2-3\%). Способ изменяет природную структуру гуминовых веществ, снижает их химическую и биологическую активность. Удобрения, полученные данным способом, являются высокобалластными, т.к. в процессе экстракционного извлечения в раствор гуматов переходит большое количество высокодисперсных частиц и примесей. Использование химического метода не дает возможности получения конечного продукта с заданными стабильными характеристиками. Кроме того, данному способу присущи такие недостатки, как длительность и сложность технологического процесса получения конечного продукта, что обуславливает значительные энергетические и экономические затраты.

Высокотехнологичной альтернативой химическому способу активации является кавитационное диспергирование органического сырья. Использование процесса кавитации в технологиях получения органоминеральных удобрений позволяет добиться большого выхода водорастворимых органических веществ, повышает их фризиологическую активность. Следует отметить, что кавитационное воздействие проводится при температуре раствора, не превышающей $35^{\circ} \mathrm{C}$, т.е. относится к мягким методам воздействия, а значит, не вызывает существенной химической деструкции сырья. Это позволяет сохранить в готовом продукте ферменты, витамины и другие биологически активные вещества, которые разлагаются при высоких температурах [10, 11].

В последнее время при производстве органоминеральных удобрений активно используются технологии ультразвукового воздействия, которые также основаны на возникновении кавитации. При распространении ультразвуковых колебаний в жидкой среде происходят чередующиеся сжатия и растяжения с частотой проходящих колебаний. В момент растяжения образуются полости, заполненные газом, паром или их смесью (так называемые кавитационные пузырьки), которые в момент сжатия захлопываются, в результате чего возникают ударные волны с большой амплитудой давления, которые приводят к диспергированию и эмульгированию жидкой части продукта. Ультразвуковая обработка ускоряет многие массообменные процессы, например, такие как растворение и экстрагирование [12,13]. Для кавитационного и ультразвукового экстрагирования применяют роторные импульсные аппараты (РИА), кавитаторы, а также ультразвуковые устройства.

Вышеописанные технологии являются современными и технологичными, однако имеют ряд существенных недостатков. В частности, они характеризуются сложностью и многоэтапностью, требуют больших энергетических и экономических затрат для их оснащения и реализации. Не обеспечивают возможность контроля в полученном продукте заданного химического и количественного содержания питательных элементов, а также не позволяют получать конечный продукт со стабильными высококачественными потребительскими свойствами.

Электрогидравлическая технология выделения гуминовых веществ из торфа, биогумуса и бурого угля базируется на действии гидравлических импульсов в зоне создания искрового разряда в жидкой среде. Для создания электрогидравлических ударов осуществляется повышение напряжения на конденсаторе до самопроизвольного пробоя формирующего промежутка, и энергия, запасенная в конденсаторе, поступает на рабочий промежуток, где и выделяется в виде короткого электрического импульса большой мощности. Это явление сопровождается кавитацией, обильным 
газо- и парообразованием. Данный тип обработки обладает многофакторным ффизико-химическим воздействием на сложные органические структуры (электромагнитные поля, высокое давление, кавитация, ультразвук, световое излучение, высокие температуры). В результате такого воздействия в реакционной среде образуются разнообразные химические продукты $[14,15]$.

Однако и этот способ получения удобрений на основе гуминовых кислот не получил широкого распространения из-за сложности аппаратурного оформления данной технологии.

Таким образом, несмотря на многочисленные теоретические исследования и наличие подтвержденных положительных результатов, промышленные технологии производства гуминовых удобрений еще недостаточно развиты. Подавляющее большинство зарегистрированных в России органоминеральных удобрений на основе гуминовых кислот имеют концентрацию действующих веществ не более 2-3\% [16]. Кроме того, получаемый разными производителями продукт зачастую имеет низкие потребительские качества: наличие балласта (остаточного торфа или вспомогательных веществ), невозможность точного дозирования микроэлементов при производстве органоминеральных удобрений на основе гуминовых, низкая концентрация действующих веществ и т.д.

В связи с вышесказанным разработка эффрективных инновационных технологий переработки органического сырья (торфа, биогумуса, сапропеля и бурого угля) в органоминеральные удобрения остается весьма актуальной задачей современной сельскохозяйственной науки.

\section{Результаты исследований}

Учеными ИТОСХ - фрилиал ФГБНУ ФНАЦ ВИМ был разработан способ производства органоминеральных и комплексных удобрений, направленный на повышение эфрфективности технологического процесса и качественных показателей получаемых удобрений, а также технологическая линия для его осуществления.

Разработанный способ основан на кавитационном диспергировании гуматсодержащего сырья с последующим дополнительным введением в раствор гуматов микроэлементов. Вначале сырье проходит предварительную подготовку, после чего подвергается щелочной экстракции и кавитационному диспергированию до момента прекращения активного образования солей гуминовых и фульвокислот; далее суспензия готовых органоминеральных удобрений проходит систему многоступенчатой очистки; затем, для получения комплексных удобрений, в поток органоминеральных удобрений вводят растворы микроэлементов.

В качестве сырья для получения органоминеральных и на их основе комплексных удобрений согласно разработанному способу может быть использован торф, сапропель, биогумус и бурый уголь. При этом процесс получения органоминеральных удобрений осуществляется на одной технологической линии, представляющей собой комплекс оборудования, не требующего дополнительной модернизации при переходе с одного вида сырья на другое.

Сырье перед осуществлением щелочной экстракции и кавитационного диспергирования проходит предварительную подготовку. Для торфа, сапропеля, биогумуса она заключается в просеивании, гидратации и отделении песка и других нерастворимых включений. Для проведения этой технологической операции разработан гидромеханический узел предварительной подготовки сырья. Благодаря совместной работе установленного в нем лопастного смесителя, создающего турбулентные потоки, и циркуляционного насоса, создающего ламинарные потоки, обеспечивается интенсивная гидратация сырья, его предварительное измельчение и активное отделение песка и других нерастворимых включений.

Экстрагирование гуминовых веществ осуществляется в реакторе при помощи дисмембратора, в котором протекают процессы диспергации и кавитации. Для дифференцированного введения 50\%го раствора КОН емкость реактора оборудована датчиком уровня $\mathrm{pH}$ и насосом дозатором.

Очистка суспензии органоминеральных удобрений от нерастворимых балластных включений фракцией от 100 мкм и более осуществляется с помощью батареи гидроциклонов (система грубой очистки), а менее 100 мкм - с помощью центрифуги (система тонкой очистки).

Для осуществления данного способа разработана схема универсальной технологической линии по получению органоминеральных и на их основе комплексных удобрений (рис.). Она включает в себя: измельчитель молоткового типа; шнековый транспортер; накопительный бункер для органического сырья с установленными на нем вибросепаратором; шнековый транспортер; гидромеханический узел предварительной подготовки сырья, оборудованный проточным водонагревателем, лопастным смесителем и циркуляционным насосом; реактор; емкость для раствора щелочи; насос-дозатор; датчик уровня $\mathrm{pH}$; дисмембратор; батарею гидроциклонов; центрифугу; емкости для микроэлементов; насосы-дозаторы, накопительную ёмкость. Разработанный способ получения органоминеральных и на их основе комплексных удобрений осуществляется следующим образом.

При производстве органоминеральных удобрений из торфа, сапропеля или биогумуса сырье влажностью не более $30 \%$ подается с места хранения на вибросепаратор, где происходит отсев посторонних примесей размерностью более 4 мм. Просеянное сырье поступает в накопительный бункер, при заполнении которого процесс просеивания останавливается и вибросепаратор отключается. Для очистки сырья от песка и других нерастворимых примесей оно перед подачей в реактор проходит дополнительную обработку в гидромеханическом узле предварительной подготовки сырья. Для этого в него через проточный водонагреватель подаётся вода, нагретая до температуры 70-80 С. Использование подогретой воды способствует интенсификации процесса экстрагирования гуминовых и фульвовых кислот. При заполнении ёмкости предварительной под- 
готовки на 2/3 объема водой начинается подача в нее просеянного сырья из накопительного бункера шнековым транспортером. Одновременно с этим включается лопастной смеситель и циркуляционный насос, работающий по замкнутому циклу: гидромеханический узел предварительной подготовки сырья - циркуляционный насос - гидромеханический узел предварительной подготовки сырья. Благодаря этому обеспечивается интенсивное отделение песка и других нерастворимых включений от рабочей суспензии. После достиже- ния необходимого соотношения вода:сырье (1:5, $1: 4,1: 3)$ подача сырья и нагретой воды прекращается путём отключения шнекового транспортера и проточного водонагревателя. При этом процесс работы лопастного смесителя и циркуляционного насоса продолжается ещё в течение 15-20 минут, после чего происходит их отключение. Затем суспензия отстаивается в течение 5 минут, после чего включается циркуляционный насос, который перекачивает ее в реактор.

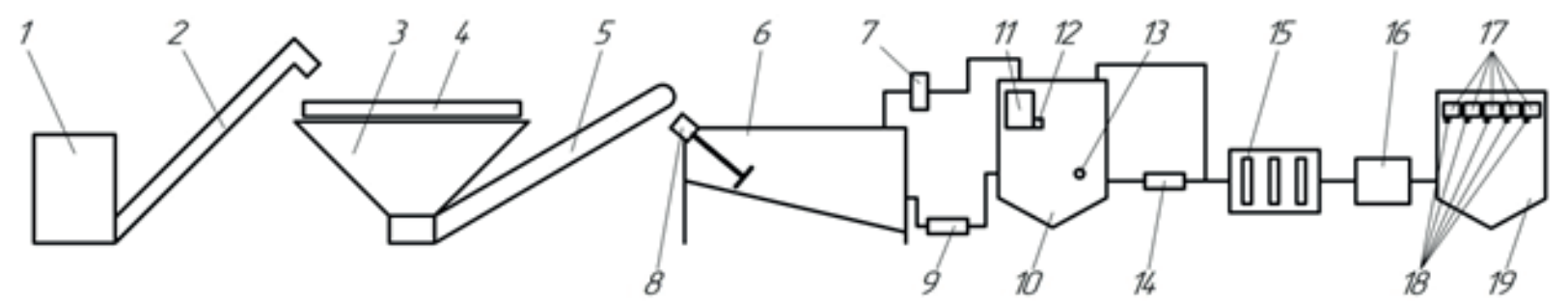

1 - измельчитель молоткового типа, 2 - шнековый транспортер, 3 - накопительный бункер,

4 - вибросепаратор, 5 - шнековый транспортер, 6 - гидромеханический узел предварительной подготовки сырья,

7 - проточный водонагреватель, 8 - лопастной смеситель, 9 - циркуляционный насос,

10 - реактор, 11 - емкость для раствора щелочи, 12 - насос-дозатор, 13 - датчик уровня $\mathrm{pH}$,

14 - дисмембратор, 15 - батарея гидроциклонов, 16 - центрифуга, 17 - емкости микроэлементов,

18 - насосы дозаторы, 19 - накопительная емкость

Рис. - Схема технологической линии по производству органоминеральных и на их основе комплексных удобрений

После завершения перекачки суспензии включается дисмембратор, работающий по замкнутому циклу: реактор-дисмембратор-реактор. Одновременно с этим на основании показаний датчика $\mathrm{pH}$ осуществляется дифференцированное введение жидкого 50\%-го раствора КОН из емкости для раствора щелочи при помощи насоса дозатора. Введение щёлочи происходит до момента прекращения активного образования солей гуминовых и фульвовых кислот и стабилизации среды. После этого дисмембратор прекращает работу по замкнутому циклу и начинает подачу суспензии на батарею гидроциклонов, где происходит отделение нерастворимых балластных остатков размерностью более 100 мкм (стадия грубой очистки). Далее суспензия поступает самотеком в центрифугу, где происходит отделение балластных остатков размерностью менее 100 мкм (стадия тонкой очистки). В итоге на выходе из центрифуги получаются безбалластные органоминеральные удобрения, которые подаются в накопительную ёмкость.

При необходимости получения комплексных органоминеральных удобрений осуществляется дозированное введение необходимых микроэлементов из емкостей для микроэлементов при помощи насосов-дозаторов непосредственно в поток органоминеральных удобрений, поступающий из центрифуги в накопительную емкость. Это способствуют лучшему смешиванию микроэлементов и органоминеральных удобрений. При этом введение микроэлементов осуществляется на основании требований, предъявляемых к конечному продукту, в связи с чем состав и доза микроэлементов может варьировать для каждой партии комплекс- ных органоминеральных удобрений.

При производстве органоминеральных удобрений из бурого угля сырье фракцией не более 5-10 мм поступает в измельчитель молоткового типа. После измельчения до фрракции 0,5-1 мм уголь подается шнековым транспортером в накопительный бункер, при этом установленный на нем вибросепаратор находится в нерабочем (поднятом) положении. После заполнения накопительного бункера подача измельченного бурого угля прекращается и измельчитель отключается. Затем через проточный водонагреватель в реактор подается вода, нагретая до температуры 70-80о С. При заполнении реактора водой на $2 / 3$ от необходимого объема начинается подача измельченного угля из накопительного бункера при помощи шнекового транспортера. Одновременно с началом подачи в реактор бурого угля включается дисмембратор, который начинает работать по замкнутому циклу: реактор-дисмембратор-реактор с целью равномерного смешивания и гидратации угля. После достижения в реакторе необходимого соотношения вода:бурый уголь (1:10; $1: 9 ; 1: 8 ; 1: 7)$ подача сырья и нагретой воды прекращается путем отключения шнекового транспортера и проточного водонагревателя. Далее процесс производства органоминеральных удобрений из бурого угля полностью аналогичен таковому из торфа, биогумуса или сапропеля.

\section{Выводы}

Таким образом, внедрение в производство предложенного способа получения органоминеральных удобрений и технологической линии для его осуществления позволит повысить эфрфектив- 
ность технологического процесса и качественные показатели получаемых удобрений. Это станет возможным за счет:

- получения органоминеральных удобрений на одной технологической линии из различных видов органического сырья (торф, сапропель, биогумус и бурый уголь);

- получения комплексных органоминеральных удобрений на одной технологической линии за счёт дозированного введения различных микроэлементов;

- очистки сырья от песка и других нерастворимых примесей, что обеспечит снижение абразивного износа рабочих органов используемого оборудования и продление ресурса их работы;

- повышения эффективности процесса экстрагирования гуминовых и фрульвокислот;

- получения безбалластных органоминеральных удобрений благодаря использованию многоступенчатой системы очистки готового продукта.

При этом способ осуществляется на одной технологической линии, представляющей собой комплекс оборудования, не требующего дополнительной модернизации при переходе с одного вида сырья на другое.

\section{Список литературы}

1. Смирнов, Ю. В. Механизм действия и функции гуминовых препаратов / Ю. В. Смирнов, В. С. Виноградова // Агрохимический вестник. - 2004. №1 - С. 22-23.

2. Горовая, А. И. Гуминовые вещества: строение, функции, механизм действия, протекторные свойства, экологическая роль / А. И. Горовая, Д. С. Орлов, О. В. Щербенко. - Киев : Наукова думка, 1995. -303 c.

3. Анализ применения различных видов гуматов и способов их использования при возделывании картофеля / М. Ю. Костенко, И. Н. Горячкина, В. С. Тетерин, Н. Н. Гапеева, Н. Н. Новиков, С. В. Митрофанов // Вестник РГАТУ. - 2018. - №3 (39). - С. 88-92.

4. Результаты полевого эксперимента применения незерновой части урожая в качестве удобрения под озимые культуры / Н. В. Бышов, А. Н. Бачурин, И. Ю. Богданчиков, А. И. Мартышов // Вестник РГАТУ. - 2014. - №3 (23). - С. 57-61.

5. Денисюк, Е. А. Технологии получения гуминовых веществ / Е. А. Денисюк, И. А. Кузнецова, Р. А. Митрофранов // Вестник НГИЭИ. - 2014. - № 2 (33). - C. 66-80.

6. Марыганова, В. В. Воздействие вида экстрагента на структуру извлекаемых из торфа гуминовых кислот / В. В. Марыганова, Н. Н. Бамбалов, С. В. Пармон // Химия твердого топлива. - 2003. - № 1. - С. 3-10.

7. Будаев, С. С. Механоактивация в центробежном измельчительном аппарате как эффрективный способ повышения выхода гуминовых кислот из торфа / С. С. Будаев, М. А. Николаев, В. Н. Ардасенов // Экологически устойчивое земледелие: состояние, проблемы и пути их решения: сб. науч. тр. Всеросс. Науч.-практ. конф. - Иваново: ПреСто, 2018. - С. 55-56.

8. Бутюгин, А. В. Изучение влияния механохимической активации на процесс извлечения гуминовых веществ из землистых бурых углей / А. В. Бутюгин, А. С. Иванов // Материалы науч.-техн. семинара стран содружеств. - 1992. - С. 26-28.

9. Касимова, Л. В. Органическое вещество торфа. Микробиологическая активация торфа как основа создания нового вида органического удобрения: монография / Л. В. Касимова, О. В. Порываева. - СибНИСХиТ Российской академии сельскохозяйственных наук. - 2005. - 294 с.

10. Получение оксигуминовых препаратов из торфа кавитационным методом / М. В. Ефанов, А. А. Латкин, П. П. Черненко, А. И. Галочкин // Современные наукоемкие технологии. - 2008. - № 2. - С. 39.

11. Влияние гидродинамической кавитации на выход гуминовых веществ из торфа / Г. А. Соколов, Н. Н. Бамбалов, В. В. Смирнова, Л. Ю. Цвирко // Весці НАН Беларусі. Сер. хім. навук. - 2010. - № 4. - C. 112-117.

12. Москаленко, Т. В. Воздействие ультразвуковым полем на торф при экстрагировании гуминовых кислот / Т. В. Москаленко, В. А. Михеев, О. С. Данилов // Горный информационно-аналитический бюллетень «Горная книга». - 2010. - С. 209-213.

13. Андреев, А.В.Ультразвуковая технология получения гуматов // Горный информационно-аналитический бюллетень, «Горная книга». -2016. -Т. 38. -С. 53-56.

14. Юткин, Л. А. Об электрогидравлической обработке торфа // ЭОМ. - 1976. - № 6.

15. Денисюк, Т. Д. Электроразрядная технология - перспективный путь получения гуминовых веществ / Т. Д. Денисюк, А. Н. Рачков // Вестник НТУ ХПИ. - 2016. - № 36 (1208). - С. 19-23.

16. Ушаков О.В., Смирных К.А. Анализ рынка агрохимикатов на основе гуминовых кислот / О. В. Ушаков, К. А. Смирных // Проблемы механизации агрохимического обслуживания сельского хозяйства : сб. науч. тр. по материалам заочной междунар. науч.- практич. конф. (г. Рязань, ФГБНУ ВНИМС, 15 декабря 2014 г.) / ФГБНУ ВНИМС. Рязань, 2014. - 326 с.

\section{METHOD AND PROCESS LINE FOR PRODUCING COMPLEX ORGANICMINERAL FERTILIZERS}

Teterin Vladimir S., Candidate of Technical Sciences, Head of the Chair №2, Senior Researcher, Labiogiant@mail.ru

Gapeeva Natalya N., Candidate of Biological Sciences, Leading Researcher, gapeevann@mail.ru

Mitrofanov Sergey V., Candidate of Agricultural Sciences, Vice-director for Science, f-mitrofanoff2015@ yandex.ru

Panfyorov Nikolay S., Candidate of Technical Sciences, Vice-director for Innovations and Development of pilot-scale production, nikolaj-panfyorov@yandex.ru

Gaybaryan Mikhail A., Candidate of technical sciences, leading researcher, gnu@vnims.rzn.ru 
Institute of Technical Support of Agriculture - branch of the Federal State Budgetary Scientific Institution "Federal Scientific Agroengineering Center VIM"

Organicmineral fertilizers containing humic substances are widely used in the modern agricultural production. They are used for increasing crops yields and quality of the products, reducing stress effect from pesticide treatment, improving soil fertility, etc. Efficiency of applying fertilizers based on humic acids is highly dependent on the production technologies, which can be subdivided into chemical, physical and combined technologies. An analysis of the existing technologies of producing organicmineral (humic) fertilizers has shown, that the most of them had a number of disadvantages, including long duration, complexity and number of stages of the technological process, high economic and energy costs, need for non-standard equipment, impossibility of producing a final product with required stable characteristics. In this context, development of efficient innovative technologies for producing organicmineral fertilizers from organic raw materials (peat, biohumus, sapropel and brown coal) is highly important. Research workers of the Institute have developed a method for producing organicmineral fertilizers and complex fertilizers on their basis, that facilitates the improvement of efficiency of the technological process and qualitative characteristics of the fertilizers being manufactured. This method involves pretreatment of raw material (grinding, screening, hydratation and extraction of insoluble inclusions) with the following alkaline extraction and cavitational dispersing until termination of active salification of humic and fulvic acids. After that, the suspension of organic-mineral fertilizers passes through multistage treatment system, and then micronutrients are differentially introduced in the flow of organicmineral fertilizers to obtain complex fertilizers. For the application of this method the authors have developed a layout scheme of a process line for producing organicmineral fertilizers and complex fertilizers on their basis:an equipment system, that does not need modification in case of changing raw material.

Key words: organicmineral fertilizers, method of production, process line, humates.

\section{Literature}

1. Smirnov Yu.V., Vinogradova V.S. Mekhanizm deystviya i funktsii guminovykh preparatov // Agrokhimicheskiy vestnik. - 2004. - №1 - S. 22-23.

2. Gorovaya A.I., Orlov D.S., Shcherbenko O.V. Guminovye veshchestva: stroenie, funktsii, mekha-nizm deystviya, protektornye svoystva, ekologicheskaya rol'. - Kiev: Naukova dumka, 1995. - 303 s.

3. Kostenko M.Yu., Goryachkina I.N., Teterin V.S., Gapeeva N.N., Novikov N.N., Mitrofanov S.V. Analiz primeneniya razlichnykh vidov gumatov i sposobov ikh ispol'zovaniya pri vozdelyvanii kar-tofelya // Vestnik RGATU. - 2018. - №3 (39). - S. 88-92.

4. Byshov N.V., Bachurin A.N., Bogdanchikov I.Yu., Martyshov A.l. Rezul'taty polevogo ekspe-rimenta primeneniya nezernovoy chasti urozhaya $v$ kachestve udobreniya pod ozimye kul'tury // Vestnik RGATU. 2014. - №3 (23). - S. 57-61.

5. Denisyuk E. A., Kuznetsova I. A., Mitrofanov R.A. Tekhnologii polucheniya guminovykh ve-shchestv // Vestnik NGIEl. - 2014. - № 2 (33). - S. 66-80.

6. Maryganova V.V., Bambalov N.N., Parmon S.V. Vozdeystvie vida ekstragenta na strukturu izvlekaemykh iz torfa guminovykh kislot // Khimiya tverdogo topliva. - 2003. - № 1. - S. 3-10.

7. Budaev S.S., Nikolaev M.A., Ardasenov V.N. Mekhanoaktivatsiya v tsentrobezhnom izmel'chi-tel'nom apparate kak effektivnyy sposob povysheniya vykhoda guminovykh kislot iz torfa // Ekologicheski ustoychivoe zemledelie: sostoyanie, problemy i puti ikh resheniya: sb. nauch. tr. Vseross. Nauch.-prakt. konf. - Ivanovo: PreSto, 2018. - S.55-56.

8. Butyugin A.V., Ivanov A.S. Izuchenie vliyaniya mekhanokhimicheskoy aktivatsii na protsess iz-vlecheniya guminovykh veshchestv iz zemlistykh burykh ugley // Materialy nauch.-tekhn. seminara stran so-druzhestv. 1992. - S. 26-28.

9. Kasimova L.V., Poryvaeva O.V. Organicheskoe veshchestvo torfa. Mikrobiologicheskaya akti-vatsiya torfa kak osnova sozdaniya novogo vida organicheskogo udobreniya: monografiya - SibNISKhiT Rossiyskoy akademii sel'skokhozyaystvennykh nauk. - 2005. - 294 s.

10. Efanov M.V., Latkin A.A., Chernenko P.P., Galochkin A.I. Poluchenie oksiguminovykh prepa-ratov iz torfa kavitatsionnym metodom // Sovremennye naukoemkie tekhnologii. - 2008. - №2. - S. 39.

11. Sokolov G.A., Bambalov N.N., Smirnova V.V., Tsvirko L. Yu. Vliyanie gidrodinamicheskoy kavitatsii na vykhod guminovykh veshchestv iz torfa // Vestsi NAN Belarusi. Ser. khim. navuk. - 2010. - № 4. - S. $112-117$.

12. Moskalenko T.V., Mikheev V. A., Danilov O. S. Vozdeystvie ul'trazvukovym polem na torf pri ekstragirovanii guminovykh kislot //Gornyy informatsionno-analiticheskiy byulleten' "Gornaya kniga»: M. 2010. - S. 209-213.

13. Andreev A. V. Ul'trazvukovaya tekhnologiya polucheniya gumatov // Gornyy informatsionno-analiticheskiy byulleten', «Gornaya kniga»: M. -2016. -T.38. -S. 53-56.

14. Yutkin L.A. Ob elektrogidravlicheskoy obrabotke torfa // EOM. - 1976. - № 6.

15. Denisyuk T.D., Rachkov A.N. Elektrorazryadnaya tekhnologiya - perspektivnyy put' polucheniya guminovykh veshchestv // Vestnik NTU KhPl. - 2016. - №36 (1208). - S. 19-23.

16. Ushakov O.V., Smirnykh K.A. Analiz rynka agrokhimikatov na osnove guminovykh kislot // Problemy mekhanizatsii agrokhimicheskogo obsluzhivaniya sel'skogo khozyaystva: sb. nauch. tr. po mate-rialam zaochnoy mezhdunar. nauch.- praktich. konf. (g. Ryazan', FGBNU VNIMS, 15 dekabrya 2014 g.) / FGBNU VNIMS. - Ryazan', 2014. - 326s. 


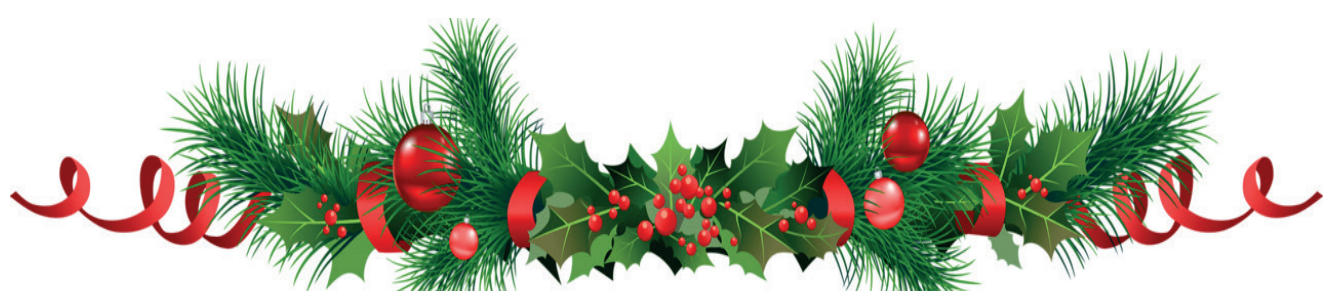

\title{
ПРОМЫШЛЕННОЕ ИСПОЛЬЗОВАНИЕ ХРОМИРОВАНИЯ ПРИ РЕМОНТЕ ДЕТАЛЕЙ СЕЛЬСКОХОЗЯЙСТВЕННОЙ ТЕХНИКИ
}

\author{
чуРИлов Дмитрий Геннадьевич, канд. техн. наук, доцент кафредры технологии металлов и \\ ремонта машин, churilov.dmitry@yandex.ru. \\ СТЕКОЛЬНИКОВ Юрий Александрович, канд. химических наук, профессор кафредры химии и био- \\ логии ФГБОУ ВО «Елецкий государственный университет им. И.А. Бунина», chimic57@mail.ru. \\ АРАПОВ Илья Сергеевич, аспирант кафредры технологии металлов и ремонта машин, arapow. \\ ilya@yandex.ru \\ ШЕМЯКИн Александр Владимирович, д-р техн. наук, зав. кафеедрой организации транспортных \\ процессов и безопасности жизни деятельности, shem.alex62@yandex.ru \\ АНДРЕЕВ Константин Петрович, канд. техн. наук, доцент кафедры организации транспорт- \\ ных процессов и безопасности жизни деятельности, kosta066@yandex.ru
}

В технологии ремонта изношенных деталей методом хромирования используются нестационарные способы нанесения хрома для повышения надежности и долговечности ремонтируемых деталей путем изменения условий электрокристаллизации. Рассмотрены основные формы поляризационного тока - импульсные и обратные, которые наиболее интенсивно влияют на показатели процесса хромирования, структуру и свойства покрытия. В работе даны рекомендации по текущему температурному режиму осаждения хрома, составу ванн, используемых для восстановления и упрочнения деталей. Рассмотрены режимы электролиза, толщина осадка, которые в приоритетном порядке определяют такие фризико-механические свойства покрытия, как адгезия к подложке, шероховатость, пористость, коррозионная стойкость, предел прочности и выносливости. Для получения высокой укрывистости в разбавленных электролитах рекомендуются следующие режимы: для обратного тока длительность импульса катода составляет 1,5-3 минуты по отношению к длительности тока анода 40-50 мин и отношению амплитуд катодно-анодные плотностей тока от 2 до 3 раз, оптимальная катодная плотность тока 160-180 A/ $\mathrm{dm}^{2}$, температура 60-65 C. По импульсу: длительность 1,5-2,5 минуты, коэфффициент заполнения 1,0-1,15, плот-

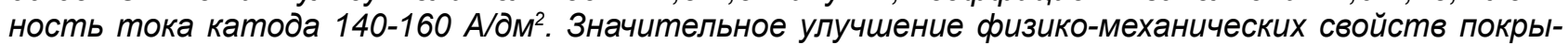
тий может быть достигнуто при использовании электролитов с добавками органических и неорганических веществ, что позволяет снизить содержание водорода в покрытии во время процесса осаждения, а в некоторых случаях позволит отказаться от последующей термообработки. В качестве анодов рекомендуются свинцовые материалы с небольиими добавками сурьмы, висмута и олова. Это позволяет снизить скорость их растворения в хромовом электролите и исключить операцию механической очистки анодов при работе ванн, а также снизить энергозатраты на $30 \%$.

Ключевые слова: ремонт деталей сельскохозяйственной техники, хромирование, электролиты, нестационарные режимы электролиза, фризико-механические свойства хромовых покрытий.

\section{Введение}

Износостойкие хромовые электрохимические покрытия широко используются для восстановления деталей, а также для изготовления и ремонта коленчатых валов и распредвалов, шатунов и всей цилиндро-поршневой группы, а также других деталей. Благодаря хрому, коэфрфициент трения которого достаточно низок $(0,03-0,12)$ для большинства материалов пар трения, используемых в машиностроении, хромовое покрытие устойчиво к износу, который является термически и химически стойким в агрессивных и абразивных средах, деталях.

\section{Материалы и методы}

Использование хромовых электролитов с тем- пературой до $85^{\circ} \mathrm{C}$ не вызывает структурных изменений в базовом материале ремонтируемой детали, что позволяет повысить износостойкость деталей в 5 и более раз. Однако это вызывает проблемы, связанные с производственным процессом, а также с высокой токсичностью, недостаточными фризико-механическими свойствами хромового покрытия. Целью работы является анализ технологий, применяемых в практике промышленного хромирования.

Для обеспечения высокого качества покрытий разложение электролитов хрома происходит при высоких плотностях тока, что позволяет добиться максимально возможного выхода хрома под воздействием тока в импульсном и обратном режи-

() Чурилов Д. Г., Стекольников Ю. А.. Арапов И. С.. Шемякин А. В., Андреев К. П., ,2019 г. 
мах осаждения. В практике промышленного хромирования широко используется универсальный электролит (УЭ), содержащий 250 г/л ангидрида хрома и 2,5 г/л серной кислоты с хорошей технологией хромирования.

Когда толщина хромового покрытия находится в диапазоне 350-1000 мкм, на поверхности образуются дендриты и ноздри, которые приводят к увеличению шероховатости и значительному снижению прочности и пластичности хромовых деталей. В целях улучшения фризико-механических свойств хромовых покрытий в электролиты хромсодержащих химикатов вводят добавки, изменяющие процесс электрокристаллизации, они могут увеличивать выход по току хрома (борная, ванадий, молибденовая кислота) и в то же время повышать производительность процесса осаждения (на 30-35\%), твердость, износостойкость, снижение внутренних напряжений в покрытиях (галловая кислота) [1 - 4].

Электролиты с низкой концентрацией ангидрида хрома (150-100 г/л) в основном используются для повышения износостойкости восстановленных деталей при их ремонте. Они имеют более высокую степень прочности и износостойкости, а также высокую токсичность по сравнению с УЭ. Было разработано много сульфатных саморегулирующихся электролитов, хромирование с добавками сульфата стронция, оксида азота, алюминия, кремнийорганических соединений, дихромата калия, боридов или нитридов титана (других частиц), что приводит к образованию мелкокристаллических структур и повышению микротвердости, износостойкости и степени выносливости хромируемых деталей $[5,6]$.

При производственных испытаниях деталей типа валов длиной до 1600 мм и диаметром от 80 до 120 мм установлено, что при шероховатости (среднеарифметическое значение отклонения профиля в пределах базовой линии) ( $\mathrm{R}_{\mathrm{a}}=1 / \mathrm{n} \sum_{\mathrm{i}=0}^{\mathrm{n}} \mathrm{A}_{\mathrm{i}}$ где $\mathrm{A}_{\mathrm{i}}$ - расстояние между любой точкой профиля и средней базовой линии, а $\mathrm{n}$ - число выбранных точек профиля на базовой линии) подложки порядка 0,08 мкм, толщине покрытия 60-70 мкм наиболее равномерные покрытия (неравномерность 1- 2 мкм на метр длины) с шероховатостью поверхности 0,09-0,10 мкм на импульсном токе получаются при плотности тока 70-110 A/дм ${ }^{2}$ в разбавленном электролите и температуре $60-63^{\circ} \mathrm{C}$, длительности импульсов 2,0-2,5 мин и скважности импульсов 1,13-1,17.

На реверсивном токе равномерные покрытия с низкой шероховатостью получаются при плотности катодного тока 80-100 A/дм ${ }^{2}$ и длительности катодного периода 2-3 мин, отношениях времени катодного импульса к анодному 50-60, а плотности катодных токов к анодным как 2:3. Шероховатость поверхности снижается при увеличении катодноанодного отношения амплитуд токов от 4 до 6 . При использовании постоянного тока шероховатость и неравномерность покрытия выше и составляет при 25-50 A/дм², температуре $55-60^{\circ} \mathrm{C}$, толщине

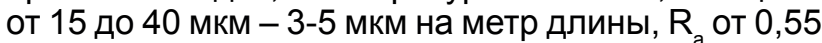
до 0,65 мкм; при толщине 85-90 мкм неравномерность покрытия возрастает до 7-10 мкм, а шероховатость до 0,65-0,75 мкм.

Отметим, что на равномерность покрытия большое влияние оказывает краевой эффект и расположение деталей в ванне. На краях и выступах деталей толщина осадка всегда выше, чем в средней части $[7,8]$. При вертикальном расположении деталей в ванне на верхнем конце толщина осадка меньше, чем на нижнем из-за влияния электропроводности электролита. Из анализа промышленных испытаний следует, что при хромировании на импульсном токе наибольшее влияние на рассеивающую способность оказывает плотность тока и наименьшее - скважность импульсов, влияние которой начинает возрастать от 1,4-1,5. На реверсивном токе наибольшее влияние оказывают плотность тока и отношение амплитуд катодных токов к анодным и времен их длительности. С увеличением плотности тока кроющая способность возрастает на всех формах поляризующего тока и в разбавленном электролите она выше, чем в УЭ. На импульсном и реверсивном токах они практически одинаковы, а при плотности тока свыше $80 \mathrm{~A} /$ дм² $^{2}$ в универсальных растворах значительно лучше, чем на постоянном.

\section{Результаты и их обсуждение}

Для получения высокой укрывистости в разбавленных электролитах рекомендуются следующие режимы: для обратного тока длительность импульса катода составляет 1,5-3 минуты по отношению к длительности тока анода 40-50 мин и отношению амплитуд катодно-анодных плотностей тока от 2 до 3 раз, оптимальная катодная плотность тока 160-180 А/дм², температура 60-65 С. По импульсу: длительность 1,5-2,5 минуты, коэфффициент заполнения 1,0-1,15, плотность тока катода 140-160 A/дм². В универсальном электролите плотность тока может быть увеличена до 200-250 А/дм². Было обнаружено, что различие в термической или химико-термической обработке образцов с нанесенными гальваническими покрытиями, выполненными из разных марок стали (т.е. разного состава и свойств стали), не влияет на свойства покрытий, которые определяются шероховатостью, микротвердостью и пористостью. Шероховатость основного металла и толщина покрытия наиболее сильно влияют на шероховатость покрытия. С увеличением толщины хрома до 0,08 мм шероховатость поверхности увеличивается в 1,5-2 раза (табл. 1).

Таблица 1 - Влияние исходной шероховатости поверхности деталей перед хромированием и толщины слоя хрома на шероховатость поверхности хрома

\begin{tabular}{|c|c|c|c|c|c|}
\hline \multirow{2}{*}{$\begin{array}{c}\text { Шероховатость } \mathrm{R}_{\mathrm{a}} \text {, мкм } \\
\text { Roughness } \mathrm{R}_{\mathrm{a}}, \mu \mathrm{m}\end{array}$} & \multicolumn{5}{|c|}{$\begin{array}{c}\text { Tолщина, мм } \\
\text { Thickness, mm }\end{array}$} \\
\cline { 2 - 6 } & 0,01 & 0,02 & 0,04 & 0,06 & 0,08 \\
\hline 0,15 & 0,25 & 0,32 & 0,42 & 0,45 & 0,50 \\
\hline
\end{tabular}


Продолжение таблицы 1

\begin{tabular}{|c|c|c|c|c|c|}
\hline 0,30 & 0,48 & 0,60 & 0,65 & 0,72 & 0,81 \\
\hline 0,50 & 0,62 & 0,92 & 1,03 & 1,13 & 1,21 \\
\hline 0,75 & 0,92 & 1,20 & 1,35 & 1,45 & 1,50 \\
\hline 1,35 & 1,45 & 1,55 & 1,62 & 1,70 & 1,88 \\
\hline
\end{tabular}

Рост толщины покрытия до 350 мкм и выше приводит к образованию дендритов. Шероховатость хромированной поверхности зависит от режимов хромирования, причем она растет при повышении плотности тока и снижении темпера-

туры электролита. Увеличение исходной шероховатости поверхности при толщине слоя 0,22 мм снижает твердость покрытия на 10\% и повышает пористость в несколько раз (табл. 2).

Таблица 2 - Влияние шероховатости перед хромированием на микротвердость

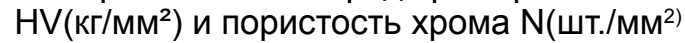

\begin{tabular}{|l|c|c|c|c|c|c|}
\hline $\begin{array}{l}\text { Шероховатость } \\
\text { хрома, мкм } \\
\text { Roughness of chromium, microns }\end{array}$ & 0,12 & 0,20 & 0,32 & 0,63 & 1,25 & 2,6 \\
\hline $\begin{array}{l}\text { Пористость } \\
\text { хрома, шт/мм }{ }^{2} \\
\text { Chromium porosity, pcs / mm² }\end{array}$ & 3 & 4 & 6 & 7 & 9 & 11 \\
\hline $\begin{array}{l}\text { Микротвердость, HV200 } \\
\text { Мicrohardness, HV200 }\end{array}$ & 910 & 880 & 865 & 860 & 840 & 830 \\
\hline
\end{tabular}

При обработке гальванической поверхности дефектный поверхностный слой отсутствует, поскольку свойства покрытия по глубине практически идентичны и не меняются в процессе механической обработки. Если деталь обрабатывается в центрах или поверхность установки совпадает с основанием измерения, то ошибка установки равна нулю, поэтому допуск будет определяться только шероховатостью поверхности и пространственными отклонениями.

Такой расчет припусков целесообразно производить при массовом производстве. При производстве небольшой партии запасы выбираются в зависимости от толщины покрытия и типа обработки. После хромирования следует учитывать припуск на шлифовку и хонингование электролитических хромовых покрытий в пределах 15-30\% от толщины слоя. Чем меньше слой, тем меньше допуск. Допуск на хонингование и шлифование после шлифования назначается 0,01-0,03 мм на диаметр в зависимости от точности полированной поверхности [9, 10]. При полировке, сглаживании припуски обычно не оставляют, поскольку размеры варьируются в пределах допусков.

В ремонтной промышленности для получения поверхности требуемого качества обычным является машинное или машинно-ручное шлифование прецизионных пар, которое выполняется на внешней и внутренней поверхностях для получения их низкой шероховатости и плотного соединения сопрягаемых пар поверхностей катушек, плунжеров и других деталей $[11,12]$. Известно, что зернистость абразивных порошков в конечном итоге определяет шероховатость поверхности. Рост размера абразивного зерна увеличивает толщину съема хрома и шероховатость поверхности, которая больше при обработке зерном зеленого карбида хрома, чем при притирке зерном электрокорунда. Лучшего качества поверхности можно добиться при введении в те же абразивы с маслом МК смеси (по массе) из 40\% олеиновой кислоты и 20\% технического стеарина, что объясняется воздействием ПАВ на удаление окисных пленок. В ряде случаев в смесь добавляют до $10 \% \mathrm{HCl}$ для удаления продуктов коррозии. В конечном итоге, шероховатость хромированной поверхности зависит от технологических факторов притирки чугунным притиром с суспензией абразивных зерен, окружной скорости вращения детали, скорости продольного перемещения притира, давления притира на обрабатываемую поверхность. Давление притира должно быть оптимальным $\left(3 \cdot 10^{5}\right.$ Па), т.к. оно может не только уменьшить шероховатость, но из-за глубокого внедрения абразива привести к ее росту, а в ряде случаев к выкрашиванию, образованию продольных рисок, схватыванию. Аналогично сказывается резкое повышение температуры притираемой поверхности, особенно при обработке с высокими окружными скоростями вращения. Шероховатость поверхности с учетом окружной скорости детали сначала уменьшается, а затем растет. Притирка с пастой ГОИ позволяет получить шероховатость $\mathrm{R}_{\mathrm{a}}=0,02-0,04$ мкм. Рост скорости продольной подачи притира до 4м/мин уменьшает параметры шероховатости, а далее не влияет. Более низкая шероховатость получается при определенном соотношении скорости продольной подачи и окружной скорости вращения детали $[13,14]$. Для механизированной притирки оно должно быть равно 1/2:1/5. Продолжительность обработок определяет только припуск, т.к. механизированной притиркой можно за 5-10 минут удалить 5-20 мкм хрома на диаметр (табл. 3) 
Таблица 3 - Влияние размера абразивного зерна на шероховатость поверхности

\begin{tabular}{|l|c|c|c|c|c|}
\hline $\begin{array}{l}\text { Paзмер зерна, мкм } \\
\text { Grain size, microns }\end{array}$ & 10 & 20 & 30 & 50 & \\
\hline \multirow{4}{*}{$\begin{array}{l}\text { Шероховатость, мкм } \\
\text { Roughness, microns }\end{array}$} & 0,062 & 0,075 & 0,092 & 0,12 & зеленый карбид кремния в пасте \\
\cline { 2 - 6 } & 0,062 & 0,072 & 0,082 & 0,12 & электрокорунд с маслом \\
\cline { 2 - 6 } & 0,035 & 0,052 & 0,072 & 0,10 & электрокорунд в пасте \\
\cline { 2 - 6 } & 0,075 & 0,085 & 0,12 & 0,15 & зеленый карбид кремния с маслом \\
\hline
\end{tabular}

Окружная скорость 13 м/мин; скорость продольной подачи 4,5 м/мин; давление 2,5·105 Па. Зависимость шероховатости от экспериментальных данных можно выразить:

$$
\begin{aligned}
& \mathrm{R}_{\mathrm{a}}(\text { мкм })=0,152-0,11 \mathrm{~V}_{\text {вр }} \cdot \mathrm{P}+0,000216 \mathrm{~V}_{\text {вр }}- \\
& -0,006095 \mathrm{~V}_{\text {прод }}^{2}+0,0113 \mathrm{P}^{2}+0,004172 \mathrm{~V}_{\text {вр }}- \\
& -0,0004557 \mathrm{~V}_{\text {вр }} \cdot \mathrm{V}_{\text {прод }}-0.0283 \mathrm{P}- \\
& -0,0007087 \mathrm{~V}_{\text {прод }} \cdot \mathrm{P}
\end{aligned}
$$

В зависимости от условий эксплуатации детали делятся на три основные группы, работающие: 1) при динамических нагрузках (коленчатые валы, оси редукторов, валы турбин и т.д.); 2) до износа при относительно низких нагрузках (цилиндры, плунжеры и т.д.); 3) при длительных статических нагрузках (болты, штоки цилиндров, шарниры и т.д.).

Технологическая последовательность восстановления изношенных деталей гальваническими покрытиями, в зависимости от типа дефектов, может заключаться в нанесении непрерывного слоя покрытия на всю поверхность детали или локальном зарастании дефекта оставшейся поверхностью, изолированной соответствующими материалами, и последующая механическая обработка (или без нее).

В то же время пластические свойства стали при статическом кручении и ударном изгибе снижаются из-за увеличения хрупкости поверхностного слоя при увеличении толщины покрытия и адгезии хрома после многократного отпуска. Выносливость стальных деталей с гальваническим покрытием можно поддерживать на уровне износостойкости сталей без гальванического покрытия, используя комплекс технологических мероприятий, определенных конкретными условиями эксплуатации. Следовательно, гальваническое покрытие может использоваться для повышения износостойкости и коррозионной стойкости при восстановлении размеров во всех случаях, когда используются детали без покрытий. Это позволяет значительно повысить надежность и расширить ассортимент восстановленных деталей, снизить расход запчастей и снизить затраты на ремонт. Во время работы сопрягаемые поверхности неподвижно соединенных частей изменяют свои геометрические размеры из-за фреттинг-коррозии. В результате экструзии возникают глубокие риски и надир, поэтому такие поверхности шлифуют перед удалением дефектного слоя, а затем восстанавливают путем глажения или хромирования. Кроме того, если твердость стального осадка мож- но варьировать, то осадок хрома всегда является твердым.

\section{Выводы}

Из всех форм поляризующего тока наиболее интенсивное воздействие на показатели процесса хромирования, структуру и свойства покрытия оказывают импульсный и реверсивный токи. При импульсном электролизе можно управлять составом компонентов сплавов хрома и получать комбинированные (двухслойные - хром беспористый и, пористый) покрытия с заданными свойствами из одного электролита. Хромирование на импульсном и реверсивном токах экономичнее, чем стационарный электролиз. За счет повышения равномерности, снижения шероховатости покрытия, отсутствия дендритов возможно значительное снижение нормативной толщины покрытия и исключение механической обработки.

\section{Список литературы}

1.А. с. 1592405 РСФСР. Электролит для получения покрытий $\mathrm{Cr}-\mathrm{Mo} \mathrm{/} \mathrm{Озеров} \mathrm{В.} \mathrm{М.}$

2.Астанин, В. К. Восстановление изношенных деталей сельскохозяйственной техники гальваническим хромированием / В. К. Астанин, Н.Ю. Стекольникова, Ю. А. Стекольников, Д. И. Максимов // Вестник ТГТУ. - 2016. - № 4. - с. 679-686.

3.Михайлов, А. А. Обработка деталей с гальваническими покрытиями / А. А Михайлов. - Москва : Машиностроение, 1981. - 144 с.

4.Молчанов, В. Ф. Эффрективность и качество хромирования / В. Ф. Молчанов. - Киев : Техника, 1978. - 230 c.

5.Пат. 2057208 Российская Федерация, МПК С 25 D 3/10. Электролит хромирования / Чернышова В. Н. ; заявитель и патентообладатель Воронежский завод радиодеталей. - № 9292012659; заявл. 16.12.1992 ; опубл. 27.03.1996.

6.Пат. 2094540 Российская Федерация, МПК C 25 D 3/10. Электролит хромирования / Фаличева А. И. [и др.] ; заявитель и патентообладатель Воронежский политехнический институт. - № 93036235/25 ; заявл. 13.07.1993 ; опубл. 27.10.1997.

7.Полищук, С.Д. Условия осаждения покрытий латуни в процессе ремонта сельскохозяйственной техники/ С.Д. Полищук, Д.Г. Чурилов, А.В.Шемякин, В.В.Терентьев //Известия Юго-Западного государственного университета. Серия: Техника и технологии. -2017. -№ 4 (25). -С. 39-48.

8.Горохова, М.Н. Технологические особенности электро - искрового упрочнения/ М.Н. Горохова, Д.Г. Чурилов, С.Д. Полищук //Вестник Рязанского государственного агротехнологического универси- 
тета им. П.А. Костычева. -2012. - 1 (13). -С. 38-43.

9.Петров, Ю. Н. Восстановление изношеных деталей гальваническими и полимерными покрытиями / Ю. Н. Петров // Межвузовский сборник статей. - Кишинев, 1982. - С. 27-31.

10.Севостьянов Б. М. Хромирование на нестационарных режимах / Б. М. Севостьянов. - Киев : Наук. Думка, 1992. - 212 с.

11.Чурилов, Д.Г. Теоретические исследования напряженности в системе покрытие-основа в процессе реализации комбинированного способа восстановления изношенных деталей машин // Политематический сетевой электронный научный журнал Кубанского государственного аграрного университета. - 2012. - № 82. - С. 232-258.
12.Чурилов Д.Г. Комбинированный способ восстановления и упрочнения деталей сельскохозяйственной техники типа «вал» с использованием легированных ферро- магнитных порошков: диссертация ... кандидата технических наук : 05.20.03 / Д.Г. Чурилов.- Мичуринский государственный аграрный университет. Мичуринск, 2014

13.Цуканов, О. В. Исследование хромирования в разбавленных электролитах для уменьшения экологической опосности : автореф. дис. ... канд. хим. наук : 02.00.04 / О. В. Цуканов. - Липецк, 2004. -23 c.

14.Черненко, В. И. Прогрессивные импульсные и переменнотоковые режимы электролиза / В. И. Черненко. - Киев : Наук. Думка, 1988. - 176 с.

\section{GRAIN SEEDS GERMINATION STIMULATION WITH INCOHERENT RED LIGHT: THEORY AND PRACTICE}

Churilov Dmitry G. - Candidate of Technical Science, Associate Professor of the Department of Metal Technology and Machine Repair, churilov.dmitry@yandex.ru

FSBEI HE "Ryazan State Agrotechnological University Named after P.A. Kostychev"

Stekolnikov Yuri A. - Ph.D. in Chemistry, Professor, Department of Chemistry and Biology, FSBEI HE "Elets State University Named after I.A. Bunin", chimic57@mail.ru.

Arapov Ilya S. - Graduate Student of the Department of Metal Technology and Machine Repair, arapow. ilya@yandex.ru

Shemyakin Alexander $\boldsymbol{V}$. - Doctor of Technical Science, Head of the Department of Organization of Transport Processes and Life Safety Activities, shem.alex62@yandex.ru

Andreev Konstantin P. - Candidate of Technical Science, Associate Professor of the Department of Organization of Transport Processes and Life Safety Activities, kosta066@yandex.ru

FSBEI HE "Ryazan State Agrotechnological University Named after P.A. Kostychev"

In the technology for repairing worn parts by chromium plating, non-stationary methods of applying chromium are used to improve the reliability and durability of the repaired parts by changing the conditions of electrocrystallization. The main forms of the polarizing current both pulsed and reverse, which most intensively affect the indices of the chromium plating process, the structure and properties of the coating, are considered. The work gives recommendations on the current, temperature conditions of the deposition of chromium, the composition of the baths used to restore and harden parts. The electrolysis modes and sediment thickness, which prioritize such physical and mechanical properties of the coating as adhesion to the substrate, roughness, porosity, corrosion resistance, strength and endurance limits, are considered. To obtain a high hiding power in diluted electrolytes, the following modes are recommended: for a reverse current, the duration of the cathode pulse is 1.5-3 minutes, with respect to the anode current of 40-50 and the ratio of the amplitudes of the cathode-anode current densities from 2 to 3, the optimum cathode current density of 160 $-180 \mathrm{~A} / \mathrm{dm}^{2}$ and temperature of $60-65^{\circ} \mathrm{C}$. For impulse current the duration is $1.5-2.5 \mathrm{~min}$, duty cycle is 1.0 - 1.15 and cathode current density is $140-160 \mathrm{~A} / \mathrm{dm}^{2}$. Significant improvement of the physical-mechanical properties of coatings can be achieved using electrolytes with additives of organic and inorganic substances, which allows reducing the hydrogen content in the coating during the deposition process, and in some cases, will allow refusing subsequent heat treatment. Lead materials with small additives of antimony, bismuth, and tin are recommended as anodes. This allows reducing their dissolution rate in the chromium electrolyte and excluding the operation of mechanical cleaning of the anodes during the operation of the baths, as well as reducing energy consumption by $30 \%$.

Key words: repair of agricultural machinery parts, chromium plating, electrolytes, non-stationary electrolysis modes, physical-mechanical properties of chromium coatings.

\section{Literatura}

1.A. s. 1592405 RSFSR. Elektrolit dlya polucheniya pokrytiy Cr-Mo / Ozerov V. M.

2.Astanin V. K. Vosstanovleniye iznoshennykh detaley sel'skokhozyaystvennoy tekhniki gal'vanicheskim khromirovaniyem / V. K. Astanin, N.YU. Stekol'nikova, YU. A. Stekol'nikov, D. I. Maksimov // Vestnik TGTU. 2016. - № 4. - s. 679-686.

3.Mikhaylov A. A. Obrabotka detaley s gal'vanicheskimi pokrytiyami / A. A Mikhaylov. - Moskva : Mashinostroyeniye, 1981. - 144 s.

4.Molchanov V. F. Effektivnost'i kachestvo khromirovaniya/V. F. Molchanov. - Kiyev: Tekhnika, 1978. - 230 s.

5.Pat. 2057208 Rossiyskaya Federatsiya, MPK S 25 D 3/10. Elektrolit khromirovaniya / Chernyshova V. N. ; zayavitel' i patentoobladatel' Voronezhskiy zavod radiodetaley. - № 9292012659; zayavl. 16.12.1992 ; 
opubl. 27.03.1996.

6.Pat. 2094540 Rossiyskaya Federatsiya, MPK S 25 D 3/10. Elektrolit khromirovaniya / Falicheva A. I. [i dr.] ; zayavitel' i patentoobladatel' Voronezhskiy politekhnicheskiy institut. - № 93036235/25 ; zayavl. 13.07.1993 ; opubl. 27.10.1997.

7.Polishchuk S.D. Usloviya osazhdeniya pokrytiy latuni v protsesse remonta sel'skokhozyaystvennoy tekhniki/ S.D. Polishchuk, D.G. Churilov, A.V.Shemyakin, V.V.Terent'yev I/lzvestiya Yugo-Zapadnogo gosudarstvennogo universiteta. Seriya: Tekhnika i tekhnologii. -2017. -№ 4 (25). -S. 39-48.

8. Gorokhova M.N. Tekhnologicheskiye osobennosti elektro - iskrovogo uprochneniya/ M.N. Gorokhova, D.G. Churilov, S.D. Polishchuk /Nestnik Ryazanskogo gosudarstvennogo agrotekhnologicheskogo universiteta im. P.A. Kostycheva. -2012. - 1 (13). -S. 38-43.

9.Petrov YU. N. Vosstanovleniye iznoshenykh detaley gal'vanicheskimi i polimernymi pokrytiyami / YU. N. Petrov // Mezhvuzovskiy sbornik statey. - Kishinev, 1982. - S. 27-31.

10. Sevost'yanov B. M. Khromirovaniye na nestatsionarnykh rezhimakh / B. M. Sevost'yanov. - Kiyev : Nauk. Dumka, 1992. - 212 s.

11. Churilov D.G. Teoreticheskiye issledovaniya napryazhennosti $v$ sisteme pokrytiye-osnova $v$ protsesse realizatsii kombinirovannogo sposoba vosstanovleniya iznoshennykh detaley mashin // Politematicheskiy setevoy elektronnyy nauchnyy zhurnal Kubanskogo gosudarstvennogo agrarnogo universiteta. - 2012. - № 82. - S. 232-258.

12. Churilov D. G. Kombinirovannyy sposob vosstanovleniya i uprochneniya detaley sel'skokhozyaystvennoy tekhniki tipa "val» s ispol'zovaniyem legirovannykh ferro- magnitnykh poroshkov: dissertatsiya ... kandidata tekhnicheskikh nauk:05.20.03/D.G. Churilov.-Michurinskiy gosudarstvennyy agrarnyy universitet. Michurinsk, 2014

13.Tsukanov O. V. Issledovaniye khromirovaniya $v$ razbavlennykh elektrolitakh dlya umen'sheniya ekologicheskoy oposnosti : avtoref. dis. ... kand. khim. nauk: 02.00.04/O. V. Tsukanov. - Lipetsk, 2004. - 23 s.

14. Chernenko V. I. Progressivnyye impul'snyye i peremennotokovyye rezhimy elektroliza / V. I. Chernenko. - Kiyev: Nauk. Dumka, 1988. - 176 s.

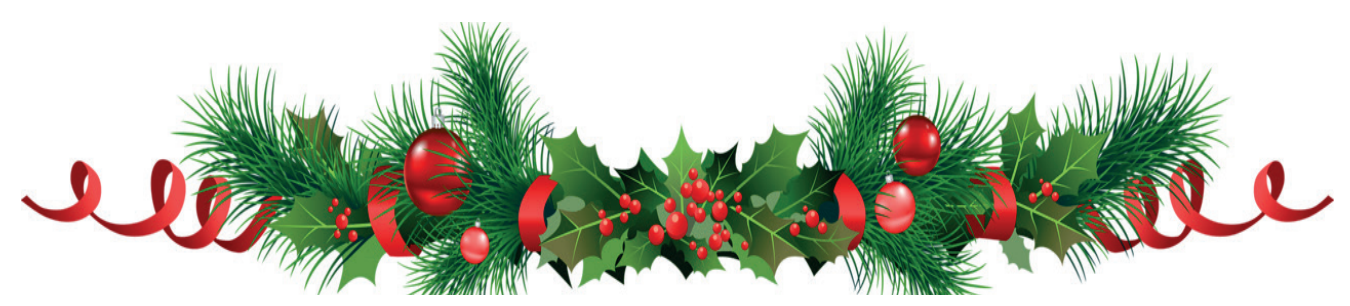




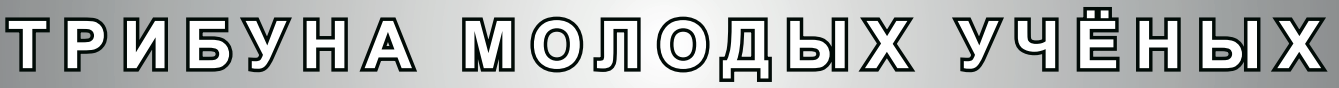

УДК 633.853.483:631.894

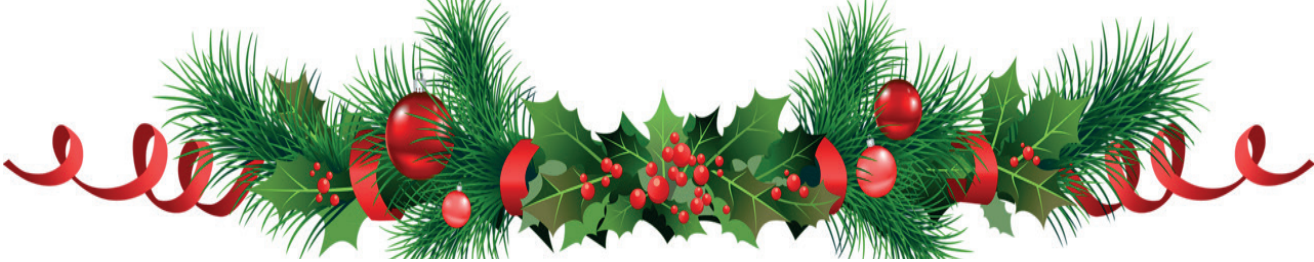

УРОЖАЙНОСТЬ ГОРЧИЦЫ БЕЛОЙ ПРИ ИСПОЛЬЗОВАНИИ СОВРЕМЕННЫХ ЖИДКИХ УДОБРЕНИЙ В НЕЧЕРНОЗЕМНОЙ ЗОНЕ РОССИИ

ВИНОГРАДОВ Дмитрий Валериевич, д-р биол. наук, профессор, зав. кафедрой агрономии и агротехнологий, vdv-rz@rambler.ru

НАУМЦЕВА Ксения Викторовна, аспирант кафредры агрономии и агротехнологий, ksyи. dyachuk.93@mail.ru

ЛУПОВА Екатерина Ивановна, канд. биол. наук, доцент кафредры агрономии и агротехнологий, katya.lilu@mail.ru

СОКОлОВ Андрей Андреевич, ст. лаборант кафедры агрономии и агротехнологий, falconagro@mail.ru

АНТОШИнА Ольга Алексеевна, канд. с.х. наук, доцент кафредры лесного дела, агрохимии, экологии, селекции и семеноводства

Рязанский государственный агротехнологический университет имени П.А. Костычева

В статье рассмотрены вопросы использования современных жидких удобрений в условиях Нечерноземной зоны России. В последнее время интересы потребителей возросли, агропромышленные предприятия ежегодно вносят дополнения в технологию выращивания масличных культур и их переработки. Получили распространение такие перспективные масличные культуры как горчица белая, соя, лен масличный, рапс, сурепица яровая, рыжик яровой и другие. В 2018 году посевная площадь, занимаемая масличными культурами, составляла 121,1 тыс.га (+ 25,7 тыс.га к 2017 году). Из них максимально 50,2 тыс.га отводится рапсу и 42,2 тыс.га подсолнечнику. В 2019 году масличными культурами в Рязанской области было занято более 150 тыс.га. Целью исследований явилось изучение действия листовых подкормок многокомпонентными жидкими удобрениями в двух фразах вегетации в посевах горчицы белой. В условиях полевых опытов проведены исследования особенностей роста и развития горчицы белой при использовании комплекса удобрений. В исследованиях растения получали необходимое количество влаги и тепла, а комплексное жидкое микроудобрение обеспечило более интенсивный рост растений, увеличило показатели фоотосинтеза. Максимальное количество семян было получено у сорта Люция, на варианте Азотовит1 л/га + Фосфатовит 1 л/га + РауАктив 1 л/га - 21,2 и/га. Используемые препараты способствовали также увеличению урожайных показателей в сорте Чайка на варианте Азотовит1 л/га + Фосфратовит1 л/га + РауАктив 1 л/га с урожайностью 18, 8 ш/а и Рапсодия - 19,5 щ/га, по сравнению с контрольным вариантом.

Ключевые слова: горчица белая, жидкие удобрения, листовые подкормки.

\section{Введение}

Условия Рязанской области, которая находится в Нечерноземной зоне России, благоприятны для выращивания масличных растений [5].

Производство масличных культур в регионе за последнее время значительно увеличилось [3]. Получили распространение такие перспективные масличные культуры как горчица белая, соя, лен масличный, рапс, сурепица яровая, рыжик яровой и другие.

В 2018 оду посевная площадь, занимаемая масличными культурами, составляла 121,1 тыс. га (+ 25,7 тыс. га к 2017 году). Из них 50,2 тыс. га отводилось рапсу и 42,2 тыс. га подсолнечнику. В 2019 году масличными культурами в Рязанской области было занято более 150 тыс. га [9].

Альтернативой культуры подсолнечника могла бы быть горчица белая, которая дает возможность увеличить производство растительного масла без ухудшения состояния почв.

Горчица белая является ценной масличной культурой $[4,6]$. В новых сортах горчицы содержится $35-50 \%$ масла, которое используется при производстве консервов, маргарина, в хлебопекарном и кондитерском деле [2]. Из белой горчицы получают высококачественное пищевое масло, содержание которого в семенах достигает $30-40 \%[3,7]$.

В последнее время интересы потребителей к культуре возросли, агропромышленные предприятия ежегодно вносят дополнения в технологию выращивания горчицы белой [2].Немаловажным фрактором является и то, что короткий период вегетации значительно сокращает природные риски недобора урожая, а денежная выручка от реализации горчицы может поступать уже в июле - первой половине августа.

() Виноградов Д. В., Наумцева К. В., Лупова Е. И., Соколов А. А., Антошина О. А., 2019 г. 
Современным направлением в повышении урожайности может стать внедрение в технологию выращивания многокомпонентных жидких удобрений, которые способны улучшить питание растений за счет набора микроэлементов. Это представляет определенный научный и практический интерес, что и определило актуальность и направление исследований.

\section{Объекты и методы исследования}

Исследования проведены на опытной агротехнологической станции ФГБОУ ВО РГАТУ (УНИЦ «Агротехнопарк») Рязанского района Рязанской области на серых лесных почвах, в 2018-2019гг.

Цель исследований - изучение действия многокомпонентных жидких удобрений на урожайность сортов горчицы белой в условиях Рязанской области.

Почва участка характеризовалась средним содержанием фоосфора (12,1-12,5 мг/100 г почвы) и калия (8,0-9,1 мг/100 г почвы). Содержание гумуса в почве было на уровне 2,5-3,1\%. В зависимости от глубины взятия образца почва была подкисленной, в среднем по слою 0-40 см кислотность составила рН 5,2-5,3.

В качестве объекта исследования были взяты сорта горчицы белой: Рапсодия - ГНУ ВНИИ рапса, г. Липецк, Люция - оригинатор Пензенский НИИСХ, Чайка - семеноводство сорта ведётся научным институтом селекции, г. Николаев, Украина

В исследованиях использовались жидкие удобрения Интермаг профи, Азотовит, Фосфатовит РауАктив по следующей схеме:

1) контроль - без обработки;

2) листовая подкормка Интермаг Профи, 2-4 настоящих листа+фаза бутонизации+инсектицид, 1 л/га;

3) листовая подкормка Азотовит 1 л/га + Фосфратовит 1 л/га, 2-4 настоящих листа;

4) листовая подкормка Интермаг Профи 1 л/га+Азотовит 1 л/га+Фосфратовит1 л/га, 2-4 настоящих листа;

5) листовая подкормка Азотовит1 л/га+Фосфатовит 1 л/га, 2-4 настоящих листа + Ра-
уАктив 1 л/га - фаза бутонизации-цветения (30\% от максимальной листовой поверхности, до цветения). Расход рабочей жидкости - 200 л/га.

Агротехнические мероприятия по возделыванию горчицы выполнялись в соответствии с существующими зональными рекомендациями.

Подготовка почвы включала в себя лущение стерни, зяблевую вспашку на глубину пахотного слоя 20-22см, ранневесеннее боронование, далее культивация 10-12 см; непосредственно перед посевом горчицы культивация 2-4 см [8]. Предпосевная культивация включала внесение удобрений, фон $\mathrm{N}_{125} \mathrm{P}_{60} \mathrm{~K}_{60}$. Посев осуществлялся в первую декаду мая. Норма высева семян - 2,5 млн шт. всхожих семян/га, фрактически 15 кг/га. Глубина заделки семян - 1,5-2 см. Способ посева - рядовой, сеялкой ССНТ-16.

В опыте проводили обработку пестицидами против вредителей культуры. В период от всходов до появления четырех настоящих листьев и в фазу бутонизации для уничтожения крестоцветной блошки и рапсового цветоеда проводилась обработка инсектицидом Фастак 0,15 л/га с нормой расхода рабочей жидкости 250 л/га. Уборка механизированная,Тарион-2010. Высота среза находилась на уровне 6-8 см.

Учеты и наблюдения в период вегетации горчицы проведены на основе «Методики госсортоиспытания сельскохозяйственных культур» (1985) [8]. Математическую обработку результатов выполняли по Б.А. Доспехову (1985) и с помощью программ на ЭВМ [1]. Общая площадь делянки $30 \mathrm{~m}^{2}$, учетная $20 \mathrm{~m}^{2}$. Повторность четырехкратная.

\section{Результаты исследований}

В опыте период появления всходов у горчицы белой составлял 6-10 дней. При благоприятных условиях всходы появлялись раньше. Полевая всхожесть зависела от температуры почвы на глубине посева семян, температуры воздуха, влажности почвы, наличия почвенных вредителей, а также почвенной корки. Показатели посевных качеств сортов горчицы представлены в таблице 1.

Таблица 1 - Показатели посевных качеств сортов горчицы белой

\begin{tabular}{|c|c|c|c|c|}
\hline \multirow{2}{*}{ Сорт } & \multirow{2}{*}{\begin{tabular}{|c|} 
Энергия прораста- \\
ния, \% \\
\end{tabular}} & \multirow{2}{*}{$\begin{array}{c}\text { Лабораторная } \\
\text { всхожесть, \% } \\
\end{array}$} & \multicolumn{2}{|c|}{ Полевая всхожесть, } \\
\hline & & & шт/M $/ M^{2}$ & $\%$ \\
\hline Люция & 90,0 & 94,0 & 231,6 & 92,6 \\
\hline Рапсодия & 88,0 & 92,0 & 228,5 & 91,4 \\
\hline Чайка & 86,0 & 95,0 & 229,9 & 93,3 \\
\hline
\end{tabular}

Сортовые показатели имели высокую энергию прорастания и всхожесть, что обеспечивало получение дружных всходов и приросты урожайности. В среднем, наибольшая полевая всхожесть была получена у сорта Люция - 231,6шт/М².

Продолжительность наступления межфразных периодов у растений сортов горчицы белой тесно связана с метеорологическими условиями года, за период от посева до созревания. В опыте погодные условия существенно влияли на прохождение растением фенофраз. Полный период развития от начала всходов до созревания у горчицы белой сорта Чайка и Люция составил 83-90 дней, у сорта Рапсодия - 64-76.

Появление ранних всходов было отмечено у сорта Люция, продолжительность периода «посев - всходы» составляла 6-8 дней. Фаза цветения наблюдалась через 20-25 дней после появления всходов и продолжалась 25-30 дней и приходилась на июнь-начало июля. Созревание стручков и семян в стручках наблюдалось со второй половины июля по август. Таким образом, при посеве в 
первую декаду мая горчица белая достигает фазы полного созревания во второй декаде августа.

Отметим, сорт Люция характеризовался ран- ним цветением (рис. 1). Это позволило сократить периоды фаз вегетации, что является важным фактором в засушливых условиях.

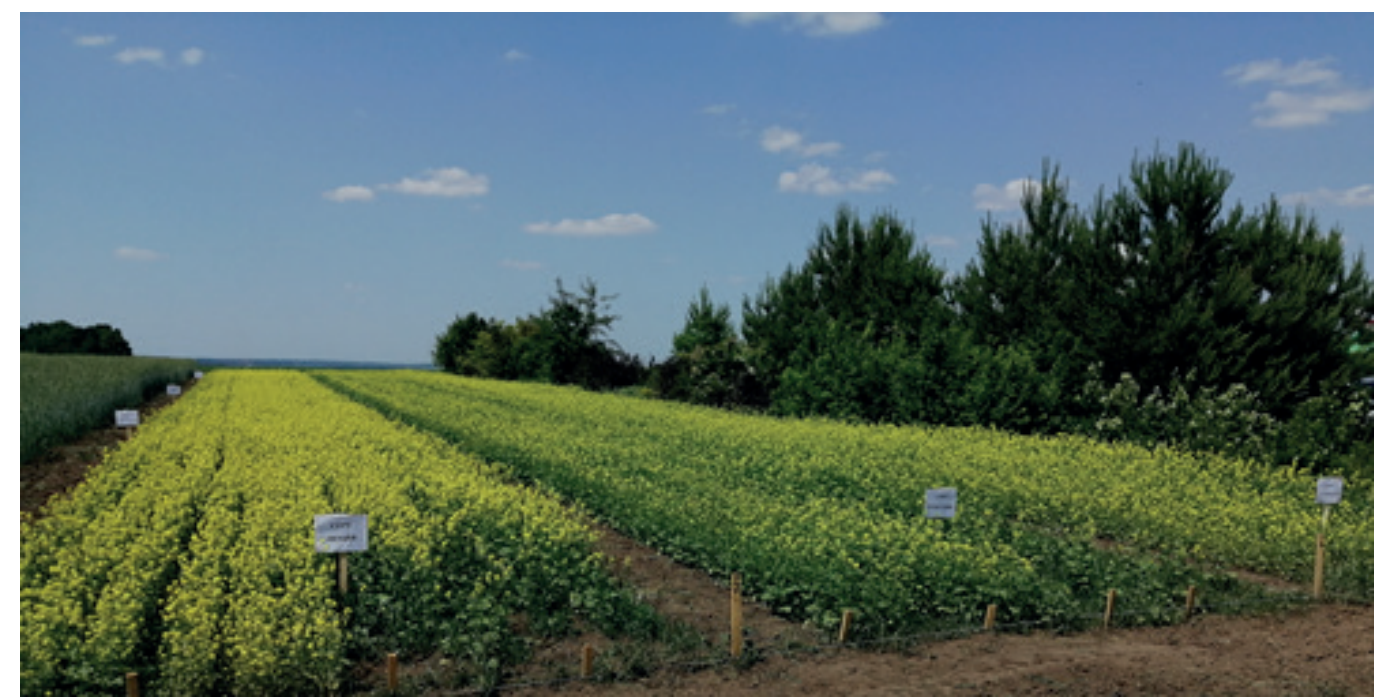

Рис. 1 - Сорта горчицы белой в зависимости от варианта исследований в фазу цветения. Раннее цветение сорта Люция.

Изучение многокомпонентных препаратов в полевых условиях подтвердило их действие на рост и развитие горчицы белой. В опыте листовая подкормка растений способствовала эффективному проникновению микроэлементов в растения. Отличительная особенность препарата Интермаг Профи - наличие титана, который является мощным активатором роста растений и усилителем переноса питательных веществ. Внесение многокомпонентных жидких удобрений в фазу 2-4 настоящих листьев позволяло скорректировать дисбаланс микроэлементов и помогало растению горчицы белой набрать силу для активного наращивания вегетативной массы. Именно к этому времени исследуемая культура нуждалась в азотном питании. В фразе цветения и плодообразования горчица хорошо отзывалась на повторную дозу макро-микроэлементов, и, как следствие, листовые подкормки влияли на продуктивность.

Листовая подкормка растений способствовала лучшей сохранности растений. Так, наибольшая сохранность растений горчицы отмечалась у сорта Люция в 2019 году, на варианте Азотовит+Фосфратовит+РауАктив - 90,1 \%, что выше контроля на 1,5\%.

Высота стеблестоя горчицы белой при раннем сроке посева равнялась 76,3-89,1 см (рис.2).

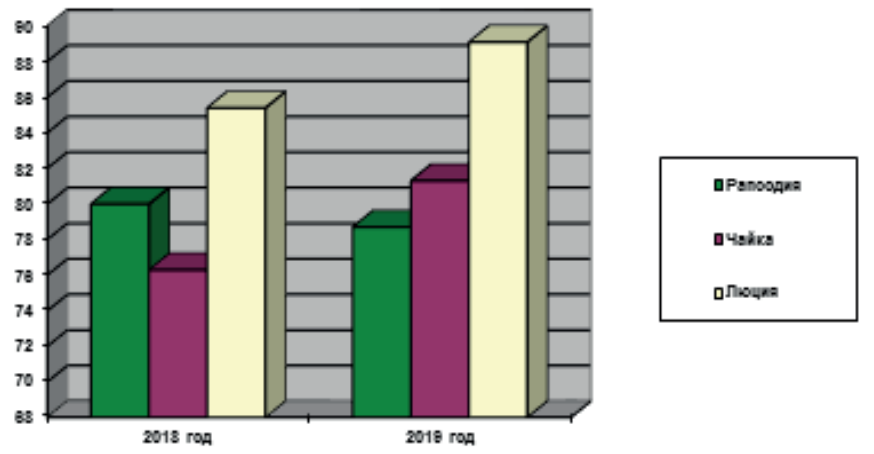

Рис 2 - Высота растений сортов горчицы белой, см

Максимальный эфрфект интенсивного роста и развития растений отмечался в 2019 году у сорта Люция, в варианте обработки Азотовит 1л/га+Фосфратовит 1л/га+ РауАктив 1л/га - 89,1 см, что выше, чем у сортов Рапсодия и Чайка, на 10 см и 8 см соответственно.
На вариантах с листовой обработкой, биологическими удобрениями повышались фотосинтетические показатели и показатели структуры урожая. Максимальное развитие листового аппарата - основного фотосинтетического органа, было отмечено у растений сорта Люция - 
9,9 тыс.м²/га, что на 0,4 тыс.м²/га больше этого показателя у сорта Рапсодия и на 0,8 тыс.м²/га у сорта Чайка (в среднем за годы исследований). Результаты исследований показали, что листовая поверхность в расчете на единицу площади различалась между сортами незначительно.

Показатель массы 1000 семян варьировался по сортам незначительно и находился в переделах 5,0-5,1 г (соответствует средним значениям для этих сортов).

Использование биоудобрений способствовало лучшему формированию плодов у растения. В 2018 году наибольшее число стручков отмечалось у сорта Люция - 38,0 шт./раст., контроль характеризовался показателем 32,5 шт./раст. Данная динамика прослеживалась в 2019 году.

Количество семян в стручке практически не зависело от применения листовых подкормок многокомпонентными жидкими удобрениями. Максимальное число семян в плоде было получено в 2019 году у сорта Люция, вариант Азотовит 1л/га+Фосфратовит 1л/га+РауАктив 1л/га - 6шт. в одном стручке, что выше контрольного варианта в 1,5 раза.

Продуктивность зерновых культур находится в зависимости от потенциальных возможностей растения: погодных, агротехнических и биологических фракторов. Важное место среди последних занимают многочисленные инфекционные болезни, они поражают растения на всех этапах их органогенеза - от прорастания семян до полной спелости зерна. Полученные данные анализа урожайности сортов горчицы белой представлены в таблице 2.

Таблица 2 - Влияние микроудобрений на урожайность горчицы белой, в среднем за 2018-2019 гг.

\begin{tabular}{|c|c|c|c|c|}
\hline \multirow{2}{*}{ Сорт } & \multirow{2}{*}{ Варианты } & \multicolumn{3}{|c|}{ Урожайность,ц/га } \\
\hline & & 2018 г & 2019 г & Среднее \\
\hline \multirow[t]{5}{*}{ Рапсодия } & Контроль (без удобрений) & 14,0 & 16,1 & 15,0 \\
\hline & Интермаг Профри & 16,4 & 18,8 & 17,6 \\
\hline & Азотовит + Фосфратовит & 15,6 & 17,8 & 16,7 \\
\hline & $\begin{array}{l}\text { Интермаг Профи + Азото- } \\
\text { вит + Фосфратовит }\end{array}$ & 17,1 & 18,9 & 18,0 \\
\hline & $\begin{array}{l}\text { Азотовит + Фосфратовит + } \\
\text { РауАктив }\end{array}$ & 17,6 & 19,5 & 18,5 \\
\hline \multirow[t]{5}{*}{ Чайка } & Контроль (без удобрений) & 12,7 & 15,0 & 13,8 \\
\hline & Интермаг Профии & 14,0 & 17,4 & 15,7 \\
\hline & Азотовит + Фоссратовит & 13,1 & 16,4 & 14,7 \\
\hline & $\begin{array}{l}\text { Интермаг Профи + Азото- } \\
\text { вит + Фосфратовит }\end{array}$ & 15,4 & 18,3 & 16,8 \\
\hline & $\begin{array}{l}\text { Азотовит + Фосфратовит + } \\
\text { РауАктив }\end{array}$ & 16,1 & 18,8 & 17,4 \\
\hline \multirow[t]{5}{*}{ Люция } & Контроль (без удобрений) & 16,6 & 18,0 & 17,3 \\
\hline & Интермаг Профии & 18,7 & 20,7 & 19,7 \\
\hline & Азотовит + Фосфратовит & 18,3 & 19,7 & 19,0 \\
\hline & $\begin{array}{l}\text { Интермаг Профии + Азото- } \\
\text { вит + Фосфратовит }\end{array}$ & 18,9 & 20,3 & 19,6 \\
\hline & $\begin{array}{l}\text { Азотовит + Фосфратовит + } \\
\text { РауАктив }\end{array}$ & 19,9 & 21,2 & 20,5 \\
\hline \multicolumn{2}{|c|}{$\begin{array}{l}\mathrm{HCP}_{05} \text { взаимодействия AB } \\
\text { по фрактору А (сорт) } \\
\text { по фрактору В (микроудобрения) }\end{array}$} & $\begin{array}{l}1,08 \\
0,48 \\
0,62\end{array}$ & $\begin{array}{l}1,08 \\
0,48 \\
0,62\end{array}$ & \\
\hline
\end{tabular}

Растения сортов горчицы белой имели короткий период вегетации. В годы исследований рас- тения получили необходимое количество влаги и тепла, что обеспечило их оптимальный рост и 
развитие. В свою очередь, применение жидких микроудобрений способствовало увеличению урожайности семян горчицы белой на всех вариантах обработки по сравнению с контролем.

Максимальное количество семян было получено сортом Люция на варианте Азотовит 1 л/га+ Фосфатовит 1 л/га+РауАктив1 л/га - 21,2 ц/га в 2019 году (сорт Чайка - 18,8 ц/га, сорт Рапсодия 19,5 ц/га), что выше контроля на 3,2 ц/га.

\section{Выводы}

Итак, в исследованиях комплексное жидкое микроудобрение обеспечило более интенсивный рост растений, все исследуемые препараты оказали положительное влияние на структуру урожая, что привело к увеличению урожайности семян горчицы белой всех сортов по сравнению с контрольным вариантом.

В среднем за два года исследований применение жидких удобрений дает максимальную урожайность (20,5 ц/га у сорта Люция на варианте Азотовит 1 л/га+Фосфатовит 1 л/га+РауАктив1 л/ га), увеличивает количество плодов и семян (6-8 шт./раст.); массу 1000 семян (1,0 г/ раст.) относительно контрольного варианта.

Полевые испытания 2018-2019 года позволяют рекомендовать многокомпонентные жидкие удобрения типа Азотовит, Фосфатовит, РауАктив с расходом препарата 1,0 л/га для применения в сельскохозяйственном производстве при возделывании горчицы белой.

\section{Список литературы}

1.Доспехов, Б. А. Методика полевого опыта с основами статистической обработки результатов исследований [Текст] / Б.А. Доспехов. - 5-е изд., доп. и перераб. - М.: Агропроиздат, 1985. -351 с.

2. Практикум по растениеводству [Текст] / Д. В. Виноградов, Н. В. Вавилова, Н. А. Дуктова, Е. И. Лупова. - Рязань, 2018. - 320с.
3.Виноградов, Д. В. Продуктивность горчицы в зависимости от уровня минерального питания [Текст] / Д.В. Виноградов // Вестник Рязанского государственного агротехнологического университета им. П.А. Костычева. - 2009. - № 3. - С. 39-42

4.Виноградов, Д. В. Возможность использования масличных культур в качестве сырья для производства экологически чистого топлива [Текст] / Д. В. Виноградов, Н. В. Бышов, Е. И. Лупова // Молодёжь в поисках дружбы : Материалы Республиканской научно-практической конференции, посвященный к 20-летию Национального примирения и году Молодежи в Республике Таджикистан. Институт энергетики Таджикистана, 2017. - C. 28-33.

5.Крючков, М. М. Горчица белая и рапс как важные элементы в биологизации земледелия [Текст] / М. М. Крючков, И. В. Смертенков // Здоровая окружающая среда - основа безопасности регионов : сборник трудов первого международного экологического форума в Рязани: посвящается году экологии в РФ. - Рязань, 2017. - С. 228-231.

6.Лупова, Е. И. Технология производства яровых рапса и сурепицы в Нечерноземной зоне России [Текст] : учебное пособи / Е. И. Лупова, Д. В. Виноградов. - Рязань, 2018. - 86 с.

7. Практикум по земледелию [Текст] / А. С. Мастеров, Д. В. Виноградов, М. В. Потапенко, С. И. Трапков, П. Н. Балабко, Е. И. Лупова. - Рязань, 2018. - 256 c.

8.Методика государственного сортоиспытания сельскохозяйственных культур [Текст] / под ред. М. А. Федина. - Москва, 1983. - Вып. 3. - 184 с.

9.Официальный сайт Федеральной службы государственной статистики по Рязанской области [Электронный ресурс]. - Режим доступа: http:// www.gks.ru. (Дата обращения: 09.10.2019).

\section{THE YIELD OF WHITE MUSTARD IN THE USE OF MODERN LIQUID FERTILIZERS}

Vinogradov Dmitry $\mathbf{V}$, dr. biol. sciences, professor, head. department of agronomy and agricultural technologies,vdv-rz@rambler.ru

Naumtseva Kseniya V, postgraduate student of the department of agronomy and agricultural technologies, ksyu.dyachuk.93@mail.ru

Lupova Ekaterina I, cand. biol. sciences, associate professor, department of agronomy and agricultural technologies, katya.lilu@mail.ru

Sokolov Andrey A, senior laboratory assistant of the department of agronomy and agricultural technologies, falcon-agro@mail.ru

Antoshina Olga A, cand.agricultural sciences, associate professor of the department of forestry, agrochemistry and ecology

Ryazan State Agrotechnological University Named after P. A. Kostychev

The article deals with the use of modern liquid fertilizers in the non-Chernozem zone of Russia. Recently, the interests of consumers have increased, agro-industrial enterprises annually make additions to the technology of growing oilseeds and their processing. The aim of the research was to study the effect of foliar fertilizing with multicomponent liquid fertilizers in two phases of vegetation, in white mustard crops. In the conditions of field experiments researches of features of growth and development of mustard white at use of a complex of fertilizers are carried out. In studies of complex liquid fertilizer has resulted in more intensive growth of plants, increasing the performance of photosynthesis. The maximum number of seeds was obtained by the cultivar Lucia, at the option Azotovit 1 l/ha + Fosfatovit 1 I/ha + RauActive 1 I/ha and 21.2 t/ha. And also used drugs contributed to the increase of productive indicators in grade Seagull, at the option Azotovit 1 l/ha + Fosfatovit 
1 I/ha + RauActive 1 I/ha with a yield of 18.8 t/ha and the Rhapsody is $19.5 \mathrm{C} / \mathrm{ha}$ compared to control variant. Key words: white mustard, liquid fertilizers, foliar feeding

\section{Literatura}

1.Dospehov, B.A. Metodika polevogo opyta s osnovami statisticheskoy obrabotki rezultatov issledovaniyi [Tekst] / B.A. Dospehov. - 5-e izd., dop. I pererab. - M.:Agropromizdat, 1985. - 351 s.

2. Vinogradov, D. V. Praktikum po rastenievodstvu [Tekst] / D. V. Vinogradov, N.V. Vavilova, N.A. Duktova, E.I. Lupova // Ryazan, 2018. 320 s.

3. Vinogradov, D. V. Productivnostgorchic v zavisimostiot urovn mineralnogo pitaniya [Tekst]/D. V. Vinogradov // Vestnik Ryazanskogo agrotechnologiceskogo universiteta im. P. A. Kostycheva. 2009. N. 3. S. 39-42.

4.Vinogradov, D. V. Vozmownost ispolzovaniya maslichkultur $v$ kachestve syryadlya proizvodstva ekologicheskichis togotopliva [Tekst] / D. V. Vinogradov, N. V. Byshov, E. I. Lupova// molodez v poiskahdruzb Material respublikanskoy nauchno-prakticheskoi konferenczii, posvyaschennoi $k$ 20-leti nacionalnogo primereniya i godu Mologezi v Respublike Tadzikistan. InstitutenergetikeTadzikistana2017. S. 28-33.

5. Vinogradov, D. V. nauchno-prakticheskie aspect introdukcii maslichnih kultur v uznoichasti Kryuchkov, M. M. Gorchica belaya I raps kak vaznie elementu v biologizacii zemledeliya [Tekst]/M.M. Kryuchkov, I. V. Smertenko // Zdorovaya okruzauschaya sreda - osnova bezopasnosti regionov sbornik trudov pervogo Mezdunarodnogo ekologicheskogo foruma v Ryazani: posvyaschyaetsyagoduekologii v RF. Ryazan, 2017. S. $228-231$.

6.Lupova E.I. Technologiya proizvodstvayrovih rapsa I surepici v nechernozemnoi zoni Rossii [Tekst] / E.I. Lupova, D.V. Vinogradov // Uchebnoe posobie. Ryazan, 2018. 86 s.

7.Masterov, A.S. praktikum po zemledeliyu [Tekst] / A.S. Masterov, D.V. Vinogradov, M.V. Potapenko, S.I. Trapkov, P.N. Balabko, E.I. Lupova // Ryazan, 2018. 256 s.

8.Metodika gosudarstvennogo sortoisputaniya selskohozyaistvennih kultur [Tekst] / Pod. red. Fedina M.A. // Moskva, 1983. vip.3. 184 s.

9. Oficialnyi sait Federalnoi sluzby gosudarstvennoi statistike po Ryazanskoi oblasti [Elektronniq resurs]. Rezum dostupa: http://www.gks.ru. (Data obrascheniya 09.10.2019).

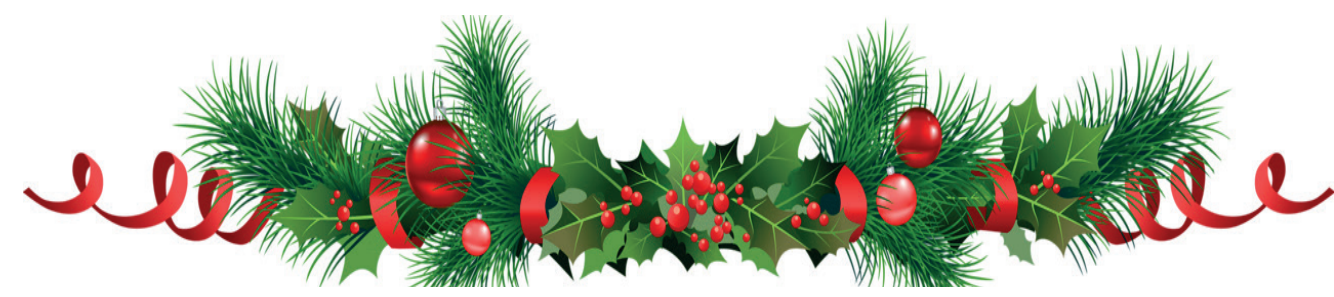

УДК 621.43.057

DOI 10.36508/RSATU.2019.68.89.023

\section{ОЦЕНКА РЕГУЛИРОВОЧНЫХ ПОКАЗАТЕЛЕЙ ДИЗЕЛЯ ПРИ ВЫСОКОТЕМПЕРАТУРНОМ} ВОЗДЕЙСТВИИ НА ДТ

КАРТАШЕВИЧ Анатолий Николаевич, д-р техн. наук, профрессор кафедры технологии машиностроения, Kartashevich@yandex.ru

ПЛОтникОВ Сергей Александрович, д-р техн. наук, профессор кафедры технологии машиноcmpoения, PlotnikovSA@bk.ru

МОТОВИЛОВА Марина Владимировна, аспирант кафедры машин и технологии деревообработки, Marina_mtd@mail.ru

Вятский государственный университет

Цель исследований - экспериментальное определение регулировочных показателей дизельного двигателя Д-245.5S2 при его работе на высокотемпературном дизельном топливе. Объект исследования - экспериментальная установка: двигатель Д-245.5S2, электротормозной стенд RAPIDO SAK N670 с балансирной маятниковой машиной. Значение установочного угла опережения впрыскивания топлива изменялось в диапазоне от 10 до 30 градусов, через каждые четыре градуса. Испытания проводились на дизельном и подогретом дизельном топливе. Температура подогрева топлива составляла $100^{\circ} \mathrm{C} \mathrm{и} 300^{\circ} \mathrm{C}$. Предварительное тепловое воздействие на топливо осуществлялось при помощи нагревательного устройства. Подогрев дизельного топлива производился на линии высокого давления между ТНВД и форсункой. Опираясь на полученные в результате испытаний экспериментальные данные, были установлены зависимости регулировочных показателей дизеля при его работе на подогретом топливе. Также выявлены изменения токсичности и дымности отработавших газов при разных значениях установочного угла опережения впрыскивания топлива. Приведены графики регулировочных характеристик по установочному углу опережения впрыскивания топлива

() Карташевич А. Н., Плотников С. А., Мотовилова М. В., 2019 г. 
без подогрева и с подогревом до $100^{\circ} \mathrm{C}$ и $300^{\circ} \mathrm{C}$ (эфффективные показатели, показатели токсичности и дымности отработавших газов при частоте вращения коленчатого вала $n=1800$ мин ${ }^{-1}$ ). В результате испытаний установлено, что применение подогретого топлива не оказывает заметного влияния на работоспособность форсунки и систему питания дизельного двигателя. Угол опережения впрыскивания топлива $\theta_{\text {впр }}$ при котором эффрективные показатели работы двигателя являются оптимальными, составляет 18-22 градуса.

Ключевые слова:дизель, топливоподающая аппаратура (ТПА), высокотемпературное топливо, эфффективные показатели, дымность и токсичность отработавших газов.

\section{Введение}

В процессе эксплуатации требования к характеристикам ДВС постоянно изменяются. Повышенное внимание уделяется увеличению мощности и КПД двигателя, снижению расхода топлива и экологическим показателям. В ходе эксплуатации и обслуживания двигателя не всегда обеспечиваются необходимые показатели его работы. Появляется необходимость в улучшении рабочих процессов дизельного двигателя. При работе двигателя существенное значение имеет качественный состав применяемого топлива, его предварительная подготовка. Дополнительное воздействие на топливо может положительно повлиять на его свойства [1-3]. Одним из способов улучшения эксплуатационных показателей двигателя является дополнительная передача тепла топливу в системе топливоподачи.

\section{Исследование показателей дизеля при использовании температурного воздействия на ДТ}

Предварительная подготовка ДТ может осуществляться на линии высокого давления. Тепло передается топливу от внешнего источника. При воздействии на него температурой до $100^{\circ} \mathrm{C}$ происходит снижение вязкости. Такое воздействие не оказывает существенного влияния на процесс сгорания. Подогрев топлива на линии низкого давления до высоких температур нецелесообразен, так как не обеспечивается сохранение тепла топливом при движении его к фрорсунке $[12,13]$. Термическое воздействие на ДТ целесообразно осуществлять перед его непосредственной подачей в цилиндры двигателя. Интерес вызывают работы авторов, направленные на исследования предварительного подогрева дизельного топлива до высоких температур [5-8]. В данных работах определялись показатели процесса сгорания двигателя, работающего на предварительно подготовленном топливе. Авторами [5,6,7] на основании проведенных экспериментальных исследований были установлены зависимости тепловыделения в цилиндрах дизеля 24 10,5/12,0 при его термофорсировании. Аналогично, авторами [8] на основании проведенных экспериментальных исследований были установлены зависимости влияния подогрева топлива на продолжительность впрысков, на изменение давления в форсунке при впрыскивании топлива. Воспламенение в дизеле - сложный и многостадийный процесс. Важным показателем ДТ является его склонность к самовоспламенению (ЦЧ). Топливо подается в цилиндр дизельного двигателя через форсунки под действием высоко- го перепада давления в виде жидкой струи. Хорошее распыливание топлива при впрыскивании форсунки имеет важное значение, так как процесс сгорания топлива длится доли секунды. Интенсивность испарения капли топлива увеличивается с ростом поверхности контакта топлива с воздухом.

Таким образом, скорость горения определяется тонкостью его распыливания [4]. Авторами данной статьи в работе [9] был проведен расчет распада топливной струи и определены ее параметры. В этой работе распад струи оценивался с помощью числа Вебера.

$$
W_{e}=\frac{\rho \cdot w^{2} \cdot d}{\sigma}
$$

где: $\rho$ - плотность газовой среды;

w - скорость струи жидкости в газовой среде;

$\mathrm{d}$ - диаметр струи (распылителя);

$\rho-$ поверхностное натяжение топлива.

При подогреве топлива до температуры $300^{\circ}$ С в линии высокого давления форсунка распыливает его сразу же на мелкодисперсные фракции. При этом достигается равномерное распределение топлива в камере сгорания. Перемешивание ДТ с воздухом происходит быстрее, а это ведет к быстрому испарению и сгоранию. Процесс сгорания ускоряется.

\section{Объекты и методы}

При дополнительной передаче тепла топливу в линии высокого давления возможны изменения показателей работы двигателя. Испытания двигателя производят для оценки его основных показателей. Дизельная ТПА должна соответствовать требованиям технических условий завода-изготовителя, а форсунка - удовлетворять основным параметрам ГОСТ 10579-2017 (ГОСТ 10579-88) $[12,13]$. Испытания на ДТ проводились в соответствии с ГОСТ 18509-88. Экспериментальные исследования проводились с помощью нагрузочного электротормозного стенда RAPIDO SAK N670 c балансирной маятниковой машиной. Испытательный стенд был оборудован приборами и устройствами для снятия эффективных показателей, а также токсичности и дымности отработавших газов.

Испытания проводились на ДТ без подогрева и с подогревом до $100^{\circ} \mathrm{C}$ и $300^{\circ} \mathrm{C}$. Показания снимались при частоте вращения коленчатого вала 1800 мин $^{-1}$. Значенияустановочного угла опережения впрыскивания топлива изменялись в диапазоне от 10 до 30 градусов, через каждые четыре градуса [11]. 


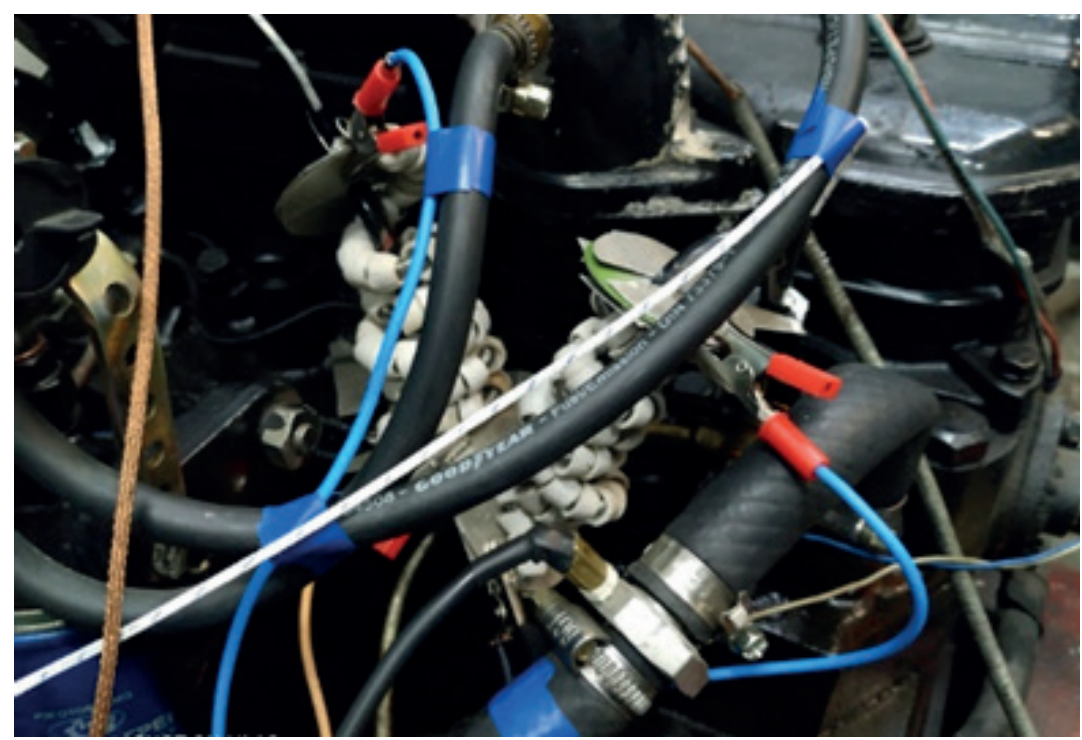

Рис. 1 - Нагревательный элемент на линии высокого давления

Значение установочного угла опережения впрыскивания топлива определялось по мениску. При проведении испытания на ДТ с подогревом использовалось нагревательное устройство. Нагревательное устройство в виде спирали с изолирующими керамическими элементами устанавливалось на линии высокого давления перед форсунками. В качестве нагревательного в устройстве использовался нихромовый элемент (провод), имеющий высокое сопротивление. Нагревательный элемент на линии высокого давления представлен на рисунке 1.

Тепло от нагревательного элемента передавалось объему топлива, равному цикловой подаче, которое сразу же поступало в форсунку. Значение температуры топлива фиксировалось при помощи четырех термопар, установленных непосредственно перед форсунками и подключенных к восьмиканальному ПИД-регулятору (рис. 2). Нагрев топлива до нужной температуры $\left(100^{\circ} \mathrm{C}\right.$ или $\left.300^{\circ} \mathrm{C}\right)$ контролировался регулятором мощности. Регулятор мощности и нагревательное устройство подключались в электрическую цепь с напряжением $220 \mathrm{~B}$.

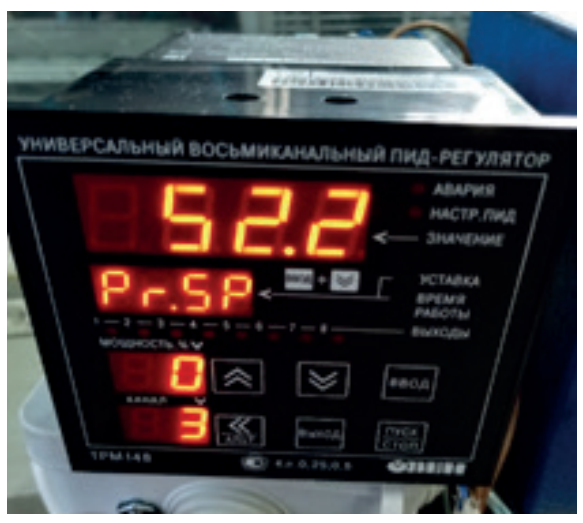

Рис. 2 - Универсальный восьмиканальный ПИД регулятор
Экспериментальная часть

На данном этапе исследования необходимо было определить влияние подогрева ДТ на регулировки двигателя Д-245.5S2. Оценка влияния подогрева топлива на значения оптимального установочного угла опережения впрыскивания топлива производилась на основе анализа регулировочных характеристик. На рисунках 3,4 представлены графрики изменения эфффективных показателей дизеля Д-245.5S2 при различных значениях установочного угла опережения впрыскивания топлива при частоте вращения 1800 мин $^{-1}$. Для каждого параметра представлены графики работы двигателя на ДТ без подогрева и с подогретом до $100^{\circ} \mathrm{C}$ и до $300^{\circ} \mathrm{C}$.

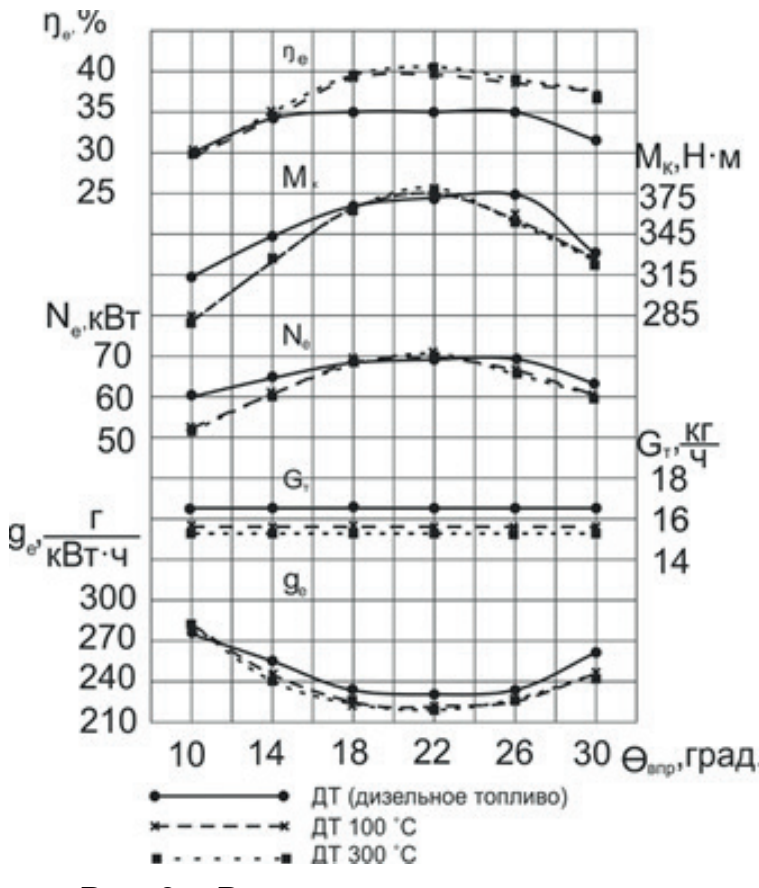

Рис. 3 - Регулировочная характеристика двигателя по установочному углу опережения впрыскивания топлива (эфффективные показатели, $\mathrm{n}=1800$ мин $\left.^{-1}\right)$ 
Из данных, представленных на графике (рис.3), видно, что при работе на дизельном топливе без подогрева оптимальным установочным углом является $\Theta_{\text {впр }}=26^{\circ}$, что соответствует руководству по эксплуатации дизеля [14]. При этом эффрективная мощность дизеля составляет $\mathrm{N}_{\mathrm{e}}=70,2$ кВт. Значение удельного эфрфективного расхода топлива составляет $\mathrm{g}_{\mathrm{e}}=232$ г/кВтхч, часового расхода топлива $G_{\tau}-16,3$ кг/ч, крутящего момента $M_{\text {кр }}-372 \mathrm{H×M}$, а значение эффрективного КПД $-36 \%$.

При работе дизельного двигателя с подогревом $100^{\circ} \mathrm{C}$ и $300^{\circ} \mathrm{C}$ характер кривых несколько изменяется. Так, значения часового расхода топлива уменьшаются от $\mathrm{G}_{\mathrm{e}}=16,3$ кг/ч при работе двигателя на ДТ без подогрева до $G_{\text {е100 }}{ }^{\circ}=15,0 \mathrm{kг/4}$ и $\mathrm{G}_{\mathrm{e} 300^{\circ} \mathrm{C}}=14,8$ кг/ч при работе дизеля с подогревом ДТ до $100^{\circ} \mathrm{C}$ и $300^{\circ} \mathrm{C}$, соответственно. Уменьшение вызывается снижением давления впрыскивания топлива.

Значения удельного эффрективного расхода топлива также уменьшаются и составляют $g_{e}=214$ г/кВтхч и $g_{e}=207$ г/кВтхч, соответственно, при работе дизельного двигателя с подогревом топлива $100^{\circ} \mathrm{C}$ и $300^{\circ} \mathrm{C}$. При этом минимум $\mathrm{g}_{\mathrm{e}}$ сдвигается в сторону более поздних углов опережения впрыскивания топлива, составляющих $\Theta_{\text {впр }}=18-22^{\circ}$ при работе двигателя с подогревом топлива.

Максимальные значения эффеективной мощности и крутящего момента незначительно увеличиваются в сравнении с работой двигателя на ДТ без подогрева и также сдвигаются в сторону поздних углов опережения впрыскивания топлива.

Максимальные значения эффективного КПД также увеличиваются и составляют 39\% и 41\%, соответственно, при работе дизельного двигателя с подогревом $100^{\circ} \mathrm{C}$ и $300^{\circ} \mathrm{C}$ (при угле опережения впрыскивания топлива $\Theta_{\text {впр }}=22^{\circ}$ )

На графике (рис. 4) представлены зависимости изменения показателей токсичности и дымности при разных значениях угла опережения впрыскивания топлива при частоте вращения 1800 мин $^{-1}$ без подогрева и с подогревом ДТ.

Из графиков показателей токсичности и дымности (рис. 4.) видно, что содержание сажи в отработавших газах при работе на ДТ с подогревом снижается. При этом минимальная концентрация сажи сдвигается в сторону более ранних углов опережения впрыскивания топлива при работе двигателя с подогревом топлива. При угле $\Theta_{\text {впр }}=26^{\circ}$ концентрация сажи составляет 6\% для ДТ без подогрева и 0,9\% и 0,8\% при работе дизельного двигателя с подогревом топлива $100^{\circ} \mathrm{C}$ и $300^{\circ} \mathrm{C.}$., соответственно.

Содержание оксидов азота при работе дизельного двигателя, как на ДТ без подогрева, так и при работе с подогревом топлива $100^{\circ} \mathrm{C}$ и $300^{\circ}$ C повышается при увеличении угла опережения впрыскивания топлива. При угле $26^{\circ}$ концентрация оксидов азота составляет $1711 \mathrm{ppm}$ для ДТ без подогрева и 1828 ррm и 1859 ррт при работе дизельного двигателя с подогревом топлива $100^{\circ}$ С и $300^{\circ} \mathrm{C}$, соответственно

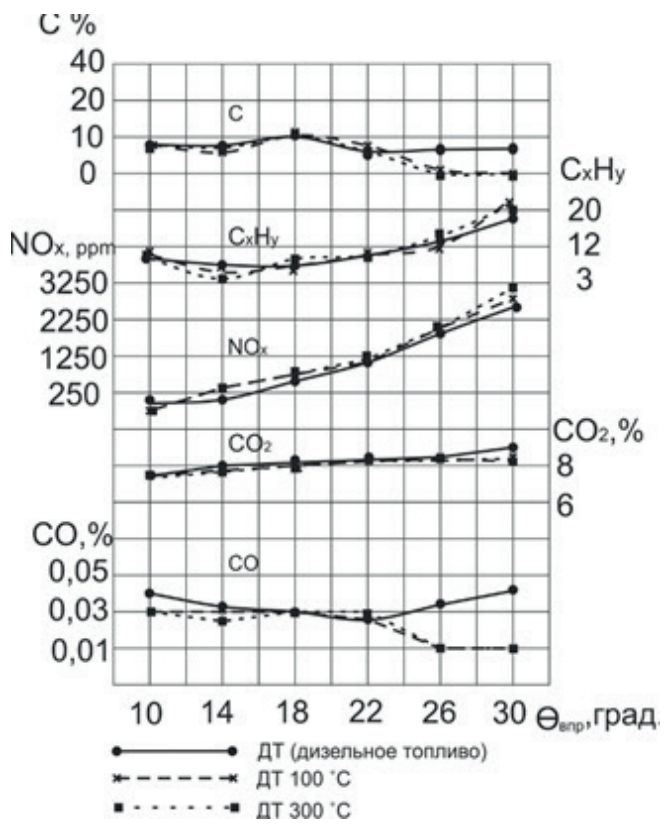

Рис. 4 - Регулировочная характеристика двигателя по установочному углу опережения впрыскивания топлива (дымность и токсичность ОГ, $\mathrm{n}=1800 \mathrm{мин}^{-1}$ )

Работа дизельного двигателя на топливе с подогревом сопровождается понижением выбросов оксидов углерода с ОГ в сторону более ранних углов опережения впрыскивания топлива. При угле $\Theta_{\text {впр }}=26^{\circ}$ выброс СО составляет 0,04\% при работе двигателя без подогрева топлива и 0,01\% при работе дизельного двигателя с подогревом топлива $100^{\circ} \mathrm{C}$ и $300^{\circ} \mathrm{C}$.

При работе дизельного двигателя с подогревом топлива наблюдается увеличение выбросов диоксида углерода. Максимальное значение $\mathrm{CO}_{2}$ смещается в сторону более ранних углов опережения впрыскивания топлива. При угле $\Theta_{\text {впр }}=22^{\circ}$ концентрация $\mathrm{CO}_{2}$ составляет 8,24\% для Дํ без подогрева и $8,13 \%$ при работе дизельного двигателя с подогревом топлива.

Снижение концентрации $\mathrm{C}_{x} \mathrm{H}_{y}$ наблюдается в сторону более поздних углов опережения впрыскивания топлива, а в целом концентрация $\mathrm{C}_{x} \mathrm{H}_{y}$ незначительно увеличивается. Так, при угле $\Theta_{\text {впр }}=22^{\circ}$ значение $\mathrm{C}_{\mathrm{x}} \mathrm{H}_{\mathrm{y}}$ составляет 8,0 ррт для ДТ без подогрева, а при работе дизельного двигателя с подогревом топлива $100^{\circ} \mathrm{C}$ и $300^{\circ} \mathrm{C}-9,0$ p pm$_{\text {. }}$.

При испытании на высокотемпературном дизельном топливе установочный угол опережения впрыскивания топлива $\left(\theta_{\text {впр }}\right)$ соответствует меньшему значению. Максимальное значение эфрфективного КПД соответствует углу опережения впрыскивания топлива 18-22 градуса.

\section{Результаты и выводы}

1. Применение подогретого топлива не оказывает заметного влияния на работоспособность форсунок и системы питания дизельного двигателя.

2. Максимальные значения эфффективной мощности, эффрективного КПД и крутящего момента достигаются при меньших значениях устано- 
вочного угла опережения впрыскивания топлива.

3. При работе дизельного двигателя с подогревом значения часового расхода топлива и удельного эффективного расхода топлива уменьшаются.

4. Оказание дополнительного воздействия на топливо положительно сказывается на его физико-химических свойствах и в целом на рабочем процессе дизеля. За счет улучшения условий сгорания топливо сгорает при максимальном количестве выделенной теплоты, имеет место мягкая работа двигателя, снижение теплонапряженности деталей и нагарообразования в прецизионных паpax.

\section{Список литературы}

1. Болотов, А. К. Конструкция тракторов и автомобилей /А. К. Болотов, А. А. Лопарев, В. И. Судницын. - М., 2006. - 108 с.

2. Николаенко, А. В. Теория, конструкция и расчет автотракторных двигателей / А. В. Николаенко. - М. : Колос, 1984. - 335 с.

3. Луканин, В.Н.Двигателивнутреннего сгорания/В. Н. Луканин.-М. : Высшаяшкола, 1995. -944 с.

4. Ассад, М. С. Продукты сгорания жидких и газообразных топлив: образование, расчет, эксперимент / М. С. Ассад, О. Г. Пенязьков. - Минск : Беларус. Наука, 2010 - 305 с.

5. Плотников, С. А. Улучшение эксплуатационных показателей дизелей путем создания новых альтернативных топлив и совершенствование топливоподающей аппаратуры : автореф. дис... д-ра техн. наук. - Нижний Новгород : НГТУ, 2011. - 40 с.

6. Плотников, С. А. Анализ процесса сгора-

\section{ESTIMATION OF ADJUSTING INDICATORS OF DIESEL UNDER HIGH-TEMPERATURE EXPOSURE TO DT}

Kartashevich Anatoly N., Dr.Sci.Tech., the professor of chair of technology of mechanical engineering, Vjatsky state university, Kartashevich@yandex.ru

Plotnukov Sergey A., a Dr.Sci.Tech., the professor of chair of technology of mechanical engineering, Vjatsky state university, PlotnikovSA@bk.ru

Motovilova Marina V., the post-graduate student of chair of technology of mechanical engineering, Vjatsky state university, Marina_mtd@mail.ru

The purpose of research - experimental determination of the adjustment parameters of the diesel engine $D-245.5 S 2$ at its operation on high temperature diesel fuel. Object of study: experimental setup (engine $D-245.5 S 2$, electric brake stand RAPIDO SAK N670 with balancing pendulum machine). The value of the angle of advance of fuel injection was varied in the range from 10 to 30 degrees, at intervals of four degrees. Tests were carried out on diesel and heated diesel fuel. Fuel heating temperature $100^{\circ} \mathrm{C}$ and $300^{\circ} \mathrm{C}$. Preliminary thermal influence on fuel was carried out by means of the heating device. Heating of diesel fuel was carried out on the high pressure line between the injection pump and the nozzle. Based on the experimental data obtained as a result of the tests, the dependence of the adjustment parameters of the diesel during its operation on heated fuel was established. Also, changes in toxicity and smoke, exhaust gases from different values of the installation angle of advance of fuel injection were revealed. The graphs of the adjustment characteristics of the installation angle of advance fuel injection without heating and heated $100^{\circ} \mathrm{C}$ and $300^{\circ} \mathrm{C}$ (effective indicators, indicators of toxicity and smoke in the exhaust gases at a speed of the crankshaft $n=1800 \mathrm{~min}^{-1}$ ). As a result of the tests, it was found that the use of heated fuel does not have a noticeable effect on the performance of the injector and the power supply system of the diesel engine. A corner of an advancing of injection of fuel $\theta в п p$ at which efficient performance of the engine are the optimum is $18^{\circ} / 22^{\circ}$.

Key words: diesel, fuel supply equipment (TPA), high-temperature fuel, effective indicators, smokiness and toxicity of exhaust gases.

\section{Literatura}

1. Bolotov, A.K. Konstruktsiya traktorov I avtomobiley /A. K. Bolotov, A. A. Loparev, V. I. Sudnitsyn. - M., 2006. - $108 \mathrm{~s}$.

2. Nikolayenko, A.V. Teoriya, konstruktsiya I raschet avtotraktornykh dvigateley / A.V. Nikolayenko. - M., 
Kolos, $1984-335$ s.

3. Lukanin, V.N. Dvigateli vnutrennego sgoraniya / V. N. Lukanin. - M.: Vysshayashkola, 1995. - 944 s.

4. Assad, M.S. Produkty sgoraniya zhidkikh I gazoobraznykh topliv: obrazovaniye, raschet, eksperiment I M.S. Assad, O.G. Penyaz'kov. - Minsk: Belarus. Nauka, $2010-305$ s.

5. Plotnikov S.A. Uluchsheniye ekspluatatsionnykh pokazateley dizeley putem sozdaniya novykh al'ternativnykh topliv I sovershenstvovaniya toplivopodayushchey apparatury. //Avtoreferat diss. dokt. tekhn. nauk. - Nizhniy Novgorod, NGTU, 2011. - 40 s.

6. Plotnikov, S. A. Analiz protsessa sgoraniya I teplovydeleniya traktornogo dizelya s termicheskoy podgotovkoy topliva / S. A. Plotnikov, SH. V. Buzikov, A. L. Biryukov // Molochno-khozyaystvennyy vestnik. 2017. №3 (27) - S. 114-124.

7. Plotnikov, S. A. Issledovaniye protsessa sgoraniya I teplovydeleniya dizelya s termoforsirovaniyem / S. A. Plotnikov, SH. V. Buzikov, V. F. Atamanyuk // Zhurnal Traktory i sel'khozmashiny. 2014. №7. S. 25-27.

8. Balabin, V. N. Osobennosti primeneniya termoforsirovaniya topliva na lokomotivnykh dizelyakh / V. N. Balabin, V.N. Vasil'yev // Zhurnal Sovremennyye naukoyemkiye tekhnologii. 2015. № 4. - S 107-113.

9. Plotnikov, S. A. Vliyanie sostava spirtosoderzhashego topliva na pokazateli prozessa toplivopodachi / S. A. Plotnikov, S. N. Gushchin, S. R. Lebedev // Dvigatelestroenie. 2004. №. 3. - 43-45.

10. Plotnikov, S. A. Opredelenie regulirovochnysh parametrov sistemy toplivopodachi trakhtornogo diselya pri rabote na toplivnyh khomposiziyah s dobavkami rapsovogo masla / S. A. Plotnikov, sh. V. Buzikov, I. S. Kozlov / / journal Vestnik RGATU. 2018. № 4 (40). - 133-137.

11. GOST 18509-88 Dizeli traktornyye I kombaynovyye. Metody stendovykh ispytaniy.

12. GOST 10579-88 Forsunki dizeley. Obshchiye tekhnicheskiye usloviya.

13. GOST 10579-2017 Forsunki dizeley. Tekhnicheskiye trebovaniya I metody ispytaniy.

14. Dizeli D-245S2, D-245.2S2, D-245.5S2, D-245.16S2, D-245.16LS2, D-245.42S2, D-245.43S2. Rukovodstvo po ekspluatatsii $245 S 2$.

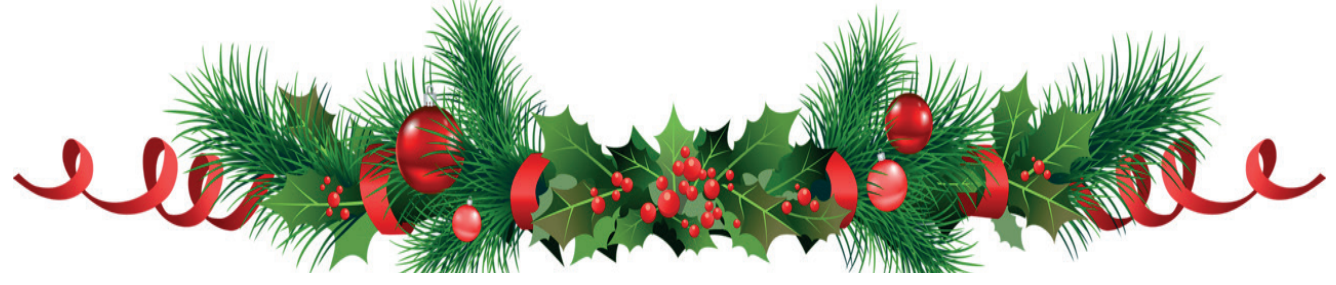

Удк 635.631.347

DOI 10.36508/RSATU.2019.34.78.024

\section{ИССЛЕДОВАНИЕ ВЛИЯНИЯ РАСПОЛОЖЕНИЯ НАСАДОК ДОЖДЕВАЛЬНЫХ МАШИН} НА КАЧЕСТВО ПОЛИВА

КУЗНЕЦОВ Александр Васильевич, соискатель кафедры технологии металлов и ремонта машин, tmirm@yandex.ru, Рязанский государственный агротехнологический университет имени П.А. Костычева

Эфрфективность дождевальной установки при поливе кассетной рассады зависит от радиуса полива и угла падения капель с ее концевых насадок. Дефлекторные насадки дождевальных машин обладают высокой дисперсностью распыла при низких давлениях и имеют простую конструкцию. Форма дефлектора насадки позволяет равномерно распределять дождь по площади орошения, а также формировать контур полива в виде сектора или полного круга. Преимуществом дуговых насадок является образование мелкокапельного дождя при рабочем давлении от 0,05 до 0,24 MПа, при этом средний диаметр капли составляет 0,35-0,48 мм. В процессе эксплуатации дуговые насадки имеют высокую технологическую надежность, меньше засоряются, не требуют дополнительной настройки. Для изучения распределения осадка по радиусу полива были проведены экспериментальные исследования дуговой насадки с плоским дефлектором. Радиус захвата дуговой насадки с плоским дефрлектором составляет около 3 м, причем распределение осадков по радиусу представляет собой параболу. При рабочем давлении 0,15 МПа дефлектороная насадка секторного действия распределяет дождь по сектору 900 радиусом около 3,0 м. Конструкция насадки обеспечивает создание реактивной силы, что возможно использовать для привода дождевальных машин. Для определения рационального расположения насадок на дождевальной установке мы применили метод обращения, поместив оси координат на вращающуюся дождевальную установку, а зону полива вращали. При определении параметров перекрытия зон полива каждой насадки нами использовались уравнения регрессии для уточнения количества осадков. В результате установлено, что в качестве концевых насадок следует применять дуговые насадки с плоским дефлектором на одинаковом расстоянии от оси вращения дождевальной установки. Дефлектороные насадки секторного действия следует располагать на различных расстояниях от оси вращения, причем одна из них располагается перпендикулярно крылу, вторая под углом $50^{\circ}$ к крылу установки в направлении оси вращения.

Ключевые слова: орошение, дождеватель, распределение осадков, дефрлекторные насадки, равномерность дождя.

(c) Кузнецов А. В., 2019 г. 


\section{Введение}

Овощеводство в защищенном грунте предполагает выращивание рассады. При кассетном способе каждое растение выращивается в отдельной ячейке с жесткими водонепроницаемыми боковыми стенками и дренажным отверстием в дне. Выращивание рассады в кассетах снижает затраты энергии на обогрев почвы, обеспечивает сокращение необходимой площади для выращивания рассады [7,8]. Для полива рассады используют как проточные системы с поддонами, так и дождевальные установки. Эффрективность дождевальной установки при поливе кассетной рассады зависит от радиуса полива и угла падения капель ее концевых насадок [9].

\section{Материалы и методы}

Дефлекторные насадки дождевальных машин обладают хорошей дисперсностью распыла при низких давлениях и поэтому довольно часто используются в теплицах. Кроме того, дефрлекторные насадки имеют простую конструкцию. В корпусе насадки имеется проходное отверстие и к нему же крепится десрлектор. При ударе струи о десрлектор (неподвижное препятствие) происходит дробление водяной струи на капли дождя. Форма дефрлектора насадки позволяет равномерно распределять дождь по площади орошения, а также формировать контур полива в виде сектора или полного круга $[1,6]$. Дефлекторные насадки, которые используются в дождевальных установках теплиц, представлены на рисунке 1.

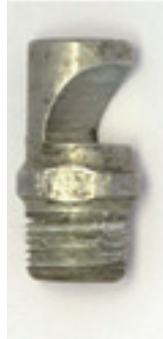

a

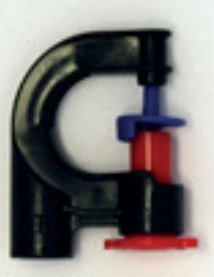

б

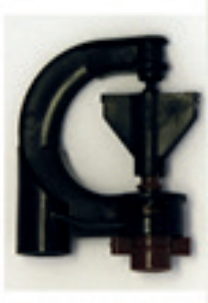

B

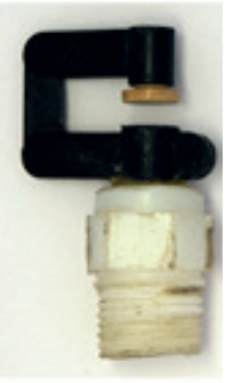

д a - дефлекторная секторного действия; б,

в - дуговая с дефлектором-крыльчаткой; д - дуговая с плоским дефлектором.

Рис. 1 - Дождеобразующие насадки для полива рассады и овощей в теплицах

Наиболее распространенные ранее дефлекторно-стержневые насадки в процессе эксплуатации показали следующие недостатки - засорение кольцевого отверстия насадки из-за небольшой величины зазора, неравномерность кольцевого зазора из-за смещения стержневого дефлектора, выпадение и потеря стержневого дефлектора. В результате такие насадки осуществляют несимметричный полив орошаемой площади, что снижает качество полива и равномерность слоя дождя.

Конструкция дуговых насадок проще дефрлекторно-стержневых, упрощает их обслуживание. Серийно выпускаемые дуговые насадки с плоским десрлектором имеют диаметр сопла следующих размеров:1,0; 1,$65 ; 2,15 ; 2,35$ мм. Преимуществом дуговых насадок является образование мелкокапельного дождя при рабочем давлении от 0,05 до 0,24 МПа, при этом средний диаметр капли составляет 0,35-0,48 мм. В процессе эксплуатации дуговые насадки имеют высокую технологическую надежность, меньше засоряются, не требуют дополнительной настройки. В сравнении с дефрлекторно-стержневыми дуговые насадки с дефрлектором создают также более равномерный дождь с равномерным распределением и меньшей интенсивностью. Это обуславливает меньший расход и небольшой радиус захвата поливаемой площади дождем, что требует тщательного планирования при установке на дождевальные машины.

Для изучения распределения осадка по радиусу полива были проведены экспериментальные исследования дуговой насадки с плоским дефлектором (рис. 2).

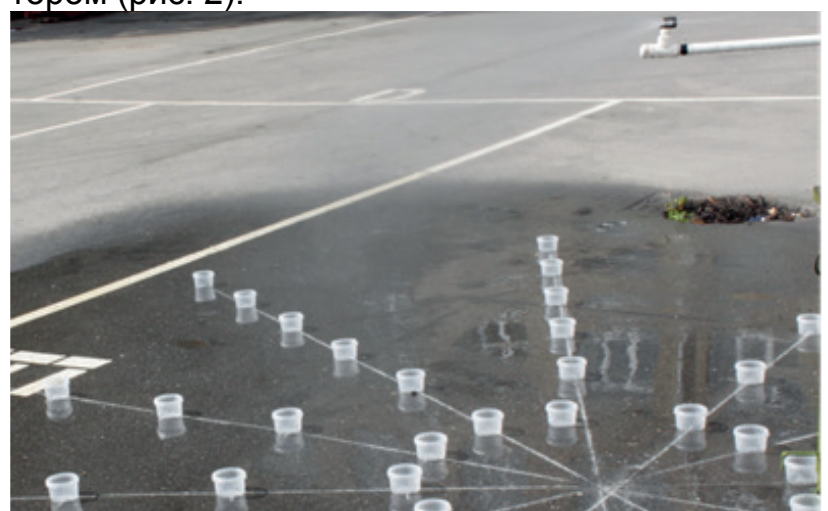

Рис. 2 - Общий вид лабораторной установки для испытания дуговой насадки с плоским дефлектором с дождемерами, расположенными по радиусу

\section{Результаты и обсуждение}

При исследовании время испытаний устанавливалось исходя из наполнения дождемеров. Рабочее давление на входе в установку составляло 0,15 МПа. На основе полученных данных построены уравнение регрессии (1)и график распределения осадков по радиусу захвата (рис. 3).

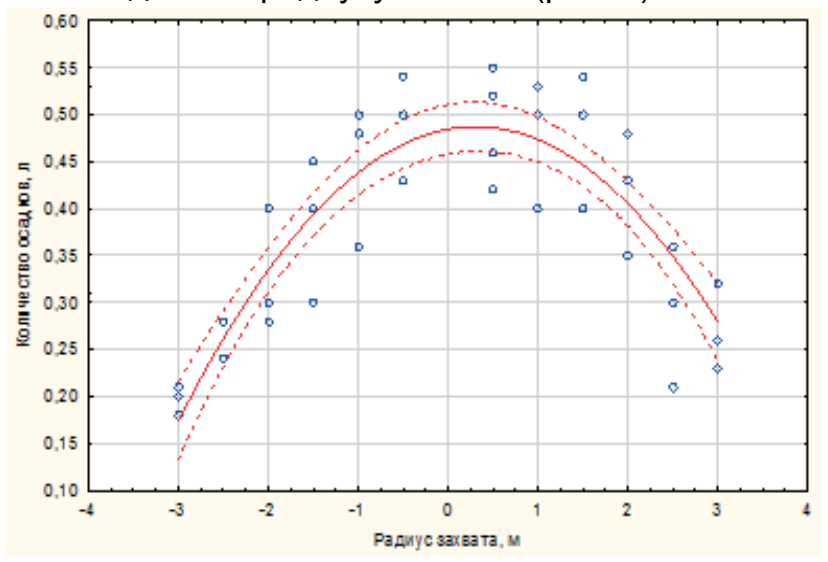

Рис. 3 - Распределение осадков по радиусу захвата дуговой насадки с плоским дефлектором с диаметром сопла $\mathrm{d}=2,0 \mathrm{~m}$ 
$\mathrm{Q}=0,4846+0,0176 \cdot r-0,0287 r^{2}$

где $Q$ - количество осадков, л.

r-радиусзахватадождеобразующейнасадки, м.

Из графрика видно, что радиус захвата дуговой насадки с плоским дефлектором составляет около 3 м, причем распределение осадков по радиусу представляет собой параболу. Поэтому для получения равномерного полива необходимо обеспечивать перекрытие зон полива соседних насадок.

Для изучения распределения осадка по радиусу дефлектороной насадки секторного действия также были проведены испытания (рис.4).

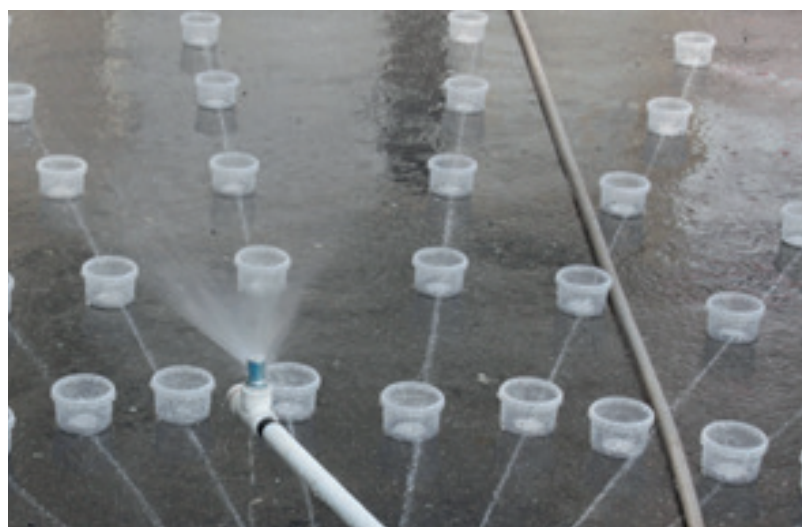

Рис. 4 - Общий вид лабораторной установки для испытания дефлектороной насадки секторного действия с дождемерами, расположенными по радиусу

На основе полученных данных построены уравнение регрессии и график распределения осадков по радиусу захвата (рис.5).

$\mathrm{Q}=0,2426+0,1563 \cdot r-0,0522 \cdot r^{2}$

где $Q$ - количество осадков, л.

$r$ - радиус захвата дождеобразующей насадки, м.

При рабочем давлении 0,15 МПа десрлектороная насадка секторного действия распределяет дождь по сектору $90^{\circ}$ радиусом около 3,0 м. Насадки секторного действия имеют мелкокапельную структуру дождя ( $d_{k}=0,4-0,6$ мм). Конструкция насадки обеспечивает создание реактивной силы, что возможно использовать для привода дождевальных машин.

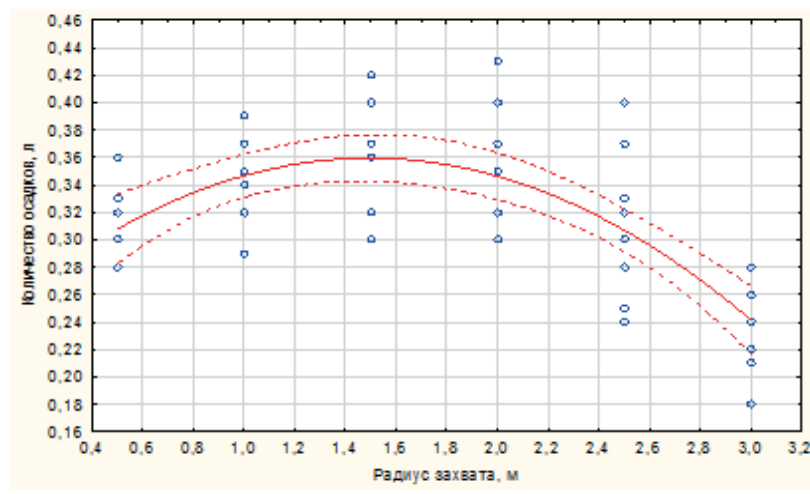

Рис. 5 - Распределение осадков по радиусу захвата дефлектороной насадки секторного действия с диаметром сопла $\mathrm{d}=3,0$ мм

Общим недостатком насадок, орошающих по кругу и эллипсу, в том числе и дефлекторных, является их конструктивное расположение на трубопроводе. Дождь попадает на конструктивные элементы дождевальной машины и каркаса теплицы, по которым вода струйно стекает и размывает почвенную смесь, поражая корневую систему растений.

Короткоструйные дефлекторные насадки кругового и секторного действия находят широкое применение на дождевальных машинах для защищенного грунта - это передвижные и позиционные дождеватели типа АП-2 и ДШ-0,6 [7,8]. Короткоструйные дефлекторные насадки также применяют на дождевальных машинах для открытого грунта «Фрегат», «Кубань», «Таврия», «ДДА100 В». Сравнительные характеристики подобных короткоструйных насадок приведены в таблице.

Таблица - Сравнительные характеристики короткоструйных насадок

\begin{tabular}{|c|c|c|c|c|c|c|c|}
\hline $\begin{array}{c}\text { Наименование } \\
\text { насадки }\end{array}$ & $\begin{array}{l}\text { Ha- } \\
\text { пор, } \\
\text { H, M }\end{array}$ & $\begin{array}{l}\text { Рас- } \\
\text { ход, } \\
\text { Q, л/с }\end{array}$ & $\begin{array}{l}\text { Диаметр } \\
\text { сопла, } \\
\text { d }_{\text {c, }} \text { мм }\end{array}$ & $\begin{array}{c}\text { Радиус } \\
\text { захвата,м }\end{array}$ & $\begin{array}{c}\text { Площадь } \\
\text { полива F, м² }\end{array}$ & $\begin{array}{l}\text { Интенсив- } \\
\text { ность } \\
\text { дождя, p, } \\
\text { мм/мин }\end{array}$ & $\begin{array}{c}\text { Диаметр } \\
\text { капли, } \\
\mathrm{d}_{\mathrm{k}}, \mathrm{mм}\end{array}$ \\
\hline Щелевая & 15,0 & 0,03 & 1,5 & 2,8 & 12,3 & 0,15 & 0,3 \\
\hline Центробежная & 15,0 & 0,3 & 10,5 & 4,5 & 63,5 & 0,28 & 0,61 \\
\hline $\begin{array}{l}\text { С винтовым } \\
\text { завихрителем }\end{array}$ & 15,0 & 0,6 & 8,5 & 7,9 & 189,5 & 0,20 & 0,81 \\
\hline $\begin{array}{l}\text { Десрлекторно- } \\
\text { стержневая }\end{array}$ & 15,0 & 0,08 & 2,75 & 2,0 & 10,2 & 0,47 & $0,38-$ \\
\hline $\begin{array}{l}\text { Дуговая с } \\
\text { плоским } \\
\text { десрлектором }\end{array}$ & 0,41 & 0,045 & 2,15 & 2,35 & 17,3 & 0,15 & 0,41 \\
\hline PBO-8 & 20,0 & 0,178 & 4,0 & 4,0 & 50,2 & 0,21 & $1,6-2,0$ \\
\hline $\begin{array}{l}\text { Секторного } \\
\text { действия со } \\
\text { сферическим } \\
\text { дефрлектором }\end{array}$ & 15,0 & 0,037 & 2,0 & 4,1 & 20 & 0,111 & 0,38 \\
\hline
\end{tabular}


Из таблицы видно, что при равном давлении наибольший радиус полива и допустимые агротребованиями диаметр капель и интенсивность дождя имеют дефлекторные насадки секторного действия. Это также подтверждается опытными данными по дождевальным насадкам в работах Васильева А.Г., Поляшова Ю.А $[1,6]$.

Преимуществом насадок секторного действия является мелкокапельная структура дождя и небольшая интенсивность, что соответствует требованиям, предъявляемым к поливу рассады овощей, выращиваемой кассетным способом.

Несмотря на преимущества десрлекторных насадок, для обеспечения равномерности осадков по площади полива необходимо тщательно рассчитывать размещение насадок на дождевальной установке. Рассмотрим позиционную дождевальную установку (рис. 6). Дождевальная установка для полива рассады и овощей в теплицах содержит опорное основание 1 , дождевальные крылья 2 с реактивными насадками направленного действия 3 и концевыми насадками кругового действия 4 [3,4,5,].

Дождевальная установка для теплиц работает следующим образом. При подаче воды в дождевальные крылья 2, установленные на опорном основании 1, под воздействием реактивных сил струй воды, вытекающих из насадок направленного действия 3, крылья начинают вращаться и производить полив центральной части круга, а концевые насадки кругового действия 4 производить полив периферийной части круга [2-5].

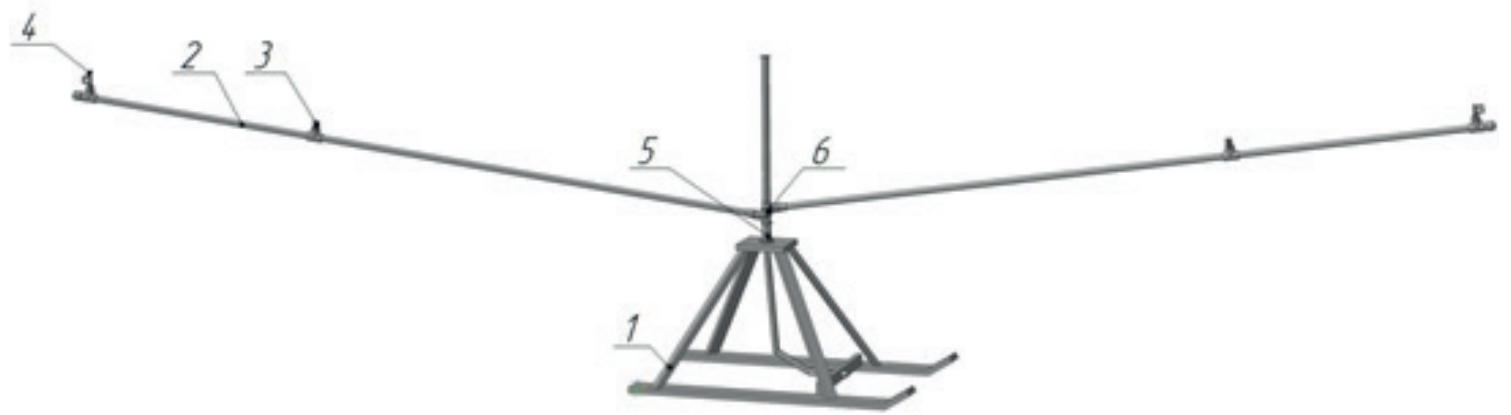

1 - опорное основание с полозьями; 2 - дождевальные крылья; 3 - реактивные насадки направленного действия; 4 - концевые насадки кругового действия; 5 - узел вращения; 6 - крестовина

Рис. 6 - Общий вид дождевальной установки

Для рационального расположения насадок на дождевальной установке мы применили метод обращения, поместив оси координат на вращающуюся дождевальную установку, а зону полива вращали (рис. 7). Это позволило легко моделировать изменение положения насадок, и, вращая зону полива, получать возможное распределение нормы осадков на площади в соответствии с распределением количества осадков по радиусу захвата различных насадок.

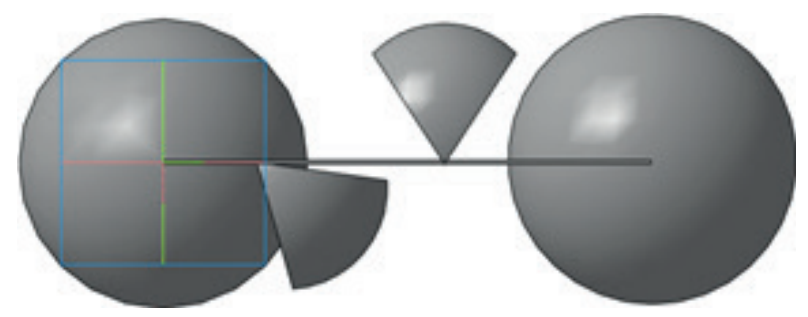

Рис. 7 - Схема расположения зон полива дождеобразующих насадок на крыльях дождевальной установки

Для определения перекрытия параметров зоны полива каждой насадки нами использовались уравнения регрессии $(1,2)$ для уточнения формы количества осадков дуговой насадки с плоским дефлектором и дефлектороной насадки секторного действия. В результате многократных попыток расстановки дождеобразующих насадок была поучена зона полива дождевальной установки с равномерным распределением осадков по всей площади (рис. 8).

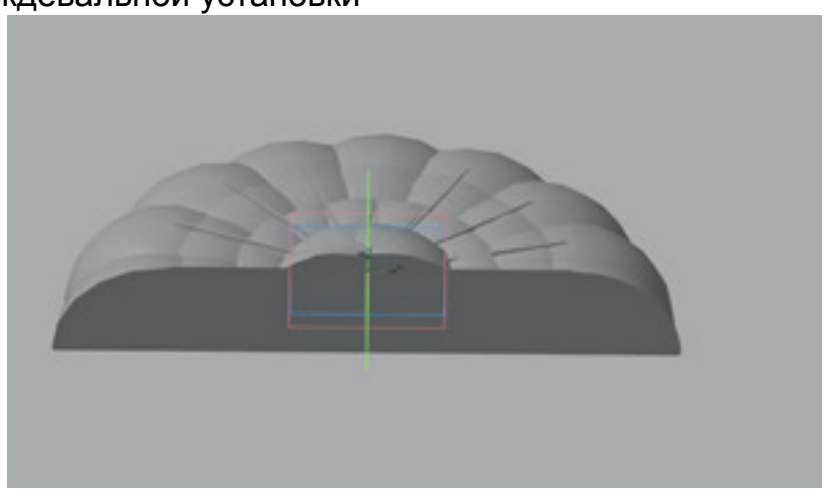

Рис. 8 - Схема распределения осадков по всей площади полива дождевальной установки

В результате установлено, что в качестве концевых насадок следует применять дуговые насадки с плоским дефлектором на одинаковом расстоянии от оси вращения дождевальной установки. Дефлектороные насадки секторного действия следует располагать на различных расстояниях от оси вращения, причем одна из них располагается перпендикулярно крылу, вторая под углом $50^{\circ}$ к крылу установки в направлении оси вращения. Расстояние между концевыми насадками составляет 10,32 м, расстояние перпендикулярно установленной дефлектороной насадки секторного действия от оси вращения дождевальной установки составляет 0,84 м, дефлектороной насадки секторного действия, установленной под углом 3,12 м. Полученные значения соответствуют режимам работы и типам применяемых насадок кон- 
кретной дождевальной установки. Подобная методика может применяться при проектировании и настройке дождевальных машин различных типов.

\section{Выводы}

Исследованиями установлено, что в качестве концевых насадок следует применять дуговые насадки с плоским дефлектором на одинаковом расстоянии от оси вращения дождевальной установки. Дефрлектороные насадки секторного действия следует располагать на различных расстояниях от оси вращения, причем одна из них располагается перпендикулярно крылу, вторая под углом 50 к крылу установки в направлении оси вращения. Вращение крыльев дождевальной установки обеспечивается реактивными струями дефлекторных насадок секторного действия, расположенных на крыльях ближе к центру вращения. Расстановка дождеобразующих насадок определяется режимом работы и типом применяемых насадок конкретной дождевальной установки.

\section{Список литературы}

1. Васильев, А. Г. Форсунки для орошения и увлажнения в теплицах [Текст] : Экспрессинформация. / А. Г. Васильев, И. И. Бронштейн. - М.: ЦБНТИ Минводхоза СССР. Серия 1, вып. 7, 1975. - 12-19 c.

2. Исследование кинематики движения рабочих элементов мобильной дождевальной установки [Текст] / Д. С. Мельничук, В. Н. Мальчиков, А. И. Рязанцев, Г. К. Рембалович, М.Ю.Костенко // Инновационное научно-образовательное обеспечение агропромышленного комплекса: Материалы 69-ой Международной научно-практической конференции 25 апреля 2018 года. - Рязань: Издательство Рязанского государственного агротехнологического университета, 2018. - Часть II. - С. 243-247.

3. Исследование траекторий движения капель дождевальной машины [Текст] / Г. К. Рембалович, А. И. Рязанцев, М. Ю. Костенко, В. С. Травкин, Р. В. Безносюк, Д.М. Юмаев // Вестник Рязанского ГАТУ имениП.А. Костычева. -2018. -№4(40). -С. 139-143.

4. Пат. 187870 Российская Федерация A01G
25/09 . Дождевальная установка для полива кассетной рассады в теплице [Текст] / Рязанцев А. И., Травкин В. С., Рембалович Г. К., Бышов Н. В., Борычев С. Н., Лазуткина Л. Н., Костенко М. Ю., Безносюк Р. В., Кузнецов А. В., Богданчиков И. Ю.; заявитель и патентообладатель Федеральное государственное бюджетное образовательное учреждение высшего образования "Рязанский государственный агротехнологический университет имени П.А. Костычева" (ФГБОУ ВО РГАТУ) - No: 2018133057, заявл. 17.09.2018; опубл.: 21.03.2019, Бюл. № 9.- 3 с.

5. Пат. 189319 Российская Федерация A01G 25/00 . Дождевальная установка для теплиц [Текст] / Рязанцев А. И., Травкин В. С., Рембалович Г. К., Бышов Н. В., Борычев С. Н., Лазуткина Л. Н., Костенко М. Ю., Безносюк Р. В., Кузнецов А. В., Богданчиков И. Ю.; заявитель и патентообладатель Федеральное государственное бюджетное образовательное учреждение высшего образования "Рязанский государственный агротехнологический университет имени П.А. Костычева" (ФГБОУ ВО РГАТУ) - No: 2018119609, заявл. 28.05.2018; опубл.: 21.05.2019, Бюл. № 15. - 3 с

6. Поляшов, Ю. А. Определение среднего диаметра капель несимметрично разбрызгивающих насадок [Текст] / Ю. А. Поляшов, Л.И.Клименко // Гидравлика и гидлротехника. Труды КСХИ им. М.В.Фрунзе. - Кишинев, 1977.- 67-72 с.

7. Рекомендации по применению низконапорного дождевателя для орошения рассады овощных культур : методические рекомендации [Текст] / Н. В. Бышов, С. Н. Борычев, А. И. Рязанцев, Г. К. Рембалович, Л. Н. Лазуткина, М. Ю. Костенко, Р.В. Безносюк [и др.]. - Рязань : ФГБОУ ВО РГАТУ, 2018. - 30 C.

8. Рязанцев, А. И. Направления совершенствования дождевальных машин и систем [Текст] / А. И. Рязанцев.-Рязань:ФГБОУВПОРГАТУ,2013.-306с.

9.Testezlaf R., Zazueta F.S., Yeager T.H. A Real - time Irzigation Control System for Greenhauses. American Sosiety of Agrikultural Engineers. Applied Engineering in Agriculture. 1997. Vol 13(3), p. 329-332

\section{STUDY OF THE INFLUENCE OF LOCATION OF SPRINKLING HEADS ON IRRIGATION QUALITY}

Kuznetsov Alexander V., Applicant, Department of Metal Technology and Machine Repair, tmirm@yandex. ru, Ryazan State Agrotechnological University named after P.A. Kostychev

The effectiveness of the sprinkler during irrigation of cluster seedlings depends on the radius of irrigation and the angle of incidence of drops of its end nozzles. Sprinkler nozzle baffles have a high dispersion pattern at low pressures and have a simple structure. The shape of the nozzle deflector allows you to evenly distribute rain over the irrigation area, as well as form a watering contour in the form of a sector or a full circle. The advantage of arc nozzles is the formation of small drip rain at an operating pressure of 0.05 to $0.24 \mathrm{MPa}$, with an average droplet diameter of $0.35-0.48 \mathrm{~mm}$. During operation, the arc nozzles have high technological reliability, less clog, do not require additional settings. To study the distribution of sediment over the irrigation radius, experimental studies of an arc nozzle with a flat deflector were carried out. The radius of capture of an arc nozzle with a flat deflector is about $3 \mathrm{~m}$, and the distribution of precipitation along the radius is a parabola. At a working pressure of $0.15 \mathrm{MPa}$, a sector-wide deflector nozzle distributes rain over sector $90^{\circ}$ with a radius of about $3.0 \mathrm{~m}$. The nozzle design provides a reactive force that can be used to drive sprinkler machines. For a rational arrangement of nozzles on the sprinkler, we applied the reversal method by placing the coordinate axes on a rotating sprinkler, and rotated the irrigation zone. To determine the parameters of the overlap of the irrigation zones of each nozzle, we used the regression equations to refine the amount of precipitation. As a result, it was found that arc nozzles with a flat deflector at the same distance from the axis of rotation of 
the sprinkler should be used as end nozzles. Sector-mounted deflector nozzles should be located at different distances from the axis of rotation, one of which is perpendicular to the wing, the second at an angle of $50^{\circ}$ to the installation wing in the direction of the axis of rotation.

Key words: irrigation, sprinkler, distribution of precipitation, deflector nozzles, uniformity of rain.

1.Vasil'ev A.G., Bronshtejn I.I. Forsunki dlya orosheniya i uvlazhneniya v teplicah. M.: CBNTI Minvodhoza SSSR. Ekspress-informaciya. Seriya 1, vyp. 7, 1975 - 12-19 s.

2.Issledovanie kinematiki dvizheniya rabochih elementov mobil'noj dozhdeval'noj ustanovki [Tekst] / Mel'nichukD.S., Mal'chikov V.N., RyazancevA.I., Rembalovich G.K., Kostenko M. YU. //Innovacionnoe nauchnoobrazovatel'noe obespechenie agropromyshlennogo kompleksa: Materialy 69-oj Mezhdunarodnoj nauchnoprakticheskoj konferencii 25 aprelya 2018 goda. - Ryazan': Izdatel'stvo Ryazanskogo gosudarstvennogo agrotekhnologicheskogo universiteta, 2018. - CHast' II. - S. 243-247.

3. Issledovanie traektorij dvizheniya kapel' dozhdeval'noj mashiny [Tekst] / G.K. Rembalovich, Ryazancev A.I., Kostenko M.YU., Travkin V.S., Beznosyuk R.V., YUmaev D.M. // Vestnik Ryazanskogo GATU imeni P.A. Kostycheva. - №4 (40). - 2018. - S. 139-143.

4.Pat. 187870 Rossijskaya Federaciya A01G 25/09. Dozhdeval'naya ustanovka dlya poliva kas-setnoj rassady $v$ teplice / Ryazancev Anatolij Ivanovich, Travkin Vladislav Sergeevich, Rembalovich Georgij Konstantinovich, Byshov Nikolaj Vladimirovich, Borychev Sergej Nikolaevich, Lazutkina Larisa Nikolaevna, Kostenko Mihail YUr'evich, Beznosyuk Roman Vladimirovich, Kuznecov Aleksandr Vasil'evich, Bogdanchikov II'ya YUr'evich; zayavitel' i patentoobladatel' Federal'noe gosudarstvennoe byudzhetnoe obrazovatel'noe uchrezhdenie vysshego obrazovaniya "Ryazanskij gosudarstvennyj agrotekhnologicheskij universitet imeni P.A. Kostycheva" (FGBOU VO RGATU) - No: 2018133057, zayavl. 17.09.2018; opubl.: 21.03.2019, Byul. No 9.-3 s.

5.Pat. 189319 Rossijskaya Federaciya A01G 25/00. Dozhdeval'naya ustanovka dlya teplic / Ryazancev Anatolij Ivanovich, Travkin Vladislav Sergeevich, Rembalovich Georgij Konstantinovich, Byshov Nikolaj Vladimirovich, Borychev Sergej Nikolaevich, Lazutkina Larisa Nikolaevna, Kostenko Mihail YUr'evich, Beznosyuk Roman Vladimirovich, Kuznecov Aleksandr Vasil'evich, Bogdanchikov II'ya YUr'evich; zayavitel' i patentoobladatel' Federal'noe gosudarstvennoe byudzhetnoe obrazovatel'noe uchrezhdenie vysshego obrazovaniya "Ryazanskij gosudarstvennyj agrotekhnologicheskij universitet imeni P.A. Kostycheva" (FGBOU VO RGATU) - No: 2018119609, zayavl. 28.05.2018; opubl.: 21.05.2019, Byul. No 15. - $3 \mathrm{~s}$

6.Polyashov YU.A., KlimenkoL.I. Opredelenie srednego diametrakapel'nesimmetrichnorazbryzgivayushchih nasadok. Gidravlika i gid $\neg$ rotekhnika. Trudy KSKHI im. M.V.Frunze. Kishinev, 1977.- 67-72 s.

7.Rekomendacii po primeneniyu nizkonapornogo dozhdevatelya dlya orosheniya rassady ovoshchnyh kul'tur : metodicheskie rekomendacii / N. V. By-shov, S. N. Borychev, A. I. Ryazancev, G. K. Rembalo-vich, L. N. Lazutkina, M. YU. Kostenko, R. V. Beznosyuk [i dr.]. - Ryazan' : FGBOU VO RGATU, 2018. - 30 s.

8.Ryazancev, A. I. Napravleniya sovershenstvovaniya dozhdeval'nyh mashin $i$ sistem [Tekst] / A. I. Ryazancev. - Ryazan' : FGBOU VPO RGATU, 2013. - 306 s.

9. Testezlaf R., Zazueta F.S., Yeager T.N. A Real - time Irzigation Control System for Greenhauses. American Sosiety of Agrikultural Engineers. Applied Engineering in Agriculture. 1997. Vol 13 (3), p. 329 - 332

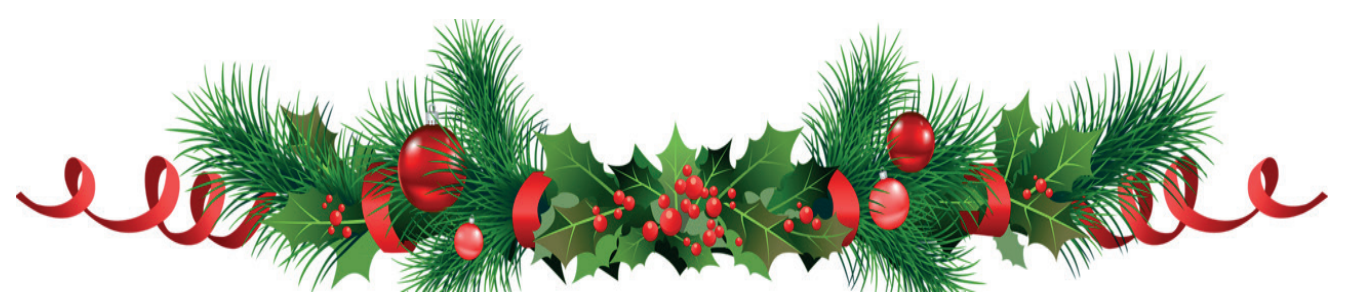




\section{УГЛАНОВ МИХАИЛ БОРИСОВИЧ}

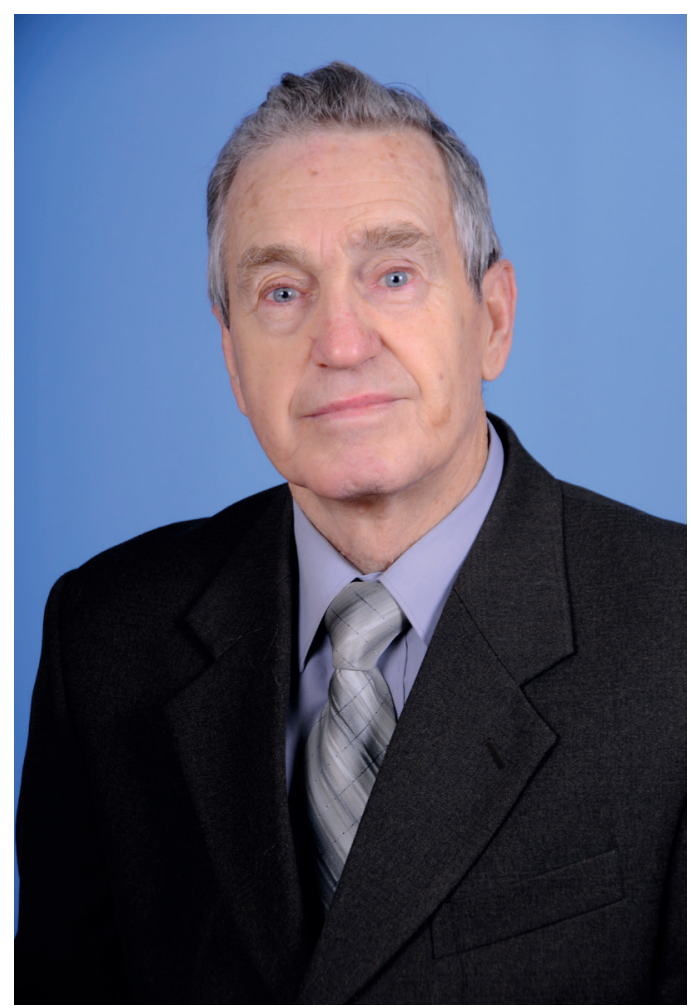

Михаил Борисович родился 8 ноября 19342. в с. Мышкар Шиловского района Рязанской области. В 19572. окончил Рязанский сельскохозяйственный институт имени профрессора П.А. Костычева, фракультет механизации.

В ноябре 19572. поступил на работу в ГСКБ по машинам для возделывания и уборки картофреля г. Рязани на должность инженера-конструктора, где проработал до 19942.

В 19632. переведен на должность заведующего научно-исследовательским отделом ГСКБ, а с 19892. - главного конструктора проекта по НИР и испытаниям.

В марте 1992 г. назначен генеральным директором ГСКБ.

Значительный вклад внёс М.Б. Угланов в создание и внедрение в производство комплекса машин для картофрелеводства. При его непосредственном участии были разработаны и внедрены в производство основные машины для уборки картофреля: ботво-

уборочная машина УБД-3; картофрелеуборочные комбайны КУ-2А, ПК-2-01, КПК-3; транспортер-загрузчик картофреля ТЗК-30, на которые имеются авторские свидетельства. За разработку и внедрение в производство машины УБД-З в 19612. и комбайна КПК-З в 1987 г. М.Б. Угланов награжден бронзовыми медалями ВДНХ.

Без отрыва от производства при кафедре «Сельскохозяйственные машины» в 19672. защитил кандидатскую диссертацию, а в 19912. - докторскую.

C 19942. Михаил Борисович работал профрессором кафедры "Сельскохозяйственные машины». В настоящее время является сотрудником кафредры «Эксплуатация машинно-тракторного парка». Активно участвует в учебнопедагогической и научной жизни кафредры и всего университета.

Основным направлением научной деятельности является создание комплекса машин для возделывания и уборки картофеля.

М.Б. Угланов - автор более 130 научных работ, из которых более 80 - авторские свидетельства и патенты.

Является автором пяти книट и справочников по картофелеводству, выпущенных издательством «Колос», ряда рекомендаций, методических пособий с грифом УМО.

Под его руководством защищены три кандидатских диссертации.

М.Б. Угланов с 19962. по 2008г. работал секретарем диссертационного совета по защите диссертаций на соискание ученой степени кандидата и доктора технических наук.

Среди коллег пользуется заслуженным авторитетом, передает свой большой практический опыт и теоретические знания студентам, аспирантам и молодым преподавателям.

Коллективы кафредры, фракультета и университета сердечно поздравляют Михаила Борисовича и желают ему крепкого здоровья и благополучия! 


\section{АМПЛЕЕВА ЛАРИСА ЕВГЕНЬЕВНА}

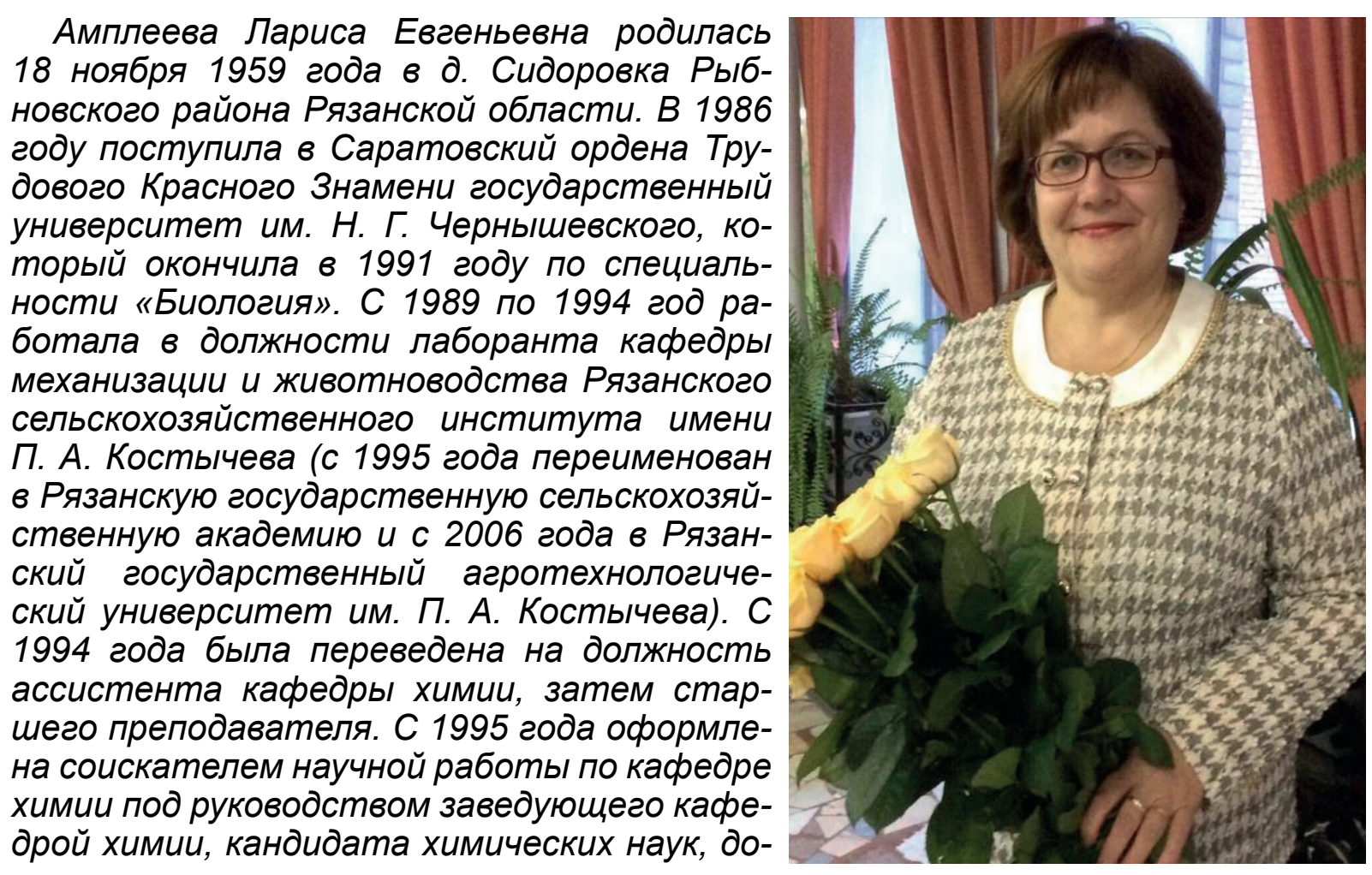
цента Полищук Светланы Дмитриевны.

В 2006 году Лариса Евгеньевна защитила кандидатскую диссертацию на тему: «Физиологическое состояние кроликов при введении в рацион вики, выращенной с использованием ультрадисперсных порошков железа и кобальта» по специальности 03.00.13 - фризиология, в связи с чем ей была присуждена степень кандидата биологических наук. С 2006 года переведена на должность доцента кафедры химии. В 2008 году Амплеевой Л. Е. было присвоено звание доцента по кафредре химии. В настоящее время работает на должности доцента кафредры селекции и семеноводства, агрохимии, лесного дела и экологии.

Лариса Евгеньевна имеет богатый опыт преподавания химических дисциплин, среди которых: химия, биохимия животных, физико-химические методы анализа, органическая, фризическая и коллоидная химия. Является автором более 50 научных и научно-методических трудов, в том числе три из них включены в международную базу данных SCOPUS.

За период работы в ФГБОУ ВО РГАТУ неоднократно награждалась почетными грамотами, дипломами, иенными подарками от руководства университета.

В 2014 году Амплеева Л. Е. получила благодарность от Министерства сельского хозяйства РФ за многолетний добросовестный труд, большой вклад в подготовку высококвалифрицированных специалистов для агропромышленного комплекса и в связи с 65-летием со дня основания университета .

Преподаватели, сотрудники и студенты технологического фракультета сердечно поздравляют Ларису Евгеньевну с юбилеем! Желают крепкого здоровья, счастья, творческих успехов и удачи во всех начинаниях! 


\section{ЛЕВИН ВИКТОР ИВАНОВИЧ}

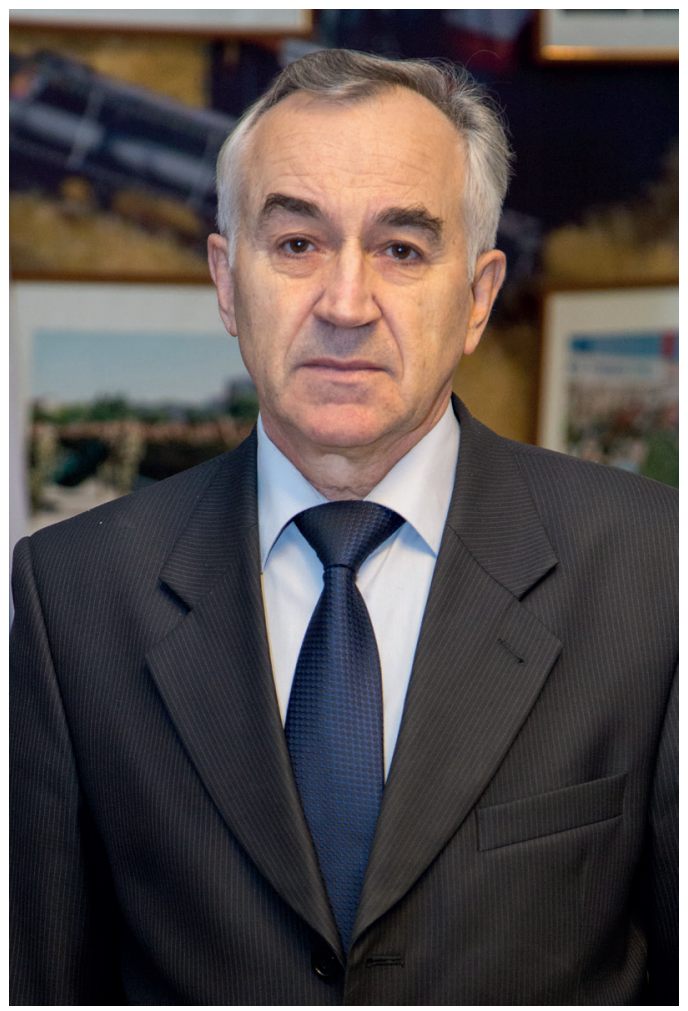

25 октября 2019 года Виктору Ивановичу Левину исполнилось 70 лет.

Виктор Иванович родился в д. Коростово, Рязанского района, Рязанской области. В Рязанском государственном агротехнологическом университете имени П.А. Костычева (тогда в сельскохозяйственном институте) Виктор Иванович работает с декабря 1973 года - вначале в должности младшего научного сотрудника, с 1974 г. - старшего научного сотрудника кафедры ботаники и физиологии растений. В июле 1981 г. был избран старшим преподавателем, с декабря 1987 г. - и.о. доцента кафредры лугового кормопроизводства и защиты растений. С февраля 1984 года - зам. декана, с 1987 г. по 1991 г. - декан заочного фракультета. С фревраля 1991 г. был заведующим кафедрой ботаники и фризиологии растений, с 2005 г. - заведующим кафредрой агроэкологии, сельскохозяйственной мелиорации и защиты растений, а с 2012 г. по 2015 г. - заведующим кафредрой лесного хозяйства, экологии и селекции растений. С ноября

2001 г. он одновременно являлся деканом агрономического, а впоследствии агроэкологического фракультета.

В декабре 2002 г. Левин В.И. награжден нагрудным знаком «Почетный работник высшей школы Российской Федерации», а в 2010 году ему присвоено почетное звание «Заслуженный работник высшей школы Российской Федерации».

В настоящее время Виктор Иванович Левин работает в должности профессора кафредры селекции и семеноводства, агрохимии, лесного дела и экологии.

Левин В.И. много внимания уделяет научно-исследовательской работе. Он имеет 8 патентов, более 100 публикаций и был награжден бронзовой медалью ВДНХ в 1984 г. В настоящее время активно участвует в разработке инновационных программ для АПК. В 1986 г. он защитил диссертацию на соискание ученой степени кандидата биологических наук, в 2000 г. - докторскую диссертацию.

Виктор Иванович является руководителем научной школы технологического фракультета «Экологический мониторинг и разработка фритосанитарных и фритомелиоративных мероприятий по сохранению почвенного плодородия земель, подверженных техногенному загрязнению и разрушению». Ученики Виктора Ивановича стали доцентами и ведущими специалистами в сельскохозяйственном производстве.

Левин В.И. вносит значительный вклад в динамическое фрункционирование агропромышленного комплекса региона. Много внимания уделяет обучению специалистов АПК, оказывает научно-методическую помощь сельскохозяйственным предприятиям Рязанской области.

Левин Виктор Иванович - высокообразованный работник, который обладает большими организаторскими способностями, требователен и принципиален в решении различных вопросов, пользуется заслуженным авторитетом среди сотрудников и студентов университета. За многолетний добросовестный труд он неоднократно поощрялся руководством области и университета. Поздравляем юбиляра с 70-летием, желаем многих лет жизни, крепкого здоровья и новых творческих планов! 